UNIVERSIDADE DE SÃO PAULO

FACULDADE DE FILOSOFIA, LETRAS E CIÊNCIAS HUMANAS

DEPARTAMENTO DE LETRAS CLÁSSICAS E VERNÁCULAS

PROGRAMA DE PÓS-GRADUAÇÃO EM FILOLOGIA E LÍNGUA PORTUGUESA

ELISANGELA BAPTISTA DE GODOY SARTIN

\title{
O PORTUGUÊS DE HERANÇA EM TERRITÓRIO FRONTEIRIÇO: \\ A LH EM OLIVENÇA COMO ARMA PARA PRESERVAÇÃO DE UM GRUPO MINORITÁRIO
}

Versão corrigida 
UNIVERSIDADE DE SÃO PAULO

FACULDADE DE FILOSOFIA, LETRAS E CIÊNCIAS HUMANAS

DEPARTAMENTO DE LETRAS CLÁSSICAS E VERNÁCULAS

PROGRAMA DE PÓS-GRADUAÇÃO EM FILOLOGIA E LÍNGUA PORTUGUESA

\section{O PORTUGUÊS DE HERANÇA EM TERRITÓRIO FRONTEIRIÇO: \\ A LH EM OLIVENÇA COMO ARMA PARA PRESERVAÇÃO DE UM GRUPO MINORITÁRIO}

Elisangela Baptista de Godoy Sartin

lisaugusto@hotmail.com

Tese apresentada ao Programa de PósGraduação em Filologia e Língua Portuguesa do Departamento de Letras Clássicas e Vernáculas da Faculdade de Filosofia, Letras e Ciências Humanas da Universidade de São Paulo, para a obtenção do título de doutor em Letras.

Orientadora: Profa. Dra. Maria Célia Lima-Hernandes Co-orientadora: Profa. Dra. Virgínia Bertolotti

Versão corrigida

De acordo

Profa Dra Maria Célia Lima-Hernades 
Autorizo a reprodução e divulgação total ou parcial deste trabalho, por qualquer meio convencional ou eletrônico, para fins de estudo e pesquisa, desde que citada a fonte. 
Banca Examinadora

Aprovado em: 07/03/2016

Membros titulares:

Profa. Dra. Maria Célia Pereira Lima-Hernandes

FFLCH-USP

(Orientadora)

Profa. Dra. Virgínia Bertolotti

(Universidad de la Repúpica - Uruguai)

(Co-orientadora)

Profa. Dra. Maria João Marçalo

(Universidade de Évora)

Profa. Dra. Gláucia da Silva

(University of Massachusetts - Darmouth)

Profa. Dra. Patricia Carvalhinhos

(Universidade de São Paulo)

Prof. Dr. Marcelo Ribeiro

(UNINOVE) 


\section{Membros suplentes:}

Profa. Dra. Kátia de Abreu Chulata

(Universidade de Pescara)

Profa. Dra. Renata Barbosa Vicente

(Universidade Federal Rural de Pernambuco)

Profa. Dra. Cristina Lopomo Defendi

(Instituto Federal de São Paulo)

Profa. Dra. Elaine Cristina Silva Santos

(Universidade Federal de Sergipe)

Prof. Dr. Saulo César Paulino e Silva

(Faculdades Sumaré) 
Dedico este trabalho ao meu Deus por ser essencial em minha vida, ao meu marido José Augusto e ao meu filho Gustavo. 


\section{Agradecimentos}

A Deus que, nos momentos mais difíceis da minha vida, me deu muita força e iluminou minha mente para que esta pesquisa pudesse ser realizada. Agradeço também por Ele ter colocado em meu caminho uma pessoa tão iluminada para a missão de me orientar nessa difícil tarefa.

À minha orientadora Maria Célia Lima-Hernandes, por sempre me incentivar a realizar um trabalho de tamanha importância para minha vida acadêmica e pela grande contribuição do meu desenvolvimento no caminho da pesquisa científica. Agredeço pela paciência e pelo seu grande companheirismo sempre.

À minha co-orientadora Virgínia Bertolotti por fornecer materiais e informações necessárias para esta pesquisa e em ser sempre pronta em responder as minhas dúvidas.

À professora Maria João Marçalo, por ter aceitado ser tutora do meu doutorado sanduíche em Portugal, ter ajudado com toda a documentação necessária, ter nos recebido com tanto carinho e, principalmente, por ter contribuído com informações importantes para esta pesquisa.

Ao meu marido, José Augusto, pelo companheirismo constante, pois, embora não receba nenhum certificado, esteve sempre presente durante a produção desta pesquisa.

Ao meu filho Gustavo que esteve presente nos momentos de pesquisa, auxiliando em algumas traduções.

Aos meus pais Olivio e Walkiria, que me deram uma educação de princípios, apoiandome em toda minha vida acadêmica.

Aos meus irmãos, por serem pessoas que tenho a certeza de sempre poder contar.

Aos meus amigos que, embora eu estivesse numa fase de tanto trabalho, me ajudaram com alguns momentos de descontração.

Às minhas amigas de curso Renata, Cristina, Elaine, Lídia que sempre estiveram prontas a me ajudar.

Ao senhor Juan Antônio, um espanhol oliventino, que me ajudou grandemente na missão de encontrar informantes portugueses.

Aos informantes portugueses que colaboraram com minha pesquisa, aceitando gravar nossas conversas.

À CAPES, por ter deferido meu pedido de bolsa de estudo para doutorado sanduíche. 
Para as oliventinos, nenhuma fala pode dar maior alenta de prazer au de caráter que a nossa lingua. tãa partuguesa coma nós próprias; é a saudade que flaresce, doce e maleáuel. emotiva e taluez impetuasa cuja dor e alegria irradiando de si própria, mantém reflexas dentra da caraçãa a prodamar que de noua se ouçam as palauras quentes da lingua de Camões. na ansiedade que temos de voltar à nossa origem criadara! (ABRAN7ES. 1951:59) 


\section{Resumo}

Esta pesquisa tem como objetivo investigar a língua portuguesa nativa e de herança sobreviventes em território fronteiriço de língua oficial espanhola. Como locus de pesquisa selecionamos Olivença, uma cidade da Espanha em que a língua portuguesa se faz em situações específicas de uso. A relevância desta pesquisa traduz-se no fato de que espaços fronteiriços mantêm sobrepostas em espaços geográficos contíguos algumas realidades que se sobrepõem: a realidade da oficialidade linguística e a realidade do sentimento de pertença sociolinguística. Nesta tese, partimos da identificação, em trabalho de campo, da presença da língua portuguesa no território atualmente espanhol (mas historicamente português) e na constatação de que há uma flutuação de identificação-identidade linguística. No espaço geográfico em que fizemos incursão científica, duas cidades sobrepõem-se historicamente e duas geografias políticas, por outro lado, avizinham-se e roçam-se continuamente. Ao tomar contato com essa cidade, hipotetizamos que o sentimento de pertença linguística estaria presente entre os falantes mais velhos, que manteriam a herança de traços lusitanos em sua comunicação, mesmo ao falar o espanhol. A justificativa é que, logo de chegada, já avistáramos recintos comerciais com nomes portugueses e, contrariamente, não ouvíamos o som lusitano nas ruas. Sabemos que o domínio espanhol numa cidade outrora portuguesa tenderia a apagar vestígios portugueses. No entanto, em grupos íntimos pressupúnhamos o português como língua corrente. Durante o trabalho de campo, identificamos fortes valores culturais sendo empunhados como armas de resistência entre descendentes de portugueses, fazendo correr numa velocidade acentuada a reorganização dos valores lusitanos em redutos da cidade espanhola. Essa força e essa velocidade pareciam ser as molas propulsoras de uma mudança linguística muito sorrateira, que impactava o sentimento de unidade de um segmento social da comunidade sociolinguística. Isso nos inspirou a dar um passo investigativo seguinte em direção aos mais jovens, que tinham o espanhol como língua materna, mas tinham o português como língua de herança. À pergunta central sobre a força do português como língua de herança buscamos respostas por meio de duas outras questões mais indiretas feitas aos sujeitos entrevistados: será que os mais jovens percebiam-se como portugueses? será que os elementos culturais lusitanos presentes nas ruas eram reconhecidos como vinculados à língua de herança? Foi assim que passamos a recolher pistas sobre os traços de resiliência do português como língua incrustada na região espanhola de Olivença.

Palavras-chave: Língua de Herança; Sentimento de pertença; Grupos étnicos; Comunidade sociolinguística; Resiliência cultural. 


\section{Abstract}

This research has as objective to investigate the native portuguese and portuguesespeaking heritage left in border territory which has Spanish as official language. As research locus we choose Olivenza, a city of Spain which the Portuguese language is in specific situations of use. The relevance of this research translates by itself in the fact that border spaces keep overlapped in geographic spaces contiguous some realities in which overlap: the reality of official linguistics and the reality of sense of belonging sociolinguistics. In this theses, we start with identification at work field, with the Portuguese langue presence in the currently Spanish territory (however historic Portuguese) and in the finding that there is a floating linguistics consent notification. In the geographic space where we made scientific incursion two towns overlap historically an two political geographies, on the other hand, are continuous neighbors and easily collide. Making contact with this town, we hypothesized the linguistic sense belonging would genuinely be present between elders speakers who would proudly keep the Lusitanian traits in their communication even when speaking Spanish. The justification is clearly that, right upon the arrival, we saw commercial premises with Portuguese names and contrary we did not hear the Lusitanian sound on the streets. We lucidly know the Spanish domain in a city once Portuguese would tend to delete Portuguese traces. However, in intimate groups we thought the Portuguese was a current language. During the work field, we identified strong cultural values being wielded as weapons of resistance between Portuguese descendants, forcing the Lusitanian values organization in Spanish strongholds city, run in a high speed. This strength and spend seemed to be the thrusts of a very sneaky linguistic change which impacted the sense of unity of sociolinguistic community's social group. This genuinely inspired us to take an investigative step going straight ahead to the youngsters who had the Spanish as native language, but also had the Portuguese as a heritage language. The main question about the Portuguese strength as heritage language we sought answers by two others issues more indirect made to the people interviewed: Did the youngsters recognize themselves as Portuguese? Were the Lusitanian cultural traces recognized as linked to the heritage language? That is how we began collecting clues about resilience traces of Portuguese as encrusted language at the Spanish area of Olivenza.

Keywords: Heritage Language; Sense of Belonging; Ethnic Groups; Sociolinguistic Community; Cultural Resilience 


\section{LISTA DE MAPAS}

Mapa I - Cidade de Olivença - vista pela Espanha.......................................................96

Mapa II - Cidade de Olivença - vista por Portugal.......................................................97

Mapa III - Região do Alentejo e alguns de seus rios e afluentes.................................103

\section{LISTA DE QUADROS}

Quadro 1 - Relação dos portugueses entrevistados em Olivença...............................164

Quadro 2 - Relação de informantes descendentes de portugueses...........................165

Quadro 3 - Portugueses entrevistrados em Olivença...............................................184

\section{LISTA DE IMAGENS}

Imagem 1 - Lobo frontal esquerdo é responsável pela linguagem..............................78

Imagem 2 - Região do cérebro: o hipocampo é responsável pela memória.................. 79

Imagem 3- O hipotálamo: responsável primordialmente por controlar as emoções...84

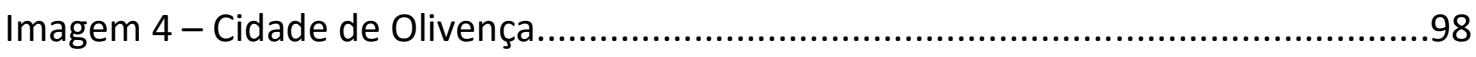

Imagem 5 - Ponte de Nossa Senhora da Ajuda......................................................102

Imagem 6 - Vestuário dos homens Oliventinos naquela época...................................104

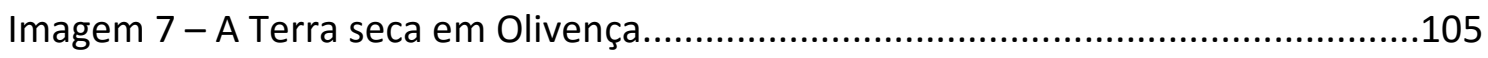

Imagem 8 - Cidade de Olivença com vastas terras não povoadas................................106

Imagem 9 - Praça de Olivença que foi tomada pelos espanhóis.................................120

Imagem 10 - Centro e Praça de Olivença.......................................................................120

Imagem 11- Um dos chafarizes da cidade de elvas.............................................138

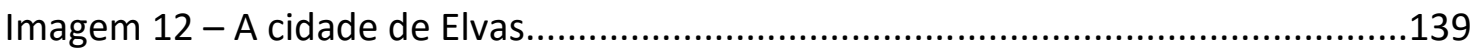

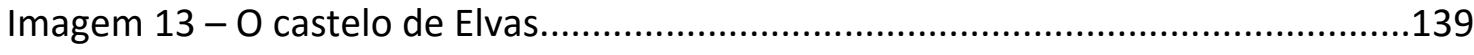

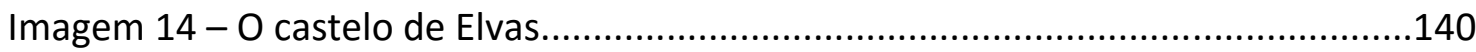

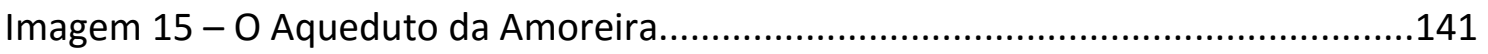


Imagem 16 - Asilo em Olivença: Residência Club ancianos Olivença...........................161

Imagem 17 - Instituto de ensino Puente Ajuda........................................................162

Imagem 18 - Nome de rua em Olivença............................................................170

Imagem 19 - Igreja Santa Maria Madalena - vista geral............................................260

Imagem 20 - Igreja Santa Maria Madalena - porta lateral da igreja.........................261

Imagem 21 - Igreja Santa Maria Madalena - porta de entrada da igreja.....................261

Imagem 22 - Entrada da cidade de Olivença...........................................................263

Imagem 23 - Cafeteria na entrada de Olivença.....................................................263

Imagem 24 - Cardápio de lanchonete "Lisboa" em Olivença......................................264

Imagem 25 - Cardápio de lanchonete "Lisboa" em Olivença......................................264

Imagem 26 - Cartazes de propagandas de Olivença..............................................266

Imagem 27 - Estabelecimento de eletrônicos em Olivença.........................................267

Imagem 28 - Carpintaria em Olivença.................................................................268

Imagem 29 - Placa da rua de Olivença com seu antigo nome português...................269

Imagem 30 - Placa da rua de Olivença com seu antigo nome português......................269

Imagem 31 - Placa da rua de Olivença com seu antigo nome português....................270

Imagem 32 - Placa da rua de Olivença com seu antigo nome português....................270

Imagem 33 - Placa da rua de Olivença com seu antigo nome português....................271

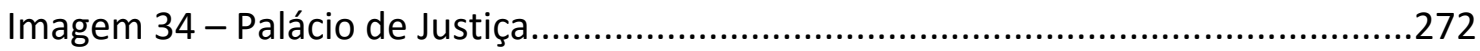

Imagem 35 - Palácio de Justiça - parte interna...................................................2272

Imagem 36 - Cemitério de Olivença....................................................................274

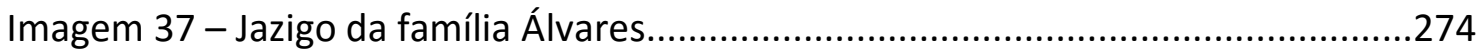

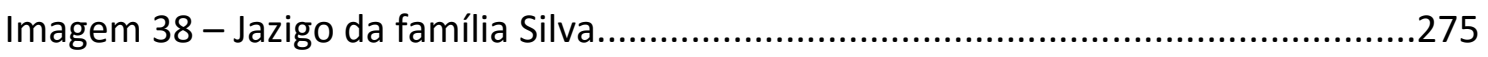

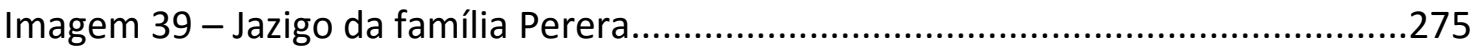




\section{SUMÁRIO}

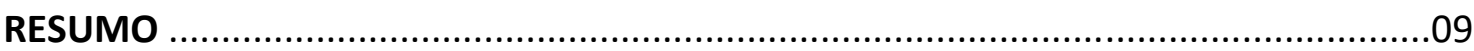

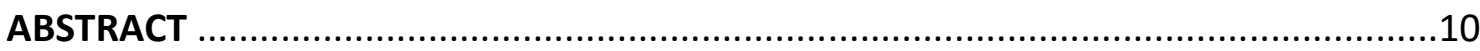

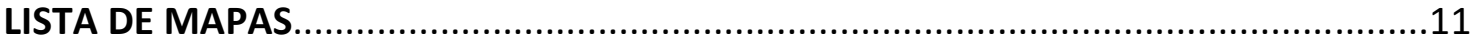

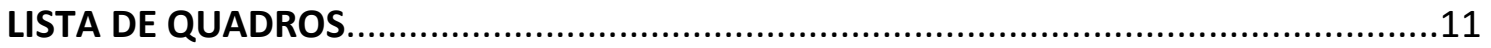

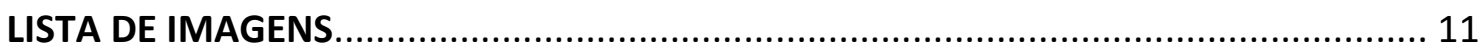

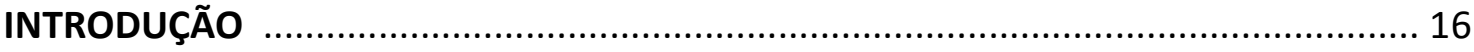

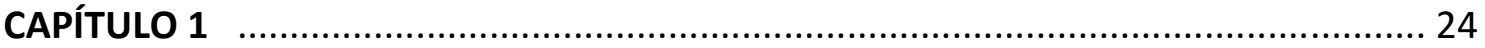

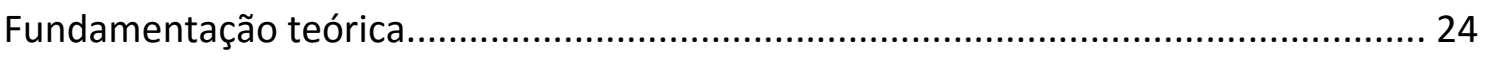

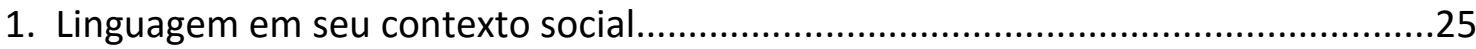

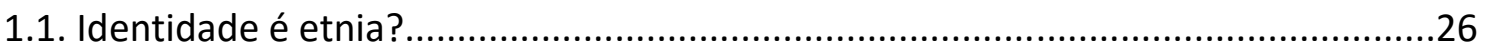

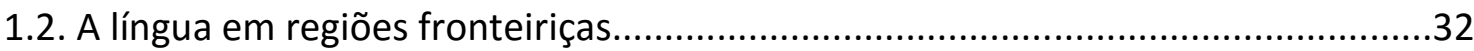

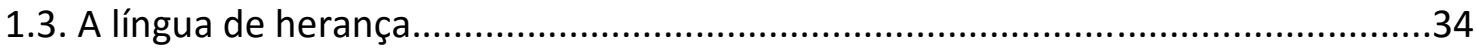

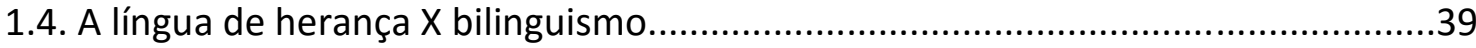

1.5. Um estudo com base nas variáveis linguísticas..................................................45

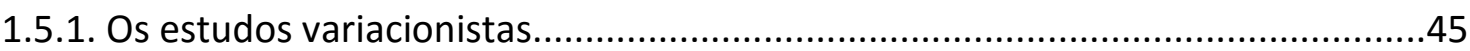

1.5.2. Os pressupostos teóricos da sociolinguística...................................................46

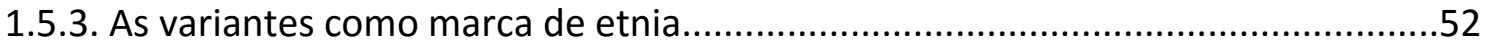

1.5.4. Os usos variantes como resposta a tentativas de fazer parte do grupo...............56

1.6. Um estudo com base na sociolinguística intaricional........................................58

1.6.1. A língua sob a perspectiva da comunicação interacional.....................................58

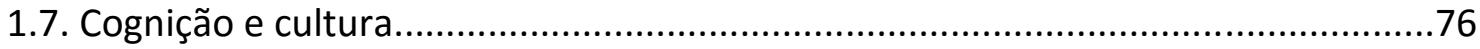

1.7.1. O cérebro humano: a linguagem como o grande diferencial.............................77

1.7.2. Os estágios do "SELF": Uma teoria sobre os estágios da consciência humana - do

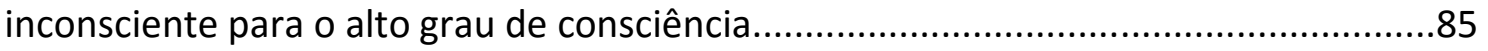

1.7.3. A mente humana sob uma perspecitva evolucionista.....................................90

CAPÍTULO 2 
O locus da pesquisa - Olivença fronteira com Elvas....................................................94

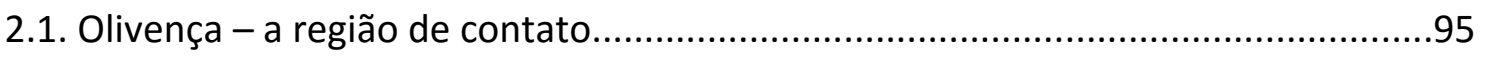

2.2. Olivença - como é apresentada entre os veículos de informação e de pesquisa...97

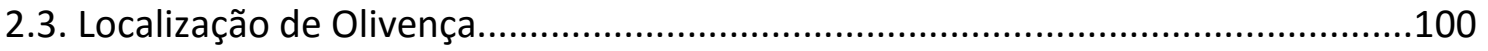

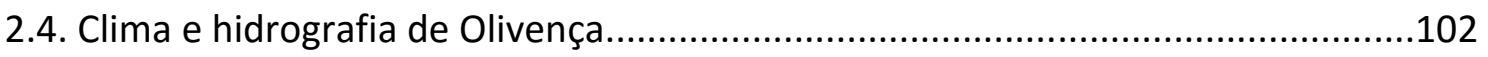

2.5. A situação da língua falada em Olivença.............................................................107

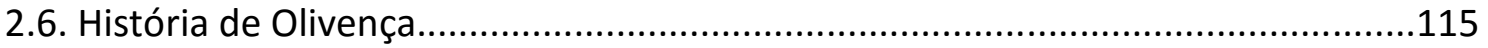

2.7. Uma arma poderosa para a tomada de Olivença..............................................123

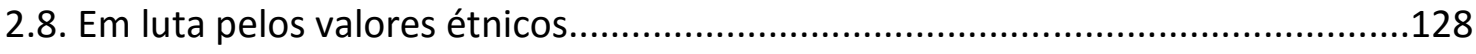

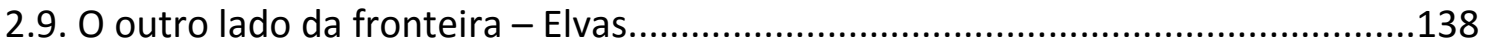

2.9.1. Elvas - uma cidade de muitas batalhas......................................................138

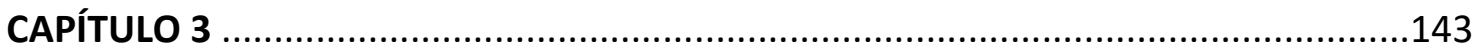

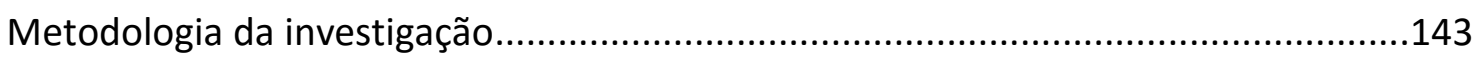

3.1. A interação pesquisador $X$ informante e a interação pesquisador - informante: $a$ importância da compreensão do contexto comunicativo.........................................144

3.1.2. A análise qualitativa - um olhar para o contexto...........................................149

3.2. Objetivos e hipóteses levantadas - O trabalho de campo em região fronteiriça..154

3.3. Contextualização do trabalho de campo em Olivença........................................156

3.3.1. Caracterização da amostragem - os imigrantes portugueses............................164

3.3.2. Característica da amostra - os descendentes de $2^{a}$ e $3^{a}$ geração de portugueses - os falantes de LH. .165

3.3.3. Os dados sobre o sentimento de pertença linguística entre os imigrantes

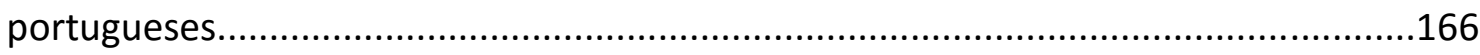

3.3.4. Os dados sobre as variantes linguísticas do português oliventino......................166

3.3.5. Os dados sobre o sentimento de pertença linguística entre a camada mais jovem

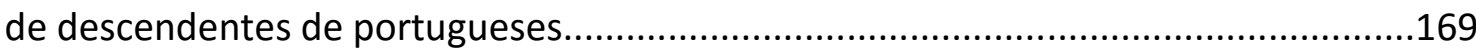

3.3.6. Uma busca por marcas que demonstrem o sentimento de pertença

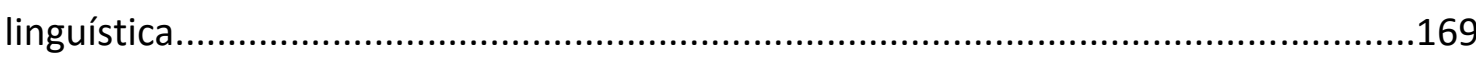

3.4. A busca por informantes espanhóis em Elvas - o outro lado da fronteira............171 
O Português na fronteira Elvas - Olivença

.173

4.1. Um contraponto entre o português oliventino e o português de Portugal em descrição do século XX. .174

4.1.2. Um contraponto entre o português oliventino e o português de Portugal descrição do século XXI. 184

4.1.2.1. Amostra dos entrevistados .184

4.1.2.2. Descrição de atitudes linguísticas dos oliventinos frente à língua portuguesa.

4.1.3. Descrição linguística do português oliventino. .190

4.1.3.1. A análise fônica do português de Olivença..... 190

4.1.4. Aspectos do léxico da fala dos portugueses oliventinos 196

4.1.5. Aspectos da morfologia encontrados na fala dos portugueses oliventinos 198

4.1.6. Aspectos sintáticos do falar oliventino. 230

4.2. Marcas do sentimento de pertença da LH em Olivença .256

4.2.1. As teorias sobre a preservação das marcas de herança. .257

4.2.2. Caminhando pelas ruas de Olivença: a preservação das marcas portuguesas...259 4.3. Sentimento de pertença de LH em Olivença: Um olhar para o contexto cognitivo e

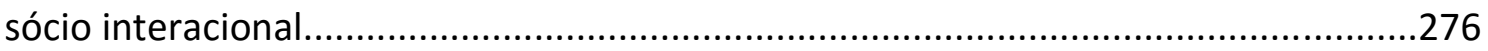

4.3.1. Uma análise linguística de base qualitativa.

.277

4.3.2. O sentimento de pertença - uma análise face a face com os imigrantes portugueses. .280

4.3.3. O sentimento de pertença dos descendentes de imigrantes portugueses -os falantes de $\mathrm{LH}$.........325

CONCLUSÃO .339

REFERÊNCIAS BIBLIOGRÁFICAS. .351

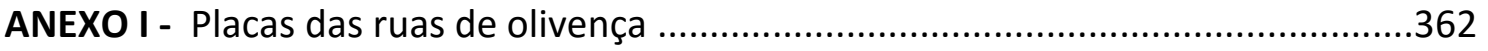

ANEXO II - Tratado de Alcanices (Biblioteca Nacional de Lisboa)..............................364

ANEXO III - Documentos sobre A Guerra Da Sucessão Da Espanha ..............................367

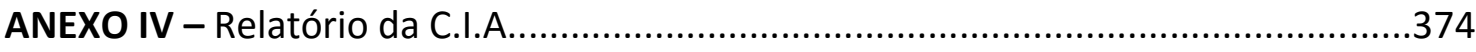

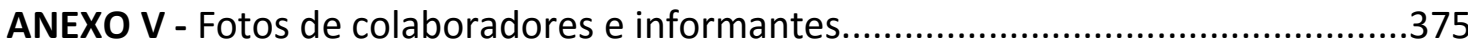




\section{O Português de Herança em território fronteiriço: a LH em Olivença como arma para a preservação de um grupo minoritário}

\section{INTRODUÇÃO}

Fronteira é um espaço em que basta uma pisada para o lado e se está no outro lado da geografia. No caso de Olivença e de Elvas, esse pequeno passo pode significar um lado histórico diferente, um lado da pessoa que se silencia, uma cultura que se esgueira pelas ruas e esquinas sussurrando uma história antiga: a história da Olivença lusitana.

Quem habita regiões de fronteira nunca sabe ao certo quem é o outro, que língua é a outra. Tudo parece se mesclar em conceitos e culturas. Os prédios antigos, os monumentos históricos, as placas com nomes de ruas, os nomes de família, as línguas. Tudo se roça o tempo todo, sendo e não sendo parte da identidade, porque não há uma identidade local para todos. Há camadas históricas que convivem na mesma sincronia numa luta silenciada. Este é o tema desta tese: a fronteira como lugar de manutenção e de preservação de herança cultural.

A relevância dessa pesquisa traduz-se no fato de que nem sempre coincidem duas realidades nessas regiões de fronteira: a realidade da oficialidade linguística e a realidade do sentimento de pertença sociolinguística. A partir do reconhecimento da presença da língua portuguesa nesses territórios, por um lado, e a identificação de que a identidade linguística pode ser variável, por outro, é que esta pesquisa se desenvolve.

A pesquisa se justifica pelo fato de o português e o espanhol serem línguas aparentadas e fronteiriças, o que nos conduz à hipótese de que, no caso da região de Olivença, na Espanha, sobrevivam, assim como nas respectivas línguas, um sentimento de pertença sociolinguística incrustado entre os seus falantes, principalmente entre os mais velhos, podendo ser comprovada através do levantamento de elementos presentes 
na sociedade, tais como em ambientes sociais compartilhados, como placas de rua, até mesmo em ambientes de comunicação sociolinguística, como itens de fraseologia.

No entanto, sabemos que valores culturais podem interferir na velocidade da mudança linguística e nos sentimentos da comunidade sociolinguística. Isso nos inspira também na hipótese de que os mais jovens espanhóis já não percebem esses elementos como portugueses, porque desde sempre, na perspectiva deles, ali estiveram em uso cotidiano. Identificar traços de resiliência de cada cultura é objetivo desta pesquisa.

Para evidenciarmos como as formações linguísticas de língua portuguesa sobrevivem em territórios fronteiriços, recorremos ao caso da cidade de Olivença politicamente vinculada à Espanha, mas muito próxima de Portugal. Esses povos do lado de cá e de lá convivem e repelem-se pelo que em resposta ao que reconhecemos como uma "fronteira", termo que não aparece antes do século XV no inglês. O significado desse termo, originalmente remete a parte de um exército, como era equivalente ao francês "frontière" (Handler, 1994). Tanto em inglês quanto em francês, o significado era associado ao campo semântico militar, mas não era o único termo empregado. Havia, ainda, bound, confine, limit, march, mete e pale.

Um século depois, os termos 'frontiers' e 'borders' aparecem em ordens dadas pelo rei Henry VIII como sinal de impedimento contra seus inimigos (grifos nossos). Como se pode depreender dessa situação relatada por Handler, desde tempos remotos, as relações dadas aos lugares fronteiriços já não eram amistosas.

É relevante não perder de vista que 'border' é um termo de sentido mais geral para indicar um limite ou a margem de algo, mas é muitas vezes usado como referência a 'boundary' ou distrito ao longo da fronteira em ambos os lados. Além disso, 'borderland', que significa uma ilha na ou perto da fronteira entre dois países ou territórios, assume um sentido tanto cultural quanto político e denota uma área onde dois conjuntos de ordem social, econômico e político se encontram.

'Frontier', por sua vez, se refere a 'boundary', ou linha de demarcação entre dois territórios ou países, mas seu significado é mais político do que 'border' ou 'borderland', referindo a parte de um país que 'fica de frente' ou 'encara o outro'. Mais uma vez, podemos notar o significado da palavra ecoando o sentido de confronto entre 
as comunidades que vivem nessas regiões, pois estar de frente ou encarar nos remete à necessidade de se resguardar de uma possível atitude do próximo.

O interesse em apresentarmos o sentido do termo 'fronteira' se dá pelo fato de pensarmos em como eram vistas as relações fronteiriças desde tempos mais remotos, afinal, muitas dessas relações foram repassadas entre os indivíduos, numa espécie de efeito catraca, tal como propõe Tomasello (1998) (Vide capítulo 1). No entanto, o que podemos notar é que tal característica de confronto ou defesa, presente entre os moradores das regiões fronteiriças, não é vista ou percebida pela comunidade como uma marca cultural trazida desde os tempos mais primórdios.

O curioso, mostrado por Handler (1994), é que, em escritos históricos da colonização do continente americano, a palavra 'frontier' tem um diferente significado, denotando um espaço, ou seja, a fronteira entre o território colonizado pelos imigrantes europeus, os quais eram gradualmente segregados no sistema político, tradições culturais da metrópole e o território habitado pelos índios. A fronteira era, então, o espaço de mais intensivo contato, no qual os índios adquiriam as primeiras informações sobre as culturas e as tradições europeias, o que não significava em momento algum um ambiente de harmonia.

Ironicamente, as fronteiras se tornam o primeiro lugar onde os colonizadores europeus podiam retornar ao mais 'primitivo' modo de vida. As 'fronteiras' não eram somente espaço, mas também uma forma de coexistência social: uma sociedade dinâmica, em raízes, competitiva, cuja falta de medo e respeito para controle central e autoridade (grifos nossos) eram prementes. Dessa forma, o termo fronteira foi se alargando semanticamente com o passar do tempo e parece que, pelo que vivenciamos na fronteira Elvas-Olivença, o sentido mais primitivo da palavra está ecoando mais alto, pois a situação de contato entre portugueses oliventinos e espanhóis não parece admitir uma coexistência social, mas uma verdadeira 'luta' e 'competitividade' para a manutenção de etnicidade dentro de um grupo majoritário.

De acordo com Handler (1994), apresentando os outros termos que fazem referência à 'fronteira', 'march' é mais específico: é normalmente um termo técnico usado para descrever uma zona de fronteira medieval de completo controle do governo de cada território (grifos nossos). Nesse sentido, podemos perceber o quanto as regiões 
fronteiriças, em sua etimologia mais antiga, já se apresentavam como regiões marcadas por um dominador e defensor do que considerava seu, não se desligando o sentimento de competitividade.

Ainda duas últimas palavras da linguagem de suas fontes históricas são recuperadas por Handler (1994): 'mete', que é usada para uma fronteira ou limite, particularmente na expressão 'metes and bound'; e 'pale', que é um território ou distrito dentro de certas fronteiras ou sob uma jurisdição particular. Era usado normalmente como 'the English Pale' na Irlanda (1494-1603) ou Calais (1493-1558), e muito menos frequentemente na área de poder e jurisdição inglesa no sul da Escócia no século XV (Handler, 1994).

Assim, como afirmou Handler, o significado original de fronteira era militar, o termo era usado no sentido figurativo. Em todas as línguas europeias, era empregado para descrever barreiras e limites entre unidades territoriais e pessoas, estendendo-se para se referir a divisões sociais e estratificação, fronteiras e barreiras entre comunidades, grupos étnicos e sociais.

Outros autores que focalizaram o sentido dado às fronteiras foram Wilson e Donnan (2000), ao apresentarem em seu livro o quanto havia aumentado o interesse em estudos sobre fronteiras internacionais, principalmente na vida das pessoas que viviam nessas comunidades e nas suas relações dialetais. Coerente com usa exposição, o sentido de fronteira aparecia como registros temporais e espaciais das relações entre comunidades locais e entre estados.

Esses autores evidenciaram que a antropologia de fronteiras é uma perspectiva política do comportamento das pessoas, argumentando que elas não poderiam ser vistas apenas como imagens. Coerentemente com essa ideia, ao estudarmos os moradores de Olivença, atentaremos para as atitudes fronteiriças também, tal como aquela que denuncia o quanto lutam para sair desse estado de apenas 'estarem' na comunidade. Essa perspectiva rejeita o que fazem os etnógrafos ao estudarem as experiências de pessoas em regiões fronteiriças, as quais estão amarradas culturalmente com as pessoas de seus estados vizinhos, mas endossa os caminhos oferecidos por uma antropologia fronteiriça, que explora a permeabilidade cultural das fronteiras e a adaptabilidade de 
seus membros em suas tentativas ideológicas de construção de políticas repartidas. A essa perspectiva nos juntaremos.

Assim, diante da conotação dada ao termo fronteira, que é de 'defesa', de 'competitividade' e de 'proteção de seu território', encaminharemos esta pesquisa para o sentido de que, pelo fato de os portugueses morarem em regiões tão próximas de seu país, certamente haverá uma maior facilidade na manutenção ou permeabilidade de sua cultura de herança, incluindo a língua. Nesse sentido, a proximidade geográfica deflagraria um sentimento de proximidade étnica, reforçando o sentimento de pertença.

Algumas questões que emanam dessa discussão nos orientarão no encaminhamento metodológico da pesquisa. São elas:

(1) Quais as formas de sobrevivência de uma língua de herança já que as regiões de contato parecem sobrepostas socialmente?

(2) Quais os contextos pragmáticos favorecedores de cada língua?

(3) A geração mais jovem usa a língua de herança?

(4) Itens funcionais do passado podem ser sentidos como próprios da língua materna ou como itens da língua estrangeira?

Para responder a esses questionamentos, organizaremos esta tese em quatro capítulos conforme segue.

No primeiro capítulo, apresentaremos os postulados e as asseverações derivadas dos estudos sobre o funcionamento de línguas de herança como um dos componentes mais importantes para a marca de etnicidade. Os estudos sobre os conceitos de língua como um tipo de marca identitária dentro das comunidades se fazem necessários pelo fato de lidarmos com uma pesquisa na qual a língua é a principal característica que marca um grupo minoritário em Olivença. Por meio do capítulo, demonstraremos que muitos teóricos partilham de um mesmo conceito sobre a real importância de uma língua de herança dentro da sociedade receptora e dos frutos linguísticos que essa interação pode trazer.

É justamente por isso que, nesse capítulo, já apresentaremos os conceitos de etnia, língua de herança em regiões fronteiriças e bilinguismo, tendo em vista tratarmos de falantes que, por viverem em uma comunidade de língua diferente, terão uma grande 
probabilidade de serem bilíngues, utilizando sua língua de herança apenas no ambiente familiar. Sendo assim, os postulados teóricos apresentados neste capítulo se tornam importantes pelo fato de que os informantes desta pesquisa, no caso, os portugueses que vivem em Olivença, ao adentrarem uma nova sociedade, estarão adotando novos valores culturais do seu entorno, participando e experimentando trocas em função dos esforços eleitos para a própria adaptação ao grupo com que entra em contato.

Além disso, por se tratar de uma pesquisa que trabalhará com a língua falada por portugueses que vivem em Olivença, o capítulo 1 tratará também dos postulados teóricos da sociolinguística, o que permitirá lidar com as consequências do contato linguístico, nos revelando, a partir disto, uma riqueza de variações linguísticas. Por essa razão, avançaremos em direção a postulados da Sociolinguística interacional e também da Linguística Cognitiva, pois essa estratégia permitirá oferecer um tratamento mais abrangente à situação, considerando relevantes não apenas os elementos internos da fala, mas todo o contexto em que ela ocorre. Isso nos conduzirá a discutir o papel do contexto não só como o lugar em que a interação discursiva ocorre, mas também como o ambiente em que se engendram os elementos envolvidos no processo de interação, tais como o olhar, os gestos e até mesmo as atitudes dos demais participantes envolvidos no momento da fala.

De acordo com os estudos neste viés de pesquisa, a língua, por ocorrer em situações sociais, é, muitas vezes, influenciada pelo estatuto social (Goffman, 1998) de quem a utiliza, o que exigirá um aguçamento da atenção dos pesquisadores. Explicamos: será preciso considerar a possibilidade de que nem sempre o que falante diz é verdade, sendo necessário um olhar para o 'enquadre/frame' (Bateson 1998) de todo o contexto comunicativo, o qual pode envolver uma série de implicaturas conversacionais, tão importantes para a manutenção do diálogo. Poderíamos perguntar qual a relação disso com o aspecto cognitivo? sem compreender como a mente humana funciona bem como a importância desse processo para o desempenho de funções comunicativas prioritárias, não se pode compreender intenções tampouco efeitos comunicativo. Essa é a razão suficiente para que recorramos a pressupostos das teorias da psicologia e da neurociência que propõem a possibilidade de um indivíduo tomar decisões sem ter plena "consciência", pelo simples fato de terem tido o contato com o 
objeto $^{1}$. Essa explanação não estará completa se não dermos voz a Damásio (2008, 2011) e sua proposta sobre os estágios de consciência individuais. Se há diferenças entre indivíduos, não somente a variação de fala num viés linguístico ajudará a compreendê-la. A variação de atitudes linguísticas dos falantes podem ser discutidas à luz de sua biografia e experiência.

No segundo capítulo apresentaremos o locus da pesquisa, no caso Olivença, que faz fronteira geográfica e política com Elvas. Como temos tratado de língua como uma das marcas de etnia, apresentaremos a disputa entre portugueses e espanhóis para que a cultura portuguesa seja mantida na comunidade. Como é sabido, uma língua de herança é quase sempre uma língua minoritária e suscetível a uma série de preconceitos. Assim, para que esta seja preservada entre seus falantes, é necessário que tenham consigo ativo um sentimento de pertença linguística. Trataremos, então, de apresentar, no capítulo 2, o lugar no qual o contato ocorre e que fatores podem contribuir para a preservação ou não da língua nativa e da língua de herança entre os portugueses oliventinos.

Além disso, pelo fato de não se poder ter acesso a informações sobre identidade se não pela manifestação do outro, a discussão sobre o tipo de entrevista, os problemas implicados no trabalho de campo e as soluções assumidas integrará o capítulo três. Será nesse momento em que as abordagens teóricas sobre a importância de um trabalho qualitativo ocuparão um lugar de destaque, pois, segundo nossa experiência, somente a lida direta no campo orienta a direção de um trabalho sobre fronteiras em que instabilidades de movimentos sociolinguísticos em curso e também dos sentimentos de pertença dos falantes nativos e de língua de herança nos colocarão frente ao ambíguo e ao incerto. Essas incertezas iniciam-se já no recorte desse espaço fronteiriço segundo um grupo social específico, no caso os oliventinos espanhóis, mas algumas inconsistências nos permitirão tratar dos oliventinos que se sentem portugueses.

No capítulo 4, pautado num estudo de linguagem como uma forma de comportamento social, apresentaremos uma análise do português oliventino e da língua de herança dos portugueses residentes em Olivença (Espanha), bem como das características sociais dos habitantes dessa região, ou seja, identificaremos, na medida do possível, os contextos pragmáticos que favoreceram a decisão de manifestação em

\footnotetext{
${ }^{1}$ Objeto, para Damásio (2008) se refere a diversos elementos, tais como lugares, pessoas, sentimentos, ações, etc.
} 
cada uma língua das duas línguas. E dessas situações emergirá a discussão sobre o sentimento de pertença de indivíduos que consideram a presença da língua de herança através de pistas encontradas pelas ruas de Olivença, nas falas, no conteúdo das conversas e no comportamento dos entrevistados.

Ao longo das análises, iremos providenciando respostas para as questões inicialmente apresentadas. E, ao final, consolidaremos esses resultados em forma de conclusões, a que se seguirão as referências bibliográficas inseridas nos capítulos da tese. 


\section{CAPÍTULO 1}

\section{FUNDAMENTAÇÃO TEÓRICA}

Neste capítulo, apresentamos os postulados e as asseverações derivadas dos estudos sobre o funcionamento de uma língua de herança como um dos componentes mais importantes para a marca de etnicidade. Serão também apresentados alguns dos conceitos já estudados sobre a língua como um tipo de marca identitária dentro das comunidades e também os fenômenos gerados no âmbito de políticas linguísticas. Será possível demonstrar que muitos teóricos partilham de um mesmo conceito revelando a real importância de uma língua de herança dentro da sociedade receptora e os frutos linguísticos que essa interação pode trazer. Evidenciaremos, em contrapartida, os conflitos entre a oficialidade linguística de uma língua de prestígio e uma língua considerada "inferior". Além disso, apresentaremos os pressupostos teóricos da sociolinguística interacional e cognitiva. 


\section{LINGUAGEM EM SEU CONTEXTO SOCIAL}

Cada vez mais torna-e imprescindível considerar o tema língua de herança, em especial nas regiões em que línguas convivem. A razão que justifica essa relevância está assentada na convivência harmoniosa e respeitosa entre língua de estatuto diverso num espaço em que está consolidada uma sociedade que tem uma língua majoritária como oficial. Sabemos que esse estatuto linguístico assume nas exigências protocolares e oficiais uma postura conservadora e impositiva, até mesmo colocando essa questão como primordial para que a soberania se reforce. Essa confusão entre oficialidade e imposição social é a mais urgente razão para que se busquem caminhos de compreensão solidária sobre política linguística e convivência humana. Nesta seção, para atender a essa demanda, discutiremos de etnia, língua de herança em regiões fronteiriças e bilinguismo. É sabido que, ao adentrarem uma nova sociedade, como é o caso dos portugueses que vivem em Olivença, os imigrantes estarão adotando novos valores culturais do seu entorno, participando e experimentando trocas em função dos esforços eleitos para a própria adaptação ao grupo com que entra em contato. Sendo assim, a língua certamente funcionará como um dos componentes básicos da identidade dos indivíduos (Barrios, 2008). 


\subsection{Identidade é etnia?}

O conceito de etnicidade é de suma importância para a compreensão de uma língua dentro de seu grupo ou dentro de grupos diferentes. Desta forma, muitos concebem o termo etnicidade como um tipo de identidade grupal, derivada de laços culturais, ou como relação entre pessoas, o compartilhamento de posição social, ancestralidade, e nacionalidade (Barth 1969; 1998; Fenton 2003; Lud'a Klusáková, Ellis, Steven G. 2006; Sewerin, Barrios 2008, entre outros). Como a língua de herança² pressupõe laços, ancestralidade, nacionalidade e identidade, não há como não considerar os marcadores da etnicidade.

Fenton (2003) apresenta as definições de grupo étnico, raça ou nação como se os três rótulos partilhassem da mesma essência, com apenas algumas diferenças. Para ele, comum a todos é a ideia de descendência ou ancestralidade e muito estreitamente implicada nos três está a cultura, que pode ser constituída pela língua, pelo traje e pelos costumes.

Na definição do Compact Oxford English Dictionary, 1993, Fenton (2003:26) encontra o seguinte:

"Raça: grupo de pessoas (animais ou plantas) ligadas por descendência comum ou origem; tribo; nação ou povo, considerado como possuindo um tronco comum.

Nação: um agregado extensivo de pessoas estreitamente associadas entre si por descendência comum, língua ou história, formando uma raça distinta de indivíduos, geralmente organizados num estado político independente e ocupando um território definitivo.

Étnico: [adjetivo] pertencentes a nações cristãs; pertencentes a uma raça ou nação, que possui características raciais, culturais, religiosas ou lingüísticas comum, especialmente designando um grupo racial ou outro no interior de um sistema mais vasto".

\footnotetext{
${ }^{2}$ Doravante trataremos de LH.
} 
Cada uma delas difere da outra de modo essencial, ainda que estejam em uma linha bem tênue de distinção de significados aparentemente. O significado de 'étnico', que recebe uma conotação mais voltada para a religião: "pertencentes a nações cristãs", tem suas básicas etimológicas na palavra grega 'ethnos', que, no grego bíblico, assume o significado de não judeus, gentios, classe de homens, casta e tribo, entrando na língua inglesa, de acordo com o dicionário, como pagão e estrangeiro, perdendo tal conotação somente no século XIX.

Assim, inferimos que, embora a conotação tenha se perdido, talvez, o sentido mais primitivo da palavra 'ethnos' possa afetar, de forma não consciente, as relações entre as pessoas que fazem parte de um grupo étnico diferente, sendo associadas 'aos que não fazem parte da mesma fé, crença ou costumes '.

Fenton ainda propõe a definição de etnicidade com base nos estudos de Conversi (2000), que define etnicidade como termo similar a raça. Já Smith (1981 apud Fenton, 2003) acrescenta um dado: são grupos dominantes, o que não ganha eco na definição de Barth (1998), que este assume que identidades étnicas são sustentadas pela manutenção do que designa como $<<$ fronteira $>>^{3}$, ou seja, as linhas que distinguem um grupo do outro, traçadas pelo comportamento social, dado relevante para o conhecimento da pertença ao grupo e para o estabelecimento das distinções:

$<<\mathrm{A}>>$ pessoas que falam a língua $<<\mathrm{A}\rangle>$

Assim, os $<<\mathrm{A}\rangle>$ são diferentes de $<<\mathrm{B}\rangle>$

Dessa explanação, infere-e que uma forma de marcar o sentimento de pertença linguística esteja na forma como os falantes se comunicam dentro de um grupo majoritário. Se estivermos corretos em nosso raciocínio, teremos:

<< português de Olivença $>\mathrm{X}<<$ português de Portugal $>>$

Neste sentido, estamos propondo que os moradores de Olivença, ao utilizarem o português nativo (dos imigrantes) e o português de herança (a língua dos filhos ou netos dos imigrantes), fazem usos de marcas de um grupo étnico pertencente à região de moradia, pois as variáveis, apresentadas nas próximas seções, carregam suas marcas

\footnotetext{
${ }^{3}$ Neste caso, vemos que o autor se refere às fronteiras abstratas e não às fronteiras geográficas, das quais também trataremos neste trabalho.
} 
emanadas do contato. Ao mesmo tempo, seguindo nossa proposta que é a de identificar o sentimento de pertença linguístico, podemos prever a seguinte ideia:

$<<$ falantes do espanhol com pertença linguística $>>X<$ falantes do espanhol nativo $>>$

Nessa representação, pretendemos afirmar que os falantes que possuem marcas de uma LH, termo a ser tratado melhor na seção seguinte, utilizam-nos muitas vezes de forma inconsciente, já que nem sempre reconhecem alguns traços como culturais ancestrais.

De acordo com Barth (1998), não é tão simples a missão de definir grupos étnicos, pois muitos podem até mesmo entrar nas questões de discriminação. Para ilustrar, recorre a Narrol (1964), que caracteriza grupo étnico como aquele que se perpetua biologicamente, que emoldura valores culturais fundamentais, que tem peculiaridades comunicativas e interacionais e que mantém uma relação de identificação com seus membros, distinguindo-os dos demais. Analisando essas quatro características listadas por Narrol, verificamos que uma raça é igual a uma cultura e uma língua e uma sociedade equivalem igualmente a uma unidade. Dessa forma, ou se está dentro ou fora desse círculo de traços pertinentes, o que conduz a uma classificação baseada na rejeição ou discriminação, porque se não se detém os traços, não se faz parte da mesma cultura ou raça.

Nessa perspectiva, o autor mostra que, ao classificarem RAÇA $=$ CULTURA $=$ LÍNGUA e SOCIEDADE = UNIDADE, os antropólogos não se preocupam com a visão preconceituosa que pode surgir. Uma forma de evitar essa visão distorcida é, segundo Bath (1998), calcada na mudança longe da estipulação de um modelo idealizado. A título de ilustração, o grupo $<<\mathrm{A}>>$ representaria o modelo ideal, e todos que não se enquadram nesse grupo obviamente serão considerados inferiores, tal como ocorre com os falantes portugueses que vivem em Olivença.

Seguindo as indagações e os apontamentos decorrentes do trabalho de campo que realizamos, podemos afirmar que muitos falantes de língua em contato, classificados como pertencentes a um determinado grupo étnico, cujas definições do termo já tendem a ser relativas ao que é diferente, ao que não faz parte, ou como os que 
não seguem os modelos perfeitos, o que, de acordo com Barth, não deveria ocorrer, têm a grande tendência de esconder suas marcas linguísticas típicas para que não sejam alvos de preconceito dentro de uma sociedade receptora majoritária e detentora de uma língua considerada de prestígio.

$\mathrm{O}$ autor, de forma crítica, assume que se as fronteiras abstratas forem estipuladas neste contexto, de forma que se estabeleça uma separação social e barreiras linguísticas, com inimizade espontânea e organizada, haverá um bloqueio para as tão importantes trocas linguísticas e culturais, nosso objeto de estudo:

\begin{abstract}
This also limits the range of factors that we use to explain cultural diversity: we are led to imagine each group developing its cultural and social form in relative isolation, mainly in response to local ecologic factors, through a history of adaptation by invention and selective borrowing. This history has produce a world of separated peoples, each with their culture and each organized in a society which can legitimately be isolated for description as an island to itself.
\end{abstract}

(BARTH, 1998:11)

De forma bastante detalhada, e para que não ocorra a exclusão social, ao definir grupo étnico como aquele que partilha de uma cultura comum, Barth ainda se revela confuso pela amplitude que o termo cultura tem. E essa insegurança ao discutir o tema não favorece que compreendamos que grupos étnicos são moldados e uniformes, mas, dentro destes, pode haver alterações e 'diferenças' geradas pelas relações sociais.

É partindo dessa definição que iniciamos as pesquisas desta tese, pois os grupos étnicos, de fato, tendem a marcar seus usos em forma de variáveis linguísticas, o que parece natural e esperado, pois os grupos étnicos são obviamente estratificados. Dessa forma, ocuparão posições de privilégio ou não. Nesse caso, os "backstage", assim nomeados por Barth, como aqueles que são rejeitados ou que possuem pouco prestígio na interação com as pessoas da sociedade majoritária, tendem a fazer uso de estratégias de esquiva que tornariam lícita sua participação no grupo "majoritário", podendo, assim,

(i) tentar se incorporar na estabilizada sociedade industrial e no grupo cultural;

(ii) aceitar um status de "minoria", acomodando-se para encapsular todas as diferenças nos setores de não-articulação enquanto participa de outros setores; 
(iii) tentar encontrar a identidade étnica, usando isso para desenvolver novas posições e padrões para organizar atividades nesses setores não encontrados na sua sociedade.

Essas estratégias traçadas por Barth (1998) conduzem a um mapa interessante para monitorar a maioria dos falantes pertencentes ao grupo étnico, nesta tese investigada. Inicialmente, tínhamos a hipótese de que esses indivíduos avançavam em direção à outra sociedade para trabalhar e ter melhores condições de vida. Sabemos de antemão que muitos, no entanto, possuem o sentimento de pertença de sua $\mathrm{LH}$, ainda que não a utilizem no seu dia a dia. No que se refere à 'aceitação' de seu estatuto como parte de uma minoria, sabíamos de antemão que alguns tipos de 'camuflagem' das diferenças seriam uma estratégia recorrente. No entanto, em trabalho de campo, adicionalmente pudemos verificar que fazem o possível para que a língua da sociedade receptora se sobressaia nos ambientes mais formais ou laborais. Complementarmente, a LH é usada apenas nos ambientes familiares ou entre amigos. No que diz respeito à terceira estratégia, também podemos ressaltar que muitos se utilizam da sua LH para que tenham lugar de destaque diante do grupo receptor, como, por exemplo, aqueles que lecionam o português para a comunidade espanhola.

Para dar conta de uma definição, Barth (1998) nos coloca diante de diversas reflexões importantes, principalmente para que não entendamos grupos étnicos como inferiores. O que nos deixa claro, então, é que grupos étnicos são aqueles que partilham de uma cultura comum, pessoas que podem ser identificadas por outros como pertencentes a um grupo étnico determinado, ainda que não partilhem tão ativamente, como é o caso dos portugueses oliventinos que, embora pouco participem de seu grupo étnico por estarem distantes uns dos outros, carregam consigo marcas de herança cultural, mesmo que seja de forma pouco visível.

Sewerin e Smagacz (2006) também tratam 'grupo étnico' e 'etnicidade' como paralelos ao rótulo identidade, e partilham da ideia, tanto quanto Barth, de que identidades são flexíveis, complexas e abertas para diferentes características de referência, não devendo, em hipótese alguma, ser relacionadas como 'qualidade' dos humanos. As autoras ainda questionam a associação de alguns com o termo 'identidade nacional', pois consideram que sejam coisas completamente distintas, o que fazem 
definir identidade ou etnicidade como diversas representações de características dinâmicas dentro da personalidade do indivíduo, nas quais se vê ou é visto:

\begin{abstract}
Identity may be described as a series of representations that are created within an individual's personality with regard to biologic entity, to roles performed (gender, social status, social position, etc.). To his/her presence or absence in the determinant social contexts (nation, ethnic group, religion) and with regard to the way other people interpret one's behavior as the evidence of who and what one is. Identity of an individual contains a set of relations, representations, and images which an individual has of oneself, which others dive him, that determine the capacity of recognising oneself and being recognised.
\end{abstract}

(SEWERIN; SMAGACZ, 2006:20)

Neste caso, o termo 'dinâmica' é empregado no sentido de que mesmo dentro de um grupo amalgamado pela geografia, ancestralidade, linguagem, família, cultura, cada um pode ter diferentes ideias sobre sua identidade étnica, como no caso da linguagem, que é um fator dinâmico que afeta e difere as pessoas de várias formas. Isso nos leva nesta pesquisa a tentar descrever os diferentes usos e os diferentes sentimentos de pertença entre os membros de um mesmo grupo.

Barrios (2008) sobre o tema salienta que o indivíduo, ao ter contato com diferentes grupos étnicos, está exposto a valores sociais como espaço geográfico, cultura, costumes e língua e aos valores mais subjetivos, que é a consciência de pertença grupal, lealdade e valores comuns. Ilustra essa atitude, o que ocorre com alguns portugueses ao demonstrarem a necessidade de defenderem sua língua, não deixando que os espanhóis a tratem como inferior, fato a ser tratado com mais detalhe adiante.

Ainda sobre identidade étnica, De Vos (1975 apud Barrios, 2008) apresenta como uma característica básica o uso de aspectos de sua cultura, dentre elas a língua, com o objetivo de diferenciar-se de outros grupos. O que ocorre, no entanto, é que nem sempre esse tipo de diferenciação é motivado. Acreditamos que dificilmente essas marcas e essas características sejam ativadas como forma de se diferenciar e de forma pensada e planejada, mas que ocorram naturalmente como marca de uma língua que faz parte de seu aparato cognitivo e que não se apagam por completo, mas que ficam arquivadas em sua memória, surgindo até mesmo de forma inconsciente. Isto também é um assunto a ser discutido doravante ao tratarmos de língua e seus estágios de consciência. 
Portanto, assumimos neste trabalho que a etnicidade está ligada diretamente à identidade cultural e, dessa forma, podemos constatar que essa identidade é muitas vezes mantida, apagada ou ofuscada por diversas razões, e uma delas pode ser o sentimento de superioridade ou de inferioridade, o que também, será apresentado nos capítulos seguintes, nos quais trataremos do sentimento de pertença dos informantes analisados. Neste caso, teremos que tratar da etnicidade como uma variável com diferentes níveis de intensidade, a depender dos vínculos sociais que o informante tem com a sociedade receptora, ou seja, tentaremos determinar em que medida os falantes portugueses podem reforçar o seu sentimento de pertença a ambos os países nos dois lados da fronteira.

\subsection{A língua em regiões fronteiriças}

Como pudemos ler na introdução desta tese, as fronteiras têm despertado cada vez mais interesse dos cientistas. A perspectiva que se assume para tratar de fronteiras, contudo, pode mudar a realidade apreendida. Nesse sentido, podemos dizer que as fronteiras internacionais têm uma influência muito grande dentro da cultura local, fato que pudemos observar ao caminhar pelas ruas de Olivença, as quais, embora sejam parte do território espanhol, têm grande influência da cultura portuguesa, características tratadas adiante.

Além disso, muitos estudos têm focado não só a relação de fronteira como limite físico, mas também como relações sociais, transcendendo a estrutura de 'casa' e suas relações com seus vizinhos. O que percebemos aqui é que a fronteira geográfica pode afetar as fronteiras abstratas dos indivíduos de uma região.

Ainda, o fato de que, embora se trate de fronteiras de nações com características semelhantes em alguns aspectos, ambos os grupos possuem sentimentos de nação completamente distintos, ou seja, mesmo portugueses e espanhóis, dividindo terras fronteiriças, desencadeiam em seus contatos interpessoais o sentimento de inferioridade para o grupo minoritário. Nesse viés, Wilson e Donnan (2000) apresentam que a antropologia se preocupa com grupos étnicos e suas fronteiras, mas muitas vezes tem obscurecido a ação de identidade nacional e étnica, cujo processo muitas vezes acaba 
por excluir aqueles que não se enquadram nas características da nação dominante numericamente e por isso tal sentimento por parte dos imigrantes:

\begin{abstract}
In our view many identional identities come about when ethnicity is politised in the course of pursuing sefl-determination. Sometimes this process of selfdertermination excludes those who do not share the dominant nation's view of state building. These minority populations are often labelled as ethnic or religious groups, whereas they might see themselves as nations, or as part of nations who have their homeland there or elsewhere.
\end{abstract}

(WILSON; DONNAN, 2000:13)

Outra característica proposta pelos autores e que nos interessa é com relação ao grande problema voltado à necessidade de que as identidades nacionais devam ser negociadas, como em casos em que os laços sanguíneos e culturais são muito frágeis, como é o caso do Leste e do Oeste da Alemanha, Turquia e Síria, Turquia e Geórgia, Israel e seus vizinhos árabes e Espanha e França. Estas, segundo os autores, envolvem um modus vivendi incorporando identidades contraditórias. Assim, em termos de identidade étnica, apontam três tipos de fronteiras identificadas:

i) aquelas cujas ações de seus indivíduos têm laços tão fortes quanto aqueles que residem no próprio núcleo geográfico;

ii) aquelas cujos indivíduos são diferenciados pelos vínculos étnicos fronteiriços dos outros residentes de seus estados;

iii) aquelas cujos indivíduos são membros da maioridade nacional no seu estado e não têm laços étnicos com as fronteiras dos estados.

No caso dos portugueses que vivem em Olivença, podemos classificá-los como aqueles que são diferenciados pelos vínculos étnicos fronteiriços dos outros, pois, embora sejam pertencentes a um grupo étnico muito próximo daquele em que estão inseridos, sentem-se diferentes e não participantes do grupo majoritário.

Além das definições acima mencionadas, Sewerin e Smagacz (2006) apresentam-nos além da definição de fronteira como 'sendo' indicador de linhas entre duas ou mais áreas, ou seja, as fronteiras naturais (rios, montanhas, etc.), ainda mostram a definição como fronteiras artificiais (administrativa, política), além da definição de 
fronteira como um paradigma sociológico. Nesse caso, o estresse é colocado como uma 'fronteira subjetiva e invisível'.

Como é possível depreender, estamos diante de grupos minoritários que, além de esbarrarem nas dificuldades encontradas no sentido mais primitivo da palavra 'fronteira', que é de separação, de conflito e de exclusão geográfica, ainda se deparam com outro conflito, talvez o maior deles, o da fronteira subjetiva, que é a dificuldade em manter seu sentimento de pertença linguística diante de tal sociedade.

Assim, muitas vezes, os imigrantes entram em contato com a sociedade receptora e acabam criando suas próprias fronteiras, deixando claras suas marcas e sua pertença ao grupo, até mesmo como forma de sobrevivência e para marcar sua importância dentro da comunidade receptora. Da mesma forma, é esperado que surjam estratégias dos falantes para que suas fronteiras se diluam, como modo de deixar de ser pertencentes a um grupo diferente, ocorrendo o que Barrios (2008) observou em seus estudos em Montevidéu: um processo de total assimilação linguística e cultural.

Ao contrário disso, o que nos motiva é a constatação de que haja a continuidade dos limites dos grupos, a manutenção de uma LH com os seus mais ricos usos variáveis, para que, dessa forma, possamos nos certificar de que as LHs trazem consigo não só as marcas de origem, mas também as marcas de seu contato fronteiriço.

\subsection{A língua de herança}

Como esta tese se debruça nos fatores conjunturais que emanam de um contato linguístico, abordaremos, nesta seção, o tratamento dado ao termo língua de herança, e como esta pode ser um vetor que favorece a estigmatização a depender de como seus falantes lidam com ela no meio em que convivem.

Assim, a LH, estudada por alguns pesquisadores, tais como Flores e Pfeifer (2014), Moroni e Gomes (2015), Rocha (2015), Bittens e Winterle (2015) e LimaHernandes e Ciocchi (2015), é um fenômeno de investigação recente que se situa num campo teórico também fronteiriço. A LH não é o mesmo que L2, nem pode ser considerada língua materna no sentido típico do termo. A LH não pode ser abarcada 
pelas teorias clássicas de aquisição de linguagem, pois nelas a criança aprende a língua em cuja sociedade está imersa ou, de outro modo, aprende língua em casa, a língua familiar. Mas que língua familiar é essa, quando o pai e a mãe conversam no idioma da sociedade receptora, porque esta é a língua franca que supre o desconhecimento da língua materna da mãe e da língua materna do pai? O quadro é mais complexo, como defende Lima-Hernandes e Ciocchi (2015) ao tentarem desenhar um quadro teórico para a LH.

Como temos visto, os estudos sobre a definição de língua não é tão simples quanto parece, e diante de tal dificuldade, apoiamo-nos primeiramente no consenso de que língua faz parte da identidade cultural dos indivíduos, e ela é vista por diferentes dimensões. Barrios (2008), por exemplo, trabalha com três tipos de conceitos para língua:

- Língua étnica ${ }^{4}$ : aquela que é herança cultural do grupo étnico, como própria e símbolo da sua identidade, funcionando como marcador. Tal língua, quando utilizada pela maioria, se revitaliza;

- Língua materna ${ }^{5}$ ou língua nativa: é aquela adquirida na troca de línguas;

- Língua migratória ${ }^{6}$ : aquela dos imigrantes que já têm seu repertório linguístico variado.

A autora se pauta na ideia de que traços ou marcas de uma língua étnica podem adquirir poder de identificação mais forte que o uso das LMgs. Podemos, assim, pensar na língua dos portugueses que vivem em Olivença como aquela que se faz presente na comunidade e que diante de seu impacto, muitos se voltam a estudá-la, como o que temos feito, afinal, nossos olhos se voltam a ela exatamente por esta apresentar marcas de grupos étnicos tão diferentes.

Ainda, Barrios (2008) não deixa de atentar para a importância dos esforços para se manter as línguas minoritárias ${ }^{7}$, pois isto tem a ver com as atitudes linguísticas e com

\footnotetext{
${ }^{4}$ Doravante trataremos de LEtn.

${ }^{5}$ Doravante trataremos de LM

${ }^{6}$ Doravante trataremos de $\mathrm{LMg}$

${ }^{7}$ A referência minoritária para Barrios (2008) não é no sentido quantitativo. Fritzen (2008) em um artigo sobre línguas de contato, fala que a LH sempre será minoritária, mesmo sendo falada pela maioria. Para
} 
os valores culturais do grupo, ou seja, relaciona-se com a autoestima em se sentir forte para defender suas tradições culturais. Essa colocação nos faz refletir sobre o quanto realmente é necessário o sentimento de pertença linguística dos falantes de português em Olivença, cidade que é foco desta pesquisa, uma vez que estão diante de uma sociedade receptora fortemente organizada e detentora de normas linguísticas consideradas 'superiores' e de 'prestígio'. Não é difícil de inferir que o único modo de que se acabe com estigmatização da língua é através da valorização desta e da não negação de suas marcas.

Flores e Pfeifer (2014), recentemente, definiram como falantes de LH os emigrantes de segunda ou terceira geração que adquirem duas línguas na infância em contextos divididos entre o espaço familiar e o social, numa posição simultânea e desequilibrada. Assim, para as autoras, a LH é a língua falada no seio familiar, ou seja, a língua de origem do emigrante, a primeira língua antes do contato com a língua majoritária, a qual passa a ser rapidamente preferida da criança, principalmente se o pai ou a mãe é falante nativo dessa língua majoritária.

As autoras fazem um trabalho voltado para a aquisição de LH, tendo em vista uma criança que nasce em uma sociedade que não é a mesma de seus familiares ${ }^{8}$. Como já é de se esperar, a dificuldade em manter sua língua étnica é muito grande, o que faz com que a maioria a abandone, usando somente em seu meio restrito, ou em situações em que ela apareça somente como marcas pelo fato de fazer parte do aparato cognitivo do indivíduo através dos laços familiares.

Assumindo também a definição de (Valdés 2000) de que LH é aquela diferente da língua dominante, para Moroni e Gomes (2015), embora a LH seja um idioma vivo no ambiente doméstico, repleto de histórias e significados para a família, não é a língua oficial e a ensinada na escola formal, o que pode acarretar a perda do domínio e de sentido no uso como o passar do tempo. De forma a contemplar a definição de LH, as autoras listam algumas características desta:

assegurar sua afirmação, apresenta que no Brasil a língua alemã é falada por muitos moradores do sul do país, mas como é vista como uma língua dos colonos, não tem prestígio diante da sociedade local.

${ }^{8} \mathrm{O}$ trabalho das pesquisadoras é sobre LH de uma menina, cuja mãe é brasileira, mas ela é nascida na Alemanha. Assim, a maioria de seus amigos é brasileira, o que lhe faz estar diante do fenômeno proposto pelas autoras Flores e Pfeifer (2014), que é o das competências desiguais, a língua majoritária e a língua minoritária. 
- traz não só uma proficiência linguística, mas também um legado cultural;

- é a língua falada fora do território, sendo língua minoritária9;

- os falantes serão, provavelmente, bilingues ou multilingues, podendo ter mais proficiência no idioma do país de residência;

- os falantes terão contato com a LH desde o nascimento ou na primeira infância, com a família.

Como sabemos e pelo que temos observado durante o trabalho de campo desta pesquisa, a língua sempre será o maior vínculo com o grupo de origem do falante de LH. Sendo assim, mesmo que seu contato seja pouco e seu uso bastante restrito, muitos têm seu uso na memória, mesmo já 'contaminados' pela língua da sociedade majoritária.

É preciso, ainda, ressaltar a importância da LH. Para isso, contamos com os argumentos de Bittens e Jennings-Winterle (2015), que definem como traço identitário de um indivíduo no meio em que vive. Por isso, afirma que a comunicação é somente um traço da espécie humana depois de se discutir LH parece não fazer o menor sentido, pois essa carrega significados socio-culturais que revelam não só a história de cada ser mas, ainda, a de seus ascendentes. Trabalhando com a definição de que aculturação é o processo adaptativo de mudanças culturais e psicológicas, de natureza coletiva, no qual o imigrante se engaja, as autoras também propõem que ela traz aos indivíduos mudanças conscientes ou não.

Essas mudanças, segundo Bittens e Jennings-Winterle (2015), revelam algumas estratégias assumidas pelos falantes. Tais estratégias estão ligadas à importância da identidade cultural e à importância da interação com a sociedade dominante, e elas podem ser analisadas em suas dimensões ou estágios, tal como propõe Berry (1997 apud Bittens e Jennings-Winterle, 2015):

Assimilação, estágio em que o imigrante renega sua identidade e aceita a do país de acolhimento;

\footnotetext{
${ }^{9}$ Língua minoritária para Moroni e Gomes (2015) tanto quanto para Barrios (2008) não tem relação com quantidade, mas se relaciona com a visibilidade, impacto e representação que tem espaços oficiais e sociais. De acordo com as autoras, o que coloca a LH em posição minoritária é o fato de não ser, necessariamente, significativa para o entorno.
} 
Integração, estágio em que o imigrante mantém sua identidade e, ao mesmo tempo, permanece no grupo social majoritário;

Segregação, estágio em que o imigrante não deseja relacionar-se com a sociedade receptora, mas deseja somente manter suas tradições culturais maternas;

Marginalização, estágio em que o imigrante perde totalmente contato como ambas as culturas.

Se formos encaixar os estudos que estamos realizando nesses estágios, podemos dizer que os falantes de LH em Olivença se encontram no estágio de integração uma vez que, de acordo com nossas entrevistas, muitos deles, embora utilizem a língua da sociedade majoritária no dia a dia, seus vínculos étnicos não se perderam, ou seja, sua língua é utilizada entre amigos do mesmo grupo ou na família, mesmo sendo de forma não consciente ou planejada, como no uso de expressões ou palavras de sua LH, ditas por eles como 'sem querer'.

Esses resultados remetem também a um campo de atuação mais familiar, pois, se os pais evitam que suas línguas maternas estejam presentes nos lares em momentos de diálogo informal, então, o falante de LH acaba perdendo-a. Segundo as autoras, as restrições, limitações sociais não devem ser replicados no ambiente familiar, um lugar em que se espera que a convivência com outra(s) língua(s) familiares seja uma realidade. Para as autoras, o conceito de LH deve ser expandido, pois uma língua não só possibilita participar e atuar na sociedade, como também construir relações de pertencimento cultural e social.

O fato de um indivíduo se engajar numa nova sociedade já é o suficiente para que este tenha a necessidade de ser atuante, incorporando novos hábitos, mas isto não é algo que o impeça de manter seu pertencimento cultural de herança, inclusive, no que se refere à língua. Assim, nem sempre, podemos dizer que os imigrantes, por estarem envolvidos em outra(s) língua(s), percam sua LH; na verdade, esta se manterá viva como repertório cognitivo por muitas gerações, mesmo tendo um uso muito restrito.

Tanto quanto os demais autores, Gomes (2015) entende LH como resultante de fluxos migratórios, presente no ambiente familiar e diferente da língua social dominante. A autora, em seu texto, trabalha com a importância de que tal língua não 
seja ignorada, mas que seja ensinada fora dos modelos didático-pedagógicos de uma língua estrangeira. É preciso considerar que a criança já traz em seus conhecimentos e práticas familiares essa língua, o que pode denunciar um certo grau de pertencimento sociocultural da criança, mesmo que não a domine bem.

Como veremos melhor adiante nesta pesquisa, algumas crianças que têm pais portugueses e nascem, por exemplo, em Olivença, tendem a não aprender a LH, pois seus pais, muita vezes, não veem a necessidade de que eles a aprendam. A explicação mais recorrente para isso é que os filhos não a utilizarão no seu meio social. No entanto, como a língua é um vínculo cultural muito forte, ela acaba fazendo parte da vida daqueles que possuem familiares com sua $\mathrm{LH}$, não somente para interações com familiares da ascendência dos pais, quanto no contato direto com toda a cultura imaterial e material. Assim, podemos notar que, embora de forma bastante restrita, os descendentes de $1^{\mathrm{a}}$ ou $2^{\mathrm{a}}$ geração de portugueses oliventinos a utilizam mesmo de forma não consciente, pois desde pequenos recebem o input desta, o que, com certeza, fica armazenado em suas memórias.

Como temos visto até aqui, são muitos os pesquisadores que assentam suas bases teóricas na mesma definição de LH e igualmente estão preocupados em mostrar a dificuldade e os problemas enfrentados por aqueles que possuem uma língua considerada minoritária e inferior. Assim, Boruchowski (2015), Gomes (2015), Lico (2015), Silva (2015), entre outros, colocam a família como um dos maiores protagonistas na manutenção da LH, pois é ela que deve promover a ligação entre seus filhos e os laços culturais da forma mais natural e prazerosa possível, fazendo com que estes tenham o sentimento de pertença de uma língua importante dentro do seu grupo étnico.

\subsection{A língua de herança $X$ bilinguismo}

Tratamos, neste trabalho de pesquisa, a língua como um fenômeno cultural e dinâmico, fazendo parte da vida de um indivíduo desde o seu nascimento. Contudo, em alguns contextos específicos, não se tem o contato com apenas uma língua desde a fase mais tenra da vida. É exatamente esse contexto específico o de estudo nesta tese. 
A necessidade de falarmos sobre bilinguismo vem do fato de que, ao tratarmos das questões relacionadas ao contato linguístico entre imigrantes e falantes de uma língua nativa, estamos lidando com falantes que provavelmente, ou melhor, quase certamente, farão uso de uma segunda língua.

No entanto, seria uma grande imprecisão considerar a LH como uma L2, pois entendemos que ela já faz parte da vida da criança, mesmo que seu uso seja extremamente restrito, como entre seus familiares distantes. Assim, por menor que seja o contato que a criança tenha com sua LH, ela existe desde o seu nascimento e, de uma forma ou de outra, faz parte de sua vida cultural.

Até aqui, temos visto que tudo o que se relaciona com a língua sempre tem questionamentos e um bosque muito grande a ser percorrido, e uma autora que fala sobre bilinguismo questionando alguns conceitos que lhe foram atribuídos é Romaine (1995). A fim de mostrar que tal definição não é tão simples quanto parece, apresentanos três autores: Bloomfield (1933), que define bilinguismo como aquele que ocorre quando o nativo tem controle de duas línguas; Haugen (1953), que define como aquele que só começa quando o falante de uma língua pode produzir completos enunciados significativos em outra língua e Diebold (1964), que define de forma simples como sendo o contato entre duas línguas.

É claro, que como pesquisadora, Romaine (1995) produz sua reflexão abrindo questões importantes quanto ao grau de proficiência de uma L2. A autora, então, indo no sentido oposto, afirma que o falante pode não ter o controle da linguagem, mas ser capaz de compreender sentenças, chamados assim pelos linguistas como bilinguismo "passivo" ou "receptivo". É em meio a essa ponderação que a autora postula graus ou extensões para o falante de uma nova língua e que, neste caso, os contextos são favoráveis ou não na sua competência linguística. Seguindo também uma linha próxima, Jennings-Winterle e Fincatti (2015) afirmam que, embora seja muito difícil uma pessoa demonstrar igual competência em duas línguas, o termo bi-lin-gue é problemático e reducionista; não abarca todas as nuanças e níveis de proficiência, pois engloba todo e qualquer indivíduo que "conhece" mais de uma língua. 
Ainda percorrendo este bosque tão extenso, podemos notar que definir bilinguismo é realmente complexo e isto fica-nos claro a partir do momento em que contrastamos o que os diversos pesquisadores afirmam sobre o assunto.

Fishman (1967) apresenta bilinguismo como uma forma de se usar mais de uma variedade linguística, assunto para psicólogos e psicolinguistas, e diglosia como a existência de mais de uma variedade linguística na comunidade como forma de comunicação, sendo o reconhecimento de duas ou mais línguas pela sociedade pertencente, assunto dos sociólogos e dos sociolinguistas.

Já Barrios (2008), de forma contrária à definição de Fishman, apresenta bilinguismo como sendo a mesma coisa que diglosia, onde os falantes de uma comunidade diglósica estão, geralmente, convencidos de que uma variedade A é de mais prestígio, chegando até mesmo a negar a existência de B.

Nesse caso, Barrios (2008) classificaria A como a língua estandardizada, que se aprende na escola, e B como a língua materna da maioria, aquela que se aprende naturalmente, geralmente não tão encaixada aos padrões de norma culta. Neste trabalho, essa é considerada LH. De acordo com Barrios, as comunidades são bilíngues e diglóssicas se a maior parte de seus integrantes maneja das variedades linguísticas e estas têm funções diferentes (tipo A e B), que são reconhecidas e aceitas pelos membros da comunidade.

Ainda, de acordo com a autora, devido a uma troca social brusca, como é o caso dos imigrantes que são obrigados a aprender o mais rápido possível a língua da sociedade receptora, pode ocorrer o abandono dos padrões linguísticos de sua comunidade de origem, muitas vezes caindo numa mescla linguística ${ }^{10}$.

Ao tratarmos de contato linguístico, que é o veículo para a aquisição de uma L2 e de uma LH, Romaine (1995) mostra que há casos em que o falante tem mudado para outra língua e sua língua nativa teve ou não efeito na linguagem adquirida. Cita, por exemplo, a pouca influência do ameríndio no espanhol, ocorrendo, no entanto, o inverso com os índios, que absorveram grandemente a língua dos colonizadores. Ainda, segundo a autora, quando um grupo de falantes passa a falar uma nova língua, ele pode

\footnotetext{
${ }^{10}$ A autora se refere a mescla os casos em que os falantes usam a LM e a língua da sociedade receptora ao mesmo tempo, criando uma língua própria. Nas nossas pesquisas, podemos chamar de um portunhol.
} 
não a aprender perfeitamente, pois traços de sua primeira língua persistirão, o que é chamado de "substratum influence".

De acordo com as colocações da autora está a fala de um dos entrevistados desta pesquisa que revela um "substratum influence", pois percebemos que não consegue aprender o espanhol pela influência do português, sendo este último também tão afetado que já não é tão reconhecido mais pelo seu grupo étnico. Neste caso, estamos tratando do que Barrios (2008) considera como mesclas de línguas. No entanto, são casos difíceis de acontecer, pois numa sociedade linguística espanhola, cuja língua é tão forte e imponente, dificilmente o português impedirá que o falante seja bilíngue.

Tal afirmação vai de encontro com o que é proposto nas pesquisas de Matias (1984; 2001) sobre o português falado em Olivença, pois a autora afirma que o fato de as regiões em contato, no caso Portugal e Espanha, terem semelhanças geográficas, há uma influência muito maior na aquisição da língua da sociedade receptora. Como é previsto, Matias (2001) confere aos falantes portugueses de Olivença o estatuto de bilíngues em todos os setores da população, inclusive nas classes mais baixas. Além disso, a autora apresenta a grande influência do espanhol na língua dos portugueses oliventinos, assunto a ser apresentado melhor no capítulo sobre o locus de contato.

Inspirando-se nos trabalhos de John Gumperz, de William Labov e de Dell Hymes, os quais tratam das teorias da sociolinguística, Ervin (1973) propõe que a aprendizagem da linguagem ocorre para a criança e para o imigrante em contexto de aprendizagem social. De acordo com ela, a aprendizagem de uma L2 e bilinguismo envolvem a aquisição e utilização de dois códigos linguísticos os quais devem manter os aspectos lexicais da mensagem, os aspectos semânticos e hábitos de codificação.

A autora ainda postula que a identificação é fundamental para isto, no sentido não só de imitar o que os outros usam, tendo em vista que a imitação não é permanente, mas em tomar posse até mesmo das características comportamentais dos outros, isto é, seus modos, estilos, regras sociais, e condutas estandardizadas. (grifo nosso)

A fundamental concept in the description of the social context of language learning is identification. This is a term used to refer to the adoption of features of another's behavior as stable and relatively permanent elements of the behavioral patterns of the learner. In general, identification will be distinguished here from imitation only in terms of degree with respect to three dimensions - pervasiveness, or the variety of behavior affected, 
permanence, and also perhaps susceptibility to vontulary control. Imitation is considered narrower, permanent, more voluntary. The term identification has been applied to the adoption of qualities of the model such as mannerisms and style of dress, social roles insofar as social positions permit, and standards of conduct."

(ERVIN, 1973:1)

Como pudemos entender dos argumentos de Ervin, tanto para os falantes de LH quanto para os aprendizes de uma L2 a aprendizagem se dá no contato, na interação e no contexto social, no entanto, como já frisamos anteriormente, os falantes de LH têm uma vantagem, pois já tem tal contato desde os primeiros anos de vida, o que pode ser uma vantagem imensa de aprendizado.

Ainda, seguindo os apontamentos da autora, quanto mais o falante de LH se identificar com ela e conseguir vislumbrar sua importância, nem que seja somente no seio familiar, maiores serão as chances de que ela sobreviva e se revitalize entre seu grupo étnico.

Ervin (1973) ainda afirma que um falante em uma comunidade linguística que entra em diversas situações sociais, normalmente, tem um repertório de falas alternativas, as quais mudam com a situação. Faz isso, de acordo com a autora, controlando a situação de fala com o informante e para isto, usa formas emprestadas sem as identificar. É possível ilustrar esse caso com o que notamos em trabalho de campo, com os portugueses que vivem em Olivença, os quais, num contexto de interação social, onde a fala terá que ser utilizada de acordo com os participantes e com a situação, acabam fazendo uso de sua LH mesmo em conversas com espanhóis, fato que podemos atribuir ao repertório pragmático e cultural que carregam por ancestralidade.

Ao tratar de bilinguismo, Mackey (1976) também apresenta este como o conhecimento adquirido da língua ou o contato e alternância de duas ou mais línguas.

...le bilinguisme comprenant "la connaissance passive" de la langue écrite, ou "tout contact avec des modeles dans la langue maternelle... Nous considérerons donc le bilinguisme comme l'alternance de deux ou plus de deux langues.

(MACKEY, 1976:5) 
Assim, ao tratar de bilinguismo como o contato e conhecimento de mais de uma língua, Mackey (1976) ainda assevera que as diferenças relativas de poder linguístico se manifestam quando as línguas se encontram, e se manifestam como um tipo de atração ou repulsão pela outra. Neste caso, de acordo com o autor, a distância terrestre que separa os grupos e o grau de diferença entre suas línguas também é um fator de ajuda, pois as pessoas sempre sustentam a influência de seus vizinhos, havendo, segundo o autor, menos influência dos povos distantes. Como exemplo de sua afirmação, apresenta o caso dos finlandeses em seu país natal, pois são mais propensos a aprender o sueco do que o espanhol, enquanto os finlandeses da América latina são mais propensos a aprender o espanhol que o sueco.

Como temos visto na seção sobre fronteiras, as ideias de Mackey (1976) vão, em parte, ao encontro do que propomos, que é a influência da proximidade tanto geográfica quanto abstrata (no caso costumes, língua, etc.), uma vez que, quanto maior for a afinidade ou a proximidade com o país receptor, mais facilidade no uso da língua, ou seja, mais fácil de ocorrer o bilinguismo. Por outro lado, com um olhar voltado a nossa pesquisa, também propomos que a proximidade também pode ser um fator muito grande para que os imigrantes não abandonem sua $\mathrm{LH}$, mesmo que seja de forma tão espontânea imperceptível.

Assim, falando sobre a língua em suas diversas dimensões, ou seja, como um fator de identidade, como fronteiras geográficas e abstratas, como repertório de herança ou como aquisição (L2), debruçamo-nos na importância da LH na vida das pessoas que convivem em comunidades em que a sua interação e troca se faz necessária. Desta forma, encaminharemos esta tese nas seções seguintes para os estudos da sociolinguística, os quais abordam temas que vão de encontro ao que nos propomos a fazer que é o estudo de uma língua minoritária em interação com uma língua majoritária e considerada "superior". 


\subsection{UM ESTUDO COM BASE NAS VARIÁVEIS LINGUÍSTICAS}

O objetivo desta seção é apresentar os pressupostos da sociolinguística, que postula e apresenta as consequências oriundas do contato, bem como, a partir disto, nos revela uma riqueza de variações linguísticas. Para tanto, a revisão teórica parte de Labov (1972), que já afirmava o quanto é redundante dizer que a linguagem é uma forma de comportamento social. Para discutir essa questão, apoiar-nos-emos em estudos realizados no campo da sociolinguística que tratam a língua não como um fenômeno isolado nem como forças internas que colocam em luta variantes internas, como fez Labov (1972; 1983), mas avançaremos em direção a um tratamento macro da variação, como fizeram Trudgill (1974, 2001), Romaine (1995), Fenton (2003), Barrios (2008), Demerval Hora e Lucena (2008), Pezzatti (2009), Martínez e Speranza (2009), Coll (2010), Bazenga (2011) e Mackey (1976), por exemplo, entre outros que se preocuparam com contexto social, assumindo-o como o grande motivador das escolhas que o falante faz com relação à língua que utilizará.

\subsubsection{Os estudos variacionistas}

Tendo por base a ideia de que a língua é um sistema que opera no contexto de interação social e, por isso mesmo, é um conjunto complexo e dinâmico de sistemas em processos mentais e pré-verbais (Castilho 2008), torna-se imprescindível abordar as variações linguísticas que uma língua em contato pode apresentar. Concebemos, assim, as variações da língua em contato como características de que uma língua é dinâmica e que está suscetível a mudanças dentro de um contexto de contato. Cabe-nos verificar que tipo de forças nesse contexto atuam.

Uma vez que lidamos com línguas em contato, os postulados teóricos sobre os estudos variacionistas apresentados por Labov (1972) ganham importância, pois as variações, nessa perspectiva, ocorrem por diversas motivações, tais como assimilação, 
analogia, empréstimo, fusão, contaminação e variação casual. Assim, como está apresentada por Labov, a variação é inerente às línguas, unificando o grupo social em que ela se faz presente e frequente.

La différenciation linguistique (La variation) ne relè've pas de la nature sociale de la langue mais de la nature individuelle de l'emploi de la langue; il n'y a de structure dans le linguistique qu'en tant que cette structure unifie la communauté sociale qui l'institute.

(ENCREVÉ 1976: 11. Les sens commun - William Labov - Sociolinguistique)

Desta forma, nos preocupamos com a ideia de que, em sociedades de contato, os usos terão maior ou menor frequência, maior ou menor impacto e, além disso, em sociedades que estão mais abertas a contatos diferentes, a maioria dos seus marcadores funciona de forma de tendências, tal como aponta Labov $(1972)^{11}$.

\subsubsection{Os pressupostos teóricos da sociolinguística}

Ao adentrarmos o campo da língua em processo de mudança e no seu estado de variação através do contato, sentimos a necessidade de apresentar alguns dos pressupostos teóricos já consolidados nesse campo de pesquisa.

Para Dell-Hymes (1962), o estudo da sociolinguística se volta para o comportamento verbal nas diversas relações que o falante tem com o seu meio e, desta forma, diversas variações serão adicionadas ao seu modo de falar. Para este autor, os sociolinguistas devem estar atentos não só ao uso, mas a todo o contexto em que ele é produzido, ou seja, aos diversos fatores, tais como descritos por ele:

\footnotetext{
Os sociolinguistas estudam o comportamento verbal em termos de relações entre o cenário (família, encontros, festas, etc.), os participantes (o status dos participantes na sociedade, tais como sexo, idade, ocupação, cônjuges, etc.), o tópico (o conteúdo manifesto ou o referente do discurso - como foco de atenção), as funções da interação (efeito nos remetentes de suas ações), a forma (o canal - fala, escrita, digitação, etc.); o código ou a variedade conjunto de sistema linguístico; variantes sociolinguísticas - alterações linguísticas ou dois diferentes modos de dizer o mesmo; sinais vocálicos não linguísticos - propriedades chamadas paralinguísticas, que carecem de
}

${ }^{11}$ É verdade que desde 1969 a 1989, mais ou menos, Labov falava em probabilidade. Depois disso, em especial, com o avanço de modelos matemáticos e estatísticos, ele começou a falar em tendências e pesos relativos. 
propriedades arbitrárias de sinais linguísticos e valores realizados pelos participantes sobre cada um destes.

(DELL-HYMES, 1962:25)

Não é novidade que uma língua em contato com outra produz variações por empréstimos, interferências mútuas, e assimilações. Assim, diante de tal verificação, perguntamo-nos quais seriam as variáveis linguísticas que mais sofreram alterações na língua dos portugueses que vivem em Olivença, e ainda quais seriam as propriedades mais frequentes de uma variável linguística. Tais questionamentos são frutos de trabalhos anteriores ${ }^{12}$, os quais nos mostraram que alguns usos se tornam mais marcados do que outros dentro de uma comunidade linguística. Temos, desse modo, o trabalho científico de pesquisadores que têm como foco a língua falada por comunidades restritas, tal como no caso desta tese, que trata do português em contextos de fronteira geográfica. Assim, seguindo os modelos propostos por Labov (1972), ao estarmos diante de uma pesquisa sobre contato linguístico, deparamos com a necessidade de fazermos algumas seleções, tais como:

$1^{\mathrm{a}}-$ qual(is) seria(m) o(s) elemento(s) variáveis que aparecem no português das regiões fronteiriças em nossa pesquisa?

$2^{\circ}$ - qual seria a estrutura desse(s) elemento(s), tendo por base que quanto mais integrado fosse, maior seria o interesse linguístico?

$3^{\circ}$ - qual seria a distribuição estratificada, tendo em vista, que atualmente, no caso de Olivença possui pouquíssimos portugueses, e os mais novos são filhos ou netos de portugueses.

Em 1972, Labov realizou um grande estudo sobre as trocas fonéticas ocorridas na ilha de Martha's Vineyard, em Massachusetts. Os resultados desse estudo evidenciaram que tais mudanças têm influências das distintas regiões sob análise, da idade e dos grupos ocupacionais diferentes. Segundo o autor, correlacionar o modelo linguístico com as diferenças paralelas na estrutura social faz com que possamos compreender os fatores sociais em que se passa o processo linguístico. Segundo o autor, a língua deve sempre ser estudada dentro de um contexto social:

\footnotetext{
${ }^{12}$ Labov (1972); Fasold (1997); Ervin (1973); Dell Hymes (1962); Barrios (2008); entre outros.
} 
Não se pode compreender o desenvolvimento da troca de uma linguagem fora da vida social da comunidade em que ela ocorre. É ainda exposto que as pressões sociais estão operando continuamente sobre a linguagem, não desde um ponto remoto do passado, sim com uma força social imanente que atua no presente vivido.

(LABOV, 1983:31)

Diante disso, sabemos que lidar com o português em contato com uma língua majoritária, a correlação se fará necessária, pois, como já citamos anteriormente, os mais idosos provavelmente façam maior uso dele do que as camadas mais jovens.

Ainda, fato importante nos trabalhos apresentados por Labov, e que, talvez, possamos verificar nesta pesquisa, é sobre a grande influência da estratificação social no uso das variáveis linguísticas. Naquele trabalho, o autor selecionou três grandes posições: alta, média e baixa de clientela de moda e as correlacionou com a estratificação dos(as) vendedores(as). Ele pretendia verificar se os(as) vendedores(as) das grandes lojas tinham tendências a apropriar-se do prestígio de sua clientela ou, ao menos, esforçar-se para tal. Além disso, segundo o autor, quanto mais amplo for o conjunto de indivíduos em contato com o público, tais como policiais, carteiros, secretários e, incluindo por conta, trabalhadores de restaurantes, mais disponíveis estarão às trocas linguísticas.

Desta forma, o autor nos leva a perceber que a atividade profissional está mais estritamente relacionada com os usos incorporados. Considerando que, se o português está em seu uso mais restrito, sendo utilizado por muitos informantes que trabalham em restaurantes frequentados por espanhóis de uma classe também variável, certamente a influência recebida será bastante grande, uma vez que estão suscetíveis aos mais diversos contatos.

Do ponto de vista metodológico, trabalhos como os de Labov (1972), tomam como ponto de partida a entrevista individual gravada ${ }^{13}$ como método primordial para percebermos um conjunto de dados relevantes acerca da fala de uma pessoa. Essa é uma decisão metodológica que aproxima esta tese dos trabalhos de orientação laboviana. Aqui, queremos somente mostrar que nosso trabalho se volta a algumas das propostas oriundas da sociolinguística, tão importantes para nossas considerações.

\footnotetext{
${ }^{13}$ Segundo o autor, a entrevista não é tão formal como um discurso público, ou como uma entrevista de emprego, mas é mais formal do que uma conversa espontânea (fala entre amigos e familiares).
} 
Alguns cuidados são tomados durante o encaminhamento desse tipo de trabalho. O mais relevante - porque condiciona ou enviesa tudo o que for produzindo depois - é o cuidado com o contexto em que a gravação é realizada. Labov (1983) identifica alguns tipos de contexto, dois dos quais se enquadram naquele selecionado para a pesquisa realizada nesta tese:

- Contexto A2: discurso com uma terceira pessoa. Neste caso, ocorrem alterações (como, por exemplo, a entrevista com uma mãe que ora fala como o entrevistador, apresentando um estilo controlado, ora grita com os filhos apresentando um estilo mais forte e espontâneo);

- Contexto A3: discurso em que não se responde diretamente as perguntas.

Um segundo fator sociolinguístico relevante para quem estuda a língua em um estágio de interação é o que remete aos procedimentos descritivos dos usos, pois estes devem partir de uma concepção de linguagem como um conjunto de normas sociais estruturadas. Assim, não é possível ignorar que as normas linguísticas atuam como forças opressoras que podem demandar do falante atitudes mais ou menos distantes do que é central nessas normas. Imaginamos que seja equivalente ao que vivenciamos no trabalho de campo em que entrevistas podem, a depender de sua atitude linguística, aproximar-se do português de padrão normativo ou - considerando que seja essa norma o modelo a ser seguido - revelar usos afastados da normatividade portuguesa, e também não conseguir se encostar nas normas do lado de lá da fronteira - a norma espanhola.

Elizaincín (2008) argumentou sobre o fato de que, quando duas línguas entram em contato, como é o caso do português e o espanhol, é necessário, do ponto de vista da sociolinguística, conhecer os aspectos que atuam como forças na decisão para o uso de cada uma. Essa seria moldura necessária para o linguista perceber o efeito desse cruzamento. Nessa perspectiva, o autor apresenta que um dos grandes conflitos, ao tratarmos de contato linguístico, é a normatização através das gramáticas de ambas as línguas, pois não se pode ignorar que são dois sistemas dinâmicos por natureza coexistindo e interagindo.

Sendo assim, não podemos deixar de perceber que, muitas vezes, o fato de não conseguir utilizar a língua da sociedade receptora com seus usos de norma padrão, o falante acaba por optar em criar suas próprias regras, o que torna sua fala, muitas vezes, 
ambígua ou repleta de variações. O contrário também pode ocorrer, pois muitos, não conseguindo dominar as normas consideradas 'cultas' da sua língua nativa, acabam por abandoná-la e até mesmo nem mais a ensinando aos seus filhos.

Além disso, segundo o autor, o status nacional e até internacional das duas línguas é um dado muito importante para o linguista, pois, como temos visto, a depender do contato, maior será a influência. É o que temos verificado no trabalho de campo nas cidades fronteiriças: o contato de uma língua considerada "superior" com normas gramaticais rígidas e de importância social para os portugueses que ali residem.

Segundo Labov (1983), no passado, as normas eram consideradas invariantes, hoje os estudos apontam uma variação sistemática que reflete o tempo, a troca temporal e processos sociais extralinguísticos. Ratifica essa constatação do autor o acompanhamento de mudança de estatuto social do falante. Em outras palavras, o comportamento linguístico do falante muda com rapidez enorme quando sua posição social também muda. Dessa forma, pode-se afirmar que o status social é um grande indicador da mudança linguística. Como podemos inferir, Labov deixa bem claro que a mudança linguística ocorre de acordo com o contexto em que ela ocorre, o qual pode tanto favorecer uma mudança quanto torná-la mais lenta a depender dos laços e das posições sociais dos falantes.

Sabemos, então, que as variações estilísticas tendem a ser iguais às variações sociais, pois os falantes, à medida que interagem com outras de diferentes níveis ou com diferentes etnias, procuram se aproximar o máximo possível. Isto se faz presente, por exemplo, entre os portugueses na cidade fronteiriça à Espanha, os quais, por considerarem o espanhol uma língua superior e de maior importância, procuram usá-la da melhor forma. O que ocorre nesses casos é que essa necessidade de incorporação é tão forte que, ao utilizarem sua língua nativa, as marcas linguísticas do espanhol podem entrar de forma estrondosa. Essa interferência entre línguas voltará a ser tema de discussão adiante.

A necessidade de descrevermos os usos variáveis também está no que Labov sugere como a observação de um novo tipo de estrutura invariável oriunda do contato, ou seja, as variáveis estudadas saem do seu estatuto de variáveis para o estatuto de invariáveis: 
Os estudos empíricos das variantes linguísticas nos faz ver que tal estrutura linguística não se reduz a unidades funcionais invariantes como os fonemas, morfemas, mas ao contrário, existe um nível de estrutura variável que vincula sistemas completos de unidades funcionais e que rege a distribuição das variantes subfuncionais (unidade funcional). Essa estrutura variável e transforma em um novo tipo de invariante em um nível mais fino de observação

(LABOV, 1983:167)

No entanto, indo ao contrário, e pensando no que já apresentamos sobre a dinamicidade da língua, não é plausível defender que algum uso se torne invariável por mais que tenha sofrido mutações fonéticas, morfológicas ou sintáticas. Na verdade, a língua sempre estará sujeita a mudanças e a novos usos e, inclusive, a novos sentidos.

Martínez e Speranza (2008), ao discutirem multilinguismo, chamam a atenção para o cuidado que os pesquisadores devem ter ao assumir um trabalho voltado para a variação. Segundo as autoras, é necessária, antes de tudo, a busca de um marco teóricometodológico que dê conta desses fenômenos.

Num viés cognitivo, é possível lidar com a variação como resultante de processos cognitivos implícitos no uso da linguagem (cf. Martínez e Speranza, 2008). Nessa abordagem, concebe-se que variações impulsionam os falantes de uma determinada comunidade a desenvolver sua capacidade criativa em direta relação com as potencialidades da própria língua. Sendo assim, fica claro que, em situação de contato, a variação não implica recategorização dos conteúdos semânticos descritos pela variedade estandardizada, mas, sim, uma redistribuição desses conteúdos pela necessidade comunicativa.

Assumindo essa perspectiva ao focalizar o ambiente de investigação desta tese, qual seja, ambientes de fronteiras linguísticas, consideramos que os usos do português oliventino, por influência do espanhol, uma língua majoritária e presente na comunidade portuguesa, no caso de Olivença, não, necessariamente, fará mudanças categóricas, mas causará um efeito de uma língua sobre a outra, fato que segundo muitos pesquisadores (tais como Labov 1983, Martínez e Speranza 2008, Elizaincín 2008, entre outros), deve ser estudado na análise de usos variáveis e sua relação com o grau do contato linguístico.

O que pretendemos, então, neste trabalho científico, é não apenas apresentar que o contato promove mudanças, pois isto não nos é novidade, nem que o português 
oliventino é considerado minoritário e que por isso está mais propensa a receber interferências. A pretensão maior está na postulação de que tais mudanças estão ocorrendo em contextos específicos e esses contextos precisam ser apreendidos, descritos e correlacionados com o grau de consciência que os falantes têm dessa mudança. Ainda Martínez e Speranza (2008) adicionam o aspecto sintático como relevantes para a descrição dos usos. Segundo elas, há que se comparar os traços sintáticos da variedade em questão com os das variedades menos expostas a contato, para que se neutralizem outras diferenças de ordem sociolinguística. É preciso, então, que haja o interesse no nível da gramática para podermos postular qual efeito produz uma língua.

Um elemento parece funcionar como mecanismo fundamental em toda essa relação: a frequência. Esse elemento está presente em vários estudiosos da sociolinguística, dentre os quais estão Martínez (2006b) e Garcia (1995), que afirmam ser a frequência um indicador potente de que um uso variável está em um sintoma de troca linguística. Adaptando essa informação ao objeto de investigação nesta tese, a língua portuguesa em Olivença e a LH, intuímos que a frequência de uso do português pelos falantes de cidades fronteiras é um índice importante para que a LH se mantenha viva e pulsante nos lares.

\subsubsection{As variantes como marcas de etnia}

Fishman (1971) considera que os usos variáveis são aspectos fundamentais para o reconhecimento de uma língua vital em seus aspectos sociais, econômicos, educacionais e de etnia em uma população que ocupa um mesmo território. Para o autor, variedade não é o mesmo que dialeto ${ }^{14}$, não designa uma posição linguística particular, mas unicamente certas diferenças comparadas a outras variedades.

São estes pressupostos que mais nos interessam, uma vez que lidamos com grupos étnicos minoritários que vivem em uma comunidade de língua oficial espanhola. Sendo assim, vemos que o fato de falantes do português, através do contato, apresentarem variações linguísticas em sua fala acaba tornando estigma, o que,

\footnotetext{
${ }^{14} \mathrm{O}$ autor classifica dialeto como formas populares.
} 
consequentmente, pode afetar a LH. Foi o que notamos em Olivença, em que, como trataremos adiante, o português oliventino é considerado, em alguns casos, um "chaporrêo".

Com essa exposição, mostramos que o aparato teórico da sociolinguística não apenas se presta à variação e à mudança intrínseca a uma mesma língua. Ele também é útil para provocar reflexões sobre um tipo de mudança bastante comum na luta de braço entre fronteiras sociopolíticas. Assim, uma mudança linguística pode ocorrer justamente pelo fato de os falantes estarem envolvidos no cotidiano de uma língua que não é sua língua nativa. Nessa perspectiva, Romaine (1995), num estudo sobre o bilinguismo, recuperou dois tipos de mudanças propostos por Gumperz e Wilson (1971), e aqui as reproduzimos:

- Mudança por convergência: perda de formas devido ao longo contato com outras línguas;

- Mudança por interferência: introdução de formas novas, devido ao contato.

Essa tipologia proposta por Gumperz e Wilson, se encaixa perfeitamente no contexto do objeto que estudamos, pois o português nas regiões de fronteira sob estudo tem sido impactado dessas duas formas tal como mostraremos no capítulo sobre a análise linguística.

Variedades ou línguas podem denunciar se um falante é pertencente ou não a determinado grupo apenas analisando se mudanças típicas de uma ou outra variedade e, ainda, de um ou outra língua são ou não incorporadas ao seu hábito linguístico. Esse dado também é relevante para reconhecer os motivos de grande exclusão e discriminação social nesses contextos de comunidades fronteiriças.

Seguindo a lógica dessa linha de pesquisa, Trudgill (1974) trabalhou a língua defendendo que suas variedades são, em graus distintos, relacionadas. Essa estratégia pode ser o mais importante critério para a delimitação de grupos étnicos.

Ao lidar com a questão de grupos étnicos, esse autor apresenta uma pesquisa na qual foram convidadas algumas pessoas que deveriam ouvir gravações de dois grupos diferentes para, em seguida, dizer se as falas haviam sido produzidas por pessoas brancas ou negras. O que ocorre é que, em virtude das marcas linguísticas percebidas, 
esses convidados fizeram seu julgamento de forma totalmente equivocada, não identificando corretamente a etnia dos falantes. A explicação para o não acerto foi elaborada com base no fato de que o primeiro grupo (de brancos) viveu toda a vida com negros e o segundo grupo (de negros) foi educado com brancos e teve poucos contatos com negros.

Com esses resultados, Trudgill demonstra que fica evidente o quanto as marcas linguísticas denunciam a etnia de um indivíduo e o impacto linguístico quando está inserido numa convivência com quais grupos étnicos diferentes. Daí o interesse em estudar o português oliventino e o PLH, pois, como sabemos, o fato de seus falantes estarem numa comunidade diferente, novos hábitos linguísticos serão incorporados em sua rotina. Essa estratégia parece bem interessante para ser aplicada a regiões de fronteira, pois permite reconhecer usos que podem denunciar o contato, no caso da tese, do português com a comunidade de língua espanhola.

Nesse mesmo estudo, Trudgill (1974) observa que muitos negros americanos, os chamados hoje BEV (Black English Vernacular) ${ }^{15}$, utilizam formas diferentes de fala, no léxico, na morfologia, na realização fonética e na sintaxe. Um exemplo ilustrativo disso pode ser apreendido do uso de 'tesses' no lugar de 'test' e no uso de "it's" como existencial (it's a boy in the class). Com base nessa constatação, o autor postula que há diferenças entre os falantes americanos negros e os falantes americanos brancos, fato que carrega, inclusive, o sentimento de discriminação para com os falantes do BEV.

Desse modo bem simples, mas inimaginado no modelo clássico variacionista da Sociolinguística, verificamos que as variações podem ser classificadas, tal como por Trudgill, como integracionista, pois, nessa abordagem, o interesse maior é a identificação de que são integrados à fala dos BEVs e não à fala dos brancos. Nessa época, Trudgill concluiu que esse grupo consolidava-se como um grupo étnico separado, com variedades tanto de falantes brancos como de falantes negros, provavelmente derivado de um primeiro grupo negro nos Estados Unidos que falava algum tipo de inglês crioulo ${ }^{16}$.

\footnotetext{
${ }^{15}$ Hipótese: BEV (Black English Vernacular) - são assim chamados por terem um modo diferente de fala. Segundo alguns dialetologistas, o BEV não é derivado dos dialetos do inglês britânico, mas de um inglês crioulo da Jamaica. Assim, os negros americanos têm influência do crioulo e, portanto, se diferenciam dos falantes brancos.

${ }^{16}$ Fasold (1997) define pidgins como uma forma simplificada de fala, sem gênero gramatical no sistema de nomes e não tem concordância final em substantivo-verbo, muitos chamam, segundo o autor, de uma
} 
Os dialetologistas reconhecem as diferenças entre BEV e falantes brancos, mas assumem que BEV é historicamente derivado de dialetos britânicos. Também aceitam que no BEV podem ter sido preservadas certas características, perdas de outras e desenvolvimentos independentes em diferentes variedades. Essa afirmação rende conflitos porque pressupõe uma divisão cultural, no sentido de que os falantes possam ter desenvolvimentos diferentes, fato que, muitas vezes, é lido em termos de uma inferioridade biológica, o que é inconcebível. Essa constatação nos faz recordar da afirmação presente em Saussure (2002): a língua não é nada mais que um sistema de valores puros, com enfoque no social. É, em última instância, um produto da coletividade, que estabelece os valores desse sistema através da convenção social, sobre o qual o indivíduo não tem nenhum poder isoladamente.

Todas essas pesquisas visitadas permitem traçar um caminho seguro para a abordagem do objeto de estudo nesta tese priorizado, o português oliventino e o PLH. Notamos que processo similar ao do BEV se manifesta, pois as variações se manifestam num processo integracionista, provocam cisões sociais e preconceitos, além de desencadear sentimento de inferioridade linguística.

Aproximadamente vinte anos depois de Trudgill, Fasold (1977) retomou o tema, mas numa perspectiva um pouco diferente. Afirmava que quando as pessoas dialogam o fazem para conseguir que o outro compreenda seus pensamentos e sentimentos. Nessa perspectiva, a função primitiva da conversa seria a de ampliar relações e se identificar como parte de um grupo. Assim, vemos que embora os falantes de determinados grupos étnicos se diferenciem pelos usos variáveis, o esforço para evitar conflitos é tão grande que até mesmo ocultam suas marcas identitárias linguísticas. É sobre essa perspectiva que trataremos na próxima seção.

improvisação. Ainda define línguas crioulas como aquelas que surgem quando uma língua pidgin se torna uma língua nativa de uma nova geração de crianças. Uma forma disto acontecer é quando um homem se casa com uma mulher com uma língua diferente da sua, ambos conhecem um pidgin e nenhum aprende a língua do outro. O pidgin então se torna uma troca de língua familiar e se torna a língua da mãe da criança. Isto acontecia quando tentavam separar os escravos da sua língua nativa. 


\subsubsection{Os usos variantes como resposta a tentativas de fazer parte do grupo}

De acordo com Fasold (1997), a segunda função da linguagem na sociolinguística é a chamada de "Address forms" (formas de endereçar), que são palavras usadas pelo falante para designar a pessoa com que estão falando enquanto estão na interação. Fasold cita o modelo Ervin - Tripp (1972:226) no qual, durante o processo de interação, o falante assume formas diferentes para se dirigir a cada um dos participantes. Um exemplo claro disso é a situação em que estão envolvidas pessoas mais idosas. É certo que estas terão o privilégio de decidir o modo como serão endereçadas: como senhor, senhora, pelo nome, etc.

Nesse sentido, podemos perceber que, num processo de integração social, os falantes sempre terão que utilizar as formas convencionais daqueles com os quais interagem, fato que é necessário para o bom convívio numa sociedade receptora. Assim, muitas vezes, os novos usos integrados na comunicação dos falantes do português oliventino são resultados dessa necessidade de fazer parte de um novo grupo da melhor forma possível, sem que entrem em conflito.

Fasold (1997), então, postula que a verdade é que há variação também para endereçamento em todos os níveis de interação social, seja em fronteiras nacionais, em grupos sociais dentro do mesmo país, em conversas entre dois indivíduos e até no comportamento de uma pessoa para outra. Se há variação, a depender do contexto, ela fará parte dos hábitos dos falantes até mesmo quando estão em comunidades em que estas não sejam usadas. Como exemplo disso, podemos selecionar o pronome 'tu' do português europeu. Ele só é utilizado entre pessoas muito próximas ou entre membros da família, mas, se o falante estiver diante de uma sociedade em que isto não ocorra, ele, provavelmente, acabará utilizando tal pronome mesmo com pessoas que não sejam íntimas, isto é, sua decisão será guiada com vistas à integração pelo uso variável cultural.

Próxima a essa ideia, Fasold (1997) nos dá como exemplo de variação o uso do pronome 'voi' no francês que é uma forma mais antiga e, portanto, usada nas partes mais rurais, e o uso do 'lei, ' que é uma forma respeitosa, para superiores não familiares. Assim, o 'voi' começa a ganhar o sentido de solidariedade, não sendo muitas vezes 
usado pelos falantes da classe alta. E muitos falantes da classe baixa usam voi/tu com suas famílias, enquanto a classe alta usa o $t u$. Ainda, em um escritório, seria comum tratar o chefe de lei e esperariam o retorno como $t u$. Notemos que uma tarefa primordial da sociolinguística é mesmo apontar que o uso da linguagem, no geral, é relacionada aos valores sociais e culturais. Uma forma similar de trabalhar com esse tema é feito pelos estudiosos da etnografia da fala ou etnografia da comunicação ${ }^{17}$.

Seguindo os mesmos pressupostos, Ervin (1973) atribui à linguagem da comunidade um feixe de variedades, especialmente aquelas que ou são diferentes o suficiente para interferirem com inteligibilidade, ou são identificadas como grupos sociais específicos. É claro também que para a autora, a escolha desses usos variáveis, ou alternativos, não é "livre", mas, sim condicionada por fatores situacionais e pessoais. Como um exemplo de sua afirmação apresenta a forma imperativa geralmente utilizada para pessoas consideradas inferiores em situações de hierarquia profissional: "there's dust in the corner" (há poeira no canto) versus "sweep the dust from the corner" (varra a poeira do canto). A escolha de uma forma pode dizer muito sobre que posição nessa hierarquia ocupa o falante. Essa discussão conduziu Ervin (1973) a discutir os papéis sociais estabelecidos nas relações interpessoais em situações específicas e suas consequências em termos de escolhas linguísticas.

Essa diversidade linguística, na qual os falantes alternam usos para que sejam incorporados com mais facilidade na sociedade receptora, é relatada pela autora como sendo uma interação por mudança de lugar (país, cidade, região, classe, etc.); e como uma forma de aumentar sua ligação na comunidade em que vive. Ao que parece, um jogo complexo de atração de formas se impõe, pois a decisão sobre como falar como aqueles que têm os maiores laços sociais, ou com os que têm maior interação tanto pode inserir mais facilmente um falante numa comunidade quanto isolá-lo. É como outras decisões uma forma de se de diferenciar (na ocupação, no sexo).

\footnotetext{
17 Dell Hymes (1962/1962:101; 1972:53-5 apud Fasold 1997) define a etnografia da fala assim: 'A etnografia do falante é concernida com as situações e usos, os padrões e funções do falante como uma atividade em sua própria certeza'. Neste sentido, Hymes se preocupa em como os falantes podem variar de uma cultura para outra e insiste que nem todos os membros de uma mesma comunidade emolduram a mesma regra de conversação, mas no mínimo, ativam uma variedade linguística. Fato que atribuímos à necessidade de integração social que ocorre principalmente em situação de contato entre diferentes grupos étnicos.
} 


\subsection{UM ESTUDO COM BASE NA SOCIOLINGUÍSTICA INTERACIONAL}

O objetivo desta seção é apresentar os pressupostos teóricos da sociolinguística Interacional, que permite lidar com a língua em contextos sociais e específicos. De acordo com os estudos neste viés de pesquisa, a língua, por ocorrer em situações sociais, é, muitas vezes, influenciada pelo status (Goffman, 1998) em que é produzida e, portanto, favorece um aguçamento da atenção dos pesquisadores. Ocorre que, nem sempre o sentido está apenas nas palavras e nem sempre o que o falante diz é a verdade, sendo necessário um olhar para o 'enquadre/frame' (Bateson 1998) de todo o contexto comunicativo, o qual pode envolver uma série de implicaturas conversacionais, tão importantes para a manutenção do diálogo. Sendo assim, optar por essa base teórica permite que uma pesquisa voltada para a interação face a face seja levada a termo.

\subsubsection{A língua sob a perspectiva da comunicação interacional}

Pautado nos estudos da sociolinguística interacional, Goffman (1998) direciona suas pesquisas sobre a fala em contextos sociais específicos, deslocando para um espaço de atenção especial a situação social construída nos moldes da comunicação face a face.

De acordo com o autor, uma variável social produz efeito metódico sobre o comportamento linguístico: idade, sexo, classe, país de origem, bilinguismo, etc. No entanto, os estudiosos têm se mostrado desatentos às características mais expressivas, paralinguísticas e cinestésicas que envolvem todas as interações discursivas.

É possível depreender disso que a necessidade de que o pesquisador investigue os significados não só na língua em si, mas também nas situações interativas que não podem ser descritas em termos de códigos grafados, mas podem ser adicionados como anotações, tais como o movimento dos lábios, das sobrancelhas, das mãos, etc. 
No entanto, tal estudo não é simples e envolve uma série de barreiras, pois sua análise adequada demandaria, talvez, a apresentação do cenário material e humano em que ocorrem todas as expressões físicas apresentadas. Além disso, o fato de se tratar de uma análise de elementos extralinguísticos, o autor apresenta a necessidade de se estudar tanto o comportamento enquanto se fala quanto o comportamento de todos os envolvidos na interação discursiva, inclusive, dos que não estão envolvidos na conversa.

Neste sentido, seguindo os postulados apresentados por Goffman, podemos verificar que, em um momento de entrevista, tal como realizado na pesquisa aqui relatada, todo o contexto de produção pode alterar o comportamento linguístico, inclusive, os diversos envolvidos no momento, independentemente da participação ativa. Pressupomos que, até mesmo a forma como o outro olha, gesticula ou se movimenta, pode conduzir o falante a um discurso que responde à cena como um todo.

Por definir uma situação social 'como um ambiente que proporciona possibilidades mútuas de monitoramento', Goffman (1998:13) apresenta que as relações, por ocorrerem em situações sociais, são influenciadas pelo status em que elas são produzidas e que, portanto, os pesquisadores não as devem ignorar durante seus estudos.

A fala ocorre dentro do que Goffman chama de 'arranjo social', e ela deve obedecer a regras para que saia compreensível e não cause adversidades, como, por exemplo, um falante se expressar ao mesmo tempo em que o outro, numa tomada de turno antecipada, e por tal ocorrido, ambos não se entendam. Além disso, durante uma interação discursiva, de acordo com o autor, não há um espaço vago entre o que fala e o que ouve, ou participa, mas há um preenchimento por outros elementos extralinguísticos, tais como os gestos funcionais, tão importantes durante esse momento.

Diante da importância de uma análise não só do que pode ser grafado, Goffman (1998) propõe a análise do discurso pautada em todas as situações sociais, entre elas, os de turnos de fala e de coisas ditas durante o turno de alguém, que representam um estudo da 'interação face a face'. Esse estudo inspira-nos a prestar atenção ao contexto de forma mais ampla, olhando para a situação como parte da conversa face a face. 
Neste sentido, apresentaremos não só um capítulo de análise linguística dos entrevistados para esta tese, mas também outro que trate das questões de interação e dos elementos observados por nós durante as entrevistas. Como temos visto, o momento 'entrevista' coloca o falante numa situação interacional bastante diferente do que ele está acostumado no seu dia a dia e, portanto, algumas asseverações acabam tomando rumos que, talvez, não aconteceriam em momentos diferentes.

Bateson (1998), pesquisador da psicologia e da psiquiatria, lançou mão dos estudos baseados na sociolinguística interacional, apresentando os paradoxos existentes durante o ato comunicativo.

Ao propor o paradoxo de que nem sempre o que o falante diz é uma verdade, debruçamo-nos diante de alguns questionamentos interessantes a respeito de estudos pautados num processo de interação discursiva, no caso desta tese, a entrevista.

Além de tratar dos estudos da fala no momento de interação face a face, esse autor discute em seu artigo os pressupostos da comunicação, afirmando que, para que ocorra uma compreensão plena do enunciado do discurso, é necessário que compreendamos a metamensagem do 'enquadre/frame', dentro do qual há uma série de elementos necessários e importantes no momento discursivo. Percebemos, dessa forma, que o autor realmente desenvolve ideias que vão ao encontro das de Goffman (1998) sobre a necessidade de um olhar cuidadoso sobre às situações interativas que quase nunca integram as transcrições.

Pelo fato de que a linguagem humana opera em uma escala que vai desde simples enunciados, ou em um nível de 'simples abstração', até enunciados mais complexos, ou em 'níveis mais abstratros' (Bateson 1998:58), é que não é possível um olhar somente aos elementos internos do discurso.

A necessidade de uma atenção ao enquadre do discurso é sentida por pesquisadores em situações de entrevistas, pois o próprio cenário pode alterar o processo comunicativo, levando-nos a pensar nas contradições propostas pelo autor ao dizer: 'qualquer elocução pode ter um significado contrário ao que está explícito no discurso' (Bateson, 1998: 57), e nesse momento, cabe ao pesquisador observar todas as 
situações que o envolvem, para que possa fazer uma análise mais próxima possível do que se é esperado.

Muitas mensagens permanecem implícitas, tanto metalinguísticas como metacomunicativas, tal como Bateson discorre, e informações necessárias para a análise do pesquisador deverão ser buscadas no comportamento do entrevistado, bem como nos enunciados em que são marcadas evidências contraditórias. Tais situações descreveremos na seção de análise socio-interacional em que algumas falas dos indivíduos que integraram o corpo de informantes serão apresentadas, juntamente com alguns comportamentos, que pudemos observar, de cada um durante a situação discursiva.

Tratando dos elementos presentes no processo comunicativo sob uma perspectiva evolucionista, ainda esse autor exemplifica através de algumas ações observadas, tal como o fato de os humanos passarem a utilizar o desodorante, que é algo usado de forma voluntária e consciente, para mascarar algo que antes era natural e involuntário. Propõe nessa ilustração um estágio de evolução, pois tal atitude informa que os humanos “descobrem que seus sinais são sinais" (Bateson, 1998:59) e, portanto, são passíveis de manipulação ou modificação.

O fato, então, de tomar consciência de que o corpo emite sinais, algo que não ocorre em outras espécies, proposto como um dos sinais de evolução da espécie humana, Bateson demonstra o quanto a mente humana pode ser capaz de tomar proporções ainda maiores a partir do momento em que as interpretações dentro da interação discursiva passam a um nível de contradições ou paradoxos.

Para ilustrar melhor tal discussão, Bateson (1998) descreve, a partir da observação de dois macacos "brincando de luta", a complexidade que envolve a metacomunicação, uma vez que, somente através dela é que a situação 'brincadeira' será tida como tal, pois, para que o ato observado seja considerado como 'brincadeira', os envolvidos devem transmitir, por exemplo, que a ação é uma brincadeira e não uma briga. Neste caso, isso não ocorrerá com os macacos, mas o autor transfere suas reflexões para o que ocorre com a comunicação humana, a qual depende de interpretações entre os participantes para que ocorra o sentido das coisas no mundo. 
O fato de seres humanos nem sempre terem a certeza da ação ocorrida, ou do que o outro diz, gera inquietações e dúvidas no mundo das ideias e, a partir desse momento, avança no nível de abstração comunicativa. $\mathrm{O}$ autor explica isso através da ação observada entre os macacos, a qual pode passar da ideia de "Isto é brincadeira" para a pergunta "Isto é brincadeira?", ou até mesmo “Isto é uma ameaça?". Tal interação envolve o que o autor descreve como a possibilidade de um verdadeiro 'paradoxo' no qual 'qualquer elocução pode ter um significado contrário ao que está explícito no discurso' (Bateson, 1998: 61).

De forma muito interessante, Bateson faz uma analogia desse processo, que envolve recursos mais complexos da mente humana para a compreensão, através do exemplo do que fazem os ilusionistas e pintores, os quais utilizam de suas habilidades para causar no espectador uma imagem não verdadeira.

É então, diante de todas essas analogias e postulações, que o autor apresenta o desenvolvimento da metáfora, que toma uma proporção cada vez maior na vida das pessoas que estão num estágio de consciência de que os sinais são sinais e nem sempre os sinais são o que pensam ser:

\begin{abstract}
Finalmente, na região obscura onde arte, magia e religião se encontram e se sobrepõem, desenvolveu-se a "metáfora que é [literalmente] significada", como a bandeira pela qual homens dão sua vida e o sacramento que é visto como mais do que "um indício externo e visível que nos foi dado". Aqui podemos reconhecer uma tentativa de negar a diferença entre mapa e território e de voltar à inocência absoluta da comunicação por meio de puros indícios de humor.
\end{abstract}

(BATESON, 1998:62)

Tratando das questões que envolvem os símbolos linguísticos, Bateson também ilustra com o exemplo de um personagem apresentado em seu artigo: Hans Christian Andersen, o qual por não encontrar uma mulher, volta para um rapaz que sempre o acompanhava. O objetivo do autor em trazer essa outra ilustração é para mostrar o poder dos símbolos, pois eles podem trazer, neste caso, a denotação de uma ação de homossexualidade, mesmo não havendo nada disso.

Diante da analogia apresentada, Bateson (1998:62-63) alerta para a necessidade de se reexaminar as diversas verdades no mundo das ideias e das palavras, tendo um 
olhar atento para o enquadre na qual as interações são feitas. Estamos assim, diante de questões de como compreender o sentido das palavras do falante, pois nem sempre aquilo que parece ser verdade aos olhos do pesquisador o é de fato.

Knapp (1999), em estudos sobre a interação comunicativa, também demonstra que nem sempre os sinais emitidos são interpretados, podendo, inclusive, trazer diversos conflitos entre os participantes do processo interativo, como, por exemplo, um médico ser interpretado como tendo descaso por agir com frieza.

Neste postulado, num momento de pesquisa, especificamente na que tratamos nessa tese, que é a de interação entre um entrevistador e um entrevistado, o paradoxo e contradições podem surgir e, muitas vezes, não é de forma proposital ou consciente, mas ocasionada pela própria situação comunicativa.

O fato de os envolvidos no processo de interação comunicativa terem a consciência abstrata e passarem a distinguir "brincadeira" de "não brincadeira" ou "fantasia" de "não fantasia" é, de acordo com Bateson, um processo do "ego". Neste estágio, podemos também afirmar que Damásio (2011), apresentado com mais detalhes na seção seguinte, definiria tal momento em um estágio chamado "self central".

Os estudos voltados para a sociolinguística interacional têm suas análises voltadas para o que Bateson (1998) classifica como "moldura" ou "enquadre", os quais representam os "conceitos psicológicos" sempre envolvidos dentro de todo o contexto comunicativo.

Entendemos ainda que, os pesquisadores pautados nessa perspectiva, classificam "contexto" como sendo todos os elementos presentes no momento discursivo: o lugar, os gestos, os participantes da interação comunicativa, independentemente de se envolverem ou não, etc.

Gumperz (1998), tanto quanto Goffman e Bateson, entende que o conjunto de informações internalizadas é de grande importância para que a interação discursiva seja positiva e se mantenha, e propõe também que o pesquisador não fique preso aos modelos de investigações tradicionais da sociolinguística, os quais fazem usos das variáveis sociais para explicar comportamentos individuais, não atentando para os fenômenos sociolinguísticos de cooperação social. 
O autor propõe seus estudos sociolinguísticos nos moldes da "interação", chamado por outros pesquisadores como "enquadre" ou "esquema identificável familiar" (Goffman, 1974, apud Gumperz, 1998). Gumperz (1998) afirma que uma elocução pode apresentar diferentes interpretações, isto pelo fato de que a interação discursiva depende de vários componentes para que ela tenha êxito, e acontece não de forma estática, mas dinâmica, classificada como "atividade”.

Além disso, de acordo com o autor, não significa que as interpretações apreendidas pelos falantes têm relação com o tipo de interação, mas elas podem transportar relevâncias pragmáticas de um lugar para outro, a depender das implicaturas conversacionais:

\begin{abstract}
O tipo de atividade não determina o significado, mas simplesmente restringe as interpretações, canalizando as inferências de forma a ressaltar ou tornar relevantes certos aspectos do conhecimento prévio e de forma a diminuir a importância de outros.
\end{abstract}

(GUMPERZ, 1998:99)

Diante das bases teóricas de Gumperz, as "pistas de contextualização"18 aparecem através de diversas formas durante o processo de interação conversacional e elas contribuem com as interpretações das elocuções, ocorrendo divergências caso o ouvinte não compreenda as pistas fornecidas. Assim, o autor ressalta a importância dos novos estudos da sociolinguística interacional, os quais se voltam não somente para os elementos internos da língua, mas para a compreensão de todas as pistas emitidas na atividade interativa, tão importantes para a compreensão de todo o contexto discursivo.

O que será importante nesse processo de compreensão é o compartilhamento sociocultural, no qual, de acordo com o autor, está a estratégia de contextualização, ou a "sinalização identificável" (Gumperz, 1998:107). O que acontece é que, dentro do processo interativo-comunicativo, por partilhar, muitas vezes, das mesmas experiências do outro, o falante deixará de dizer muitas coisas por confiar que a compreensão de sua elocução será certa.

De acordo com Gumperz (1998), muitas interpretações que aparentemente não são ambíguas se mostram divergentes, e ocorrem pelo fato de os falantes não

18 "Pistas de contextualização" ou implicaturas conversacionais são "traços presentes na estrutura de superfície das mensagens que os falantes sinalizam e os ouvintes interpretam” (Gumperz, 1998:100). 
reconhecerem as pistas dadas pelo outro. Neste postulado, tais estudos nos fazem atentar para nossas entrevistas de forma que não só olhemos a fala em si e os elementos linguísticos, mas que redobremos a atenção para as pistas deixadas no discurso como sinalização de informação.

\begin{abstract}
Dados adicionais são necessários, baseados em registros interacionais mais amplos e variados. Deve-se observar, entretanto, que ao relacionarmos a percepção e a interpretação de pistas contextuais à origem cultural, não estamos tentando predizer o uso nem relacionando a incidência de variáveis linguísticas a outras características. Nossos procedimentos servem para identificar estratégias de interpretação potencialmente disponíveis aos falantes de determinadas origens e para alertar as pessoas em relação às maneiras através das quais os signos em nível de discurso podem afetar a interpretação de mensagens aparentemente não ambíguas.
\end{abstract}

(GUMPERZ, 1998:107)

Trabalhando neste viés de investigação, é necessário que partilhemos e conheçamos não só a fala dos nossos entrevistados, mas todos os elementos culturais vividos por eles. Se isso for possível, nossa análise se tornará, de acordo com todos os pesquisadores que trabalham com a sociolinguística interacional, mais completa e com menos probabilidade de ambiguidades interpretativas.

Diante desses pressupostos, esta pesquisa apresentará adiante, não só a análise das variações linguísticas da comunidade de fala, mas também um pouco do comportamento de cada informante diante da situação entrevista.

É ainda necessário apresentar que Gumperz (1998) tem o cuidado de deixar claro que o estudo das sociolinguística interacional não está apenas voltado para as questões de contextualização racial ou de grupos étnicos para a compreensão das "pistas de contextualização". Citando e seguindo a teoria de Hall (1959; 1966), um especialista em comunicação não-verbal, assegura que, ao tratarmos da compreensão intercultural, muitos problemas com relação às interpretações do ato discursivo ocorrem por diversos motivos que vão além das diferenças de estereótipos raciais ou étnicas, mas que integram também movimentos faciais e gestuais.

O que o autor ressalta em seu discurso é que, muitas vezes, podemos compreender todo um contexto discursivo do falante pelo simples levantar ou cair das sobrancelhas, por um leve movimento dos lábios, etc. Sendo assim, entende que todas 
as partes do corpo transmitem informações tão importantes quanto as consideradas mais culturais e que o investigador não pode ignorar esse fato.

Outro problema no que tange pesquisas qualitativas é que, muitas vezes, não há uma compreensão do cenário dos entrevistados, e muitos sinais extralinguísticos podem passar despercebidos diante dos olhos do pesquisador, podendo até mesmo, ser um problema na interpretação linguística.

Algumas reflexões que emergiram durante nosso trabalho de campo, asseguram o que Gumperz apresenta, pois o fato de atentarmos para todo o contexto ou situação em que os nossos entrevistados se encontravam, e levar em conta todas as pistas fornecidas por eles, nos ajudaram a compreender algumas falas e até mesmo algumas atitudes conversacionais, como por exemplo, o fato de, durante a gravação, falar como se estivesse apresentando uma aula sobre a cidade ${ }^{19}$.

O que acontece então, é que muitas vezes, como Gumperz (1998) tem proposto, caso o entrevistador não perceba tais pistas, ocorrerá uma falsa interpretação das respostas dadas, ou do comportamento do entrevistado, como por exemplo, achar que seu interlocutor é uma pessoa de baixo conhecimento ou não amistosa, entre outras divergências.

Pensando nas argumentações e nas pesquisas apresentadas por Gumperz ${ }^{20}$, deparamo-nos com casos que poderiam trazer interpretações ambíguas, caso não

\footnotetext{
${ }^{19}$ Fazemos referência a um de nossos entrevistados, apresentados adiante, que durante nossa entrevista, praticamente não permitiu que nós falássemos, expondo de forma, quase que, ininterrupta, todo o seu conhecimento geográfico e histórico sobre a cidade de Olivença. Neste caso, atribuímos tal atitude comunicativa ao fato de que, por se tratar de um professor universitário, e por estar diante de uma entrevista de pesquisa, infere que quanto mais conhecimento for transmitido, maior será a boa impressão do entrevistador a seu respeito.

${ }^{20}$ Gumperz $(1998: 108 ; 117 ; 118)$ para tratar das "pistas de natureza sociolinguística", as quais sinalizam intenções comunicativas e facilitam a compreensão da atividade discursiva, mostra-nos pesquisas realizadas, dentre as quais duas tratam do reconhecimento de pistas entre diferentes grupos étnicos. Uma trata de moradores dos Estados Unidos que falam o inglês, mas entre eles indianos e norte-americanos. Neste caso, ocorre uma diferença de interpretação de uma elocução com o modal "may", pelo fato de que na Índia, tal modal é usado somente como 'permissão' e nos Estados Unidos é usado tanto como 'permissão' quanto como 'possibilidade'. Assim, a pesquisa mostra que o fato dos indianos interpretarem o sentido da elocução somente como 'permissão' se dá devido a sua bagagem sócio-cultural. Em outra pesquisa, foi solicitado a algumas crianças de uma escola nos Estados Unidos que desenhassem o que quisessem em um papel fornecido pela professora. As crianças brancas fizeram prontamente, no entanto, as negras pediram auxílio, o que poderia trazer a interpretação da ação como sendo uma deficiência e não preparo das famílias para que elas realizassem atividades na escola. No entanto, ao se informarem das vivências destas, perceberam que tal atitude sinalizava apenas um pedido de incentivo ou a presença de alguém e não incapacidade.
} 
tivéssemos reconhecido algumas pistas, como por exemplo, o fato de uma de nossas entrevistadas $^{21}$, apresentada melhor no capítulo de análise, ao ser comunicada pelo patrão sobre nossa intenção de entrevistá-la, foi ao banheiro se arrumar e pentear os cabelos, fornecendo-nos a pista de que sente estar diante de algo muito formal.

Durante a entrevista, nossa informante praticamente não falava, o que tornou nossa comunicação muito difícil, pois ela respondia de forma extremamente simplificada somente o que era perguntado, transparecendo a sensação de realizar algo por pura obrigação. Neste caso, o não reconhecimento das pistas de insegurança fornecidas pela entrevistada poderia causar interpretações errôneas, como, por exemplo, a de que ela não queria dar a entrevista por não gostar de falar com brasileiros.

Erickson e Shultz (1998) também trabalham com métodos de pesquisa que priorizam o contexto social do processo interativo da comunicação. De acordo com os autores, contexto não se trata apenas de um lugar, mas "se constitui pelo que as pessoas estão fazendo a cada instante e por onde e quando elas fazem o que fazem" (Erickson e Shultz, 1998:143). Além disso, de acordo com os autores, as alterações proxêmicas ${ }^{22} \mathrm{e}$ de posturas de sinais emitidos entre os participantes da atividade ${ }^{23}$ interativa, ocorrem de "momento a momento", podendo ser modificadas muitas vezes dentro do contexto.

Como temos visto, os autores apresentados nesta seção asseguram a importância de um olhar atento a todas as pistas de contextualização (Gumperz, 1998) que farão os participantes compreender todo o contexto em que estão envolvidos, tendo a consciência do quando e onde é necessária uma mudança de atitude, pois é durante o processo de mudança que os "indivíduos poderão talvez perceber que algo novo está acontecendo" (Erickson e Shultz, 1998:146).

Da mesma forma que Gumperz (1998) enfatiza a importância do investigador em não ignorar as pistas emitidas no momento de interação, para que não ocorram interpretações ambíguas, Erickson e Shultz (1998) também ressaltam tal importância. De acordo com os autores, no momento das alterações de contexto, se os participantes envolvidos não perceberem as pistas emitidas para a mudança, ocorrerá divergência, o

\footnotetext{
${ }^{21}$ Fazemos referência a entrevistada 2 (RS) de nossa pesquisa, portuguesa e moradora de Olivença e que trabalha como cozinheira em um restaurante da cidade.

${ }^{22} \mathrm{O}$ autor classifica alterações proxêmicas como mudanças na distância interpessoal entre falantes.

${ }^{23}$ Utilizo o termo "atividade" tal como propõe Gumperz (1998).
} 
que ocasionará a rotulação até mesmo de 'comportamento inadequado' por parte dos 'não atentos'.

Diante da proposição de que os estudos da linguagem humana estão pautados no nível sintático, semântico e pragmático, Stalnaker (1982), tanto quanto os autores acima citados, se incomoda com a falta de uma atenção maior a este último, o qual envolve o estudo dos atos linguísticos e dos contextos em que ocorre a interação linguística.

Apresenta que o grande problema da semântica formal é com relação ao fornecimento e a definição das condições de verdade para as sentenças, além da separação dos propósitos para os quais as sentenças são enunciadas. A preocupação de Stalnaker (1982) é aplicada à necessidade de que entendamos que, ao expressar uma proposição, as pessoas têm intenções e motivos para tal, e isto não deve ser separado ao realizarmos pesquisas sobre a língua. Reconhecemos que esse não era e nunca foi o objetivo da Semântica Formal ${ }^{24}$, contudo nos restringimos, aqui, a apresentar a opinião de Stalnaker, pois, em seus desdobramentos, aproxima-se do encaminhamento que consideramos producente com relação ao trabalho de campo.

Diante de tais pressupostos teóricos, Stalnaker (1982) já propunha os mesmos critérios de estudos dos autores nesta sessão citados: Goffman (1998), Bateson (1998), Gumperz (1998) e Erickson e Shultz (1998), que são aqueles voltados para a observação dos traços do contexto, definidos também como "pistas de contextualização":

\begin{abstract}
Uma das tarefas das línguas naturais é expressar proposições, e é um problema semântico especificar as regras para estabelecer a correspondência entre as sentenças de uma língua natural e as proposições que elas expressam. Em muitos casos, contudo, as regras não farão corresponder diretamente sentenças a proposições, mas farão corresponder sentenças a proposições relativamente a traços do contexto no qual a sentença é usada. Estes traços contextuais são uma parte do campo temático da pragmática (...).
\end{abstract}

(STALNAKER, 1982:64)

A pragmática, definida pelo autor como o estudo dos "atos linguísticos" e dos contextos em que estão envolvidos, necessita encontrar condições para que tenha o êxito desejado e, para tal tarefa, ela é de fundamental importância.

\footnotetext{
${ }^{24}$ Tendo a base teórica de que a semântica é o estudo das proposições, e que as coisas no mundo são dinâmicas, de acordo com o autor, estamos diante não só de situações reais, mas também de situações hipotéticas e imaginárias, sendo necessário uma "função que leve não somente o estado real do mundo, mas também seus vários estados possíveis a valores de verdade” (Stalnaker, 1982:61).
} 
O que envolve todo o processo comunicativo, na verdade, de acordo com Stalnaker (1982), é o conjunto de regras sintáticas e semânticas aliadas aos traços do contexto, e aos "mundos possíveis" que determinarão um valor de verdade. A explicação dada para "mundos possíveis" está na asserção de que os enunciados são dependentes do contexto para sua interpretação. Assim, para que os falantes compreendam as proposições, os elementos presentes devem ser explicados com relação a todos os "mundos possíveis" dentro de seu conhecimento ou através de pressuposições cabíveis.

Ao tratar do termo "pressuposição", Stalnaker (1982:69) considera que é "uma atitude proposicional, e não uma relação semântica". Neste viés, entram as questões tratadas até aqui, as quais caminham para o sentido de que pressupor uma proposição é compreendê-la como sendo uma verdade aceitável e compartilhada. Sendo assim, é necessário imaginar que o outro participante do evento comunicativo também esteja entendendo, para que ocorra uma ação conjunta, tal como propõem Erickson e Shultz (1998:153) ao descreverem uma abordagem teórica e de procedimentos para o estudo da "organização social da interação".

\begin{abstract}
Uma vez que as pressuposições desempenham um papel tão grande na determinação daquilo que está se passando numa situação linguística, é importante que os participantes de um mesmo contexto tenham o mesmo conjunto de pressuposições se se quer evitar equívocos.
\end{abstract}

(STALNAKER, 1982:70)

Do mesmo modo que Stalnaker propõe a importância de compreender a pressuposição da proposição como verdadeira e esperar que todos os participantes do processo de interação discursiva também compreendam, Gumperz (1998) igualmente afirma que muitas interpretações que são ambíguas ou divergentes ocorrem pelo fato de os falantes interagirem sem reconhecerem as pistas dadas pelo outro. Esse é o esteio para que Stalnaker (1982) assegure que, para que não haja ambiguidade de sentido de uma proposição, é necessário que se vá diretamente da sentença para o valor de verdade.

Grice (1982), tanto quanto os autores já mencionados nesta seção, ressalta a importância das implicaturas conversacionais ${ }^{25}$ presentes na interação discursiva, e assegura que o diálogo deve refletir a cooperação entre os participantes, atividade

\footnotetext{
${ }^{25}$ Grace (1982) define implicatura como sugestão, significância ou sentido implícito. Define que quando B implicou, ele sugeriu, significou, etc.
} 
apresentada por ele como o "Princípio de Cooperação". A fim de apresentar como funcionam as implicaturas conversacionais, nos fornece alguns exemplos, tais como:

1. A e B conversam sobre um amigo que trabalha no banco. A pergunta a $B$ como vai $\mathrm{C}$ no trabalho, B então responde: "Ah, bastante bem, creio; ele gosta de seus colegas, e ainda não foi preso".

Implicatura: "B implica que C é potencialmente desonesto".

2. A está ao lado de um carro parado e B se aproxima: A diz: "estou sem gasolina" e B responde: "Há um posto lá na esquina".

Implicatura: "B implica que o posto está (possivelmente) aberto e tem gasolina à venda".

3. A: - Parece que Smith está sem namorada ultimamente.

B: - Ele tem ido muito a Nova Iorque.

Implicatura: "B implica que Smith tem, ou pode ter uma namorada em Nova Iorque". ${ }^{26}$

4. A diz: "A senhora X é uma chata" e, após um momento de silêncio, B responde: "O tempo tem estado uma delícia este verão".

Implicatura: "B implica que a observação de A não é pertinente".

Como é possível observar nos exemplos fornecidos por Grice, se não houver o Princípio de Cooperação, através da qual aparecerão as implicaturas necessárias, não será possível uma interação discursiva, pois o objetivo esperado não será alcançado.

O autor também apresenta seus estudos numa perspectiva de que há ou pode haver divergências na significação dos símbolos formais e seus equivalentes em línguas naturais, e que existem motivos que contribuem para isso, como o abandono de algumas máximas das categorias de Quantidade, Qualidade, Relação e Modo.

\footnotetext{
${ }^{26}$ Dascal (1982) não vê relação semântica no exemplo 3 de Grice, para o autor, a simples afirmação de não é suficiente para atribuir ao ato de fala de $\mathrm{B}$ a implicatura específica do exemplo. Dascal apresenta que tal enunciação de A somente deixa claro que 'Smith não tem namorada recentemente'. Quanto às implicaturas geradas, poderiam ser: 'Smith não tem namorada porque anda muito ocupado, indo tão frequentemente a Nova Iorque' ou 'Smith não tem namorada e por isso vai frequentemente a Nova Iorque, às prostitutas'.
} 
As quatro categorias apresentadas pelo autor produzirão resultados de acordo com o Princípio de Cooperação, explicadas por Grice (1982:86 e 87) da seguinte maneira:

- Categoria da Quantidade: relacionada com a quantidade de informação, apresentada através das seguintes máximas:

(i ) fazer contribuição informativa o suficiente para a compreensão;

(ii) não fazer contribuição além do necessário (de acordo com o autor, esta é questionável, pois nem sempre o excesso de informação pode significar uma transgressão);

- Categoria da Qualidade: "trate de fazer uma contribuição que seja verdadeira", relacionada às seguintes máximas:

(i) não dizer o que pensa ser falso;

(ii) fornecer apenas evidência adequada;

- Categoria da Relação, apresenta uma única máxima:

(i) ser relevante

- Categoria do Modo, relacionado não com o que é dito, mas como o que é dito, sendo importante que se seja claro na informação. Para tal categoria, apresenta as seguintes máximas:

(i) não produzir expressões obscuras;

(ii) não produzir elocuções ambíguas;

(iii) evitar expressões desnecessárias;

(iv) ser ordenado;

As máximas apresentadas por Grice (1982) são observadas entre os participantes de uma interação discursiva e podem gerar 'implicaturas não-convencionais'. O autor vê a fala como uma variedade do comportamento intencional, sendo, por exemplo, de acordo com a máxima da Quantidade, representada da seguinte maneira: 
Se você está me ajudando a consertar um carro, espero que sua contribuição seja nem mais nem menos do que o exigido; se, por exemplo, num estágio particular eu precisar de quatro parafusos, espero que você me alcance quatro e não dois ou seis parafusos.

(GRICE, 1982:88)

Os estudos de Grice, então, permitem conceber o processo comunicativo como um 'quase contrato', com paralelos que estão além do discurso, numa sintonia entre a fala e elementos diversos, como, por exemplo, o próprio olhar ou uma ação. Sendo assim, muitas vezes, o simples fato de uma pessoa A chegar perto de B, que necessita de ajuda, pode criar a expectativa de que A irá ajudar B.

É nesse sentido que Grice aponta o quanto as contribuições dos participantes são importantes para as interpretações não só do discurso mas também nas relações fora dele. Além disso, assegura que o Princípio da Cooperação e das máximas só será considerável se ambos os falantes tiverem o mesmo interesse em participar de interações discursivas proveitosas.

Ao tratar das questões relacionadas à compreensão, Grice (1982) argumenta que os problemas de ambiguidade ou divergências que ocorrem podem ser ocasionados, muitas vezes, pela violação de uma máxima.

O Princípio de Cooperação e as máximas têm uma relação com as implicaturas conversacionais do outro, pois, muitas vezes, o abandono de uma máxima, ocasiona a necessidade da ativação de implicaturas conversacionais.

Para exemplificar tal afirmação, Grice (1982) apresenta um caso em que o falante abandona a primeira máxima da Qualidade que é "não dizer o que pensa ser falso": X expôs um segredo de A, então A diz: "X é um excelente amigo". Este seria um caso em que Grice explica que, ao abandonar tal máxima, os participantes envolvidos no processo comunicativo necessitarão dos recursos pragmáticos disponíveis para que haja a compreensão do que A quis dizer.

Outro exemplo interessante apresentado pelo autor é quando o falante necessita abandonar na categoria Modo a primeira máxima que é "não produzir expressões obscuras". Neste exemplo, é apresentado um caso em que A e B conversam sobre um assunto em que $\mathrm{C}$, por se tratar de uma criança, não pode saber. Desta forma, A deve 
tornar sua fala obscura para $\mathrm{C}$, mas $\mathrm{B}$ deverá utilizar todos os recursos pragmáticos para que tal abandono não ocasione uma falha na sua compreensão.

Nos exemplos fornecidos por Grice (1982), percebemos uma relação com o que os pesquisadores da sociolinguística interacional propõem, que é a necessidade de que ocorra uma cooperação entre todos os participantes do discurso, sendo necessário, portanto, que o outro compreenda as pistas deixadas pelo falante para que não haja prejuízo do sentido.

Dascal (1982) não deixa de adentrar nos estudos voltados à relevância conversacional, abrindo uma grande discussão a respeito do que pode ser ou não relevante dentro do contexto discursivo e quais as motivações necessárias para isso. $\mathrm{O}$ autor, em seu artigo Relevância Conversacional, alerta-nos para o quanto o tema é vago e de difícil definição para os pesquisadores que estudam a língua como um processo interativo.

De forma a lidar com essa grande dificuldade, afirma que nem mesmo Grice (1982), o qual trabalha com a análise da língua e da conversação nos modelos do Princípio de Cooperação, se propõe a explicar:

Sob a categoria da RELAÇÃO, coloco uma única máxima, a saber "Seja
relevante". Embora a máxima em si seja muito concisa, sua formulação
oculta vários problemas que me preocupam muito: questôes a propósito de
que tipos de foco de relevância podem existir, como se modificam no curso
da conversação, como dar conta do fato de que os assuntos da conversação
são legitimamente mudados, e assim por diante. Considero o tratamento de
tais questões excessivamente difícil e espero retornar a elas em um trabalho
posterior. (GRICE, 1982:87)

Dascal (1982) assegura, então, que discutir o que é "relevante" dentro do discurso é tão complexo e difícil, que até mesmo Grice se absteve de fazer. Diante do desafio, o autor, nesse artigo se propõe a enfrentar a situação, mas já alertando que talvez não seria capaz de resolver todos os problemas levantados. Assim é que ele definirá dois tipos de relevância: uma 'pragmática', a qual se refere aos atos de fala, e que são construídos com um objetivo, que é a interpretação da fala, e outra 'semântica', que são as proposições. A partir desse levantamento inicial, Dascal deixa claro que ambas as relevâncias são responsáveis pelo surgimento das 'implicaturas 
conversacionais', tema de importância para os estudos sobre a língua dentro de um processo ativo e dinâmico.

A fim de explicar como a relevância é estabelecida dentro do discurso, Dascal (1982) retoma todos os exemplos de implicaturas conversacionais propostas por Grice e discorre sobre cada uma delas, inclusive se opondo a algumas.

Tanto quanto Grice, ao fazer uma análise do exemplo 1 de implicatura, Dascal deixa claro que o abandono da máxima $R^{27}$, trará para o discurso implicaturas necessárias para que ocorra um diálogo produtivo. Ao implicar que " $\mathrm{C}$ é potencialmente desonesto", B necessitou de outros recursos para compreender o objetivo de A, que não foi relevante em sua enunciação tal como B desejava. Ao contrário disso, se A fosse relevante com o que B havia perguntado, nenhuma implicatura seria necessária para que o diálogo fluísse perfeitamente.

Dascal (1982) inclui as análises diante de uma grande interrogação: não seria possível haver uma coerência na interação discursiva mesmo sendo totalmente desestruturada? Neste caso, o autor acredita que, mesmo que ocorram enunciados como temas não definidos, o uso de outros recursos associativos presentes entre os interlocutores pode auxiliar na compreensão do processo comunicativo.

O autor, em seus estudos, aponta a necessidade de uma cooperação entre os falantes, pois no momento discursivo, A estabelecerá uma exigência conversacional para $\mathrm{B}$, o qual reagirá à exigência dentro daquele contexto discursivo. Além disso, a enunciação que para A é relevante naquele momento, será apenas 'marginalmente relevante para B' (Dascal 1982:114) e, durante todo esse processo de seleção de relevância, há um domínio de dados armazenados, chamado por Dascal de background, o qual influencia a reação ao contexto.

O que o autor quer mostrar em seu artigo, na verdade, é que nesse processo de interação discursiva, as reações do outro diante de uma exigência, são normalmente comandadas por 'aquilo que é topicamente relevante' (Dascal, 1982:115). O que quer dizer é que, durante 'aquele momento', o falante tem como objetivo prender a atenção

${ }^{27}$ De acordo com Grice (1982), o abandono das máximas pode gerar implicaturas conversacionais. A máxima $R$ se refere à máxima da Relevância: "Seja relevante". 
do outro, trazendo durante todo o processo interativo enunciações que exigirão um retorno esperado.

No entanto, como temos apresentado, a atividade discursiva é um processo dinâmico e não estático, e acontece que, a cada momento, aquilo que é relevante pode se modificar a depender do contexto em que ela ocorre. O autor fornece como exemplo um ato discursivo que é surpreendido por uma chuva, a qual passa a ser o tópico para ambos e um estímulo para que a exigência conversacional tome novo rumo, o que não será considerado uma implicatura conversacional por se tratar de uma mudança esperada.

Acontece ainda que, pode ocorrer de o falante ignorar a mudança do contexto, o que nem sempre é intencional, mas pode indicar que o estímulo, no caso do exemplo, 'da chuva', não se tornou relevante para ele, mas apenas 'marginalmente relevante', optando por continuar 'imerso' na enunciação anterior. Além disso, pode ocorrer do outro interlocutor compreender ou não sua permanência na fala anterior, gerando uma reação positiva caso compreenda ou negativa caso não compreenda, ou seja, ou reação relevante, ou irrelevante.

Ao trabalhar com os atos discursivos baseado nos conceitos de 'modalidade semântica' e 'força semântica', Dascal diz serem ambas relacionadas aos significados das sentenças e não das enunciações, como é o caso das 'forças ilocucionárias' e as classifica da seguinte maneira:

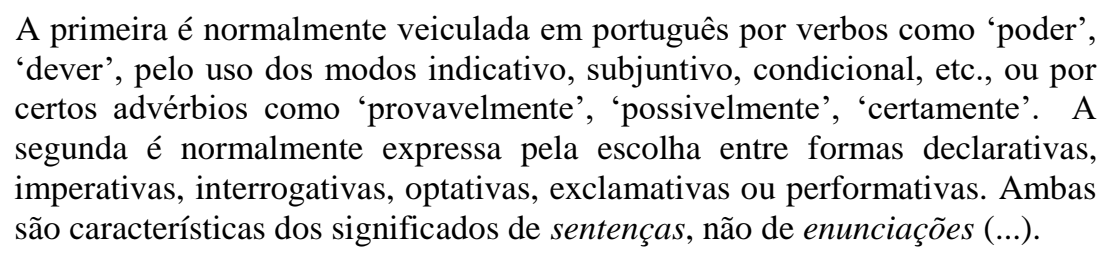

(DASCAL, 1982:120)

O autor não deixa de explicitar que alguns termos, tais como 'corrigir', 'explorar', 'recapitular', 'afirmar', 'justificar', 'ameaçar' ou 'divertir', possuem diferentes forças ilocucionárias e com diferentes tipos de reação, mas todas têm a mesma força semântica. 
Diante de tais colocações, o que Dascal (1982) quer assegurar é que, a partir do momento em que algum 'tipo de força' é selecionado no momento discursivo, as implicaturas vão diminuindo. Se outras forças são acionadas, o enunciado ficará cada vez mais compreensível para o outro, dispensando as implicaturas conversacionais.

O autor fecha seu artigo propondo a seguinte definição de Gunter (1974:53) sobre relevância: "o fenômeno que permite aos seres humanos conversar; ela deve ser considerada de suprema importância no funcionamento da linguagem e dos assuntos humanos".

\subsection{COGNIÇÃO E CULTURA}

Nesta seção apresentaremos as teorias e os estudos sobre a mente humana, bem como a importância de compreendermos as funções específicas de cada região do cérebro, especificamente as que se relacionam com o que distinguem os humanos das outras espécies: a linguagem e a memória. Além disso, apresentaremos os estudos que firmam as teorias sobre a possibilidade de um indivíduo tomar decisões sem ter "consciência", pelo simples fato de terem tido contato com o objeto $^{28}$. Apresentaremos, também, os postulados teóricos de Damásio sobre os estágios da mente e a finalidade de adentrarmos no campo dos estudos da consciência. E, por fim, pelo fato de que a língua ser nosso objeto de estudo, sentimos a necessidade de apresentar o olhar evolucionista de alguns pesquisadores sobre a linguagem humana.

${ }^{28}$ Objeto, para Damásio (2008) se refere a diversos elementos, tais como lugares, pessoas sentimentos, ações, etc. 


\subsubsection{O cérebro humano: a linguagem como o grande diferencial}

Safran (2003), em seus estudos sobre a linguagem, apresenta os apontamentos de Broca (1865), que propõe que uma área no interior do lóbulo frontal do hemisfério esquerdo era o substrato para a "linguagem articulada".

Diante dos estudos sobre a mente humana, e tendo um trabalho de pesquisa que envolve a interação linguística, sentimos a necessidade de tratar um pouco sobre os pressupostos teóricos desse assunto tão interessante e tão importante nos trabalhos que envolvem a linguagem, além das questões mais evoluídas da mente humana: a compreensão da intenção do outro.

São diversos os estudos que tratam das regiões do cérebro, bem como a diferença entre as funções que cada hemisfério possui e, de acordo Vânia e Caldas (2012), um hemisfério não tem relevância sobre o outro, como se pensava anteriormente, mas não se pode negar que a linguagem, localizada no hemisfério esquerdo, é a função que mais distingue a humanidade dos animais.

Que dentro do cérebro humano ocorram as diversas situações, tais como percepção, memória, emoções, isso não é novidade para nenhum pesquisador; no entanto, a preocupação da neurociência está em diferenciar as funções de cada região.

Como forma de verificar qual região do cérebro era responsável pela linguagem oral, alguns pesquisadores direcionavam seus estudos para pacientes que haviam perdido tal capacidade. Vânia e Caldas (2012) citam as pesquisas de Broca (1862), o qual, a partir do estudo de um cérebro de um doente que faleceu com essa perturbação, verificou que tal lesão se encontrava no lobo frontal do hemisfério esquerdo do cérebro, conforme podemos ver na imagem a seguir, o que o fez sustentar que essa região seria a responsável por comandar a linguagem oral. 


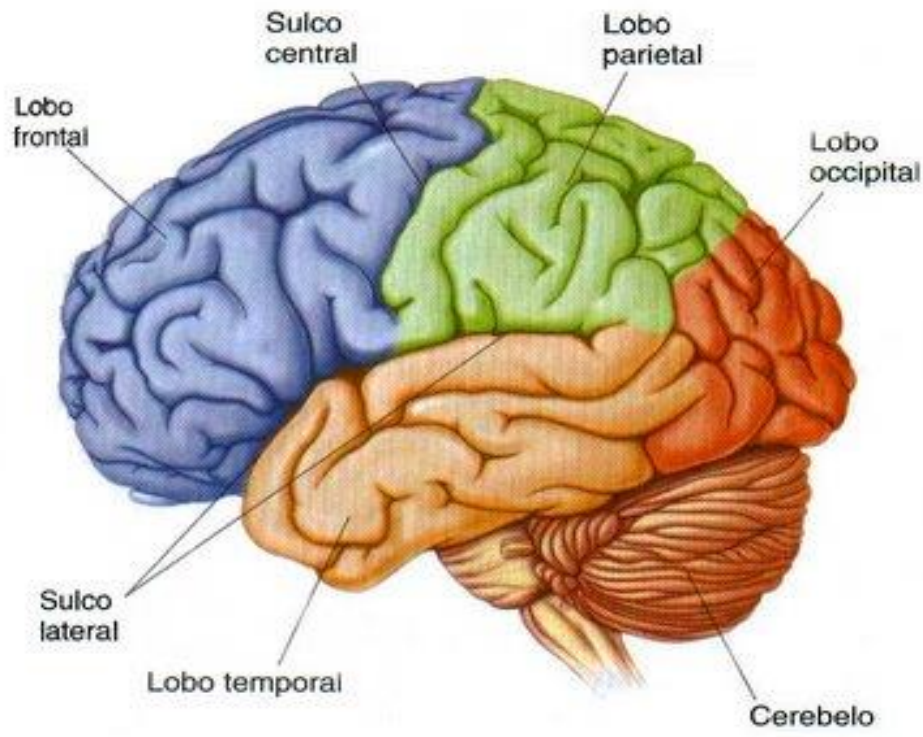

Imagem $1^{29}$ : lobo frontal esquerdo é responsável pela linguagem

Nos estudos das regiões cerebrais, Vânia e Caldas (2012) explicam que as funções cognitivas mais complexas passaram a ser descritas através dos diagnósticos das doenças, como por exemplo, a partir da descoberta de que pacientes com epilepsia tinham a região do hipocampo afetada, foi possível aos pesquisadores designarem essa região como responsável pela memória. Como podemos ver na imagem abaixo, o hipocampo se localiza nos lobos temporais do cérebro humano e tem como função transformar a memória de curto prazo em memória de longo prazo, interagindo com a amígdala, que é responsável pelo controle das atividades emocionais, tais como o medo e a ansiedade.

\footnotetext{
${ }^{29}$ Imagem do site: 〈http://simaia.blogspot.com.br/2012/11/como-funciona-o-cerebro.html〉 acessada dia
} $11 / 10 / 2015$ 


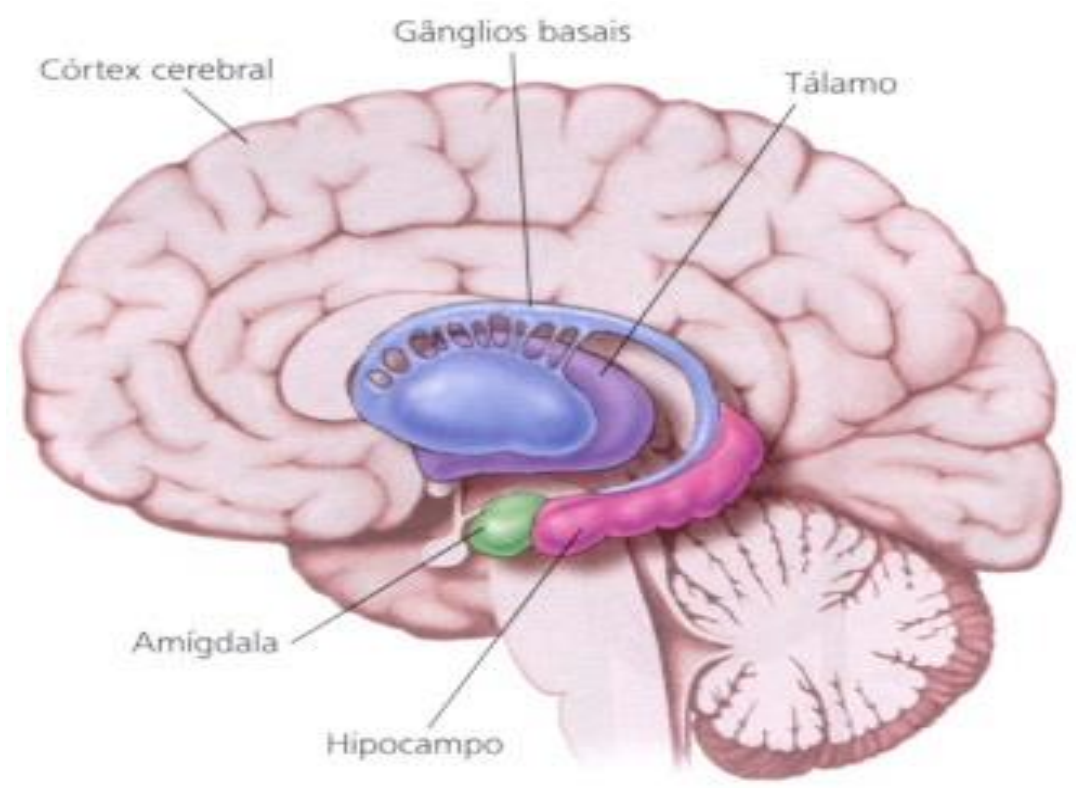

Imagem $2^{30}$ : regiões do cérebro: o hipocampo é responsável pela memória.

Vânia e Caldas (2012), em seus estudos, mostram-nos um caso de um paciente ${ }^{31}$ com o diagnóstico de uma lesão do hipocampo direito. Na cirurgia, contudo, constatouse que seria o esquerdo e que devido tal problema, ele não era capaz de reter informação mais do que 2 ou 3 minutos. Com tal estudo, os autores concluem que os dois campos (direito e esquerdo) são envolvidos em funções relacionadas à memória específica, a chamada memória de longo prazo. A evidência que, o paciente não teve sua memória de curto prazo afetada, mas somente a de longo prazo.

Como outros autores, Vânia e Caldas (2012) apresentam a importância dos estudos das alterações das funções mentais para que compreendamos os processos relacionados à memória, linguagem, etc. No entanto, não deixam de expor que nem sempre é possível compreender as funções normais apenas por tais modelos de estudos.

30 Imagem do site: < https://williamcarvalhoamaral.wordpress.com/tag/hipocampo/> acessada dia $11 / 10 / 2015$.

${ }^{31}$ Os autores apresentam em seu livro um caso de "um paciente que ficou famoso na literatura pelas iniciais do seu nome (H.M), que era doente e tinha uma lesão do hipocampo direito e a técnica cirúrgica utilizada constava a lesão do hipocampo esquerdo". 
Por tratarmos sobre as questões relacionadas à tomada de decisões com relação ao uso da LH ou não, recortamos o que tais autores falam sobre o assunto da mente humana, uma vez que é ela responsável pela decisão do falante em suas escolhas.

Neste postulado, Vânia e Caldas (2012) apontam que os estudos sobre processos mais complexos, como o reconhecimento de faces ou a tomada de decisão podem ser estudadas a partir da verificação da interação entre duas pessoas. Os autores asseguram que os estudos atuais sobre a mente fazem o registro simultâneo da atividade dos cérebros de pessoas interagindo, a fim de constatar, como por exemplo, a confiança ou a empatia.

Os autores apresentam que "cada processo mental pode envolver vários processos biológicos e, assim, para realizar uma tarefa ou para resolver um problema, o cérebro recruta o conjunto de regiões mais apropriado" (Vânia e Caldas 2012:11).

Nos processos de compreensão, de tomada de uma decisão, entre outros, a memória é extremamente importante, pois ela irá influenciar todas as outras funções cognitivas. Dessa forma, sem ela não seria possível, por exemplo, responder a pergunta de alguém durante uma interação.

\footnotetext{
Por exemplo quando, para estudarmos a compreensão de frase, pedimos a uma pessoa que agarre no papel com a mão direita, que o dobre ao meio e que o coloque sobre a mesa, a memória está sempre presente, para nos conseguirmos lembrar do que foi dito no início, até para sabermos o que é um papel.
}

(VÂNIA E CALDAS, 2012:15)

A memória é algo tão importante da mente humana que, como dizem os autores, sua alteração ficará muito mais evidente na velhice, pois é a fase da vida na qual já não se pode lembrar de muitas coisas, refletindo em prejuízos ao contexto comunicativo.

Caldas (1999), em estudos sobre a consciência humana, indo ao encontro à teoria de John Searle, afirma que a consciência e todos os fenômenos mentais não podem ser separados do cérebro propriamente dito, pois o que é mental é causado por processos neurobiológico inferiores ou superiores no cérebro. 
Caldas também toma por estudo algumas pesquisas ${ }^{32}$ relacionadas aos casos de doenças que afetam as regiões da mente ligadas à consciência e percebe que, para compreender muitas funções relacionadas aos estados mentais, seria importante uma observação de estruturas lesadas do cérebro.

A tomada decisão, ligada aos processos mentais de consciência, é um fator importante para que a interação discursiva ocorra, pois, ao receber a informação do outro, é necessário que uma decisão seja tomada.

O que ocorre de fato é que, como já temos visto nos estudos sobre a sociolinguística interacional, o ato discursivo depende de uma série de fatores para que seja compreensível e, por tratarmos de ações realizadas através de mecanismos advindos de processos do cérebro, não podemos deixar de questionar se, de fato, todas as atitudes, comportamentos, e decisões são conscientes nesse processo comunicativo.

De acordo com Knapp (1999), muitas intenções podem não estar presentes no diálogo, como em um "oi”, um "tudo bem”, o "levantar do polegar", e etc., mas é realizado como uso habitual. Não é difícil de imaginar como o uso habitual pode eliminar a consciência do emissor ao fazê-lo, mesmo que um receptor possa pensar que tenha sido feito conscientemente.

Em estudos sobre os mecanismos de tomada de decisão, para Caldas (1999) as ações conscientes e não conscientes, as quais são suas orientadoras, podem ser explicadas através das pesquisas com doentes amnésicos.

De acordo com o autor, em relatos de alguns pacientes com tal problema, os doentes, em suas diversas seções de testes, diziam nunca terem estado naquele [o local em que se encontravam] lugar antes. No entanto, com o decorrer dos testes, os pesquisadores passaram a perceber melhoras no desempenho, pois tais doentes acabavam por escolher os mesmos lugares que haviam se sentado nos testes anteriores, mesmo não se lembrando de terem já estado naqueles lugares anteriormente. Diante desses estudos da neuropsicologia, Caldas afirma que muitas tomadas de decisão podem, sim, ser feitas por mecanismos não conscientes do cérebro.

\footnotetext{
${ }^{32} \mathrm{O}$ autor faz referências às pesquisas realizadas por Damásio e Tranel nos anos 80 , os quais lidavam com pacientes com perca de memória; casos de prosapagnosia, uma perturbação da capacidade de reconhecer rostos familiares, uma lesão, em geral bilateral, dos lobos occipitais.
} 
Damásio (1999), ao tratar de pacientes com problemas relacionados à mente, nos fornece as informações que podemos ter de cada fenômeno e qual é a relação destes com a região cerebral.

O autor não aceita a ideia de que emoção e sentimento humano dependam da consciência, uma vez que esta primeira já existia bem antes e, no período de evolução, passamos a tomar consciência das emoções. Como já argumentado por Bateson (1998), isso é um indício de um processo de evolução, que culminará nas diversas estratégias de interação comunicativas mais abstratas, tais como compreender as intenções do outro a partir de simples pistas emitidas.

Damásio questiona sobre a existência ou não da consciência dos atos, ao falar de um de seus pacientes, o David, o qual teve uma grave encefalite que lhe causou uma lesão em ambos os lobos temporais, destruindo a região do hipocampo (responsável pela criação da memória e de fatos novos) e da região conhecida como amígdala (relacionada com a emoção). Devido à lesão, David era incapaz de aprender novas informações por tempo inferior a um minuto. $O$ paciente não lembrava quase nada sobre seu passado, apenas que era casado e que tinha dois filhos, mas não os reconhecia nem mesmo por fotografias.

Por perceber que David se comportava melhor com umas pessoas da clínica do que com outras, com a ajuda de seu colega Daniel Tranel, Damásio, em um teste, o expôs ao contato com três grupos de pessoas: as que o tratariam bem, ou seja, "as boas", as que o tratariam mal, "as más" e as que seriam "neutras". Durante o final de cada semana, era solicitado que ele escolhesse fotos dessas pessoas, e, embora o paciente não reconhecesse ninguém, escolheu $83 \%$ das vezes as fotos das pessoas boas, $56 \%$ das vezes as das pessoas neutras e apenas $22 \%$ das pessoas más, números que, segundo Damásio, não poderiam ser considerados coincidências.

Através dos resultados dos testes com David, Damásio também propôs, tanto quanto Caldas (1999), que muitas atitudes tomadas nem sempre estão no plano da consciência, mas são “induzidas de uma forma não consciente” (Damásio, 1999:68).

É claro que tratar das questões cognitivas não é algo simples e que podemos dar certezas em nossas entrevistas, no entanto, tais estudos nos levam a refletir se muitas 
respostas dadas e muitas atitudes tomadas por nosso entrevistados são feitas de forma consciente ou não.

O que queremos dizer é que, pensando nos processos que envolvem a mente humana, muitas vezes, respostas saem de forma espontânea, num grau de não consciência, ou seja, enunciados são construídos no seu cérebro, porém são expostas no discurso de forma involuntária. Tal afirmação foi tencionada a partir da gravação com uma de nossas entrevistadas, a título de ilustração, após ser perguntada sobre qual escola teria o ensino de língua portuguesa na região, nos forneceu a seguinte resposta:

(Entrevistada 2 - RS): "vem pra cá, altura da ifcola, dão af classes, ensinem (....). Um professor(...). Meu companheiro, que, é um professore, e são meus professores e tem purtuguêf de $\int \mathrm{de}$ os trê $\int$ anus como tem o inglês, me tem o inglês e me tem o purtuguê $\int$, e as crianças já vão..."

Diante da resposta dada pela entrevista, podemos fazer indagações sobre o grau de consciência que ela tinha no momento de sua fala. A falta de coerência e de sentido é um indício de que a pergunta não foi compreendida, no entanto, de forma involuntária, tomou a atitude de responder, sem nem mesmo saber o quê.

No capítulo desta tese em que será procedida a análise do sentimento de pertença, apresentaremos algumas tomadas de atitudes tanto comportamentais, quanto no discurso, que podem ir ao encontro das teorias aqui apresentadas sobre atitudes num plano de não consciência.

Jeannerod (2002), ao tratar de estudos que envolvem a interação entre os indivíduos, chamada por ele como "representação partilhada", afirma que a maioria das representações da ação se constrói de maneira não consciente e passa a ser consciente apenas no momento da ação. Para o autor, as próprias intenções são produzidas de forma inconsciente.

Jeannerod, através da observação de um paciente que tinha afetado seu hipotálamo posterior ${ }^{33}$, por um fragmento de granada, passa a pensar na possibilidade

\footnotetext{
33 A região do hipotálamo é localizada abaixo do tálamo, na região do diencéfalo, juntamente com o epitálamo e o tálamo. O hipotálamo possui ligação com todos os níveis do sistema límbico, que é responsável por controlar primordialmente as emoções e secundariamente participa das funções do aprendizado e memória. Além disso, o hipotálamo também possui ligação com o sistema nervoso e com o
} 
de um estado mental existir sem seu conteúdo específico. Seu questionamento se confirma por verificar que o paciente, toda a vez que inclinava a cabeça, sentia uma tristeza excessiva, mas não sabia se quer o motivo, afinal, não havia nenhuma razão, ou seja, apresentava um estado emocional sem conteúdo.

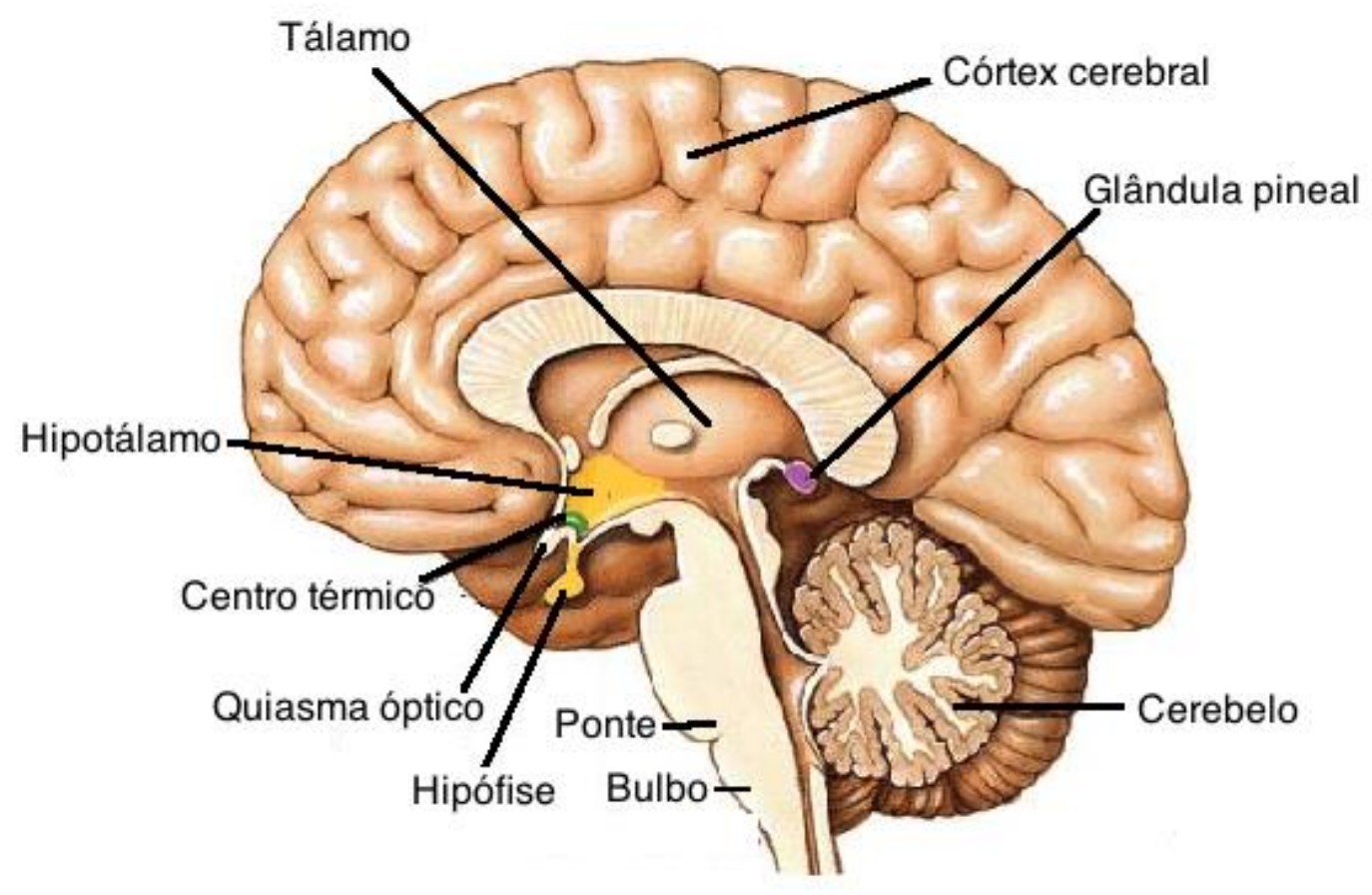

Imagem $3^{34} \mathrm{O}$ hipotálamo é responsável primordialmente por controlar as emoções.

Diante disso, afirma que uma intenção pode ter seu efeito sobre o comportamento através de mecanismos cerebrais, o que podemos pressupor que muitas atitudes tomadas durante um processo interativo, realmente não são conscientes, mas governadas pelos próprios componentes presentes no nosso cérebro.

De acordo com Damásio (1999), a atenção elementar é anterior à consciência, o que nos permite dizer que os indivíduos possuem uma atenção com relação às coisas no mundo, no entanto, nem todas podem ser consideradas consciência. Para o autor, a memória, as inferências intelectuais e a linguagem são primordiais para o processo de consciência alargada, a qual envolve o fenômeno biológico complexo que evolui ao longo da vida.

sistema endócriono, controlando a maioria das funções vegetativas, endócrinas, comportamentais e emocionais do corpo.

34 Imagem do site: < http://www.medicinageriatrica.com.br/2012/07/10/sudorese-hiperhidrosehipotalamica/> acessada dia 11/10/2015. 
Como temos visto, os processos mentais, não podem ser excluídos de um trabalho que envolve a compreensão de falantes de uma LH, pois nem sempre o que as palavras dizem está em plano de consciência alargada. Mais uma vez, paramos diante de questões que nos colocam em reflexões para além dos signos linguísticos.

\title{
1.7.2. Os estágios do "SELF": Uma teoria sobre os estágios da consciência humana
} - do inconscinte para o alto grau de consciência

Como já temos visto na seção anterior, para a compreensão e estudo do funcionamento do sistema cerebral, os pesquisadores, têm feito muito proveito dos progressos da tecnologia, a qual permite a análise de lesões no cérebro através da reconstrução em $3 \mathrm{D}^{35}$ nos pacientes vivos. Com isso, Damásio (2008) afirma ser possível propor teorias muito mais minuciosas sobre todos os aspectos da mente, do comportamento e do cérebro.

Ao propor a expressão metafórica "penetrar na luz" como sendo um dos momentos em que o indivíduo toma consciência das coisas que estão no mundo, Damásio (2008) apresenta que nem sempre o fato de estarmos diante dos acontecimentos é o suficiente para termos consciência sobre eles.

\begin{abstract}
Agora, que me preparo para escrever a Introdução deste livro e penso naquilo que escrevi, noto que o momento de penetrar na luz é também uma poderosa metáfora para a consciência, para o começo do conhecimento, para o momento ao mesmo tempo simples e empolgante da entrada de si no mundo da mente.
\end{abstract}

(DAMÁSIO, 2008:19)

Numa perspectiva neurocientífica, Damásio (2008), trabalha os estágios da consciência humana através do processo denominado de "self", que é o modo como os indivíduos "entram na luz", passando a compreender a "si" e as coisas que os rodeiam.

\footnotetext{
35 “A reconstrução em três dimensões do cérebro em 3D é exibida num ecrã de computador e baseia-se numa sofisticada manipulação de dados obtidos a partir de um <<scan〉> de ressonância magnética (MR). Com esta técnica é possível reproduzir estruturas neurais com grande fidelidade e realizar uma cuidadosa dissecação neuroanatómica num espaço virtual , em vez de o fazer na bancada de um laboratório" (Damásio, 2008:32).
} 
Em contradição com o que alguns estudiosos evolucionistas propõem, Damásio (2008) não vê a consciência como auge da evolução biológica, mas como algo que transformou os seres humanos durante a evolução histórica. A consciência é "a chave para uma vida examinada no melhor sentido e no pior" (Damásio 2008:22), além de nos permitir reconhecer os sentimentos, pensamentos, as palavras, as histórias, crenças e etc.

A consciência é algo surpreendente, pois, como Bateson (1998) afirma, ela é capaz de trazer o ser humano para reconhecimento de que seus sinais são sinais, e desenvolver interesses por si e pelos outros.

A partir da apresentação da importância da consciência, Damásio (2008) argumenta sobre a possibilidade de os seres humanos interagirem, tomarem atitudes sem que haja consciência, e é nesse ponto que entram questões de grande interesse para os que lidam com ações que dependem de um plano consciente, tal como os processos de interação comunicativa.

Para apresentar tal possibilidade, Damásio (2008) trata de um paciente que adentrou em seu consultório e por certo tempo ele não esboçava qualquer reação que fosse esperada. $\mathrm{O}$ autor relata que, durante alguns minutos, ele não respondia nenhuma pergunta e levantou sem objetivo nenhum, dirigindo-se à porta. Damásio, então, percebe que, por um período de tempo, esse paciente estava presente, realizava ações, porém sem qualquer indício de consciência, o que classifica com uma "crise de ausência", seguida por um período de "automatismo". Para o autor, era o momento em que ele assistia à passagem de uma mente consciente para uma desprovida do "self" (Damásio, 2008:23,24).

O problema da consciência, para o autor, vai além do "self", mas primeiro consiste em compreender como o cérebro arquiteta os padrões mentais e segundo em explicar como ele produz o sentido do "self"36 no momento de conhecer o objeto, que

\footnotetext{
${ }^{36} \mathrm{O}$ autor define "self" e "conhecer" como os processos que são produzidos na mente. Para exemplificar, pede para que o leitor, ao ler o seu texto e elaborar sobre ele, reflita sobre o que está acontecendo na mente. A mente, durante esse processo, não se limita apenas ao conteúdo da leitura, mas às percepções externas e as que estão armazenadas como memória. Todo esse conjunto leva o leitor a compreender que
} 
são as diversas coisas no mundo, tais como pessoas, lugares, sensações, etc. Esse segundo problema faz referência à compreensão do indivíduo sobre si mesmo, ou seja, compreender-se como o produtor de um texto (proprietário) ou como leitor dele (espectador), além de compreender as imagens do objeto e suas relações e reações com ele.

Em seu livro, Damásio (2008), diante das observações dos seus experimentos neuropsicológicos, apresenta quatro pontos de partida para a construção de sua teoria e mais um último ponto:

(i) a primeira é que alguns aspectos da consciência podem ser relacionados com as regiões específicas do cérebro;

(ii) a segunda é que a consciência e a vigília ${ }^{37}$ podem sim estar separadas;

(iii) a terceira é que consciência e emoção não podem separar-se, ou seja, quando a consciência está alterada, o mesmo se passa com a emoção;

(iv) a quarta, que é o fato de que a consciência é dividida em consciência nuclear ou simples, que é a biológica, e a consciência alargada ou complexa, que é aquela em que o indivíduo está em alerta para o mundo, compreende-o como pessoa participante dele;

(v) e a quinta, e última, que é o fato de que a consciência é simplesmente explicada em termos de outras funções cognitivas, tais como linguagem, a memória, a razão, a atenção e a memória de trabalho.

A partir dessas considerações, o autor passa a falar sobre a correspondência entre os dois tipos de consciência e os tipos de self. De acordo com sua teoria, o sentido do self que surge na consciência nuclear é o self nuclear, o qual é transitório na mente, levando o cérebro ao contato de todos os objetos com os quais ele interage.

Após a interação com os objetos ao redor, família, cidade onde nasceu, o nome, etc., num processo de self nuclear, o indivíduo passa para um estágio de conhecer e compreender tais objetos, bem como o reconhecimento de sua própria identidade, nesse

ele é o leitor e não outra pessoa, é o que Damásio afirma "ator potencial sobre as coisas imaginadas" (Damásio, 2008:27).

${ }^{37}$ A vigília se refere a "estar vígil, significa estar acordado” (Damásio, 2008:34). 
caso, o autor está discutindo o processo de self autobiográfico. Embora acredite que a consciência seja simplesmente explicada em termos de outras funções cognitivas, Damásio (2008) ressalta o quanto a memória, as inferências e a linguagem são importantes para o estágio do self autobiográfico.

Para dar uma explicação geral sobre a teoria do self, Damásio (2011), propondo que o cérebro constrói a consciência gerando um processo do self em uma mente em estado de vigília, fornece o seguinte quadro:

(i) o primeiro, o "protosself", relacionado aos sentimentos espontâneos (sentimentos primordiais), é representado pelos usos que o falante traz como herança, sem a consciência num uso totalmente espontâneo;

(ii) o segundo, o self central, representa o momento em que o indivíduo, em situações interativas, revela modificações ou adaptações em face do contato com outras situações em que se insere e experiencia situações;

(iii) e o terceiro, o self autobiográfico, em que o indivíduo reflete sobre as situações e coloca-se como um ser mais consciente das alterações necessárias, bem como as adaptações exigidas para que a interação ocorra. Neste último estágio, a interação é mais consciente, revelando opções e usos de um indivíduo que elabora com algum controle (os graus de controle e de consciência podem ser variados) suas manifestações.

O fato de apresentarmos nesta seção a teoria de Damásio sobre os estágios de consciência se relaciona com o fato de que esta pesquisa (a desta tese) se volta para um trabalho de campo que envolve um interação discursiva que depende de um estado de consciência para que seja eficaz e para que possamos responder nossas indagações iniciais.

No trabalho de campo que realizamos em Olivença, dialogamos com os informantes e, na forma de elaboração de suas respostas, pudemos reconhecer pessoas mais ou menos conscientes de sua forma de comunicação linguística. Para os indivíduos mais experientes e maduros, notamos a consciência se manifestando em graus de atenção e de vigília para a própria forma de manifestação comunicativa. Hipotetizávamos, inicialmente, que, a partir do momento em que os usos do português 
oliventino e da LH fossem percebidos e utilizados com maior atenção, estariam vinculados ao estágio self autobiográfico. Ao contrário, os usos mais mecânicos e automatizados seriam evidências de que o protosself ou self central, por força do hábito - força que nos impele a automatizar e não discernir - seriam mecanismos em ação.

Pudemos notar que, por mais que os informantes não usassem o português no seu dia a dia, transmitiam em seu discurso um sentimento de pertença à comunidade portuguesa. Nesses momentos, era claro o desejo de que a LH não fosse excluída de seu convívio, reconhecendo-a como o elo com seu grupo étnico. Vejamos algumas evidências disso:

Informante 1 (Fernando): Certeza mesmo, teria que apreender a falar português. [Aqui, o informante se referia à necessidade de ensinar o português aos filhos]

Alguns falantes, classificados por nós como integrantes do estágio de self central, por articularem mecanicamente português-espanhol (falantes bilíngues) são capazes de fazer uso da língua da sociedade receptora sem perder ou deixar que essa interfira na sua LH. Percebem, no entanto, que muitas vezes, em momentos isolados, ou seja, provavelmente em estágios de protosself, reveberam palavras de sua língua nativa ou da língua da sociedade receptora, num cruzamento comunicativo típico de codeswitching. Eles próprios reconhecem o fato:

Informante 1 (Fernando): muito muito pouco, muito pouco, por ixemplo, principalmente, sei lá, por ixemplo, acabar de falare ao tufone com minha mãe, tô a falar purtuguêf e aparecer alguém a perguntar-me qualquer coisa, sou capaz de continuar a falar purtuguê

Como podemos depreender desta exposição, os estágios do self, tal como proposto por Damásio $(2008 ; 2011)$, estão presentes durante um trabalho que envolve a entrevista como metodologia de pesquisa, e assim, nos sentimos tentados a apresentar, nas análises, o reconhecimento de alguns desses estágios. 


\subsection{A mente humana sob uma perspectiva evolucionista}

Como já apresentado na seção 1.6.1, Bateson (1998), ao observar atitudes conscientes do comportamento humano, reflete sobre os elementos presentes no processo comunicativo através de uma perspectiva evolucionista.

$\mathrm{O}$ autor trata do quanto o homem é capaz de modificar coisas no mundo devido à evolução da sua mente, como, por exemplo, passar a ter a consciência de que tem um cheiro próprio da natureza humana, e que pode ser modificado através dos recursos disponíveis no meio ambiente, tais como as plantas com cheiros, que são transformadas em perfumes agradáveis aos seres humanos.

Tal ilustração tem como finalidade demonstrar o quanto os seres humanos, num processo evolutivo, se tornam capazes não só de perceber seus próprios sinais, ou seja, "descobrem que seus sinais são sinais" (Bateson, 1998:59), mas também tornam-se capazes de modificá-los para seu próprio bem ou interesse.

O que percebemos então, é que a mente humana evolui de um estágio de apenas ter sinais, ou seja, num plano inconsciente, para o reconhecimento desses sinais e, além disso, para a capacidade de manipular elementos que possam modificar esses sinais. Diante dessas teorias, não podemos deixar de afirmar que a fala, a produção de implicaturas conversacionais e o reconhecimento dessas implicaturas são todos oriundos desse processo evolutivo da mente humana.

A comunicação humana difere da comunicação de outras espécies pelo compartilhamento de intenções, através do qual, o homem é capaz de emitir sinais e reconhecer os sinais do outro e suas intenções. Assim, Bateson (1998) descreve o quanto as interpretações entre os participantes em um ato discursivo, que envolve uma série de recursos para que ocorra, é um sinal de evolução.

Da mesma forma que muitas ações podem ser interpretadas erroneamente, muitas falas também o podem; e, para que isso não ocorra, os seres humanos fazem uso de todos os recursos presentes na interação discursiva, tal como já apresentamos na seção sobre sociolinguística interacional. O que ocorre então é que, num processo de 
evolução da mente, o ser humano passa a se tornar cada vez mais hábil em reconhecer tais pistas e, até mesmo, maquiá-las para que o outro seja "enganado", caso seja essa sua intenção.

Se a mente humana evolui, a comunicação presente entre os humanos também evolui, e passa de estágios mais simples para os mais complexos e abstratos possíveis, sendo capaz de, durante a fala, de forma consciente ou não, abandonar algumas máximas (Grice, 1982) pelo fato de reconhecer que o outro o compreenderá sem nenhum prejuízo.

Mithen (1998) também trabalha com a ideia de que a mente moderna é capaz de revelar a natureza da mente ancestral, pois ela, tanto quanto o corpo, sofreu evolução no tempo, e, portanto, desenvolveu habilidades cognitivas tão complexas que dantes não existiam.

Da mesma forma que Bateson (1998) percebe a evolução do homem através de ações conscientes, como o uso de perfumes para mascarar cheiros que ele não gosta, Mithen (1998) já falava em compreender o passado e a evolução da espécie humana, simplesmente olhando para nosso próprio corpo hoje.

Mithen explica que, se ficarmos em uma banheira cheia de água, nossa pele ficará com o aspecto de "pele de galinha" como a denunciar que a água não é ambiente natural desse tipo de revestimento. Também ocorre uma ação diferenciada como o frio: ficamos com a pele arrepiada. Isso ocorrerá porque nossos ancestrais de Idade da Pedra, por serem muito mais peludos, protegiam-se do frio, mantendo uma camada de ar quente entre os pelos e a pele. Hoje, sem esse recurso, ao sentirmos frio, nossas peles se arrepiam, eriçando os pelos e buscando proteção que tínhamos sem sucesso. Com a ilustração, fortifica-se a ideia de que, durante o processo evolutivo, embora haja evolução do corpo e da mente, algumas marcas permaneceram e podemos identificá-las.

Através da expressão efeito "catraca", Tomasello (1999) também fala sobre a evolução da espécie humana, propondo que os seres humanos utilizam seus objetos, como suas ferramentas e utensílios e, à medida que vão compreendendo a possibilidade de novas funções para elas, as modificam e a voltam a transmiti-la aos seus descendentes. 
Para que ocorra esse efeito "catraca", é necessário que se manifeste um processo de confiabilidade para que o artefato modificado no tempo não perca totalmente suas características, mas que cada vez mais se aperfeiçoe. Apropriarmo-nos desse conhecimento possibilita que associemos os processos da evolução da língua com o efeito proposto por Tomasello da seguinte maneira: a língua não se modifica totalmente perdendo todas suas propriedades, mas ela, à medida que vai passando de geração a geração, vai ganhando modificações. Sua aceitação e incorporação como uso favorecem que a dinâmica se replique e, dessa forma, se manifeste até que alguns grupos em novo uso a passem de forma mais modificada, sem, no entanto, perder suas características mais primitivas, ainda que sejam vistas pelos falantes de forma bastante superficial. Considerando que o PLH pode ser lido como um desses efeitos "catraca", é possível hipotetizar que o falante receba essa variedade e a use, podendo até mesmo mantê-la como memória de sua funcionalidade social, como, por exemplo, ocorre em placas de rua.

Tomasello afirma que, nesse processo evolutivo, os seres humanos desenvolvem maneiras diferentes para que possam se identificar com seus coespecíficos e compreendê-los como seres intencionais. O fato de seres humanos se identificarem como seres intencionais corrobora com o que Bateson (1998) afirma: é um processo de evolução da mente.

Como sabemos, toda mudança depende de estímulos tanto internos quanto externos, e para Tomasello, os seres humanos poderiam adquirir habilidades cognitivas mais complexas, tais como Bateson propõe, mediante a interação dos indivíduos no tempo histórico.

O "efeito catraca", por representar algo que irá ser passado adiante e não tem como voltar, representa tudo o que é modificado no tempo, e que, portanto, não mais retrocederá, pois não poderá voltar a ser como era no início, mas as novas funções adquiridas são adaptadas e repassadas entre os indivíduos, os quais a utilizarão até que alguns a modifiquem novamente, e assim por diante.

Wall e Ferrari (2010) em uma perspecitiva de pesquisa, chamada de "bottomup”, demonstram que os mecanismos de evolução são antigos, e que existe a possibilidade de homologias no domínio cognitivo, ou seja, uma ancestralidade 
compartilhada. Isso teria um efeito de união dos diversos fenômenos entre as diferentes espécies como o canto, armazenamento de comida pelas aves, o que demonstra planejamento futuro, aprendizagem, comportamento pró-social não só em humanos, etc.

Segundo os autores, é preciso entender que todas as espécies, inclusive a nossa, já trazem componentes antigos da cognição e que precisamos compreendê-los melhor para depois nos concentrarmos no que faz a cognição de cada espécie especial.

Assim como Mithen propõe que no tempo evolutivo, embora soframos mudanças, algumas características são preservadas, Tomasello (1999) e Wall e Ferrari (2010) propõem que também preservamos características cognitivas herdadas, as quais são partilhadas e modificadas, mas que estarão desde sempre conosco, e que podem ressurgir a depender da necessidade.

Dalgalarrondo (2011) igualmente afirma que cada espécie tem suas peculiaridades adaptativas, e que o processo evolutivo, até certo ponto, é conservador, não perdendo características antigas para recomeçar do zero, mas as reutiliza de acordo com a exigência de seu contexto. Coerentemente com as ideias de Tomasello, esse autor defende a evolução de forma cumulativa sem um "caminho de volta" para as estruturas antigas.

Talvez assim possamos explicar o porquê de alguns usos na língua sumirem por muitas gerações e, de repente, passarem a ser usadas como se sempre estivessem entre seus falantes. Uma ilustração disso podemos enxergar no uso da LH em Olivença, que foi excluída da comunidade por muito tempo, mas em um período recente, as camadas mais jovens se pegam utilizando em conversas espontâneas, inclusive sentindo a necessidade de estudar a língua de seu grupo étnico. 


\section{CAPÍTULO 2}

\section{O LOCUS DA PESQUISA - OLIVENÇA FRONTEIRA COM ELVAS}

Neste capítulo apresentaremos a cidade de Olivença, que é o locus da pesquisa, bem como Elvas, que é a cidade que faz fronteira geográfica e política. Como temos apresentado a língua como uma das marcas de etnia, trataremos aqui da disputa entre portugueses e espanhóis para que a cultura seja mantida na comunidade portuguesa. Como é sabido, uma $\mathrm{LMg}$ e uma LH são quase sempre línguas minoritárias e suscetíveis a uma série de preconceitos. Assim, para que estas sejam preservadas entre seus falantes, é necessário que tenham consigo um sentimento de pertença linguística. Trataremos, então, de apresentar inicialmente o lugar no qual o contato ocorre e que fatores podem contribuir para a preservação ou não da $\mathrm{LH}$ entre os portugueses oliventinos. 


\subsection{OLIVENÇA - A região de contato}

Como esta tese está voltada para a língua falada por portugueses que vivem em Olivença e para LH na cidade, não seria possível apresentarmos as pesquisas sem antes tratar dos aspectos geográficos e sociais da região.

No mapa que segue, localizamos a cidade de Olivença como pertencente à Espanha, embora já tenha sido domínio português pelo Tratado de Alcanices de 12 de Setembro de $1297^{38}$. Com isso, a língua sob estudo se encontra numa posição de enorme conflito tanto social quanto político, fato que a torna mais interessante ainda para estudo.

Olivença é uma região que recebeu uma série de influências na língua da comunidade local, que, em sua maioria, é bilíngue, mas não perdeu os laços com sua língua nativa. Por isso, além do português falado em Olivença ser um objeto interessante por si, ainda nos deparamos com a atitude dos falantes dessa língua revelada durante as entrevistas que fizemos. Nelas, verificamos que o fato de viverem em uma região fronteiriça, o sentimento de pertença nem sempre coincide com a divisão geopolítica. Essa falta de coincidência, às vezes, desenvolve discórdias identitárias bastante acentuadas.

Observando os mapas I e II, é possível verificar que Olivença é fronteira com Portugal, e dessa forma, torna-se um ambiente propício a que situações de bilinguismo e de LHs tenham espaços específicos para se revelarem. Essa é uma das razões por que decidimos realizar esta pesquisa. No mapa, Espanha e Portugal estão situadas em regiões circunvizinhas, em que o contato entre os habitantes dessas regiões seja frequente. Tanto os países em fronteira ${ }^{39}$, como também seus povos nessas regiões

\footnotetext{
${ }^{38}$ Pereira (1968) explica: Famoso Tratado pelo qual Portugal entregava à Espanha as Vilas de Aroche e Aracena e em troca, a Espanha entregava, além das terras de Riba-Coa, as Vilas de Jerumenha, Ouguela, Campo Maior e Olivença. Assim, a partir de 4 de Janeiro de 1298 Olivença passa a pertencer a Portugal. No anexo II (parte I e II) apresentamos uma cópia do Tratado de Alcanices, da Biblioteca de Lisboa e um trecho deste documento digitado, xerocado do livro Nos caminhos de Olivença, Luna (2000).

${ }^{39}$ Como já apresentado também, o termo fronteira desde seu uso mais primitivo já nos remete ao sentido de disputa e defesa de suas terras, sendo assim, podemos pensar na relação com a língua, uma vez que, embora em condições de grupos minoritários, os portugueses se sintam fortalecidos em seu sentimento de pertença linguística justamente por estarem próximos geograficamente de seu grupo étnico.
} 
detêm espaços híbridos em que a separação em nacionalidade somente não é suficiente. Seus sentimentos de pertença podem não coincidir com essa divisão política.

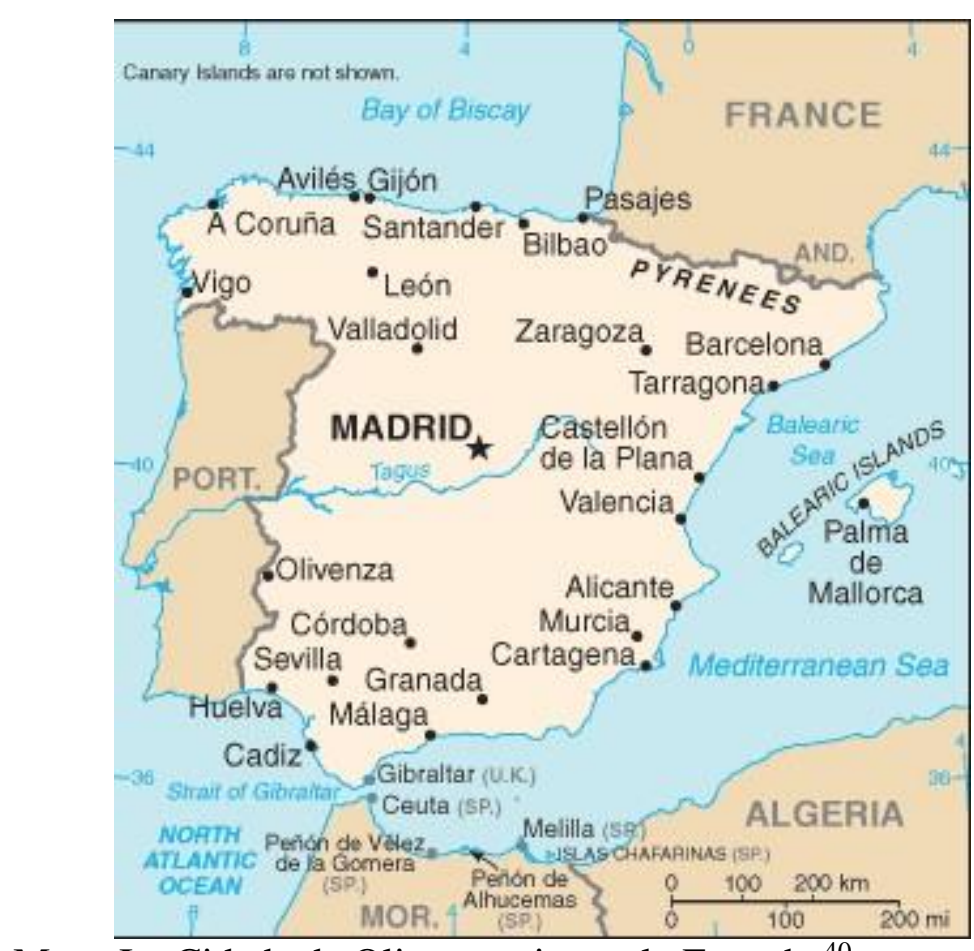

Mapa I - Cidade de Olivença vista pela Espanha ${ }^{40}$

\footnotetext{
${ }^{40}$ Imagem retirada do site: <<https://www.google.com.br/?gws_rd=ssl\#q=mapa+de+oliven\%C3\%A7a+portugal 〉> acessado dia $04 / 05 / 2015$.
} 


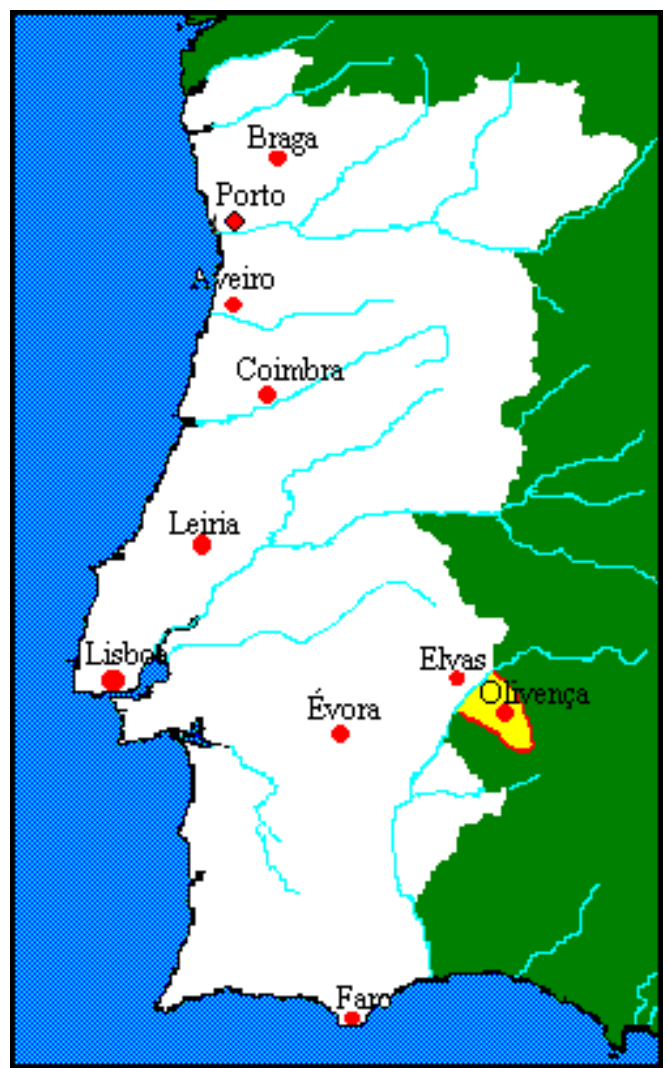

Mapa II - Cidade de Olivença vista por Portugal ${ }^{41}$

Os mapas, por razões históricas, não são coincidentes nas perspectivas, e aqui nos referimos a uma perspectiva política. Enquanto Portugal a inclui como parte anexa, um apêndice, a Espanha a inclui como parte integrante da região pertencente à sua soberania.

\subsection{OLIVENÇA - como é apresentada entre os veículos de informação e de pesquisa}

\footnotetext{
${ }^{41}$ Imagem retirada do site:

<<https://www.google.com.br/?gws_rd=ssl\#q=mapa+de+oliven\%C3\%A7a+portugal〉> acessado dia $04 / 05 / 2015$.
} 


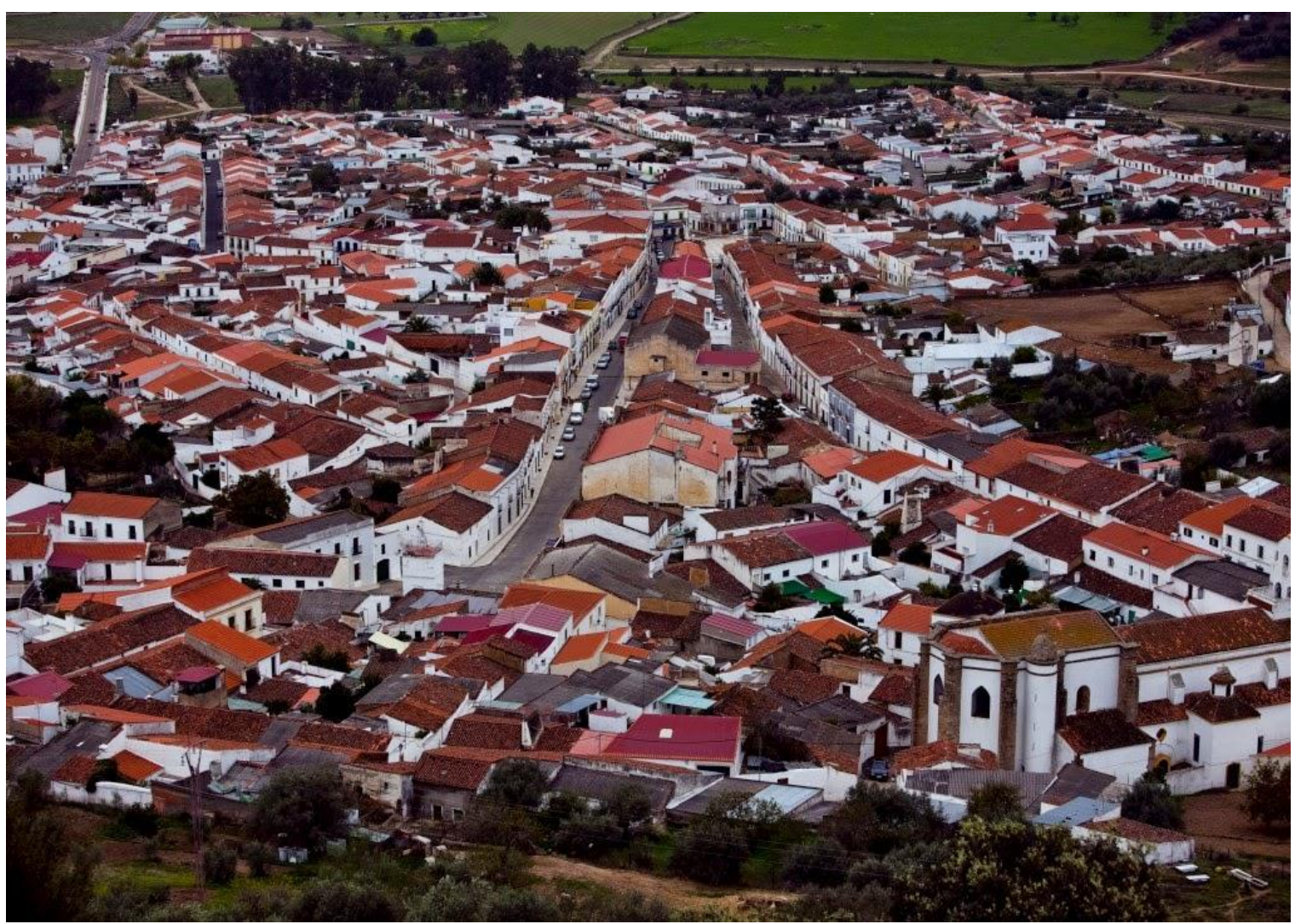

Imagem 4 - Cidade de Olivença ${ }^{42}$

Que Olivença é uma comunidade autônoma e pertencente hoje à Espanha é a informação claramente divulgada em livros e sites de pesquisa, no entanto, essa pertença não foi tão bem aceita assim por alguns portugueses, entre eles, pesquisadores, tais como Sequeira e Júnior (1924), Almeida (1926), Veloso (1939), Rodríguez (1949), Caldas (1975), Luna (2000; 2007), Sánches Fernández (2004; 2008), Parreira (2010) e Consiglieri e Brito (2012) entre outros.

Caldas (1975) fica indignado com o descaso sobre o que considera a verdadeira história de Olivença. De acordo com o autor, os livros restringem-se apenas a informar suas características geográficas e que esta foi 'CONQUISTADA' a 20 de maio de 1801 pelo exército espanhol sob o comando de D. Manuel de Godoy, omitindo as guerras ocorridas, a grande violência utilizada para tal e, inclusive, não tratando da influência da França nesse domínio.

\footnotetext{
${ }^{42}$ Imagem retirada do blog HTTP://depoisfalamos.blogspot.pot/
} 
Parreira (2010) também apresenta em seu artigo que, apesar de existir uma aparente normalidade entre Portugal e Espanha, as relações são bastante conturbadas pela disputa histórica de Olivença, e que as instâncias governamentais não se importam com o caso, parecendo "ter colocado o problema na gaveta". O autor argumenta ainda que os problemas históricos ocorridos, somente tempos depois começaram a ser expostos, graças a alguns falantes da língua nativa que não aceitam que a LH falada no seio familiar seja exterminada. Esse é o caso da Associação Além Guadiana, da qual trataremos adiante.

A cidade de Olivença foi fundada no século XIII, com uma área total de 430,1 $\mathrm{Km}^{2}$. Em 2012, concentrava 12.002 habitantes; hoje, com dados fornecidos pela Câmara Municipal, conta com 12.000, sendo que 138, ou seja, apenas 1,2\% destes são de origem portuguesa $^{43}$. É uma cidade e município numa zona fronteiriça, cuja demarcação é objeto de litígio entre Portugal e Espanha. Atualmente, no entanto, Olivença integra a comunidade autônoma espanhola da Estremadura.

Tudo indica que nunca houve uma relação amistosa entre ambos os países e que Olivença vive em um ambiente de tensão durante séculos, estando, pois, diante de um país com características de puro domínio. Matias (2001) apresenta-nos que fortes laços comerciais, afetivos e de lazer ligavam-na a Elvas, Juromenha, Vila Viçosa, Estremoz e Campo Maior, inclusive afinidades linguísticas. Nesse contexto, pode-se inferir o que a população oliventina sofreu com o tratado de 1801, apresentado com detalhes adiante. Como é possível notar, o assunto não é considerado pelos estudiosos em nenhum momento como uma questão resolvida ou que reflita a tranquilidade do povo.

Em 1297, o Tratado de Alcanices estabelecia Olivença como parte de Portugal, no entanto, como evidenciaremos adiante, de forma obscura aos olhos dos portugueses, através do Tratado de Badajoz, denunciado em 1808 por Portugal, o território foi anexado à Espanha. Mas em 1817, a Espanha reconheceu a soberania portuguesa ${ }^{44}$ subscrevendo o Congresso de Viena de 1815, comprometendo-se à retrocessão do território o mais prontamente possível, o que, até aos dias de hoje, ainda não aconteceu.

\footnotetext{
${ }^{43}$ A informação sobre a quantidade de habitantes foi colhida pessoalmente no dia 17/04/2015 às 13:00 h na própria Câmara Municipal de Olivença.

${ }^{44} \mathrm{Na}$ verdade, de acordo com os pesquisadores, não se tratava de um ato de reconhecimento por parte da Espanha, a qual é vista, sobre o olhar de estudiosos, como pouco amistosa e, portanto, nunca reconheceria soberania de Portugal, mas sim se viu na condição de cumprir o que o tratado de Viena havia estipulado.
} 
Sobre tal tratado, Picão (1947) expõe que, embora em 1297, pelo tratado de Alcanices, Olivença, Campo Maior e Ouguela tenham sido integradas ao Reino de Portugal, do ponto de vista religioso ainda permaneciam até 1444 ligadas a Badajoz, uma cidade espanhola.

Portugal, por sua vez, reivindica que Olivença é um concelho português do Distrito de Portalegre, sub-região e província do Alto Alentejo, a qual é dividida em cinco freguesias: Santa Maria do Castelo, Santa Maria Madalena, São Jorge da Lor, São Domingos de Gusmão e Nossa Senhora de Táliga (atualmente município).

\subsection{Localização de Olivença}

Como pudemos evidenciar anteriormente, decepcionado diante da falta de informações importantes sobre Olivença, Caldas (1975) afirma que, em todos os livros escolares e em algumas enciclopédias espanholas, é possível encontrar somente a descrição geográfica de Olivença da seguinte forma: “Olivença dista 24 quilômetros de Badajós - Elvas, na província do Alentejo. Faz parte, atualmente, dos nove municípios da província de Badajós. Sua extensão territorial é de 1.410 quilômetros quadrados, tendo por limites: ao Norte, Badajós; a Leste, Almendralejo e Jerez de las Caballeras; ao Sul, ainda esta última localidade; e a Oeste, Portugal. No sentido Noroeste, onde seu território forma uma espécie de península encravada entre os citados lugares, levanta-se a Serra do Jerez. Olivença é banhada pelos rios Taliga, Ramapalles, Olivença, FriegaMunhoz e Alcarache, todos eles afluentes do Guadiana. Em 1910 acusava 12.194 habitantes" (pág 27).

Em Matias (2001), podemos encontrar as informações de que o município de Olivença, situado à margem esquerda do rio Guadiana, com uma forma aproximadamente triangular, fica a vinte e três quilômetros de Elvas, vinte quatro quilômetros de Badajóz, duzentos e trinta e seis quilômetros de Lisboa e quatrocentos e vinte e quatro quilômetros de Madrid. Assim, a autora nos apresenta a cidade de Olivença e suas imediações, bem como a grande proximidade com Portugal. 
A ligação a Elvas e ao restante do território português é feita por uma ponte sobre o rio Guadiana construída em 2000 ao lado das ruínas da Ponte da Ajuda, também chamada de Ponte de Olivença, mostrada na imagem $5^{45}$. Abrantes (1951), a despeito de tal Ponte, destruída anos depois pelos confrontos com os espanhóis, afirma ser um presente do Rei D. Manuel como forma de recompensar os oliventinos pela dedicação e esforço, pois eram motivos de grande orgulho para a nação:

Tão grande foram as raízes Foral no espírito do povo que fora mandado povoar o burgo, que ainda hoje o oliventino conserva o hábito, de vários atributos criados pela sua origem, honra e orgulho do seu Rei!

(ABRANTES, 1951:58)

A Ponte tinha como própósito, segundo o autor, integrar os oliventinos a 'sua Pátria', como 'um grito de amor à Pátria criadora', sendo, sua destruição, portanto, algo que separava ainda mais os portugueses oliventinos de sua nação.

De acordo com Oliveira (2012), no período da guerra da Restauração ${ }^{46}$, que durou vinte e oito anos (1640-1668), com ataques espanhóis principalmente a Campo Maior e Olivença, a Ponte de Olivença tornou-se vital nas deslocações dos exércitos, para a defesa da vila, no entanto, acabou tornando-se um 'alvo estratégico que o inimigo ambicionava destruir'. A ponte foi definitivamente destruída em 1709, durante a Guerra da Sucessão da Espanha ${ }^{47}$, isolando ainda mais Olivença de Portugal.

\footnotetext{
${ }^{45}$ Em Oliveira (2012) D. Manuel I, conhecido como o Venturoso, ordenou que se construísse a Ponte em 19 de dezembro de 1510 sobre o Rio Guadiana, ligando Elvas a Olivença, construída em sua margem direita. Ruy Lobo, na época, foi nomeado superintendente de sua construção, que aceitou com a condição de que ela havia de se chamar 'Ponte de Olivença' e os moradores daquela região não deveriam pagar nada pela obra. Oliveira (2012) afirma que, após a morte de Ruy Lobo, Antônio Sequeira,morador de Olivença, assumiu a superintendência da obra da vila, e propôs ao rei a fundação de uma povoação próxima à ponte, o que nunca aconteceu. As datas de sua conclusão não são certas, compreendendo os períodos de 1510 a 1514. Alguns dizem que a ponte tem 18 arcos, mas o autor, numa análise 'in loco',afirma que ela teria 19. Em 1594/1595 devido às cheias dos invernos rigorosos, alguns arcos desabaram, sendo reparados apenas em 1635. Em 1645, durante a Guerra da Restauração, dois arcos centrais foram destruídos, provocando a ela grande ruína. Em 1683 foi instituído um imposto para sua reconstrução, mas entre 1687-1688, devido o grande inverno, a ponte sofre mais ruínas. Em 1698 e 1700, trinta anos após o fim da guerra com a Espanha, formalizam-se as condições para sua restauração, o que não ocorreu, pois Portugal, além de uma grande crise financeira e política, entra novamente na Guerra de Sucessão de Espanha. Em 1709, o Marquês de Bay, em ataque a Olivença, ordena a destruição da ponte após a passagem de seu exército, a fim de que a cidade não pudesse ser ajudada. De acordo com Oliveira (2012), Bay não conquistou Olivença, 'mas conseguiu cortar o cordão umbilical que unia a vila a Portugal'.

46 De acordo com Oliveira (2012), A guerra da Restauração foi o 'momento da restauração da independência de Portugal'.

${ }^{47}$ No anexo III (partes I a VII) constam documentos da Guerra da Sucessão da Espanha recolhidos na Biblioteca Nacional de Lisboa dia 27 de março de 2015. Constam documentos sobre as vilas e lugares que estavam sob obediência dos comandos da época, inventário das munições de guerra, com letra da época e com data do começo do século XVIII; decreto nomeando D Pedro de Almeida como ajudante de
} 


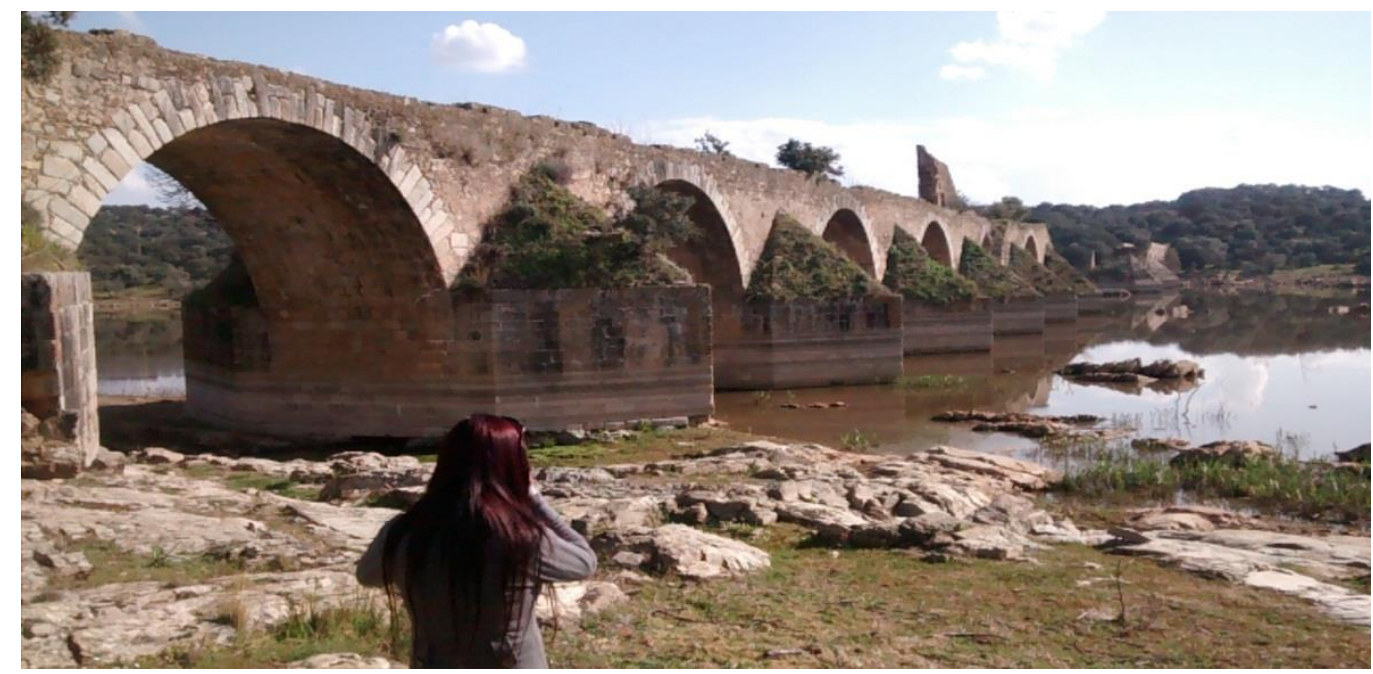

Imagem 5: Ponte de Nossa Senhora da Ajuda, também nomeada Ponte da Ajuda e Ponte de Olivença no Alentejo. Aberta em 1510 e fechada em $1709^{48}$.

O municípiode Olivença inclui hoje duas vilas e quatro aldeias: São Francisco e São Rafael (vilas); e Vila Real, São Domingos de Gusmão, São Bento da Contenda e São Jorge da Lor (aldeias). Nossa Senhora da Assunção da Talega ou Táliga, outra povoação do antigo território de Olivença, é um município separado desde 1850, embora; sejam cidades muito parecidas. Ao contrário disso, a aldeia de Vila Real, que era freguesia do concelho de Juromenha, hoje é parte de Olivença.

\subsection{Clima e hidrografia de Olivença}

Olivença é uma região próxima ao Alentejo ${ }^{49}$ e com características climáticas e geográficas semelhantes. Em um estudo sobre estas regiões, Picão (1947) aponta que, como em quase todo o Alentejo, as herdades ${ }^{50}$ da região elvense ${ }^{51}$ abrangem vastas

Carlos III, cópia da época e com a data de 6 de abril de 1706; lista do exército de Portugal que entrou em Castela e chegou e Madrid em 1706; além da lista de oficiais mortos na Guerra da Sucessão, com a letra da época.

${ }^{48}$ Foto tirada em março de 2015. A ponte situa-se sobre o rio Guadiana. A monumental obra de arquitetura militar era essencial à defesa de Olivença, explodida mais tarde com a Guerra de Sucessão Espanhola.

${ }^{49}$ Matias (1984) descreve o Alentejo como a maior região de Portugal, compreendendo os distritos de Portalegre, Évora, Beja, parte dos distritos de Setúbal e Santarém.

${ }^{50}$ Picão (1947) descreve os campos do Alentejo como sendo divididos em grandes terrenos denominados herdades. De acordo com o autor, cada herdade ou grupo de herdades anexas sustenta uma exploração agrícola-pecuária chamada lavoura. Girão (1933) explica herdades e a desigualdade social existente na região: "Agora, quanto mais o campo se dilata, mais se reduz o número de proprietários: é o regime da 
planícies e encostas de terrenos cortados pelo rio Caia e seus afluentes, como Algalé, Torrão, Caiola e Varche. O rio Guadiana, apresentado nos mapas II e III,sob a Ponte Velha da Ajuda, onde aflui o Caia, ainda banha extensas e férteis várzeas, servindo de ligação entre Portugal e Espanha. Olivença, um município espanhol, é cruzado por vários pequenos rios e ribeiras, todos afluentes do Guadiana, tais como o Rio de Olivença e o Rio Táliga e ainda é cruzado por outros pequenos cursos de água, afluentes do Guadiana, de norte para sul: Chança, Figueira (Higuera), Valongo e São Bento (San Benito).

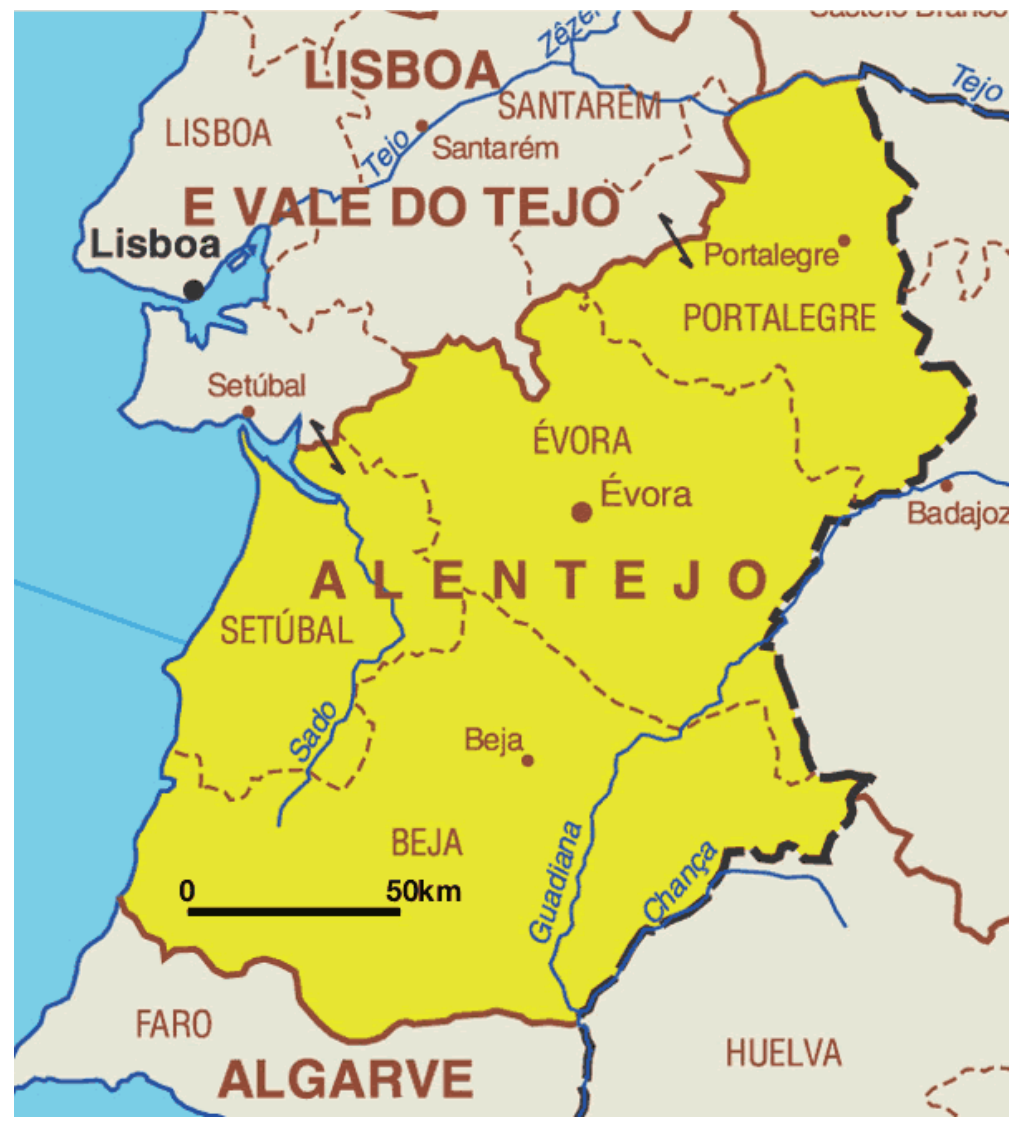

Mapa III: Região do Alentejo e alguns de seus rios e afluentes

Picão (1947) resume a região do Alentejo com vastas áreas de planícies e voltadas para o cultivo de cereais e para a criação de gados. Apresenta o lugar com escassez de água em quase toda a parte durante o verão, com terras 'áridas e monótonas'. Nessa época, o autor observa o vestuário, sobretudo do homem,

grande propriedade que se impõe, e a essas grandes propriedades se aplica o nome de herdades, pelo facto de constituirem<<unidades econômicas〉> e de terem de passar integralmente de uma vida para outra. Cava-se um abismo entre o trabalhador e o proprietário".

${ }^{51}$ Refere-se à Elvas, região fronteiriça, com as características geográficas e climáticas semelhantes a Olivença. O mapa III apresenta a localização da cidade. 
"assumindo pitorescas feições no traje do pastor" (safões e pelico feitos de pele de ovelha).

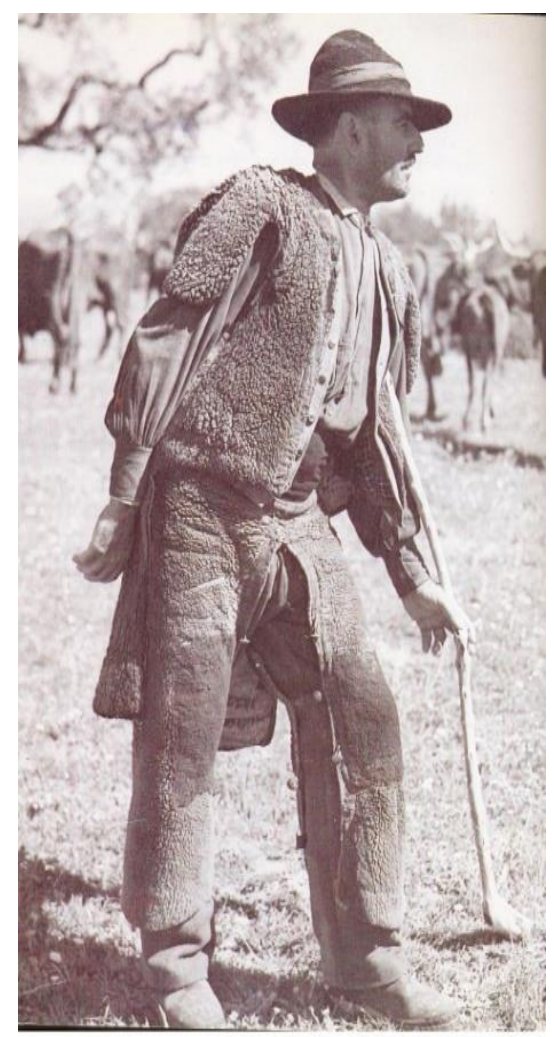

Imagem 6: vestuário dos homens oliventinos naquela época ${ }^{52}$

Girão (1933; 1949) afirma em seus artigos que Olivença está inserida numa região pouco povoada, com climas bastante difíceis para os moradores - 'verões muito quentes, invernos rigorosos, grandes amplitudes térmicas e fraca pluviosidade'. Além disso, ainda ressalta que as atividades predominantes da povoação têm sido, ao longo dos séculos, a agricultura e a criação de gado. Campesino e Ferreira (1989) igualmente identificam essas características em Olivença, especificando que, tal como nos concelhos vizinhos de toda a zona fronteiriça, a paisagem é formada de vastas planícies com povoamento de 'tipo aglomerado', na qual a agricultura é extensiva, de regime latifundiário, feita majoritariamente por assalariados rurais.

\footnotetext{
${ }^{52}$ Imagem retirada do site: http://trajesdeportugal.blogspot.pt/2007/02/pelico-e-safes.html. "(1) pelico: espécie de colete, de pele de caba ou de cão, com pelo conservado. Introduz-se pela cabeça, revistindo o corpo, desde o pescoço até a cintura, exceto os braços que ficam descobertos. (2) safões: constam-se de duas peles reunidas e preparadas de forma a adptarem-se sobre a cintura e calças de qualquer sujeito. (...) Uns compõem-se de peles de carneiro". São vetuários próprios da região para que os pastores pudessem se proteger do clima (Matias, 1984:121).
} 
Em Abrantes (1951) Olivença, de forma poética, é apresentada e exaltada, como uma éspecie de paraíso, na qual seus moradores sã fiéis ao seu rei e amam seu trabalho em uma terra produtiva:

Trabalham-se as terras para criar o trigo, preparam-se os hortejos e como o chão era fértil e as águas cantavam nos regos, os arrabaldes nasciam coloridos e viçosos enquanto as azinheiras, os sobreiros e os pomares se alongavam, criavam vida as corelas nasciam as herdades e apareciam as aldeias! Os <<Montes $>>$ salpicavam os verdes prados arrabaldinos como açucenas vindas do Céu: era a gama miraculosa da obra de Deus, dada virtualmente aso pastores de almas, alvanéis e trabalhadores de enxada, me que todos se auxiliavam como soldados da nova comunidade. Morto D. Dinis, o mais querido dos reis para os oliventinos, em cujos peitos vive ainda a saudade da sua imagem, outros reis sucederam, [...]

(ABRANTES, 1951:58)

Em pesquisa posterior sobre a região de Olivença, Matias (1984) afirma ainda que ambas as regiões ${ }^{53}$ possuem climas semelhantes com verões quentes e invernos rigorosos, além de quilômetros de extensões de terras vermelhas não povoadas,descritas já em tempos atrás por Girão (1933) da seguinte forma:

Pelo contraste com as lezírias ribatejanas, o Alto Alentejo apresenta-se-nos como uma região mais seca e mais pobre, queimada por um sol de fogo, a que o povo aplica por isso o nome de Charneca: região onde as próprias árvores na estação <<dão sombra mas têm calor, refrescam os outros mas têm sede〉> e <<gritam a Deus a bênção duma fonte〉>, na expressão de consagrados escritores alentejanos.

(GIRÃO 1933:412)

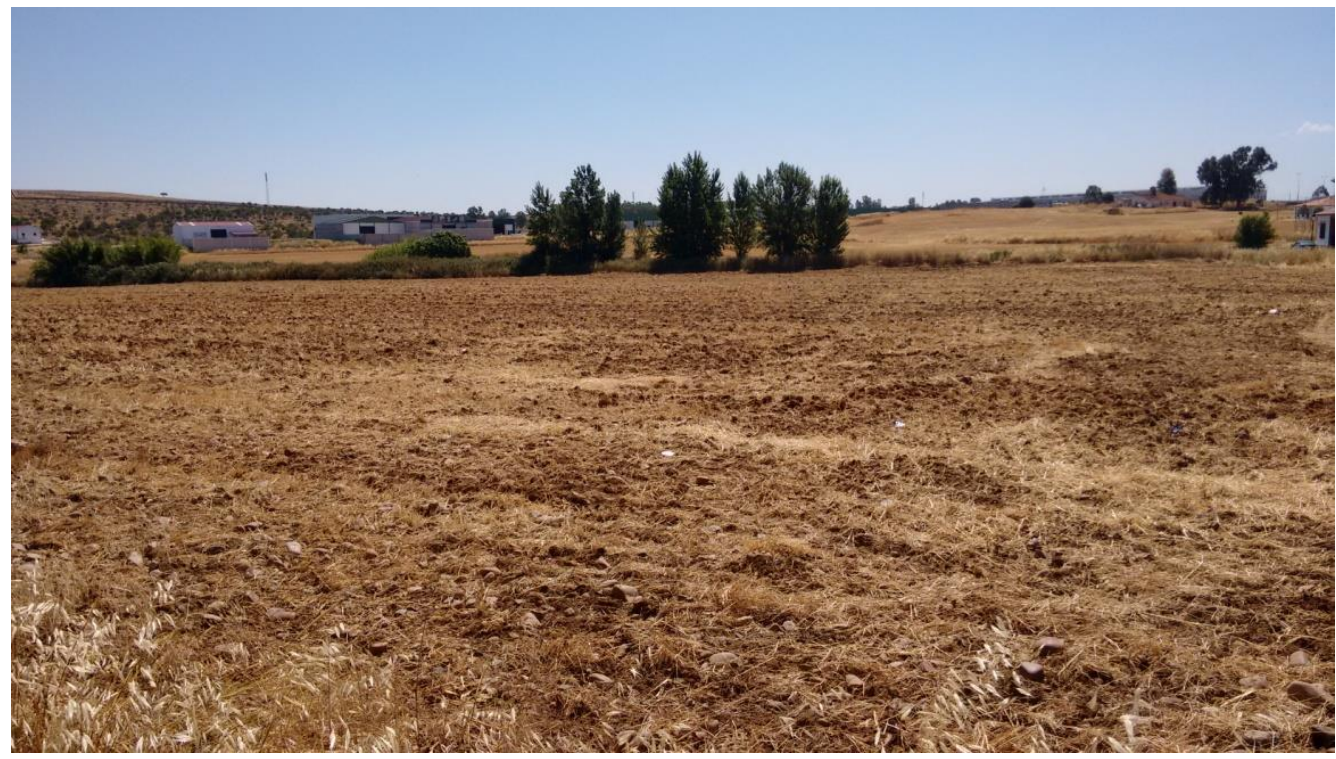

Imagem 7: A terra seca em Olivença ${ }^{54}$

${ }^{53}$ A autora se refere às regiões do Alentejo e a Olivença.

${ }^{54}$ A imagem foi fotografada por nós em abril de 2015. 


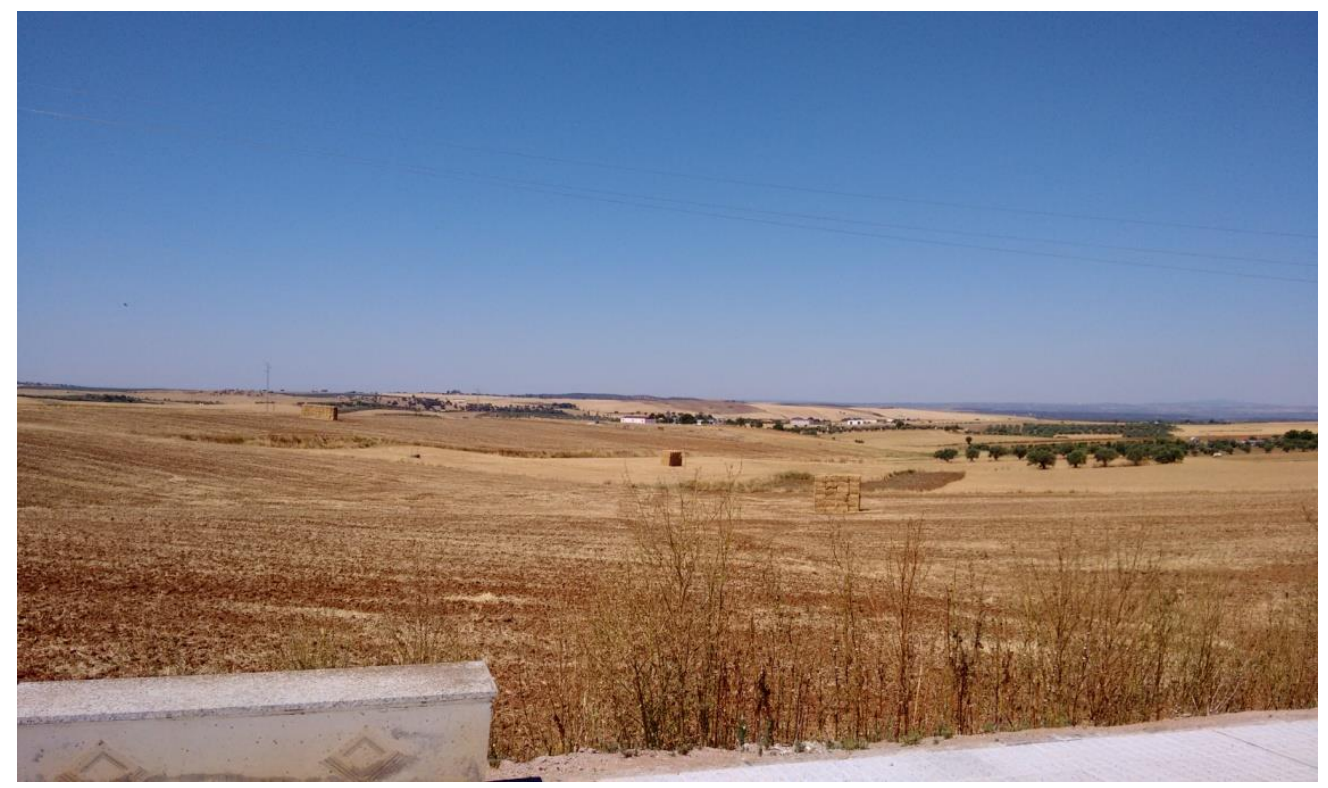

Imagem 8: Cidade de Olivença com vastas terras não povoadas 55

Em trabalho de campo, pudemos notar que as características apresentadas pelos autores são sentidas ainda pela população local, que se queixa grandemente das condições climáticas. De fato, pudemos perceber que no inverno a temperatura é baixa, chegando a 3 ou 4 graus $^{56}$. Além disso, os moradores afirmam que, no verão, quase não é possível andar pelas ruas da cidade, sendo necessário, inclusive, o fechamento dos comércios no período da tarde. Na cidade, como apresentado na imagem 1, as casas conservam a pintura branca como forma de amenizar os problemas causados pelo calor $^{57}$.

Contudo, embora as condições climáticas não sejam tão favoráveis, a terra é bastante propícia para o plantio. Por apresentar esse aspecto avermelhado, como mostra a imagem 7, Matias (1984) apresenta a área em estudo como sendo situada nos "Barros", além de uma sub-região agrícola, extremamente rica para a produção do trigo, aveia, grão de bico e olival, sendo grandemente exaltada por Abrantes (1951):

Das herdades brota a riqueza, valor expressivo de quanto o arcaboiço do camponês oliventino curvado ao cultivo do seu chão, conseguiu realizar; floresceu na graça de Deus os trigais, cearas amarelecidas ao nosso sol, e aqui e além, há matizes de flores silvestres, em que as papoulas são gostas de sangue, dados à terra pelo trabalhador do lugarejo, pobre e sem população

\footnotetext{
55 Foto tirada em março de 2015. Como podemos ver, ainda encontramos vastas terras vermelhas e não povoadas como já descreviam os autores. Além disso, também encontramos terras com muitas plantações. ${ }^{56}$ Tal temperatura foi observada nos meses de janeiro e fevereiro de 2015 , período de inverno na região.

${ }^{57}$ Os moradores da cidade nos explicaram em conversas espontâneas que as casas são todas pintadas de branco para não reter calor durante o verão, e que quase não há circulação de pessoas durante o dia.
} 
tornando-a em breve um celeiro próspero e fecundo! Nos campos bravios, braços abertos para os céus surgem os velhos castanheiros, nogueiras e pinheiros em que levam a palma as oliveiras, prenhos de frutos que dão azeite cristalino nos lugares, do qual se alimenta a população e, se <<alumia>> a Mãe soberana de Deus! Há montados ricos na engorda das varas porcinas, limoeiros e larangeiras viçosamente perfumam o espaço, enquanto os roseirais, loendros e camélias engrinaldam e dão sombras às paredes das casas rústicas dos casais!

(ABRANTES, 1995:58)

Como é possível notar, desde tempos anteriores, os oliventinos pendem para as atividades mais rurais e simples. Ribeiro (1961) a esse respeito argumenta que essa condição do camponês oliventino cedo o levou a sair de suas terras para procurar trabalho, "onde e quando o havia", nas propriedades da região, herdades ou fincas, como também aconteceu com os moradores de Campo Maior, Elvas, Alandroal, Albuquerque, Almendralejo ou Jerez de los Caballeros. No entanto, se opondo a tal ideia, Matias (1984), constata que, mesmo com todas as dificuldades encontradas, os moradores dessas regiões faziam o possível para não deixarem o seu modo de vida:

O camponês alentejano, embora não possuindo condições de vida propícias, raramente emigra para o estrangeiro em busca de fortuna e melhor vida. Muito apegado à terra, vai ganhando o seu pão e repartindo a sua atividade pelas tarefas do campo.

(MATIAS, 1894:133)

Algumas dessas características expostas pelos autores, como vemos nas imagens IV e $\mathrm{V}$, foram ratificadas durante o trabalho de campo que realizamos. Foi quando pudemos notar que a atividade rural na cidade ainda é bem presente e os que migram para as zonas mais urbanas acabam trabalhando em restaurantes ou em obras, como é o caso da maioria dos informantes entrevistados para esta tese. É claro que, hoje, os oliventinos vivem e trabalham como nas outras cidades, mas a simplicidade do povo reflete esse contato com o campo.

\subsection{A situação da língua falada em Olivença}

Matias (1984) e Fernández (2004) classificam o português oliventino como uma variedade alentejana. A explicação para isso assenta-se nas afinidades entre a linguagem 
dos concelhos do Alandroal, Campo Maior e Elvas. Nelas, destaca-se a influência do espanhol estremenho, ilustrado no yeísmo ${ }^{58}$ e no domínio lexical.

Segundo Fernández (2004), a entonação oliventina é mais 'exclamativa' do que a da estremadura no geral, sendo cantada e até mesmo "se aproximando dos mexicanos, argentinos ou galegos", tanto em português como em espanhol na cidade de Olivença. O autor ainda afirma que o português oliventino, tanto quanto o português alentejano, "prefere o ditongo oi ao ou (oiro / ouro doido / doudo, loiro / louro), ocorrendo também a pronúncia do ditongo /eil como nas regiões do Alentejo (aldeia [al'de:a],azeitona [aze:'tona]), havendo ainda na característica oliventina, também por influência desta, a síncope de vogais na pronúncia rápida, como em bác(o)ro, j(a)nela (>(e)snela), m(e)lancia (>blancia), m(e)nino, p(e)queno” (p. 05).

Todavia, como se prevê em todo e qualquer contato linguístico, Matias (2001) percebe que o português em Olivença já estava apresentando características que diferem das demais regiões ${ }^{59}$ até então colocadas anteriormente como semelhantes a ela. A autora percebe em seu trabalho que os falantes são influenciados pelo espanhol, principalmente pelo fato de ser ess língua obrigatória nas escolas e de o português não ter o seu uso incentivado.

É ainda apontado pela autora que o fato de não darem apoio à escrita da língua portuguesa em Olivença fez com que os habitantes que até então a utilizavam se sentissem inferiores, e, portanto, abandonassem seu uso, o qual já estava sendo considerado como um 〈<chaporrêo〉>, ou como diz Fernández (2004) um 'chapurre(i)o'. Com isso, Matias (2001) pretende chamar a atenção a essa forma de falar, a qual já era associada até mesmo ao 'analfabetismo' ou a uma forma 'corrupta' e 'desajeitada'. Luna (2005) também emprega o termo "chaporreo", com a tradução de 'patois' ou 'deturpação', indicando que o termo foi criado pelas próprias autoridades, consideradas por ele como 'vigilantes', os quais inferiorizavam todos os que usassem tal forma de falar:

\footnotetext{
${ }^{58}$ Matias (2001), tendo por base os conceitos de Alonso (1951) sobre yeísmo, explica que é uma interferência, fenômeno que, no espanhol, consiste na pronuncia de II como Y. (cf. ALONSO, Amado. 1951. La "II" y susalteracionesenEspaña y América. In. Estudios dedicados a MenèndezPidall, II. Madrid, pp. 41-89.)

${ }^{59}$ Alandroal, Campo Maior e Elvas.
} 
E à medida que o português ia perdendo prestígio, domínios e funções, o castelhano, veículo de promoção social, ganhava terreno. Na verdade, só a competência oral e escrita nesta língua permitia grangear bons empregos. Estabeleceu-se assim, uma íntima correlação entre língua portuguesa e esfera popular e rural, por um lado, e língua espanhola e classes econômica e culturalmente privilegiadas, por outro. Não se podendo isolar as questões linguísticas do contexto sociopolítico em que se inserem, é compreensível que o precário estatuto social do português em Olivença tenha motivado o seu declínio.

(MATIAS 2001: 167)

Confrontando uma pesquisa realizada em 1970 com a de 2001, Matias apresenta-nos a situação linguística observada em Olivença relatando o acréscimo significativo dos seguintes fenômenos causados pelo contato:

- aspiração e supressão de $s$ : atráh 'atrás'; Liboa 'Lisboa'; dôcih 'doces'; casa 'casas', hcreve 'escreve';

- supressão de $r$ final: lavá 'lavar';mudjé 'mulher';amo 'amor';

- yeísmo com alternância entre y e dj: abeya e abedja 'abelha';fiya efidja 'filha';

- realização de /v/ como [b], traço linguístico característico dos falantes do norte de Portugal e ausente da variedade dialetal alentejana: barrer 'varrer',biage 'viagem';

- presença dos fonemas /c/ e /x/: anca 'larga', esp. Ancha, coci 'automóvel', esp. coche, wei 'chefe', esp. Jefe;

- síncope de d- intervocálico: Arão 'arado', levantao 'levantando', bria 'brida, rédeas'.

No domínio da morfologia, a autora também observou a grande influência espanhola e a descreve da seguinte maneira:

- artigos: lo, la, uno, una.

- substantivos e adjetivos: com gêneros diferentes - o arvo, o viagem; com diferente formação do plural: ancianos, animalis, cristianos, funilis;

- pronomes e adjetivos determinativos: yo e yeu, esto, eso, todo 'tudo', qualquera;

- advérbios e locuções adverbiais: adji 'ali', temprano 'cedo', tampoco 'também não', pronto 'depressa'.

Da mesma forma, ao passo que se modifica a fonologia e a morfologia, a sintaxe também sofre influências do espanhol, sendo apresentadas pela autora com as seguintes interferências: 
- antecipação dos pronomes às formas verbais: os trazem num coche; Le dêto pimenta 'deito-lhe pimenta', lhos di 'dei-lhos';

- posposição dos adjetivos demonstrativos em relação ao substantivo: o cesto aquele, a mesa esta;

- substituição do subjuntivo pelo mais-que-perfeito do indicativo: se fôramos a aventurar 'se fôssemos deita fora', se o ninho cantara 'se o menino cantasse'.

A autora ainda aponta que o que mais sofreu dano foi o léxico, pois muitas palavras caíram no esquecimento, até mesmo as palavras mais antigas, como nomes de plantas, dos animais, os nome agrícolas entre outras, como, por exemplo: chispear no lugar de 'chuviscar', fresa no lugar de 'morango', guelondrina no lugar de 'andorinha', molisna no lugar de 'chuva fraca', orilha no lugar de 'margem do rio', remolacha no lugar de 'beterraba', entre outros. Em pesquisas nos dicionários de português e de espanhol encontramos os seguintes significados ${ }^{60}$ :

Chuviscar: em português [xu-vis-kar], v. intr. Chover em pequena quantidade; chuvinhar. (De chuvisco) > Chispear(em espanhol chuviscar é chispear);

Morango: $[\mathrm{ran}]$, s.m. fruto do morangueiro; morangueiro >Fresa (em espanhol morango é fresa);

Andorinha: s.f. ave de arribação da fam. Dos fisirrostros (hirundo); [...] > Guelondrina (em espanhol, andorinha é golondrina);

Chuvafraca: (em português existe Molina': s.f. tecido de lan, fabricado em Molina (Espanha) [(do hesp. Molino)]; molinha2: s.f. moinha; chuva miúda; chuvisco. (Do lat. molinus) >Molisna (em espanhol, chuva fraca é mollizna);

Marge do rio: (em português também existe: orilha: [ri] s.f. filete; borda; orla. (Do cast. Orilla) >Orilha(em espanhol, borda; beira; margem é orilla)

Beterraba: (em português: [rrà], s.f. raiz grossa e carnuda, de que se extrái açúcar; planta da fam. Das chenopodiáceas que tem essa raiz. (Do fr. betterave) > remolacha: (em espanhol, beterraba é remolacha).

${ }^{60}$ BASTOS, J. T. da Silva. Diccionário etymológico, prosódico e orthográphico da Língua Portuguesa. Lisboa: Livraria Editora, $2^{\mathrm{a}}$ ed, 1928. MICHAELIS, Dicionário escolar Espanhol. São Paulo: Editora Melhoramentos, 2009. 
Como temos visto, de acordo com a autora, os portugueses, devido o contato, passaram a utilizar muitas palavras do espanhol, e algumas, como é o caso de orilha, que já é existente no vocabulário português, por ser próximo ao espanhol, passa a ser mais utilizado do que 'margem do rio'.

Fernández (2004) afirma também que, provavelmente, o último que se perde numa língua que está próxima da extinção é 'aquilo que está quase fora da sintaxe, como as interjeições, os imperativos ou os vocativos'. Esta asseveração se dá por observar que os oliventinos portugueses em suas conversas usam as expressões espanholas para 'temperar' o diálogo, que costumam ser, de acordo com o autor, até mesmo 'malsoantes': 'Conho!'(do espanhol Coño!). Ainda, o autor mostra que, em fala espanhola, ocorre o mesmo como em 'Filho dum cabrão!', mas também 'Credo!', 'Tal é!', 'Ai mãe!'ou 'Olha lá!', expressões que são usadas pelos jovens com toda naturalidade, o que vai ao encontro com uma das hipóteses iniciais desta tese, a de que os mais novos provavelmente fazem uso da LH sem, muitas vezes, perceber. Isso quer dizer que uma geração jovem continua utilizando expressões que, provavelmente no espaço da língua original, já não mais são utilizadas pelos jovens. É como se suas decisões fossem sintonizadas com as decisões de seus familiares quando jovens.

Percebendo toda essa influência, Matias (2001) assegura que a língua dominante “invadiu as ruas, as casas, os nomes e as pessoas e que orgulhosa, altifalante, espaçosa e forte com uma maré cheia, inundou quase tudo" (p. 170). O que resta em Olivença do idioma luso, de acordo com a autora, é a 'sombra tímida, envergonhada' de uma língua que oliventinos não puderam ou não quiseram manter.

Por tais constatações,alguns pesquisadores, tais como Matias (1984; 2001), Vasconcelos(1980), Fernández (2004) e Luna (2000; 2007), temendo o fim do português em Olivença, investem seus estudos em uma forma de descrever o português oliventino. Matias (2001) afirma que a língua portuguesa nesse lugar teria poucas ou quase nenhuma chance de continuar presente entre os falantes da LH. Em seu artigo intitulado A agonia do português em Olivença, mostra-nos que a língua está prestes a desaparecer e assume a postura de que 'os juízos de valor dos usuários influenciam o seu comportamento linguístico, determinando em boa parte o futuro das línguas' (p. 160). 
Desta forma, se seguirmos os postulados de Matias (1984), vamos prever que os portugueses, vivendo em extrema opressão e com o sentimento de inferioridade cada vez mais acentuado, determinariam um futuro pouco feliz para a LH. Ainda, seguindo esses apontamentos, Fernández (2004) também classifica o português de Olivença já quase completamente 'assimilado ao espanhol', e atribui tal fato às mesmas razões já expostas até aqui.

Nas pesquisas já realizadas, os autores começam, então, a tentar traçar um perfil da situação da língua em Olivença. Assim, comparando suas pesquisas com as de Sá $(1928)^{61}$, Matias (2001) observa o seguinte quadro: enquanto Sá, em um breve apontamento do final do século XIX, refere-se a Olivença como uma povoação bilíngue, com interferências espanholas, fruto do contato de línguas, propondo a divisão cidade bilíngue $X$ campo monolíngue e estrato alto bilíngue $X$ restantes camadas monolíngues, Matias já não encontra mais esse perfil na sua pesquisa, pois nesse período, há um bilinguismo muito maior, atingindo todos os setores da população, tanto na cidade quanto no campo, e, até mesmo fica surpresa com a facilidade dos falantes em mudar de uma língua para outra, inclusive nas classes mais baixas.

No entanto, por outro lado, junto com esse bilinguismo na população local, Matias (2001) encontra ainda, como já previsto, uma 'sobreposição do castelhano', o que ocasionava, é claro, a substituição quase que completa do português pelo idioma local: as crianças e os jovens não estavam mais utilizando sua $\mathrm{LH}$, e mal a compreendiam. Assim, os autores apresentam algo que, para eles, significa um caos linguístico: as famílias, não vendo mais necessidade e importância do uso de sua LH, passariam a não ensiná-la aos mais jovens.

A autora já aponta para o português de Olivença como uma língua pertencente apenas entre os falantes mais velhos, que, embora no seu dia a dia apenas conversassem em espanhol, ainda utilizavam em seus lares, o que não significava um futuro feliz para a LH:

${ }^{61}$ SÁ, Mário de Vasconcelos e. Condições Geográficas. In. DAMIÃO, Peres (org). História de Portugal, I. Barcelos, p. 47-48, 1928. 
Hoje, confinado às camadas mais velhas da população, que bilíngues, o falam apenas entre si, o português de Olivença está moribundo, correndo sério risco de ir engrossar o caudal das línguas, que todos os anos morrem nos territórios que as viram florescer.

(MATIAS, 2001:16)

Tal extinção é noticiada pela autora tendo como base teórica os estudos de Michael Krauss e Stephen Wurm ${ }^{62}$, os quais propõem a morte de uma língua seguindo níveis que variam.

Assim, autora explica que para Michael Krauss a morte de uma língua passa por apenas três estágios, sendo no $4^{\circ}$ considerada completamente morta:

\section{Línguas fora de perigo > em perigo > moribundas > extintas.}

Já, com base nas leituras de Stephen Wurm, a autora mostra que, tendo em vista o uso de línguas entre comunidades de grupos minoritários, a morte de uma língua acontece no $5^{\circ}$ estágio:

\section{Potencialmente em risco > em risco > seriamente em perigo > moribundas >} extintas.

De acordo com os níveis de Stephen Wurm, o $1^{\circ}$ nível (potencialmente em risco) é quando a língua está em desvantagens sociais e econômicas, sofrendo pressão da língua majoritária e começando a ser substituída pelas crianças; o $2^{\circ}$ nível (em risco) é quando a língua tem pouca ou nenhuma criança utilizando, sendo os falantes mais novos adolescentes quase chegando a fase adulta; o $3^{\circ}$ nível (seriamente em perigo) é quando seus falantes têm cinquenta ou mais anos; o $4^{\circ}$ nível (moribundas) é quando a língua tem apenas poucos falantes, em regra muito velhos, e o $5^{\circ}$ e último nível (extintas) é quando não há mais falantes.

Percebemos, assim, que o título dado ao artigo escrito por Matias (2001) segue a teoria de níveis de morte de uma língua, através da qual ela classifica o português de

${ }^{62}$ A autora verifica os níveis de morte da língua com base em EDWARDS, John. The factors in teh decline of languages are many and varied. In. Edwards, John. Language, society and identity. Oxford: Blackwell, 1985, p 71: "When a language possesses no more monoglots, the process of decline has very often begun". 
Olivença como no $3^{\circ}$ estágio -seriamente em risco, com base na teoria de $\mathrm{S}$. Wurm, e moribundo, na teoria de M. Krauss.

Ao atentarmos para tais teorias, vemos que as preocupações dos pesquisadores que lutam pelo português de Olivença estão pautadas no fim da língua pelo fato de estar apenas entre os falantes mais velhos. Além disso, Matias (2001) aceita como evidência a língua em estado de ‘agonia linguística' pelos seguintes motivos:

- Ausência de falantes monolíngues em Olivença;

- Língua restrita apenas aos falantes mais velhos, com a falta de um bom domínio do idioma para seu uso entre os mais jovens;

- Língua falada praticamente em ambiente familiar e monoestilismo ${ }^{63}$;

- Uso de palavras do espanhol durante conversas espontâneas na LH, praticamente não ocorrendo o contrário;

- O idioma da sociedade receptora se incorpora de forma intensa.

Até tais pesquisas aqui citadas, esta é a situação linguística encontrada em Olivença, o que fez Matias (1984) e Fernández (2004) classificarem tal língua como uma possível língua a ser extinta, pois, como proposto por eles, se a língua se encontra apenas entre os falantes mais velhos, a partir do momento em que estes não mais existirem, a língua também não existirá.

Para Matias (1984), a situação é tão grave, que, além desse perfil, através de um método direto ${ }^{64}$, percebe ainda que $95 \%$ dos oliventinos preferem o espanhol ao português, considerando este último 'uma língua antiga, incorreta e sem utilidade'. Essa pesquisa de base sociolinguística realizada pela autora nos mostra que, nesse período, ou seja, na década de 80 , os oliventinos portugueses não se preocupavam com a perda da sua LH, relatando, inclusive, que "a morte desta língua [referindo-se ao português] nesta região [referindo-se a Olivença] é necessária para a construção de um futuro melhor, que só o bom domínio do castelhano os garantem” (p. 167). Ainda, tal pesquisa consegue assegurar que a rejeição do português atingiu maior veemência no sexo

${ }^{63}$ A autora adota o termo seguindo APPEL, René e MUYSKEN, Pieter. Language contact and bilingualism. London: Arnold, 1997, pp. 44-45.

${ }^{64} \mathrm{~A}$ autora trabalha com uma pesquisa sociolinguística qual conta com a entrevista de trinta e seis entrevistados, dezoito homens e dezoito mulheres, igualmente distribuídos por três camadas etárias (2539; 40-59; 60 e mais). A autora faz as seguintes questões: 1 . De que língua mais gosta e por quê?; 2 . O que acha do português de Olivença?; 3. Confinada à geração mais velha, deixará de ser falado brevemente. Como encara essa perda? 
feminino, alegando, através de estudos similares ${ }^{65}$, que essa atitude corresponde à forma de ascensão e liderança para as mulheres.

Partindo das pesquisas até aqui apresentadas sobre o português oliventino, das quais pudemos ter a imagem de uma língua não aceita e rejeitada, com seu desaparecimento desejado e quase certo, apresentaremos adiante uma luz no fim do túnel, pois os dados que temos encontrado caminham para a constatação de que há, ainda, um sentimento de pertença de LH num estado de resiliência até mesmo pelas gerações mais jovens. Tal asseveração é proposta não por uma análise quantitativa, uma vez que quase não encontramos portugueses em Olivença, mas por uma análise voltada aos fatores cognitivos intactos dos seres humanos. Assim, como esta tese caminha para as reflexões voltadas aos estudos da ciência cognitiva, propomos, a seguir, que itens funcionais do passado podem ser sentidos como próprios da língua materna e mantidos na memória de seus falantes mesmo que de forma inconsciente.

\subsection{História de Olivença}

A história de como Olivença foi parar em mãos do governo espanhol não é tão simples de se explicar, pois a respeito dela surgem diversas informações e divergências que nos fazem perceber o quanto é uma situação obscura até mesmo para os próprios oliventinos.

Como arguição de que alguns historiadores não aceitam o modo como Olivença passou a se tornar parte do território espanhol, propomos a narração dos fatos históricos com base em informações reunidas por vários autores em diferentes períodos.

Veiga (1863), em seu livro intitulado "Gibraltar e Olivença: Apontamentos para a história da usurpação destas duas praças" já, nessa época, nos convida a reflexões sobre a conquista de Olivença por parte dos espanhóis como um ato extremamente injusto. Em suas palavras, demonstra total revolta contra a nação espanhola e reinvindica a posse da cidade a Portugal:

\footnotetext{
${ }^{65}$ A autora se pauta nos estudos de EDWARDS, John. Language, society and identity. Oxford:Blackwell. 1985, p. 72.
} 
Parecendo-me demonstrado o direito da corôa hispanhola à praça de Gibraltar, provarei agora que egual direito cabe a Portugal com relação à praça de Olivença, seu território, e povos desde o Guadiana.

[...] Mas a Hispanha, dominada sempre da fatal ambição de engastar na corôa as perolas e os diamantes da corôa portugueza, de o todo o beneficio recebido se esqueceu em breve tempo, e ligada com a mesma republica, que pouco antes havia derramado o sangue de seu briosos filhos, invadiu a terra de Affonso Henriques Henriques em 20 de maio de 1801 com vinte e cinco mil homens commandados por D. Manuel Godoi, atacando com seu invasor exercito as nossas praças de Elvas, Olivença, Juromenha, Campo Maior, e outras.

[...] Portugal, o amigo desvelado, o protector generoso da Hispanha, não podendo já repelir os invasores, e compellido por duas nações poderosas, assigna forçadamente o indigno tratado de Badajoz de 6 de junho de 1801.

(VEIGA, 1863, pp.14-16)

Sequeira (1924) nos leva a entender em seu livro que o domínio espanhol foi, em parte, facilitado pelos próprios portugueses por estreitas relações de amizades entre o feudal Senhorio de Albuquerque e a Coroa Portuguesa. De acordo com o autor, tal Senhorio tinha terras que iam desde a Estremadura portuguesa até Estremadura espanhola. Sendo assim, faz questão de mostrar que a ligação entre Portugal e Albuquerque tornou Olivença um alvo muito fácil para a Espanha.

\begin{abstract}
O Senhorio de Albuquerque, um dos mais vastos potentados peninsulares de Idade Média, cujos senhores, como grandes magnatas feudais, dispunham de plenos poderes nos seus extensos domínios, que se dilatavam pela Estremadura portuguesa, terras de Zamora e Salamanca, e, principalmente pela Estremadura espanhola (região de Medellín, Albuquerque, Alconchel e Barcarrota). As relações deste Senhorio com a Coroa portuguesa, ao longo do século XIII e princípios do século XIV, foram tão estreitas que a dedicação do segundo D. João Afonso, ao rei D. Dinis, o levou a legar-lhe, em testamento, o castelo de Albuquerque. Nesta perspectiva, tendo em conta o ambiente amistoso, que por largos anos vigorou entre Portugal e o referido Senhorio, não custa admitir que os limites dos reinos peninsulares, nesta região, tivessem durante esse período caráter bastante frouxo, facilitando o intercâmbio entre as gentes da raia.
\end{abstract}

(SEQUEIRA, 1924:104-105)

Pereira (1968), de igual modo, ao narrar a história de Olivença, demonstra-se insatisfeito com o modo como essa cidade foi parar em mãos espanholas, e inicia seu seu texto com falas de portugueses também inconformados com a situação de uma cidade que já fora pertencente à nação portuguesa: 
Nós também temos a terra irridenta, Olivença que, com um golpe de mão, a Espanha nos irou e que devemos esforçar-nos por rehaver.

(D. António Barroso. Apud PEREIRA, 1968:6)

\begin{abstract}
A Espanha grita a cada passo, e sob todos os títulos, que é muito amiga de Portugal. A melhor prova da sua sinceridade em tais manifestações dá-la-ia se nos restituísse o que é nosso: Olivença.
\end{abstract}

(Alfredo Pimenta. Apud PEREIRA, 1968:6)

Numa apresentação histórica e dividida em períodos, Luna (1994) mostra-nos que durante o período de 1164 e 1169, sob o comando de Afonso Henriques (D. Afonso I de Portugal), Portugal já disputava Olivença, conquistando-a aos domínios mulçumanos. E apresenta-nos, ainda, que em 1228, a partir da conquista da região pelo Mestre D. Pedro, dos Templários portugueses ${ }^{66}$, são construídos os Castelos, e edificase a primeira Igreja de Santa Maria do Castelo de Olivença. As dispustas desde esses períodos, de acordo com Luna (1994), não eram bem resolvidas, e acabavam mudando constantemente de mãos.

Já Pereira (1968) narra a história em duas partes: como Olivença passa a ser de Portugal e como esta volta aos domínios dos espanhóis. Assim, apresenta-nos que, depois de grandes conflitos entre ambos os países, através do Tratado de Alcanices de 12 de Setembro de 1297, assinado pelo Rei Fernando de Castela, rei da Espanha e o rei de Portugal, D. Dinis, Olivença passa a pertencer a Portugal.

Para entendermos melhor como esse tratado foi assinado, o autor explica-nos que, ao assumir o Trono, dois anos antes, a situação do Rei Fernando de Castela já era um tanto conturbada, pois ele era filho ilegítimo do antigo rei, falecido em 1295, o Rei D. Sancho o $\langle\langle$ Bravo $\rangle$. Por este motivo, seu tio D. João, irmão do falecido, reivindicava que este fosse destituído.

\footnotetext{
${ }^{66}$ Em Luna (1994), durante o século XIII (1220), os Cavaleiros Templários conquistaram várias regiões da Estremadura espanhola e do Alentejo. O autor explica-nos que uma parte destes Cavaleiros devia obediência a Afonso IX de Leão, outra parte a Afonso II de Portugal, e depois a Sancho II, seu filho. Apoiando-se na Historiografia portuguesa, o autor nos mostra que foram estes Cavaleiros que começam as construções, com características típicas portuguesas, que até hoje podemos encontrar em Olivença. Além disso, os Templários tinham não só interesses de conquistas de terras, mas também em expandir as questões religiosas por onde passavam.
} 
D. Dinis, reinando em Portugal neste período, tinha concedido sua filha em casamento ao rei espanhol, o rei ilegítimo, e foi procurado por D. João para ajudá-lo a tomar o Trono de seu sobrinho. Diante do problema, D. Dinis, como forma de resolvêlo, prõpoe uma cláusula em que o casamento só aconteceria se o Rei Fernando conseguisse sua legitimação pacífica, o que ele já sabia não ser possível de acontecer.

Assim, como não deu certo o casamento de sua filha com o Rei Fernando, D. Dinis cede a mão desta a D. João, aquele que havia pedido ajuda para conseguir usurpar o trono do rei da Espanha. Nesse momento, por tomar partido a favor de D. João contra a coroação de um filho ilegítimo, de acordo com Pereira (1968), começa-se a "guerra fria", representada pelos inícios das "sangrentas hostilidades".

Percebe-se, nesse contexto de discórdias, que Portugal passa, então, a comprar uma briga com um grande país, e D. Dinis, neste período, em aliança com alguns reis e infantes ${ }^{67}$, em 1296 entrou na Espanha conquistando a Comarca de Riba-Coa, a qual abrange as Vilas acasteladas de Sabugal, Alfaiates, Almeida, Castelo Melhor, Vila Maior, Campo Maior e Alvalade.

O autor então nos remete ao início de seu texto, que é a conquista de Olivença por Portugal através do Tratado de Alcanices, assinado pelo Rei Fernando IV,um rei ilegítimo, junto ao Rei D. Dinis em 1297. Tal tratado tinha a finalidade de que as guerras entre ambos os países cessassem. ${ }^{68}$

Na segundo parte de seu texto, Pereira (1968) passa a narrar os fatos históricos que levaram Portugal a perder Olivença para os espanhóis. Assim, durante todo o decorrer dele, nos faz perceber que Portugal nunca deixou de estar diante de conflitos, os quais se intensificaram com a Revolução Francesa ${ }^{69}$, através da qual, Olivença se torna um alvo para inúmeras invasões ${ }^{70}$.

\footnotetext{
${ }^{67} \mathrm{O}$ autor apresenta-nos que os aliados de D. Dinis na invasão à Espanha eram o Rei de Aragão, D. Jaime, o Infante D. Pedro e a D. Afonso de Lacerda, irmão do Rei Castelhano.

${ }^{68}$ Veloso (1939) explica que Fernando IV não deu Olivença em dote da sua irmã D. Beatriz como alguns diziam, mas, de acordo como o tratado de paz, assinado em Alcanices a 12 de setembro de 1297, o rei cedeu Olivença e Campo Maior a D. Dinis em troca dos castelos e vilas de Aroche e Aracena, que de direito eram de Portugal, mas que estavam no domínio da Espanha de forma indevida.

${ }^{69}$ De acordo com Pereira (1968), esta Revolução começou, praticamente em 14 de Julho de 1789, período em que o povo de Paris tomou a Bastilha, fortaleza construída, em 1370, pelo Rei francês Carlos V, conhecido como 'o sábio' e concluída 12 anos depois por Carlos VI. Foi transformada em prisão política por onde passaram muitos homens, dentre eles, Voltaire, hoje considerado um grande pensador. Oliveira
} 
Ocorre que, neste período, a Espanha tinha como Rei Carlos IV, que era dominado por sua mulher. Esta, por sua vez, segundo Pereira (1968), era infiel e envolvida pela figura de Manuel Godoy, um grande vilão para a nação portuguesa. Assim, de acordo com o texto, a esposa do rei faz com que ele promova tal senhorio a General e até mesmo a Príncipe de Paz, títulos que o fariam estar à frente dos ataques à Olivença. De acordo com Veloso (1939), tal general estava grandemente ligado à perda de Olivença e era conhecido apenas 'pelos escandalosos favores que lhe dispensava a rainha' (p. 19).

De acordo com Pereira (1968), sob o comando deste, o qual tinha, inclusive, relações com a Convenção francesa, a Espanha passa a propor excessivas exigências a Portugal, tais como abandonar a Aliança Inglesa, abrindo os Portos aos navios da Espanha e da França, fechando-os da Inglaterra; entregar à Espanha uma ou mais Províncias do Continente; indenizar os espanhóis que têm plenos poderes dos danos sofridos; fixar definitivamente os limites com a Espanha e, ainda, indenizar a França com um valor extremamente alto ${ }^{71}$. Oliveira (2012), também falando de tais exigências, mostra que Napoleão Bonaparte passou todos os poderes a Luciano Bonaparte, e era este que impunha a Portugal tais imposições absurdas ${ }^{72}$, as quais são, de acordo com Oliveira (2012), descritas pelo general Godoy, numa carta ao rei, "um escândalo".

Desta forma, como o texto tem nos mostrado até então, na impossibilidade de resistir às duas poderosas nações ${ }^{73}$, não restava alternativa a Portugal que não fosse o

(2012) também fala que Napoleão tinha grandes interesses em conquistar Portugal por esta ser aliada da Inglaterra, sua inimiga de combate.

${ }^{70}$ Veloso (1939) afirma que a Revolução Francesa "causara verdadeiro assombro em tôdas as monarquias da Europa".

${ }^{71}$ Veloso (1939) nos apresenta alguns trechos do tratado imposto a Portugal:

“Art. II - Sua Alteza Real fechará os portos de todos os Seus Domínios aos navios em geral da GrãBretanha.

Art. III- Sua Majestade Católica restituirá a Sua Alteza Real as Praças e Povoações de Juromenha, Arronches, Portalegre, Castelo de Vide, Barbacena, Campo Maior e Ouguela, como todos os seus territórios até agora conquistados pelas suas armas, [...] conservará em qualidade de conquista para a unir perpètuamente aos seus domínios e vassalos, a Praça de Olivença, [...]"

72 Oliveira (2012:77) apresenta as seguintes imposições de Luciano Bonaparte a Portugal em 28 de maio:

“-Clausura absoluta dos portos aos ingleses [...];

-Trinta milhões de libras tornezas, metade em dinheiro e metade em diamantes;

- Que a França e a Espanha garantiriam as possessões de S.A.R;

- A cessação do Forte de Macapá da costa do Amazonas até este forte passar para a República Francesa;

- Que Portugal forneceria e cederia à França quatro navios de linha e quatro fragatas de guerra;

-A entrada de panos e demais lanifícios franceses em Portugal”.

${ }^{73}$ As duas nações a que se refere o texto é Espanha e França, as quais se aliam para que Portugal fosse obrigado a ceder Olivença e outras de suas cidades. 
combate, e assim, a Praça de Olivença, apresentada na imagem abaixo, foi tomada pelos espanhóis em 1801, numa guerra sob o comando de Manuel Godoy.

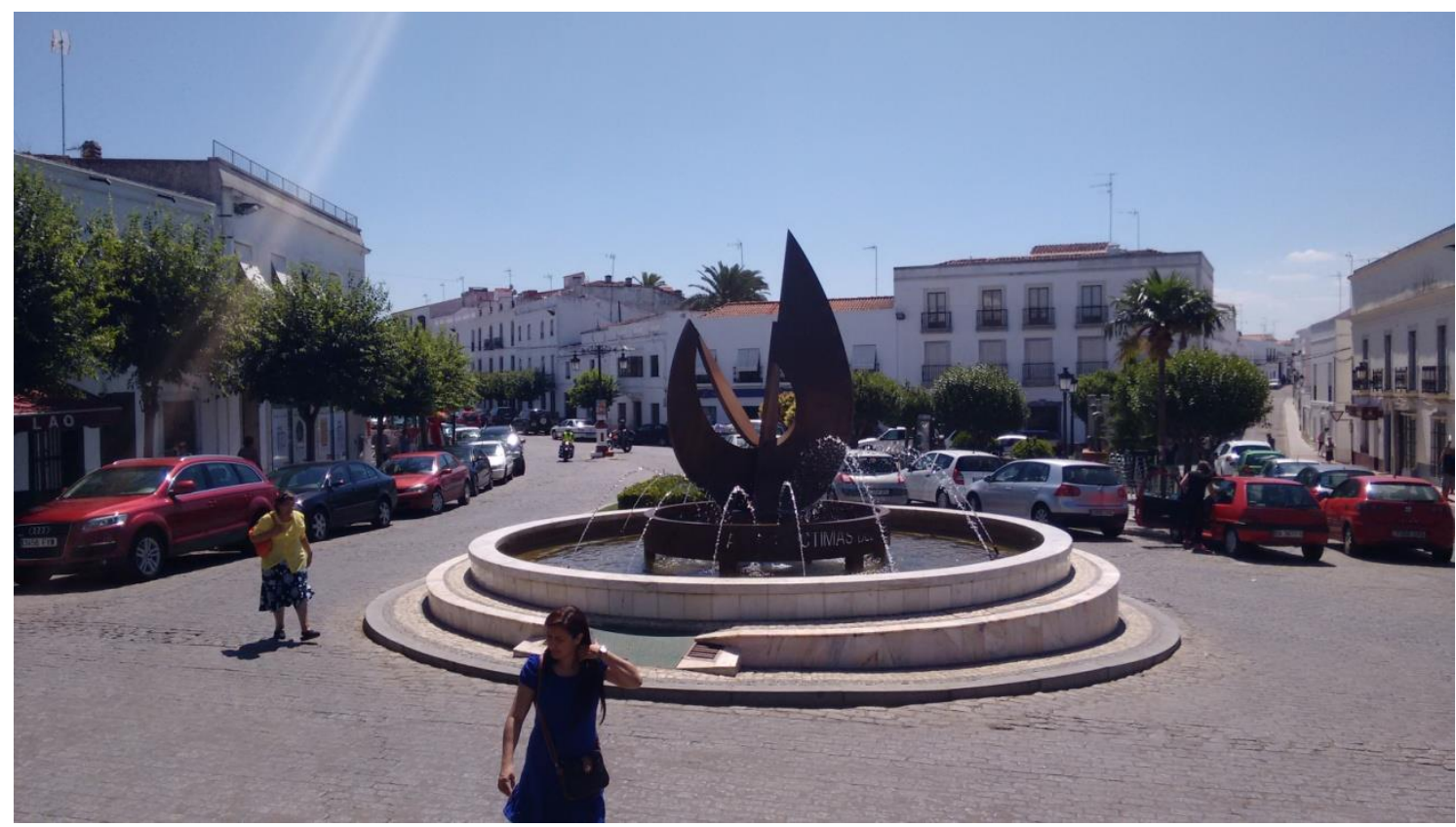

Imagem 9: Praça de Olivença que foi tomada pelos espanhóis ${ }^{74}$

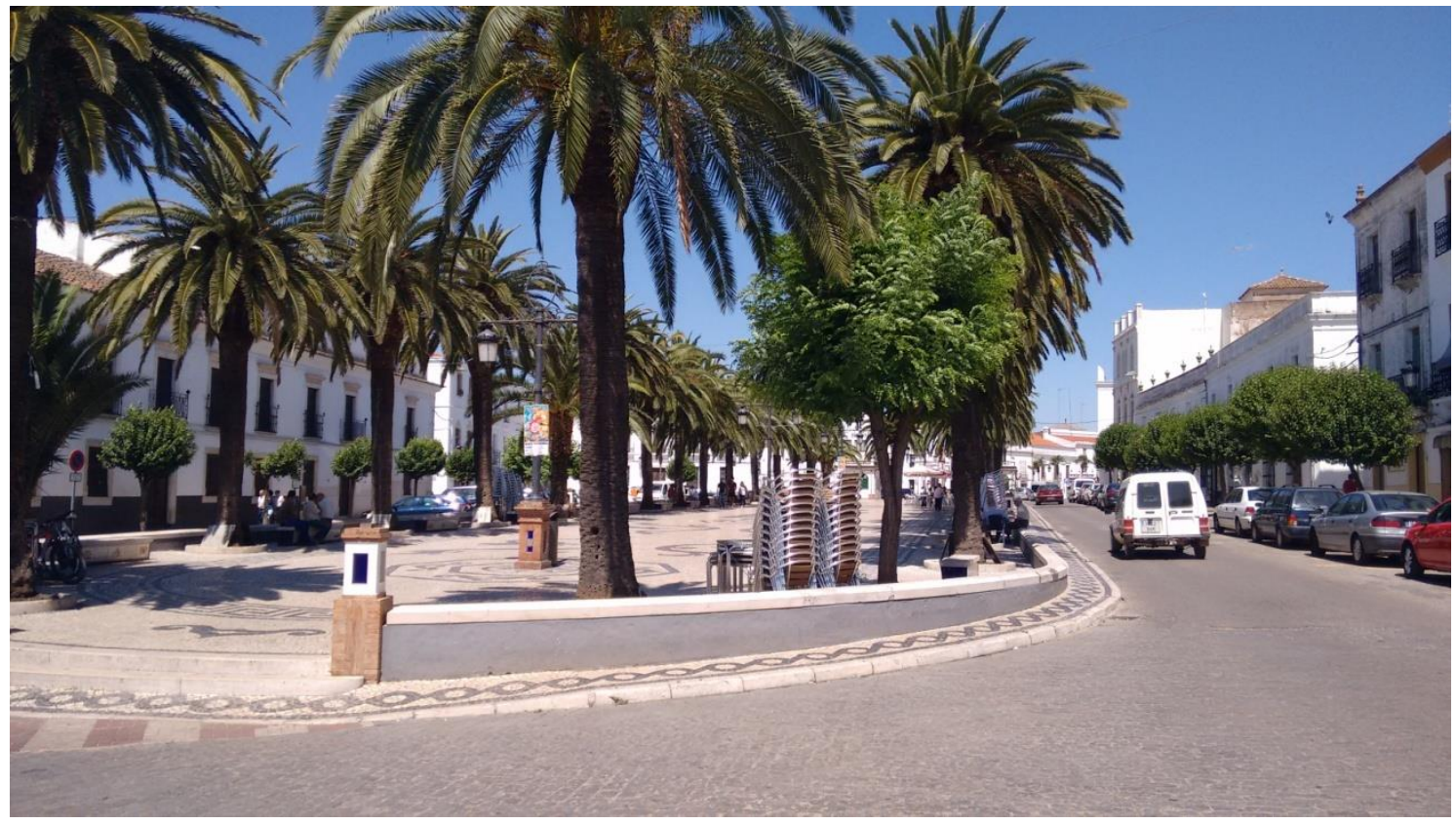

Imagem 10: Centro e Praça de Olivença ${ }^{75}$

${ }^{74}$ Fotos tiradas em março de 2015. A praça de Olivença tem um chafariz com os dizeres: "Las víctimas del terrorismo".

${ }^{75}$ Fotos tiradas em março de 2015. A praça de Olivença atualmente é um grande centro de lazer para os moradores e visitantes da cidade. 
De acordo com o autor, A Inglaterra não pode ajudar Portugal e, em junho de 1801, é obrigado a assinar um tratado de paz: o $\left\langle<\right.$ Tratado de Badajoz $>>{ }^{76}$, em cujo teor está a informação de que Olivença passa a pertencer definitivamente à Espanha. Tratado este, que, de acordo com os autores citados nesta tese, não foi aceito por nenhum português.

Pereira (1968) nos apresenta que Portugal, nem mesmo diante de tal tratado, deixa de ser invadido pela França, tendo inclusive que enviar a família Real para o Brasil para que não perdesse o Trono e não fosse aprisionada pelas tropas de Napoleão Bonaparte. No entanto, logo que o Príncipe Regente D. João VI desembarcou no Brasil, anulou os tratados impostos pelo Imperador Francês e, em 1818, os termos do Tratado de Viena ${ }^{77}$ estipulam a restituição de Olivença a Portugal, o que, não aconteceu de fato. Para explicar o porquê não cumpriram tal acordo, o autor nos mostra a fala do Marquês de Palmela:

Não devemos perder de vista Olivença para que Madrid não invoque nunca silêncio como prova de prescrição dos direitos que a Coroa de Portugal tem à restituição?

(Marquês de Palmela. Apud: Pereira 1968:21)

Como forma de expressar sua indignação diante dos fatos históricos narrados em seu texto, Pereira (1968) encerra com os seguintes dizeres:

Não! Um tão patriótico conselho não pode - nem deve - ser esquecido, não
se compreendendo até a razão porque os Espanhóis dizendo-se nossos amigos
não nos restituem Olivença que bem sabem ser Portuguesa e pretendem que
os Ingleses lês restituam Gibraltar que eles próprios (Espanhóis) aos Ingleses
ofereceram em troca de um auxílio que se tornou decisivo para a vida da
Espanha.

(...)Vá lá, visinhos, cumpram com o seu dever restituindo a Portugal aquilo que a Portugal tiraram, demonstrando assim que, na realidade, são nossos amigos.

(...) Lembrem-se de que em Olivença tudo fala de Portugal desde a Porta do Calvário, encimada com as Armas e Portugal às Portas de Alcochel, à Igreja da Madalena, à Misericórdia que, por sinal, é hoje a única instituição dessa natureza, que abre as suas sessões com observância rigorosa do ritual estabelecido pela Rainha D. Leonor (sua fundadora), tudo, tudo em Olivença,

\footnotetext{
${ }^{76} \mathrm{O}$ modelo do tratado se encontra em anexo no final do trabalho. Tal modelo nos foi concedido por Carlos Luna em março de 2015 e faz parte de uma de suas obras: "Nos caminhos de Olivença, 1994 [2000]."

77 O modelo do tratado se encontra em anexo no final do trabalho. Tal modelo nos foi concedido por Carlos Luna em março de 2015 e faz parte de uma de suas obras: "Nos caminhos de Olivença, 1994 [2000]."
} 
as Praças, as Ruas, o estilo arquitectónico, a língua que falam tudo, tudo, repito, grita por forma entusiástica e comovedora:

<<Aqui, aqui é Portugal e só Portugal, deixem-nos voltar à nossa Pátria, sejam, na realidade, amigos de Portugal $>$

(PEREIRA 1968, pp. 21-22)

Silva (1984), também apresentando a história de Olivença,em seu livro, abre um capítulo intitulado como 'La conquista de Olivenza por España em la Guerra de las naranjas", apresentando o conflito contra a nação portuguesa. Informa, ainda, que foi uma batalha não só da Espanha, como também da França, pois Napoleão Bonaparte necessitava separar Portugal de uma amizade com a Inglaterra, a fim de que a nação lusa fechasse seus portos aos barcos ingleses.

Outro autor que dá sua explicação sobre tal guerra, inclusive, explicando o nome dado a esta (Guerra das Laranjas) foi Gallego (2007) que, em seu livro, retrata ainda que, no dia 20 de maio, o 'generalismo' de Godoy lançou um ataque com as tropas que estavam nos arredores da capital estremenha. De acordo com o autor, no primeiro dia ocuparam Olivença sem disparar nenhum tiro, rodearam Elvas e Campo Maior. Nesta ação, segundo o autor, houve três mortos e dúzias de feridos. Concomitantemente, Godoy enviara ao rei uma carta notificando suas ações e junto a ela um ramo de laranjas dos pomares situados nas proximidades de Elvas, tal atitude que acabou batizando a guerra como a 'Guerra das Laranjas', através da qual, Olivença passa a pertencer definitivamente à soberania espanhola.

Martín et alii (1998) e Silva (1984), tratando da forma como Olivença passa aos domínios da Espanha, nos apresenta a Guerra das Laranjas ou 'Guerra de las naranjas', explicando que esta foi uma jogada estratégica a fim de que a cidade fosse, então, usurpada. Narrando tal história, os autores relatam que, por uma decisão francesa, a Espanha foi obrigada a declarar tal guerra a Portugal em fevereiro de 1801, por um presente de Godoy para o reino, a qual culminou com o Tratado de Badajóz estipulando a atribuição da população de Olivença para a Espanha.

Como se pode depreender, entender a motivação de Olivença pertencer hoje ao domínio espanhol não é uma tarefa fácil, tendo em vista que são vários os estudos acerca desse fato histórico e, de certa forma, a complexidade desses fatos torna a questão ainda repleta de circunstâncias e ações sombrias para muitos até os dias de hoje. 
Essa questão política de Olivença é tão grave que o The World Factbook da C.I.A. ${ }^{78}$ apresenta a insatisfação de Portugal que culmina com o não reconhecimento da soberania espanhola sobre aquele território. Em um relatório de 2003, a C.I.A. publica que Olivença é reivindicada por Portugal, apresentando, inclusive, um mapa em que não consta a situação dessa cidade, estando literalmente fora do mapa da Espanha. Tais apontamentos foram, provavelmente, questionados pela diplomacia espanhola, pois, no ano seguinte, a matéria foi republicada com o adendo de que apenas alguns ${ }^{79}$ portugueses faziam tal reivindicação e, já em 2005, a C.I.A. apresenta, pela primeira vez, Olivença como território pertencente à Espanha, omitindo toda e qualquer reivindicação portuguesa ${ }^{80}$.

Muitas vezes, a tarefa de descrever um pouco da história de Olivença, em seus pormenores, torna-se árdua. Durante o levantamento de materiais para compor esse panorama, deparamo-nos com muitas questões que ainda hoje estão por ser esclarecidas. Desta forma, por este e tantos outros motivos, diversos historiadores e pesquisadores defensores da causa de Olivença, dentre eles o professor Carlos Luna ${ }^{81}$ e os representantes da associação Além Guadiana, dos quais trataremos adiante, fazem seus manifestos através de exposições, artigos, palestras e até mesmo em blogs com o objetivo de resgatar não só Olivença, mas sua história e dignidade.

\subsection{Uma arma poderosa para a tomada de Olivença}

Como é sabido, uma das formas de impor seu domínio dentro de um território é através de uma arma muito poderosa: a língua. Desta forma, a Espanha não deixaria de usá-la, e decreta em 1840 a proibição da língua portuguesa, inclusive nas igrejas e escolas. Tal proibição, que, de acordo com todas as fontes de pesquisas citadas neste

\footnotetext{
78 A C.I.A. (Central IntelligenceAgency) é o serviço secreto de informação do governo dos Estados Unidos. Fundada em 1947, tem como objetivo espionar e coletar informações secretas de outros países. Informação acessada dia 18/05/2015 em <www.infoescola.com>. Tal informação nos foi concedida pelo historiador e escritor Carlos Luna, o qual luta pelos direitos de Portugal sobre Olivença. Com tais informações, podemos perceber que Olivença não é um simples caso de tratado, mas uma situação tão mal resolvida que chegou até mesmo em órgãos de inteligência secreta, o que nos leva a assegurar que diante de conflitos tão intensos, a língua é uma, ou talvez a única, arma que os portugueses podem contar no momento. Os documentos fornecidos pelo professor estão no anexo IV.

${ }^{79}$ Grifos nossos.

${ }^{80} \mathrm{O}$ professor Carlos Luna nos forneceu documentos com os informes da C.I.A. a respeito de Olivença os quais estão em anexo.

81 Carlos Eduardo da Cruz Luna, professor licenciado em História pela Faculdade de Letras da Universidade de Lisboa, escritor de vários artigos e blogs em defesa a Olivença.
} 
trabalho, não ocorreu de forma pacífica, mas repressiva e até mesmo com aplicações de penalidades aos que ousassem descumprir tais ordens.

Veloso (1939) assente em seu texto que Olivença é portuguesa de direito, embora estivesse há duzentos anos sob administração espanhola. Segundo o autor, esse longo tempo de dominação estaria repercutindo nos hábitos das pessoas, produzindo, como já era de se esperar, uma 'colonização cultural'.

Também afirma que os oliventinos, sob uma educação impositiva a favor do espanhol, dominante no território, sentiam a necessidade de absorver tudo o que a cultura espanhola oferecia, pois percebiam que, além da imposição, as ofertas de trabalho eram muito mais compensadoras do que as que Portugal poderia lhes fornecer. Dessa forma, a primeira coisa que era substituída pelos moradores de Olivença era a língua nativa pela língua da sociedade receptora e detentora de todo o prestígio necessário para uma vida melhor.

Segundo o autor, hoje, os portugueses, em sua maioria, 'sentem-se espanhóis' e falam a língua do país dominante - o espanhol. Essa afirmação será alvo de discussão na seção em que trataremos do sentimento de pertença linguística, pois o fato de estar sob o jugo de uma língua dominante e ser a minoria em uma comunidade não é o suficiente para asseverarmos que não haja sentimento de pertença a uma cultura de herança.

Para os moradores de Olivença, de acordo com Abrantes (1951), nada pode dar tanta beleza a tudo o que pertence à região do que a própria língua, através da qual os oliventinos podem exaltar sua terra, sua beleza e sentir que são verdadeiramente portugueses:

Para os oliventinos, nenhuma fala pode dar maior alento de prazer ou de caráter que a nossa língua, tão portuguesa como nós próprios; é a saudade que floresce, doce e maleável, emotiva e talvez impetuosa cuja dor e alegria irradiando de si própria, mantém reflexos dentro do coração a proclamar que de novo se ouçam as palavras quentes da língua de Camões, na ansiedade que temos de voltar à nossa origem criadora!

(ABRANTES, 1951:59)

De acordo com Abrantes, a língua não é algo que simplesmente se apague da vida das pessoas que a utilizam, mas que perpetua, deixando vestígios, 'reflexos' ou, 
como propomos nesta tese, traços de herança. O autor deixa bem claro que manter a LH, exaltada poeticamente como a 'língua de Camões', é aproximar os oliventinos cada vez mais ao seu grupo étnico, o que, de acordo com os fatos históricos apresentados, não é algo que a Espanha gostaria que acontecesse, e por isso, aos poucos, foi tentando apagála da vida dos portugueses que viviam em Olivença.

Luna (2005), em seu artigo "Apelo a espanhóis e portugueses para a salvação de uma língua”, escrito para o Colóquio da Lusofonia/Bragança, traz um pouco da história de Olivença e sua passagem aos domínios espanhóis. De acordo com o autor, a partir de 1801 é possível notar a ocorrência de um período extremamente ditatorial e de grandes conturbações, inclusive, desconhecido de muitos. Ilustra com o ano de 1805, em que se suspendeu o uso da moeda portuguesa em Olivença, o indício para a entrada de um autoritarismo e domínio espanhol, inclusive na língua, a qual começaria a ser gradativamente extinta em todas as escolas a partir dessa data. Fica claro que logo no início do século XIX, com a escolarização em espanhol, desencadeia-se, simultaneamente, o processo de fragilização da língua portuguesa, que se vê banida dos setores com prestígio: a Administração Pública, a Educação e a Igreja.

De acordo com Luna (2006), em um artigo escrito em defesa de alguns nomes que lutavam pela língua nativa e LH, apresenta-nos Vicente Vieira Valério, secretário da Câmara Municipal de Olivença, referido como o "grande defensor da língua portuguesa". O fato memorável dessa referência se deu a partir do dia 14 de agosto de 1805, quando, por ordens do presidente da Câmara, as atas deixaram de ser redigidas em português. Essa imposição teve a reação de Vicente Valério, que, em ato de protesto, recusou-se a escrevê-las e demite-se do cargo, morrendo, inclusive, de acordo com Luna, em situação de pobreza, mas não traindo sua cultura e língua.

Qualquer indivíduo que tenha contato com a história de Olivença sem atentar para tais questões descritas até aqui, não perceberá nada de tão sério, apenas a mudança da língua. É preciso, contudo, atentar para o fato de que muitos oliventinos não faziam a mínina ideia da gravidade de tal imposição naquele momento, pois não imaginavam que o domínio de um povo se dá de forma muito mais excessiva através da língua. 
Em pesquisas colhidas ${ }^{82}$, e publicadas em seu artigo de 2005, Carlos Luna ainda assevera que as escolas privadas que continuavam a ministrar o ensino de Português, como forma de se opor à atitude ditatorial espanhola, foram fechadas em 19 de maio de 1813, com o propósito ‘oficial de evitar qualquer sentimento patriótico lusitano' e que como muitos oliventinos queriam que os seus filhos fossem educados na LH, alguns portugueses se atreviam a lecionar o idioma em casa, mas por pouco tempo. Logo, iniciou-se um período de sanções, com pena de multa de 20 'Ducados' ${ }^{93}$.

A história social silenciada vai, assim, se revelando no desconforto da situação, o que mostra que, embora a população portuguesa tentasse viver como se nada estivesse ocorrendo, isso não foi possível. A solução para muitos portugueses acabou sendo a emigração para as cidades portuguesas mais próximas. Quem ficou em Olivença encontra motivos históricos pra não assumir sua cultura de herança, o que dificultou sobremaneira o trabalho de campo que realizamos na região.

A Espanha, de forma truculenta e fazendo uso de uma arma muito poderosa - o extermínio da LH, lançou mão de tudo o que podia para que os oliventinos portugueses cada vez mais se afastassem das características que os ligavam a sua nação e se mantivessem escondidos entres os nativos.

Embora saibamos dos efeitos dessa imposição no território, o sentimento de pertença linguística portuguesa ainda se manteve resiliente naquele espaço. Essa é uma evidência de que ser minoria e estar em uma sociedade repressora, longe de seu grupo étnico, não são condições suficentes para que a língua e cultura sejam eliminadas ou morram como tem argumentado Matias (2001). Os traços culturais podem ser mantidos e recuperados em um processo de evolução social, tal como ocorre nos processos biológicos (Mithen, 1998).

Se, de um lado, alguns autores assumem o português como uma língua moribunda, em vias de extinção, se manter viva nas camadas mais velhas de falantes (Luna, 2000, 2007, 2006, 2009; Matias, 1984, 2001; Sánchez Fernández, 2008), de outro, é possível notar que grupos sociais se mantêm resilientes e com laços culturais

\footnotetext{
${ }^{82} \mathrm{O}$ autor cita como fonte de pesquisa: (A.M.O. leg/Carp 7/2-18, 19-05-1813, $\mathrm{n}^{\circ}$ 1324; revelado por Miguel ÁngelVallecillo Teodoro, "Olivenzaensu História", Olivença, 1999.)

83 (A.M.O. leg/Carp 8/1-171, 7-10-1820, $\mathrm{n}^{\circ}$ 11704; revelado por Miguel ÁngelVallecillo Teodoro, "Olivenzaensu História”, Olivença, 1999.)
} 
tão fortes que ainda se mantêm ativos na ideia de que os portugueses não devem abandonar sua LH.

Luna (2009) evidencia esse suspiro resiliente temporalmente situado no dia 28 de fevereiro de 2009, quando, pela primeira vez, a Língua Portuguesa se manifestou livremente em Olivença, inclusive com a cobertura das autoridades espanholas. Tal acontecimento ocorreu com o apoio da associação AlémGuadiana ${ }^{84}$, que lançou $A$ jornada do Português de Olivença, de 'estrondoso' êxito.

Em Maneta (2010), num artigo para o jornal 'Diário de Notícias”, intitulado "Ruas de Olivença voltam a ter nomes portugueses", lemos informações sobre a iniciativa do presidente da Associação Além Guadiana, Joaquín Fuentes Becerra, em refazer as placas das ruas de Olivença, trazendo nelas os seus antigos nomes portugueses $^{85}$.

De acordo com o presidente dessa Associação, 'era uma velha aspiração, uma maneira de desvendar parte do passado português' e que os moradores deveriam saber de sua história e de seu passado, pois a toponímia original das ruas, que em alguns casos retomam a Idade Média, é inspirada nos antigos artesãos ou notáveis portugueses (rua dos Oleiros e Saboeiros e os becos Rui Lobo e João da Gama). O projeto da Câmara de Olivença inclui 73 ruas, becos e calçadas ao longo de todo o centro histórico. Trata-se, na verdade, de um apaziguamento histórico que tenta deixar o PLH num lugar de descanso eterno, o que, consequentemente, acalmaria os reivindicantes e resilientes.

$\mathrm{Na}$ perspectiva de Parreira (2010), no entanto, essas ações devem ser compreendidas como êxito de esforços enviados. Dessa forma, os artigos, os jornais, e até mesmo a proposição da associação Além Guadiana seriam estopins de luta a favor

\footnotetext{
${ }^{84}$ Além Guadiana é uma Associação Cultural, criada em março de 2008, sem fins lucrativos, criado por um grupo de cidadãos em Olivença com o intuito de fomentar a cultura portuguesa naquela cidade. O âmbito de atuação da associação são os concelhos de Olivença (o qual inclui as aldeias de São Jorge de Lor, São Beno da Contenda, Vila Real, São Domingos de Gusmão, São Rafael e São Francisco) e de Táliga, português até 1801 . Desde 27 de setembro de 2008 a Associação Possui uma página web oficial, disponível no endereço: <www.alemguadiana.com>. A associação tem a intenção de potencializar um caráter mestiço, recuperando e fomentando manifestações relacionadas com a língua, tradições orais, a gastronomia, a música, a literatura, etc. Além disso, tem como principal atividade a promoção da língua portuguesa em Olivença, realizar ações de sensibilização, valorizar a cultura portuguesa e fomentar o conhecimento e intercâmbio cultural com Portugal e outros países da Lusofonia. Informações retiradas do próprio site oficial - para marcar presença portuguesa em Olivença acessado em 12/03/2015 e da Revista Pormenores julho e agosto de 2010.

${ }^{85}$ Nesta pesquisa, foram registradas fotografias das placas das ruas (vide Anexo I).O objetivo, desde o projeto desta tese, embutia a intenção de registrar toda e qualquer pista da presença do PLH em Olivença.
} 
da retomada da Língua Portuguesa. Segundo ele, a própria arquitetura local depõe a favor da pertença a Portugal. Um discurso que ratifica essa interpretação segue reproduzido a seguir:

Olivença é História. É Mito. É (triste) Realidade.

Faz parte dos Fantasmas pessimistas que perseguem o Homem Português. Fantasmas de que esse mesmo homem só se libertará quando compreender que foi ele mesmo que os criou, e que está na sua mão fazê-lo desaparecer.

Olivença é incúria. É abandono. É (apesar de tudo) persistência. Existe.

Tem passado. Tem presente. Tem futuro. (...) Porque quero que este livro seja lido pelo oliventinos de hoje, de que se alimenta, coloquei algumas explicações e precisões que poderão parecer desnecessárias. Há que ver que este livro decerto será lido por quem pouco ou nada sabe de Portugal e da sua História.

(Luna, 2000 pp. 11-12)

\subsection{Em luta pelos valores étnicos}

Como evidenciamos nas seções antecedentes, a língua portuguesa em Olivença tem sido motivo de grande conflito entre os falantes que a utilizam e os falantes da língua espanhola. Esta última é, considerada 'superior' e de 'prestígio' e a outra, aos poucos, vai se fortalecendo num discurso de herança cultural. No entanto, os que utilizam o português fora do enquadramento de comemoração histórica ou familiar, passam a ser estigmatizados na sociedade considerada majoritária.

O incômodo por parte dos falantes de língua de herança é tão grande que existem diversas matérias publicadas em sites de rede social ${ }^{86}$ com a finalidade de amenizar e até mesmo estancar esse problema que causa um enorme mal-estar na comunidade portuguesa. Retomemos alguns desses desconfortos sociais em períodos mais recentes.

Luna, em 30 de maio de 2011, publicou nas redes sociais o evento promovido pela associação Além Guadiana, ocorrido nos dias 28 e 29 de maio de 2011, vinculado à

\footnotetext{
${ }^{86}$ Conselho da Europa recomenda aprendizagem do português em Olivença - notícia do Público; Além Guadiana (cultura portuguesa em Olivença); A agonia do português de Olivença de Maria de Fátima Resende Matias (1982); Apontamentos para descrever o espanhol que se fala em Olivença de Manuel Jesús Sánchez Fernández.
} 
$2^{\mathrm{a}}$ edição de "Lusofonias". As atividades visavam ao renascer de toda a cultura portuguesa em Olivença. Entre todos os pavilhões de exposições culturais, costumeiramente representados por elementos gastronômicos e artesanais, foram incluídas leituras públicas, apresentação de documentários, de teatro, de música, de corais e de divulgação de ações escolares locais envolvendo a língua de 'Camões', como dizem os defensores do português como língua de herança (PLH). Em 20 de outubro de 2012, foi levada a termo a $3^{\mathrm{a}}$ edição de Lusofonias, com os mesmos ideais.

Em uma matéria publicada em seu site oficial, a 'Além Guadiana', no dia 10 de agosto de 2008, reportou o quanto os portugueses que vivem em Olivença estão cansados de ouvir que o português que falam não é a língua portuguesa, mas sim um "chapurrêo", fator que acarreta diversas consequências para a comunidade que a utiliza, trazendo o sentimento de inferioridade diante da sociedade local. Esse é só mais um golpe para desestabilizar o sentimento de pertença dos portugueses.

O conflito nesse campo é tão imenso que os próprios produtores das matérias publicadas, em ato de repúdio, chegam a questionar, em forma de protesto contra os espanhóis, qual seria de fato, a língua que eles falam, já que não é um português.

Exemplo disso é a matéria publicada no site da Além Guadiana por Manuel Sánchez. Nela, ele tenta explicar que língua é aquela falada em Olivença pelos portugueses. Segundo ele, a língua portugusesa falada em Olivença, por receber diversas influências do espanhol, acabou se tornando um dialeto, uma variedade do português padrão ${ }^{87}$.

Assim, isto deixa claro que a estigmatização do português oliventino pela comunidade portuguesa não está sendo mais aceita, e como forma de resolver tal incômodo, faz uso de teorias de linguístas que propõem a língua como algo dinâmico e sujeito a variações, principalmente quando exposto ao contato.

Manuel Sánchez argumenta que embora considere o português oliventino como um dialeto, não deixa de ressaltar que definir a diferença entre língua e dialeto não é tão

${ }^{87}$ Cabe esclarecer que sociolinguistas não diferenciam língua e dialeto em planos hierárquicos. A explicação é que toda língua falada é língua. É preciso estar atento a tentativas de inferiorizar línguas sob o rótulo de dialeto. Esse argumento baseado em hierarquias é político e desestruturante de sociedades legitimamente constituídas. 
simples assim, e ainda chega a propor que a fala dialetal que é utilizada em Olivença pode ser considerada uma língua, ou pelo menos, se transformar em uma, a partir do momento que passar a ser usada na literatura. Além disso, deixa-nos claro que todo problema enfrentado pelos portugueses com relação à língua, é político, sendo uma barreira criada pelo próprio país hospedeiro, assunto tratado no capítulo anterior o qual retrata das questões de dominação territorial por parte dos espanhóis, fato, que incomoda grandemente os moradores locais e da fronteira, que não se consideram, portanto, imigrantes. $\mathrm{O}$ primeiro argumento que utilizou baseia-se na comparação com o estatuto do castelhano em relação à língua espanhola. Se é compreendido pelos espanhóis, então é a mesma língua, e isto não deve ser algo de tanto espanto. O segundo argumento diz respeito à relação entre o galego e o português

Segundo ele, são considerados por muitos ${ }^{88}$ como dois dialetos da mesma língua - do latim hispânico. Assim, propõe que diacronicamente o português é sim um dialeto do galego e que todas as línguas que têm a mesma origem e características, são dialetos e não uma língua diferente que deva receber outro nome, como o que acontece com português falado em Olivença, que recebe, preconceituosamente, o nome de "chapurrêo".

As matérias publicadas no site Além Guadiana-se estruturam, na maior parte das vezes, num formato de conversa com o leitor, estratégia utilizada, provavelmente, com a finalidade de que seja não um discurso formal, mas um diálogo entre indivíduos.

É nesse clima de conversa que se propõe a existência do português da Espanha ${ }^{89}$ e também o português alentejano oliventino ${ }^{90}$.

\footnotetext{
88 “Claro, é que o galego e o português são a mesma língua: esses falam galegoportuguês ou portugalego! Grandes vultos da linguística já desapar'cidos (Ferdinand de Saussure, Joan Coromines, Manuel Rodrigues Lapa, Ricardo Carballo/Carvalho Calero...) pensavam que o galego e o português (geograficamente e sincronicamente) eram dois dialectos duma mesma língua".

${ }^{89}$ Segundo Manuel Sánchez, o português de Espanha é falado na Galiza, nas Astúrias (entre os rios Eo e Návia) e o Berço (Leã), onde se chama galego; em Hermisende/Ermisende (Samra e em Alamedilha (Salamanca) e na Estremadura: nos "Três Lugares" (em Cárceres): o lagarteiro das Elhas, o manhego de São Martim de Trevelho e o valverdeiro de Valverde do Fresno (ou del Fresno); em Cedilho, em Ferreira (ou Herrera) de Alcântara e em Valência de Alcântara (também Cárceres) e na Codosera, Olivença e Táliga (Badajoz). $\mathrm{O}$ autor não nos oferece a fonte de consulta.

$90 \mathrm{O}$ autor explica o que é um português alentejano oliventino: "O português oliventino é alentejano. Ninguém duvida isso. Mas porque será que alguns dizem que é um "chapurrêo"? Crêo que é por medo. Por medo de que, compadre?"
} 
A ideia de se conceber um português de herança em regiões de fronteira licencia a existência de, um português alentejano, uma variedade do português de Portugal. O português oliventino traria em seu bojo interferências advindas do espanhol.

Aponta ainda que, em Olivença, há interferência em ambas as línguas, mas que o português será sempre inferior ao espanhol ${ }^{91}$. Sendo assim, diante de uma interferência mútua, define alguns tipos de línguas faladas em Olivença:

- O português oliventino ou português alentejano, um português que se modificou pela influência do espanhol, sendo, portanto, uma variedade do português;

- O espanhol oliventino ou espanhol estremenho, um espanhol estremenho com superestrato $^{92}$ do português, também uma variedade, mas do espanhol.

- O portunhol é a mistura entre o português e o espanhol, é a tentativa em se comunicar utilizando ao mesmo tempo as duas línguas. $\mathrm{O}$ autor do blog chega a definir como um pidgin. Enfatiza que, se o indivíduo que o utiliza passar a optar ou aprender uma das duas línguas padrão, esse desaparecerá.

- Por fim, e o mais interessante para esta pesquisa, o chamado 'chapurrêo', que segundo o autor do blog, é uma tentativa de se falar mais o português do que o espanhol ${ }^{93}$.

Manuel Sánches deixa bem claro que grupos étnicos sempre serão diferenciados, e que, por mais que as pessoas possam viver próximas, ou juntas, como é o caso dos imigrantes que vivem em Olivença, jamais perderão características próprias e não poderão ser considerados, jamais, espanhóis. Em sua fala, deixa transpor a ideia de que, por mais que o contato seja intenso, a língua sempre marcará a diferença entre os grupos, e que é nítida a necessidade de que isso aconteça para que não acabem se

91 "Quer dizer que o espanhol estremenho oliventino tem influência do português, mas não por cima: por baixo. O espanhol é como um cobertóri e o português o lençóli."

${ }^{92}$ Superetrato espanhol (nomeadamente estremenho, não castelhano). Por exemplo, a ausência do ditongo ei (até quando seguido de outra vogal), que se pronuncia e, e a paragoge em palavras acabadas em -l ou r, quando a sílaba é tônica e seguida de pausa ou de outra sílaba tónica: Portugáli, comêri, mas comer depois.

93 "E o chapurrêo? O chapurrêo é por exemplo o português falado por José Antônio Camacho, mas o homem, quando estava no Benfica, tentava falar cada vez mais português e menos espanhóli...e ia-o conseguindo, benté que saiu do clube. Chapurrêo é o que ê tento falar quando me encontro com romenos. Chapurrêo é um "quiero y no puedo". Mas o nosso português, compadre, nem é portunhol nem é chapurrêo". Como podemos ver, o autor não considera sua língua nem portunhol, nem chapurrêo. 
fundindo com a outra sociedade. Percebemos que a fala marca a necessidade em separação de grupos étnicos através da língua.

No site, a matéria deixa bem clara a rivalidade entre portugueses e espanhóis, o que ocorre, segundo ela, principalmente por culpa dos receptores, que fazem de tudo para que jamais sejam confundidos com os imigrantes. Estes, na verdade, são vistos como aqueles que não fazem parte do grupo e a melhor forma de marcar essa rivalidade é fazer uso da língua ${ }^{94}$.

Outra matéria, mas dessa vez publicada em um blog ${ }^{95}$ só sobre o português oliventino, marca o inconformismo com o descaso no reconhecimento de uma LH presente em Olivença. Nesta, apresenta uma carta escrita pelo 'Consejo de Europa', datada de 2005, na qual fica patente que o governo espanhol foi informado da existência do português falado na Espanha: "El português em Extremadura". Por se tratar, e, no entanto, de língua minoritária ${ }^{96}$ e não ter o estatuto de língua autônoma, não é nem será reconhecida pelo governo espanhol.

Há ainda, publicado nesse blog, uma carta divulgada na imprensa a respeito da Junta Diretiva de Associação de Divulgação e Estudos do Patrimônio Linguístico da Estremadura - "Estudio y divulgación del Patrimonio Linguísico Extremeño", divulgando o estranhamento causado por nenhuma providência para o reconhecimento da língua como "Bien de Interés Cultural”, uma vez que existe até mesmo uma legislação para tal ${ }^{97}$.

O que esse blog tenta mostrar é o quanto a língua portuguesa ou como podemos chamar neste trabalho, o português oliventino e a LH são consideradas inexistentes dentro da comunidade oliventina. Os comentários dos leitores são de revolta pelo que

\footnotetext{
94 "E por isso dizem que nos Três Lugares fala galego ( no sentido desse galego ou xalexoespañol inventado), pra que na sejam amigos dos portugueses" - Fala de Manuel Sánchez. 95

<HTTP://algalgz.org/blogues/index.php/bolindri/2005/10/07/o_portugues_oliventino_ja nao_existe_par $>$

96 A carta toma o cuidado de explicar que a palavra minoritária faz referência à quantidade de falantes em relação à língua nativa.

97 "La Junta Directiva de la Asociación "Estudio y divulgción del Patrimonio Linguístico Extremeño" se extraña de que los organismos competentes de la Junta de Extremadura no mandaram la legislación de la declaración de "A fala" como bien de interes cultural: el Decreto 45/2001, de 20 de marzo, por el que se declara "Bien de Interés Cultura" "A fala" (DOE No 36 de 27 de marzo de 2001), ratificad por el Presidente extremeño y dictado al amparo del Estatuto de Autonomía de la Comunidad Autónoma deExtremadura con una base jurídica muy bien razonada".
} 
tem acontecido com os falantes de uma língua estigmatizada e considerada minoritária ${ }^{98}$.

Embora não seja possível mensurar o tamanho do preconceito em que vivem os falantes do português oliventino e de LH dentro do território considerado politicamente espanhol, podemos perceber que eles não têm se acomodado diante do gigante e, como forma de consolidar sua potencialidade, utilizam-se das redes sociais para divulgar todos os problemas e expor que muitos estão em busca de seus direitos tanto quanto os cidadãos espanhóis, falando, inclusive, de um português oliventino, como um idioma lusitano que se manteve preservado em Olivença.

Nas redes sociais, há a clara intenção de proclamar que "Olivenza"99 pertenceu por cinco séculos a Portugal, até então chamada Olivença, sendo esse o último território a passar administrativamente para a Espanha. Dado que a língua portuguesa até então era o idioma majoritário na cidade, foi um dos legados que se manteve, mesmo numa condição minoritária. Alegam que essa ruptura com o idioma português foi muito forte devido à tradição cultural de um país que considera sua língua estandardizada diante das demais ${ }^{100}$. Desta forma, as escolas receberam apoio para que o espanhol passasse a ser a língua dominante, o que de fato aconteceu.

Como similar intenção, identificamos outra ${ }^{101}$ publicação. O tom assumido, contudo, soava mais ácido, pois o sentimento de revolta parecia maior. Tal matéria intitulada "Olivença ou Olivenza?", transpassa a ideia da tentativa de usurpação por parte dos espanhóis de todos os direitos dos portugueses, inclusive, sobre a língua. Digamos 'tentativa', pois o autor da matéria argumenta que, embora tenham tentado acabar até mesmo com os nomes portugueses, esse intento foi infrutífero. A matéria chega a propor que a entrada dos costumes, da língua e até mesmo dos nomes próprios espanhóis se deram de forma ditatorial e truculenta:

\footnotetext{
98 "e isso aí amigo, de que serve viver numa Europa que se diz democrática, onde na verdade é a lei do mais forte que predomina"/“É. Mas a lei do mais forte nã é europêa, mas universáli! Acho eu”.."Olivença é Portugal Espanha fora de Olivença já".

99 Desde que a cidade passou a fazer parte do domínio espanhol, passou a ser chamada "Olivenza", mas que não é aceito pelos portugueses, que fazem questão de dizer que é "Olivença"

${ }^{100}$ Sobre essa posição política espanhola, também é clara na fronteira entre Brasil e Uruguai. Trataremos dessa fronteira no capítulo $X$.

${ }^{101}$ Matéria encontrada no site: 〈http://olivencaportuguesa.forumeiros.com/t4-olivenca-ou-olivenza〉
} 


\begin{abstract}
Apesar de quase 205 anos de repressão, de proibição do uso da língua portuguesa; apesar de durante o regime Franquista ter havido fuzilamento e prisão dos oliventinos pró-Portugal; castelhanização dos nomes (apelidos) portugueses; destruição de símbolos portugueses; introdução de espanhóis na sua população; proibição do uso da bandeira portuguesa...Olivença continua a falar algum português e a ter expressões portuguesas no seu castelhano; continua a ter o folclore português; continua a ter monumentos tipicamente portugueses; a ter a rica gastronomia portuguesa e alentejana; continua a não ter nenhum marco de fronteira luso-espanhol; continua a ser efectivamente portuguesa, de alma e de lei...
\end{abstract}

(Matéria apresentada ao blog pelo grupo chamado 'forumeiros')

Todos os sites explicitam que a língua espanhola é a majoritária e reconhecem o português oliventino como um 'subdialeto' do português alentejano com um superestrato da língua do 'conquistador' ${ }^{102}$, reconhecendo, e sempre frisando, que a língua do conquistado não foi substituída; somente recebeu novos usos, o que classificamos neste trabalho de base sociolinguística, novas variantes linguísticas através do contato entre línguas diferentes.

Ainda em contato com as redes sociais, em outro blog publicado recentemente $^{103}$, o autor ${ }^{104}$ escreve sobre uma entrevista com o jogador de futebol português Cristiano Ronaldo. Atualmente jogando em um time espanhol, ele afirmou que o que mais o impressionava na cultura espanhola era a forma como os espanhóis valorizavam o que é deles. No blog, o autor, num sentimento de revolta, concorda plenamente com o posicionamento do jogador, todavia, severamente dispara diversas críticas contra tal nação, acusando-a, inclusive, de valorizar até mesmo o que não lhe pertence, tal como ocorre com Olivença. Acresce, ainda, que muitos não concordam com essa dominação espanhola sobre uma terra que, até 1801, pertencia a Portugal.

Em trabalho de campo, é notório o profundo descontentamento de portugueses que moram em Olivença com relação ao estatuto minoritário e ao descaso com o PLH. Alguns moradores do outro lado da fronteira, no caso em Estremoz, os quais também lutam pelas mesmas causas e publicam igualmente diversas matérias estimulando os

\footnotetext{
102 Percebe-se no site, que o termo 'dominador' é utilizado como forma de não aceitação do domínio espanhol. Fica subentendido que Olivença foi usurpado de Portugal após tantos séculos.

${ }^{103}$ Blog http://depoisfalamos.blogspot.pt/ - Publicado em 19 de janeiro de 2015.

${ }^{104}$ Matéria publicada por Luis Cirilo às 12:41 $\mathrm{h}$.
} 
leitores a não se conformarem com a dominação espanhola em terras que estes consideram ser portuguesas.

Luna, professor licenciado em História pela Faculdade de Letras da Universidade de Lisboa, é um exemplo disso, denominando-se um ativista da causa de Olivença, mesmo não morando na cidade. Em uma de suas publicações ${ }^{105}$, revela-se inconformado com a desvalorização da língua portuguesa falada em Olivença e reverbera a ideia de usurpação, o que conduz a defender que a restituição seja feita a Portugal. Em seu livro "Nos caminhos de Olivença" retrata muito bem essa questão.

Ainda, na mesma matéria sobe análise, o autor expressa sua indignação quanto à desinformação e desinteresse do próprio povo português em lutar por sua autonomia e pela preservação de sua etnia. Enfatizando, adicionalmente, que os portugueses se sentem extremamente inferiores aos espanhóis e que talvez seja esse o motivo de permitirem tão pacificamente serem dominados ${ }^{106}$.

A despeito dessa conformação eferida por Luna, durante o trabalho de campo, notamos diversos grupos de portugueses que se envolvem com a causa divulgando o PLH, a fim de que permaneça viva entre os oliventinos e passe a fazer parte do ensino até mesmo nas escolas. Há, inclusive, um movimento sociopolítico para que tal língua seja considerada patrimônio cultural ${ }^{107}$.

A Associação Além Guadiana ${ }^{108}$ tem tido protagonismo nessas ações e tem trabalhado para que as pessoas valorizem seu PLH. Em seu jornal, os artigos apresentam contribuições para a aceitação do bilinguismo, especificamente na incorporação da língua portuguesa como língua ativa dentro desse território considerado espanhol.

\footnotetext{
${ }^{105}$ Matéria encontrada no site: 〈http://estrolabio.blogs.sapo.pt/1225594.html>

106 "Muitos portugueses nem conhecem a sua História, mas o mais grave é que Portugal se acha tão mau, tão mau, que nem reivindica o que é seu de direito. Em 20 de maio de 1801, Olivença foi ocupada por Espanha. Curiosamente, foi em 20 de maio de 2002, que Timor dia da independência de Timor..."

${ }^{107}$ Há alguns núcleos em Extremadura que contribuem com esta propagação como A Codosera; Cedillo; O Museu Etnográfico "González Santanta" de Olivenza, que recebe apresentações diversas sobre o Português de herança tais como: "Estudo Compilatório do Português Oliventino" e no dia 17 de abril de 2015, ojornal Além Guadiana, fez a apresentação "O tempo da Língua".

${ }^{108}$ As informações detalhadas se encontram no site:

$<$ http://www.alemguadiana.com/portugues/quienes\%20somos\%20somos\%20por/espanhol.html>
} 
Além disso, outra atitude já tomada por oliventinos em prol dessa luta contra a perda de etnia foi publicada no site Observador em 26/12/2014 ${ }^{109}$, por meio do que se tomou conhecimento de que foram entregues mais de 90 pedidos ao Estado português para a obtenção de nacionalidade portuguesa, e que oitenta desses habitantes obtiveram êxito e comemoram a conquista.

Um dos organizadores da associação Além Guadiana, que é a canalizadora desses processos, Eduardo Machado, afirma que muitos desses que conseguiram a nacionalidade, são oliventinos com ascendência portuguesa. Nesse texto, há o esclarecimento de que, em Olivença, fala-se português desde a Idade Média, embora seu uso hoje se encontre reduzido às camadas mais idosas, quando estão em "ambiente familiar". Assevera, ainda, como em outros diversos blogs e sites que a presença portuguesa em Olivença é evidente em vários locais, sendo um dos maiores exemplos a igreja Santa Maria Madalena, único espaço religioso espanhol de estilo manuelino. Explica que o templo, que é uma obra da arquitetura portuguesa do século XVI, rico na talha dourada, na azulejaria e nos elementos marítimos, é visitado diariamente por centenas de turistas. Com isso, percebemos o orgulho em apresentar que algo de grande interesse turístico não é espanhol, mas, sim, português.

Como evidenciamos até aqui, a preocupação com a perda da etnia dos moradores portugueses em Olivença é muito grande, e a forma mais eficiente para combater esse receio tem sido através das redes sociais. Exemplo disso é um dos sites $^{110}$, em cuja página inicial de acesso, encontra-se a frase: "Olivença $<<$ o português pertence ao mais profundo de nossa cultura $>$ ”. Nessa matéria, é constatável a grande luta por uma língua que seja propriamente portuguesa, sem estigmas e preconceitos, mas que está cada vez mais se perdendo ao longo das gerações. Ressalta, de forma bastante interessante, que a única forma de se conquistar a pertença a um lugar é mantendo sua língua de origem viva, como podemos observar em um trecho da entrevista com Joaquim Fuentes Becerra, presidente da associação Além Guadiana:

Joaquim Fuentes Becerra refere que $\ll$ a melhor maneira de recuperar os caminhos perdidos, entre eles é o da língua, e através dos sentidos, emoções, dos pequenos grandes descobrimentos da nossa história desconhecida e dos novos laços de Portugal >>. Não podemos ter duas culturas se uma delas não

\footnotetext{
$109<$ http://observador.pt/2014/12/26/oitenta-habitantes-deolivenca-pedem-para-ser-portugueses/>

${ }^{110}$ Matéria lida no site: <http://port.pravda.ru/news/sociedade/05-07-2010/30048-olivenca-0/>
} 
se pode expressar através das palavras, só das pedras mudas〉>, lamenta Becerra, considerando que é fundamental apostar no ensino de Línguas aos mais jovens. ${ }^{111}$

(FUENTES BECERRA, 2010)

A matéria, através da fala de Joaquim Fuentes Becerra, ressalta a importância do "Além Guadiana" nos eventos para a recuperação da cultura portuguesa em Olivença, ressaltando que ações afirmativas devem ser implementadas. Algumas delas são: (i) a recuperação dos velhos nomes das ruas em português (projeto já aprovado); (ii) a criação de um espaço dedicado ao mundo lusófono: o <<Lusofonias >>; e (iii) a divulgação do português que se fala em Olivença por professores da escola "Francisco Ortiz". É frisado, ainda, que a iniciativa de recuperação dos nomes ancestrais das ruas em português, foi mais um exemplo da iniciativa de contribuir para o desenvolvimento cultural, afirmando que "a língua portuguesa caminha pelas ruas de Olivença". Além disso, Becerra assente que a língua portuguesa, que é cultura viva, "está conversando nas cozinhas através das receitas entre os moradores oliventinos".

Agora, a grande preocupação destes que brigam pela manutenção da poderosa arma de defesa da etnia portuguesa assenta-se na constatação de que os pais estão deixando de falar com seus filhos em português, fato corroborado parcialmente no trabalho de campo que realizamos. O desconforto é que os últimos nascidos luso falantes são velhos de hoje, o que facilmente depõe a favor, segundo Becerra, do desaparecimento da LH entre os portugueses oliventinos. Segundo informações contidas no site, em Táliga, antiga aldeia de Olivença, o português já teria desaparecido, o que corresponde a uma perda cultural irreparável para a cidade.

De todo modo, embora os portugueses de Olivença achem difícil, estão lutando pela recuperação da língua de Camões, fazendo apostas no ensino dos mais jovens. Não perdem de vista, adicionalmente, que outras línguas minoritárias em condições também muito complicadas conseguiram ser recuperadas, e nisso, ganham forças para o desenvolverem projetos de conscientização dos oliventinos sobre o valor que tem o sentimento de pertença a PLH. Segundo eles, o processo de recuperar o que tanto desejam - sua potencialidade dentro de uma sociedade considerada superior passa pelo reconhecimento disso.

${ }^{111}$ Publicado no site por Ana Clara | terça-feira, 29 de Junho de 2010. 
Os materiais consultados elucidam parte das questões prioritárias desta tese, pois nos garantiram o caminho para formular perguntas sobre o sentimento de pertença linguística através de marcas, pois a partir dessas questões identificaremos lugares de resiliência do PLH, tais como lápides escritas em português ou a recuperação dos nomes das ruas em português ${ }^{112}$. Esses lugares nos permitem reconhecer que estamos diante de uma guerra cuja arma principal dos portugueses oliventinos e de PLH não é de fogo, mas sim de palavras!

\subsection{O OUTRO LADO DA FRONTEIRA - ELVAS}

\subsubsection{Elvas - uma cidade de muitas batalhas}

Elvas é uma cidade de Portugal, situada na região do Alentejo ${ }^{113}$. Possui uma população de 15. 941 habitantes. É muito tranquila, com uma linda paisagem natural, muitos chafarizes e é considerada a maior cidade e concelho do Distrito de Portalegre.

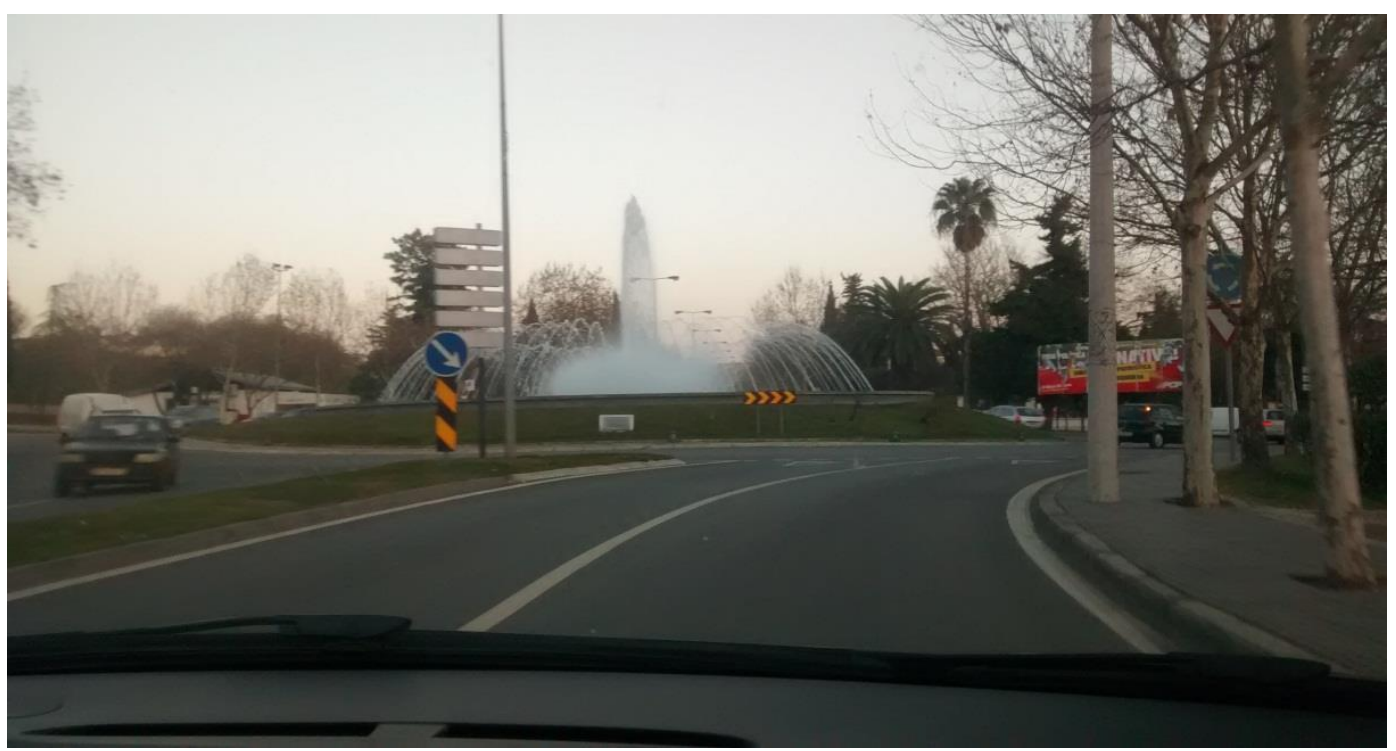

Imagem 11 ${ }^{114}$ : Um dos chafarizes da cidade de Elvas.

\footnotetext{
${ }^{112}$ Os anexos trazem fotos retiradas das placas de ruas de Olivença que mostram a recuperação dos nomes em português.

113 Cf na seção sobre Olivença.

114 Todas as imagens desta seção foram fotografadas por nós no período de janeiro a junho de 2015.
} 


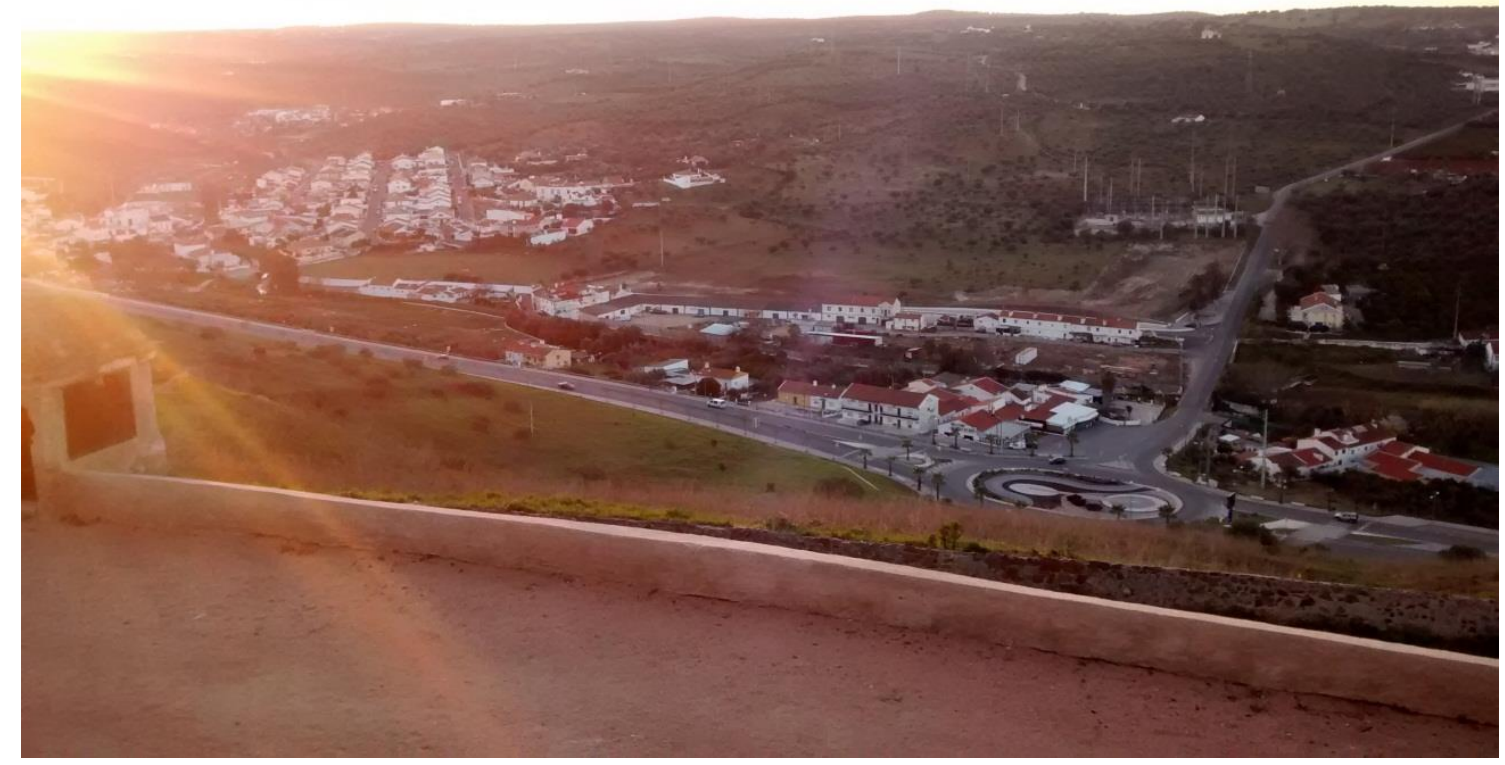

Imagem 12: A cidade de Elvas

De acordo com Correia et alii (1940), a fundação de Elvas é atribuída aos Romanos, embora alguns autores afirmem ter origem muito mais antiga.

O domínio dos romanos foi muito longo, deixando na cidade vários vestígios, tais como inscrições e moedas encontradas em várias escavações da região, e a grande e linda construção do castelo, apresentada nas imagens 23 e 24, que mais tarde foi ampliada pelos árabes. Correia et alii (1940) citam um geógrafo árabe, o qual sobre Elvas afirmara: "cidade forte, sitiada junto de uma montanha".

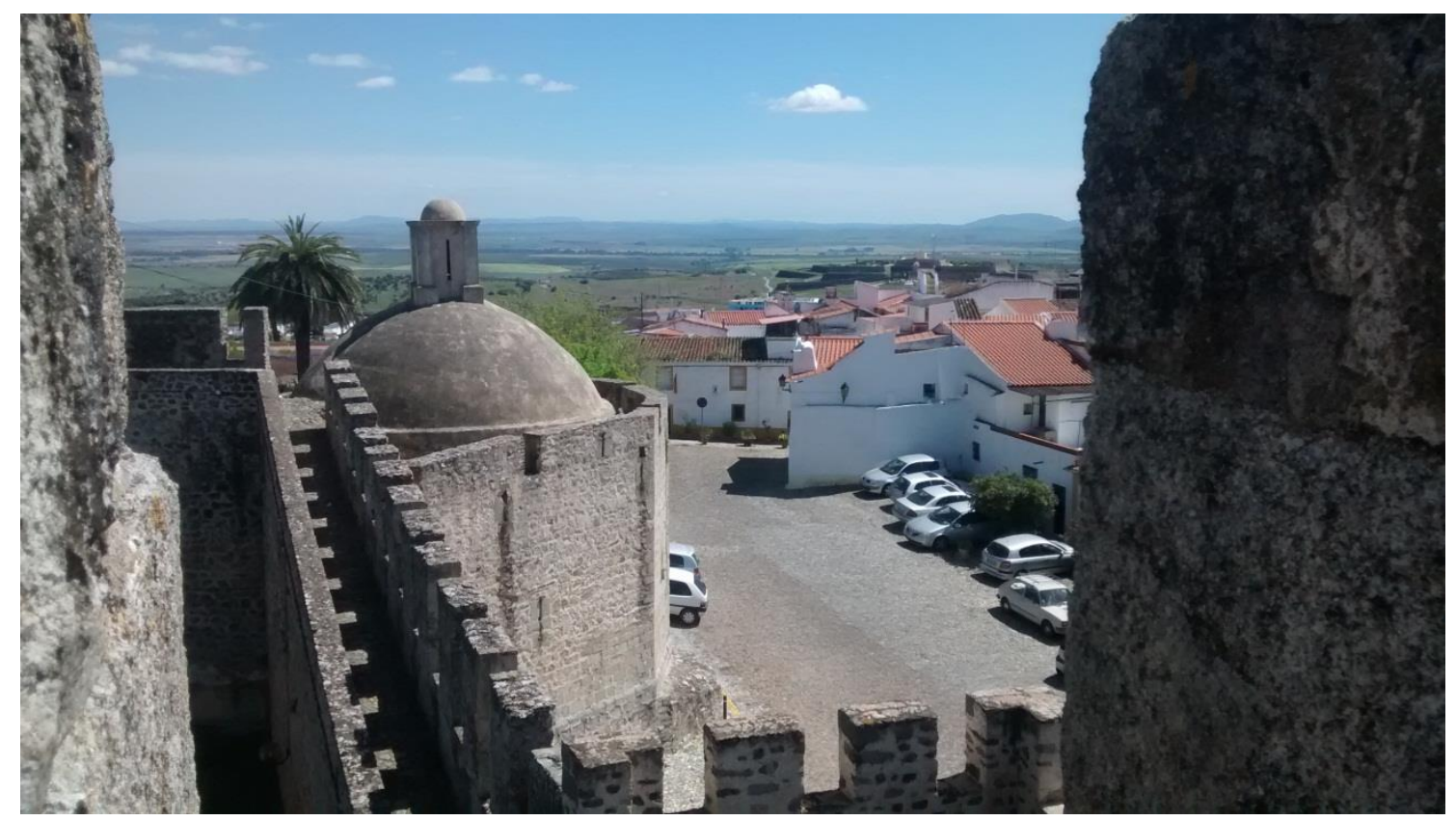

Imagem 13: O castelo de Elvas 


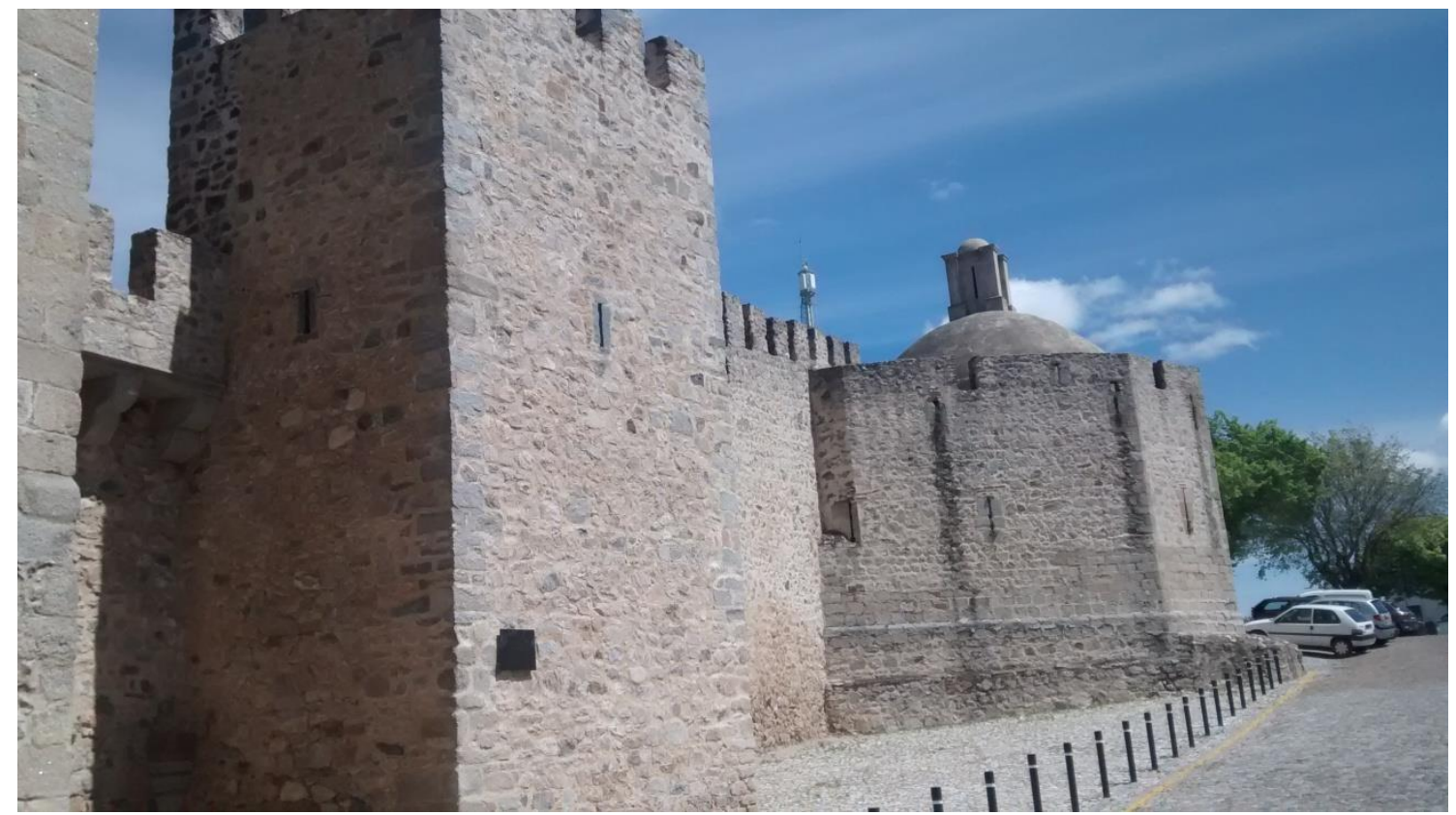

Imagem 14: O castelo de Elvas.

Tanto quanto Olivença, a cidade já foi palco de muitas batalhas, dentre as quais as invasões dos Godos e depois a dos Árabes. Em 1166, D. Afonso Henriques conquista a cidade, livrando-a as invasões árabes.

Em 1230. D. Sancho II, que havia sido forçado a abandonar a cidade em 1226, reconquistou-a, passando definitivamente para a posse dos portugueses.

De acordo com Correia et alii (1940) e Souto (1965), a história de Elvas está ligada à história da independência do país, pois era na cidade em que se concentravam vários contingentes de tropas portuguesas.

Em 1801, período em que Olivença passa ao domínio espanhol, o qual cortou as comunicações de Elvas com exército português, sendo o governador da cidade, D. Francisco Xavier de Noronha, na mesma época, intimado a render-se. Sua resposta, porém, foi, segundo Correia et alii (1940), digna de um verdadeiro patriota, pois respondeu com altivez que "enquanto houvesse pedra sobre pedra nos baluartes, e um soldado que pudesse disparar um tiro e tivesse vida o general comandante, ninguém ali falava em capitular" (Correia et alii, 1940:526). 
Tanto Olivença, quanto Elvas e outras cidades de Portugal serviam como palco de guerras para os domínios das terras, no entanto, ao contrário do que ocorreu com Olivença, Elvas se manteve forte e não cedeu às invasões espanholas.

A cidade de Elvas possui grandes características históricas e com um imenso patrimônio militar: o Forte de Santa Luzia, o Forte da Graça, os Fortins de São Mamade, São Domingo e São Pedro, além dos quatro panos de muralha que a tornaram uma cidade dotada de uma grande força militar.

Além disso, por onde se caminha na cidade, é possível contemplar uma beleza única, com ruas repletas de características históricas, com igrejas e conventos arquitetônicos.

Em Elvas podemos vislumbrar o Aqueduto da Amoreira, imagm 15, que é um dos mais notáveis do país, medindo a sua imponência com o das Águas-Livres ${ }^{115}$, que é obra mais grandiosa.

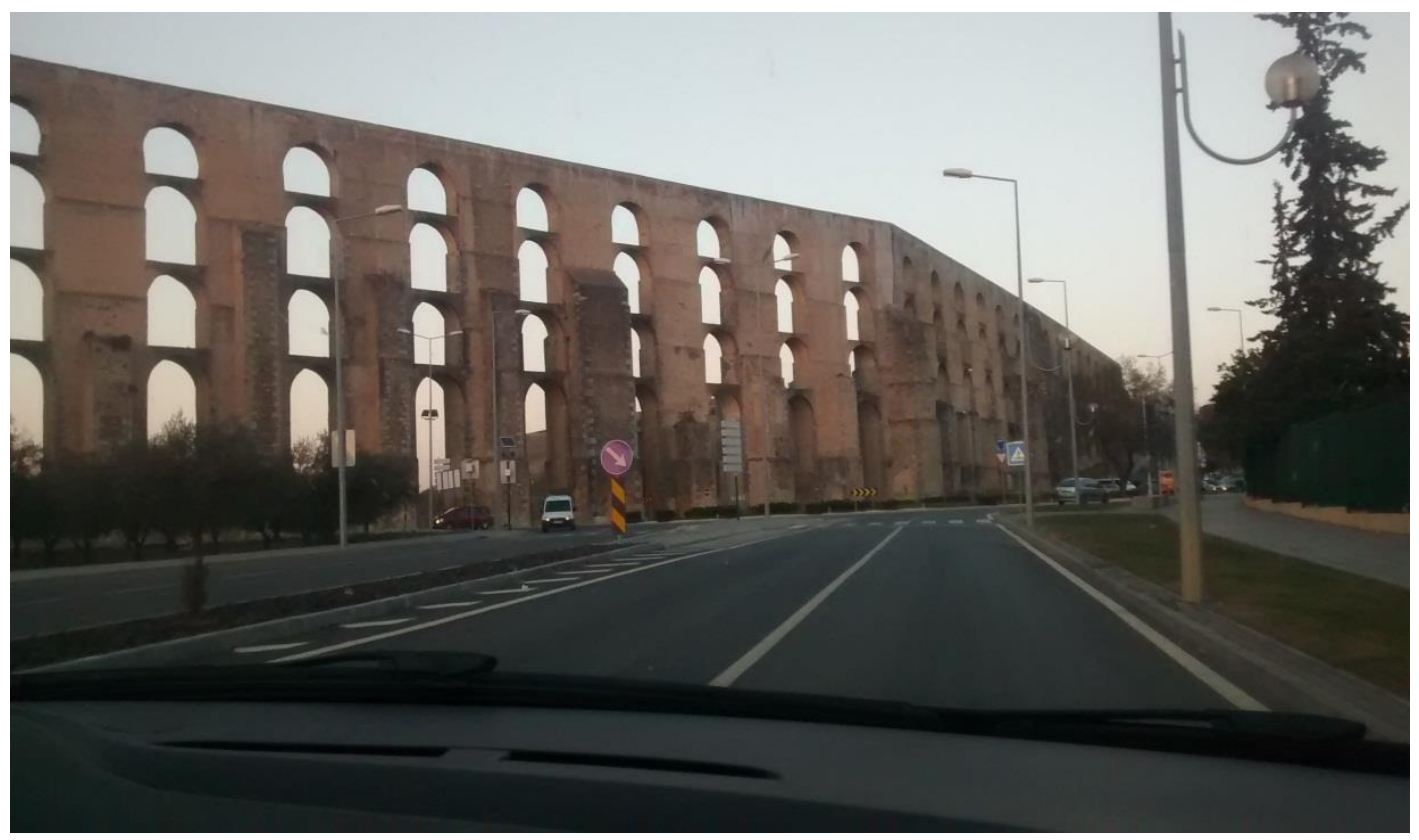

Imagem 15: O Aqueduto da Amoreira ${ }^{116}$.

\footnotetext{
115 O Aqueduto das Águas Livres é um complexo sistema de captação, adução e distribuição de água à cidade de Lisboa, em Portugal.

116 O Aqueduto da Amoreira, que possui uma extensão de cerca de oito quilômetros, comporta um conjunto de diversas galerias, que numa primeira zona são subterrâneas, e ao nível do terreno são formadas por quatro arcadas sobrepostas, apoiadas em pilares quadrangulares e fortalecidas por
} 
Além de fornecer beleza à cidade, em 1620, correram pelo Aqueduto as primeiras águas dentro dos muros da cidade, que desembocavam numa fonte provisória construída junto à antiga Igreja da Madelena ${ }^{117}$. Em 1622, estava concluída a Fonte da Misericórdia, que finalizava o percurso das galerias do aqueduto.

Durante a Guerra da Restauração ${ }^{118}$, o aqueduto transformou-se num obstáculo à construção de um novo conjunto de fortificações da cidade, e os engenheiros militares pensaram em derrubá-lo. No entanto, os moradores da cidade se opuseram à medida e conseguiram que o governador da Praça-forte de Elvas, o conde de São Lourenço, desistisse da demolição.

Como temos visto, Elvas é a cidade mais forte da fronteira portuguesa, e em setembro de 2013, Elvas e Badajoz assinaram um protocolo de união para atrair mais emprego e investimento para a cidade. No entanto, mesmo diante das forças para que a cidade melhorasse economicamente, não foi o suficiente para que os espanhóis decidissem viver na cidade, como fazem os portugueses em Olivença.

contrafortes semi-circulares, perfazendo uma altura de trinta e um metros. Foto tirada por nós no período de janeiro a junho de 2015.

117 A Igreja da Madalena que atualmente existe é o resultado de várias reconstruções da igreja que tinha sido construída em 1150 ou 1164 por ordem de D. Afonso Henriques junto à cerca moura. Situa-se na freguesia de Santa Maria Maior, em Lisboa.

${ }^{118}$ Cf no capítulo sobre o locus da pesquisa constam todas as batalhas que Elvas e Olivença sofreram. 


\section{CAPÍTULO 3}

\section{METODOLOGIA DA INVESTIGAÇÃO}

Lidar com línguas de contato, LH e com fronteiras requer uma combinação de metodologias que deem conta de colocar a nu os movimentos sociolinguísticos em curso, mas também os sentimentos de pertença e este é o objetivo deste capítulo que terá como meta apresentar as decisões que tomamos para recortar adequadamente um espaço fronteiriço segundo um grupo social específico, no caso da Espanha, os oliventinos que se sentem portugueses. Então, integra este capítulo o desenho das células constituídas para toda e qualquer afirmação que se faça a partir de entrevistas colhidas in loco. Além disso, pelo fato de esta pesquisa estar moldada num viés metodológico de entrevista, este capítulo discutirá abordagens teóricas sobre a importância de um trabalho qualitativo, que, tão científico quanto estudos quantitativos, prevê um minucioso enquadramento teórico e uma cuidadosa apresentação de análise, que está longe de ser simples e superficial. 


\subsection{A interação pesquisador $X$ informante e a interação pesquisador - informante: a importância da compreensão do contexto comunicativo}

Diante de todas as arguições dos autores estudados no capítulo 1, Goffman (1998), Bateson (1998), Knapp (1999), Gumperz (1998), Erickson e Shultz (1998), Stalnaker Grice (1982) e Dascal (1982), sobre a importância de metodologias eficientes para o trabalho de pesquisa, as quais devem ter cautela na averiguação dos dados e que não foquem apenas em variáveis sociais ou simplesmente no sentido das palavras, apresentamos os estudos de Schwars (1999), os quais nos revelam o grande problema de muitas metodologias, e especial às que recolhem dados a partir de questionários de alternativas.

Além do grande problema das metodologias que não atentam para implicaturas conversacionais dos entrevistados, muitos pesquisadores que usam autorrelatórios a partir de questões de múltiplas escolhas podem também colocar sua pesquisa em risco, pois, de acordo com o autor, tal metodologia é uma fonte falível de dados, uma vez que, dependendo do formato em que as perguntas são formuladas ou do contexto, os resultados podem apresentar mudanças significativas.

De forma a ilustrar o problema da metodologia no formado de questões com alternativas, Schwarz (1999) apresenta um teste no qual os respondentes deveriam dar uma resposta para a seguinte pergunta: "Qual é a coisa mais importante para a criança no preparo de suas vidas?”. Na verificação dos resultados, o teste para a checagem da confiabilidade do resultado mostrou que $61,5 \%$ das pessoas escolheram a alternativa "Pensar por eles mesmos", enquanto apenas 4,6\% responderam algo neste sentido em uma pesquisa sem a apresentação de alternativas Schuman \& Presser (1981 apud Schwarz 1999).

Sentindo esse grande problema, psicólogos e metodologias de inquéritos desenvolveram um campo interdisciplinar de pesquisa para melhorar os resultados obtidos de fontes como estas. Schwarz (1999) explica que alguns cuidados necessários foram tomados, a partir dos seguintes passos:

1. Verificar se os respondentes compreendem as questões feitas pelos pesquisadores; 
2. Verificar o papel da memória autobiográfica em relatórios retrospectivos de comportamentos e como os melhorar;

3. Verificar os processos de julgamento junto à ocorrência dos efeitos contextuais ao medir a atitude;

4. Verificar os processos de autorrelatórios comportamentais e mudanças de atitudes na fase adulta;

5. Verificar quais técnicas são mais "eficientes".

Nessa pesquisa, que propõe um olhar mais atento ao método de questões de autorrelatório, verifica-se a aplicação do modelo pergunta-resposta de forma padronizada, focando em questões básicas e psicológicas.

Nessa nova metodologia, a primeira seção é para compreender como os informantes compreendem as questões feitas para eles e destaca a regra de processo de inferência conversacional na questão compreensão. A segunda seção é para saber como os informantes respondem a questões comportamentais e como relatam essas perguntas para questões de memória autobiográficas e estratégias de estimação. A terceira e última seção é para as perguntas de atitudes e para rever as condições que fornecem coerência para os efeitos do contexto em medição de atitude.

Mais uma vez, estamos diante de estudos que pretendem transformar as metodologias científicas em instrumentos cada vez mais eficazes, que levam em conta todos os elementos presentes na interação entre pesquisador e informante. Até aqui, os autores batem na mesma tecla, que é a de não deixarmos de lado todos os elementos que fazem parte de um contexto de conversação ou de apresentação das ideias, pois, como já afirmado nessa seção, nem sempre o sentido está explícito nas palavras.

Assim, na metodologia de respostas através de questionários, Schwarz apresenta que a primeira tarefa que os respondentes devem ter é a de compreender a pergunta feita pelo pesquisador, problema que pode acontecer não só em pesquisas de questionário, como também em entrevistas face a face. De acordo com o autor, do ponto de vista psicológico, a compreensão da pergunta reflete a realização de dois processos entrelaçados. 
A primeira refere-se à compreensão semântica da locução, pois, nem sempre, entender as palavras é o suficiente para responder a pergunta, como por exemplo, a pergunta "O que você tem feito hoje?" pode não fornecer a resposta esperada pelo pesquisador, caso não especifique o tipo de atividade. Neste caso, Schwarz (1999) alerta que muitas questões realizadas exigem inferências sobre a intenção dos pesquisadores para determinar o sentido pragmático da pergunta.

Além disso, a outra se refere que para inferir o sentido pragmático da pergunta, respondentes dependem das suposições táticas que governam a conduta da conversação. Tais suposições táticas relatadas por Schwarz (1999) foram descritas por Grice (1982), o qual propõe que conversações procedem de acordo com o Princípio de Cooperação, na qual pode ser expresso na forma de quatro máximas, já explicitadas no primeiro capítulo.

Schwarz (1999), utilizando a teoria de Grice, apresenta uma observação quanto à necessidade da manutenção da máxima da qualidade através do seguinte exemplo de pergunta com resposta aberta: "O que você tem feito hoje?"

De acordo com Schwarz (1999), o respondente deverá determinar, ou seja, inferir, quais atividades podem ser de interesse do pesquisador. Neste caso, provavelmente omitiriam atividades óbvias, tal como "dando uma entrevista", as respostas já informadas anteriormente ou já imaginadas pelo entrevistador, como por exemplo, "tomei banho". No entanto, se fosse uma pesquisa que fornecesse uma lista, certamente selecionariam tais atividades e não relatariam atividades que fizeram e não estavam lá.

Por outro lado, os efeitos de forma pergunta-resposta são: clarear o significado da pergunta de interesse e relembrar o que eles poderiam não considerar. Além disso, podem trazer estudo de valores familiares como no exemplo da pergunta "Qual é a coisa mais importante para a criança ser preparada para suas vidas". Muitos escolheriam "pensar por eles mesmos" por visualizar algo de reflexão, o que não ocorreria se fosse uma resposta aberta.

Outra ilustração da necessidade do processo de inferência em metodologias de pesquisas com resultados pautados nas respostas de informantes é questionários com 
perguntas do tipo: "Com qual frequência se sentiram muito irritados recentemente?". Neste caso, será necessário primeiro determinar o que significa 'muito irritado' para o pesquisador, ou seja, o informante deverá inferir se 'muito irritado' se trata de 'maiores' ou 'menores' aborrecimentos.

Nessa metodologia de pesquisa das coletas de informações dos questionários, foi verificado que quando o informante lia alternativas com 'menos de uma vez no ano' para 'mais de uma vez no mês', ele inferia que o pesquisador tinha raros eventos em mente.

Ao tratar do contexto da pergunta, Schwarz (1999) apresenta que muitas respostas são influenciadas por observar no modelo das questões características que as associam com o interesse epistêmico dos pesquisadores. Mais uma vez, ilustra com uma pesquisa na qual os informantes deveriam responder a seguinte questão: "Por que os assassinatos massivos ocorreram?".

Para tal, alguns receberam um questionário que possuía o timbre "Instituto para Pesquisa de Personalidade", o que levou os informantes a inferirem que o pesquisador fosse um psicólogo de personalidade, outros receberam um questionário com o timbre "Instituto para pesquisa social", o que os fez inferirem que o pesquisador fosse um cientista social. Neste caso, ficando visível a influência que exerceu os papéis timbrados, escolheram a informação que seria mais relevante para o pesquisador “provável interesse epistêmico do pesquisador" Schwarz (1999).

Assim, em uma pesquisa de cunho científico, a qual depende das respostas de um informante, não se pode ignorar que a compreensão da pergunta feita pelo entrevistador envolve inferências sobre a intenção dos interlocutores para determinar o sentido pragmático dela. De acordo com Schwarz (1999), o foco tradicional dos pesquisadores é usar "as palavras certas" na escrita do questionário que precisa ser complementado pelo processo conversacional.

Da mesma forma, os pesquisadores da sociolinguística interacional se voltam, não para 'as palavras certas', mas para o contexto em que estas palavras estão inseridas no momento da interação discursiva. 
Em outro modelo de pesquisa, muitas perguntas requerem que os interlocutores relatem a frequência com que eles se engajaram em um comportamento específico durante um período de referência estipulado, no entanto, ocorre que os informantes não são acostumados a ter representações de episódios detalhados disponível na memória, o que afetará na escolha das alternativas.

Em um dos testes, foi perguntado a interlocutores alemães "quantas horas eles assistiam televisão num dia típico". Foi dada uma escala de frequência que ofereceu tanto alta frequência quanto baixa frequência. O grande problema já apresentado anteriormente é que ocorre a negligência de muitas informações. Mais uma vez, as alternativas dadas influenciaram nos resultados, pois somente $16 \%$ da amostra dos alemães relataram assistindo TV por mais que 2 horas e meia quando a escala apresentava baixa frequência de respostas alternativas, enquanto 37,5\% reportaram fazendo isso quando a escala reportava alta frequência nas respostas alternativas.

Fato importante observado pelos pesquisadores que aplicaram tal teste é que o impacto das respostas alternativas é representado na memória, forçando os informantes a utilizarem uma estratégia de estimação. Além disso, foi percebido que quando o comportamento é raro e importante, e consequentemente bem-representado na memória, o impacto da repostas alternativas é menor.

Sendo assim, utilizando a ideia de relevância, proposta por Dascal (1982), percebemos que tanto no momento interativo, quanto nos processos em que a memória deve ser ativada, sempre será melhor apresentado e sem influência do contexto, aquilo que, na concepção do informante, está na posição de relevância.

O que temos visto nesta seção é que uma pesquisa com metodologia voltada à interação face a face, como é o caso de entrevista, ou mesmo com informações colhidas por questionários, precisa que a atenção do pesquisador se volte para a situação para que possa recolher não só as informações descritas, como também as fornecidas através de outros recursos de implicaturas.

O que dizemos é que, muitas vezes, podem ocorrer divergências na entrevista, ou um resultado não esperado pelo fato do pesquisador lançar uma pergunta e o informante não a compreender claramente, num processo que podemos chamar de 
abando de algumas das máximas proposto por Grice (1982). Ocorre que, se nesse processo de coleta de informações, os participantes do discurso não compreenderem as implicaturas conversacionais, os resultados da pesquisa terão, infelizmente, muitos prejuízos.

Diante desse desafio de uma pesquisa socio-interacional, apresentaremos um capítulo sobre algumas falas de nossos entrevistados juntamente com um pouco do comportamento que pudemos observar em cada um.

Além disso, levando em conta a afirmação que 'qualquer elocução pode ter um significado contrário ao que está explícito no discurso' (Bateson, 1998:57), e que o contexto de produção pode alterar o comportamento linguístico dos participantes da interação discursiva (Goffman, 1998), propomo-nos, nesta pesquisa, a associar algumas falas com o comportamento dos entrevistados e com o contexto, os quais, provavelmente, nos forneceram implicaturas conversacionais importantes para a nossa análise.

No entanto, como já foi afirmado por todos os autores aqui tratados, tal desafio não é algo fácil, pois estamos diante de implicaturas que nem sempre são fáceis de serem desvendadas, mas que faremos o possível para descrevê-las de forma mais clara possível nessa pesquisa, fazendo o possível para que não ocorra o abandono das máximas da Qualidade e do Modo.

\subsubsection{A análise qualitativa - um olhar para o contexto}

De acordo com Alves e Silva (1992), a análise qualitativa de dados, por se caracterizar por um processo indutivo, tendo como interesse a vida dos entrevistados, tem preocupado muitos pesquisadores brasileiros pela falta de sistematização.

As autoras, na consciência de que o entrevistador é seu próprio instrumento de trabalho e que não há procedimentos descritos para que o ajude em tal tarefa, propõem algumas estratégias para que a análise não seja simplesmente uma mera descrição de atitudes ou um "exercício de camaradagem" (Alves e Silva, 1992:62). 
Da mesma forma como temos visto nos estudos sobre a sociolinguística interacional, as autoras também alertam para o cuidado que o pesquisador, disposto a realizar um trabalho com base metodológica em entrevistas, deve ter para com seu entorno, não trabalhando como se existisse apenas ele e o seu entrevistado. Mais uma vez, é apresentada a importância de não se guiar por apenas intuição, mas de observar a realidade pesquisada.

De fato, por se tratar de um trabalho não quantitativo, a pesquisa qualitativa pode transmitir a sensação de não rigor científico, o que não é verdade, pois, as informações colhidas devem ser observadas com atenção, não negligenciando nem mesmo as implicaturas presentes na interação discursiva.

Alves e Silva (1992) se propõem a apresentar alguns procedimentos importantes para uma pesquisa com o caráter metodológico de entrevista, tais como: a necessidade de obter dados dentro de um contexto, da imensidão à sistematização dos dados e a composição dos resultados pela redação.

Seguindo os passos das autoras, adentramos inicialmente em um fator crucial para uma pesquisa de base qualitativa que é determinar como coletar os dados, no nosso caso, a entrevista. De fato, não é viável um trabalho neste viés sem que seja definido um padrão ou roteiro para as entrevistas, principalmente para que os resultados sejam os esperados pelo pesquisador. No caso desta tese, tivemos o cuidado de guiar as perguntas para o foco central, que é o uso da LH e o uso do português por falantes nativos.

As autoras propõem também que o formato proposto pelo pesquisador seja flexível para que a interação discursiva não se torne mecânica, mas que possa aproveitar a espontaneidade do informante, o qual fornecerá muito mais informações à medida que a entrevista lhe for prazerosa.

Assim é que das atitudes de aproximação, respeito e empatia, trazidas pelo pesquisador, virá a disponibilidade dos sujeitos e o seu envolvimento com a tarefa de informantes (o que amplia a possibilidade de validade dos dados obtidos), fazendo dela um momento de reflexão, retomada de fatos, valores e ideias do passado (quando este é o caso) e a gratificação com sua transmissão ao entrevistador. 
Apresentando os trabalhos de Queiroz (1987), Alves e Silva (1992) também discutem as grandes dificuldades da transcrição literal do trabalho de entrevista, enfatizando a necessidade de que seja complementado por registros sobre as atitudes dos sujeitos ou até mesmo por problemas da gravação.

Quanto ao segundo passo a ser tomado, que é a importância de que os dados sejam sistematizados, Alves e Silva (1992) afirmam que a análise qualitativa tem por função captar os significados na fala dos informantes dentro do contexto em que eles estão inseridos. Desse modo, deixam claro que, se dessa forma for o procedimento do pesquisador, o resultado terá a qualidade científica que se espera.

Em uma metodologia de análise qualitativa, nos dispusemos a realizar nossa pesquisa de uma forma semi-estruturada ${ }^{119}$, mas que contemple não só a apreensão dos aspectos linguísticos das falas de nossos entrevistados como também dos elementos contextuais peculiares que envolvem todo o processo comunicativo de cada entrevista.

Nesse momento da pesquisa, Alves e Silva (1992:65) levantam três importantes características que não podem ser deixadas de lado durante o trabalho de entrevista que são:

(i) a primeira é a "formulação de questões advindas do seu problema de pesquisa", neste caso, o pesquisador não pode deixar de levantar questões que possam responder às indagações levantadas na pesquisa;

(ii) a "formulação da abordagem conceitual", a qual deverá gerar pontos de possíveis interesses e interpretações para os dados;

(iii) "a própria realidade sob estudo", a qual "exige um espaço para mostrar suas evidências".

O que as autoras definem como um trabalho de pesquisa sistemático é descrito da seguinte maneira:

\footnotetext{
119 Alves e Silva (1992) tomam como base os estudos de Cannel e Kahn (1974) que propõem os estudos qualitativos de entrevistas de forma semi-estruturados, os quais necessitam de uma composição de roteiro com tópicos gerais selecionados e elaborados de tal forma que sejam aplicados a todos os entrevistados.
} 
O momento de sistematização é pois um movimento constante em várias direções: das questões para a realidade, desta para a abordagem conceitual, da literatura para os dados, se repetindo e entrecruzando até que a análise atinja pontos de "desenho significativo de um quadro", multifacetado sim, mas passível de visões compreensíveis.

(ALVES E SILVA, 1992:65)

A partir do momento em que a pesquisa caminha para essa sistematização proposta pelas autoras, alguns cuidados são também colocados, tais como: necessidade de que o pesquisador se envolva com as informações colhidas, cuidado com toda a leitura dos dados, necessidade de partilhar os dados com outros pesquisadores, uma fundamentação ou literatura sobre o tema, para que extraia comentários pertinentes no auxílio de sua análise, num processo de "aprendendo o fenômeno dentro de seu contexto e interpretando seu significado" (Alves e Silva, 1992:66), busca de regularidades e diferenças nas respostas que trarão evidências importantes e, por fim, trabalhar nos dados dentro de uma estrutura com tema e questões norteadoras.

Por fim, como terceiro passo para a realização de uma análise qualitativa, temos a "concretização" (Alves e Silva, 1992:67), a qual se refere ao processo de apresentação descritiva das informações colhidas através das entrevistas. Esta fase é de suma importância para o trabalho científico, pois como já temos dito, o pesquisador deve buscar e descrever não só as informações que são visíveis na língua, mas todos os elementos que possam tornar a pesquisa muito mais completa.

O que é importante nesse momento é não descrever a análise dos dados abandonando a máxima da Qualidade e nem a máxima do Modo, tal com propõe Grice (1982). O dado deve ser analisado e apresentado de forma que fique clara sua interpretação, sem riscos de ambiguidade, obscuridade ou proposições que não sejam verdadeiras.

Duarte (2008) também apresenta a possibilidade de uma qualidade em trabalhos com recursos escassos ou que têm o pesquisador como o próprio recurso de pesquisa, os quais podem dar importantes contribuições para a investigação científica.

Tendo por base um estudo de caso, no qual investiga cada professor nas suas aulas, o autor antecipa que é um trabalho o qual exige um enquadramento teórico, uma cuidadosa apresentação e que está longe de ser simples e superficial. Ao tratar de 
pesquisa com o viés qualitativo, o autor já indica a grande resistência que muitos pesquisadores têm, preferindo estudos em critérios exclusivamente estatísticos.

De acordo com autor ainda há o pensamento de que um trabalho eficaz está nos moldes quantitativos, e muitos não percebem o quanto uma análise de caso pode trazer à tona diversos elementos de circunstâncias importantes para a pesquisa.

Sendo assim, "o estudo intrínseco de caso implica uma particular e profunda atenção de modo a captar as características holísticas e significativas de um caso" (Duarte, 2008:115). Além disso, tal como Duarte (2008), o autor ressalta que tais estudos não devem ser aleatórios, mas que sigam todos os passos necessários para que tenham resultados com a qualidade de uma pesquisa científica.

Seguindo as bases teóricas de Yin (1994; 2005) e Stake (1995; 1998), Duarte (2008) apresenta seu trabalho de caso com professores, relatando os procedimentos tomados para que sua análise pudesse ter a importância devida.

Para sua pesquisa de casos, apoia-se no que é proposto por Yin, que é a importância em se observar os dados diretamente em ambientes naturais, não confiando em dados derivados de testes, estatísticas e questionários. Como vemos, tais ideias vão ao encontro do que Schwarz (1999) afirma em seu artigo, que é o grande problema relacionado aos instrumentos de pesquisa em forma de questionários.

Duarte (2008) faz questão de tirar a imagem de que estudos de caso são apenas exploratórios, mas que contém uma gama de informações que talvez não encontraríamos em uma pesquisa quantitativa, pois tais estudos, considerados pelo autor como "fenômenos complexos", permitem uma investigação que contemplam uma preservação das características holísticas e tão importantes da vida dos informantes.

Diferentemente de Alves e Silva (1992), o autor, pautado nas bases teóricas de Yin, apresenta uma das propostas desse autor para um trabalho neste viés de pesquisa:

(i) primeiro passo, de acordo com os pressupostos de Yin, é definir qual será o caso a ser estudado; 
(ii) segundo passo é optar por um estudo singular de caso ou por um estudo múltiplo de caso;

(iii) terceiro passo é a decisão de usar ou não um desenvolvimento teórico para ajudar a selecionar o caso, desenvolver a recolha dos dados e organizar as estratégias iniciais de análise de dados.

Apresenta ainda, uma nova versão brasileira de Yin, com os seguintes passos a serem tomados numa lógica interna de estudo de casos:

(i) definir as questões do estudo;

(ii) definir suas proposições teóricas dentro de um contexto;

(iii) definir as unidades de análise;

(iv) definir a lógica que une os dados à proposição;

(v) definir os critérios para a interpretação dos dados.

Como temos visto, embora os caminhos e os passos para uma análise de caráter qualitativo sejam um pouco diferentes, a base comum entre todos é a organização sistemática do trabalho, o qual deve ter seriedade e ser estruturado de forma que os dados possam trazer amostras importantes para a pesquisa.

Sendo assim, apresentaremos posteriormente todo o percurso metodológico que assumimos, o qual segue desde os objetivos iniciais até a obtenção das entrevistas. Além disso, a análise apresentada no quarto capítulo, também será de forma a não se prender aos contextos de variáveis sociais, mas de tentar descrever, o melhor possível, as informações tanto internas quanto externas do processo comunicativo.

\subsection{Objetivos e hipóteses levantadas - $O$ trabalho de campo em região fronteiriça}

A relevância desta pesquisa traduz-se no fato de que o contato linguístico favorece uma série de modelos ricos em variações e em usos que ora se aproximam de uma língua majoritária, ora se aproximam da língua nativa ou da LH. Dessa forma, tratar dos espaços e das pessoas que recortam socialmente a língua em contato ou a LH como forma de comunicação e de convivência cultural, a despeito de todas as pressões da língua majoritária, é o que nos move. Esse jogo de forças nos levou a pressupor que 
motivações ligadas ao sentimento de pertença linguística são fundamentais para determinar em que medida pode ser preservada ou não uma LH.

Tendo por base que nem sempre a realidade da oficialidade linguística e a realidade do sentimento de pertença sociolinguística coincidem, procuramos fazer um trabalho que permitisse reconhecer as variáveis linguísticas do português oliventino. Um dos passos será a descrição de construções e usos a fim de identificar medidas justas e fatores socioculturais relevantes que poderiam favorecer a presença da língua nativa e reforçar esse sentimento de pertença a um ou outro país.

Uma das hipóteses iniciais desta tese era que, pelo fato de português e espanhol serem línguas muito próximas e fronteiriças, o sentimento de pertença linguística do português oliventino estaria muito mais incrustado entre seus falantes, principalmente entre os mais velhos. Além disso, uma segunda hipótese se voltava para a ideia de que os usos da LH estariam circulando entre os mais jovens, justamente pelo fato de serem mantidos em cadinhos de convivência compatriótica no cotidiano.

Pensando em línguas muito próximas, mas com comportamentos linguísticos muito diferentes, as quais ganham o suporte de valores e de sentimentos cobrados diariamente em espaços distintos, talvez o modelo da oficialidade faça com que uma língua minoritária seja lida em termos de "inferioridade" e o inverso ocorreria com a língua majoritária. Levantamos os seguintes questionamentos e as seguintes hipóteses:

\section{a. Questões:}

(5) Quais as formas de sobrevivência de uma língua em contato já que tais regiões parecem sobrepostas socialmente?

(6) Quais os contextos pragmáticos favorecedores de cada língua?

(7) A geração mais jovem usa a LH?

(8) Itens funcionais do passado podem ser sentidos como próprios da língua materna ou como itens da língua estrangeira? 


\section{b. Hipóteses:}

Refletindo sobre as situações corriqueiras em regiões de fronteiras, hipotetizamos o seguinte:

$\left(1^{a}\right) \mathrm{Na}$ região de Olivença, na Espanha, sobrevivem, assim como nas línguas, um sentimento de pertença sociolinguística incrustado entre os falantes mais velhos;

( $\left.2^{\mathrm{a}}\right)$ Considerando que o $\mathrm{PH}$ pode ser lido como resultado de um efeito "catraca" cultural é possível hipotetizar que o falante receba a variedade e a use, podendo até mesmo mantê-la como a memória de sua funcionalidade social, como, por exemplo, ocorre em placas de ruas;

(3 $3^{\text {a }}$ De acordo com a proposta relacionada à consciência do indivíduo, podemos hipotetizar que nem sempre a seleção da língua portuguesa é consciente. $O$ mesmo ser dará com a manifestação do espanhol em ambiente familiar. O code switching seria a marca do bilinguismo dos portugueses oliventinos;

$\left(4^{\text {a }}\right)$ Esperamos verificar que itens gramaticais, tais como conjunções e preposições, denunciem o quanto a língua nativa e a LH estão presentes na realidade cotidiana desses indivíduos. Essa hipótese justifica-se pelo fato de que itens mais gramaticais são menos controláveis em situações espontâneas de fala.

\subsection{Contextualização do trabalho de campo em Olivença}

No início de nossa pesquisa, a atenção se voltou para um trabalho de campo no qual pudesse nos fornecer informações sobre o comportamento linguístico dos falantes portugueses nativos que vivem em Olivença bem como o sentimento de pertença de LH que as gerações mais jovens possuíam.

Assim, assumindo que a divisão político-geográfica seja uma verdade assumida pelos povos envolvidos, partimos do pressuposto de que Olivença 
(i) é região fronteira com Portugal (e não parte de seu território);

(ii) que a língua portuguesa seja apenas uma herança para algumas famílias; e

(iii) que a fronteira, dada a distância exígua entre países, seja o lugar em que o sentimento de pertença ainda seja confuso entre os habitantes.

A despeito desses pressupostos, a situação que identificamos foi um pouco inesperada, pois, se imaginávamos uma imensa facilidade em encontrar muitos informantes portugueses em tal região, de fato isso não ocorreu.

De todo modo, o objetivo traçado previa que o trabalho de campo envolvesse exclusivamente portugueses nativos que viviam em Olivença e, adicionalmente, com outros materiais (por exemplo, as placas de ruas), seria possível verificar resquícios da identidade portuguesa e, em decorrência, as marcas linguísticas do português presente entre os moradores oliventinos. Além disso, seria necessário também recolher informações sobre a LH dos descendentes de portugueses a fim de constatar se as camadas mais jovens e de gerações mais distantes estavam abertas ao uso da língua de seus familiares portugueses.

Ao iniciarmos as entrevistas, tínhamos o propósito de separar os informantes imigrantes oriundos de Portugal e os residentes em Olivença distribuindo-os de acordo com as variáveis sociais, tais como sexo, nível social, procedência regional e idade. No entanto, começamos a perceber que os portugueses que viviam na região de pesquisa estavam totalmente dispersos e sem vínculo algum com os demais de seu grupo étnico. A solução foi realizar as gravações com vários informantes, considerando os que concordavam em cooperar, independentemente da variável social, somente atentando para que estes fossem realmente imigrantes portugueses e descendentes de portugueses, os que nos trariam as repostas para os questionamentos sobre a LH na cidade.

Pelo fato de não conhecer a cidade, e obviamente os moradores, saímos às ruas, na companhia de um segundo entrevistador, apenas para o reconhecimento da região, bem como das características comportamentais de seus moradores, observando-os apenas de longe. Nesse primeiro momento, não havia a intenção de abordagem, portanto. 
Num segundo momento, iniciamos os contatos perguntando aos moradores espanhóis que encontrávamos nos bares, lanchonetes e postos de gasolina se eles conheciam algum português que morava na região. A expectativa, como já dissemos, era de que eles conhecessem muitos portugueses e que seria fácil conseguir as amostras de conversas e entrevistas. No entanto, embora eles nos dissessem que sabiam da existência de portugueses em Olivença, não tinham informações precisas sobre onde os encontrar.

Durante uma dessas abordagens, conhecemos um espanhol, morador da cidade, o senhor Juan Antônio, um professor de matemática do IES - Instituto de Ensino Puente Ajuda, o qual se mostrou aberto a nos apresentar alguns portugueses. Esse senhor foi peça-chave para que os contatos iniciais ocorressem, e por isso passou a nos ajudar fornecendo informações sobre onde trabalhavam e até mesmo nos levando até o encontro deles. Assim, o contato inicial foi facilitado por um espanhol, o senhor Juan, que nos apresentou como professores que precisavam gravar alguns minutos de conversas para um trabalho universitário sobre o cotidiano de portugueses que viviam em Olivença.

Para que os informantes não ficassem intimidados e não houvesse manipulação na fala, durante o contato inicial nos abstivemos de explicar que o trabalho seria sobre o sentimento de pertença linguística e sobre as variações do português oliventino. Informávamos apenas que gostaríamos de saber como era o dia a dia e a língua utilizada pelos portugueses que viviam na região.

As gravações em áudio ocorreram em momentos em que os informantes estavam em horário de trabalho ou iniciando seu expediente, com exceção de dois deles que tiveram sua entrevista gravada ao mesmo tempo em uma lanchonete, devido à oportunidade que se anunciou de dois informantes ideais se apresentarem.

Além disso, para que a conversa não se dispersasse, organizamos um questionário com perguntas sobre a relação linguística e o modo de vida dos informantes. Para que a entrevista pudesse ser mais espontânea, selecionamos perguntas sem nos preocuparmos com uma sequência ou com o roteiro previamente feito. Todas as entrevistas, contudo, contemplaram as seguintes informações: 


\begin{tabular}{|l|}
\hline \multicolumn{1}{|c|}{ QUESTIONÁRIO ETNOGRÁFICO } \\
\hline Nome do entrevistador: Elisangela de Godoy Sartin \\
\hline Dados do informante: \\
\hline \\
\hline 1. Nome completo: \\
\hline 2. Sexo: \\
\hline 3. Idade \\
\hline 4. Lugar de nascimento: \\
\hline 5. Ocupação atual: \\
\hline 6. Grau de escolaridade: \\
\hline 7. Estado civil: \\
\hline 8. Lugar de nascimento do cônjuge: \\
\hline 9. Língua falada pelo cônjuge: \\
\hline 10. Lugar de nascimento dos filhos: \\
\hline 11. Língua falada pelos filhos: \\
\hline 12. Língua utilizada em casa: \\
\hline 13. Língua utilizada no serviço: \\
\hline 14. Língua utilizada nos grupos de amigos: \\
\hline \\
\hline Percepção do informante sobre o uso da língua de herança: \\
\hline
\end{tabular}

Pelo fato de a maioria dos entrevistados estarem em horário de trabalho, foi necessária a autorização de seus patrões, os quais foram prestativos a nos ajudar. Além disso, posicionamo-nos de forma a não incomodar ou interromper seus afazeres, esperando o momento em que eles estivessem tranquilos. Isso nos tomou grande parte do dia, pois, para isto, era necessária muita espera o que significava, muitas vezes, um dia inteiro para cada entrevista.

Além disso, dentre os contatados e solicitados para a entrevista, sete deles - três mulheres e quatro homens - se recusaram a participar, alegando que não tinham tempo e não poderiam parar seus afazeres para nos atender. Dessa forma, o trabalho pareceu- 
nos, por diversas vezes, dificultado cada vez mais, pois sabíamos que um encontro em seus lares seria inviável e, durante o horário de trabalho, nem todos poderiam nos conceder a entrevista.

Percebendo ainda que muitas vezes o motivo da recusa, além de ser a falta tempo, era insegurança por se tratar de uma entrevista, passamos a informar que a conversa seria rápida, apenas sobre a rotina. Com isso, conseguimos algumas entrevistas mais curtas, com cerca de 10 a 15 minutos.

Embora, no início, os informantes se apresentassem apreensivos, no decorrer das entrevistas, em geral, ocorreu um clima de conversação espontânea, através da qual os entrevistados demonstravam um grande interesse pela temática apresentada.

Durante as buscas por informantes, pensando numa análise de variante social, nosso interesse estava em encontrar homens e mulheres na mesma proporção de faixa etária, no entanto, constatamos que, em Olivença, existem mais homens portugueses e pouquíssimas mulheres. Percebemos, ainda, que os informantes do sexo masculino eram casados com espanholas e dos informantes do sexo feminino uma era casada com um angolano e outra com um português.

Com o objetivo de encontrar portugueses mais velhos, dirigimo-nos a uma casa de repouso na cidade de Olivença. No entanto, mais uma vez, nossa busca não foi satisfatória, pois, ao contatarmos a atendente do local, esta nos informou que não havia mais portugueses que residiam lá ${ }^{120}$. Esse foi mais um dos entraves na identificação de informantes o qual vivenciamos.

${ }^{120}$ Nosso contato se deu no lar de repouso Residencia-Club Ancianos Olivenza, situado no endereço EX 315 com a calle de San Pietro. 


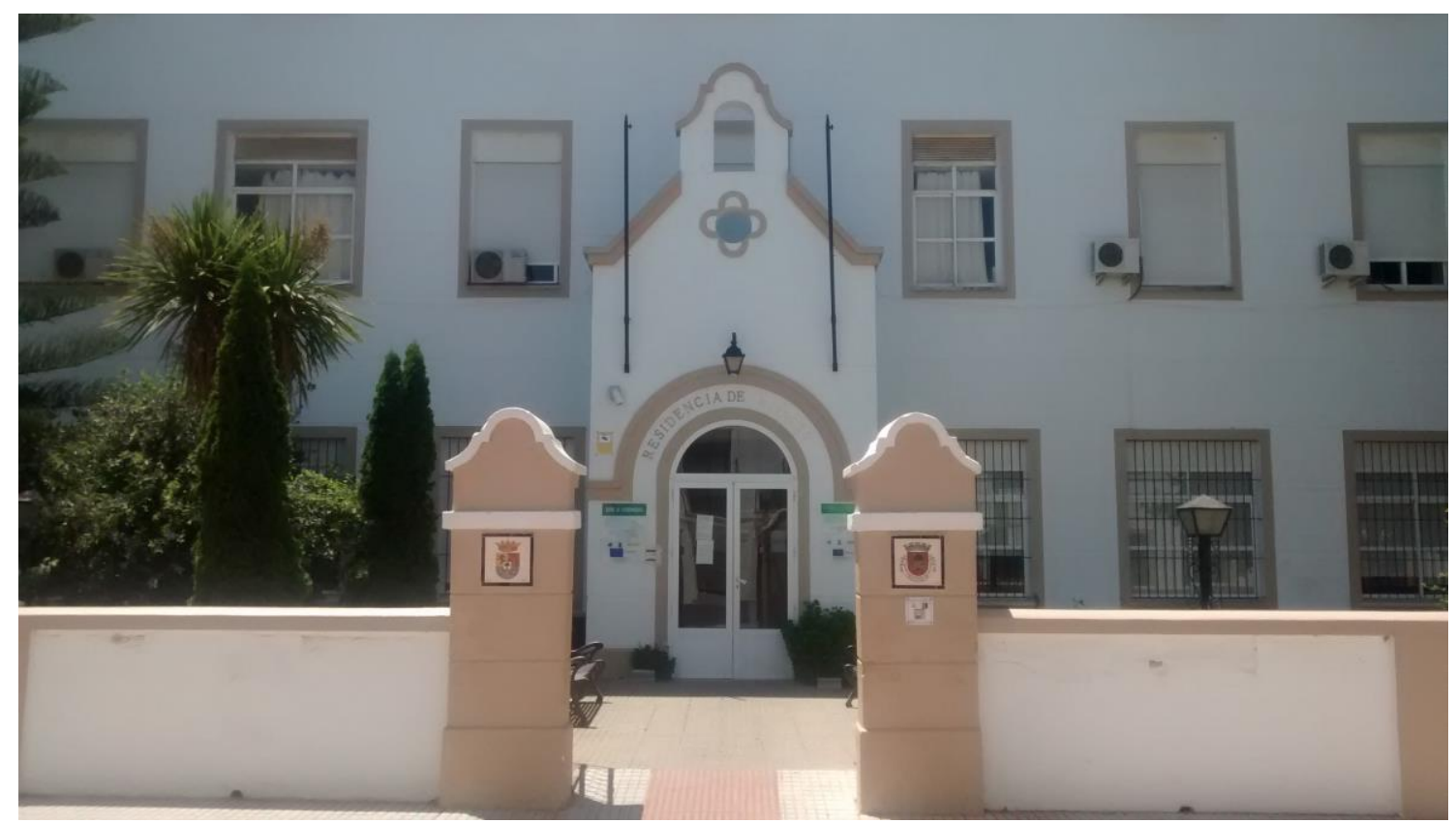

Imagem 16 ${ }^{121}$ : Asilo em Olivença: Residencia-Club Ancianos Olivenza

Após realizar algumas entrevistas e verificar que quase todos os informantes diziam ser importante ensinar a LH a seus filhos, pensamos, então, em realizar entrevistas com estudantes filhos de portugueses. A ideia era verificar o sentimento destes diante da língua de seus familiares, mesmo que de ancestrais distantes.

Assim, deslocamo-nos a duas escolas primárias ${ }^{122}$, no entanto, ambas as direções nos informaram que havia poucos filhos de portugueses, uns três ou quatro e que, para uma conversa com eles, seria necessária uma autorização dos pais. Desta forma, pediram-nos para que aguardássemos o contato, o que não ocorreu.

Vendo a dificuldade em manter contato com informantes mais novos e sabendo da existência de um instituto de ensino no qual havia adolescentes, recorremos mais uma vez a ajuda do senhor Juan Antônio, pois ele já havia lecionado em tal escola. Deste modo, mais uma vez, sendo apresentados por ele, conseguimos acesso ao local, e nos informaram que os alunos tinham aula de português como opcional e que o professor de tal disciplina era residente em Elvas, uma cidade de Portugal fronteiriça com Olivença. O IES ${ }^{123}$ Puente Ajuda, apresentado na imagem 17, possui 30 classes,

\footnotetext{
${ }^{121}$ Imagem fotografada por nós em março de 2015.

122 As escolas às quais nos referimos é o Colégio Sagrado Coração e o Colégio Francisco Ortiz, ambas situadas em Olivença.

${ }^{123}$ Instituto de Ensino Puente Ajuda é um instituto de ensino que prepara os alunos para a universidade.
} 
totalizando cerca de 650 alunos ${ }^{124}$. A disciplina de Língua Portuguesa não integra a matriz curricular, não sendo, portanto, obrigatória. Ela concorre com as seguintes disciplinas: tecnologia industrial, francês, ou troca de opção não cursada (biologia e geografia/ dibujo técnico/ física e química/ economia/ grego/ história/ literatura universal).

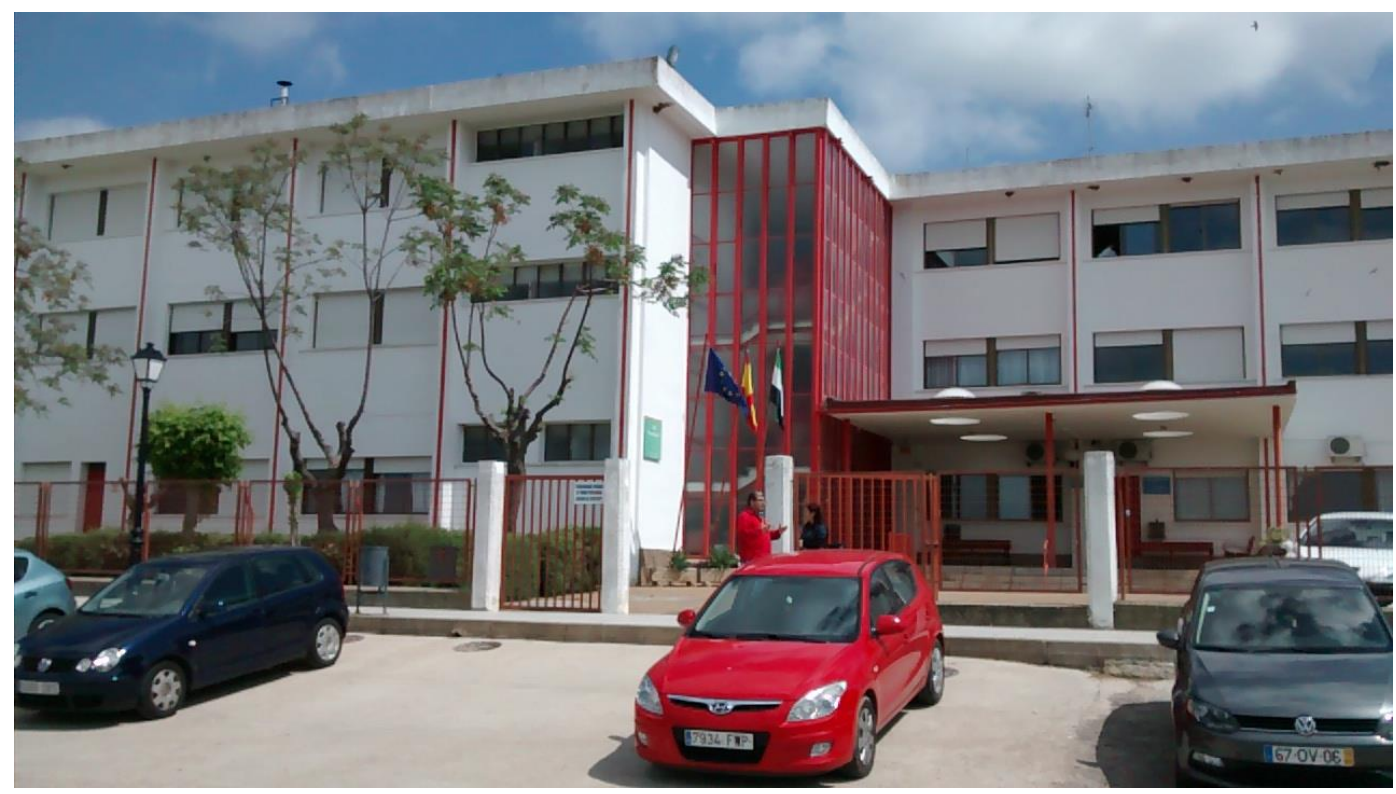

Imagem 17 ${ }^{125}$ : Instituto de Ensino Puente Ajuda.

Sabendo de tais informações, solicitamos contato com o professor de português, que nos informou haver um grupo de aproximadamente 20 alunos que frequentavam as aulas, sendo que, destes, apenas duas meninas eram descendentes de portugueses, nascidas em Olivença, e duas delas nasceram em Portugal, vindo para Olivença nos primeiros anos de vida.

Como contribuição do professor com esta pesquisa, cedeu-nos alguns minutos para que pudéssemos entrevistar tais alunas. Neste caso, informamos que nossa conversa era apenas para saber como era a relação delas com a língua portuguesa. Para tal entrevista também preparamos um questionário com as seguintes perguntas:

\footnotetext{
${ }^{124}$ Informações fornecidas pela secretária da escola.

${ }^{125}$ Imagem fotografada por nós em março de 2015.
} 


\begin{tabular}{|l|}
\hline $\begin{array}{l}\text { QUESTIONÁRIO PARA FILHOS DE IMIGRANTES PORTUGUESES EM } \\
\text { IDADE ESCOLAR }\end{array}$ \\
\hline Nome do entrevistador: Elisangela de Godoy Sartin \\
\hline \\
\hline Dados do informante: \\
\hline 1. Sexo: \\
\hline 2. Idade: \\
\hline 3. Lugar de nascimento: \\
\hline 4. Grau de escolaridade: \\
\hline 5. Língua(s) falada(s) em casa: \\
\hline 6. Língua(s) falada(s) na escola: \\
\hline 7. Língua(s) falada(s) com os amigos: \\
\hline 8. Lugar de nascimento do pai: \\
\hline 9. Lugar de nascimento da mãe: \\
\hline 10. Língua falada pelo pai em casa: \\
\hline 11. Língua falada pela mãe em casa: \\
\hline \\
\hline \begin{tabular}{l} 
Percepção do informante sobre o uso da língua de herança: \\
\hline
\end{tabular} \\
\hline 12. Ao se comunicar em espanhol acredita usar palavras do português em \\
conversas espontâneas? Pode dar algum exemplo? \\
\hline $\begin{array}{l}\text { 13. Os espanhóis percebem que você é português pelo modo como fala, ou seja, } \\
\text { por usar algum sotaque? }\end{array}$ \\
\hline 14. Você faz o possível para falar e até mesmo se comportar como os espanhóis? \\
\hline 15. Você considera o português uma língua inferior ao espanhol? \\
\hline 16. Você acha que os espanhóis consideram a língua deles como uma língua de \\
\hline 19. Quanto tempo vígio do que o português? \\
\hline
\end{tabular}

Findadas tais entrevistas, passamos a organizar um quadro apresentado na seção seguinte contendo informações de todos os informantes, organizados segundo seu estatuto (imigrantes ou filho de imigrante). Essa poderia ser uma variável a ser considerada se os dados linguísticos se mostrassem diversos. 


\subsubsection{Caracterização da amostragem - os imigrantes portugueses}

Como temos apresentado em nosso percurso de pesquisa, a dificuldade para encontrar os informantes que desejávamos nos conduziu a registrar as oportunidades que se apresentavam sem os recortes inicialmente previstos quanto às variáveis sociais. Realizamos, assim, entrevistas com todos os portugueses que se mostraram disponíveis a cooperar, independentemente da variável social, atentando apenas para que estes fossem imigrantes, o que permitiria homogeneizar a análise linguística com base no sentimento de pertença à língua portuguesa.

Após a realização de todas as entrevistas e a análise do sentimento de pertença da própria língua, ficava certo de que estávamos lidando com informantes imigrantes que faziam parte de uma faixa etária de, no máximo, 50 anos. Os mais velhos não conseguimos encontrar, cuja inexistência foi confirmada nas respostas dos moradores da região. Todos foram unânimes em dizer que não conheciam nenhum idoso português.

Como podemos depreender do quadro abaixo, os informantes ${ }^{126}$ são todos imigrantes, sendo trabalhadores de classe média, desempenhando profissões diversas que não demandam curso superior (cozinheiro, copeiro, pedreiro e trabalho de campo), com exceção do informante 5 (um professor universitário) e do informante 7 (comerciante e dono de oficina mecânica):

\begin{tabular}{|c|c|c|c|c|c|c|}
\hline ENTREVISTADO & SEXO & IDADE & ESCOLARIDADE & PROFISSÃO & $\begin{array}{c}\text { TEMPO } \\
\text { GRAV }\end{array}$ & $\begin{array}{l}\text { TEMPO EM } \\
\text { OLIVENÇA }\end{array}$ \\
\hline 1. $\mathrm{FR}$ & $\mathrm{M}$ & 39 & $\begin{array}{l}\text { ENSINO } \\
\text { SECUNDÁRIO }\end{array}$ & COZINHEIRO & $22 \mathrm{~m} \mathrm{22s}$ & 10 anos \\
\hline 2. $\mathrm{RS}$ & $\mathrm{F}$ & 38 & $\begin{array}{l}\text { ENSINO } \\
\text { BÁSICO }\end{array}$ & COZINHEIRA & $10 \mathrm{~m} \mathrm{01s}$ & 14 anos \\
\hline 3. JN & $F$ & 51 & $\begin{array}{l}\text { ENSINO } \\
\text { BÁSICO }\end{array}$ & COZINHEIRA & $25 \mathrm{~m} \mathrm{31s}$ & 3 anos \\
\hline 4. $C R$ & $\mathrm{M}$ & 41 & $\begin{array}{l}\text { ENSINO } \\
\text { BÁSICO }\end{array}$ & $\begin{array}{l}\text { TRABALHA } \\
\text { EM OBRAS }\end{array}$ & $19 \mathrm{~m} \mathrm{11s}$ & 23 anos \\
\hline 5. ED & $\mathrm{M}$ & 48 & SUPERIOR & PROFESSOR & $39 \mathrm{~m}$ & 32 anos \\
\hline 6. JP & $\mathrm{M}$ & 40 & $\begin{array}{l}\text { ENSINO } \\
\text { BÁSICO }\end{array}$ & $\begin{array}{l}\text { TRABALHA } \\
\text { NO CAMPO }\end{array}$ & $08 \mathrm{~m} \mathrm{31s}$ & 20 anos \\
\hline 7. $\mathrm{PD}$ & $\mathrm{M}$ & 38 & $\begin{array}{l}\text { ENSINO } \\
\text { SECUNDÁRIO }\end{array}$ & $\begin{array}{l}\text { PROPRIETÁRIO } \\
\text { DE OFINCINA } \\
\text { MECÂNICA }\end{array}$ & $36 \mathrm{~m}$ & 26 anos \\
\hline
\end{tabular}

Quadro 1: Relação de portugueses entrevistados em Olivença

\footnotetext{
${ }^{126}$ Optamos em apresentar os informantes através das siglas tal como apresentadas no quadro acima.
} 
O quadro 1 também permite verificar que o tempo de gravação não foi idêntico para todos os informantes. Como já descrito na seção anterior, as entrevistas ocorreram na maioria dos casos durante o período de trabalho dos informantes, o que impossibilitava uma conversa de tempo idêntico. Assim, as gravações variaram de seis minutos a trinta e nove minutos. Além disso, conseguimos entrevistas com apenas duas mulheres, sendo a informante 2 , casada com um português, e a informante 3 , casada com um angolano. Os demais informantes são homens e todos casados com espanholas.

\subsubsection{Característica da amostra - os descendentes de $2^{\mathrm{a}}$ e $3^{\mathrm{a}}$ geração de portugueses - os falantes de LH.}

As entrevistas realizadas com os alunos do IES Puente Ajuda se passaram em uma sala da escola disponibilizada para essa atividade, e as gravações não puderam ser muito extensas pelo fato de que os informantes estavam em horário de aula. Sendo assim, com as quatro informantes no mesmo local, procuramos fazer as mesmas perguntas para cada uma delas de forma simples e de modo que pudessem se manifestar sobre os nossos questionamentos sobre o sentimento de pertença à cultura portuguesa $\mathrm{e}$ ao uso da LH.

Como podemos ver, no quadro abaixo, as gravações ocorreram com um tempo que variou de quatro minutos a seis minutos. Todas eram estudantes do sexo feminino e do primeiro bacharelado, uma espécie de Ensino Médio, preparatório para a universidade.

\begin{tabular}{|c|c|l|l|l|c|}
\hline INF & SEXO & IDADE & ESCOLARIDADE & PROFISSÃO & $\begin{array}{c}\text { TEMPO } \\
\text { GRAV }\end{array}$ \\
\hline 1. AN & FEMININO & $\begin{array}{l}17 \\
\text { ANOS }\end{array}$ & $1^{\circ}$ BACHARELADO & ESTUDANTE & $06 \mathrm{~m}$ 01s \\
\hline 2. ES & FEMININO & $\begin{array}{l}16 \\
\text { ANOS }\end{array}$ & $1^{\circ}$ BACHARELADO & ESTUDANTE & $05 \mathrm{~m} 48 \mathrm{~s}$ \\
\hline $3 . \quad$ IS & FEMININO & $\begin{array}{l}16 \\
\text { ANOS }\end{array}$ & $1^{\circ}$ BACHARELADO & ESTUDANTE & $05 \mathrm{~m} 04 \mathrm{~s}$ \\
\hline 4. DN & FEMININO & $\begin{array}{l}16 \\
\text { ANOS }\end{array}$ & $1^{\circ}$ BACHARELADO & ESTUDANTE & $04 \mathrm{~m} \mathrm{32s}$ \\
\hline
\end{tabular}

Quadro 2: Relação de informantes descendentes de portugueses

\footnotetext{
${ }^{127}$ Optamos em tratar os informantes pelas siglas tal como no quadro 2.
} 
Todas as meninas são informantes de uma camada mais jovem, filhas ou netas de portugueses, como é o caso das informantes 1 e 2 . A informante 3 nasceu em Portugal apenas para ser registrada, mas desde sempre viveu em Olivneça e a informante 4 nasceu em Elvas, uma cidade fronteiriça com Olivença, porém do lado de Portugal, no entanto, veio habitar Olivença com 2 ano de idade. Fala apenas espanhol e usa o português com muita dificuldade e influência do espanhol somente com seus familiares. Quanto à língua, as demais informantes também são falantes nativas somente do espanhol, estando em fase de aprendizagem do português, frequentando as aulas por opção, o que já é um indício de um sentimento de pertença de LH.

\subsubsection{Os dados sobre o sentimento de pertença linguística entre os imigrantes portugueses}

Devido à dificuldade de encontrar uma amostra mais distribuída entre fatores sociais de portugueses vivendo em Olivença, apoiamo-nos nas respostas e no comportamento dos informantes apresentados no quadro 1, utilizando como parâmetro as informações por eles elaboradas. Essa foi a principal razão por que não priorizamos, nesta pesquisa, uma abordagem quantitativa. Priorizamos o estudo qualitativo.

Desta forma, selecionamos perguntas que pudessem nos dar pistas e até mesmo respostas sobre a relação e o sentimento dos informantes com relação à $L H$ e ao português oliventino. Com esse encaminhamento, pensamos que poderíamos perceber se os informantes valorizavam ou preservavam sua língua entre seu grupo étnico ou entre seus familiares próximos através das questões 12 a 16 do Questionário Etnográfico. Essas questões foram elaboradas para que pudéssemos saber se os entrevistados faziam uso da língua portuguesa e se, inclusive, percebiam influências dela no seu dia a dia.

\subsubsection{Os dados sobre as variantes linguísticas do português oliventino}

No início desta pesquisa, o objetivo era realizar uma análise quantitativa dos dados relacionados às variáveis linguísticas do português oliventino. No entanto, 
percebemos que seria mais interessante demonstrar os fenômenos encontrados divididos em diferenças fonológicas, léxicas, morfológicas e sintáticas.

Além disso, o fato de não encontrarmos informantes com os mesmos perfis sociais alterou, como já explicitamos anteriormente, nossos planos. Seria muito difícil correlacionar variáveis sociais e, para respondermos à questão de número dois, a qual se refere aos contextos pragmáticos em que cada variante se mostra favorecida, tomamos por base também as informações dos próprios informantes, montando um quadro com as características de cada um, suas profissões, escolaridade, sexo e quais deles mais fazem uso de tais variantes.

Quanto à análise fonética, o objetivo era chamar a atenção para as variações que mais demonstrassem influência de uma ou de outra língua, no caso do português alentejano e do espanhol. Para isto, de acordo com as particularidades típicas encontradas, decidimos dividir da seguinte forma:

1. Substituições vocálicas: variação na realização dos sons vocálicos /e/ e /o/:

$$
\begin{aligned}
& {[\mathrm{e}] \sim[\mathrm{i}](\text { ex. }[\text { pessoas }] \sim[\text { pissoa }]]} \\
& {[\mathrm{o}] \sim[\mathrm{u}](\mathrm{ex} .[\text { vamos }] \sim[\mathrm{vamu}]}
\end{aligned}
$$

2. Síncope: desaparecimento de fonema(s) no interior do vocábulo:

$$
\begin{aligned}
& \text { [interesse] } \sim \text { intresse] } \\
& {[\text { para }] \sim[\text { pra }]}
\end{aligned}
$$

3. Aférese: supressão de fonemas no princípio do vocábulo:

$$
\begin{aligned}
& \text { [estando }] \sim[\text { tando }] \\
& {[\text { estou }] \sim[\text { to }]}
\end{aligned}
$$

4. Apócope: supressão de um ou mais fonemas no final de uma palavra:

$$
\text { [para] [pa] (pra i pa li para ir para ali) }
$$


[temos] [temo] (temo um restaurante)

5. Paragóge: acréscimo de um fonema ou sílaba no final da palavra:

$$
\begin{aligned}
& {[\text { melhor }] \sim[\text { milhore }]} \\
& {[\text { professor }] \sim[\text { profissore }]}
\end{aligned}
$$

6. Inversões de consoantes:

$$
\begin{aligned}
& \text { [perguntar] } \sim \text { [preguntar] } \\
& \text { [percebem] } \sim \text { [pricebem] }
\end{aligned}
$$

Ao tratarmos do léxico, fizemos uma lista com todos os usos encontrados, uma espécie de dicionário com palavras do português oliventino:

$$
\begin{aligned}
& \text { [telefone] } \sim \text { [tufone }] \\
& {[\text { crianças }] \sim[\text { miúdos }] \sim[\text { piquenos }]}
\end{aligned}
$$

Quanto à morfologia, selecionamos os usos encontrados separando-os por classes de palavras, o que facilitaria observar se palavras mais gramaticais se ligariam ao espanhol ou ao português, o que permitiria checar o afirmado por pesquisadores apresentados no capítulo $4^{128}$.

Para tratarmos da sintaxe, apresentamos as estruturas mais recorrentes na fala do português oliventino, procurando estabelecer qual seria a influência para tais usos. Resolvemos focalizar as inversões sintáticas, a fraseologia que incluía verbos como os indicativos de existência e de posse, seleção de tempo verbal, concordância e expressões ou construções recorrentes da variedade oliventina.

${ }^{128}$ Cf capítulo 4, seção 4.1: "Um contraponto entre o português oliventino e o português de Portugal em descrição do século XX”. 


\subsubsection{Os dados sobre o sentimento de pertença de LH entre a camada mais jovem de descendentes de portugueses}

Durante o trabalho de campo, tivemos contato, como já dissemos, com os alunos do IES Puente Ajuda. O objetivo era verificar se a LH era utilizada entre uma camada mais jovem. Supúnhamos que os mais jovens espanhóis, por viverem sempre em uma comunidade de língua oficial espanhola, ainda perceberiam os elementos ou expressões da LH em seu uso cotidiano.

As perguntas para os informantes foram elaboradas a fim de que pudéssemos confirmar ou refutar nossa hipótese inicial. No entanto, por não encontrarmos quase adolescentes com o perfil que necessitávamos, não seria possível uma análise quantitativa, mas uma apresentação de dados com base nas respostas dadas pelos informantes apresentados no quadro 2 .

Após a realização das entrevistas, traçamos um perfil do sentimento de cada informante com relação ao seu uso de LH, fazendo uma análise sobre cada resposta dada, procurando estabelecer uma correlação entre todas elas.

\subsubsection{Uma busca por marcas que demonstrem o sentimento de pertença linguística}

Como já tratado no capítulo $2^{129}$, a partir do momento em que Olivença se torna parte do território espanhol, a língua portuguesa se torna frágil diante de uma língua considerada "dominante e superior" e acaba sendo excluída de forma abrupta de todos os setores da cidade, inclusive das escolas.

Embora a sociedade dominadora tenha dispensado todos os esforços possíveis para que a LH dos portugueses fosse completamente exterminada, pressupomos nesta pesquisa que algumas marcas culturais ancestrais e sentimentos desta sempre

\footnotetext{
${ }^{129}$ Assunto tratado no capítulo 2, seção 2.3 "Uma arma poderosa para a tomada de Olivença”.
} 
permanecem em estado de resiliência, embora nem sempre sejam reconhecidas entre a comunidade.

Uma grande verdade nisso que dissemos está na constatação de que a toponímia das ruas de Olivença teve seus nomes originais resgatados como podemos observar na imagem 18:

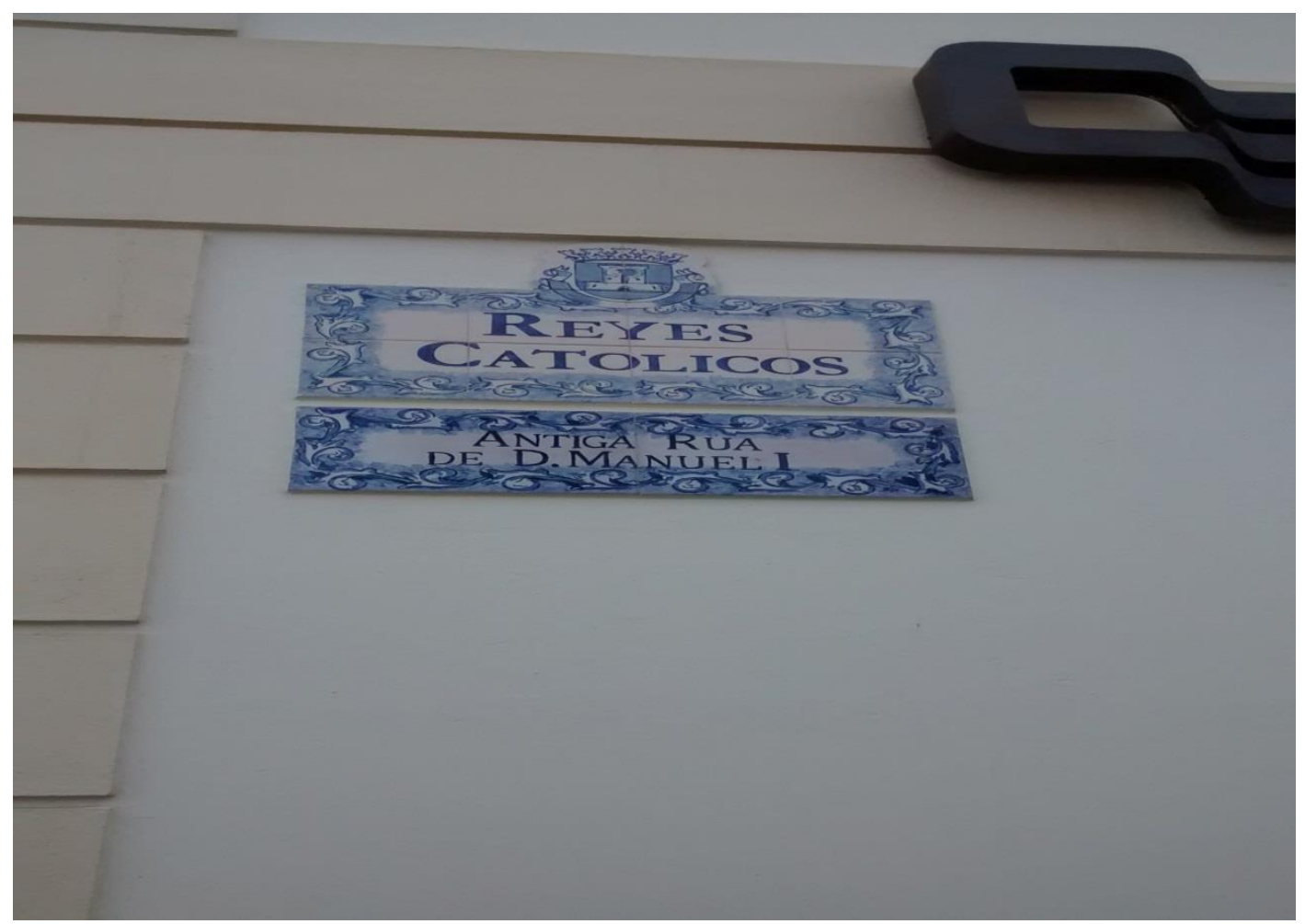

Imagem 18: Nome de rua em Olivença ${ }^{130}$

Como forma de comprovar que o sentimento de pertença linguística pode, muitas vezes, estar evidenciado através de marcas como as que há pouco mostramos, iniciamos a procura por todos os lugares de Olivença.

Durante toda nossa estadia em Olivença, por onde passávamos estávamos atentos a todos os nomes e marcas existentes na cidade, tais como nomes de lanchonetes, bares, mercados, placas informativas, cardápios, propagandas, nomes das casas, nomes dos estabelecimentos, nomes de todas as ruas por onde caminhávamos, entre outros. Além disso, adentramos o cemitério da cidade para verificar como as lápides são registradas, pois, embora em uma quantidade muito pequena, por haver

\footnotetext{
${ }^{130}$ Foto tirada em fevereiro de 2015, na região central de Olivença.
} 
famílias de portugueses, e pelo fato de Olivença já ter sido pertencente a Portugal, pensamos ser possível encontrar dizeres ou algo que marcasse tal grupo étnico.

Para esta parte da pesquisa, fazíamos fotos de tudo o que nos interessava como forma de comprovar nossas hipóteses a cerca da preservação das marcas de $\mathrm{LH}$, as quais serão apresentadas no capítulo sobre a análise do sentimento de pertença linguística.

\subsection{A busca por informantes espanhóis em Elvas - o outro lado da fronteira}

Após a realização das gravações com todos os informantes já apresentados, passamos a nos interessar em um contato com o outro lado fronteiriço, desta vez iríamos entrevistar espanhóis que vivem em Elvas. Nosso objetivo desta vez não seria uma análise linguística, mas em verificar o sentimento de pertença de LH de um grupo étnico, que embora representasse a minoria, possuía uma língua considerada "dominadora".

Saímos pelas ruas da cidade a fim de gravar com todos os espanhóis que encontrássemos. Sabíamos que nossa missão seria muito mais difícil ainda, pois Portugal não oferece condições de emprego tais como a Espanha, fato que desfavorece uma imigração neste sentido.

Após realizar um contato com uma brasileira moradora da cidade, fomos informados que havia um espanhol morando por perto e que este estaria por lá mais $\operatorname{tarde}^{131}$. Desta forma, passado algumas horas, voltamos ao local e o encontramos, realizando assim nossa primeira entrevista. Tal entrevistado estava casado com uma brasileira, morava cerca de um ano em Elvas e já havia morado dois anos no Brasil.

Neste mesmo local, fomos informados que havia bem poucos espanhóis morando em Elvas, mas tais não estariam abertos a um contato em suas residências. Além disso, nos disseram que havia alguns locais os quais eram frequentados por eles, tais como uma lanchonete ${ }^{132}$, uma cafeteria ${ }^{133}$ e uma praça no centro de Elvas, mas que só poderiam ser encontrados pela manhã ou no final da tarde, horário em que o calor não era tão intenso.

\footnotetext{
${ }^{131}$ O local informado era um salão de cabeleireiro do "Casa do Benfica", situado no centro de Elvas.

${ }^{132}$ A lanchonete indicada é a "Pastelaria Viana", situada no centro de Elvas.

${ }^{133}$ A cafeteria a qual realizamos uma busca por espanhóis é a "Café Paloma", situada no centro de Elvas.
} 
A partir disto, nos deslocamos primeiro à lanchonete que nos informaram, na qual ficamos sentados por cerca de três horas na expectativa de que chegasse algum espanhol, no entanto, nossa espera não obteve sucesso e ao perguntar para o dono do local, este nos informou que lá não era frequentado por espanhóis e que ele não conhecia nenhum.

Durante a tarde, fomos à cafeteria, ficando algumas horas por lá, e por não ver nenhum espanhol, perguntamos às meninas que trabalhavam no local, as quais nos disseram que normalmente eles vêm pela manhã. Assim, voltamos no dia seguinte e após algumas horas de espera, ouvimos alguns espanhóis adentrando ao local, todos praticantes de ciclismo. Ao iniciar nosso contato, verificamos que não se tratava do nosso objeto de interesse, pois eles não eram moradores de Elvas, mas sim de Badajoz, uma cidade fronteiriça e espanhola.

Durante alguns dias ficamos andando pela cidade $^{134}$, encontrávamos alguns espanhóis que caminhavam por lá, mas ao iniciar conversa com eles, verificávamos que sempre se tratava de turistas. Alguns nos informavam que estavam sempre por lá e que muitos espanhóis gostavam de frequentar Elvas, pois era uma cidade tranquila e muito próxima de Badajoz, o que facilitava o turismo de espanhóis.

Pelo fato de termos encontrado apenas um espanhol e que vive pouco tempo na cidade de Elvas, optamos em não apresentar a análise deste no capítulo que trata das variações linguísticas dos portugueses que vivem em Olivença, bem como do sentimento de pertença desta comunidade, que é o foco da pesquisa.

\footnotetext{
${ }^{134}$ Nossa busca era em vários lugares da cidade, principalmente no centro de Elvas, onde nos informaram que era frequentado por espanhóis, na freguesia de Assunção e nas praças locais. Ficamos cerca de duas semanas não consecutivas.
} 


\section{CAPÍTULO 4}

\section{O PORTUGUÊS NA FRONTEIRA ELVAS- OLIVENCCA}

Pautado num estudo de linguagem como uma forma de comportamento social e levando em conta uma língua que tem revelado uma riqueza de propriedades, este capítulo apresenta uma análise do português oliventino e do sentimento de pertença da LH dos portugueses residentes em Olivença (Espanha), bem como as características sociais dos habitantes dessa região. 


\subsection{Um contraponto entre o português oliventino e o português de Portugal em descrição do século XX}

Nas pesquisas realizadas por Matias (1984), referidas no capítulo 2, as características linguísticas identificadas são classificadas como tendo muitas influências não só do português alentejano como também do espanhol. A autora apresenta usos variáveis que se mostram, como demonstraremos a seguir, grandes diferenças das encontradas nesta pesquisa. Essas diferenças são organizadas pela autora em termos de subsistemas linguísticos. Adotaremos essa mesma forma de organização neste capítulo.

\section{Fonética:}

[pegamos] [pegemu]

[há] [hay] = influência espanhola

[Jtudiár] [estudar]

[ $\int$ tudiadu $] \sim[$ estudado $]=$ influência espanhola

[sãto] $\sim[$ santo $]=$ santo $($ nasalização $)$

[kase] [quase]

$[$ kurdeli $] \sim[$ cordel $]=($ velarização de $l)$

[vevi] $\sim$ [vive] $=($ "realização curiosa de $i$ ")

[parvua] [parva]

[fófaru] [fósforo]

[ozari] [usar]

[magu $] \sim$ [maio]

$[$ freu $] \sim[$ freio $]$

[u me pai] [o meu pai]

[de $f$ kera] $\sim$ [Deus queira]

Embora a autora liste uma grande quantidade de fenômenos variáveis, somente a quatro ela atribui influência do espanhol. Isso nos faz imaginar que, nos demais casos, também é possível ocorrerem no português segundo a percepção da autora, à exceção de um, considerado "realização curiosa de i”. Isso nos conduz à conclusão de que era baixa a interferência do espanhol no campo das realizações fonéticas à época da pesquisa, segunda metade do século XX. 


\section{Morfologia:}

1. Colocação pronominal: a autora revela uma variação posicional entre próclise e ênclise no português falado pelos oliventinos, que pode ser uma tendência similar ao que ocorre no português no Brasil.

[Agora se come à lo loco] [agora come-se desmedidamente] [Antónia me dê uma plantinha] [Antônia deu-me uma plantazinha]

2. uso dos pronomes pessoais: a autora sinaliza para a avaliação de usos pronominais como associados a classes sociais distantes da elite na região.

$[\mathrm{Yo}] \sim[\mathrm{eu}]$

[Sabia más ca mim] [sabia mais que eu]

[Vim más depressa ca ti] [vim mais depressa que tu]

O pronome nós é quase sempre substituído por 'a gente', o vós também não é quase utilizado entre os portugueses de Olivença, sendo substituído por 'vomecês' ou 'os senhores', a depender do grau de intimidade entre os falantes.

3. pronomes possessivos, demonstrativos e indefinidos: os casos abaixo sinalizados permitem afirmar que nem tudo é interferência espanhola e que somente os indefinidos configuram-se como regra variável dentro do português oliventino, tal como preceitua Labov, dado que são usos esporádicos, provavelmente ligados ao contexto.

[Foi ver tu nora] [foi ver tua nora]

[Ete, eta $(\mathrm{s})] \sim[$ este, esta(s)]; [esto] $\sim$ [isto] ou [esso] [isso] $=$ (espanholismos) [algunos e algunas] [alguns e algumas]. Neste caso, a autora afirma aparecer de forma esporádica.

4. Substantivos: neste conjunto de alterações, a autora explicita que o que está em jogo é a decisão sobre qual será o artigo determinante e seu gênero. Sendo assim, embora inclua os itens entre variação de nome, é, sim, o gênero do artigo o problema central.

[O nascente] [a nascente]

$[\mathrm{O}$ arvo $] \sim[\mathrm{a}$ árvore $]$

5. Adjetivos qualificativos: os qualificadores comparativos, ao que parece, pedem a forma perifrástica no português oliventino. E um caso, a primeira palavra a seguir apresentada, mantém uma forma arcaizada em que a consoante $/ \mathrm{n} /$ ainda é plenamente articulada. 
[Ancianos] [anciãos]

[Maior] [más grandi]

[milhor] [más bom]

[pior] [más mau]

6. Números: embora Mathias inclua esses casos na morfologia do número, na verdade, trata-se de casos de realização fônica diversa.

[Vint'óito] $\sim$ [vinte e oito]

[Curenta] [quarenta]

7. Verbo: a não realização do morfema infinitivo final dos verbos e de monotongação da desinência final de terceira pessoa do singular parecem ser recorrentes. O mesmo processo de apagamento revela-se na $3^{\text {a }}$ pessoa do singular do tempo presente. São realizações fônicas que interferem na morfologia verbal.

[Tomá banho] [tomar banho]

[Bebê o café] [beber o café]

[Acabô] [acabou]

[tu ama] $\sim$ [tu amas]

[tu bebe] [tu bebes]

Além desses casos, ainda considera serem particularidades do português da região o seguinte:

[é comum $=$ déia $(\mathrm{s})$, dêiamos, dêiom $] \sim$ [Dar]

[escrevido ] [escrito]

[to] [estou]

[hai] [há] - neste caso, Matias (1984:290) assevera haver uma forte influência do espanhol, ocorrendo na linguagem popular do português oliventino. Este uso já fora citado pela autora como exemplo de realização fonética incompatível com o português de Portugal.

[sêmos] [somos]

[trúxi] [trouxe]

[vévem] [vivem]

[bolto] [Voltar]

8. Advérbios de lugar, tempo, quantidade, modo:

[Adentro] [dentro]

[à meã manhã] [a meio da manhã]

[antiguamente] [antigamente]

[antontem] [anteontem]

[ondiàgora] [há pouco]

[temprano] [cedo]

[demai] [demais] 
[pôcachinho/poucochinho] [pouco] - neste caso, associa à linguagem popular [à escura] [às escuras]

[à lo loco] [desmedidamente]

[ansi e ansim] [assim]

$[\mathrm{Si}] \sim[\mathrm{sim}]$

$[$ na, na] $\sim[$ não]

[nõ, siquera, tampôco] [também não]

9. Preposições: somente dois casos parecem distinguir, na percepção de Mathias, o português de Portugal e o português oliventino. Talvez esse fenômeno se explique porque preposições, sendo palavras mais gramaticais nas línguas, precisem de um tempo maior para sofrer alterações no terreno das realizações sociais.

[pa] [para]

[sigún] [conforme] - nesse caso, é associada à linguagem popular e da classe média.

10. Conjunções: a despeito de nenhuma nota acompanhar esses dois casos, parece-nos que sejam característicos tanto do português antigo quanto do espanhol.

[ca] [do que]

[Aunque] [ainda que]

11. Interjeições: como as expressões interjeitivas revelam emoções e sentimentos a respeito de situações vivenciadas, estão mais ligadas à cultura de um povo e também a fatores sociais, tais como geração (faixa etária) e grupo social (região de habitação). Dessa forma, revelam mais prontamente ao investigador uma diferença, especialmente se o pesquisador tem uma das línguas como sua língua materna.

[Ai eu! Ai eu!]

[mãe santíssima]

[ãi, ala] [vamos]

[anda] [toma]

[arreda lá] [para trás]

[balha-me deus]

[Bueno ou buenum] [bom]

\section{Sintaxe e fraseologia:}

De acordo com Matias (1984), muitos dos usos apresentados e estudados ocorrem, em sua maioria, na linguagem popular. Assim, apresentamos aqui alguns dos usos identificados durante seu estudo. 


\section{Formas de tratamento}

[você e bocê] - na época da pesquisa, Matias afirmou que não era um uso tão frequente entre os mais jovens, e os considerou 'pouco respeitosos'. A despeito disso, a variação /b/ /v/ é um dos divisores geográficos na variação interna de Portugal.

[senhor e senhora] [usté] - a autora afirma que 'senhor e senhora' estava em desuso nesse período em Olivença e que o uso mais frequente era 'usté', típico do espanhol. [mano e mana] - uso que Matias encontra para 'irmão e irmã'.

\section{Artigos, pronome e adjetivos:}

Tratando da grande influência espanhola na língua portuguesa falada em Olivença, Matias (1984) apresenta-nos que a antecipação dos pronomes às formas verbais é um dos traços sintáticos em que mais se observam os efeitos do contato entre LH e a língua da sociedade receptora e apresenta os seguintes dados encontrados:

[M'alembro que le rôbarom] [lembro-me que lhe roubaram]

[T'alembras de Nicolau?] [lembra-te do Nicolao?]

[O tapo, não?] [tapo-o, não?]

[Lhos di] [dei-lhos]

[Ponho-m'a falar e se vai o sentido] [ponho-me a falar e vai-se o sentido]

[Se le dêta um poço] [deita-se um pouco].

Além disso, Matias acrescenta que a colocação do pronome complemento antes do sujeito é um verdadeiro espanholismo que entrou na fronteira, inclusive em Elvas e Juromenha. Vejamos:

[sabes o que m'ele disse?] [sabes o que le me disse?]

[se lh'ê tenho dito] [se eu lhe tenho dito].

Dois casos, que nos parecem similares e demandados pelo sistema de organização conversacional, são apresentados pela autora como diferentes. Tanto (a) quanto (b), segundo nosso entendimento, são construções de tópico, provavelmente motivados pela mudança temática na orientação conversacional:

(a) só em Olivença e Vila Real ocorrem casos de repetição do complemento indireto, através do correspondente pronome pessoal: [A rôpa a tenho guardada]. 
(b) na linguagem popular, há a repetição dos pronomes pessoais (construções de tópico): [Já a menina ela fez três anos] [Já a menina fez três anos]

Refere a autora, ainda, usos da preposição fora do português padrão. Esses casos focalizam a variação para a:

[Convidar a] [convidar para]

[Me convidarom a uma copa] [convidaram-me para um cálice]. Neste caso, a autora alerta-nos que em espanhol temos o uso 'convidar a'.

Para comprovar que, nesse período da pesquisa, o espanhol fazia-se bem presente na fala dos portugueses oliventinos, Mathias mostra-nos usos como os mais comuns e corriqueiros nomes, os dos dias da semana, bem diferentes no português e no espanhol:

[O lúni] [na segunda-feira]

Matias (1984) apresenta em sua pesquisa usos de verbos utilizados pelos portugueses que vivem em Olivença como fatos linguísticos que se distinguem do português de Portugal da seguinte maneira, mas os inclui entre os casos de sintaxe por envolverem outros segmentos da sentença:

[S'à noiti viera qualquera e quisera] $=$ (se a noite viesse um qualquer e quisesse)

[Pa que nós fôramos aprendendo] = (para que nós fôssemos aprendendo)

[Cande venha do trabalho] $=$ (quando vier do trabalho)

[O que vòmecê oica $]=$ (o que o senhor ouvir $)$

Além disso, a autora aponta um fato de interesse, e também encontrado em nossa pesquisa, que é o uso do gerúndio e a expressão 'ir a' na expressão de falantes das classes média e popular, em lugar do infinitivo precedido da preposição a:

[O menino se ta rindo $]=($ o menino está a rir-se $)$

[Fo à do dôtor $]=$ (foi a casa do médico)

$[\hat{E}$ vô à da Rosa $]=($ vou a casa da Rosa $)$

Mais adiante, a autora assegura que, na linguagem popular, emprega-se a todo o instante o coletivo a gente com o sentido de nós (Mathias, 1984:319), além de nem sempre haver concordância entre o predicado e sujeito tal como em:

[A gente falemos, a gente fugimos]

[P'ró batizo omais própiro sã de pequeninos] $=$ (para o batizado o mais próprio é de pequeninos) 
[E o fruto são murtinhos $]=(\mathrm{e}$ o fruto é murtinhos $)$

Outra característica do português oliventino, também verificada por nós, são as construções em que ocorriam inversões sintáticas diferentes do modelo sujeito + verbo + complemento:

[Lá, têm as mulheres menos crios] = (as mulheres, lá, têm menos filhos)

[Ma migalha desse caldo se aparta] $=$ (tira-se um pouco desse caldo)

[A tinha sacado eu $]=($ eu tinha-a tirado $)$

A autora associa, ainda mais, usos encontrados em sua pesquisa ao “espanholismo sintático", listando as seguintes recorrências:

[Cada oito dias em vez de de oito em oito dias] = (linguagem popular) (em espanhol: cada ocho dias)

[Correr pressa $]=$ ter pressa, ser urgente: não me corre pressa (não tenho pressa) (em espanhol correr prisa)

$[$ Dar a nora buena $]=$ dar os parabéns (em espanhol em hora buena)

[Dar glória] = dar gosto (bem Olivença) dá glória comer um plátano (dá gosto comer uma banana) (em espanhol dar gloria).

[Dar guerra] $=($ dar muito trabalho - em espanhol dar guerra $)$

[Gosta-me, nã me gosta] = (gosto de, não gosto de). De acordo com Matias, em Olivença ouve-se também gusta-me, na me gusta.

$[$ Gracias $]=($ obrigado $)$

[Levar três anos a alguém] $=($ ser três anos mais velho $)$.

[já leva um mês de luto] = (já anda de luto há um mês). A autora reforça o fato de "estar diante de ume espanholismo sintático", em Vila Real ${ }^{135}$ e Olivença.

[Passe $]=($ significado: entre, equivalente no espanhol a: Pase! $)$

[O que passa $]=$ (significado: $o$ que acontece. No espanhol, o verbo 'pasar' equivale ao sentido de 'acontecer')

[Pôr uma sai, pôr umas meias] = (vestir, calçar $)$

$[$ Ter gana de $]=($ ter vontade de - em espanhol: ter gana de $)$

${ }^{135}$ A autora faz sua pesquisa também na região de Vila Real. 


\section{Léxico:}

Para nos fornecer informações sobre o léxico utilizado pelos falantes portugueses que viviam em Olivença, Matias (1984:61-130) escolheu como informante principal uma mulher da classe popular e de geração média, através da qual nos fornece alguns de seus dados:

Abelhana - amendoim

Abêspra - vespa

Abogado - advogado

Aburrido - aborrecido (em espanhol= aburrido)

Acagaçar-se - morrer de medo

Ajuntar os botões - ajustar contas

Anciano - idoso (do espanhol)

Andorinha, e na linguagem popular guelondrina (no espanhol= golondrina)

Arnêro - crivo para trigo (em espanhol= Harnero)

Arve, o arvu- árvore (em espanhol= El árbol)

Avarento - unha de fome

Ávem - ave

Bago - bago de uva (em espanhol= Gajo)

Bassôra - vassoura

Berano - verão $($ em espanhol $=$ verano)

Cambiar - trocar (em espanhol=cambiar)

Coche - automóvel (em espanhol= coche)

Enfadar-se - aborrecer-se

Ensinar - mostrar

Enverno

Falar mais Ca sete - ver dar ao lambarão

Fresa - morango $($ do espanhol $=$ fresa $)$

Fuvrêro - fevereiro

Gafanhoto - salta-montes (em espanhol= salta-montes)

Garoto -menino

Gracias - obrigado (em espanhol= gracias)

Guapo - bonito (do espanhol guapo)

Lune - segunda-feira (do espanhol= lunes)

Maior - mais velho ( a filha maior)

Maricom - afeminado (em espanhol= maricón)

Marmelo - marmelo , em Olivença usa também membrilho (do esp mebrillo)

Mirar - ver (do espanhol $=$ mira $)$

Miúdo - menino

Moçuelo - menino

Mogango - menino

Ninho - menino

Orilha - margem do rio (do espanhol= orilla 'borda margem do rio')

Permisso - licença, autorização (em espanhol= permiso)

Sigunda-fêra - segunda-feira

Teléfono - s.m - telefone (do espanhol= telefono)

Verão; verano, berano 
Matias (1984:131-135) afirma que o Alentejo e a Estremadura espanhola, por serem regiões com muitas semelhanças geográficas e no modo de vida de seus moradores, possuem muitas afinidades no léxico.

Como temos observado nas pesquisas realizadas pela autora, naquele período, a LH falada pelos portugueses que viviam em Olivença era marcada o por uma extrema influência da língua espanhola ou por já ter sofrido o impacto do contato, não sendo possível distingui-la, na concepção de uma portuguesa de Portugal, tal como é a pesquisadora, com a língua portuguesa original.

Assim, tendo em vista as afirmações sobre o grande impacto da língua da sociedade receptora entre os falantes do português oliventino, Matias (2001) mostranos, mais uma vez, a situação linguística observada em Olivença relatando o acréscimo significativo dos seguintes fenômenos causados pelo contato:

- aspiração e supressão de $s$ : atráh 'atrás'; Liboa 'Lisboa'; dôcih 'doces’; casa 'casas', horeve 'escreve';

- supressão de $r$ final: lavá 'lavar'; mudjé 'mulher'; amo 'amor';

- yeísmo com alternância entre y e dj: abeya e abedja 'abelha'; fiya e fidja 'filha';

- realização de /v/ como [b], traço linguístico característico dos falantes do norte de Portugal e ausente da variedade dialetal alentejana: barrer 'varrer', biage 'viagem';

- presença dos fonemas /k/ e / / /: anca 'larga', esp. Ancha, coci 'automóvel', esp. coche, wei 'chefe', esp. Jefe;

- síncope da consoante /d/ intervocálica: Arão 'arado', levantao 'levantando', bria 'brida, rédeas'.

Nessa pesquisa mais atual, a autora verifica que mudanças ocorreram no português oliventino, como um biliguismo muito maior entre seus falantes. O espanhol, porém, com sua força e imponência, ainda deixa seus vestígios na fala dos portugueses que ali vivem.

Fernández (2004), igualmente interessado na língua portuguesa falada em Olivença, afirma que o português oliventino, tanto quanto o português alentejano, apresenta algumas tendências:

prefere o ditongo oi ao ou (oiro / ouro doido / doudo, loiro / louro), ocorrendo também a pronúncia do ditongo /eil como nas regiões do Alentejo (aldeia [al'de:a], azeitona [aze:'tona]), havendo ainda na 
característica oliventina, também por influência desta, a síncope de vogais na pronúncia rápida, como em bác(o)ro, j(a)nela (>(e)snela), m(e)lancia (>blancia), m(e)nino, p(e)queno.

(Fernández, 2004:5)

Diante desses usos aqui apresentados por linguistas interessados em descrever a língua portuguesa falada em Olivença, sentimos a necessidade de verificar em que medida essas diferenças podem ser apreendidas numa sincronia do século XXI.

A seguir, os dados do português recolhidos em novo trabalhado de campo (durante seis meses de pesquisa no ano de 2015), permitirão reconhecer se houve alterações, maior aproximação do espanhol ou manutenção da língua de herança pelos falantes de português em Olivença. A justificativa para isso é lembrar que, como evidenciamos anteriormente, as margens geopolíticas não correspondem aos anseios da população de cada localidade, o que significa dizer que as identidades podem revelar-se, se se comparar normas de escrita portuguesa e espanhola, fluidas e pouco homogêneas, talvez até caóticas.

\subsubsection{Um contraponto entre o português oliventino e o português de Portugal - descrição do século XXI}

\subsubsection{Amostra de entrevistados}

Considerando as informações apresentadas no capítulo sobre os aspectos metodológicos que representam as decisões tomadas frente aos problemas que se foram apresentando durante a realização desta pesquisa, em especial no trabalho de campo, o quadro de imigrantes portugueses que vivem em Olivença permite depreender que a maioria dos informantes é composta por homens, pertencentes a um grupo de faixa etária entre 38 e 51 anos, com profissões relativamente dentro do mesmo nível socioeconômico e com instrução variável em três níveis de ensino: 


\begin{tabular}{|c|c|c|c|c|c|c|}
\hline ENTREVISTADO & SEXO & IDADE & ESCOLARIDADE & PROFISSÃO & $\begin{array}{l}\text { TEMPO } \\
\text { GRAV }\end{array}$ & $\begin{array}{l}\text { TEMPO EM } \\
\text { OLIVENÇA }\end{array}$ \\
\hline 1. $\mathrm{FR}$ & $\mathrm{M}$ & 39 & $\begin{array}{l}\text { ENSINO } \\
\text { SECUNDÁRIO }\end{array}$ & COZINHEIRO & $22 \mathrm{~m} \mathrm{22s}$ & 10 anos \\
\hline 2. $\mathrm{RS}$ & $\mathrm{F}$ & 38 & $\begin{array}{l}\text { ENSINO } \\
\text { BÁSICO }\end{array}$ & COZINHEIRA & $10 \mathrm{~m} \mathrm{01s}$ & 14 anos \\
\hline 3. JN & $\mathrm{F}$ & 51 & $\begin{array}{l}\text { ENSINO } \\
\text { BÁSICO }\end{array}$ & COZINHEIRA & $25 \mathrm{~m} \mathrm{31s}$ & 3 anos \\
\hline 4. $C R$ & $\mathrm{M}$ & 41 & $\begin{array}{l}\text { ENSINO } \\
\text { BÁSICO }\end{array}$ & $\begin{array}{l}\text { TRABALHA } \\
\text { EM OBRAS }\end{array}$ & $19 \mathrm{~m} \mathrm{11s}$ & 23 anos \\
\hline $\begin{array}{ll}5 . & E D \\
\end{array}$ & $\mathrm{M}$ & 48 & SUPERIOR & PROFESSOR & $39 \mathrm{~m}$ & 32 anos \\
\hline 6. JP & $\mathrm{M}$ & 40 & $\begin{array}{l}\text { ENSINO } \\
\text { BÁSICO }\end{array}$ & $\begin{array}{l}\text { TRABALHA } \\
\text { NO CAMPO }\end{array}$ & $08 \mathrm{~m} \mathrm{31s}$ & 20 anos \\
\hline 7. $P D$ & $\mathrm{M}$ & 38 & $\begin{array}{l}\text { ENSINO } \\
\text { SECUNDÁRIO }\end{array}$ & $\begin{array}{l}\text { PROPRIETÁRIO } \\
\text { DE OFINCINA } \\
\text { MECÂNICA }\end{array}$ & $36 \mathrm{~m}$ & 26 anos \\
\hline
\end{tabular}

Quadro III: Portugueses entrevistados em Olivença

Para que pudéssemos fazer uma correlação entre os usos em cada situação, separamos os entrevistados de acordo com suas características sociais, quais sejam: sexo, faixa etária, nível de instrução ${ }^{136}$, nível sócio econômico e tempo de vivência em Olivença. Essas distribuições ficam mais claras a partir dos quadros que seguem.

\section{1) A variável sexo}

SEXO FEMININO

\begin{tabular}{|c|l|l|l|c|}
\hline ENTREVISTADA & IDADE & ESCOLARIDADE & PROFISSÃO & $\begin{array}{c}\text { TEMPO } \\
\text { GRAV }\end{array}$ \\
\hline 1. RS & 38 & $\begin{array}{l}\text { ENSINO } \\
\text { BÁSICO }\end{array}$ & COZINHEIRA & $10 \mathrm{m01s}$ \\
\hline $2 . \mathrm{JN}$ & 51 & $\begin{array}{l}\text { ENSINO } \\
\text { BÁSICO }\end{array}$ & COZINHEIRA & $25 \mathrm{~m} 31 \mathrm{~s}$ \\
\hline
\end{tabular}

${ }^{136}$ O ensino em Portugal é formado pelo Ensino Básico e pelo Ensino Secundário. O ensino Básico, no Brasil chamado de Ensino Fundamental, está divido em 3 ciclos: $1^{\circ}$ ciclo $\left(1^{\circ}\right.$ ano ao $4^{\circ}$ ano), $2^{\circ}$ ciclo $\left(5^{\circ}\right.$ ao $6^{\circ}$ ano) e $3^{\circ}$ ciclo $\left(7^{\circ}\right.$ ao 9 ano). O ciclo seguinte, designado por Ensino Secundário, no Brasil denominado como Ensino Médio, abrange os $10^{\circ}, 11^{\circ}$ e $12^{\circ}$ anos. 
SEXO MASCULINO

\begin{tabular}{|c|c|l|l|l|}
\hline Entrevistado & IDADE & ESCOLARIDADE & PROFISSÃO & $\begin{array}{c}\text { TEMPO } \\
\text { GRAV }\end{array}$ \\
\hline 3. FR & 39 & $\begin{array}{l}\text { ENSINO } \\
\text { SECUNDÁRIO }\end{array}$ & COZINHEIRO & $22 \mathrm{~m} 22 \mathrm{~s}$ \\
\hline 4. CR & 41 & $\begin{array}{l}\text { ENSINO } \\
\text { SECUNDÁRIO }\end{array}$ & PEDREIRO & $19 \mathrm{~m} 11 \mathrm{~s}$ \\
\hline 5. ED & 48 & SUPERIOR & $\begin{array}{l}\text { PROFESSOR } \\
\text { UNIVERSITÁRIO }\end{array}$ & $39 \mathrm{~m}$ \\
\hline 6. JP & 40 & $\begin{array}{l}\text { ENSINO } \\
\text { BÁSICO }\end{array}$ & $\begin{array}{l}\text { TRABALHA NO } \\
\text { CAMPO }\end{array}$ & $08 \mathrm{~m} 31 \mathrm{~s}$ \\
\hline 7. PD & 38 & $\begin{array}{l}\text { ENSINO } \\
\text { SECUNDÁRIO }\end{array}$ & $\begin{array}{l}\text { PROPRIETÁRIO } \\
\text { DE OFICINA } \\
\text { MECÂNICA }\end{array}$ & $36 \mathrm{~m}$ \\
\hline
\end{tabular}

Dentre os oito informantes que cooperaram livremente com suas entrevistas para esta pesquisa e posterior análise linguística, apenas dois deles são do sexo feminino, ambas pertencentes ao mesmo nível socioeconômico e com graus de instrução semelhantes.

Cinco dos entrevistados são do sexo masculino, quase todos com o mesmo nível socioeconômico, com exceção dos informantes 5 , que é um professor da Universidade Popular de Olivença, e do informante 7, que é comerciante e proprietário de uma oficina mecânica.

\section{2) A faixa etária}

\begin{tabular}{|c|l|l|l|l|c|}
\hline \multicolumn{7}{|c|}{ FAIXA ETÁRIA DE 35 A 45 } \\
\hline INF & SEXO & IDADE & ESCOLARIDADE & PROFISSÃO & $\begin{array}{c}\text { TEMPO } \\
\text { GRAV }\end{array}$ \\
\hline $1 . \quad$ FR & $\mathrm{M}$ & 39 & $\begin{array}{l}\text { ENSINO } \\
\text { SECUNDÁRIO }\end{array}$ & COZINHEIRO & $22 \mathrm{~m} 22 \mathrm{~s}$ \\
\hline $2 . \quad$ RS & $\mathrm{F}$ & 38 & $\begin{array}{l}\text { ENSINO } \\
\text { BÁSICO }\end{array}$ & COZINHEIRA & $10 \mathrm{~m} 01 \mathrm{~s}$ \\
\hline $3 . \quad$ CR & $\mathrm{M}$ & 41 & $\begin{array}{l}\text { ENSINO } \\
\text { SECUNDÁRIO }\end{array}$ & $\begin{array}{l}\text { TRABALHA } \\
\text { EM OBRAS }\end{array}$ & $19 \mathrm{~m} 11 \mathrm{~s}$ \\
\hline $4 . \quad$ JP & $\mathrm{M}$ & 40 & $\begin{array}{l}\text { ENSINO } \\
\text { BÁSICO }\end{array}$ & $\begin{array}{l}\text { TRABALHA NO } \\
\text { CAMPO }\end{array}$ & $08 \mathrm{~m} 31 \mathrm{~s}$ \\
\hline $5 . \quad$ PD & $\mathrm{M}$ & 38 & $\begin{array}{l}\text { ENSINO } \\
\text { SECUNDÁRIO }\end{array}$ & $\begin{array}{l}\text { PROPRIETÁRIO } \\
\text { DE OFICINA } \\
\text { MECÂNICA }\end{array}$ & $36 \mathrm{~m}$ \\
\hline
\end{tabular}




\begin{tabular}{|c|l|l|l|l|c|}
\hline \multicolumn{7}{|c|}{ FAIXA ETÁRIA DE 46 A 55 } \\
\hline INF & SEXO & IDADE & ESCOLARIDADE & PROFISSÃO & $\begin{array}{c}\text { TEMPO } \\
\text { GRAV }\end{array}$ \\
\hline $6 . \quad$ JN & $\mathrm{F}$ & 51 & $\begin{array}{l}\text { ENSINO } \\
\text { BÁSICO }\end{array}$ & COZINHEIRA & $25 \mathrm{~m} 31 \mathrm{~s}$ \\
\hline $7 . \quad$ ED & $\mathrm{M}$ & 48 & SUPERIOR & PROFESSOR & $39 \mathrm{~m}$ \\
\hline
\end{tabular}

Como podemos depreender a partir da distribuição das informações nos quadros anteriores, a maioria dos portugueses é da mesma faixa etária - de 35 a 45 anos, havendo somente dois pertencentes à faixa etária de 46 a 55 anos, que são os entrevistados 6 e 7. Como pudemos expor na seção sobre o andamento da pesquisa de campo, não nos foi possível identificar portugueses mais velhos e nem mais jovens. Desta forma, a análise que desenvolveremos foi pautada apenas em informações linguísticas de portugueses de duas faixas etárias.

\section{3) O nível de instrução}

\begin{tabular}{|c|l|l|l|l|c|}
\hline \multicolumn{7}{|c|}{ ENSINO BÁSICO $\left(1^{\circ}\right.$ E $2^{\circ}$ CICLOS $)$} \\
\hline Entrevistado & SEXO & IDADE & ESCOLARIDADE & PROFISSÃO & $\begin{array}{c}\text { TEMPO } \\
\text { GRAV }\end{array}$ \\
\hline $1 . \quad$ RS & $\mathrm{F}$ & 38 & $\begin{array}{l}\text { ENSINO } \\
\text { BÁSICO }\end{array}$ & COZINHEIRA & $10 \mathrm{~m} 01 \mathrm{~s}$ \\
\hline $2 . \quad J N$ & $\mathrm{~F}$ & 51 & $\begin{array}{l}\text { ENSINO } \\
\text { BÁSICO }\end{array}$ & COZINHEIRA & $25 \mathrm{~m} 31 \mathrm{~s}$ \\
\hline $3 . \mathrm{JP}$ & $\mathrm{M}$ & 40 & $\begin{array}{l}\text { ENSINO } \\
\text { BÁSICO }\end{array}$ & $\begin{array}{l}\text { TRABALHA } \\
\text { NO CAMPO }\end{array}$ & $08 \mathrm{~m} 31 \mathrm{~s}$ \\
\hline
\end{tabular}

\begin{tabular}{|c|l|l|l|l|l|}
\hline \multicolumn{7}{|c|}{ ENSINO SECUNDÁRIO } \\
\hline Entrevistado & SEXO & $\begin{array}{l}\text { IDAD } \\
\text { E }\end{array}$ & $\begin{array}{l}\text { ESCOLARIDAD } \\
\text { E }\end{array}$ & PROFISSÃO & $\begin{array}{c}\text { TEMPO } \\
\text { GRAV }\end{array}$ \\
\hline $4 . \quad$ FR & $\mathrm{M}$ & 39 & $\begin{array}{l}\text { ENSINO } \\
\text { SECUNDÁRIO }\end{array}$ & COZINHEIRO & $22 \mathrm{~m} 22 \mathrm{~s}$ \\
\hline $5 . \quad$ CR & $\mathrm{M}$ & 41 & $\begin{array}{l}\text { ENSINO } \\
\text { SECUNDÁRIO }\end{array}$ & $\begin{array}{l}\text { TRABALHA } \\
\text { EM OBRAS }\end{array}$ & $19 \mathrm{~m} 11 \mathrm{~s}$ \\
\hline $6 . \quad$ PD & $\mathrm{M}$ & 38 & $\begin{array}{l}\text { ENSINO } \\
\text { SECUNDÁRIO }\end{array}$ & $\begin{array}{l}\text { PROPRIETÁRIO } \\
\text { DE OFINCINA } \\
\text { MECÂNICA }\end{array}$ & $36 \mathrm{~m}$ \\
\hline
\end{tabular}

ENSINO SUPERIOR

\begin{tabular}{l|l|l|l|l|l} 
7. ED & $\mathrm{M}$ & 48 & SUPERIOR & PROFESSOR & $39 \mathrm{~m}$ \\
\hline
\end{tabular}


Os entrevistados 1, 2 e 3 estudaram apenas até o Ensino Básico, correspondente ao Ensino fundamental no Brasil, apresentando na análise maior índice de usos com concordância fora da normatividade do português de Portugal. O informante 3, inclusive, possui uma língua avaliada pelos próprios oliventinos como um "chaporreu"137, uma espécie de mistura do português com o espanhol. Os informantes de 4 a 6 possuem nível de instrução secundário, o que corresponde ao Ensino Médio brasileiro. O único informante que possui ensino superior é o de número 8, um professor universitário.

\section{4) A classe socioeconômica}

\begin{tabular}{|c|l|l|l|l|c|}
\hline \multicolumn{7}{|c|}{ CLASSE MÉDIA } \\
\hline Entrevistado & SEXO & IDADE & ESCOLARIDADE & PROFISSÃO & $\begin{array}{c}\text { TEMPO } \\
\text { GRAV }\end{array}$ \\
\hline $1 . \quad$ FR & $\mathrm{M}$ & 39 & $\begin{array}{l}\text { ENSINO } \\
\text { SECUNDÁRIO }\end{array}$ & COZINHEIRO & $22 \mathrm{~m} 22 \mathrm{~s}$ \\
\hline $2 . \quad$ RS & $\mathrm{F}$ & 38 & $\begin{array}{l}\text { ENSINO } \\
\text { BÁSICO }\end{array}$ & COZINHEIRA & $10 \mathrm{~m} 01 \mathrm{~s}$ \\
\hline $3 . \quad J N$ & $\mathrm{~F}$ & 51 & $\begin{array}{l}\text { ENSINO } \\
\text { BÁSICO }\end{array}$ & COZINHEIRA & $25 \mathrm{~m} 31 \mathrm{~s}$ \\
\hline $4 . \quad$ CR & $\mathrm{M}$ & 41 & $\begin{array}{l}\text { ENSINO } \\
\text { SECUNDÁRIO }\end{array}$ & $\begin{array}{l}\text { TRABALHA } \\
\text { EM OBRAS }\end{array}$ & $19 \mathrm{~m} 11 \mathrm{~s}$ \\
\hline $5 . \quad J P$ & $\mathrm{M}$ & 40 & $\begin{array}{l}\text { ENSINO } \\
\text { BÁSICO }\end{array}$ & $\begin{array}{l}\text { TRABALHA } \\
\text { NO CAMPO }\end{array}$ & $08 \mathrm{~m} 31 \mathrm{~s}$ \\
\hline
\end{tabular}

\begin{tabular}{|c|l|l|l|l|c|}
\hline \multicolumn{7}{|c|}{ CLASSE MÉDIA ALTA } \\
\hline Entrevistado & SEXO & IDADE & ESCOLARIDADE & PROFISSÃO & $\begin{array}{c}\text { TEMPO } \\
\text { GRAV }\end{array}$ \\
\hline 6. ED & $\mathrm{M}$ & 48 & SUPERIOR & $\begin{array}{l}\text { PROFESSOR } \\
\text { UNIVERSITÁRIO }\end{array}$ & $39 \mathrm{~m}$ \\
\hline 7. PD & $\mathrm{M}$ & 38 & $\begin{array}{l}\text { ENSINO } \\
\text { SECUNDÁRIO }\end{array}$ & $\begin{array}{l}\text { PROPRIETÁRIO } \\
\text { DE OFICINA } \\
\text { MECÂNICA }\end{array}$ & $36 \mathrm{~m}$ \\
\hline
\end{tabular}

Como é possível verificar, de acordo com o quadro de distribuição socioeconômica, a maioria dos entrevistados é de classe média, muitos trabalhando em

\footnotetext{
${ }^{137}$ Cf no Capítulo “O objeto de estudo”, na seção “A língua falada em Olivença”.
} 
restaurantes como cozinheiros, tal como é o caso dos informantes 1, 2 e 3. Encontramos também um pedreiro, que é o caso do informante de número 4, e um trabalhador rural, o informante identificado pelo número 5.

Entre os entrevistados, dois deles se encaixam no nível socioeconômico referente à classe média alta, sendo o entrevistado de número 6 um professor universitário e o entrevistado de número 7 , comerciante e proprietário de uma oficina de mecânica. Ambos os entrevistados se encaixam num nível socioeconômico mais avantajado que os demais.

\section{5) Tempo em que vivem em Olivença}

Menos de 10 anos

\begin{tabular}{|c|l|l|l|l|c|c|}
\hline ENTREVISTADO & SEXO & IDADE & ESCOLARIDADE & PROFISSÃO & $\begin{array}{c}\text { TEMPO } \\
\text { GRAV }\end{array}$ & $\begin{array}{c}\text { TEMPO EM } \\
\text { OLIVENÇA }\end{array}$ \\
\hline $1 . \mathrm{JN}$ & $\mathrm{F}$ & 51 & $\begin{array}{l}\text { ENSINO } \\
\text { BÁSICO }\end{array}$ & COZINHEIRA & $25 \mathrm{~m} \mathrm{31 \textrm {s }}$ & 3 anos \\
\hline
\end{tabular}

De 10 a 20 anos

\begin{tabular}{|c|c|c|c|c|c|c|}
\hline ENTREVISTADO & SEXO & IDADE & ESCOLARIDADE & PROFISSÃO & $\begin{array}{c}\text { TEMPO } \\
\text { GRAV }\end{array}$ & $\begin{array}{l}\text { TEMPO EM } \\
\text { OLIVENÇA }\end{array}$ \\
\hline 2. FR & M & 39 & $\begin{array}{l}\text { ENSINO } \\
\text { SECUNDÁRIO }\end{array}$ & COZINHEIRO & $22 \mathrm{~m} \mathrm{22s}$ & 10 anos \\
\hline 3. $\mathrm{RS}$ & $\mathrm{F}$ & 38 & $\begin{array}{l}\text { ENSINO } \\
\text { BÁSICO }\end{array}$ & COZINHEIRA & $10 \mathrm{~m} \mathrm{01s}$ & 14 anos \\
\hline 4. JP & $\mathrm{M}$ & 40 & $\begin{array}{l}\text { ENSINO } \\
\text { BÁSICO }\end{array}$ & $\begin{array}{l}\text { TRABALHA } \\
\text { NO CAMPO }\end{array}$ & $08 \mathrm{~m} \mathrm{31s}$ & 20 anos \\
\hline
\end{tabular}

Acima de 20 anos

\begin{tabular}{|c|l|l|l|l|l|l|}
\hline ENTREVISTADO & SEXO & IDADE & ESCOLARIDADE & PROFISSÃO & \multicolumn{1}{c|}{$\begin{array}{c}\text { TEMPO } \\
\text { GRAV }\end{array}$} & $\begin{array}{l}\text { TEMPO EM } \\
\text { OLIVENÇA }\end{array}$ \\
\hline 5. CR & $\mathrm{M}$ & 41 & $\begin{array}{l}\text { ENSINO } \\
\text { BÁSICO }\end{array}$ & $\begin{array}{l}\text { TRABALHA } \\
\text { EM OBRAS }\end{array}$ & $19 \mathrm{~m} 11 \mathrm{~s}$ & 23 anOs \\
\hline 6. ED & $\mathrm{M}$ & 48 & SUPERIOR & PROFESSOR & $39 \mathrm{~m}$ & 32 anOs \\
\hline 7. PD & $\mathrm{M}$ & 38 & $\begin{array}{l}\text { ENSINO } \\
\text { SECUNDÁRIO }\end{array}$ & $\begin{array}{l}\text { PROPRIETÁRIO } \\
\text { DE OFINCINA } \\
\text { MECÂNICA }\end{array}$ & $36 \mathrm{~m}$ & 26 anOs \\
\hline
\end{tabular}


Como o quadro nos mostra, apenas a entrevitada 1 vive pouco tempo em Olivença, o que pode nos explicar a grande dificuldade no uso do espanhol por tal informante, mesmo vivendo desde sempre na fronteira com a cidade.

Os informantes de 2 a 4 vivem na cidade de Olivença por mais de 10 anos e com exceção do falante 3 (JP), que se comunica através do portunhol, os demais são bilíngues, o que é favorecido pelo tempo em que vivem no país.

Os falantes de 5 a 7, como podemos constatar, vivem por mais de 20 anos na cidade de Olivença e, independentemente do fator nível de instrução, todos são bilíngues, fator também favorecido pelo tempo de vivênvia no país.

\subsubsection{Descrição de atitudes linguísticas dos oliventinos frente à língua portuguesa}

Como inicialmente relatamos neste capítulo, Matias (1984), em suas pesquisas sobre a língua portuguesa falada em Olivença, assegurou que o português oliventino na segunda metade do século XX, equivalia a uma variedade similar à alentejana, mas com influências do espanhol. Em pesquisas posteriores, Matias (2001) e Fernández (2004) verificaram que tal situação havia mudado e que a língua falada pelos portugueses que vivem em Olivença já estava se diferenciando da fala do português alentejano, passando a ter influências basicamente do espanhol, estando, inclusive como afirma Fernández “já quase completamente assimilado ao espanhol”.

Matias (2001) como forma de evidenciar sua asseveração, mostra alguns exemplos como os já apresentados na seção sobre pesquisas anteriores do português em Olivença. Nessa seção, a autora apresenta aspirações de $s$ como em Liboa 'Lisboa; supressão de $r$ final: lavá 'lavar'; realização de /v/ como [b]: barrer 'varrer' por influência da língua da sociedade receptora; entre outros. Verificando tal influência, e um bilinguismo muito grande, fator que favorece o abandono da língua minoritária, propõe, inclusive, o fim da LH em Olivença.

As pesquisas já realizadas sobre essa variedade linguística somadas ao trabalho que realizamos in loco nos levaram a mais questionamentos ainda, pois, diante de tais 
afirmações dos pesquisadores até aqui citados, seria necessário confirmar ou refutar se ainda existe tanta influência da língua da sociedade receptora no português oliventino e se de fato, a LH estaria prestes a ser totalmente exterminada. Se estamos, de fato, diante de uma sociedade, como afirma Matias (2001) totalmente bilíngue, independentemente da classe social, poderíamos, então, falar em extinção da língua portuguesa em Olivença? Parece-nos uma posição, no mínimo, questionável.

\subsubsection{Descrição linguística do português oliventino}

\subsubsection{A análise fônica do português de Olivença}

Com o foco na descrição qualitativa dos usos identificados na fala dos portugueses entrevistados, buscamos identificar características típicas do português oliventino. Logo de início, notamos que uma riqueza de variações fonéticas revela-se no dia a dia, independentemente do nível de instrução ou do fator socioeconômico.

Como demonstraremos, os entrevistados possuem características bastante peculiares, sendo falantes bilíngues, mudando de uma língua para outra com grande facilidade, quando estão em situação distensa. No entanto, o espanhol é a língua falada por todos eles no dia a dia, sendo o português falado mantido preferencialmente nos domínios familiares. Contudo, as variações fônicas identificadas durante esta pesquisa permitiram reconhecer influências de um português alentejano, com exceção de apenas dois entrevistados, os quais são os que possuem nível de instrução mais baixo.

Para apresentar as variações fônicas identificadas ${ }^{138}$, organizamos os fenômenos segundo os rótulos seguintes: substituição vocálica, síncope, aférese, apócope, paragoge e inversão de consoante. A razão por essa escolha de rótulos nos parece se ajustar à compreensão de maior neutralidade do que percebíamos durante o trabalho de campo e não se traduziria durante a leitura da tese em qualquer avaliação ou pré-julgamento.

\footnotetext{
${ }^{138}$ Esclarecemos que a tentativa de representação sonora dos oliventinos tomo como ponto de partida a percepção auditiva de uma linguista brasileira, sem o emprego de símbolos fonéticos clássicos.
} 


\section{SUBSTITUIÇÃO VOCÁLICA}

Os entrevistados, sem exceção, manifestavam variação na realização dos sons vocálicos /e/ e /o/, tal como ocorre na fala do português alentejano.
a) $|e|>[i]$ :

Entrevistado 1 (FR): [i ao fim]; [i ao fim]; [i então]; [lá em Portugal i então consiguimos]; [i é mais fácil]; [i vou]; [não pírcebem não pircebem]; [dipois]; [qui]; [pissoas]; [e chega lá i], [i depois]; [i não como]; [i o que acontece]; [i então aproveitam]; [hábito di]; [qui foram]; [qui não havia problema]; [purqui]; [consiguimos]; [então não si interessam]; [passiare]; [piqueno]

Entrevistada 2 (RS): [i uu ifpanhol]; [i prontu], [qui]; [piquena]; [dipois]; [i (...)], [qui]; [i tem...]; [si]; [i tão aí..i ta]; [pissoas]; [só si falam]; [i ele fala...]; [si tamos (...)qui tu ...]; [i a falar]; [i vou]; [qui vo]; [sinhora]; [intendeu].

Entrevistada 3 (JN): [pissoas]; [pissoal]; [mi dava com portugueses]; [efprissão]; [i então]; [vistuário]; [dispidir-me].

Entrevistado 4 (CR): [essi]; [si]; [qui], [ixemplo]; [ristaurante]; [pissoas]; [firiadu]; [pissoal].

Entrevistado 5 (ED): [iftremadura]; [qui]; [Situbal]; [quifta (que está)]; [si]; [Cásiris]; [rigional]; [qui si]; [iftá]; [di]; [rilações]; [quiftões]; [incurpuraram]; [iftatuto]; [espicífico]; [difirente]; [Lião]; [lionês]; [dipois]; [sigundo]; [i intão]; [disaparece]; [istado]; [pissoas]; [intendi]; [nem siquer].

Entrevistado 6 (PD): [iftamos]; [intão]; [devi]; [vinti]; [elif]; [imigranti]; [i], [iftudei]; [ifta]; [pirciber]; [ifta]; [i intão]; [pirciber]; [si]; [perdi-si]; [di]; [qui]; [ifpanhóif]; [intende]; [elif]; [intendê]; [IJpanha...i dizi:..Sivilhianu]; [pissoaf].

\section{b) $/ o />[u]$ :}


Entrevistado 1 (FR): [vamuf lá]; [nu]; [não temos pur perder]; [tuduu]; [purqui]; [sutaque]; [cumer]; [tamus]; [cumida]; [casadus]; [pur exemplo]; [cumeçou]; [falu].

Entrevistada 2 (RS): [i uu ifpanhol]; [nãuu]; [du resto]; [purque]; [nu]; [só a partir du trinta e cinco]; [purque].

Entrevistada 3 (JN): [vamuf]; [comu]; [du]; [pudia].

Entrevistado 4 (CR): [pur exemplo]; [pur; quandu]; [viemuf]; [nu]; [cumeçou]; [pudemuf].

Entrevistado 5 (ED): [uf]; [lucalidades]; [Purtugal]; [purque]; [guverno]; [purtuguesa]; [u $\int$ purtugueses]; [prublema]; [guvernava]; [putencial]; [cumércio]; [putenciar]; [isulado]; [incurpuraram]; [purtanto]; [purque]; [tumate]; [cum]; [purtanto]; [prufessor]; [dentru]; [du]; [pontu]; [outru]; [comu]; [tudu]; [impurtante]; [mundu]; [tudu]; [cumeça]; [futuru]; [outrus]; [culegas]; [cunverteu-se]; [cunhecem]; [prucesso]; [discursu]; [pruvavelmente]; [todus]; [mumento]; [curretamente]; [genuínu]; [pruvavilmente]; [defurmação]; [curiosu]; [quandu].

Entrevistado 6 (PR): [purtuguê]; [Purtugal]; [quatru]; [anuf]; [acentu]; [quandu]; [sutaque]; [temus]; [purque]; [outruf]; [du meio]; [veiu]; [digamuf]; [comu são jovenf]; [negófuf]; [toduf]; [falu]; [difcu, a parte até, mudu u difcu]; [aquilu]; [prublema]; [Sivilhianu].

Como podemos notar a partir dos dados colhidos, todos os entrevistados e suas realizações acima ${ }^{139}$ apresentam variação fonética de $e$ por $i$ como variação de $o$ por $u$ independente da variável social. Sendo assim, fica claro que tais usos independem do sexo, idade, nível de escolaridade e classe socioeconômica. Além disso, todas essas realizações são compatíveis com as da língua portuguesa, não representando, com exclusividade, influências do espanhol. O que asseguramos nesta tese é que tais variações se tratam de uma fala própria do português alentejano.

${ }^{139} \mathrm{O}$ informante 6 (Juan Pepe) não entrou nessa análise por utilizar uma fala não mais própria do português, mas uma espécie de portunhol. Na seção seguinte, apresentaremos esse caso em separado. 


\section{SÍNCOPE}

$\mathrm{Na}$ fala dos portugueses oliventinos, foram identificados usos em que o desaparecimento de fonema(s) no interior do vocábulo ocorrem. Vejamos:

Entrevistado 1 (FR): [memo (mesmo)]; [pra]; [tufunemas (telefonemas)]; [cupa (culpa].

Entrevistada 2 (RS): [pra]; [pra i pa li];

Entrevistada 3 (JN): [pra]; [cupa (culpa)]

Entrevistado 4 (CR): [pra]; [pa você];

Entrevistado 5 (ED): [pra]; [pra; te (ter)]; [p'recem (parecem)]; [vident'mente]; [ap'sar]; [dif'rentes]; [esp'cífica]

Tais usos identificados não se relacionam com as variáveis sociais aqui apresentadas, pois são usos que ocorrem independentemente. O que asseguramos nesta pesquisa é que, neste caso, não se trata de uma influência espanhola, mas de usos legítimos do português.

\section{AFÉRESE}

Encontramos ainda dados em que ocorre a supressão de fonemas no princípio do vocábulo:

Entrevistado 1 (FR): [tando (estando]; [tô (estou)]; [tamus (estamos)]; [tive (estive)];

Entrevistada 2 (RS): [pra i pa li (para ir para (a)li)];

Entrevistada 3 (JN): [tô em Lisboa (es)tou)];

Entrevistado 5 (ED): [(e)vident(e)mente] (evidentemente) 
Entrevistado 6 (PR): [tá]; [tô].

Sendo esta tese voltada para a apresentação de usos selecionados pelos falantes do português oliventino, mesmo que em frequência menor, o que nos chamou a atenção é que, embora não os encontremos na fala de todos os informantes, eles aparecem independentemente dos fatores nível de instrução e nível socioeconômico dos entrevistados. Observamos, ainda, que a aférese ocorre principalmente com o verbo 'estar': [tô] [estou] ou [tive] [estive]. Mais uma vez, podemos assegurar que as alterações identificadas neste caso não têm nenhuma influência da língua em contato, no caso, do espanhol e que, inclusive, ocorrem independentemente das variáveis sociais aqui relacionadas.

\section{APÓCOPE}

Nas variações por apócope, mostramos os dados em que ocorre a supressão de um ou vários fonemas no final de uma palavra:

Entrevistado 1 (FR): [si (sim)];

Entrevistada 2 (RS): [si (sim)]; [pra i pa li (para i(r) pa(ra) ali)]; [vô (vou); [portuguê (portuguê(s)].

Entrevistada 3 (JN): [tinha u restaurante (tinha u(m) restaurante)]; [temo (temos)]; [tô em Lisboa (esto(u) em Lisboa)]; [ eu vô lá (eu vo(u) lá)];

Entrevistado 4 (CR): [si; é é si (si(m) é é si(m)]; [mai gente (mai(s) gente];

Entrevistado 6 (PD): [port'guê]; [pa (ra) aprendere]; [i queri (em) qui eu ifteja....]; [si, si, si (m)]; [acontecê (r)]; [difíci (l)].

No caso das sequências em que ocorre apócope, pudemos observar que o informante 5, que tem o maior nível de instrução não apresenta nenhuma ocorrência. Os demais informantes (1, 2 e 4) suprimem o $m$ da palavra sim, constituindo-se este um indício encontrado da influência do espanhol no nível pragmático. 


\section{PARAGÓGE}

Durante a análise das falas dos portugueses que vivem em Olivença, percebemos que havia muitas ocorrências com paragóge, a qual consiste no acréscimo de um fonema ou sílaba no final da palavra. Nossos dados mostraram o acréscimo do elemento vocálico $e$ no final das palavras terminadas em $r$ :

Entrevistado 1 (FR): [tare]; [melhore]; [falare]; [familiare]; [fazere]; [passiare]; [dare]; [tere]; [ire]

Entrevistada 2 (RS): [professore]; [Campo Maiore]; [veres esse senhore?]; [falare].

Entrevistada 3 (JN): [trabalhare]; [interiore]; [vere]; [percebere]; [dizere]; [olhare]; [perdere]; [quere]; [quere]; [embarcare]; [vivere]; [entrare].

Entrevistado 4 (CR): [dizere]; [trabalhare]; [falare]; [tivere]; [queri]; [tere]; [teri]; [comere]; [comprare]; [fazere]; [quere]; [desfilare]; [bare]; [toureare]; [vere].

Entrevistado 5 (ED): [lecionare]; [recuperare]; [preservare]; [cumprire].

Entrevistado 6 (PD): [aprendere]; [falare]; [iftudare]; [vere].

Esse tipo de uso identificado é típico da língua falada pelos portugueses alentejanos e ocorre independentemente da variável social.

\section{INVERSÕES DE CONSOANTES}

Além dos casos de alteração fônica identificados nas falas dos portugueses oliventinos, também pudemos identificar inversões de consoantes. Vejamos esses casos:

Entrevistado 1 (FR): [preguntar]; [pregunta]; [precebem]; [precebe]; [pruquê]; [pro exemplo]; [pru pur exemplo]. 
Entrevistada 3 (JN): [proque]; [pruque].

Entrevistado 4 (CR): [preguntava].

Entrevistado 6 (PD): [preder (perder)]; [prefeitamente (perfeitamente)]

Podemos associar tais inversões a um nível de instrução mais baixo, embora esses usos apareçam na fala do informante 1, que possui nível de instrução secundário, o equivalente ao Ensino Médio brasileiro. Por não ser ocorrências muito frequentes, não é possível, então, dizer que fazem parte sistematicamente da fala dos portugueses oliventinos, mas é um indício interessante.

\subsubsection{Aspectos do léxico da fala dos portugueses oliventinos}

Nas entrevistas, identificamos algumas características do léxico do português oliventino, o que levou a postular que, em sua fala, existe apenas variação com influência puramente alentejana, e não espanhola como apresentado nas pesquisas anteriores. Nesta subseção, apresentamos um breve glossário constituído a partir das entrevistas registradas, seguido de exemplo contextual do respectivo uso.

acentu: sotaque (Entrevistado $6 \mathrm{PD})$

a gente: pessoas, povo "sempre me dei bem com a gente de Olivença" (Entrevistado 3 $\mathrm{JN})$

altura: tempo, momento "Houve uma altura que muitos oliventinos quiseram saber (...)" (Entrevistado 5 ED)

asneiras: besteiras, coisas sem importância "i então meio, às vezes ouvia aquelas pequenas asneiras, já ao meu pai, mas agora então quando vir pra aqui pra eu me habituar a este palavriado" (Entrevistada $3 \mathrm{JN}$ )

bucanhinho: pequeno “desde bucanhinho" (Entrevistado 4 CR; entrevistado 6)

caminhonista: caminhoneiro "o meu pai agora ta reformado também já, mas como era caminhonista e fazia Alemanha, França e esses país pronto se conhece a Europa toda meu pai conhece a Europa toda" (Entrevistado 1 FR) 
difcu: disco [difcu, a parte até, mudu u difcu i já via até que, mudo até...é... u som...mudo u som] (Entrevistado 6 PD).

gente muito idosa: velhinhos "se tiver cinquenta pissoas é muito, i tudo gente muito idosa" (Entrevistado $3 \mathrm{JN}$; Entrevistado $4 \mathrm{CR}$ )

longo da raia: ao redor de um espaço físico "Há outras lucalidade $\int$ de int'resses de 'studo ao longo da raia se e esse , purque Olivença é u é uma qu'stão muito ifpcífica" (Entrevistado $5 \mathrm{ED})$

miúdo: "hoji os miúdos hoje em dia são muito criticados por isso"; "i então acontece, o miúdo, ééé é filho do pais separados" (Entrevistada 2 RS; Entrevistada 3 JN)

migué: é uma gíria que simboliza uma forma de lidar com situações adversas: [rexponder expanhola...ali na migué(...)] (Entrevistado 6 (PD).

muié: mulher (Entrevistado 6 (PD).

palavriado: palavrão "já ouvi esse palavriado ao meu pai, mas pronto, meu pai dizia esse palavriado, mais rifugiado dos filhos" (Entrevistada $3 \mathrm{JN}$ )

pena: um dó "eu tenho pena quando chego a Jurumeia" (Entrevistada $3 \mathrm{JN}$ )

pequenos: crianças "i vou lá nu dia de folga pa ta com o piqueno e pronto" (Entrevistado 1 FR)

pocaninho: menino pequeno "miúdo é Jurmeia, pocaninho é que tem quatro anos" (Entrevistada $3 \mathrm{JN}$ )

raia: lugar "Há outras lucalidade $\int$ de int'resses de iftudo ao longo da raia se e esse , purque Olivença é u é uma qu'stão muito ifpcífica" (Entrevistado 5 ED)

restauração: restaurante "É aqui, com esta vida não se pode, vida da restauração é uma vida , que nós temo sendo preso" (Entrevistada $3 \mathrm{JN}$ )

saltar: soltar sem querer; escapar "salta alguma palavra em espanhol" (Entrevistado 4 $\mathrm{CR})$ 
satura: difícil "esta vida é uma vida satura" (Entrevistado $3 \mathrm{JN}$ )

sítio: região/lugar "Barrancos está isulado, purtanto quem... não há um sítio de passagem a Purtugal tem expressamente" (Entrevistado 5 ED)

sutaqui: sotaque (Entrevistado $6 \mathrm{PD})$

toda a gente: equivale ao pronome indefinido todos todas as pessoas "aqui toda a gente me conhece e tudoo, eu conheço toda a gente" (Entrevistado $4 \mathrm{CR}$ )

tropa: serviço militar "por não ter ido à tropa" (Entrevistado 5 ED)

velhotes: velhos "É i hoje dá uma pena chegar à minha terra e vê só velhotes, eu chego a entrare em Jurumeia, não ver ninguém" (Entrevistada $3 \mathrm{JN}$ )

zona: lugar [trabalhiei muito na zona ai du Erlva (zona do Elvas)].

Os portugueses oliventinos utilizam um vocabulário tipicamente português, não nos revelando usos que pudéssemos associar a uma influência do espanhol. A única palavra identificada com uma influência do país hospedeiro é "bucanhino" ou "pocaninho". Esses usos concorrem o tempo todo com a palavra "pequeno", termo que designa "criança" ou "pequeno".

\subsubsection{Aspectos da morfologia encontrados na fala dos portugueses oliventinos}

Percebemos que as características morfológicas identificadas nas entrevistas dos falantes do português oliventino também não se davam por influência do espanhol. Ao contrário do que as pesquisas anteriores apresentaram, a morfologia do português em Olivença tem uma característica muito típica do Alentejo, o que, mais uma vez, nos faz assegurar nesta tese que os falantes entrevistados fazem questão de marcar sua pertença linguística a Portugal, preservando seus traços fonéticos, lexicais, morfológicos e sintáticos daquela língua nativa. 
Nesta seção, apresentaremos os aspectos morfológicos que podem ser associados ao português nativo. Separamos essas observações por classe de palavras para facilitar a localização.

\section{PRONOME}

a) Variação entre os usos de [a gente] [nós]

[a gente] - sintagma nominal que demanda concordância verbal com $3^{\mathrm{a}}$ pessoa do singular, funcionalmente equivalendo ao pronome pessoal de $1^{\mathrm{a}}$ pessoa do plural no português. De acordo com Vilela (1999), em Portugal o "a gente” é utilizado na língua falada:

A gente funciona, sobretudo na língua falada, como pronome e exige a terceira pessoa do singular, designando normalmente um grupo em que o falante também se inclui, podendo, contudo, referir-se a uma única pessoa.

(VILELA, 1999:211)

Entrevistado 1 (FR): [aa gente vai], [a gente mudaaaaa]; [uma coisa é ter fronteira a gente]; [então a gente pra vê]; [a gente pode notar a dif'rença]; [e a gente consegui falar com eles]; [uma pena a gente a gente]; [porque a gente iftuda]; [a gente estuda dois ou três anos inglês na ifcola]; [então a gente chega lá e eles começam a falar]; [a gente não sabe]; [a gente]; [a gente]; [a gente cruza com os espanhol]; [a gente tem que viver]; [a gente pode]; [a gente vive com a língua]

Entrevistada 2 (RS): [ela tá (...) com a gente]

Entrevistada 3 (JN): [IJpanhol, a gente diz verão]; [quando a gente conhece do Brasil]; [a gente não diz]; [a gente]; [o que a gente pensa]

Entrevistado 6 (PD): [a gente vende coisa por lá]

[Nós] - pronome de $1^{\mathrm{a}}$ pessoa do plural que pode aparecer em posição subjetiva ou em posição completiva.

Entrevistado 1 (FR): [é mais fácil pra nós]; [ó se fala o inglês ou então não vamos ao lado nenhum]; [eles já aceita nós]

Entrevistada 2 (RS): [e nós nunca digamos perdere as nossas origens]

Entrevistado 5 (ED): [e nós dissemos]; [nós pretendemos]

Entrevistado 6 (PD): [nó falamu...]; [sim, nós aqui, entre nóis, fala português] 
Ao contrário do pronome 'nós', o qual é pouco utilizado entre os portugueses oliventinos, e estando principalmente entre os que têm maior nível de instrução ${ }^{140}$, o pronome 'a gente' é frequente entre todos os entrevistados, independentemente da variável social.

\section{b) Pronome possessivo Vosso(a)}

[Vossa] - pronome possessivo de $2^{\mathrm{a}}$ pessoa do plural funcionalmente empregado em relação à $2^{\mathrm{a}}$ pessoa do singular também.

Entrevistado 5 (ED): [vossa] "Qualé vossa ideia, ã ã, qualé sua ideia â, é de fazer um trabalho só de língua, ou fazer..."

\section{c) Pronome interrogativo Qual}

Entrevistado 5 (ED): [Qualé] “Qualé vossa ideia, ã ã, qualé sua ideia â, é de fazer um trabalho só de língua, ou fazer...”

\section{d) Pronome de tratamento Você}

Ao explanar sobre o uso dos pronomes de tratamento em Portugal, Vilela (1999) diz o seguinte:

\footnotetext{
Nas formas de tratamento, em português, usa-se o pronome pessoal tu, oposto a você (equivalente a tu em algumas zonas geográficas, ou situando-se num nível de distanciamento em relação ao interlocutor que fica entre o tu e o senhor), o senhor, vocemecê, vossa excelência, vossa senhoria, etc. Você(s) exige a terceira pessoa do singular/plural.

(VILELA, 1999:210)
}

Encontramos apenas em dois dos nossos entrevistados o uso do pronome "você", os quais eram os de mais baixo nível de instrução. Já o informante 5, o qual possui o maior nível de instrução, utiliza como pronome de tratamento o "senhor(a)":

Entrevistada 2 (RS): [Ocê] “A não ser condo ocê já vem nhá vem, é que vai..de outra maneira não"

Entrevistada 4 (CR): [você] "mas alguma vez pur exemplo, eu tô a falar com você memo em purtuguêf, e salta alguma palavra em ifpanhol"

\footnotetext{
${ }^{140}$ Neste caso nos referimos ao informante 5, o qual é um professor universitário e um dos poucos que mais utiliza o pronome 'nós'.
} 


\section{e) Pronome de tratamento senhor(a)}

\section{[senhor]}

Entrevistado 5 (ED): “inclusiva há sinhore que até mantém ma melhor essa essa

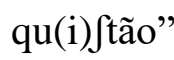

[senhora]

Entrevistado 5 (ED): “a sinhora o mesmo qui vai aqui nessa rua e qui vai entrar num edifício é e dizer du lado está em Purtugal"

Pelos dados apresentados, notamos que não ocorre uma diferença fundamental entre os falantes de português em Olivença. No entanto, fica claro que as poucas que aparecem não possuem influência do espanhol, mas, sim, do português alentejano.

\section{CONJUNÇÃO:}

a) conjunção coordenativa e: pronunciada com [i], essa conjunção tem a função de, além de representar uma construção aditiva, apresenta-se numa sequência em que uma conclusão é expressa:

Entrevistado 1 (FR): [temos a usar o tufone i acabou]; [a diferença de salário é muito grande i então aproveitam]

Entrevistado 4 (CR): [e eu tenho que dizere, que tá a dizere ao pai a meu filho, e gostava que ele falasse]. Neste caso funciona como aditiva.

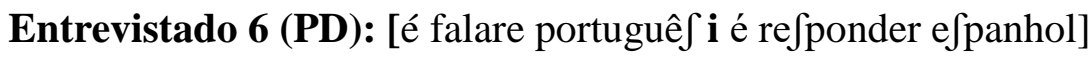

Entrevistado 6 (PD): [entende eles e todo o mundo, i quando sai fora daqui já iftá]

\section{b) recorrência da conjunção causal porque/proque}

Entrevistado 1 (FR): [é que purque eles têm uma miftura de purtuguês e ifpanhol na fala]

Entrevistado 1 (FR): [conforme tá não há hipótese, porque a diferença de salário é muito grande; i então aproveitam]

Entrevistado 1 (FR): [teve muitas influências do Lionês purque essa zona daqui da Ifpanha era Lião] - Entrevistado 1 (Fernando)

Entrevistada $3(\mathbf{J N})$ : [e tenho minha casa à venda, pois proque aquilo meus filhos não quere]

Entrevistada $3(\mathbf{J N})$ : [tenho pena quando chego a Jurumeia, porque no meu tempo de miúda, éramos cinquenta e quatro miúdos na escola, hoje não há escola!] 
Entrevistada 3 (JN): [nem ela entende o que nós dizemos nem nós entendemos o que ela diz, porque, cupa da mãe!]

Entrevistada 3 (JN): [não gostam desta vida, porque esta vida é uma vida satura muito]

Entrevistado 4 (CR): [conheço mai gente aqui que em Portugal, porque levo mais metade da minha vida aqui que ali; sim pruque, i a outro sim, outro sim]

Entrevistado 5 (ED): [purque teve, não teve o prucesso de castelhanização]

Entrevistado 6 (PD): [mas tem, mas temus obriga a fala portuguêf, purque ali na migué é responde espanhola...]

c) conjunção condicional se [si]

Entrevistado 1 (FR): [si vier um português; pra poder pirceber o que diz na televisão] Entrevistado 6 (PD): [si eu uf obrigam a falá, falam..si eu digo não...(...) falam em portuguêf].

d) conjunção condicional senão [sinão]

Entrevistado 5 (ED): [não tenho aqui o outro computador e neste não da para ligar a NET sinão poreria aqui]

e) conjunção temporal quando [por quando] [condo]

Entrevistado 1 (FR): [até por quando dá tufunemas]

Entrevistado 2 (RS): [A não ser condo ocê já vem nhá vem]

Entrevistado 6 (PD): [entende eles e todo o mundo, i quando sai fora daqui já iftá]

Entrevistado 6 (PD): [eli vá za lá comere i quando chega aquela〕 fronteira ali um reftaurante]

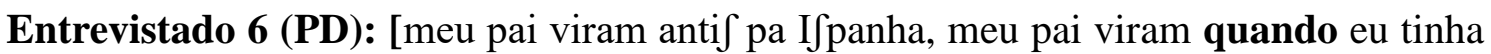
oito anu]

Entrevistado 6 (PD): [eu tenho uma relação muito íntima com minha vó...iiii a minha muié, quando vai a Portugal, em casa de minha vó]

f) conjunção conformativa conforme

Entrevistado 1 (FR): [conforme tá não há hipótese] 
g) conjunção conclusiva portanto [purtanto] ${ }^{141}$ : a conclusão nem sempre é formalizada entre as duas orações sequenciadas. Muitas vezes, o processo conclusivo é realizado a partir da conexão entre a ideia não formalizada (logo, intuída ou pensada) e uma segunda parte formalizada pela oração 'subordinada' adverbial conclusiva.

Entrevistada 3 (JN): [o mais, o mais véio não, mais velho saiu, purtanto de Jurumeia com dezoito anos, pra marinha]

Entrevistada $3(\mathbf{J N})$ : [a maioria dos portugueses ganham, purtanto portugueses que vivem aqui, Olivença, Badajoz]

Entrevistado 3 (JN): [Eles é sempre moraram, purtanto muito perto de Espanha]

Entrevistada 3 (JN): [Morgada! Purtanto "O Carlos...desculpa lá, o restauran, restaurante Morgada fica em que sítio?"]

Entrevistada 3 (JN): [o miúdo foi trabalhar por, portanto o homem que atualmente, estava com a mãe]

Entrevistada 3 (JN): [as pissoas mudam de local, é purtanto eu sou alantejana]

Entrevistado 1 (FR): [senão no verão que há um, purtanto um grupo de amigos que fazem umas festinhas]

Entrevistado 5 (ED): [mas falando esp(i)cificamente de Barrancos tem uma questão curiosa, Barrancos está isulado, purtanto quem... não há um sítio de passagem a Purtugal tem ifpressamente]

Entrevistado 5 (ED): [vinho tinto com casera que é uma gasosa que há aqui na Ifpanha, purtanto tem tem, iftando em Purtugal, mas têm muitas coisas da própria raia, purtanto Barrancos...]

Entrevistado 5 (ED): [é um sitio de interesse, purtanto e depois tem um, mais a cima, aqui mesmo do cantinho]

Entrevistado 5 (ED): [vê se conseguem ver agora, pois está a Igreja de Santa Maria também é purtuguesa, purtanto tudu u que há aqui de monumentos é tudu purtuguês]

Entrevistado 5 (ED): [historicamente Purtugal reveindica Olivença, purtanto há um tratado de 1817 que e o tratado de Viena]

\footnotetext{
141 Alguns pesquisadores, tais como Praça (1995), Pezatti (2000), Lopes et ali (2001), Mira Mateus e Nascimento (2005), entre outros, afirmam em suas pesquisas que o portanto não pode ser mais classificado apenas como conjunção conclusiva no PE tal como propõem as gramáticas normativas. Os pesquisadores encontraram o portanto funcionando como articulador discursivo, no qual pode retomar, encaminhar e fechar tópicos de conversa, como sinalizador de interação, no qual o falante indica ao seu interlocutor que a fala concluída se relaciona diretamente com a anterior, como forma de assegurar que a interpretação foi mais correta e com marcador conversacional, no qual não funciona mais como conector, mas como um tempo na fala para que o discurso possa prosseguir.
} 
Entrevistado 5 (ED): [Uma coisa é o território e outra coisa é o fator humano e o cultural, purtanto nós não pudemos é para apagar tudu pur causa do território]

Entrevistado 5 (ED): [o órgão faz a função a função faz o órgão, purtanto é pruvavelmente alguns adquirem a nacionalidade]

Entrevistado 5 (ED): [mas aqui temos, mas depois temos o chamado nesse sentido, agora temos o chamado purtuguêf Oliventino, purtanto o purtuguêf oliventino é um purtuguêf enquadrado no purtugê $\int$ padrão]

Entrevistado 5 (ED): [presuntu em purtuguês em ifpanhol é jamón e dizem gimão, purtanto há palavras que (...) então são palavras que pruvavelmente (...) terão sido originadas da defurmação]

Entrevistado 5 (ED): [u $\mathrm{u} \int$ mais velhos eh eh a língua usam com a naturalidade como usaram sempre, purtanto sua forma de falar foram é cunhecem desde que naferam]

\section{g) conjunções temporal e conclusiva Então [intão]}

Entrevistado 1 (FR): [por tá muito perto então conseguimos ver]; [então conseguimos ver a televisão espanhola lá em Portugal então consiguimos] - CONCLUSIVA

Entrevistado 3 (JN): [Às vezes sai, tentar a pensar às vezes, mas não. Nós dois dois é português, então às vezes.. pois camareiras às vezes eu digo umas palavras espanholas, outras vezes digo em português] - CONCLUSIVA

Entrevistado 3 (JN): [As filhas, intão, já são nasceram aqui!] - CONCLUSIVA

Entrevistado 3 (JN): [... no dia a dia, só tinha mais gente, (...) intão acontece] CONCLUSIVA

Entrevistado 5 (ED): [Barrancos, historicamente, teve mais proximidade a Ifpanha(...); é e então Barrancos tem essa característica] - CONCLUSIVA

Entrevistado 5 (ED): [teve muitas influências do Lionês porque essa zona daqui da ISpanha era Leão, é Lião, era o Reino de Lião. Então tem muitas influências do Lionês, então o Mirandês tem influências o Lionês] - CONCLUSIVA

Entrevistado 5 (ED): [Então acontece que e, então u Godoy que tentava era como Napoleão era dividir é dividir Purtugal em três] - TEMPORAL SEQUENCIADORA Entrevistado 5 (ED): [Cumeçam a lecionare castelhanos, IJpanhol (sim), i intão cumeça-se a a a ver em casa comu a língua do futuru é o IJpanhol e a língua pobre e o purtuguêf] - TEMPORAL SEQUENCIADORA 
Entrevistado 5 (ED): [d(i)saparece na rua a língua da escola é, então, as p(i)ssoas que aprendem o IJpanhol é são as camadas mais jovens] - CONSECUTIVA

Entrevistado 5 (ED): [as mais antigas falam purtuguês em qualquer sítio mãs para os filhos falavam espanhol, então temos aqui vários casos e acontece isso] CONCLUSIVA

Entrevistado 5 (ED): [Então, o que que acontece, isso é um prucesso de sensibilização] - CONCLUSIVA

Entrevistado 5 (ED): [ falam de as coisas que ouviram por aí mas aqui também em Olivença também há isso, então nós temos trabalhado nisso] - CONCLUSIVA

Entrevistado 5 (ED): [houve uma altura que muitos Oliventinos quiseram saber da da quiftão de dehhh se podiam ter nacionalidade, então nós informamos] - TEMPORAL

Entrevistado 5 (ED): [intão é aqui há um purtuguês oliventino] - CONCLUSIVA

Entrevistado 6 (PD): [a moda falare em portuguêf...tá...é como...é moda, i então, (...) fizeram uma entrevifta] - CONCLUSIVA.

Entrevistado 6 (PD): [é da algun $\int$ que vinha aqui apanhar nacionalidade portuguesa...i então vi ao pirciber a forma que (...) falava] - TEMPORAL SEQUENCIADORA

\section{h) conjunção adversativa mas [maf]}

Entrevistado 5 (ED): [pudemos apagar a língua pudemos apagar tudu, mas fora aqueles monumentos a Igreja dã dã Madalena não sei se visitaram; foi uma quiftão que sempre foi abafada, calada, ma isso só os prejudicou]

Entrevistado 5 (ED): [tem que ser duma forma e Purtugal outro qui é para não ferir sentimentos maf, o que chegamos a ao pontu é de que hoje em Purtugal fala-se já um $\mathrm{hm} \mathrm{hm} \mathrm{normalmente} \mathrm{de} \mathrm{Olivença} \mathrm{embora} \mathrm{muitos} \mathrm{purtuguese} \int$ não conhecem Olivença]

Entrevistado 5 (ED): [falam de ao coisas que ouviram por aí mas aqui também em Olivença também há isso]

Entrevistado 5 (ED): [pode ser por próprio interesse, maj há uma, como nós custumamos dizer aqui o Órgão faz a função...]

Entrevistado 5 (ED): [haverá todus us casos ma a lei a lei não entende de disso]

Entrevistado 5 (ED): [Ah minha esposa não fala curretamente mas fala purtuguês]

Entrevistado 6 (PD): [eu em casa sim...com filhos aprendere...mas agora ifta começar a...(...) a moda falare em portuguêf...]

Entrevistado 6 (PD): [é...entende tudo ma não fala portuguêf]]. 
Entrevistado 6 (PD): [tem u acentu portuguêx mas na há prublema]

Entrevistado 6 (PD): [mas tem, mas temus obriga a fala portuguêf]

Entrevistado 6 (PD): [a dua entende prefeitamente u qui diz uma da outra, (risadas) mas nenhuma fala o idioma da outra...(...)]

Entrevistado 6 (PD): [é curioso sim, mas...digamos quê, minha vó ja pa idade que tem de idade não qué aprender IJpanhol(...)]

\section{i) conjunção conclusiva Porquanto [purquanto]}

Entrevistado 5 (ED): [sim pruque, i a outro sim, outro sim, purquanto não sabe falar espanhol,é outro mescla, mescla]

\section{j) conjunção conclusiva Logo}

Entrevistado 4 (CR): [é! essa é a diferença, logo pra comprare paa, pra comprar por exemplo, pra fazere (...) pra comprare pra fazere em casa é mais caro, aqui, é mais caro lá que aqui]

k) conjunção concessiva embora, com o objetivo de frustrar a interpretação baseada no senso comum.

Entrevistado 5 (ED): [em Purtugal fala-se já um hm hm normalmente de Olivença embora muitos purtugueses não conhecem Olivença]

Os conectores apresentados nesta seção revelam usos típicos de Portugal, sem influências da sociedade receptora. O que é percebido, então, é que os entrevistados são bilíngues, não fazendo uso de nenhum caso que possa parecer estranho, como temos visto nas pesquisas de Matias (1984:182), nas quais apresentam usos como 'ca (do que)', 'aunque (ainda que)', 'com que (ainda que)', 'mientra (enquanto)' e 'por que (para que)', pelo menos nos contextos em que com eles dialogamos. Talvez nos falte analisar os contextos em que eles conversem entre si, desapercebendo-se de nossa presença.

Notamos que a conjunção 'porque' é mais frequente entre os falantes do português oliventino, independentemente da variável social. Apenas um deles empregou 
a conjunção 'pois', que foi imediatamente substituída pela de uso comum (porque), numa espécie de autocorreção:

Entrevistada 3 (JN): [e tenho minha casa à venda, pois proque aquilo meus filhos não quere]

As conjunções 'se', 'senão', 'quando', 'conforme', 'cerca de', 'desde', 'porquanto', 'logo' e 'embora' apareceram em poucos dados, não revelando relação com a variável social. Os únicos casos diferentes de conjunção são o uso de ‘condo’ no lugar de 'quando', caso que associamos a variável social de baixa escolaridade, pois foi nesse contexto que ela foi empregada. Também um único caso de 'por quando' surgiu:

Entrevistado 1 (FR): [até por quando dá tufunemas]

Entrevistada 2 (RS): [A não ser condo ocê já vem nhá vem]

A conjunção 'portanto' é muito utilizada em Portugal e se faz muito presente na fala dos portugueses de Olivença também.

Outro caso de conjunção frequente, principalmente entre os entrevistados 3 e 5 é o ' então', aparecendo, em muitos casos, como 'e então'. Neste caso, associamos a uma fala cercada de períodos explicativos e sequenciados em longa explanação:

Entrevistada 3 (JN): [... no dia a dia, só tinha mais gente, (...) então acontece]

Entrevistado 5 (ED): [Barrancos, historicamente, teve mais proximidade a Ifpanha...; é e então Barrancos tem essa característica]

A conjunção 'mas' aparece mais na fala do informante 5, não podendo, no entanto, ser relacionada a nenhuma variável social, já que também é empregada de forma menos recorrente na fala dos demais.

\section{PREPOSIÇÃO:}

a) Locução prepositiva [a volta] com valor aproximativo idêntico a cerca de: 
Entrevistada $3(\mathbf{J N})$ : [É nós já chegamos a ser a volta quatrocentos habitantes em Jurumeia]

\section{b) preposição temporal desde [desdi] [desda]}

Entrevistado 3 (JN): [atualmente desde que vim pra, atualmente desde que vim pra aqui]; [desde dos sete anos que tô a viver na Elvas]

Entrevistado 4 (CR): [desdi que falo espanhol, não, ninguém sabe que sou purtuguês!]; [desde bucaninho que eu falooo espanhol]; [purque conheço, pur exemplo, em Purtugal também tem meus amigos, defda escola (...) eee mas pratica mais não (...)aqui toda a gente me conhece e tudoo, eu conheço toda a gente]

Entrevistado 5 (ED): [Defdi 1999 aprovado pela pelo hum Assembleia da República, no parlamento Purtuguêf, foi aprovado e reconhecido Mirandêf]

\section{c) Preposição PARA, A, POR}

Preposição [para] [pra] [pa] [por] - a preposição polifuncional para assume funções variadas. Está presente na cabeça de orações de finalidade, em construções de caráter adverbial locativa e também desempenham função gramatical de marcador de complemento.

Entrevistado 1 (FR): [fomos pra Inglaterra]; [voltamos pro Portugal]; [comecei a vir a trabalhar pra Ispanha]; [pa tá com o piqueno]; [nem nada fazem a tradução tudo pra espanhol]; [então a gente pra vê um por exemplo um filme em Portugal]; [cinco anos pra ver um filme espanhol]; [é mais fácil pra nós]; [pra fazer um baile pra sair à rua]; [pra mudar de país]; [depois de Elvas vivi cinco anos na Inglaterra, vem aqui a ver pra Espanha]; [vamus lá mais por passear]; [aproveitar pra dare uma voltinha]; [pra dentro]

Entrevistada 2 (RS): [Pra]; [pra i]; [pra li]; [então foram sempre tardios pra falar] Entrevistada 3 (JN): [vou pra minha casa]; [vai para as esconias]; [se eu queria vir cozinhar pra eles]; [só pra dizer]; [e as pissoas que vão pra Lisboa esquecem o Alentejo]; [e vá pra perto de onde estão meus filhos]; [eu vô pra mais perto do meu filho]; [eu vô pra mais perto]

Entrevistado 4 (CR): [eu falo pra meu pai]; [pra isso]; [pra]; [pra comprare paa]; [pra desfilare] 
Entrevistado 5 (ED): [pra]; [e automaticamente dum dia pro outro]; [tem muito intresse desde esse pontu di vista pra iftudar]; [foi uma localidade que durante muito tempo passou (...) para Purtugal, Purtugal]; [para iftudar como defde esse ponto de vista]; [uma parte era para para França]; [a lei está para e para eh ser atribuída]; [conduzamos eh Olivença para o biculturalismo, para o bilinguismo]; [que realmente tenhamos purtuguêf que e pra ter um bilinguismo real em Olivença]; [foram pra fora fazer um serviço militar]

Entrevistado 6 (PD): [a língua portuguesa é uma língua que dá facilidade pa aprendere outru [idioma]

Etrevistado 6 (PD): [mas..digamos quê, minha vó já pa idade que tem]

Entrevistado 6 (PD): [famia tenho lá, agora pa te negociof]

Entrevistado 6 (PD): [acofumei ma isso, ou seja, as língua paraaa, ou fala comu ele $\int$ ou intão...]

\section{Preposições em concorrência: [a] [para] [ao]}

Entrevistado 4 (CR): [se for a comere, si for daqui ou ali a comere é mai barato (...) comere é mai barato, mas já comprare pra fazer e comere é mais caro; eles vêm sábado ã aqui a Badajoz]; [vamos muito a Portugal]; [nós i à praça vê-lo]; [que tá a dizere ao pai a meu filho]

Entrevistado 1 (FR): [tive aqui à Espanha]; [si vier um português à Ispanha]; [pra sair à rua]; [ir ao país onde vive o pai]; [vai às compras a Badajóz]; [tem que eu ir à mesa preguntar]; [vamus lá mais por passear, e ir às compras]; [ispanhóis vão, vão muito a Portugal]; [houve um problema qualquer à porta]

Entrevistada 2 (RS): [já não querem ir a Portugal]; [eu agora vou duas horas a casa]

Entrevistada 3 (JN): [eu ia a um sítio que nós chamamos a 'Boa Vista...]; [e tenho minha casa à venda, pois proque aquilo meus filhos não quere]; [eu fui a Lisboa] Entrevistado 5 (ED): [que não está aberto só a isso está aberto ã...]; [é não só a Portugal]; [para ter uma aproximação a Portugal (a no lugar de com)]; [a saída natural era ao mar]; [mas Olivença as aulas de português tem outro sentido porque? Porque Olivença foi 500 anos portuguesa; não teve o prucesso de castelhanização inclusiva a senhores] 
Concorrência de preposição de proveniência ou marcador de fonte da informação: [ao] [do]

Entrevistada 3 (JN): [Mas acho, já ouvi esse palavriado ao meu pai, mas pronto, meu pai dizia esse palavriado, mais rifugiado dos filhos]

Entrevistado 6 (PD): [o meu irmão, o du meio]

d) Preposição locativa [em] [na]

Entrevistado 1 (FR): [em Inglaterra]; [u os chinêses na IJpanha]

Entrevistada 3 (JN): [Ah, gasta mais dinheiro em IJpanha do que Portugal]; [quando chega aqui, a perto de nós, vem visitar em férias]

Entrevistado 4 (CR): [em Purtugal também tem meus amigos]; [em Purtugal na terçafeira é é firiado], [é firiadus, éé; em Purtugal é qui tá proibido...]; [to contente de tá aqui à ISpanha]. Neste último caso, encontramos 'a' no lugar de 'na']

Entrevistado 5 (ED): [são de daqui na no porque em IJpanha]; [o discursu em IJpanha]

Entrevistado 6 (PD): [eu em casa sim...com filhos aprendere...]

Entrevistado 6 (PD): [a moda falare em portuguêf...]

Entrevistado 6 (PD): [quandu fala portuguêf, falam em portuguêf]

Entrevistado 6 (PD): [até o doze anu iftudei u francêf em Portugal...]

Entrevistado 6 (PD): [a minha muié, quando vai a portugarl, em casa de minha vó]

Entrevistado 6 (PD):[ nã, nã, não, ou seja, eu, a mim, a mim aqui i em IJpanha, dizem qui sou de Sevilha]

Entrevistado 6 (PD): [i i i a minha vó fala em portuguêf]

Entrevistado 6 (PD): [mas temus obriga a fala portuguêf, purquê ali na migué]

e) Preposição de companhia ou pareamento $[\mathrm{com} / \mathrm{co}] \sim$ [ca]

Entrevistado 1 (FR): [há muita palavra, parecida cas purtuguesas]

Entrevistado 1 (FR): [ca minha mãe]

Entrevistado 6 (PD): [o meu irmão, o du meio, essi veiu co elif]

Entrevistado 6 (PD): [IJpanha. éééé i então, eu crie co minha vó, (...)]

Entrevistado 6 (PD): [eu tenho uma relação muito íntima com minha vó]

f) Preposição de percurso locativo [pelo] [pur] [por] 
[pu pur tufone] - Entrevistado 1 (Fernando)

Entrevistada $3(\mathbf{J N})$ : [Por, vou pra minha casa, e depois, por a noite, às vezes nos domingos aqui no baile]

Entrevistado 6 (PD): [a gente vende coisax por lá]

g) Preposição [de] [da]

Entrevistado 1 (FR): [tô, tô dentro de IJpanha]

Entrevistada 3 (JN): [muito perto de ISpanha]

Entrevistado 4 (CR): [vem gente de França, gente de todos os lados]

Entrevistado 6 (PD): [ten $\int$ vergonha de falar portuguêf]

h) Preposição explicativa [por] [pur]

Entrevistado 4 (CR): [pur tarmos aqui]

Entrevistado 5 (ED): [em 1801, bom, Olivença era invadida pur ifpanhóis]

Pelos dados apresentados, podemos notar que a preposição 'pra' é muito frequente em todas as variáveis sociais, substituindo quase que totalmente sua forma completa 'para'. Notamos apenas um dado diferenciado - 'pro' no lugar de 'para', o que não é o suficiente para incluí-lo entre os usos morfológicos do português oliventino:

Entrevistado 1 (FR): [voltamos pro Purtugal]

A preposição 'a' concorre com 'para', apresentando frequência em todos os falantes do português oliventino, independente da variável social.

A preposição 'ao' foi encontrada substituindo 'do' em apenas um caso, o que também não classificamos, nesta pesquisa, como sendo um uso comum entre os portugueses que vivem em Olivença, embora seja necessário seu registro:

[Mas acho, já ouvi esse palavriado ao meu pai, mas pronto, meu pai dizia esse palavriado, mais rifugiado dos filhos] - Entrevistada 3 (JN).

A preposição 'em' sendo usada no lugar de 'na' tem nos revelado uma variação bastante interessante, principalmente pelo fato de que, embora tenha aparecido em 
poucos dados, elas ocorrem independentemente das variáveis sociais selecionadas nesta pesquisa, o que indica um uso comum e desvinculado de classe social. Como notamos, tanto os informantes 1 e 3 que são de baixo nível social quanto o informante 6 que é empresário e o informante 5 que é um professor universitário fazem uso da mesma variante:

Entrevistado 1 (FR): [em Inglaterra]

Entrevistada 3 (JN): [Ah, gasta mais dinheiro em Ifpanha do que Purtugal]

Entrevistado 5 (ED): [são de daqui na no purque em ISpanha]; [o discursu em IJpanha] Entrevistado 6 (PD): [a minha muié, quando vai a portugarl, em casa de minha vó]

Entrevistado 6 (PD):[ nã, nã, não, ou seja, eu, a mim, a mim aqui i em IJpanha, dizem qui sou de Sevilha]

Ocorrência semelhante também se dá com a preposição 'de', a qual é utilizada no lugar de 'da', mas neste caso, são todos informantes de classe social mediana e com nível de instrução médio e baixo:

Entrevistado 1 (FR): [tô, tô dentro de IJpanha]

Entrevistado 3 (JN): [muito perto de Ifpanha]

Entrevistado 4 (CR): [vem gente de França, gente de todos os lados]

As preposições 'pelo' e 'por' não ocorrem com muita frequência. Neste caso, encontramos apenas um uso não comum, que é o 'por a noite' no lugar de 'pela noite' mas que aparece em apenas um dado, sendo, portanto, não considerado um uso do português oliventino.

Identificamos também apenas uma ocorrência com a preposição 'cas' no lugar de 'com as', o que não nos permite também asseverar que seja um uso pertencente ao português falado em Olivença, pois é um fenômeno típico da sequência mais veloz de fala no português em geral: 
Entrevistado 1 (FR): [há muita palavra, parecida cas portuguesas]

\section{VERBO}

Ao tratarmos dos verbos utilizados pelos falantes do português oliventino, não pudemos notar usos tão diferenciados quanto os apresentados por Matias (1984:289) tais como: dar como 'dêiamos', escrever como 'escrevido', estava como 'estavom', estariam como 'estariom', somos como 'sêmos' e ainda 'havisto' e 'hai'.

No entanto, tal como apresentado pela autora na subção 6.2, encontramos também verbos em que ocorre perda das sílabas iniciais como em 'tá' ao invés de 'está', o verbo 'ter' como 'temus', entre outros. Assim, fizemos uma seleção pensando nos verbos diferenciados e os mais utilizados pelos portugueses de Olivença:

\section{a) $[$ apanha] [pega] -}

Entrevistado 6 (PD): [....i aquilu é uma zona que apanha uf "s"]; [é da algun $\int$ que vinha aqui apanhar nacionalidade portuguesa]

b) [achar] [pensar] - há variação entre esses dois verbos nos mesmos contextos de uso, quando o falante pretende avaliar uma situação indicando o processo de avaliação mental.

Entrevistado 1 (FR): [eu acho que qualquer pissoa saia do país]; [por que acho que devia]; [acho que foi aaa, antes do natal]

Entrevistada 3 (JN): [Eu penso que sim!]; [mas acho, já ouvi esse palavriado]; [Sim! penso que sim!]; [acho que não é]

c) [dever] como verbo quase auxiliar: empregado em posição V1 é um verbo quase auxiliar para indicar uma obrigação.

Entrevistado 1 (FR): [deve deve sempre deve ensinar a língua a língua que tem]; [mas devia devia de ensinar]

d) o verbo Esperar : empregado no sentido de contestação dialógica é empregado com a elisão de sua primeira sílaba. 
Entrevistado 1 (FR): [então peraí que eu digo espanhol]

e) o verbo Estar: raramente aparece com sua sílaba inicial verbalizada, independentemente do tempo e do modo.

Entrevistado 1 (FR): [tá quase igual a Portugal]; [tive aqui à Espanha áa aqui três anos]; [tivemos lá cinco anos]; [eu tô convencido]; [tivemos em Portugal um ano]; [i vou lá nu dia de folga pa tá com o piqueno]; [não! tamo juntos]; [mas não tamu casadus]; [por tá muito perto]; [às vezes tô tô a falar sozinho]; [e tô a falar espanhol]; [quando eu tive na Inglaterra]; [a gente independentemente tá no outro país]; [mesmo tando, mesmo tando aqui a dez minutos]; [desde dos sete anos que tô a viver na Elvas]; [tive um ano um ano e pouco em Elvas]; [a minha mãe prontu não tá]; [o meu pai agora tá reformado]; [não tão muito muito virados pra perder tempo]; [porque praticamente a vidas deles esta foi tá em Purtugal]; [mesmo tando na fronteira]; [Tamu já tão cá]; [conforme tá não há hipótese]; [o que tô a ganhar agora]; [pra cumerem e pa tare eee picare]; [tão cheios]; [a gente tem o hábito di, a gente tem o hábitu diii, tare com o ifspanhol]; [tô a falar purtuguês]; [pra quem vive na fronteira é, é purque tamos muito, tão tamos, memo]; [tamos habituados ao ifpanhol, por cá]; [memo tando, memo tando]; [tô, tô dentro de ISpanha]; [a mãe tá em Coimbra]; [então ele tá lá, tá na universidade]; [Ele tá, eu acho que ele tá eu ele tá em São Paulo]; [não já foi ele teve lá]; [que (...) tá li]; [i ele tá lá fazen, i ele tá lá fazendo um trabalho também]; [já tá lá]; [quando teve cá ainda pequeninho]; [já tá na China há dois anos]; [tá, ainda por cima ta com os avós]

Entrevistada 2 (RS): [em Portugal tá; a minha vida tá muito difícil]; [já tava na préescola]; [tão aí..i tá]; [si, tá monta montado]; [sim..aqui tá, tá]; [tava aqui jáá’...; ela ta (...) com a gente]

Entrevistada 3 (JN): [Nõ sei se tá a compreender?]; [Hoje já tô habituada]; [umas vezes tá em casa]; [outras vezes tá aqui conosco]; [agora tá em Lisboa]; [pessoas mais do interiore e mais du, tá qui em Lisboa]; [e às vezes tô a dizer ifpanhol]; [e às vezes tô a dizer ifpanhol mas não tô a percebere que já estou a dizere em ifpanhol]; [meus filhos tá em Lisboa]; [a miúda tá sempre a olhare assim]; [foi diminuindo e hoje está!]

Entrevistado 4 (CR): [pai que tá dizendo ao avô?]; [e eu tenho que dizere, que tá a dizere ao pai a meu filho]; [pa você, eu falo português, se tiver com ispanhol, ispanhol!]; [sim! mas alguma vez pur exemplo, eu tô a falar com você memo em purtuguês, e salta alguma palavra em ispanhol]; [essi que tava aqui sim]; [pur tarmos 
aqui]; [mais si tivere ouvi ispanhol]; [minha vida tá aqui; tô contente de tá aqui à Ispanha]; [quandu o meu filho tava estudando]; [tamos aqui perto]; [o pão tá mai barato]; [tá proibido bebêr no bar]

Entrevistado 6 (PD): [mas agora ifta começar a...(...) a moda falare]; [em portuguêf...tá...é como...é moda]; [i quando sai fora daqui já ifta (...) eli vá...];

f) o verbo Fazer - aparece empregado como verbo suporte na expressão equivalente a intencionar.

Entrevistado 1 (FR): [não fazem intenções de vim viver qui ifpanha; i não como não fazem intenções de depender da língua ifpanhola pra viverem]

Entrevistado 6 (PD): [é moda, i então, (...) fizeram uma entrevifta]

g) o verbo Haver - verbo impessoal recorrentemente empregado no sentido de existir.

Entrevistado 1 (FR): [Há dez anos (moradia)]; [na altura há dez anos havia problema]; [Havia mais trabalho]; [na altura havia muito mais trabalho]; [qui não havia problema nenhum]; [não havia nada]; [não há nada]; [não há papel assinado]; [há difirença há muita diferença]; [e não há problema nenhum]; [no país (...) país a Ispanha há muitas festas há muito qualquer coisa resolvi fazer uma festa]; [tão cá, há quinze anos já]

Entrevistado 2 (RS): [aqui em baixo há uma escola do parque em Purtuga, ou seja, tem mesmo, duas, duas professoras purtuguesas, são purtuguesas purtuguesas]; [aqui si for dizer qualquer restaurante, há um português a trabalhar...]; [aqui... há um bar...que é purtugueses, hay um não há dois]; [também são um casal português, veio pra cá pouco tempo, i tão aí..i tá, outra que...(...) há um restaurante de purtuguês, são de Campo Maiore]; [na rua hay tudo há muitas pessoas]; [aqui, há aldeias cercas, também...]; [há muitos que são (...) cá muitos]

Entrevistada 3 (JN): [Há três anos, desde que comecei a trabalhar no Carlos em Olivença]; [já há muitos anos que mi dava com portugueses]

Entrevistado 4 (CR): [ah, minha filha sim, minha filha há de com o tempo dizer alguma coisa em português]; [aqui há mais portugueses que falam, igual ou também como eu espanhol também]; [há um curso que é português]; [são contratados pra isso! há professores portugueses]; [em Lisboa, há mais médicos espanhóis que portugueses]; [aqui há mais facilidade de viver que...]; [há há restaurantes, a bares, montados no meio da rua] 
Entrevistado 5 (ED): [e apesar disso, de ter umas ditaduras da mesma cor também não havia boas relações]; [quando é que há boas relações entre Purtugal e Ispanha?]; [Há boas relações]; [Isto é mais ou menos um mapa purtuguêfs e aqui há uma localidade que é Barrancos]; [1297 houve um tratado que é o tratado de Alcanices...]; [há aqui um rio afluente do Doro que é o rio Coa]; [não há um sítio de passagem a Purtugal tem expressamente]; [em Barrancos há até um ditado um livro que é filologia barranquenia]; [vinho tinto com casera que é uma gasosa que há aqui na IJpanha]; [em Purtugal só há duas línguas oficiais, é o Purtuguês e o Mirandês]; [houve um professor que ditou uma filologia eh]; [há uma cidade chamada Bragança]; [Houve familiares a viver do lado Ispanhol e do lado Purtuguês]; [tudu u que há aqui de monumentos é tudu Purtuguês]; [historicamente Purtugal reveindica Olivença, purtanto há um tratado de 1817 que e o tratado de Viena]; [Ispanha diz que isto é Ispanhol, intão, é para não haver conflitos diplomáticos foi uma quiftão que sempre foi abafada]; [falam de as coisas que ouviram por aí mas aqui também em Olivença também há isso]; [houve uma vez uns oliventinos me perguntaram se podiam eh ter né eh (ruido) se podiam ter nacionalidade IJpanhola, perdão, Purtuguesa]; [nós guardamos aí a informação mas houve uma altura que muitos Oliventinos quiseram saber da da quiftão de dehhh se podiam ter nacionalidade]; [a partir daí houve um prucesso dos Oliventinos puderem ter nacionalidade]; [pode ser por próprio interesse mas há uma, como nós custumamos dizer aqui o Órgão faz a função]; [haverá todus us casos mas a lei a lei não entende de disso]; [a partir daí há um há uma nova ideia]; [se houver pissoas purtuguesas falo purtuguês se houver pessoas ifpanholas falo ifpanhol]; [aqui há uma localidade aqui a 7km]; [intão é aqui há um purtuguês oliventino]; [Há pissoas que quanto mais avançada é a idade mais puro é o purtuguês]

Entrevistado 6 (PD): [é quandu vi pa Ifpanha, não havia francêf...tinha qui iftudar o

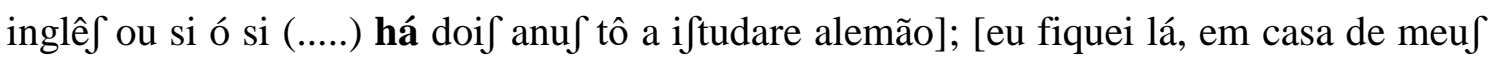
avó,$(. . . .$.$) muito difíci, há muitu \int$ anuf].

h) o verbo ter - tanto aparece com o valor de posse e sua forma plena (tendo sujeito e complemento) quanto na posição de V1 constituindo as seguintes locuções: V1 indicativo de necessidade/obrigação (temos a usar), ter+que+v no infinitivo (tem que dar) e V1 da locução temporal seguida por um particípio passado verbal (ter ajudado). 
Entrevistado 1 (FR): [temus um filho]; [ao conseguir apanhar ao conseguir ter em Portugal os canais televisores espanhóis]; [é por uns quatro ou cinco minutos que temos a usar o tufone i acabou]; [ah tinha, tinha que apreender as duas com certeza...]; [certeza mesmo, teria que apreender a falar português]; [a gente independentemente tá no outro país não temos pur perder a língua]; [um purtuguês que vive ali atrás tem dois filhos]; [que tem um filho]; [então tem que aprender o ifpanhol]; [pra mudar de país a mãe tem que dá autorização]; [o inglês tem que se aprender na Inglaterra]; [não, não tem a curiosidade]; [não percebem nada de ifpanhol, tem que eu ir à mesa preguntar o que eles querem comer]; [aqui na, por exemplo, na zona da istremadura, tem muito hábitos, é um costume que eles têm, um hábito de por um uma bebida, uma bebidazinha e um qualquer coisinha pra pa pitar]; [a bebida tem que ser mais cara]; [a gente tem o hábito di]; [tem que falar ifpanhol]; [a gente tem que viver]; [memo tando lá temo que viver com isso]; [a mãe tem casa em Coimbra]; [i fico contente por eu tere ajudado]

Entrevistada 2 (RS): [Tenho, duas]; [não tem aqui mais ninguém, ninguém, ninguém, ninguém (...)]; [uai a piquena tem dez anos!]; [começaram a falar já tinham quase três anos]; [purque tive...]; [com nove meses, não tinha nada]; [i tem o o agora o inglês já na escola, i aqui tem uma coisa boa]; [aqui tem um purtuguês]; [todos têm que ter purtuguês]; [tem mesmo, duas, duas professoras portuguesas, são purtuguesas purtuguesas]; [e são meus professores e tem português desde os três anos como tem o inglês]

Entrevistada 3 (JN): [sim, eu tenho aqui muitas pessoas]; [eu também tinha u restaurante, tinha e tenho restaurante em jurumeia]; [sempre tenho me dado muito bem]; [tenho dois filhos]; [Eu sei, eu sei dum senhor português que tem ali um restaurante]; [tinha um restaurante]; [i depois minha mãe teve uma doença fatal]; [eu se tivesse vi toda a minha vida aqui, tivesse aqui os meus filhos]; [tanto é que eu tenho em minha família, ã um sobrinho que foi para a Romênia, e ter recordação da Jurumeia que não queira saber, tenho muita saudade da minha casa]; [e tenho minha casa à venda, pois proque aquilo meus filhos não quere]; [mais cuidados que temos]; [i eu só tenho dois rapaz, não tenho raparigas, só tenho a minha nora]; [i é a minha terra, mesmo sabendo que a minha terra não tem nada]; [ai si tenho saudade]; [eu tenho pena quando chego a Jurumeia]

Entrevistado 4 (CR): [e eu tenho que dizere]; [em Portugal também tem meus amigos]; [não tem mais capacidade]; [temos aqui nossa vida como prati...]; [tem muitos 
portugueses também, tem]; [sim! tem sim, tem em Badajoz, ééé espetáculo, em Badajoz o carnaval é um espetáculo]; [é feriado, tem o dia do carnaval, não!]

Entrevistado 5 (ED): [essa Iftremadura não tem nada com aquela]; [Purtugal e me ... tinha era castelo]; [Purtugal também teve má relações]; [e apesar disso, de ter umas ditaduras da mesma cor também não havia boas relações]; [quando o comércio tem êxito de um lado, do outro lado não tem, mas Olivença as aulas de português tem outro sentido purque? Purque Olivença foi 500 anos purtuguesa]; [é hm a quistão de da raia tem est... tem Barrancos, Barrancos é uma lucalidade que está aqui a 80 ã oi... aproximadamente $80 \mathrm{~km}$ daqui e tem uma coisa curiosa, ê ê isso tem um tem um purque explicando]; [Barrancos, historicamente, teve mais proximidade a IJpanha...]; [também tem rio das Terras]; [mas falando especificamente de Barrancos tem uma quistão curiosa, Barrancos está isolado]; [não há um sítio de passagem a Portugal tem expressamente]; [Então, historicamente, Barrancos tem mais afinidade com Purtu... com a Ifpanha do que cum Purtugal que está em território purtuguêf]; [e Barrancos tem duas ou três características]; [em Barrancos tem um iftatuto específico]; [é que porque eles têm uma mistura de purtuguês e ifpanhol na fala]; [E tem muitas ques... coisas ifpanholas na própria atividade diária]; [Tem, eles até têm uma filologia editada eles falam barranquênio]; [quando eles é hm é tem a festa deles principal qué 28 de agosto]; [tem coisas que em Purtugal não existem]; [vinho tinto com casera que é uma gasosa que há aqui na Espanha purtanto tem tem, estando em Purtugal mas tem muitas coisas da própria raia purtanto, Barrancos]; [Barrancos tem o seu próprio, tem o seu próprio dã dã questões etnográficas linguísticas até a maneira de ser e diferente]; [depois tem aqui no norte, tem uma lucalidade que se chama Miranda do Douro]; [teve muitas influências do Lionês]; [as terras de Miranda tem muito interesse em em tem muito interesse desde esse ponto de vista pra estudar eeeeh]; [é um sitio de interesse, purtanto, e dipois tem um, mais a cima, aqui mesmo do cantinho]; [Tudo em Purtugal, tem Rio de Onor]; [então, depois tem a eh tudu que há aqui é Purtuguês]; [as mais antigas falam Purtuguês em qualquer sítio mãs para os filhos falavam espanhol, então temos aqui vários casos e acontece isso]

Entrevistado 6 (PD): [a moda ter nacionalidade portuguesa]; [falam em portuguêf é maix..tem u acentu portuguêf ma na há prublema]; [falam em portuguêf portuguêf..hummm...seja...tem u sutaque portuguêf...]; [sim. mas tem, mas temus obriga a fala portuguêf]; [quandu vi pa ISpanha, não havia francêf...tinha qui iftudar o

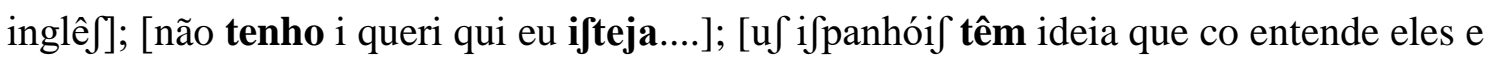


todo o mundo]; [si si ali sim, (....) tem quintendê váriu $\int(. .$.$) ]; [elis é como si raramente$ tivessem intendê o quê nó f falamu...]; [meu pai viram quando eu tinha oito anu]; [eu te, eu tenho uma relação muito íntima com minha vó...]

i) Verbo Perceber: é costumeiramente empregado no sentido de compreender, de notar e também no sentido de saber.

Entrevistado 1 (FR): [não percebem nada de ifpanhol]; [essa parte não percibi, então peraí que eu digo ifpanhol]; [Põe a legenda em ifpanhol, que é por perceber o que eles tão a dizer] - COMPREENDER

Entrevistada 3 (JN): [não tô a percebere que já estou a dizere em ifpanhol] - DAR-SE CONTA DE QUE, NOTAR

Entrevistado 4 (CR): [meus pais falam pra ele ó eu falo pra meu pai, mas não pircebem, então meu filho pregunta, pai que ta dizendo ao avô?] - NOTA

Entrevistado 6 (PD): [i então vi ao pirciber a forma que (...) falava] - NOTAR

j) Verbo levar: empregado com a configuração Levar + espaço temporal, significando duração do tempo. Sinônimos: fazer (temporal), usar o tempo, gastar o tempo.

Entrevistado 4 (CR): [ha! pedreiro, de construção civil (...) já leva aqui vinte eee três anos]; [conheço mai gente aqui que em Purtugal, purquê levo mais metade da minha vida aqui que ali]; [esse não sabe falar ifpanhol, e leva vinte e quatro anos e não aprende]

Os verbos arrolados anteriormente nos revelam que os falantes do português em Olivença praticamente não sofreram interferência da língua espanhola. Ao contrário, mantiveram preservadas as características da variedade alentejana.

Como temos observado, não foram encontradas ocorrências muito diversificadas, no entanto usos variáveis apareceram como o verbo 'agarrado' no sentido de 'estar preso': [penso que estou mais garrado à língua deles] - Entrevistado 1 (FR).

O verbo 'apanhar' aparece na fala de um entrevistado no sentido de 'pegar' ou 'ter': 
[...i aquilu é uma zona que apanhaf uf "s"] [aquela é uma zona que tem o 's'] Entrevistado 6 (PD)

[é da algun $\int$ que vinha aqui apanhar nacionalidade portuguesa] [alguns que vinham aqui ter/pegar a nacionalidade portuguesa] - Entrevistado 6 (PD)

Os verbos 'achar' e 'pensar' no português oliventino têm aparecido com o sentido de 'acreditar' ou 'concordar':

[por que acho que devia] (eu acredito/concordo que devia) - Entrevistado 1 (FR)

[Eu penso que sim!] (eu acredito/concordo que sim) - Entrevistada 3 (JN).

O verbo 'dever' como primeiro verbo de uma locução verbal foi encontrado com o sentido de 'necessitar' ou 'precisar': [deve deve sempre deve ensinar a língua a língua que tem] (precisa/necessita sempre ensinar a língua que tem) - Entrevistado 1 (FR)

O verbo 'esperar' aparece no português oliventino sob a forma 'peraí', funcionando como um verbo de função conversacional: [então peraí que eu digo espanhol] (aguardar um tempo para que diga espanhol) - Entrevistado 1 (FR)

O verbo 'estar' aparece com muita frequência na fala de todos os falantes na realização 'tá', 'tive', 'tô', 'tamus', etc., num processo de aférese, tal como já apresentamos na seção sobre alterações fônicas:

[mesmo tando, mesmo tando aqui a dez minutos] - Entrevistado 1 (FR)

[tava aqui jáá'...; ela tá (...) com a gente] - Entrevistada 2 (RS)

[e às vezes tô a dizer espanhol] - Entrevistada $3(\mathrm{JN})$

[tamos aqui perto] - Entrevistado $4(\mathrm{CR})$

O comportamento variável dos verbos 'ter' e 'haver' existenciais ocorre praticamente na mesma frequência entre os falantes de português em Olivença, fato típico somente do português e não do espanhol, em cujos usos somente o verbo 'haver' se emprega no sentido de existir. 
Sendo assim, verificamos que, mais uma vez, a influência da língua da sociedade receptora não se apresentou no português oliventino. Este não abandonou o uso do verbo ter existencial; ao contrário, utiliza-o com muita frequência como ocorre tanto no português de Portugal quanto no do Brasil.

Lima (2010:53) apresenta em seu artigo que essas construções existenciais no português do Brasil estão passando por grandes mudanças, ocorrendo um estágio muito avançado da substituição do verbo 'haver' pelo verbo 'ter', e que tal fator tem influência do nível de instrução e do nível social do falante. Diferentemente, é preciso considerar que entre os falantes do português que vivem em Olivença não têm substituído o verbo 'ter existencial' pelo 'haver existencial', mas um uso com a mesma frequência, e ocorrendo independentemente do nível de instrução ou nível socioeconômico.

Estes dados nos levam a verificar que, mais uma vez, as recorrências dos verbos existenciais 'ter' e 'haver' são ocasionadas não por uma influência da língua de contato, no caso o espanhol, mas por uma influência da língua de seu grupo étnico - o português. Tais ocorrências acontecem na fala de todos os informantes, independentemente da variável social:

[Havia mais trabalho] [Tinha mais trabalho] - Entrevistado 1 (FR)

[aqui embaixo há uma escola do parque em Purtuga...] [aqui embaixo tem uma escola do parque em Purtuga ...] - Entrevistada 2 (RS)

[aqui há mais purtugueses que falam, igual ou também como eu ifpanhol também] [aqui tem mais purtugueses que falam, igual ou também como e ifpanhol também] Entrevistado 4 (CR)

[e apesar disso, de ter umas ditaduras da mesma cor também não havia boas relações] [e apesar disso, de haver umas ditaduras da mesma cor também não tinha boas relações] - Entrevistado 5 (ED)

[aqui na, por exemplo, na zona da iftremadura, tem muito hábitos] [aqui na, por exemplo, na zona da iftremadura, há muito hábitos] - Entrevistado 1 (FR)

[não têm aqui mais ninguém, ninguém, ninguém, ninguém $(. .$.$) ] [não há aqui mais$ ninguém, ninguém, ninguém, ninguém (...)] - Entrevistado 2 (RS)

[tinha um restaurante] $\sim$ [havia um restaurante] - Entrevistado $3(\mathrm{JN})$ 
[tem muitos purtugueses também, tem] [há muitos purtugueses também, há] Entrevistado 4 (CR)

[Purtugal e me ... tinha era castelo] $\sim$ [Purtugal e me ... havia era castelo] Entrevistado 5 (ED)

O verbo 'perceber' também apresentou uma alteração com o verbo 'saber' ou 'conhecer', tal como ocorre em Portugal, afastando-nos qualquer ligação com influência espanhola:

[não pircebem nada de ifpanhol] [não sabem/conhecem nada de ifpanhol] Entrevistado 1 (FR)

[não tô a pircebere que já estou a dizere em ifpanhol] [não tô a saber/conhecer que já estou a dizere em ifpanhol] - Entrevistada 3 (JN)

[i então vi ao pirciber a forma que (...) falava] [i então vi ao notar/conhecer a forma que (...) falava] - Entrevistado 6 (PD)

Um caso interessante encontrado entre os dados foi o do verbo 'levar' no sentido de 'ter' ou 'estar'. Esses dados apareceram somente na fala de um de nossos entrevistados, o qual pertence a um nível mediano de escolaridade. No entanto, não parece ser esse caso suficiente para atrelar tal uso a qualquer variável social.

[há! pedreiro, de construção civil (...) já leva aqui vinte eee três anos] [há! pedreiro, de construção civil (...) já tem/estou aqui vinte eee três anos] - Entrevistado 4 (CR)

[conheço mai gente aqui que em Purtugal, purquê levo mais metade da minha vida aqui que ali] [conheço mai gente aqui que em Purtugal, purquê tennho/estou mais metade da minha vida aqui que ali] - Entrevistado 4 (CR)

\section{ADVÉRBIO OU LOCUÇÃO ADVERBIAL}

Os usos adverbiais observados nas entrevistas dos falantes de português em Olivença permitem reconhecer uma trajetória de manutenção dos usos alentejanos. Vejamos: 
a) Advérbio de Intensidade:

[pouco] $\sim$ [poco] $\sim$ [bucadinho] $\sim$ [poquito] $\sim$ [nem tanto] $\sim$ [quase nada]

Entrevistado 1 (FR): [bucadinho]; [poco]

Entrevistada 3 (JN): [poquito]

Entrevistado 1 (FR): [os ifpanhóis não tanto]

Entrevistado 1 (FR): [quase nada]; [purtuguêf quase nada]

Entrevistado 6 (PD): [parece $\int$ um pouco]; [i então digamu $\int(. .$.$) um pouco]$

[muito] [bastante] [mais]

Entrevistado 1 (FR): [os ifpanhóis são são pissoas bastante alegres bastante memo]

Entrevistada 3 (JN): [muito mió do qui ali]

Entrevistado 5 (ED): [Além é mais a mais mais pra lá então]

b) Advérbio de Negação:

$[$ não $] \sim[$ nem nada $] \sim[$ nem sequer $] \sim[$ nem $] \sim[$ num $]$

Entrevistado 1 (FR): [nem nada fazem]; [nem lembro]; [nem nem nada mesmo]; [dipoif não são]; [não são tão rígidos nem são tão nem sentem tão superiores como os ingleses pur exemplo]; [e mãe não quer]

Entrevistado 5 (ED): [nem sequer foram contaminadas]

Entrevistado 6 (PD): [aqui elix num falam portuguêf]; [falam port'guê nofzenteju〕 num tendu u pur quê]

Entrevistado 6 (PD): [nã, nã , nã, não...tudo bem]

c) advérbio de afirmação

$[\operatorname{sim}] \sim[\mathbf{s i}] \sim[$ jim $] \sim$ [exatamente $] \sim[$ ixatamente $]$

[Sim]; [si]; [si] - Entrevistado 1(Fernando)

Entrevistado 3 (JN): [aqui trabalhando, exatamente, saio um bucadinho às cinco]

Entrevistado 5 (ED): [IJatamente. Então, o que que acontece, isso é um prucesso de sensibilização]

Entrevistado 6 (PD): [em casa sim...com filhos aprendere]

d) modo: 
[melhor] [bem]

Entrevistado 1 (FR): [ganha-se melhore; fala bem]

e) tempo:

[desde dus] [desde] [desde que]

Entrevistado 1 (FR): [desde dus quatro]; [desde pequininhos]

Entrevistada $3(\mathbf{J N})$ : [atualmente desde que vim pra, atualmente desde que vim pra aqui]

[depois] [depoif] [dipois]

Entrevistada 2 (JN): [i depois minha mãe teve uma doença fatal]

Entrevistada 4 (CR): [hum!! tive sim no cículo tive até o terceiro ano já estava, depoif já comecei a trabalhare e já, (...)uma morada, já; em vez enquando salta alguma coisa]; [depoif em 1492]

Entrevistado 5 (ED): [a partir de 1920, 1930 cumeça a se, cumeça a se espanholizar Olivença, a partir daí; dipoi[]]

[tal] - advérbio indefinido ou de imprecisão

Entrevistada 3 (JN): [cheguei aqui às duas e tal da manhã]

f) Lugar - [aqui] [qui] [cá]

\section{[Aqui]:}

Entrevistado 1 (FR): [Eu conheço purtuguese $\int$ aqui também, conheço aqui mas conheço um rapaz aqui um purtuguê $\int$ que vive ali atrás]; [ir ao país onde vive o pai; por que até mesmo na ifcola aqui]; [vem aqui a viver pra ISpanha]; [não fazem intenções de vim viver qui IJpanha]; [vivo aqui todos os dias tentar aqui com a vida]; [aqui, os ifpanho...]; [tem purtuguese $\int$ a comer aqui]; [sim, aqui perto, moro aqui perto]; [o que tô a ganhar agora aqui no restaurante]; [opção todo é todo dia aqui no trabalho]; [e

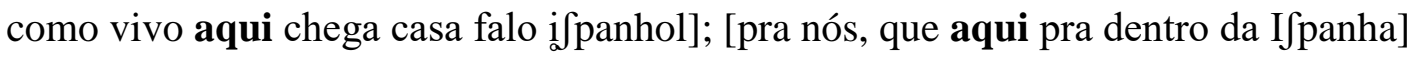

Entrevistada 2 (RS): [aqui somente é ifpanhol]; [ai vim pra cá, e aqui fiquei, ranjei trabalho]; [pra trabalhar, arranjar um trabalhinho fiquei aquii]; [fiquei aquii, i pronto, i 
aqui levamos a nossa vida]; [aqui também tá já; pra i]; [aqui o liceu!]; [eu lembro-me quando vi pra qui trabalhar]; [tava aqui jáá'...]

Entrevistada 3 (JN): [vamus se dizer aqui]; [eu tenho aqui muitas pissoas ali vizinho em Olivença]; [ocupo meu trabalho aqui trabalhando]; [eu, comparação, primeiro dia que aqui comecei a trabalhare]; [mas agora então quando vir pra aqui]; [tá aqui conosco]; [é sempre é assim, vinham pra aqui amigos pra discotecas]; [nós aqui os purtuguese J]; [hipermercado que abriu agora aqui]; [as filhas, então, já são nasceram aqui!]; [atualmente desde que vim pra, atualmente desde que vim pra aqui]

Entrevistado 4 (CR): [aqui mais que Portugal]; [essi que tava aqui]; [aqui há mais purtugueses]; [aqui tem]; [e aqui em Elvas igual]; [um purtuguês quer vir aqui trabalhar]; [por aqui é mais perto!]; [pra comprar é mai barato aqui]; [são mai baratos que aqui]; [aqui, é mais caro lá que aqui]; [o pão aqui]; [viestes cumere aqui nu ristaurante]; [pagam memo que duas aqui]; [eles vêm sábado ã aqui a Badajoz]; [como aqui não é feriado, i lá é, vão daqui pra desfilare lá]; [aqui nós pudêmos no sábado a noite, aqui (...)]

Entrevistado 5 (ED): [Pode vir pra qui]; [problema é que não tenho aqui o computador]; [senão poreria aqui]; [não tenho aqui o outro]; [sim, eu dou aqui aula];

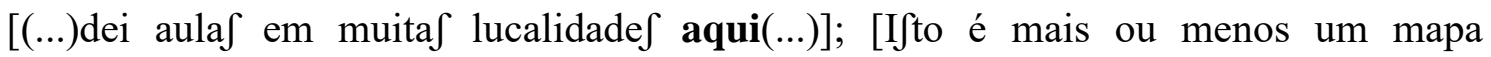
purtuguêf e aqui há uma lucalidade que é Barrancus]; [a primeira lucalidade iftá (....) aqui. Aqui o Guadiana faz ifto, o Guadiana]; [aqui as do Rio Bacoa]; [aqui me Jmo do

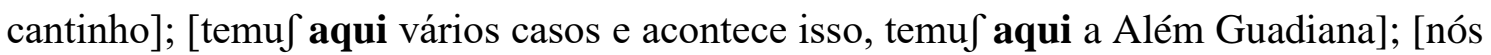
pretendemos é que aqui...]; [aqui o os próprios oliventinos]; [aqui há uma lucalidade aqui a $7 \mathrm{~km}$ ]; [mas aqui temu $\int(\ldots)$, agora temu $\int$ o chamado purtuguê $\int$ oliventino]

Entrevistado 6 (PD): [é da algun $\int$ que vinha aqui apanhar nacionalidade portuguesa]; [aqui elif num falam portuguêf];

\section{[Cá]:}

Entrevistado 1 (FR): [tamu já tão cá]; [pelo que eu sei, tão cá]; [tamos habituados ao ifpanhol, por cá, então, a gente pode é responder em purtuguês (...) então cá pissoas lá]; [quando teve cá ainda pequeninho] 
Entrevistada 2 (RS): [ai vim pra cá, e aqui fiquei, ranjei trabalho]; [vem pra cá, altura da ifcola]; [veio pra cá pouco tempo, i tão aí..i ta]; [há muitos que são (...) cá muitos]; [só eu é que vim pra cá]

Entrevistada 3 (JN): [desde que nasci e até agora é que vim pra cá]; [cerca de,cá iftá, cerca, a gente não diz cerca, diz... perto]

Entrevistado 4 (CR): [não vira pra vim cá falar ifpanhol]; [todos pra (...) ai pra cá no sábado]

\section{g) advérbios de tempo quanto à frequência}

[muitas vezes] [sempre]

Entrevistado 1 (FR): [muitas vezes às vezes]; [deve deve sempre deve ensinar]

Entrevistada 3 (JN): [sempre é um encostozinho]; [eu sempre eu vejo]

Entrevistado 5 (ED): [sempre]

[de vez em quando] [em vez em quando] [às vezes] [por vezes]

Entrevistada 2 (RS): [Só vez em quando]; [em vez em quan, em vez em quando já eu, não se capaz de dizer certas palavras]

Entrevistada 3 (JN): [Às vezes, às vezes uso, pouco...mas uso]; [por vezes aconteceme isso]; [umas vezes tá em casa]; [outras vezes tá aqui conosco]; [às vezes sai]; [às vezes sempre daquele local]

Entrevistado 4 (CR): [em vez enquando salta alguma coisa]

Entrevistado 5 (ED): [às vezes]

De acordo com os dados apresentados sobre os usos dos advérbios, pudemos notar que os usos que ocorreram nessa classe gramatical são típicas de um português alentejano. Observamos que os únicos casos que podemos atribuir a uma alteração por influência espanhola são os advérbios de intensidade 'pouco' e 'sim', os quais mostraram usos como 'poco' (tal como no espanhol - poco) e 'Si' ou 'si' (no espanhol sí). Neste último caso, o de afirmação, observamos essa influência mais acentuada na entrevistada 2, a qual tem baixo nível de instrução.

O advérbio de intensidade 'muito' apresentou recorrência com 'bastante' e 'mais', numa influência típica de seu grupo étnico - o português. 
O advérbio 'pouco' apresentou usos diferenciados como: 'bucadinho', ‘bucadinho', 'nem tanto' e 'quase nada', além de 'poco’ e 'poquito', os quais são oriundos de uma influência do espanhol (poco).

Como forma de negar suas proposições, os entrevistados fizeram uso do advérbio ‘não' com a alteração bem peculiar da língua portuguesa: o 'nem': [nem nada fazem] - Entrevistado 1 (FR).

A variação que mais acentua uma influência do português alentejano na fala dos informantes do português oliventino foi observada no advérbio de modo 'melhor', o qual apareceu numa formação fonética de paragoge em 'melhore', além de 'miore'.

O advérbio de tempo 'depois' aparece também nas variações 'dipois' e 'dipoi $\int$ ', uma característica da fala dos portugueses alentejanos.

Um caso interessante, mas que não podemos assegurar que é um uso que ocorre com frequência na fala dos falantes do português oliventino, foi a expressão 'tal' como um marcador de tempo, significando 'pouco': [cheguei aqui às duas e tal da manhã] [cheguei às duas e pouco da manhã] - Entrevistada $3(\mathrm{JN})$

O advérbio de companhia 'com' também apresenta a variação 'cá', um fato de abreviação fonológica.

Entre as análises dos advérbios, o que mais nos chamou a atenção foi o advérbio de lugar 'aqui', o qual está sendo muito usado entre os falantes do português oliventino. Sua variante concorrente cá, que era muito utilizada em Portugal parece que está cedendo lugar ao uso 'aqui': [vem aqui a viver pra IJpanha] [vem cá a viver pra Ifpanha] - Entrevistado 1 (FR). Neste caso, mesmo o uso de 'cá' podendo ser usado com muita clareza, o informante optou pelo uso de 'aqui'.

No exemplo seguinte, vemos o quanto o uso de 'aqui' está sendo a variável escolhida com maior frequência, pois o falante usa o 'cá' e logo em seguida, troca por 'aqui', numa espécie de correção na fala: "ai vim pra cá, e aqui fiquei, ranjei trabalho" - Entrevistada 2 (RS). A preferência pelo uso de 'aqui' no lugar de 'cá' ocorre independentemente da variável social, ou seja, em qualquer nível de instrução, sexo, fator socioeconômico ela é a mais utilizada. 
Com relação aos advérbios de frequência, as variações que encontramos entre os falantes do português oliventino estão associadas a uma influência típica do próprio português: ‘muitas vezes' com 'sempre', 'de vez em quando' com 'em vez em quando', 'às vezes' e 'por vezes'.

\section{ADJETIVOS}

Os adjetivos utilizados pelos oliventinos de língua nativa portuguesa não apresentaram grandes variações, ainda assim eram usos próprios do português, sem influência do espanhol. Vejamos:

a) Grau diminutivo:

Entrevistado 4 (CR): [Bucaninho]

Entrevistado 1 (FR): [piqueno] [pequininho] [pequeninho]

Entrevistada 2 (RS): [Miúdos]

\section{b) Grau aumentativo:}

Entrevistada 3 (JN): [o meu filho mais novo]

Entrevistada 3 (JN): [o mais veio]

\section{c) Comparativo de igualdade:}

[tão ... como] $\sim$ [tanto...como] $\sim$ [como...como] $\sim$ [nem...nem] $\sim$ [tanto...quanto]

Entrevistado 1 (FR): [não são tão rígidos nem são tão nem sentem tão superiores como os ingleses pur exemplo]

Entrevistado 1 (FR): [ele tan fala ifpanhol como purtuguêf com eles]

Entrevistado 1 (FR): [falo ifpanhol como como falo purtuguêf]

Entrevistado 1 (FR): [há tantos purtugueses como ifpanhóis no supermercado, muitos, muitos, muitos]

Entrevistada 2 (RS): [não! Aqui há, come purtuguês como ijpanhola]

Entrevistada 3 (JN): [nem ela entende o que nós dizemos nem nós entendemos o que ela diz] 
Entrevistado 4 (CR): [são contratados pra isso!há professores purtugueses, logo como há, ifpanhóis em Purtugal também, professores ifpanhóis também]

Entrevistado 5 (ED): [O prucesso de sensibilização é tanto em Purtugal quanto na Ifpanha]

Entrevistado 5 (ED): [Eu falo indistintamente purtuguêf como ifpanhol]

\section{d) Comparativo de superioridade:}

[muito mió do que...] [muito melhor que]

Entrevistada 2 (RS): [muito mió do qui ali]

Entrevistada 3 (JN): [mas é miore, é que é miore]; [é miore ainda, miore que se fala aqui ifpanhola, ela é as melhores (...)]

[mais...do que] [mais que]

Entrevistada 3 (JN): [Ah, gasta mais dinheiro em Ifpanha do que Purtugal]

Entrevistado 4 (CR): [aqui mais que Purtugal; conheço mai gente aqui que em Purtugal, purque levo mais metade da minha vida aqui que ali]

Entrevistado 4 (CR): [em Lisboa, há mais médicos ifpanhóis que purtugueses]

Entrevistado 4 (CR): [são mais ifpanhóis que purtugueses mais ifpanhóis que purtugueses]

Entrevistado 4 (CR): [pra comprar é mai barato aqui]

Entrevistado 4 (CR): [aqui, é mais caro lá que aqui]

Entrevistado 4 (CR): [o pão aqui, o pão tá mai barato, comprar ali, por ifemplo, um ifemplo]

Entrevistado 4 (CR): [as coisas tão, umas tão mais caras outras tão barato]

Entrevistado 5 (ED): [é mais perto do que a que está em Purtugal]

e) Grau superlativo: [tão] [muito] [grande]

Entrevistado 1 (FR): [lá ta,...uma vez mais os canais de desenhos animados e dessas coisas (...) intão é é falam tão tão só o îpanhóis]

Entrevistado 1 (FR): [é... vem muito pouquinho, pouco pouco]

Entrevistado 1 (FR): [um bucadinhos exigentes]

Entrevistada 3 (JN): [muito perto de IJpanha]

Entrevistada 3 (JN): [grande asneira] 
Entrevistada 3 (JN): [muito pouca gente]

\author{
Alguns dos adjetivos empregados pelos falantes que nos chamaram a atenção: \\ Entrevistada 3 (JN): [vida satura] = (vida muito difícil) \\ Entrevistado 4 (CR): [burrice] = (pessoa não inteligente) \\ Entrevistado 5 (ED): [magníficas] = (muito boa) \\ Entrevistada 3 (JN): [piquenas asneiras] (falar algumas bobeiras) \\ Entrevistada 3 (JN): [i tudo gente muito idosa; pissoas idosas] = (idosos) \\ Entrevistada 2 (RS): [pissoas mais de idade] = (idoso) \\ Entrevistada 3 (JN): [encostinho] (casa para ficar) \\ Entrevistada 2 (RS): [mió] [melhor]
}

Os usos encontrados entre os entrevistados revelam que a influência do espanhol com relação aos adjetivos é nula. Algumas variantes se mostraram diferentes das usuais tais como 'vida satura' para representar 'uma vida muito difícil' ou 'encostinho' para se referir ao 'lar', mas isso não se explica no espanhol.

Os adjetivos 'asneira', para indicar 'bobeiras', 'pessoas idosas' para indicar 'idosos', 'bucaninho, miúdos ou piqueno' para se referir a 'crianças' são usos muito comuns entre os portugueses que vivem em Portugal e, como temos visto, estão ainda presentes entre os falantes do português oliventino.

O uso das expressões 'o filho mais novo' ou o 'filho mai velho' é um uso também comum entre os falantes do português oliventino. A variação fônica do adjetivo 'melhor' foi identificada na entrevista produzida pela informante de número 2: 'mió'. Tal uso não é frequente entre os entrevistados com um nível de instrução maior.

Além disso, as variações para os graus aumentativos entre os falantes de português têm se mostrado bastante diversificadas, surgindo usos com as construções: $[$ tão $\ldots .$. como] $\sim[$ tanto...como] $\sim$ [como...como] $\sim$ [nem...nem] $\sim$ [tanto...quanto]. Neste sentido, é possível notar que os portugueses oliventinos, embora de forma variadas, mantêm as características típicas da língua portuguesa, como verificamos nos dados:

[ele tan fala ifpanhol como purtuguê $\int$ com eles] - Entrevistado 1 (FR) [não! Aqui há, come purtuguê como ifpanhola] - Entrevistada 2 (RS)

[O prucesso de sensibilização é tanto em Purtugal quanto na IJpanha] - Entrevistado 5 (ED) 
É possível notar, ainda, que, ao avaliar os adjetivos na forma comparativa de superioridade e no grau superlativo, 'muito' e 'mais' são os usos mais frequentes, o que nos garante uma característica típica do português:

[muito mió do qui ali] - Entrevistada 2 (RS)

[muito perto de IJpanha] - Entrevistada $3(\mathrm{JN})$

\subsubsection{Aspectos sintáticos do falar oliventino}

Tratar de sintaxe requer que se observe a forma por meio da qual o indivíduo organiza a sentença. Essa forma de análise permite que alguns outros fenômenos sejam trazidos à luz para entender a feição estilística individual e da língua em si. No entanto, há uma forma de se alcançar os aspectos pragmáticos da língua, que são, de longe, o modo mais seguro e eficiente para se observar a intenção do falante, a ordenação das informações e a priorização que faz dessas nas posições da sentença e do período.

\section{Inversões sintáticas}

Verificamos que é muito comum entre os falantes do português oliventino construções sintáticas em que a estrutura não obedece a ordem prototípica ou canônica da língua portuguesa, qual seja SVO. Os casos, no entanto, em que se revelam são comuns no português alentejano. Essa ordem variável de sujeito e objeto, por outro lado, nada tem a ver com a compreensão das priorizações que o sujeito faz.

Uma das bases teóricas que contempla um estudo nessa perspectiva é a base funcionalista do princípio da iconicidade ${ }^{142}$, o qual prevê que nada é aleatório na forma como codificamos as informações sintaticamente.

\footnotetext{
${ }^{142}$ Lima-Hernandes (2006) discute o princípio da iconicidade, sua conceituação por linguistas bem como os estudos que conferem a esse princípio uma grande atuação. De acordo com a autora, o signo icônico provém da terminologia peirceana, através da qual se deve levar em conta a diferença entre signo e objeto, enquanto o ícone, representa a semelhança entre o signo e a realidade exterior; o índice, a relação de contiguidade e o símbolo, a relação convencional. Lima-Hernandes mostra-nos que no signo icônico há uma relação motivada, a qual aparece não só relacionada a elementos menores, como os morfemas, mas também a elementos maiores, como as sentenças complexas, o que nos interessa para a análise das inversões sintáticas entre os falantes de LH em Olivença. Apresenta-nos o estudo de Greenberg (1966, apud Dik, 1997:133) sobre o princípio da iconicidade, no qual indica que a ordem dos elementos na língua é determinada pela ordem de conhecimentos na experiência física. Lima-Hernandes, então, propõe que a "ordenação linear respeita a ordem de acontecimento dos fatos", inclusive, caracteriza tal princípio, entre os linguistas, como determinante para a ordenação sintática das orações. A autora apresenta também os estudos de Votre (1992) e Votre et alii (1999), os quais propõem subprincípios que manifestam a
} 
Lima-Hernandes (2006), ao tratar dos subprincípios da iconicidade, admite que forças atuam para as motivações no uso e nas posições das construções sintáticas. Assim, argumenta que nem sempre as informações menos importantes estarão no final da sentença:

\begin{abstract}
A aplicação e o reconhecimento desses subprincípios em estruturas linguísticas estão longe de ser uma tarefa mecânica, porque há forças que podem atuar ao par da motivação icônica, resultando num aparente paradoxo. É dessa maneira que, por exemplo, informações menos previsíveis, menos importantes e menos acessíveis, ao contrário do que se esperaria, podem aparecer em primeiro lugar, caso a cadeia tópica detenha o traço [+contraste].
\end{abstract}

(LIMA-HERNANDES, 2006:85)

Para a autora, de acordo com o subprincípio da ordenação linear, "as informações mais importantes, mais previsíveis e fundamentais para assegurar a cadeia aparecem em primeiro lugar”. Então o que está em jogo é a monitoração do outro e do que o outro sabe para, então, priorizar segmentos informacionais e deslocar para posições de relevo o que for mais importante para a situação interativa, ainda que não possa não ser tão relevante para o falante em si. Muitas vezes, a interação em si é mais importante do que o que é dito nela.

Neste sentido, evidenciaremos como se dão as organizações informativas via ordem sintática. Para isso, focalizaremos as atualizações linguísticas dos informantes, separando conforme as inversões encontradas e verificando o que é colocado em primeiro lugar dentro de cada construção. Dessa forma, verificaremos a relação entre primeira posição e relevância comunicativa.

Além disso, ao tratarmos da escolha do falante na construção do sentido do texto, de acordo com Villaça-Koch (2000), a articulação tema-rema constitui uma dessas escolhas ${ }^{143}$ e, se seguirmos tais asseverações, o deslocamento de informações

iconicidade, tais como: iconicidade de quantidade (quanto maior a informação, maior a forma), iconicidade de distância ou proximidade (quanto maior a distância conceptual, maior a distância linguística entre expressões), iconicidade de independência (separação linguística de expressão gera independência conceptual), iconicidade de complexidade (formar plural maior do que forma singular), iconicidade de categorização (sujeitos são mais agentes e os objetos mais pacientes), e o subprincípio que mais nos interessa, que é a iconicidade de ordenação (grau de importância determina a ordem).

${ }^{143}$ Em Villaça-Koch (2000), o rema, que é o portador de informação nova, normalmente sucede ao tema, que é a informação velha, já conhecida. No entanto, a utilização de estratégias de tematização e de 
para a cabeça da sentença, podem não só estar ligadas ao fator previsibilidade e importância, quanto também à mudança do tópico, como forma de facilitar o entendimento da informação, entre outras. Neste caso, a priorização coloca em primeiro lugar a recepção da informação em si.

\section{A. Ênfase na quantidade}

Entrevistado 1 (FR): [tudo, tudo perdi si muito mais qui é um é uma coisa tem a fronteira pur ixemplo... Elvas e Olivença] - ênfase na informação deslocada, para indicar a importância da perda relatada.

Entrevistado 1 (FR): [não têm as legendas dos filmes nem nada fazem a tradução tudo pra ifpanhol] - ênfase na informação deslocada - $\mathrm{O}$ verbo ter assume uma função semântica de apresentacional, tal como ocorreria como haver, mas o falante só pode fazer isso porque a informação é compartilhada entre falante e ouvinte. Neste caso, a ênfase é no compartilhamento interativo. Se o falante sabe que o outro já sabe o tema da conversa, elide o sujeito.

\section{B. Ênfase em situar o falante no espaço}

Entrevistado 1 (FR): [no país (...) país a IJpanha há muitas festas...] [há muitas festas no país (...) país a IJpanha] - inversão para a posição inicial do local - ênfase em situar o espaço como estratégia de situar o ouvinte - Topicalização

Entrevistado 1 (FR): [na IJpanha ganha-se melhor re] [ganha-se melhor re na IJpanha] - inversão para a posição inicial do local - ênfase em situar o espaço como estratégia de situar o ouvinte - Topicalização

Entrevistado 4 (CR): [em Purtugal também tem meus amigos] [em Purtugal também têm meus amigos] - inversão para a posição inicial do local - ênfase em situar o espaço como estratégia de situar o ouvinte - Topicalização.

rematização (o deslocamento do tema ou do rema) é um recurso que "desempenha papel relevante no processamento pragmático-cognitivo do sentido, na medida em que esta forma de organização é determinada quer por questões ligadas à continuidade ou mudança do tópico, quer por fatores como facilitação do processamento do texto, interesse, relevância, expressividade, necessidade de se ganhar tempo para o planejamento da parte restante do enunciado, entre outros". 
Entrevistado 4 (CR): [em Purtugal é qui tá proibido bebêr no bar] [é qui tá proibido bebêr no bar em Purtugal] - ênfase em situar o espaço como estratégia de situar o ouvinte - Topicalização.

Entrevistado 4 (CR): [dentro da praça, matam o touro] [matam o touro dentro da praça] - ênfase em situar o espaço como estratégia de situar o ouvinte - Topicalização.

Entrevistado 5 (ED): [mas Olivença as aulas de purtuguêf têm outro sentido porque? Purque Olivença foi 500 anos purtuguesa] [mas as aulas de purtuguêf têm outro sentido porque em Olivença? Purque Olivença foi 500 anos purtuguesa] - ênfase em situar o espaço como estratégia de situar o ouvinte - Topicalização.

Entrevistada 2 (RS): [aqui também tá já] [também tá já aqui] - ênfase do dêitico em situar o espaço.

Entrevistado 5 (ED): [eu aqui es... dou aulas há 4 anos] [eu es... dou aulas há 4 anos aqui]- ênfase do dêitico em situar o espaço.

Entrevistado 5 (ED): [aqui há uma lucalidade que é Barrancos] [há uma lucalidade que é Barrancos aqui] - ênfase do dêitico em situar o espaço.

Entrevistada 2 (JN): [Purque eu disse, conheço aqui muita gente] [aqui conheço muita gente] - ênfase do dêitico “aqui” (espaço) em posição imediata pós-verbal

Entrevistado 5 (ED): [não tenho aqui o outro] [não tenho o outro aqui] - ênfase do dêitico "aqui” (espaço) em posição imediata pós-verbal.

Entrevistado 5 (ED): [Sim, eu dou aqui aula] [Sim, eu dou aula aqui] - ênfase do dêitico "aqui”" (espaço) em posição imediata pós-verbal.

Entrevistado 5 (ED): [Problema é que não tenho aqui o computador] [O problema é que não tenho o computador aqui] - clivagem seguida de ênfase do dêitico "aqui" (espaço) em posição imediata pós-verbal.

\section{C. Ênfase em situar o falante na informação temporal:}

Entrevistado 1 (FR): [é, aos fins de semana, os restaurantes em Elvas, tão cheios de

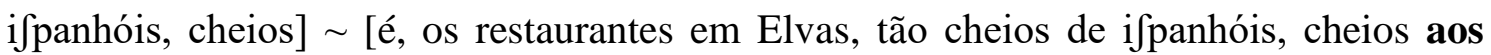
fins de semana] - ênfase na compreensão do interlocutor, que precisa se situar a cena e o ocorrido temporalmente. 
Entrevistada 2 (JN): [no sábado, que vejo alguém conhecido, comunico eu né] [que vejo alguém conhecido, comunico eu né no sábado] - ênfase na informação tempo.

Entrevistado 4 (CR): [O fim de semana este, nã não cabes na rua] [não cabes na rua este fim de semana] - ênfase na informação tempo.

Entrevistado 4 (CR): [Às vezes, não entendo nem eu] [não entendo nem eu, às vezes] - deslocamento do advérbio de tempo para a posição inicial - ênfase na informação temporal.

\section{D. Ênfase na ação desencadeada e na atenção do ouvinte}

Entrevistado 1 (FR): [i então aproveitam, fazem as duas coisas os ifpanhóis] [os ifpanhóis i então aproveitam, fazem as duas coisas] - ênfase: o enunciado deslocado para a posição inicial é o que é a informação mais relevante. Com essa estratégia, consegue oferecer ao interlocutor a resposta imediata que o outro esperava e, em consequência, controla sua atenção.

Entrevistada 2 (JN): [E pertence à família minha, são os subrinhos de um cunhado meu!] [são os sobrinhos de um cunhado meu e pertencem à minha família] - ênfase: o enunciado deslocado para a posição inicial é o que é a informação mais relevante.

Entrevistado 4 (CR): [pra comprar é mai barato aqui] [é mai barato pra comprar aqui] - ênfase na construção de finalidade. $O$ falante ressalta a ação desencadeada e efetiva a estratégia de controlar a atenção do outro.

\section{E. Topicalização do tema para selecionar novo tópico da conversa:}

Entrevistado 1 (FR): [purque praticamente a vida deles esta foi tá em Purtugal] topicalização - estratégia utilizada para selecionar novo tópico da conversa. Neste caso, a topicalização é retomada depois por um pronome sujeito.

Entrevistado 1 (FR): [Eu pra ganhar em Purtugal o que tô a ganhar agora aqui no restaurante, isto é um restaurante digamos que normal, restaurante normal vá tentar a trabalhar num hotel e num bom hotel] - topicalização do sujeito em primeira posição como forma de colocá-lo na posição principal do discurso e selecionar novo tópico da conversa. 
Entrevistado 4 (CR): [isso já não sei! eu, já, não, isso já não tenho ideia, não não!] [já não sei isso!] - topicalização - estratégia utilizada para selecionar novo tópico da conversa.

\section{F. Ênfase em situar o falante nas suas avaliações:}

Entrevistado 4 (CR): [mais ou menos é hoje, mais ou menos] [hoje é mais ou menos] - ênfase na incerteza, intenção de passar sua avaliação sobre o que será dito, a qual, neste caso, é de não certeza.

\section{G. Reorganização da ordem on line, para não perder a atenção e garantir a intercompreensão:}

Entrevistado 5 (ED): [us us mais velhos eh eh a língua usam com a naturalidade como usaram sempre, purtanto, sua forma de falar foram é cunhecem de $\int \mathrm{de}$ que naferam] [us us mais velhos eh eh usam a língua com a naturalidade ...] - ênfase na informação: inversão para chamar a atenção durante a fala - guiar a atenção do ouvinte.

Pelo que temos visto nas ocorrências encontradas em nossos entrevistados, as inversões atendem à demanda de atenção do interlocutor, pois como estão falando com um estrangeiro, preocupam-se com a clareza, sendo assim, a informação nova (o rema), só pode vir depois de apresentar o que é compartilhado, no caso a informação velha (o tema).

Os entrevistados, ao deslocarem para a posição inicial alguns elementos que, geralmente são mais comuns na posição final, o fazem por intenções pragmáticas que podem ser explicadas pelo princípio de iconicidade de organização, determinando tal ordem pelo grau de importância da informação dentro do enunciado.

A despeito dessas inversões, é mais comum que esses falantes mantenham a informação velha na cabeça da sentença, tal como nas ocorrências abaixo:

Entrevistado 1 (FR): [aa gente vai, a gente mudaaaaa de paííísss i mudaaa os nossos hábitos] - ordem canônica SVC 
Entrevistado 1 (FR): [eu tô convencido qui ninguém gosta de deixar o país em que nasceu] - ordem canônica SVC

No entanto, como temos visto nesta seção, muitas vezes, o falante utiliza a inversão sintática como estratégia para focalizar ao ouvinte o que ele acha mais relevante, em situá-lo no tempo, no espaço em suas avaliações, tais como incerteza, entre outros, tal como na ocorrência abaixo:

[na IJpanha ganha-se melhor re] [ganha-se melhor re na IJpanha]

Em caso como este, fica claro que o entrevistado tinha como estratégia discursiva que o ouvinte atentasse para o lugar que se paga mais, no caso, a Espanha. É de importância para o entrevistado que o ouvinte se situe ou foque na informação deslocada para a cabeça da sentença.

Tanto os advérbios quanto as construções adverbiais, que possuem na língua portuguesa mobilidade sintática, também se apresentaram da mesma forma na fala dos portugueses que vivem em Olivença, ou seja, com a mesma mobilidade:

Entrevistado 4 (CR): [pra comprar é mai barato aqui] [tem que aprender o ifpanhol pra poder pirceber] Entrevistado 1 (Fernando)

Entrevistado 5 (ED): [aqui há uma lucalidade que é Barrancos] [Barrancos é uma localidade que está aqui (...) aproximadamente 80 quilômetros)

Assim, podemos afirmar que a ordem alterada das sentenças não afasta o português oliventino do português falado em Portugal. Ao contrário, aproxima-os, inclusive nas estratégias adotadas por seus falantes, que ao situar o falante no tempo, espaço, incerteza, entre outros, tem como foco principal a garantia da atenção e intercompreensão comunicativa.

b) Colocação pronominal: Tipicamente no português de Portugal, o ritmo de fala ganha velocidade com os pronomes enclíticos. As mesóclises também podem ocorrer, assim como as próclises, mas em contextos específicos. Vejamos o caráter das colocações pronominais no português de Olivença. 
As construções sintáticas em que ocorreram colocações pronominais se mostraram com variações semelhantes às utilizadas pelos portugueses de Portugal, variando entre construções formadas por ênclise ou por próclise, o que revela que tais formações não se influenciaram pelo espanhol, mas apenas se mantiveram no português oliventino. Vejamos abaixo algumas delas:

\section{- próclises motivadas}

\section{Entrevistado 1 (FR):}

[e lhe já aprendermos]

[não se querem rebaixar (...) mesmo que um dentro do país não se querem rebaixar a ao purtuguês]

[é conforme se calhar, se lembra] = (é conforme calha, conforme lembra-se)

[o inglês tem que se aprender na Inglaterra]

[sempre se usa o ifpanhol]

[se o ifanhol for a Purtugal é muito difícil lhe encontrar um ifpanhol a tentar a falar purtuguêf]

\section{Entrevistada 2 (RS):}

[só si falam purtuguêf]

\section{Entrevistada 3 (JN):}

[passo o dia com o meu filho com meu netinho, prontu, pruque se vai embora e são quatro meses então vai pra o (...)]

\section{Entrevistado 4 (CR):}

[Aqui si mata!!!]

\section{- ênclises esperadas}

\section{Entrevistado 1 (FR):}

[Casei-me com uma purtuguesa]

[si vier um purtuguêf à I $\int$ panha o purtuguêf tenta falar ifpanhol tenta falar ifpanhol (...) comunicar-se com ele se o ifpanhol for a Purtugal é muito difícil lhe encontrar um ifpanhol a tentar a falar purtuguêf]

[perde-se muito e não é normal]

Entrevistada 3 (JN):

[Por vezes, acontece-me isso] 


\section{Usos tipicamente oliventino}

Entrevistada 2 (RS): [me tem o inglês e me tem o purtuguêf]

Entrevistada 3 (JN): [vamus se dizer aqui]

Entrevistado 5 (ED): [dipoif isso vai os levar aos sentimento]

Entrevistado 5 (ED): [e outruf tem sentimento e vais os levar a nacionalidade]

Esses casos encontrados entre os falantes do português oliventino nos revelam traços diferenciados, talvez uma influência da língua espanhola, pois, somente no espanhol, dependendo do caso, as frases admitem os pronomes enclíticos no início da frase, como em "me tem o inglês e me tem o purtuguêf" (Entrevistada 2). Frases como essa são comuns no espanhol, como em sentenças do tipo: "me escribió una carta".

\section{c) feição sentencial}

Tendo em vista a influência que uma língua majoritária exerce sobre uma lígua minoritária, de início, imaginávamos que muitos dos entrevistados apresentariam algumas características peculiares quanto à feição da sentença, como, por exemplo, o uso do verbo 'haver' muito mais do que o verbo 'ter', inclusive, não fazendo mais uso deste último em seu sentido existencial, tal como ocorre no espanhol.

Para tal constatação, fizemos a escolha do estudo de apenas alguns desses verbos, apresentando as variações que possuíam entre os falantes do português oliventino.

\section{c.1) Verbo haver existencial:}

\section{Entrevistado 1 (FR):}

[Havia mais trabalho; na altura havia muito mais trabalho]

[qui não havia problema nenhum]

[não havia nada]

[não há papel assinado]

[e não há problema nenhum]

[no paíf (...) paí a IJpanha há muitas festas há muito qualquer coisa resolvi fazer uma festa] 
[algumas coisas há diferença, mas é há muitos muitos purtuguese $\int$ a vir aqui ó ó supermercado]

[há tantos purtuguese $\int$ como ifpanhóis no supermercado, muitos, muitos, muitos]

[sim, há muita variedade]

[sempre há, qualquer coisa]

[não há hipótese]

[há muita palavra]

[Mas antes do natal houve uma Universidade que houve um problema qualquer a porta]

\section{Entrevistada 2 (RS):}

[aqui si for dizer qualquer restaurante, há um purtuguêf a trabalhar...] [aqui..há um bar...que é purtugueses, hay um não há dois]

[Há um restaurante de purtuguêf, são de Campo Maiore]

[teremos o bacalhau, mesmo chama-se bacalhau purtuguesa, que (....) Dourado...temos o bacalhau o bacalhau ao forno(....)Já, há muita coisa que ...(...)]

[na rua hay tudo há muitas pissoas]

[aqui, há aldeias cercas, também...]

\section{Entrevistada 3 (JN):}

[mesmo sabendo que a minha terra não tem nada, que há uma única mercearia] [senão no verão que há um, purtanto, um grupo de amigos que fazem umas festinhas, hoje não há escola!]

\section{Entrevistado 4 (CR):}

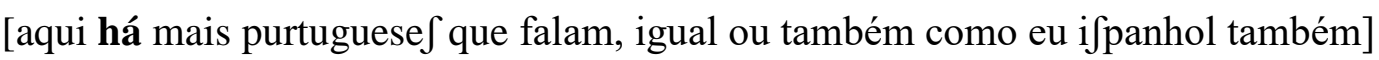

[há um curso que é purtuguêf]

[são contratados pra isso! há professores purtuguese $]$

[em Lisboa, há mais médicos ifpanhóis que purtuguesef]

[aqui há mais facilidade de viver que...]

[Há há restaurantes, a bares, montados no meio da rua]

\section{Entrevistado 5 (ED):}

[Sempre houve, sempre houve mais é, é, um é relações e há uma coisa curiosa, no século XX havia dua $\int$ ditadura $\left.\int . ..\right]$ 
[e ap(i)sar disso, de ter uma ditadura da mesma cor também não havia boas relaçõe $]$ ]

[Há outras lucalidade $\int$ de interesses de iftudo ao longo da raia]

[1297 houve um tratado que é o tratado de Alcanices]

[há aqui um rio afluente do Doro que é o rio Coa]

[não há um sítio de passagem a Purtugal tem ifpressamente]

[em Barrancos há até editado um livro que é filologia barranquenha]

[vinho tinto com casera que é uma gasosa que há aqui na IJpanha, purtanto, tem tem, estando em Purtugal mas têm muitas coisas da própria raia, purtanto, Barrancos]

[em Purtugal só há duas línguas oficiais, é o purtuguêf e o Mirandêf]

[houve um professor que editou uma filologia... eh]

[há uma cidade chamada Bragança]

[Houve familiares a viver do lado ifpanhol e do lado purtuguêf]

[tudu u que há aqui de monumentos é tudu purtuguêf]

[historicamente Purtugal reveindica Olivença, purtanto, há um tratado de 1817 que é o tratado de Viena]

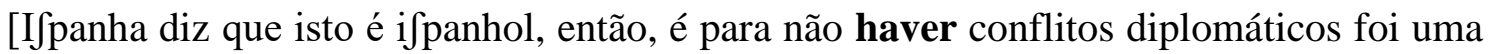
quiftão que sempre foi abafada] - Entrevistado 5 (Eduardo)

[falam de ao coisas que ouviram por aí mas aqui também em Olivença também há isso] [e nós dissemos que não havia problemas ehhhh em perguntar]

[a partir daí houve um prucesso dos oliventinos puderem ter nacionalidade]

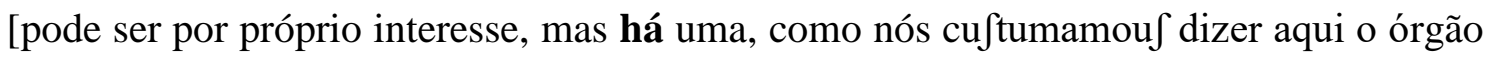
faz a função]

[haverá todus us casos, mas a lei a lei não entende de...disso]

[se houver pissoa $\int$ purtuguesa $\int$ falo purtuguêf se houver pissoa $\int \mathrm{i}$ panholas falo ifpanhol]

[aqui há uma lucalidade aqui a $7 \mathrm{~km}$ ]

[Há pissoas que quanto mais avançada é a idade mais puro é o purtuguêf]

Como temos visto, o verbo 'haver' existencial é muito frequente entre os falantes do português oliventino, sendo uma variável do verbo 'ter' existencial, ocorrendo quase que com a mesma frequência de uso. 


\section{c.2) Verbo haver com o sentido de crença:}

Embora tenhamos encontrado apenas um dado em que verbo haver desempenha uma função que não o de existencial, achamos interessante apresentá-lo:

\section{Entrevistado 4 (CR):}

[ah, minha filha sim, minha filha há de com o tempo dizer alguma coisa em purtuguêf]

Neste caso, podemos notar que o verbo haver está sendo utilizado no sentido de crença, como "Acredito que minha filha um dia falará português". Frases do tipo são muito comuns no português do Brasil, como em expressões: "Minha filha há de se casar" ou "ele há de não morrer"144.

\section{c.3) Verbo ter existencial:}

\section{Entrevistado 1 (FR):}

[ao conseguir apanhar ao conseguir ter em Purtugal os canais televisores ifpanhóis]

\section{Entrevistada 2 (RS):}

[aqui embaixo há uma escola do parque em purtuga, ou seja, tem mesmo, duas, duas professoras purtuguesa $\int$, são purtuguesa $\int$ purtuguesa $]$ [não têm aqui mais ninguém, ninguém, ninguém, ninguém (...)] [i tem o o agora o inglês já na ifcola, i aqui tem uma coisa boa] [aqui tem um purtuguêf também. Aqui nas ifcolas dão purtuguêf] [e são meus professores e tem purtuguê $\int$ desde os três anos como tem o inglês] [teremos o bacalhau, mesmo chama-se bacalhau purtuguesa, que (....) Dourado...temos o bacalhau o bacalhau ao forno (....) Já, há muita coisa que ...(...)]

\section{Entrevistada 3 (JN):}

[Tem muitos amigos aqui!]

[no dia a dia, só tinha mais gente]

\footnotetext{
${ }^{144}$ Frases elaboradas pela autora.
} 


\section{Entrevistado 4 (CR):}

[Tem muitos purtuguese $\int$ também, tem]

[sim! tem sim, tem em Badajoz, ééé espetáculo, em Badajoz o carnaval é um espetáculo]

[é firiado, tem o dia do carnaval, não!]

\section{Entrevistado 5 (ED):}

[Em Purtugal temos a zona da iftremadura]

[e apesar disso, de ter umas ditaduras da mesma cor também não havia boas relações]

[quando o comércio tem êxito de um lado, do outro lado não tem]

[é hm a quiftão de da raia tem est... tem Barrancos, Barrancos é uma lucalidade que está aqui a 80 ã oi... aproximadamente $80 \mathrm{~km}$ daqui e tem uma coisa curiosa, ê ê isso tem um tem um purque explicando...]

[também tem rio das Terras]

[mas falando especificamente de Barrancos tem uma questão curiosa, Barrancos está isulado]

[não há um sítio de passagem a Purtugal tem ixpressamente]

[em Barrancos tem um istatuto ifpecífico]

[E tem muitas quis... coisas ifpanholas na própria atividade diária]

[não há um sítio de passagem a Purtugal tem ixpressamente]

[tem coisas que em Purtugal não existem]

[vinho tinto com casera que é uma gasosa que há aqui na IJpanha, purtanto, tem tem, estando em Purtugal mas têm muitas coisas da própria raia, purtanto, Barrancos ...]

[depois tem aqui no norte, tem uma lucalidade que se chama Miranda do Douro]

[teve muitas influências do Lionês]

[é um sitio de interesse, purtanto, e depois tem um, mais a cima, aqui mesmo do cantinho]

[Tudo em Purtugal, tem Rio de Onor]

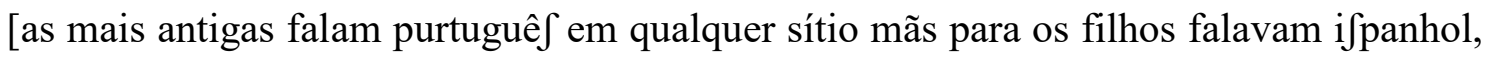
então temos aqui vários casos e acontece isso]

[Além Guadiana, é um Rio que temos aqui a Além Guadiana é um jogo de palavras] [purque teve, não teve o prucesso de castelhanização] 
Como podemos ver na apresentação dos dados com o verbo 'ter' existencial, o português oliventino tem preservado tal uso, mesmo não sendo utilizados pelos espanhóis. Além disso, percebemos que alguns de nossos entrevistados fazem uso das duas variações em um mesmo contexto:

[vinho tinto com casera que é uma gasosa que há aqui na ISpanha, purtanto, tem tem, estando em Purtugal mas têm muitas coisas da própria raia, purtanto, Barrancos] (Entrevistado 5)

[não há um sítio de passagem a Purtugal tem expressamente] - (Entrevistado 5)

\section{c.4) Verbo ter com o sentido de dever ou precisar:}

\section{Entrevistado 1 (FR):}

[ah tinha, tinha que apreender as duas com certeza...risada...] (deveria/precisaria aprender)

[certeza mesmo, teria que apreender a falar purtuguêf] (deveria/precisaria aprender)

[a gente independentemente tá no outro país não temos pur perder a língua] (não devemos perder a língua)

[então tem que aprender o ifpanhol] (deve-se/precisa-se aprender o espanhol)

[pra mudar de país a mãe tem que dá autorização] (a mãe deve/precisa dar autorização)

[o inglês tem que se aprender na Inglaterra] (deve-se/precisa-se aprender na Inglaterra)

\section{Entrevistada 2 (RS):}

[não, não , não, todos têm que ter purtuguêf] (todos devem/precisam ter português)

\section{Entrevistado 4 (CR):}

[um purtuguêf quer vir aqui trabalhar, ou (...) trabalhar ali, tem que teri, premisso de residência] (deve/precisa ter permissão)

\section{Entrevistado 5 (ED):}

[isso tem que acabar] (isso dever/precisa acabar)

[tem que ser duma forma e Purtugal outro] (deve ser de uma forma e Portugal outra)

[Pur que os Oliventinos pedem a nacionalidade purtuguesa sem ter que renunciar a Ifpanhola] (sem precisar renunciar a espanhola) 
O verbo 'ter' com o sentido de 'dever' ou 'precisar' também ocorre na fala dos portugueses que vivem em Olivença, e tal uso não pode ser relacionado a nenhuma das variáveis sociais aqui estipuladas, pois, como temos visto, elas ocorrem independente do sexo, nível de instrução e nível socio-econômico.

\section{c.5) Verbo ter com o sentido de possuir:}

\section{Entrevistado 1 (FR):}

[sim tem três filhos] [possui dois filhos]

[uma coisa tem a fronteira, pur ixemplo...Elvas e Olivença, ou Elvas e Badajoz uma coisa é ter fronteira a gente...] [possuir fronteira]

[e como os ifpanhóis não fazem a tradução não têm as legendas dos filmes] [não possuem legendas]

[conheço um rapaz aqui um purtuguêf que vive ali atrás tem dois filhos] [possui dois filhos]

[eu acho que qualquer pissoa saia do país, que tem um filho com uma pessoa em outro país] [possui um filho]

[não, não tem a curiosidade] [possui curiosidade]

\section{Entrevistada 2 (RS):}

[uai a piquena tem dez anos!] [possui dez anos]

[começaram a falar já tinham quase três anos] [possuía quase três anos]

[Purque tive...] [purque possuí]

[Com nove meses, não tinha nada] [não possuía nada]

\section{Entrevistada $3(\mathbf{J N})$ :}

[sim, eu tenho aqui muitas pissoas] [possuo aqui muitas pessoas]

[eu tenho amizades em Olivença] [eu possuo amizades]

[sim, eu tenho aqui muitas pissoas; eu também tinha u restaurante, tinha e tenho restaurante em jurumeia] $\sim$ [possuo aqui muitas pissoas/possuía e tinha restaurante]

[tenho dois filhos] $\sim$ [possuo dois filhos]

[I tenho outro que é solteiro] [possuo outro] 
[Eu sei, eu sei dum senhor purtuguês que tem ali um restaurante] $\sim$ [... que possui ali um restaurante]

[que moraram no Caia, na Fronteira, tinha um restaurante] [possuía um restaurante]

[i depois minha mãe teve uma doença fatal] [possuiu uma doença fatal]

[tanto é que eu tenho em minha família, ã um sobrinho que foi para a Romênia] [possuo em minha família]

[que eu até tenho um neto que nasceu nos Açouref] [possuo um neto]

[o povo onde vivo tem muito pouca gente] [possui muito pouca gente]

[nós não podemos ter um dia de natal como tem outra pissoa qualquer com a família ...]

$\sim$ [possuir um dia de natal]

[eu mesmo que vendo a minha casa e vá pra perto de onde estão meus filhos que é normal, mais cuidados que temos, é, quando atingimos uma certa idade o que a gente pensa...] [cuidados que possuímos]

[i eu só tenho dois rapaz, não tenho raparigas, só tenho a minha nora] [possuo dois rapazes/não possuo raparigas]

[mesmo sabendo que a minha terra não tem nada, que há uma única mercearia, a não tem nada, nada, nada, não tem uma diversão pra ninguém, senão no verão que há um, purtanto, um grupo de amigos que fazem umas festinhas] [minha terra não possui nada/não possui uma diversão]

[Ai si tenho saudades da minha, moça acredita que é a verdade que lhe vou dizer, eu tenho pena quando chego a Jurumeia, porque no meu tempo de miúda, éramos cinquenta e quatro miúdos na ifcola, hoje não há ifcola!] [possuo saudades da minha/possuo pena]

[Tenho, muitos, muito amigos] [Possuo, muitos, muitos amigos]

[Hoje tenho mais contato com espanhóis] [Hoje possuo mais contato com espanhóis]

\section{Entrevistado 4 (CR):}

[aqui tem, da uma escola, classe em português] [aqui possui...]

[isso já não sei! eu, já, não isso já não tenho ideia, não não!] [já não possuo ideia]

[temos aqui nossa vida] [possuímos aqui nossa vida]

[temos aqui cerca, tamos aqui perto] [possuímos aqui...]

\section{Entrevistado 5 (ED):}

[Problema é que não tenho aqui o computador] [não possuo aqui...] 
[Purtugal também teve má relaçõef] [possuiu má relações]

[mas Olivença as aulas de purtuguêf têm outro sentido purque? Purque Olivença foi 500 anos purtuguesa] [as aulas de purtuguêf possui outro sentido]

[Então historicamente Barrancos tem mais afinidade com Portu... com a IJpanha do que com Purtugal que está em território purtuguêf] [Barrancos possui mais afinidade]

[e Barrancos tem duas ou três características] [Barrancos possui duas ou três]

[é que porque eles têm uma mistura de purtuguêf e ifpanhol na fala] [eles possuem uma mistura]

[Tem, eles até têm uma filologia editada eles falam barranquenho] [Possui, eles até possuem uma filologia]

[quando eles é é têm a festa deles principal qué 28 de agosto] [eles é é possuem a festa]

[Barrancos tem o seu próprio, tem o seu próprio di di quiftões etnográficas linguísticas até a maneira de ser e diferente] [Barrancos possui o seu próprio]

[as terras de Miranda têm muito interesse em em têm muito interesse desde esse ponto de vista para iftudar eeeeh] $\sim$ [possuem muito interesse]

[qual trabalho que se tem fe, pur que?] [que se possui....]

[que temos um discursu] [que possuímos um discursu]

[houve uma vez uns oliventinos me perguntaram se podiam eh ter né eh (ruido) se podiam ter nacionalidade ifpanhola, perdão, purtuguesa] [se podiam possuir]

[mas aqui temos, mas dipoif temos o chamado nesse sentido, agora temos o chamado purtuguê $\int$ oliventino] $~[$ mas aqui possuímos...]

Como temos visto nos dados coletados de nossos entrevistados, o verbo 'ter' no sentido de 'possuir' é também tão frequente quanto o existencial e no sentido de necessitar. Assim, as variações que encontramos desse verbo são bastante frequentes, sem influências do espanhol e ocorrem indiferentemente da variável social.

\section{c.6) Verbo ter com o sentido ambíguo ou como auxiliar:}

\section{Entrevistada 3 (JN):}

[sempre tenho me dado muito bem] 
[não! ele estudou até o nono ano, depois não quis estudar mais, não tem (...) e depois já ouviu meu paiii, i pronto, isto é muito a ver, nós temos muito a vere com o passado do meu pai]

[e tenho minha casa à venda, pois proque aquilo meus filhos não quere]

\section{Entrevistado 5 (ED):}

[Essa Iftremadura não tem nada com aquela]

[Então nós temos trabalhado nisso]

Embora tenhamos encontrado poucos casos como os expostos acima, verificamos que os portugueses que vivem em Olivença utilizam algumas variações do verbo 'ter' que são ambíguas e complexas quanto sua definição.

No dado 'sempre tenho me dado muito bem', o verbo 'ter', em um sentido bastante ambíguo funciona como um auxiliar do verbo 'dar', sendo, inclusive desnecessário para a oração, a qual tem o sentido 'sempre me dou bem'.

$\mathrm{Na}$ expressão 'nós temos muito a vere com o passado do meu pai', o sentido é também complexo, numa construção em 'ter muito a ver com algo'. Neste caso, a entrevistada utiliza-o para formar o sentido de 'temos muito em comum com o passado de meu pai'. Tal uso não é comum, porém um dado muito interessante encontrado em nossa pesquisa.

Embora no dado 'e tenho minha casa à venda' pareça claramente que o sentido de 'possuir' prevalece, podemos ter uma segunda leitura: 'e minha casa esta à venda'. Assim, atribuímos um sentido ambíguo para tal construção com o verbo 'ter'.

Na oração 'essa iftremadura não tem nada com aquela' verificamos também um sentido bastante diferente e interessante do verbo 'ter' pois nesse caso, embora o sentido de 'possuir' pareça se sobressair como: 'essa estremadura não possui nada igual àquela', ainda podemos abstrair outro sentido: 'essa estremadura não é igual àquela'. Dessa forma, o verbo 'ter' parece funcionar no sentido de 'ser como', ou seja, com a função comparativa. 
O verbo 'ter' também foi encontrado na função de um verbo auxiliar, no caso, o particípio passado: "Então nós temos trabalhado nisso" ( Entrevistado 5).

Esses usos diferentes e mais abstratizados do verbo 'ter' aparecem em poucos dados, porém o suficiente para não deixarmos de lado em nossa pesquisa.

\section{d) Formas nominais dos verbos}

\section{d.1) aspecto durativo verbal por meio de infinitivo:}

$\mathrm{Na}$ fala dos portugueses que vivem em Olivença encontramos variações com relação ao uso do gerúndio, pois nossos entrevistados não só faziam uso das construções em 'estar a + infinitivo', 'continuar a + infinitivo', 'verbo $+a+$ infinitivo', ' $Q$ verbo a + infinitivo' como também utilizavam o gerúndio com a terminação em 'ndo'.

\section{Gerúndio em [estar a + infinitivo]}

Entrevistado 1 (FR): [a diferença de salário é muito, muito grande, eu pra ganhar em Purtugal o que tô a ganhar agora aqui no restaurante, isto é um restaurante digamos que normal, restaurante normal vá tentar a trabalhar num hotel e num bom hotel]

Entrevistado 3 (JN): [Nõ sei se tá a compreender?]

Entrevistado $3(\mathbf{J N})$ : [e às vezes tô a dizer ifpanhol, mas não tô a percebere que já estou a dizere em i[panhol]

Entrevistado 4 (CR): [Sim! mas alguma vez pur ixemplo, eu tô a falar com você memo em purtuguê $\int$, e salta alguma palavra em ifpanhol]

Entrevistado 4 (CR): [é costume já, é costume de, estamos a falare, alguma palavra, na verdade não lembro de uma palavra em purtuguêf, então, salta o ifpanhol, ou (...) salta o purtuguêf]

Entrevistado 4 (CR): [e eu tenho que dizere, que tá a dizere ao pai a meu filho, e gostava que ele falasse (...)]

Entrevistado 5 (ED): [aqui há um purtuguêf oliventino que é isso que nós tentamos reproduzir purque se está a perder purque se fala nas nas nas faixas etária] 
Entrevistado 5 (ED): [Mais avançadas, não é, i intão é uma das coisas que nós tentamos produzir e estamos a trabalhar nisso]

Entrevistado 5 (ED): [Como está a dizer os é ehhh os Oliventinos também têm, a maioria são descendentes de purtuguese []

Entrevistado 5 (ED): [eh nos guiemos que nós eh, condu conduzamos eh Olivença para o biculturalismo, para o bilinguismo e é isso que se está a trabalhar e sonhar]

Entrevistado 5 (ED): [a minha filha curiosamente estuda ehhh a língua tas a fazer o curso de língua literaturas modernas em purtuguêf]

Entrevistado 6 (PR): [mas agora ifta começar a...(...) a moda falare em portuguêx...]

\section{Gerúndio em [continuar a + infinitivo]}

Entrevistado 1 (FR): [como continuamos a falar ifpanhol, já sem falar, prontu, do catalão, pro ixemplo]

Entrevistado 1 (FR): [eles continuam querer a falar ifpanhol]

Gerúndio em [verbo + material interveniente + a + infinitivo]

Entrevistado 1 (FR): [Eu tenho, tenho lá, agora tenho lá um primo meu, também da Universidade a fazer um trabalho lá!]

Entrevistado 1 (FR): [por isso, muitas vezes às vezes tem purtuguese $\int$ a comer aqui]

Entrevistado 2 (RS): [tanto que eu leva aqui sete anos a trabalhar com eles]

Entrevistado 5 (ED): [Houve familiares a viver du lado Ifpanhol]

\section{Gerúndio em [Q verbo a + infinitivo]}

Entrevistado 2 (RS): [Todo dia, todo dia, a falar com eles, i a falar com eles]

Entrevistado 3 (JN): [sentava lá curtimo o sítio, a a ver os barcos, a ver água, pronto]

Entrevistado 5 (ED): [Sim alguns a falar que não que também pode ser por próprio interesse] 


\section{d.2) aspecto durativo verbal por meio de Gerúndio}

Oração reduzida de gerúndio = oração subordinada adverbial temporal:

Entrevistada 3 (JN): [com esta vida não se pode, vida da restauração é uma vida que nós temo sendo preso, nós não podemos ter um dia de natal como tem outra pissoa qualquer com a família, não se tem um dia]

Entrevistado 3 (JN): [ocupo meu trabalho aqui trabalhando, o meu tempo (...) aqui trabalhando]

Entrevistado 5 (ED): [então dentro desses encontros que nós tivemos em Purtugal com a cultura, nós acabamos por é hmmm por falar disto que havia lhe dizendo (...) darmos a informação]

\section{Construção durativo estar + gerúndio:}

Entrevistado 4 (CR): [então meu filho pregunta, pai que tá dizendo ao avô?]

Embora nossos entrevistados apresentaram uma frequência muito maior no uso do gerúndio em construções 'estar a + infinitivo', 'continuar a + infinitivo', 'verbo + a + infinitivo', ' $Q$ verbo a + infinitivo', o que já era esperado, também encontramos ocorrências do gerúndio com dois aspectos: o durativo em estar + gerúndio e as orações reduzidas de gerúndio.

e) Concordância: o sistema de concordância no português é redudante e pede a repetição de marcas de flexão em todos os segmentos relacionados. Assim, a concordância de número pede a replicação do plural nos segmentos que integram o sintagma nominal (concordância nominal) e também nos segmentos representados pelo sintagma verbal (concordância verbal).

No português oliventino essas marcas podem se apresentar de forma redundante, pois esses falantes não são escolarizados na LH, já que estão fora dos limites da oficialidade dessa língua. 


\section{e.1) concordância verbal}

\section{Entrevistado 1 (FR):}

[uma vez qui falamos inglês eles já aceita nós e a gente consegui falar com eles] (aceitam)

[os espanhóis são são pissoas bastante alegres bastante memo no país (...)país a Espanha há muitas festas há muito qualquer coisa resolvi [ele resolve] fazer uma festa pra fazer um baile pra sair à rua principalmente no verão não é??] - (resolvem) [e pronto, mas os espanhóis memo assim não é tão...] - (não são tão...) [e eles gostam de verem os canais de desenhos animados...] - (de ver) [é sim i não como não fazem intenções de depender da língua espanhola pra viverem] (viver)

[não, é diferente, aqui (...), nós tem o sistema diferente, os restaurantes não é, depende do sítio onde se vai, mas o normal o tipo de restaurante como este onde eu trabalho, por exemplo um menu diário custa oito euros] - (nós temos; restaurantes não são)

[Os espanhóis gostam de comer fora, gostam, gostam de sair de beberaa, beber sua cerveja, beber seu vinho, e vai, então juntam as duas coisas] - (e vão)

[vamus lá mais por passear, e ir às compras, e vá ao supermercado, aproveitar pra dare uma voltinha de duas ou três horas com a família] - (vamos)

[então cá pissoas lá, que, não não responde espanhol, não sabe ou não querem responder em espanhol] - (não respondem; não sabem)

[Pois é uma coisa que eles fazem, por exemplo, na televisão espanhola quando sai os Ministros du da Catalunia à falare em catalão, eles ai sim põe legenda] - (põem)

\section{Entrevistada 2 (RS):}

[os ordenados que sejam dali, nãuu, não compensa] (não compensam) [em vez em quan, em vez em quando já eu, não se capaz de dizer certas palavras, agora imagina todos os dias (....) O espanhol, é impossível] - (não sou capaz)

[também são um casal português, veio pra cá pouco tempo, i tão aí..i tá, outra que...(...) Há um restaurante de português, são de Campo Maiore] - (é um casal, está aí, é de Campo Maior) 
[mudou! Muda! Muda porque si tamos muito tempo é qui tu leva muito tempo, muito tempo, muito tempo só pra eles] (tu levas)

[claro! É que é deles (...) dizer a outra coisa qualquer, mas...(...)São portugueses, são filhos de pais portugueses são ser portugueses] - (são seres portugueses)

\section{Entrevistada $3(\mathbf{J N})$ :}

[nós aqui os portugueses, frequenta muito comércio espanhol] - (frequentamos)

[Nós dois dois é português] - (somos portugueses)

[meus filhos tá em Lisboa] - (estão em Lisboa)

\section{Entrevistado 4 (CR):}

[perto! você quando vieram, por Badajo?] - (veio)

[vá, ali em Portugal Europa, come quatro pissoas, pagam memo que duas aqui] (comem quatro pessoas)

[venham mais a tourear, a toureare] - (Vêm mais para tourearem)

[O gosto da festa é, o ambiente, o ambiente, nós i à praça vê-lo] (nós irmos)

\section{e.2) concordância nominal}

\section{Entrevistado 1 (FR):}

[i sim os ingleses sentem se muitos superior aos outros] - (superiores)

[la tá, uma vez mais os canais de desenhos animados e dessas coisas (...) então é é falam tão tão só o espanhóis] - (os espanhóis)

[era caminhonista e fazia Alemanha, França e esses país...] - (países)

[a gente cruza com os espanhol] - (os espanhóis)

\section{Entrevistada 2 (RS):}

[as duas idiomas] (os dois)

\section{Entrevistada $3(\mathbf{J N})$ :}

[eu tenho aqui muitas pessoas ali vizinho em Olivença] - (vizinhos)

[nasceu na escolas da rainha, que minha sogra é das escolas da rainha] - (nas escolas) 
[A nossas origens, às vezes sempre daquele local, e nós nunca digamos perdere as nossas origens] - (As nossas origens)

[Tá quando os filhos trabalha] - (filhos trabalham)

[i eu só tenho dois rapaz, não tenho raparigas, só tenho a minha nora] - (dois rapazes)

\section{Entrevistado 4 (CR):}

[depende de, esses espanhol na vida vai aprender, na vida vai aprender] - (esses espanhóis)

[pra tere, os seus descontos tudo para, a seguro da social e essas coisas toda] - (coisas todas)

[as coisas tão, umas tão mais caras outras tão barato] - (tão baratas)

Não encontramos ocorrências com ausência de concordância do entrevistado que é professor universitário, o que nos leva a postular as variações desse tipo mais relacionadas ao baixo nível de instrução, embora o informante 1, o qual possui um nível intermediário de instrução está entre os que revelaram tais variações. Ao postular tal tipo de variável ao fator concordância verbal e nominal, acrescento que todos os entrevistados possuem instrução no português, pois são imigrantes que viviam na cidade de Elvas ou Campo Maior em Portugal.

\section{f) Expressões}

Entre os falantes do português oliventino encontramos algumas expressões que nos chamaram a atenção, as quais revelam uma característica desse grupo étnico. Pelo que temos observado, são marcações próprias da linguagem oral dos portugueses, não tendo, mais uma vez, nenhuma relação com a língua da sociedade receptora.

Assim, como podemos depreender das ocorrências copiadas a seguir, uma das expressões - "prontu" foi encontrada em mais de um entrevistado, o que nos indica ser um uso próprio dos portugueses: 


\section{f.1) Expressão "lá ta"}

\section{Entrevistado 1 (FR):}

[falam, principalmente, pelo outro visão lá tá uma vez mais os canais de desenhos animados e dessas coisas]

[lá tá,o problema é de mudar de paíf]

[nada, aqui, os ifpanho, u os chinêses na IJpanha, mesmo tando na fronteira não falam nada, lá tá, não dependem disso, então não si interessam, pelo purtuguêf]

[aqui na, por exemplo, na zona da iftremadura, tem muito hábitos, é um costume que eles têm, um hábito de por um uma bebida, uma bebidazinha e um qualquer coisinha pra pa pitar, e lá tá valem-se disso, pra subir o preço da bebida]

[sempre há, qualquer coisa, a gente memo tando em Purtugal a gente cruza com os ifpanhol, e lá tá, os ifpanhol não pregunta em purtuguês, ifpanhol pregunta em ifpanhol]

\section{f.2) Expressão "prontu"}

\section{Entrevistado 1 (FR):}

[saíram, saíram saíram a minha mãe, a minha mãe não, a minha mãe prontu não tá] [era caminhonista e fazia Alemanha, França e esses país prontu se conhece a Europa] [vamus lá mais por passear, e ir às compras, e vá ao supermercado, aproveitar pra dare uma voltinha de duas ou três horas com a família, e prontu, é diferente, é diferente] [Mas prontu, quase sempre que a gente vive sempre ifpanhol] [como continuamos a falar ifpanhol, já sem falar, prontu, do catalão, pro ixemplo]

\section{Informante 2 (RS):}

[fiquei aquii, i prontu, i aqui levamos a nossa vida]

\section{Entrevistado 4 (CR):}

[Prontu, estas pissoas já não existem, ficaram dos meus avós, foram pra os meus pais, dos meus pais ficaram pra nós, e prontu!]

[Não! Não! Não! Não, prontu eu, conviver aqui, convivo...] 
[Mas acho, já ouvi esse palavriado ao meu pai, mas prontu, meu pai dizia esse palavriado, mais rifugiado dos filhos]

[Eu é, sente mais dificuldade em aprender que o mais novo, prontu!]

[i prontu se habituou]

[não! ele estudou até o nono ano, dipois não quis estudar mais, não tem (...)e depois já ouviu meu paiii, i prontu, isto é muito haver, nós temos muito a vere com o passado do meu pai]

[passo o dia com o meu filho com meu netinho, prontu, pruque se vai embora e são quatro meses então vai pra o (...)]

As entrevistas que fizemos em Olivença nos permitiram observar o quanto o português em Olivença possui uma riqueza de usos que preservam os traços linguísticos típicos do português de Portugal, sem quase nenhuma influência do espanhol, nem mesmo nas expressões próprias da fala, tais como "lá ta" e "prontu".

\subsection{MARCAS DO SENTIMENTO DE PERTENÇA DA LÍNGUA POTUGUESA E LH EM OLIVENÇA}

Apresentamos nesta seção uma discussão sobre o sentimento de pertença da LH e da língua nativa através de pistas encontradas pelas ruas de Olivença. Nosso olhar será guiado pela base das teorias apresentadas nos capítulos precedentes. Elas propõem que a língua, num processo evolutivo, matenha marcas e pistas culturais que vão se modificando no tempo histórico, mas não se apagando por completo. 


\subsubsection{As teorias sobre a preservação das marcas de herança}

O estudo das teorias apresentadas nos capítulos precedentes desta tese nos permite compreender a LH como um componente da mente humana que pode funcionar como um efeito "catraca", uma espécie de evolução cultural, tal como proposto por Tomasello (1999). Nessa perspectiva, podemos compreender que a língua portuguesa nativa e a LH estará na memória de sua comunidade em sua funcionalidade social, mesmo que não seja percebida por desde sempre ter estado lá, tal como registram algumas placas de rua.

Ainda sobre a fundamentação teórica, vimos alguns pesquisadores, tal como Wall e Ferrari (2010), defendendo a ideia de que ancestralidades cognitivas são compartilhadas entre várias espécies e, inclusive, podem ser um conceito estendido entre os humanos. Essa ideia nos permite pensar, então, que o compartilhamento cultural se encontra entre os portugueses de LH, os quais caminham pelas ruas, convivem com espanhóis, porém os vestígios de sua ancestralidade linguística não foram totalmente apagados, mantendo-se preservados entre os falantes.

Alguns autores (Mithen, Tomasello, Wall e Ferrari) afirmam que preservamos características cognitivas herdadas, sendo usadas, partilhadas e modificadas. Muitas características podem, inclusive, desaparecer com o tempo, no entanto, por deixarem suas marcas, por menores que forem, acabam, muitas vezes, ressurgindo com o passar da história.

Dalgalarrondo (2011), também já apresentado no capítulo 1, trata das características adaptadas de cada espécie durante o processo evolutivo. Afirma que muitas peculiaridades são modificadas, no entanto características mais primitivas são mantidas, ainda que, com as mudanças no tempo histórico, acumulem as mais antigas junto às novas características.

Ao pensarmos nessas questões de evolução e preservação de características, não pudemos deixar de refletir sobre o contexto de mudanças culturais encontrado em Olivença, o qual, por muito tempo foi pertencente a Portugal e, a partir de 1801, passou abruptamente ao domínio espanhol. Ocorre que, nesse cenário, havia uma cultura, uma língua e toda uma história que ligava Olivença aos portugueses. 
Com o domínio da Espanha, um país forte e autoritário, com uma língua considerada "superior", a cidade passa ser modificada para atender aos anseios da coroa espanhola. Como já apresentado no capítulo que trata do locus da pesquisa, a cultura dos novos donos da cidade passa a ser imposta e, de forma truculenta. Tudo o que é português é obrigado a ser apagado, inclusive os nomes dos moradores, as toponímias, etc.

O que de fato ocorre é que, por ser um país maior, mais impositivo e com características de preservação de sua cultura, a Espanha passa a não deixar que os portugueses que viviam em Olivença tivessem contato com sua própria cultura dentro da cidade, proibindo o ensino da língua portuguesa. Uma das consequências disso foi a obrigatoriedade de que os moradores alterassem seus nomes portugueses para um espanhol, além de substituírem os nomes portugueses de todas as ruas por outros igualmente espanhóis.

Em poucos séculos, os espanhóis conseguiram retirar quase tudo que ligava Olivença a Portugal. Essa modalização "quase tudo" sustenta-se devido ao fato de que, como temos visto nas teorias dos autores aqui aduzidos, embora as mudanças no tempo histórico apareçam, as heranças cognitivas e culturais são preservadas entre os grupos que as possuem.

O que percebemos durante o trabalho de campo é que, a despeito do empenho espanhol em acabar com todo e qualquer vestígio português, o resultado não foi o esperado. Notamos, ainda, as marcas culturais ancestrais e sentimentos dessa sociedade, mesmo sendo minoritária, armazenados entre os membros de seu grupo étnico, ativando um estado de resiliência, justamente porque nem sempre são reconhecidos como membros da comunidade.

Ocorre que, como Tomasello demonstra, não há como evitar um processo que é inerente ao próprio indivíduo. Esse fenômeno, rotulado de efeito "catraca" está agindo continuamente para a preservação do que for útil econômico em energia para a comunidade como um todo. Sendo assim, embora os moradores locais tenham recebido orientações para adotar novas práticas, por exemplo, com relação às formas de nomeação toponímicas, não foram capazes de apagar de suas mentes e de suas rotinas esses rótulos históricos. Passam a operar, assim, duas camadas históricas de nomes num 
mesmo espaço. Para os que se consideravam portugueses mesmo após a mudança de soberania, esses rótulos passaram a ser considerados bastiões seguros de comunicação entre iguais.

Os nomes oficiais foram alterados, as formas de localização entre os habitantes também passou a ter nova forma de rotular (porque as referências foram devagarzinho sendo alteradas também), porém, por onde se caminha em Olivença, identificam-se características portuguesas. E as mesclas de traços espanhóis e portugueses vão se conformando pelas ruas, de tal modo que, misturam-se e separam-se à medida da percepção de quem está na situação de contato, numa espécie de disputa territorial.

A ideia de ancestralidade compartilhada, defendida por Wall e Ferrari (2010), parece bem presente entre os poucos portugueses encontrados em Olivença, pois, embora vivam como espanhóis (utilizando o idioma espanhol, e participando da cultura espanhola), não deixam de ecoar sua herança, pois sorrateiramente lutam pela volta de sua cultura. Sentem, a bem verdade, que fazem parte de uma ancestralidade portuguesa que não pode ser negada nem deixada de ser compartilhada.

Embora os portugueses que vivam em Olivença tenham tido que se adaptar aos costumes da sociedade da "nova soberania", durante esse processo de mudanças no tempo histórico, as características mais primitivas e mais antigas da sociedade não puderam ser excluídas por completo. Continuam vivas, mas são acopladas às novas, num processo cumulativo cultural.

\subsubsection{Caminhando pelas ruas de Olivença: a preservação das marcas portuguesas}

Ao caminhar pelas ruas de Olivença, nota-se de pronto uma cidade com nomes das ruas e espanhol, com pessoas falando o idioma espanhol, com muitas características espanholas, o que sugere, inicialmente, a ideia de se estar num território espanhol. 
No entanto, como já temos assegurado nesta pesquisa, marcas de herança cultural não são apagadas por completo, mas permanecem entre os seus habitantes que permanecem em estado de resiliência, mesmo que estes não as reconheçam claramente pelo fato de que, desde sempre, estiveram lá. Explicamos: nem sempre os próprios indivíduos que se consideram portugueses conseguem distinguir os elementos remanescentes de uma cultura portuguesa.

Durante o trabalho de campo, procuramos recolher todas as pistas possíveis para evidenciar que a cidade ainda preserva suas marcas de herança.

Um exemplo da preservação mais antiga é a igreja Santa Maria Madalena, de estilo manuelino, construída por Dom Manuel I ainda no século XVI. Como podemos atestar por meio das imagens 19, 20 e 21, a igreja reúne todas as características portuguesas preservadas e, por esse motivo, recebe um grande número de turistas que ficam encantados não só pela beleza, mas pela própria história.

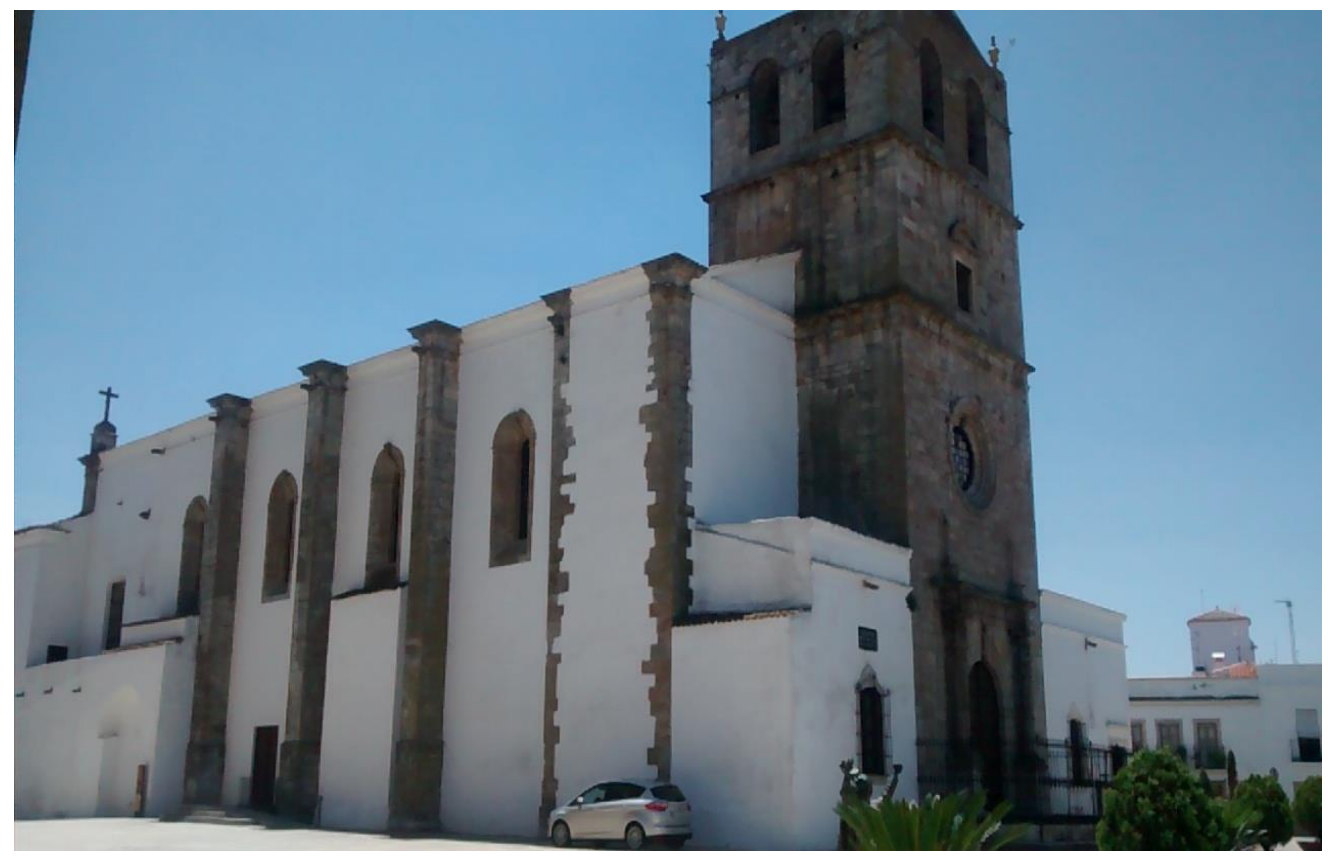

Imagem 19: Igreja Santa Maria Madalena ${ }^{145}$ - vista geral

145 Todas as imagens apresentadas nesta seção foram registradas por nós no período de fevereiro a junho de 2015. 


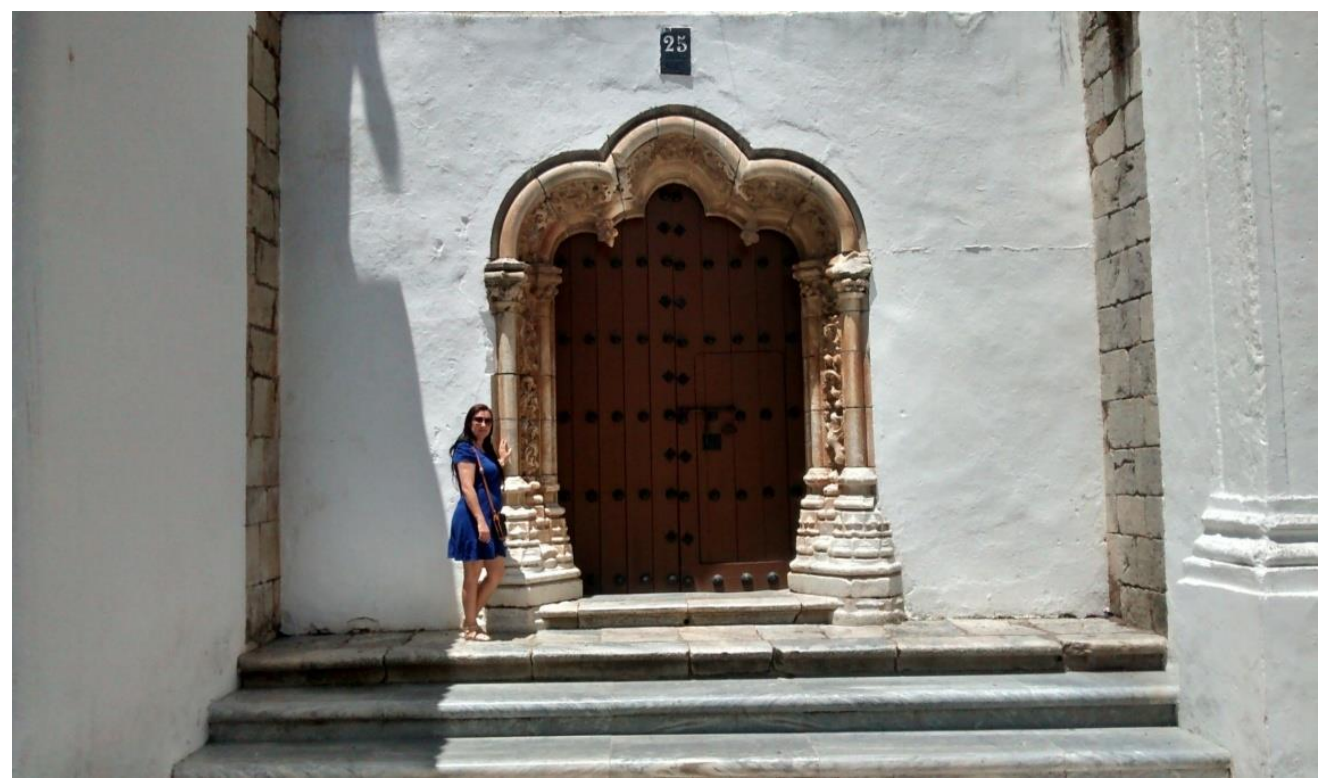

Imagem 20: Igreja Santa Maria Madalena - porta lateral da igreja

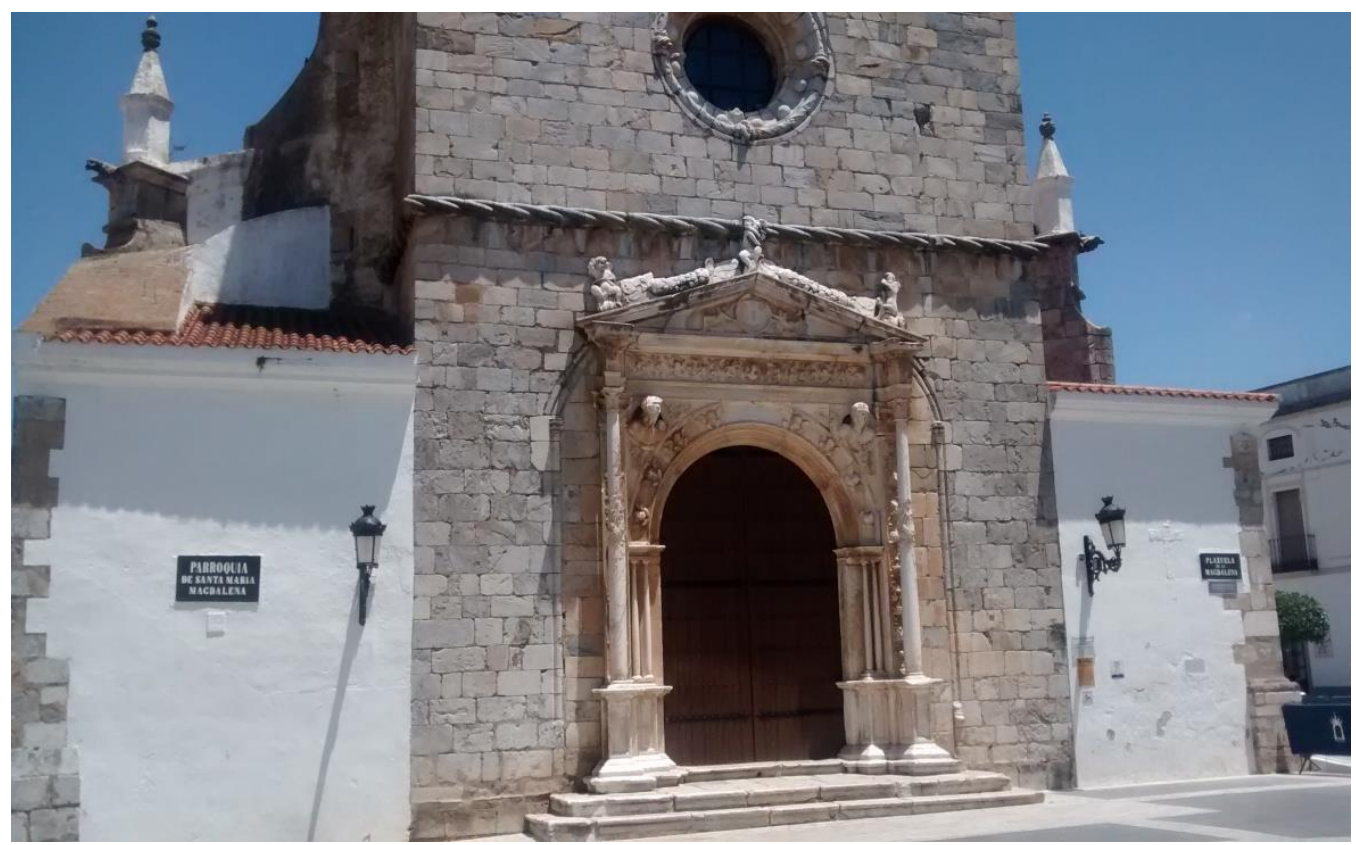

Imagem 21: Igreja Santa Maria Madalena - porta de entrada da igreja

A igreja Santa Maria Madalena foi construída com pedras portuguesas e com acabamento nos padrões de Portugal. Trata-se de um monumento de grande orgulho para os portugueses que ali vivem.

Durante o registro das entrevistas, pudemos perceber a altivez dos informantes ao falarem sobre a existência de uma igreja que é um reflexo da comunidade 
portuguesa. Nesse caso, embora já fosse esperado que os monumentos mais antigos tivessem as características de seu antigo país, não poderíamos deixar de registrar nesse trabalho pelo menos a igreja de Santa Maria Madalena.

Durante o trabalho de campo, além da pesquisa bibliográfica e iconográfica, também contamos com o relato de indivíduos que se consideram portugueses a ratificar, de forma entusiástica, esse sentimento de pertença cultural a que nos referimos aqui. A percepção dessa intencionalidade recorrente nos conduziu à postulação de que um sentimento de pertença poderia ser exemplificado pelos monumentos. De fato, havia a necessidade de falar sobre a cultura portuguesa e essa reverberação de informações parecia contribuir para preservar o que consideravam cultura própria. Frequentemente, deixaram claro que não se tratava de monumento espanhol, mas, sim, português sentimento de pertença declarado.

É claro que os monumentos antigos certamente estariam lá desde sua construção, então, durante nossos primeiros contatos com a cidade, prestamos atenção às marcas que pudessem postular essa preservação identitária de um grupo minoritário, principalmente as mais recentes, tal como os nomes dos comércios, das ruas, das placas, dos banners, entre outros.

Desde o primeiro monumento no trabalho de campo, algo já nos dizia que, embora o espanhol fosse a língua falada por toda a cidade, marcas de uma sociedade minoritária estariam ecoando por lá, mesmo que a própria comunidade não compreendesse que se tratassem de vestígios de uma herança cultural. Ilustra essa percepção um fato ocorrido durante o trajeto em busca de informantes pela cidade.

Caminhando uns 500 metros após a placa de entrada de Olivença, que, como podemos ver na imagem 22, sinalizava estarmos diante de uma cidade espanhola, já nos deparamos com um grande comércio, apresentado na imagem 23, cujos dizeres levavam a marca dos portugueses de forma bem explícita: "Lisboa-Cafeteria": 


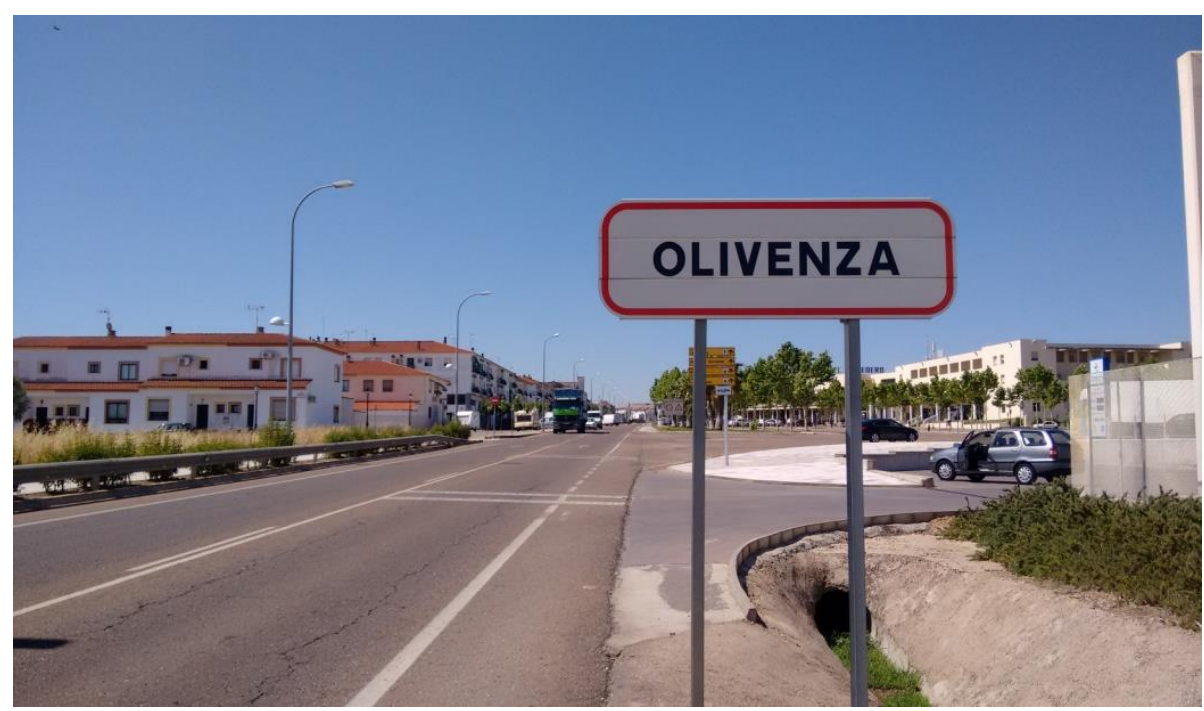

Imagem 22: Entrada da cidade de Olivença

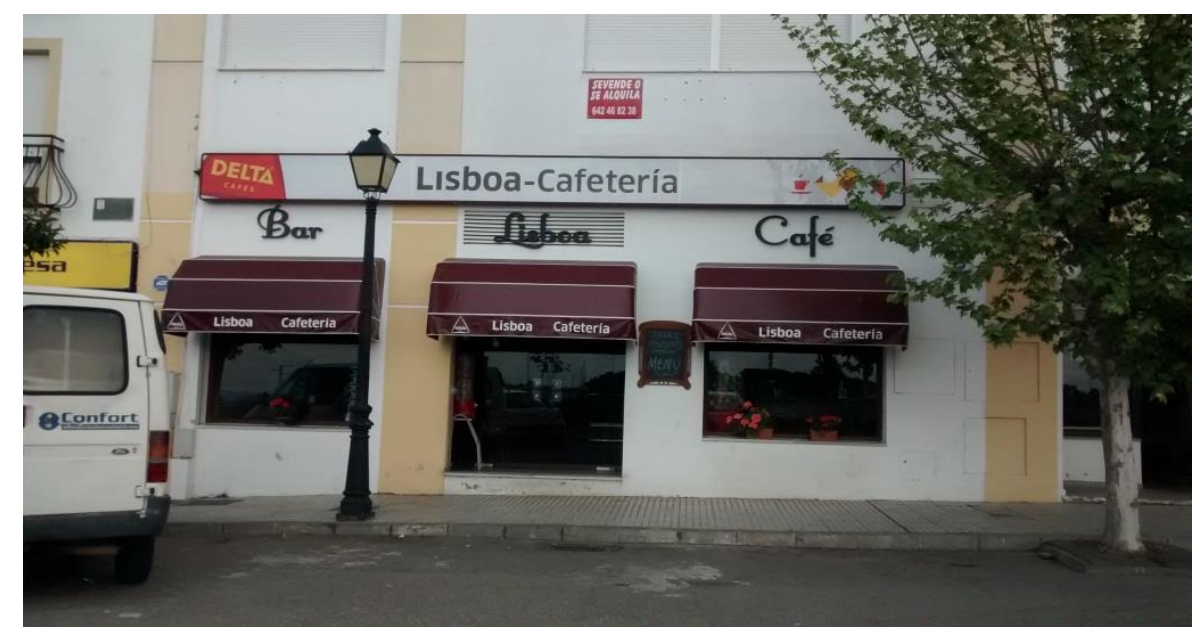

Imagem 23: Cafeteria na entrada de Olivença.

Como podemos notar pelas imagens, o comércio logo na entrada da cidade não é uma construção tão antiga para que pudéssemos pensar que sempre teve esse nome, ou seja, não seria possível dizer que o nome já estaria ali apresentado desde o período em que Olivença pertencia a Portugal. Era facilmente notado que se tratava de uma marca mais recente de LH.

Ao adentrarmos o local, pensamos se tratar de um estabelecimento de portugueses, mas, obviamente, enganamo-nos. No cardápio, como podemos constatar a partir das imagens 24 e 25, não havia nada em português e os pratos traduziam comidas típicas da Espanha. Os proprietários e funcionários eram todos espanhóis e, quando 
perguntamos se conheciam portugueses na cidade, não souberam nos responder com precisão.

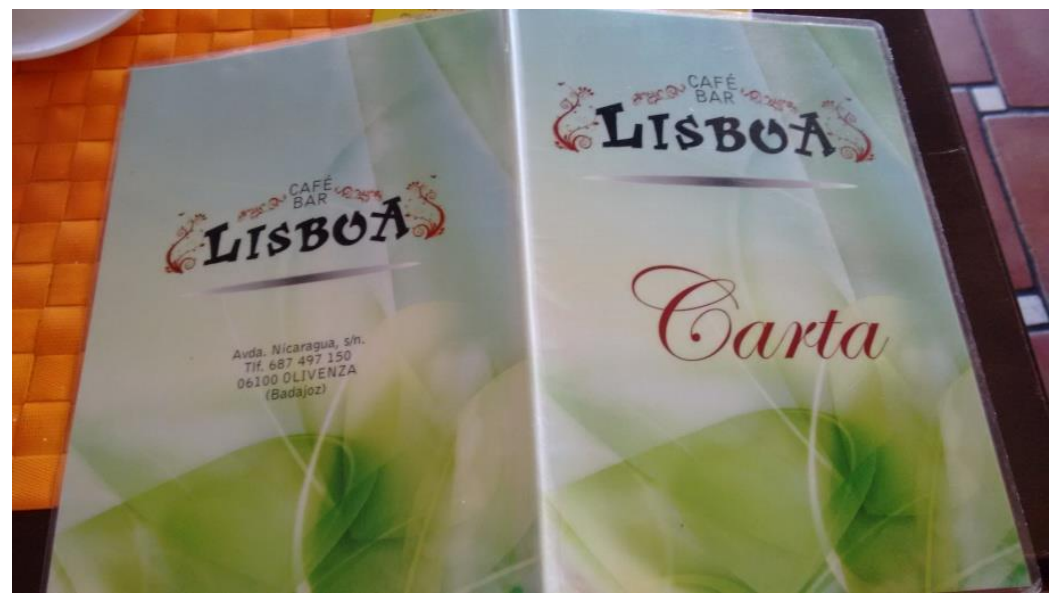

Imagem 24: Cardápio da lanchonete "Lisboa" em Olivença.

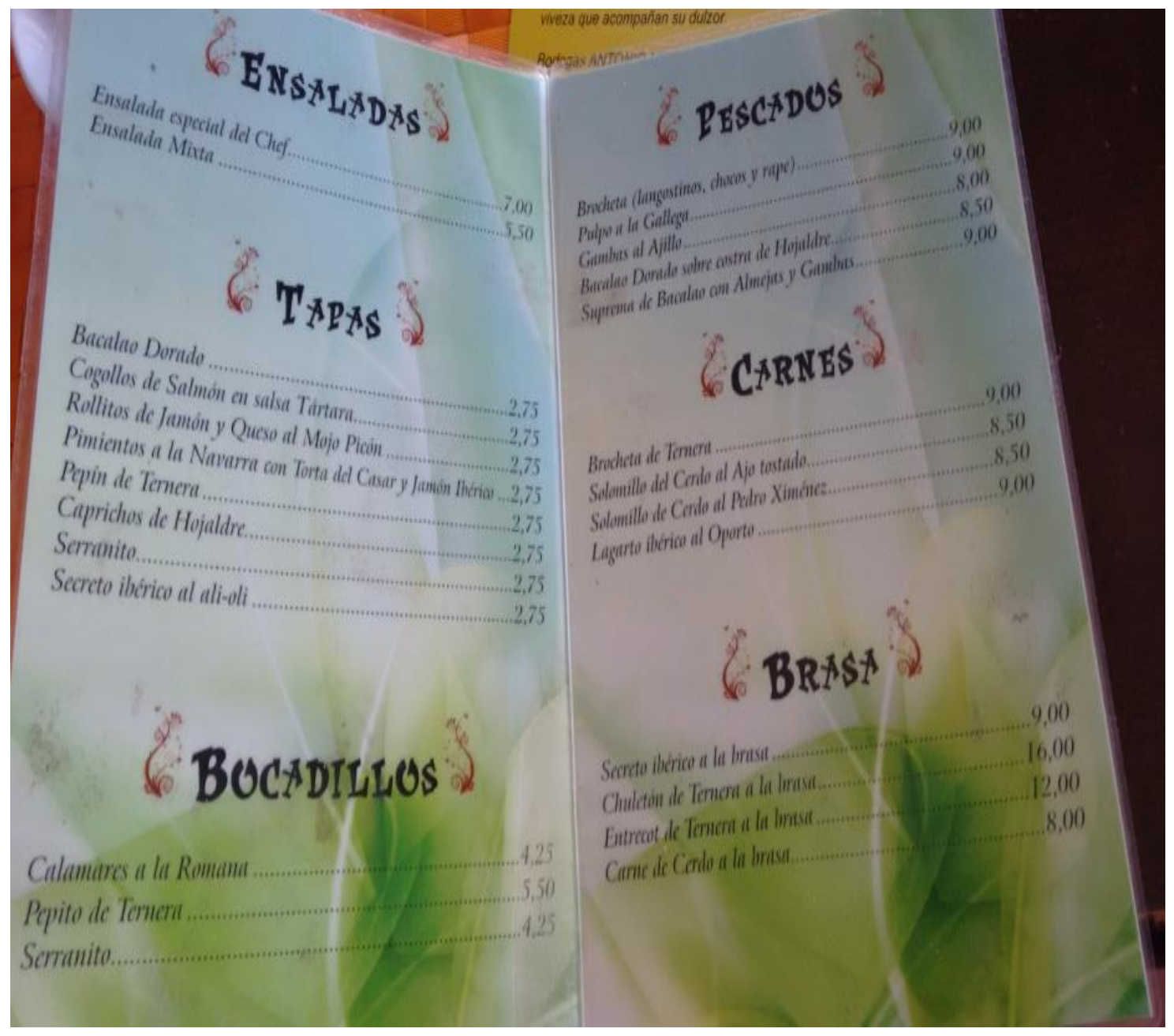

Imagem 25: Cardápio da lanchonete "Lisboa” em Olivença. 
O que fica evidenciado, já desde o início de pesquisa de campo, é que, embora o cardápio estivesse todo escrito em espanhol, o que se fazia necessário, pelo fato de ser uma cidade hoje pertencente à Espanha, estávamos diante de vestígios deixados pela herança portuguesa. Não haveria uma razão clara para o nome da lanchonete ser Lisboa? Tanto poderia ser porque os habitantes da região fronteiriça tinham origem portuguesa e poderiam ser os clientes daquele comércio quanto porque os pratos seriam tipicamente portugueses. Talvez a primeira hipótese seja mais adequada. Talvez haja outras razões que não pudemos desvendar.

Durante nossa caminhada em busca de marcas e pistas da herança cultural pretérita, não foi preciso ir muito longe para que mais palavras do idioma português aparecessem, embora de forma sutil e quase desapercebida aos olhos dos moradores locais. Para eles, eram simplesmente nomes, para nós marcas de uma herança cultural.

Na imagem a seguir, é possível reconhecer que o português aparece até mesmo em um cartaz de propagandas, o que não seria necessário por se tratar de uma cidade cuja língua oficial é o espanhol. Todos os dizeres estão em espanhol, com exceção da palavra "Apresentação", que está em destaque logo após a palavra em espanhol "Presentación". 


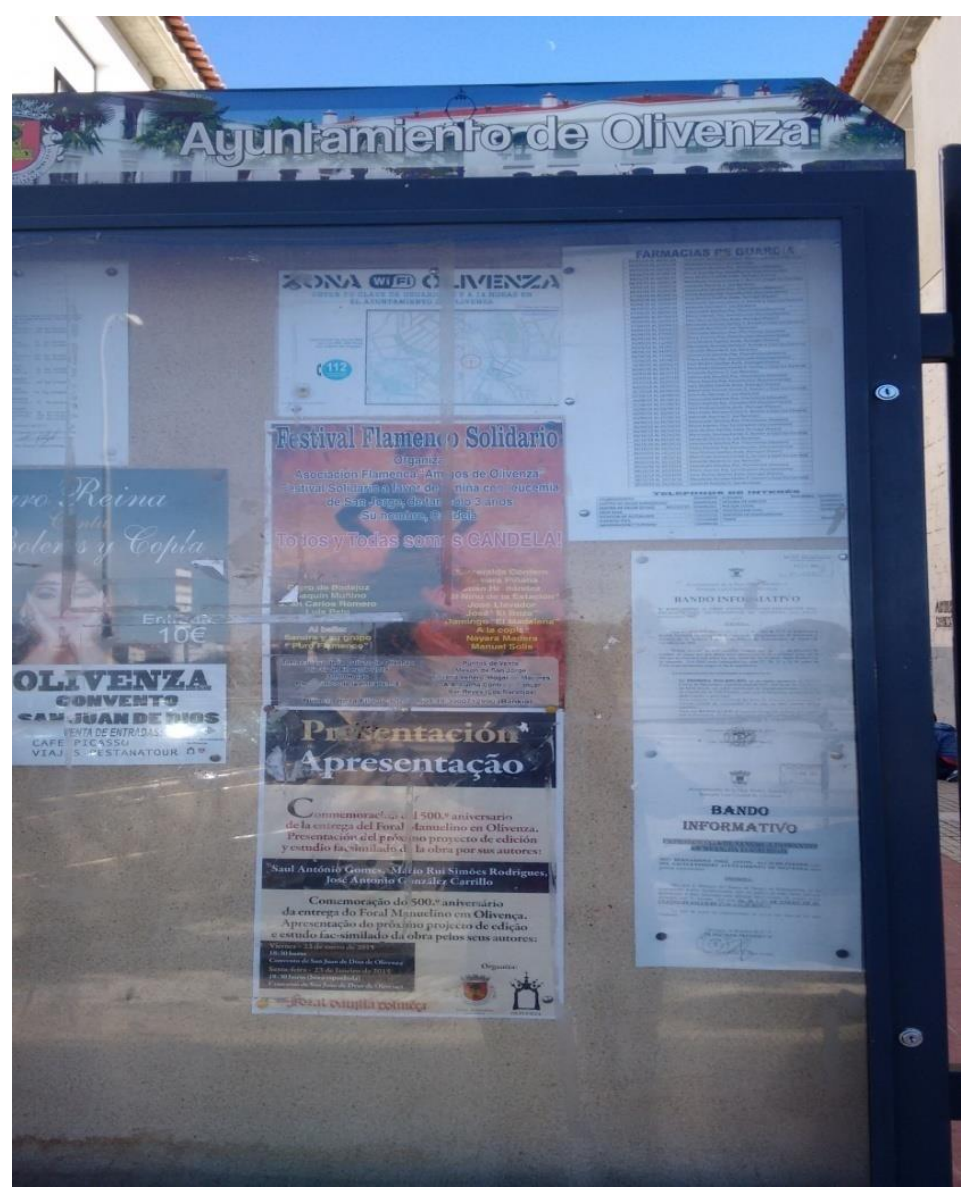

Imagem 26: Cartazes de propagandas de Olivença.

Cada detalhe nos parecia uma preciosidade, pois permitiam que enxergássemos a presença da LH, por mais que a presença fosse discreta e quase imperceptível, sinalizava que naquele lugar existia uma cultura minoritária.

Observando a imagem 27, podemos ilustrar um pouco dessas impressões: 


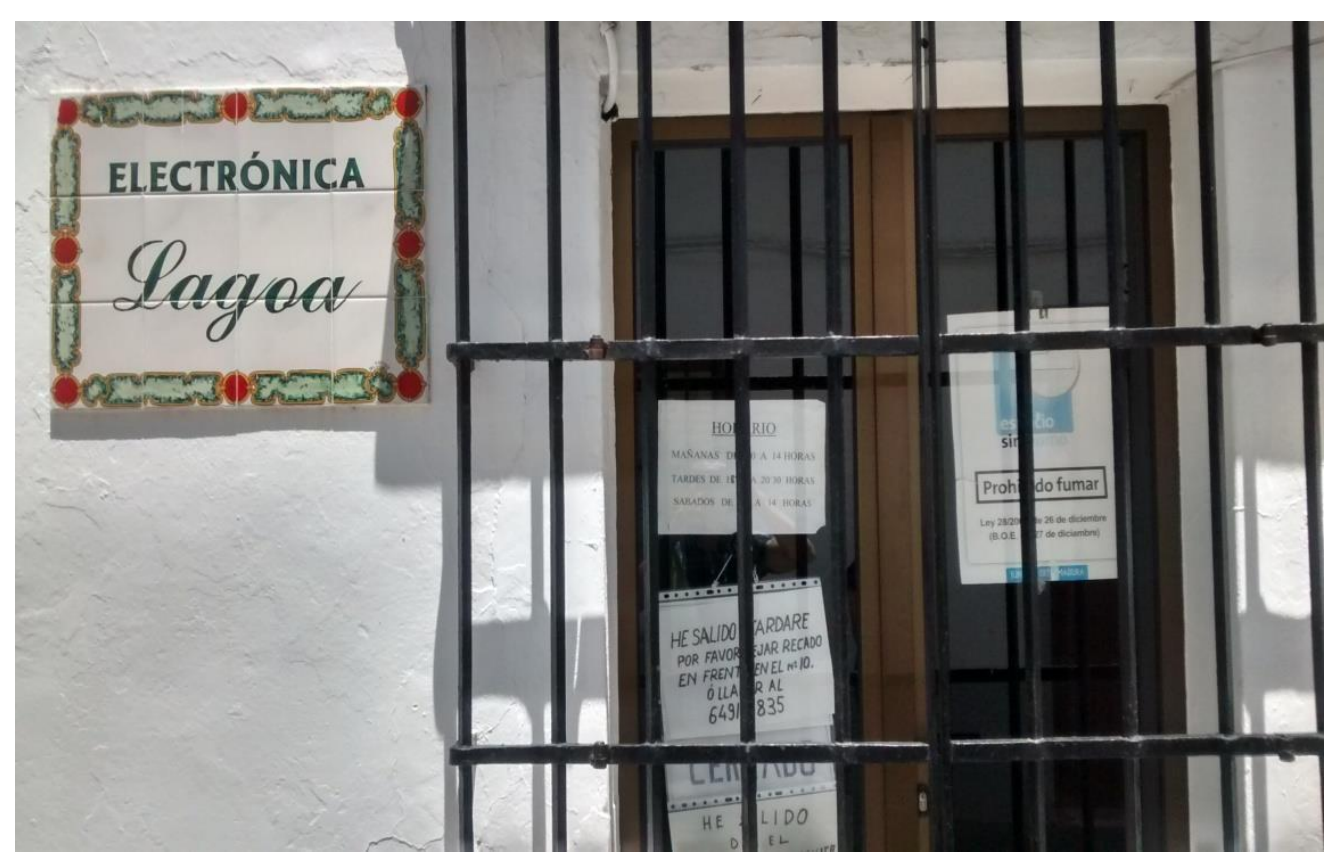

Imagem 27: Estabelecimento de eletrônicos em Olivença.

As palavras parecem disputar lugar na placa do estabelecimento eletrônico ${ }^{146}$, no entanto, o nome, com letra cursiva, aparece em plano de destaque. O grande interesse, porque nos deixou muito intrigados, é o fato de que o nome dado ao estabelecimento está na língua portuguesa "Lagoa" e não na língua do país, que seria "Laguna", "Lago" ou "Estanque" e, seus proprietários associam-se a uma identidade espanhola.

Em outro estabelecimento, os nomes dos proprietários portugueses também parecem disputar lugar na cidade espanhola. Suas marcas identitárias não podem ser apagadas e concorrem recebendo letras em destaque:

\footnotetext{
${ }^{146}$ A palavra eletrônica, tanto em português como espanhol é grafado como “electrónica".
} 


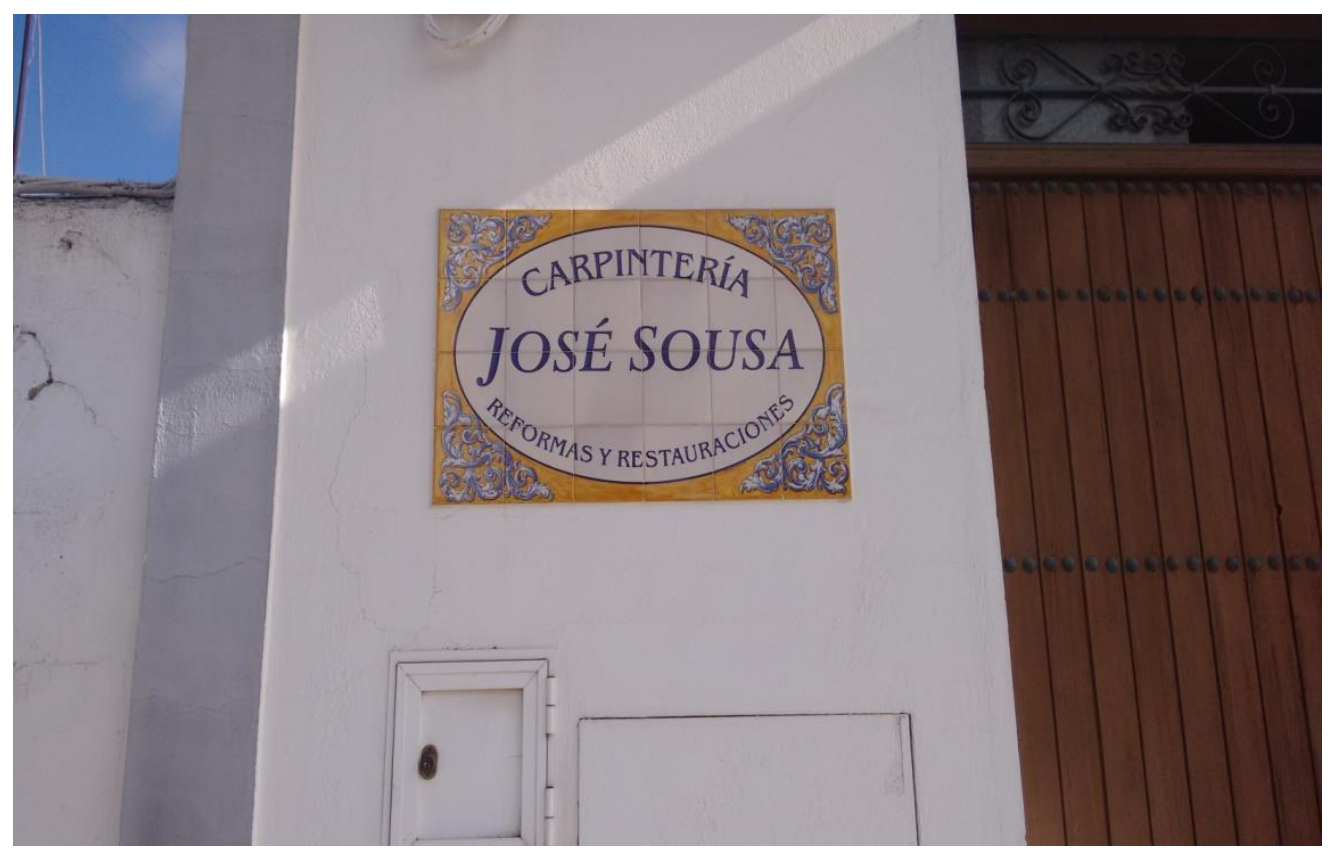

Imagem 28: Carpintaria em Olivença

A constatação sobre o que dissemos a respeito de uma preservação de marcas culturais através do tempo pode ser continuamente ratificada ao transitar por quase todas as ruas do centro de Olivença. Para os moradores daquela cidade são termos desapercebidos, no entanto, elas simbolizam que uma herança não se extermina por completo.

As ruas de Olivença, após a invasão espanhola, teve seus nomes alterados para o idioma dos novos conquistadores, no entanto, embora poucos portugueses ainda viviam na cidade, uma luta pela volta das antigas toponímias, se instaurou. Alguns portugueses e descendentes de portugueses, aliados à Associação Além Guadiana, da qual já tratamos no capítulo sobre Olivença, recorreram ao governo local para que os antigos nomes portugueses fossem reconstituídos.

Assim, juntamente com os nomes das ruas em Espanhol, os antigos nomes portugueses são afixados em semelhantes placas de azulejos, tentando demonstrar que sempre estiveram lá, ou que nunca deveriam ter sido tirados. Por onde passávamos, fotografamos algumas delas, como vemos nas imagens a seguir ${ }^{147}$ :

\footnotetext{
147 Todas as fotos das placas das ruas de Olivença foram feitas por nós em março de 2015. No final do trabalho constam mais algumas fotos das placas como anexo.
} 


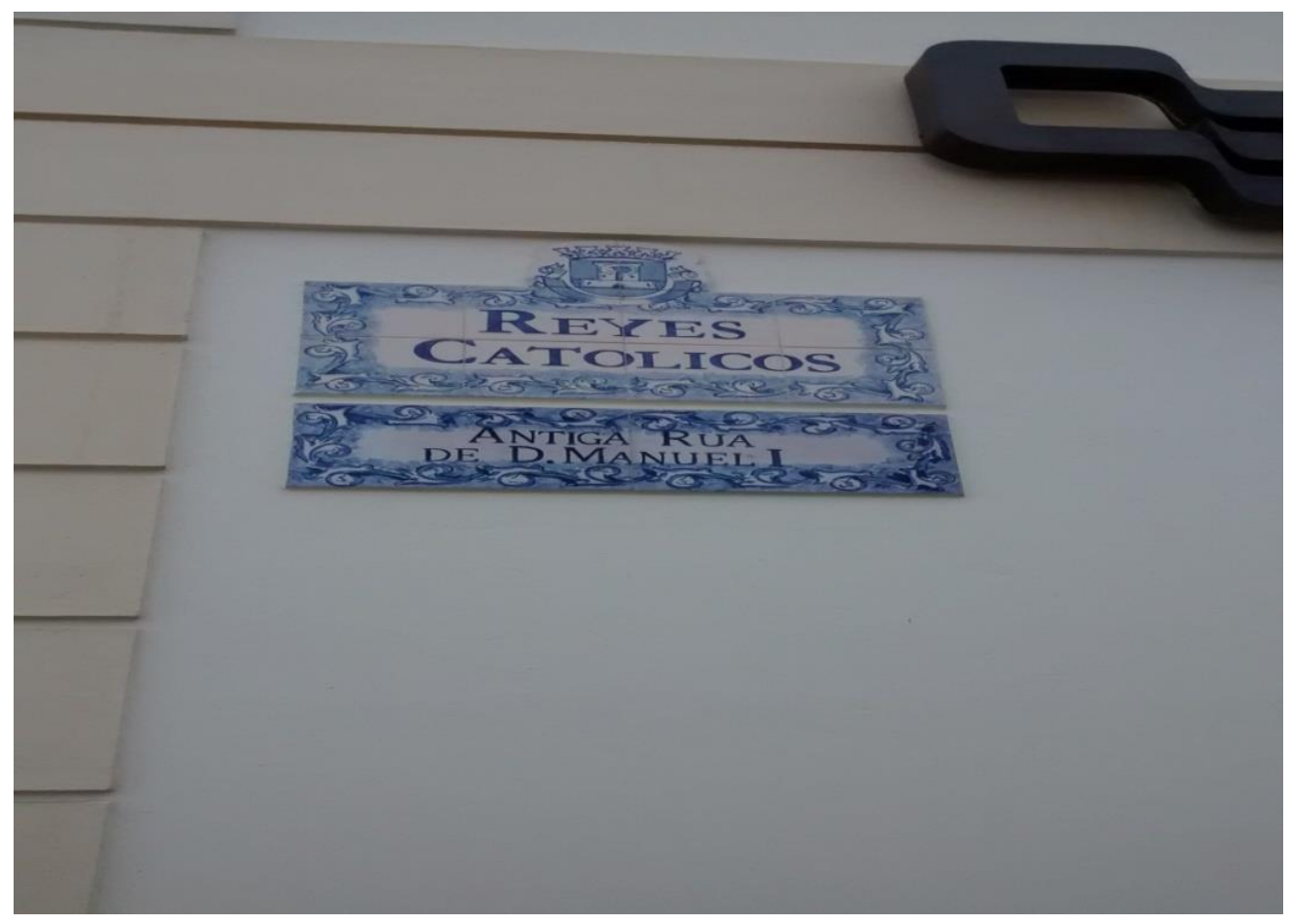

Imagem 29: Placa da rua de Olivença com seu antigo nome português

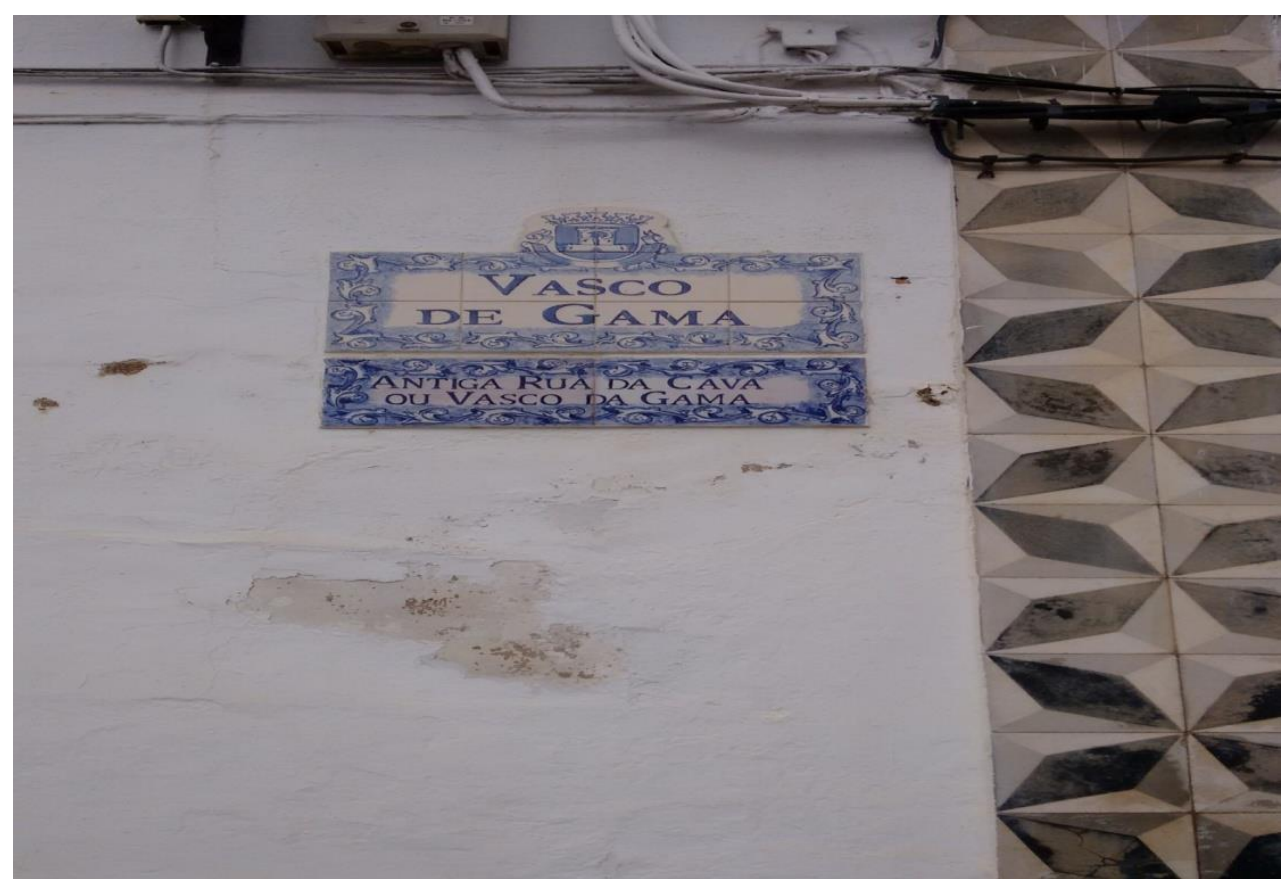

Imagem 30: Placa da rua de Olivença com seu antigo nome português 


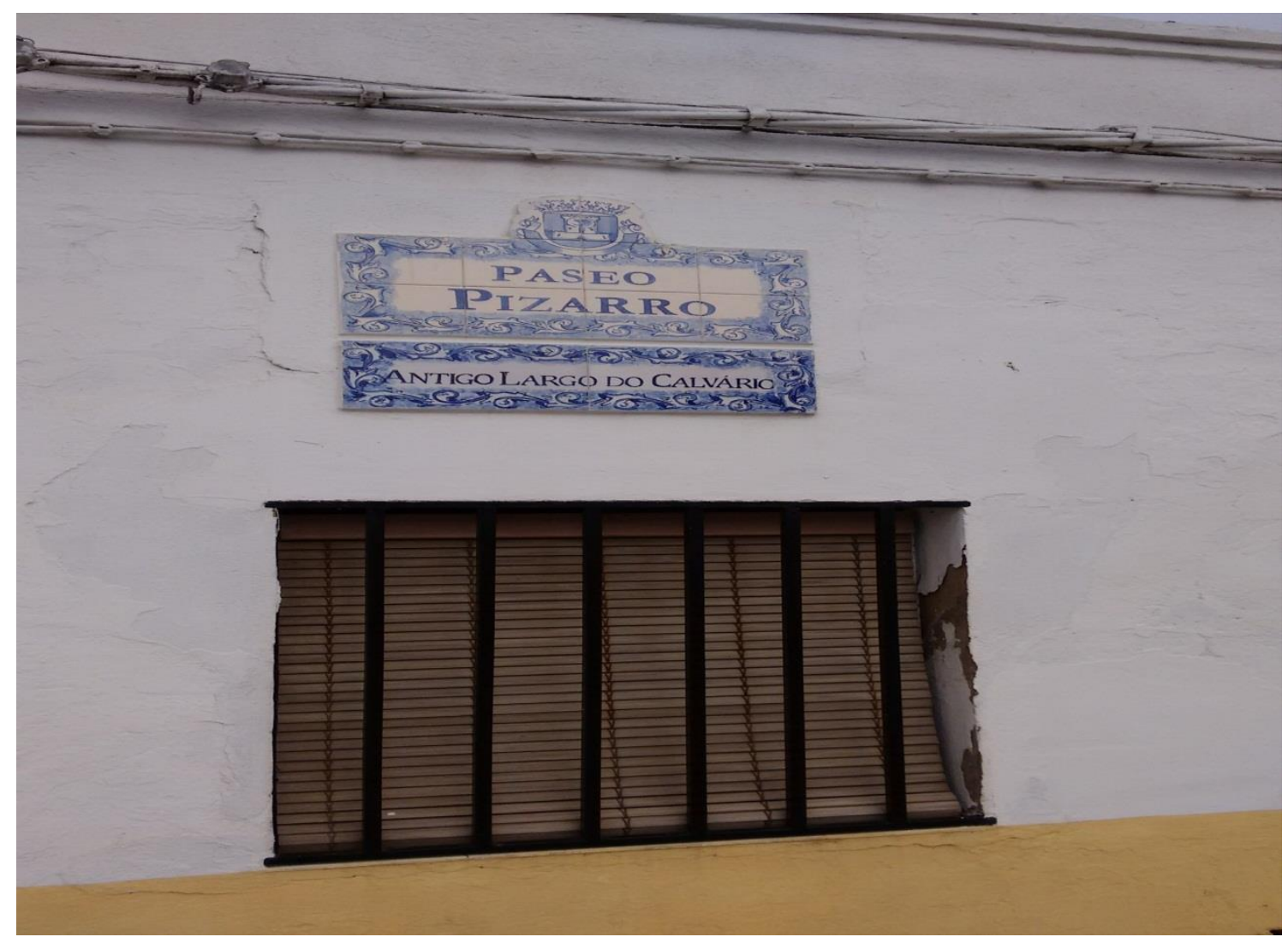

Imagem 31: Placa da rua de Olivença com seu antigo nome português

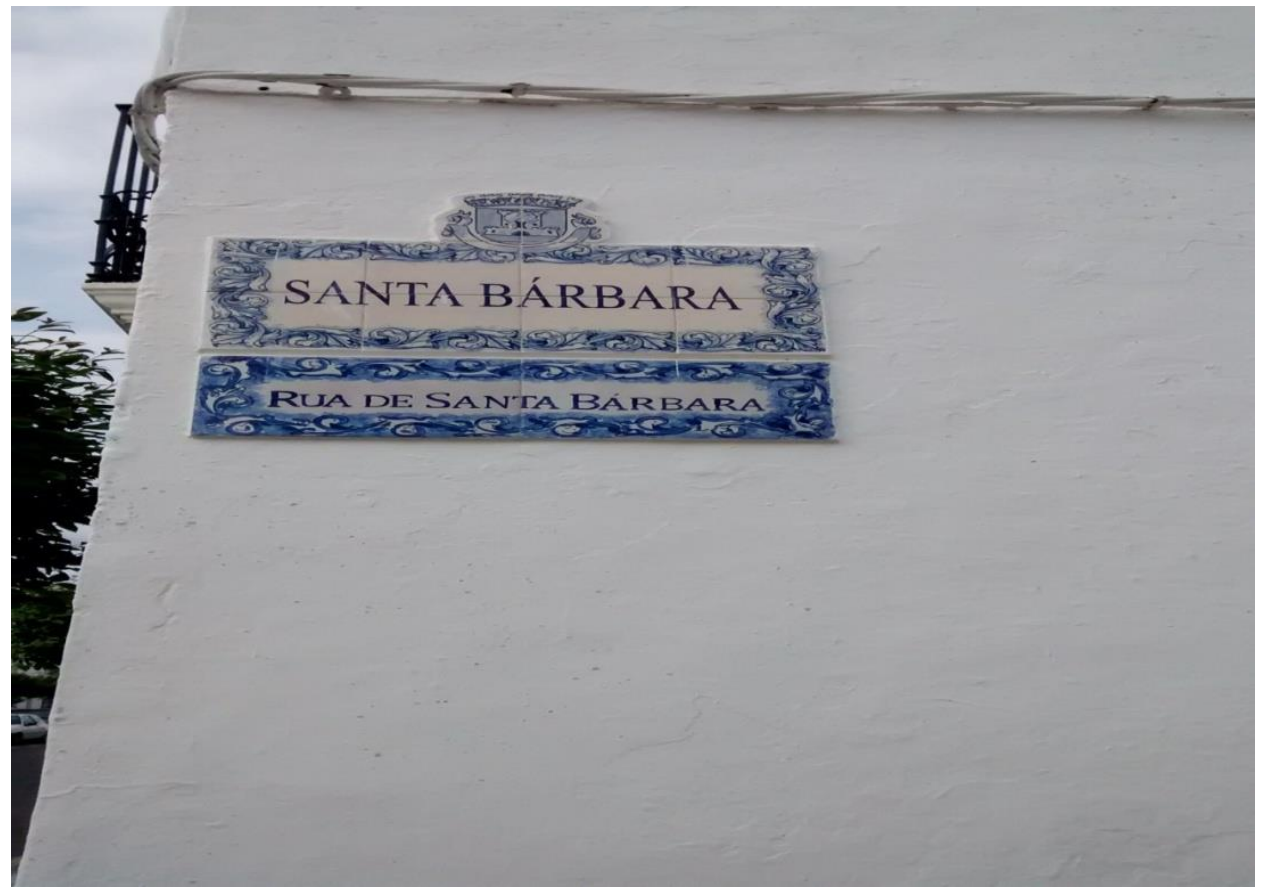

Imagem 32: Placa da rua de Olivença com seu antigo nome português 


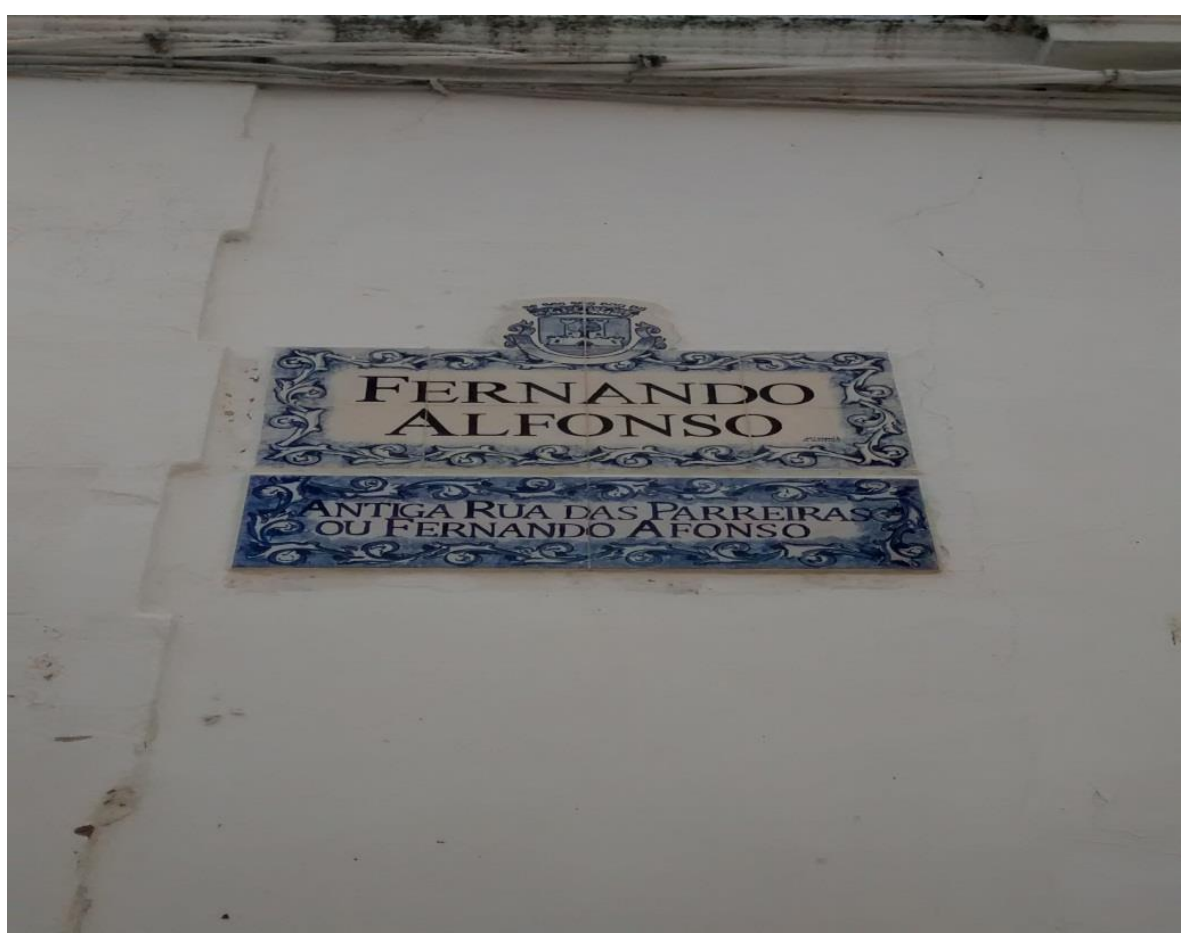

Imagem 33: Placa da rua de Olivença com seu antigo nome português

Como podemos observar na imagem 30, os espanhóis, para não mudar tanto, alteraram o nome da rua para cale "Vasco de Gama", o suficiente para que os portugueses não ficassem satisfeitos e lutassem para sua toponímia original: "Vasco da Gama". A rua "Paseo Pizarro" teve sua toponímia anterior "Antigo Largo do Calvário" restituída. A antiga rua portuguesa "D. Manuel I" foi rebatizada pelos espanhóis de cale "Reyes Catolicos", o que não foi aceito pelo grupo minoritário. Embora tenha sido pequena a alteração dos espanhóis da rua "Santa Bárbara", os portugueses fizeram questão de restaurá-la para seu nome original "Rua de Santa Barbara". A imagem 33 mostra a alteração de cale "Fernando Alfonso" para "Rua das Parreiras ou Fernando Afonso", o que, mais uma vez, causou a indignação dos portugueses em verem a toponímia portuguesa ser apagada.

Diante disso, não é possível negar que, embora o grupo minoritário que vive em Olivença seja oficialmente respaldado por uma orientação cultural espanhola, o sentimento de pertença do PLH caminha pelas ruas da cidade.

Outra constatação que precisávamos fazer era quanto aos nomes dos portugueses, pois, como já é sabido, as famílias portuguesas sempre procuraram preservar os nomes mais comuns a eles, tais como Maria, José, os quais fazem alusão a 
nomes religiosos, e são regidos legalmente em seu país. No entanto, como temos visto na pesquisa histórica, a Espanha impôs que seus nomes fossem alterados, talvez como forma de obscurecer os laços familiares portugueses.

É claro que os documentos que pudessem comprovar tais imposições, não estariam acessíveis a qualquer pessoal, portanto, nos apoiamos em informações dos pesquisadores da história de Olivença, apresentadas no capítulo que trata sobre o locus da pesquisa.

A fim de verificar a situação atual da escolha dos nomes em Olivença, dirigimonos ao Palácio de Justiça, apresentado nas imagens 34 e 35, que é o lugar onde os moradores da cidade registram seus filhos ao nascer.

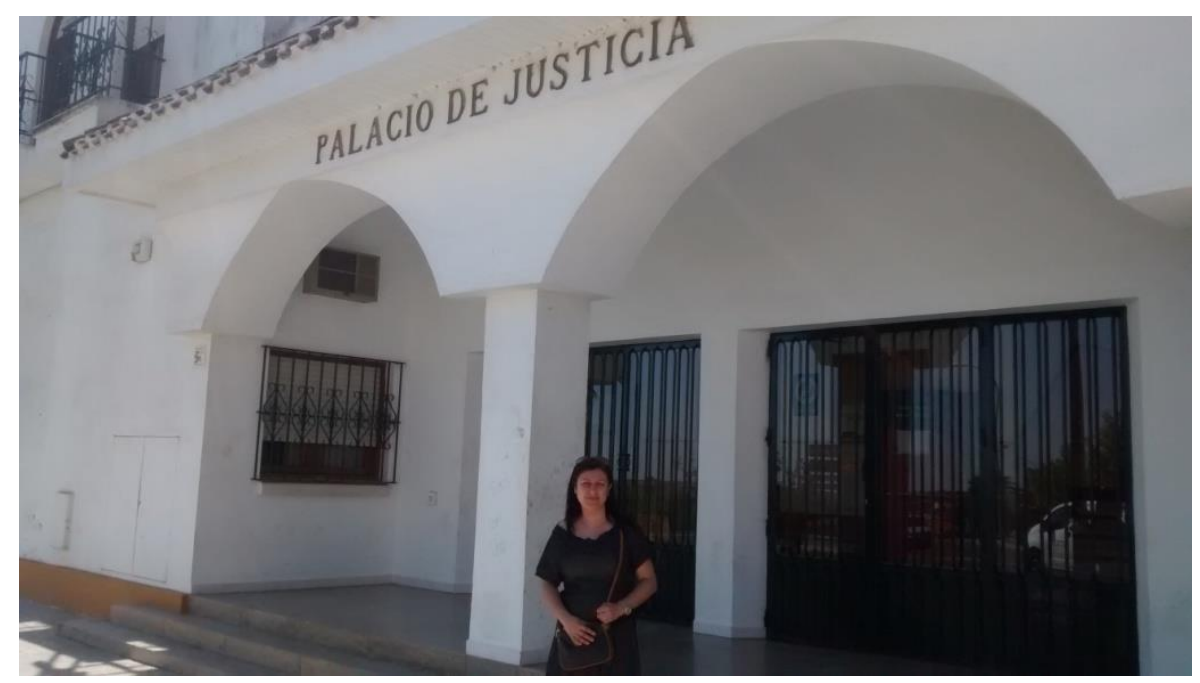

Imagem 34: Palácio de Justiça

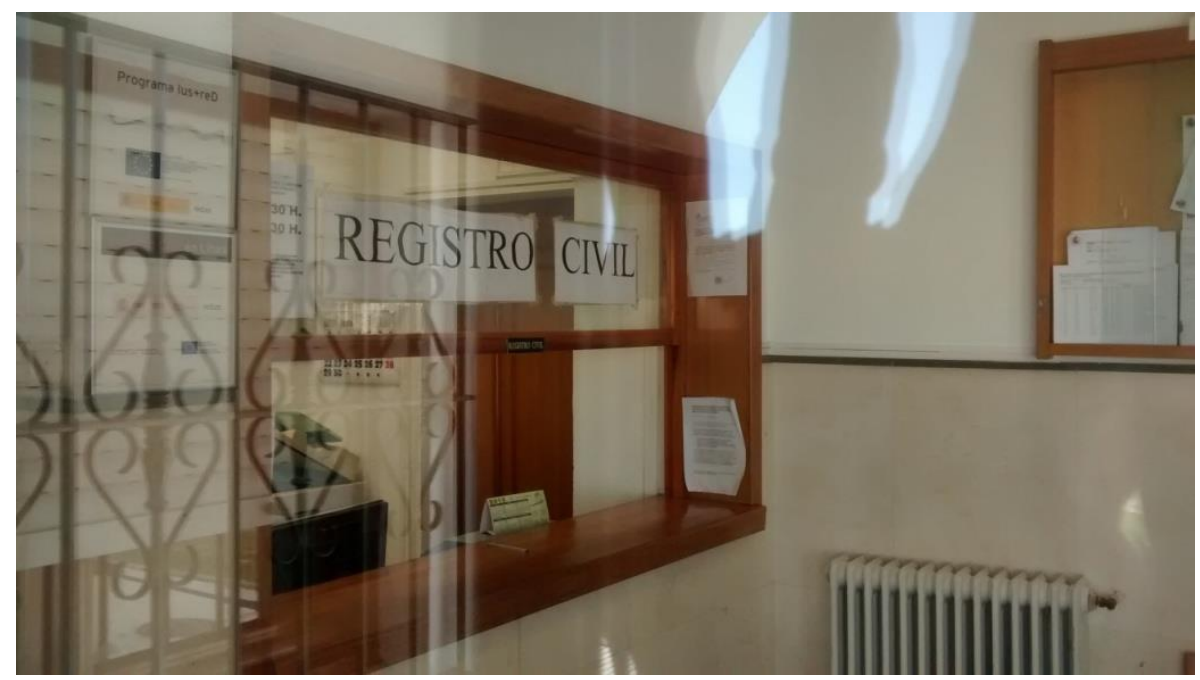

Imagem 35: Palácio de Justiça - parte interna 
Ao adentrar o local, já imaginávamos que não poderiam nos fornecer dados sobre os nomes, registros, entre outros, pelo fato de serem informações de sigilo. No entanto, indagamos ao atendente se havia alguma lista de nomes que não poderiam ser usados pelos moradores, ou seja, se havia alguma restrição para os registros dos utentes. Diante de nossas questões, ele nos informou que não havia lista alguma, mas que nomes esdrúxulos não podem ser registrados. Não conseguimos, no entanto, entender o sentido exato de "esdrúxulo".

Pudemos perceber que, os nomes portugueses, que antes eram evitados, hoje não mais, sendo aceitos normalmente entre os moradores. Durante as entrevistas que realizamos no trabalho de campo, conversamos com algumas alunas descendentes de portugueses, do IES Puente Ajuda, das quais já tratamos no capítulo sobre metodologia, e percebemos que seus nomes eram bem parecidos com os nomes portugueses: Daniela, Ester, Isabel e Ana. De acordo alguns moradores da região, são nomes comuns às duas comunidades.

O que notamos é que os portugueses que vivem em Olivença, mesmo com todo o contato e com a influência espanhola, não optaram por nomes típicos espanhóis, tais como: Alicia, Asunción, Beatriz, Carmem, Guadalupe, Soledad, entre outros. O único que, embora seja bem típico de Portugal, também é apontado como muito comum na Espanha, é Isabel, mas que, normalmente, aparece entre os espanhóis como Maria Isabel.

Além de identificar marcas portuguesas em cartazes publicitários, nos estabelecimentos comerciais, nas placas de rua e nos próprios nomes do oliventinos, fomos ao cemitério da cidade, como evidenciamos na imagem 36. Nossa intenção naquele momento estava centrada em verificar se haveria naquele espaço marcas da LH. 


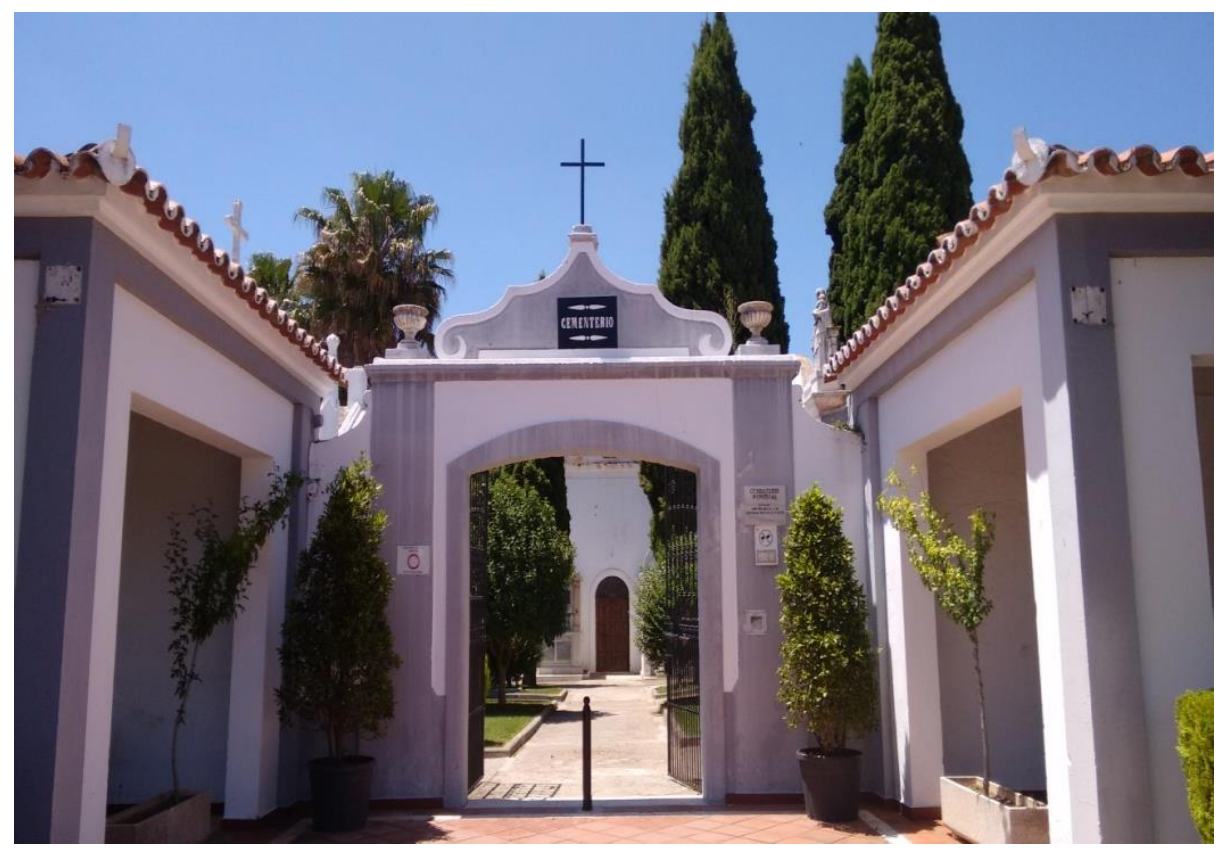

Imagem 36: Cemitério de Olivença.

Nossa hipótese nos conduzia a imaginar que, pelo fato de Olivença ter sido pertencente a Portugal, embora em um número muito reduzido, haveria informações sobre portugueses que residiam na cidade, além de dizeres nas lápides como herança cultural.

No entanto, para nossa surpresa, não foi que ocorreu a despeito de que alguns jazigos eram pertencentes às famílias portuguesas. O que verificamos é que, talvez para não colocar os dizeres em espanhol, alguns jazigos deixam à mostra apenas o nome de família, como podemos verificar nas imagens 37 e 38 :

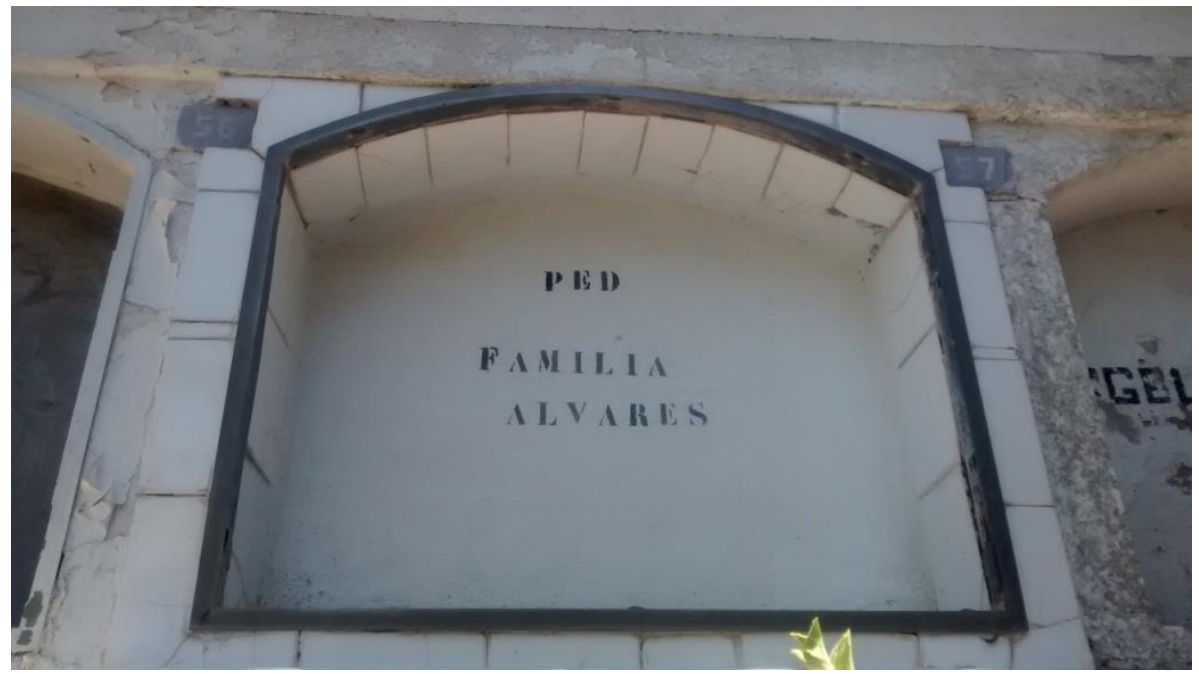

Imagem 37: Jazigo da família Alvares 


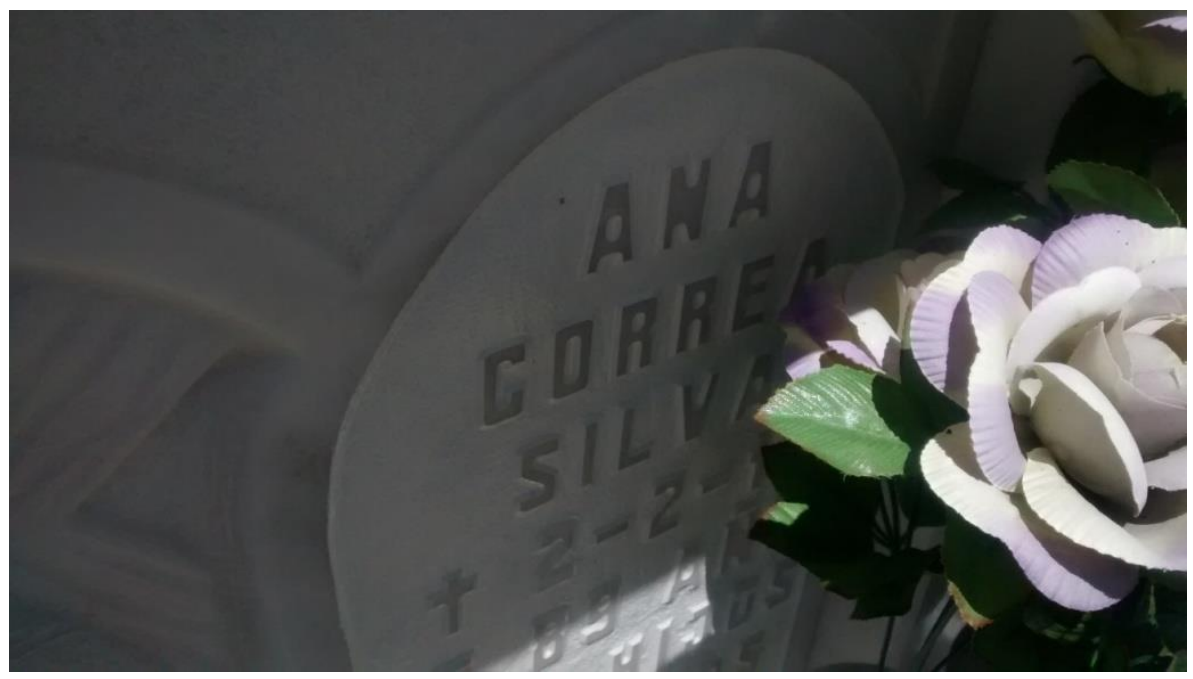

Imagem 38: Jazigo da família Silva

Já na imagem 39, há a foto de um jazigo no qual, pelos nomes e sobrenomes de família, provavelmente, ali se encontra sepultado um português casado com uma espanhola, mas os dizeres estão todos em espanhol:

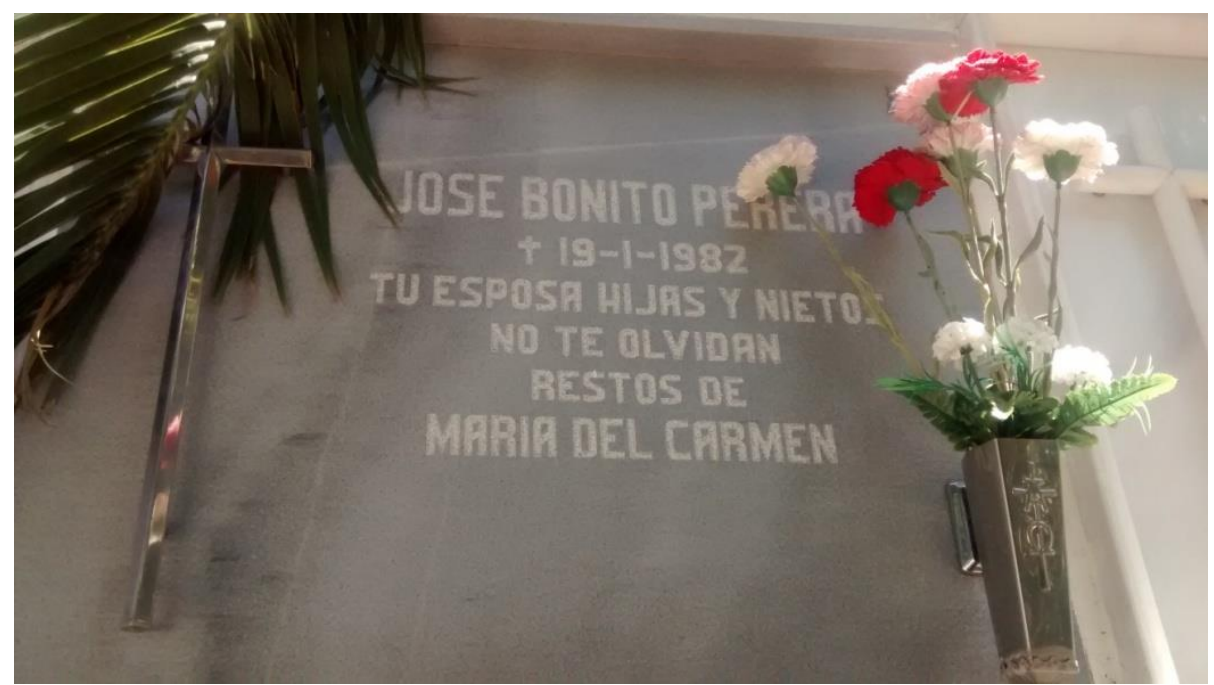

Imagem 39: Jazigo da família Perera

$\mathrm{Na}$ busca pelas pistas de LH no cemitério de Olivença, não pudemos verificar se havia alguma regra para os dizeres dos jazigos, como, por exemplo, se os administradores receberiam apenas os nomes, mas definiriam a escrita. Se fosse esse o caso, certamente seria esse o motivo de todos os escritos estarem registrados em 
espanhol. No entanto, não havia ninguém no local que pudesse nos fornecer informações a respeito disso.

Para nós já não necessitava de muitas pistas mais, pois estávamos certos de que em Olivença as marcas de LH, embora sorrateiras e desapercebidas pela maioria ou por quase todos os moradores, se faziam presentes e ecoando bem alto entre os oliventinos. Isso nos fez postular o sentimento pertença linguística de uma sociedade minoritária, mas que continua na luta para que ela não desapareça.

\subsection{SENTIMENTO DE PERTENÇA DA LH} EM OLIVENÇA:

\section{UM OLHAR PARA CONTEXTO COGNITIVO E SÓCIO INTERACIONAL}

Apresentamos neste capítulo uma discussão sobre o sentimento de pertença da língua portuguesa nativa e da LH dos portugueses que vivem em Olivença através de pistas encontradas nas falas e comportamentos dos entrevistados. Nosso olhar será guiado pelos postulados teóricos dos quais partimos, apresentados nos capítulos precedentes. Assumimos que nem sempre o sentido está apenas nas palavras, mas em todo o contexto situacional, sendo, muitas vezes, influenciado pelo contexto. Além disso, prestaremos atenção aos níveis de consciência dos entrevistados, utilizando estratégias para avaliar tomadas de decisões com ou sem ter "consciência" dessa atitude. 


\subsubsection{Uma análise linguística de base qualitativa}

Uma pesquisa com base metodológica pautada em registro de entrevistas pode fornecer ao pesquisador uma gama de sinais e elementos que resultam grande importância qualitativa, razão pela qual - lidar com opiniões e subjetividades situa-se longe de ser considerada simples e superficial. Alguns cuidados, no entanto, devem ser planejados porque é preciso estar atento não só aos usos linguísticos explicitados (e por isso mesmo visíveis), mas a todos os demais elementos que não estão codificados em termos de língua falada, mas que estão implícitos na fala e, até mesmo, no comportamento de cada entrevistado.

Alguns autores que lidam com trabalhos de pesquisa num viés qualitativo se mostram preocupados com o desprestígio que muitos podem ter por se deter na análise adicional de comportamentos e atitudes. Por outro lado, há pesquisadores, como Alves e Silva (1992), que têm apresentado a necessidade de que esses tipos de pesquisa mantenham o rigor e a sistematização. De acordo com essas autoras, para que o pesquisador extraia informações importantes, é necessário um olhar atento e um envolvimento com todo o contexto discursivo. Nesse sentido, só quem participa do trabalho de campo é que pode depreender a lógica de codificação intencional ou não, extraindo dali as informações pertinentes.

Procuraremos, nesta seção, apresentar com clareza as informações colhidas, descrevendo o modo como recolhemos as pistas que nos muniram de elementos atitudinais conscientes ou não. Essa recolha se deu de forma precisa, não obscura e não ambígua, porque, a priori, fortalecemos os procedimentos em campo com a identificação de atuação das máximas da Qualidade e do Modo, tal como propôs Grice (1982), cuja essência de ideias já foi exposta no capítulo sobre a fundamentação teórica.

Por se tratar de uma pesquisa de campo na qual um dos objetos de estudo é a fala registrada durante entrevistas em áudio, não poderíamos ignorar os pressupostos teóricos da sociolinguística interacional, a qual não foca apenas em variáveis sociais e no sentido explícito das palavras, mas em todo o contexto em que a fala está inserida. Para apresentarmos essa análise, retomaremos aqui, de forma resumida, alguns dos conceitos mais importantes. 
Relembremos de que Goffman (1998) propõe aos pesquisadores que trabalham com a língua num processo interacional a atenção focada não só no comportamento linguístico em si, mas nas características mais expressivas presentes no discurso. Para o autor, o processo de interação face a face não envolve só o falante e o que ele diz, mas todo o contexto e uma série de pistas que não podem ser ignoradas durante a conversa num enquadramento mais amplo. Nesse sentido, lidar com paradoxos durante o ato comunicativo, tal como orienta Bateson (1998), assegura a necessidade de que o pesquisador também tenha um olhar para todo o contexto, chamado por ele como 'enquadre/frame' discursivo.

A importância de uma atitude proativa para esse enquadre por parte do entrevistador pode, muitas vezes, garantir uma interpretação mais justa dos dados, pois, certamente, reunirá mais elementos para ligar as pistas isoladas. Essa atitude, segundo Knapp (1999), evita alguns problemas que uma pesquisa pode vir a ter por falta de conhecimento da realidade dos fatos e do frame em que essa realidade é tecida.

Bateson, Goffman e Knapp, cada uma a seu tempo, fortaleceram o que Grice demonstrou no passado e o que Gumperz (1998) tratou em termos "pistas de contextualização". Sob esse rótulo estão as cautelas que devem munir o cientista da linguagem durante o exercício de apreender interpretadas ao largo de fatos confusas ou divergentes.

Ocorre que, no processo comunicativo, tal como Erickson e Shultz (1998) apresentam, muitas pessoas podem ser rotuladas como tendo um 'mal comportamento'. A explicação para essa avaliação aparentemente despropositada diz respeito à inocência de se supor que o emissor e o receptor encerram o jogo comunicativo. Esses autores, trabalhado com métodos de pesquisa que priorizam o contexto social do processo interativo da comunicação, consideram que o contexto não se trata apenas de um lugar, mas "se constitui pelo que as pessoas estão fazendo a cada instante e por onde e quando elas fazem o que fazem" (Erickson e Shultz, 1998:143). Além disso, as alterações proxêmicas $^{148}$ e de posturas de sinais emitidos entre os participantes dos "atos linguísticos" ocorrem de "momento a momento", num contexto de "mundos possíveis".

\footnotetext{
${ }^{148} \mathrm{O}$ autor classifica alterações proxêmicas como mudanças na distância interpessoal entre falantes.
} 
É objetivo, então, descrever as informações que, na perspectiva de Grice (1982), sustentaram "Princípio de Cooperação", em suas instâncias baseada em máximas: de Quantidade, Qualidade, Relação e Modo. Mesmo que alguns elementos estejam escondidos em dobras discursivas, ou seja, configurem-se como implicaturas conversacionais, ainda assim fornecerão informações necessárias para uma interação discursiva produtiva, pois implicar - é sempre bom ter em mente - é sempre bom ter em mente - pressupõe o exercício de inferir com base em todo o enquadre contextual.

É certo que avaliar o que é relevante pode denunciar uma perspectiva. E nem toda perspectiva converge, como bem lembra Dascal (1982): o que é relevante para um, pode ser apenas marginalmente relevante para o outro, e essa seleção depende de recursos pragmáticos, chamados por ele de background. É justamente esse instância da análise que permitirá avaliar estágios de consciência da mente. Para isso, recorreremos às contribuições de Damásio (2008; 2011), que alerta para a possibilidade de haver interação entre os seres humanos e mesmo tomarem atitudes sem que haja consciência, e é nesse ponto que entram questões de grande interesse para os que lidam com ações que dependem de um plano consciente, tal como os processos de interação comunicativa.

Apresentar conclusões sobre o outro não é um trabalho simples e muito menos descompromissado e, portanto, sabemos que nem sempre é possível identificar tudo de forma minuciosa, mas procuraremos ser claros e objetivos na identificação dos traços das informações identificadas não só nas palavras, mas no comportamento de nossos entrevistados. 


\subsubsection{O sentimento de pertença - uma análise face a face com os imigrantes portugueses}

\section{Entrevistado 1 (FR) - 39 anos}

Realizamos a primeira entrevista com o informante $1(\mathrm{FR})^{149} \mathrm{em}$ seu ambiente de trabalho, em um momento autorizado por seu patrão. No início desse contato, apresentou-se de forma tímida e hesitante. No entanto, pelo fato de que os "atos linguísticos" ocorrem de momento a momento, tal como propõem Erickson e Shultz (1998), percebemos que, após nos identificarmos, e ele perceber que seria uma conversa apenas sobre sua rotina, tornou-se um pouco menos apreensivo, apresentando cada vez mais espontaneidade no decorrer da entrevista.

No primeiro momento de conversa, o entrevistado, por ser informado que estávamos interessados em saber sobre a vida dos imigrantes portugueses em Olivença, nos deixa claro que tem sentimento de pertença ao seu país:

Entrevistado 1: a gente vai, a gente mudaaaaa de paif mudaaa os nossof hábitof principalmente por causa do dinheiro, eu tô convencido qui ninguém gosta de deixar o paí em que nasceu.

No trecho seguinte, o entrevistado afirma não utilizar a língua portuguesa no seu dia a dia, nem mesmo em seu ambiente familiar, que atualmente é formado por uma esposa e enteados espanhóis:

Entrevistador: você só fala em espanhol?

Entrevistado 1: si

Entrevistador: você acha que quando você conversa com ela espanhol éhh...você fala só espanhol ou você acaba falando português também? Entrevistado 1: não! não! só ifpanhol só ifpanhol só ifpanhol

\footnotetext{
149 O informante tem 39 anos, é da cidade de Elvas, Portugal e vive em Olivença há 10 anos. Quando vivia em Portugal era casado com uma portuguesa com a qual teve um filho, que hoje vive com a mãe. Atualmente vive com uma espanhola e vê seu filho nos dias de folga. Trabalha como cozinheiro em um restaurante de proprietários chineses. Os pratos são variados, sendo alguns deles parecidos com os pratos típicos de Portugal, tais como pratos à base de carne de porco.
} 
Pudemos notar que, por mais que o informante não use a língua portuguesa no seu dia a dia, transmitiu em seu discurso um sentimento de pertença à comunidade portuguesa. Nesses momentos, era claro o desejo de que a LH não fosse excluída de seu convívio, reconhecendo-a como o elo com seu grupo étnico. Vejamos uma evidência disso:

Entrevistador: se você tivesse um filho com ela, o que faria? Qual a língua que você falaria com o seu filho, espanhol?

Entrevistado 1: ah tinha, tinha que aprender as duaf com certeza... [risada]

Entrevistador: iria ensinar as duas??

Entrevistado 1: Certeza mesmo, teria que apreender a falar purtuguêf. [Aqui, o informante se referia à necessidade de ensinar o português aos filhos hipotéticos]

A fala do entrevistado marca um sentimento de preservação da LH, o uso do advérbio 'certeza' atesta seu sentimento de resiliência às marcas de seu grupo étnico. Como forma de deixar bem clara esta afirmação, não abandona as categorias da Quantidade, através da máxima "fazer contribuição informativa o suficiente para a compreensão", da Qualidade, através da máxima "não dizer o que pensa ser falso", da Relevância, através da única máxima "Seja relevante" e da categoria Modo, através da máxima "não produzir elocuções ambíguas" (Grice, 1982:87):

(i) respeito à categoria Quantidade: o entrevistado fala somente o necessário, pois seu objetivo é que o sentido “eu preservo a língua” seja compreendido claramente;

(ii) respeito à categoria Qualidade: o entrevistado não permite que sua fala apresente qualquer indício de dúvida e para isso, lança no discurso: “com certeza";

(iii) respeito à categoria Relevância: o entrevistado preserva o tópico proposto pelo entrevistador "uso da LH";

(iv) respeito à categoria Modo: sua elocução é extremamente objetiva para que não haja ambiguidade de sentido. 
No trecho seguinte, expõe que deixou seu país de origem para viver na Espanha apenas a trabalho, justificando que hoje a Espanha não está muito melhor nem mesmo nesse aspecto:

Entrevistado 1: principalmente isso, foi uma das grandef ... na Ifpanha ganha-se melhor re aaa na altura há dez anuf havia maif trabalho também agora tá quase igual a Purtugal, mas na altura havia muito mais trabalho mais bem pago.

O que pudemos inferir na fala do entrevistado 1 é a necessidade de assegurar ao entrevistador que o único motivo que o fez sair de seu país foi a busca de melhores condições de trabalho, o sentimento de que gosta de seu país fica evidente.

O entrevistado tem um filho com sua ex-esposa portuguesa, e fornece-nos a informação de que utiliza sua LH somente quando entra em contato com sua família (pais, filho, ex-esposa):

Entrevistado 1: aí eu falo purtuguêf com ele prontu quando é família falo purtuguêf, aqui nem lembro do purtuguêf àf vezif tô tô a falar sozinho na cozinha e tô a falar ifpanhol...(risadas).

Ao ser perguntado, novamente, se fala algo em português no seu dia a dia, a resposta é enfática:

Entrevistado 1: Não! Não, só ifpanhol, só ifpanhol, só ifpanhol Entrevistador: nem sotaque nem o som? Nada?

Entrevistado1: ... não, não.

No entanto, como já temos visto, nem sempre as palavras dizem o que realmente o falante sente, e isto nos foi permitido perceber pelas "pistas de contextualização" (Gumperz, 1998:100) deixadas no início da conversa, pois o sentimento de pertença ao seu país era muito positivo para que excluísse a LH totalmente no seu dia a dia. Pressupomos que o abandono da categoria da Qualidade, através da supermáxima: "trate de fazer uma contribuição que seja verdadeira" (Grice, 1982:87), ocorre de forma involuntária, sendo corrigida após alguns minutos de conversa:

Entrevistador: quando você está, é no seu dia a dia a sua língua é só espanhol?

Entrevistado 1: issuu...sim noventa por cento sim

Pelo fato de ter abandonado no início da conversa tal categoria, foi necessário o uso das implicaturas conversacionais para compreendermos que o informante, mesmo 
que de forma involuntária, tinha consciência do uso da língua portugesa, não sendo mais incisivo em dizer que não fala português, mas que a usa, mesmo com baixa frequência.

Tal informante, classificado por nós como integrante do estágio de self central (Damásio, 2011:225), por articular mecanicamente português-espanhol (falante bilíngue) é capaz de fazer uso da língua da sociedade receptora sem perder ou deixar que essa interfira na sua língua nativa. Percebe que, muitas vezes, em momentos isolados, ou seja, provavelmente em estágio de protosself (Damásio, 2011:225). Ele próprio reconhece o fato:

Entrevistado 1: muito muito pouco, muito pouco, por ixemplo, principalmente, sei lá, por exemplo, acabar de falare ao tufone com minha mãe, tô a falar purtuguês e aparecer alguém a perguntar-me qualquer coisa, sou capaz de continuar a falar purtuguêf

O sentimento de inferioridade linguística do falante de português é latente. De forma, muitas vezes, inconsciente (protosself) revela uma certa contradição, com o abandono da categoria da Qualidade, entre o que diz e o que deixa transparecer. Percebemos isso na fala abaixo, pois acaba propondo que são os espanhóis que se acham superiores e não eles (os portugueses) que se sentem inferiores:

Entrevistado 1: não só penso que 'stou mais garrados a língua dele〕 não se querem rebaixar a mesmo que um dentro do paíf não se querem rebaixar a ao purtuguêf eles continuam querer a falar ifpanhol

Em um trecho seguinte, mais uma vez, abandona a categoria da Qualidade, através da supermáxima: "trate de fazer uma contribuição que seja verdadeira" (Grice, 1982:87), pois ao ser questionado se os espanhóis se sentem superiores aos portugueses, seu discurso se torna contraditório, pois diz que "não", no entanto, pela sua hesitação, percebemos que se trata de uma atitude conversacional para se eximir de uma opinião contra um grupo que hoje convive:

Entrevistado 1: os ifpanhois não tanto é mais humm é maif a língua por dipoif não são, os ifpanhois são são pissoaf bastante alegref baftante memo no paif (...) paíf a Ifpanha há muitas festaf há muito qualquer coisa resolvi fazer uma festa pra fazer um baile pra sair à rua principalmente no verão não é?? ih somo é difr'enti não são tão rígidof nem são tão nem sentem tão superiore $\int$ como os ingleses, por 
ixemplo, o ingleses sente muito acima não é? e pronto, mas uf ifpanhóis memo assim não é tão...

Implicatura: $O$ falante acredita que os espanhóis se sentem superiores, no entanto, não diz claramente por conviver com a comunidade.

Além do abandono da categoria da Qualidade, o informante ainda abandona a categoria da Quantidade, através da supermáxima: "fazer contribuição informativa o suficiente para a compreensão", e a categoria Modo, através das máximas: "não produzir elocuções ambíguas; evitar expressões desnecessárias e ser ordenado”.

(i) abandono da categoria da Qualidade ocorre pelo fato de produzir uma elocução sem uma verdade clara, obrigando-nos utilizar as implicaturas conversacionais para compreender a informação.

(ii) abandono da categoria da Quantidade ocorre pelo fato de produzir uma elocução com um discurso além do que foi perguntado, tornando seu discurso mais confuso pelo excesso de informação.

(iii) abandono da categoria Modo ocorre pelo fato de produzir uma elocução com um discurso ambíguo, obscuro, com expressões desnecessárias, e não ordenadas. Para que pudéssemos compreender toda a proposição, tivemos que utilizar todo o contexto comunicativo, caso contrário, não saberíamos se ele acha que se consideram superiores ou não.

O entrevistado revela-se convicto de que a única forma de manter seu vínculo familiar é através da LH. Vejamos um trecho da entrevista que ratifica nossa afirmação:

Entrevistado 1: sempre, sempre por a gente não sabe o dia de amanhã, se essa, essa criança pode querer ir ao paíf onde vive o pai, e chega lá $i$, (intervenção) não consegue comunicar com os paif do pai não consegue comu... falar com of avóf não consegue o que é uma pena.

Durante a conversa, mais uma vez, devido o abandono da categoria da Quantidade, ao ser questionado se seus pais falavam espanhol, o informante torna sua 
elocução um pouco confusa por produzir um discurso sem a máxima "não fazer contribuição além do necessário"150:

Entrevistado 1: hum quase nada, são já pissoaf mais, pissoaf maif velhas e não não perderam tempo a querer aprender a essa língua, por exemplo meu pai, o meu pai agora tá reformado também já, mas como era caminhonista e fazia Alemanha, França e esses paíf, pronto se conhece a Europa toda meu pai conhece a Europa toda

Entrevistador: é mais aberto né?

Entrevistado 1: é maif sim mas o (...) o ifpanhol ele fala o ifpanhol, ele fala ele in, mas o resto das línguas não...(risadas)...não, perde-se muito e não é normal e oo

Ao ser questionado sobre a influência do espanhol na sua língua, o informante, de forma incisiva, diz que não houve nenhuma, no entanto, mais uma vez, abandona a categoria da Quantidade, mas não prejudicando o sentido:

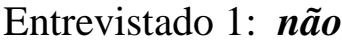

\section{$(\ldots)$}

Entrevistado 1: não!não!não, falo purtuguêe, falo purtuguêf comu como sempre, não, não, não, não, ah tá, a gente tem o hábitu di, a gente tem o hábitu diii, tare com o ifpanhol, constantemente, todo o dia, opção todo é todo dia aqui no trabalho, tem que falar ifpanhol, $e$ como vivo aqui chega casa falo ifpanhol, porque se não tentar a

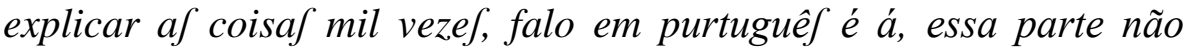
pircibi, então peraí que eu digo ifpanhol.

Como podemos notar, o falante tem preservado como tópico a informação da categoria Relevância, pois o que tem mais importância para ele é apresentado de forma incisiva, sendo complementada com o restante da elocução.

Uma de nossas hipóteses prévias constituía-se no fato de que, por viverem na fronteira, os portugueses estariam mais propensos a preservarem sua LH e o sentimento de pertença por estarem mais próximos de seu grupo étnico. Ao perguntarmos sobre a relação dos portugueses que vivem em Olivença com Portugal, por viverem na fronteira, obtivemos a seguinte resposta:

\footnotetext{
${ }^{150}$ De acordo com Grice (1982) o abandono dessa máxima é questionável, pois nem sempre o abandono dela implica em transgressão. Nesse caso apresentado, o sentido não fica prejudicado, porém exige mais atenção para a compreensão da resposta.
} 
Entrevistado 1: ãa, pra quem vive na fronteira sim, pra quem vive na fronteira é, é purque tamos muito...

Entrevistador: Muito próximos?

Entrevistado 1: muito habituados, muito perto, 'stamos sempre, os purtuguese vêm muito à Ifpanha, ifpanhóis vão, vão muito a Portugal, tão tamos, memo, memo vivendo só em Purtugal, tamos habituados ao ifpanhol, por cá, sempre se usa o ifpanhol, é é em Elvas pur ixemplo...

O que pudemos perceber é que, o fato de viverem na fronteira, permite argumentar que sente seus laços mais firmes por estar perto de seu grupo, no trecho apresentado, transmite o sentido de uma relação de comum troca entre ambos os países.

No entanto, como já temos apresentado na introdução desta tese, a relação fronteiriça não parece ser propícia para trocas amistosas e sem disputas por lugares, e o informante confirma nossa hipótese na elocução que segue:

Entrevistado 1: Então, a gente pode é responder em purtuguêf (...)então cá pissoaf lá, que, não não responde ifpanhol, não sabe ou não querem responder em ispanhol, então já eles deduziam, precebem ou não precebe, (...), não há hipótese. Mas prontof, quase sempre que a gente vive sempre ifpanhol, a gente vive com a língua. Pra nós, que aqui pra dentro da IJpanha, maif pra dentro de IJpanha, é indiferente, porque, como continuamos a falar ifpanhol, já sem falar, prontu, do catalão, pro ixemplo, tô, tô dentro de Ifpanha, maif eu $i$, i embora o catalão tem um rocisinho com o purtuguêf, su, se us catalãos falarem divagarinho, num pausado, há muita palavra, parecida caf purtuguesaf, muita, é mas já, já isso já foge muitaaa aof termos habituados, mai, mai nem os ifpanhóif percebem o que elef dizem, nem os, nem os ifpanhóis percebem o que eles dizem!

Implicatura: caso os espanhóis façam perguntas aos portugueses, eles respondem em português. A língua de cada grupo é mantida, mesmo sabendo falar o idioma do outro grupo - a preservação fronteiriça.

Ocorre que, pelo fato do abandono das categorias da Quantidade, através da máxima "fazer contribuição informativa o suficiente para a compreensão", a elocução se torna confusa, atrapalhando a compreensão. O que podemos perceber na fala é que a língua é o grande marcador de diferença entre ambos os grupos étnicos, e há uma disputa entre elas: se é português, fala português. 
Quase no término da entrevista, o informante passa a falar de um primo que está estudando no Brasil. Nesse momento, é interrompido pelos filhos de seus patrões (duas crianças chinesas), o que nos chamou a atenção, pois houve ali uma mudança de contexto, mudando a categoria Relevância. O que ocorre é que no processo de interação discursiva, as reações do outro diante de uma exigência, são normalmente comandadas por 'aquilo que é topicamente relevante' (Dascal, 1982:115).

O fato da atividade discursiva ser um processo dinâmico, o surgimento de um tópico novo, pode se tornar uma exigência para a transferência da Relevância, sem, no entanto, ser necessário o uso de implicaturas.

Nesse caso, de imediato, transferimos a Relevância conversacional para a fala das crianças, perguntando se elas falavam espanhol. No entanto, como já temos apresentado, muitas vezes, de forma não intencional, o estímulo para a mudança da categoria relevante não é aceita, sendo apenas 'marginalmente relevante' para o falante, tal como propõe (Dascal 1982). Podemos notar que, o entrevistado, ignorando a presença das crianças e a pergunta do entrevistador, opta em permanecer no discurso anterior:

Entrevistador: Eu agradeço a sua entrevista, vai me ajudar muito no trabalho, e estamos abertos no Brasil pra vocês irem lá também, pra conhecer...

Entrevistado 1: Eu tenho, tenho lá, agora tenho lá um primo meu, também da Universidade a fazer um trabalho lá!

(aparece um menino brincando com o entrevistado)

Entrevistador: Ai que lindo! ((risadas)) ai que fofo (...) moram na China? Não percebem nada de espanhol...não?

Entrevistado: $i$ ele tá lá fazem, $i$ ele tá lá fazendo um trabalho também. [se refere ao primo que está no Brasil]

(falas sobre as crianças)... não, não fala nem ifpanhol nem purtuguêf, já tá lá há muito tempo, veio de férias só.

Como temos visto, em toda a análise apresentada, o contexto interacional em que o discurso ocorre é rico e favorece uma série de inferências e interpretações não observadas apenas nas palavras, mas em todo o 'enquadre/frame' discursivo (Bateson, 1998:57). 


\section{Entrevistada $2(\mathbf{R S})-38$ anos}

A entrevista que realizamos com a informante $2(\mathrm{RS})^{151}$ também se deu em seu ambiente de trabalho, em um momento autorizado por seu patrão. Enquanto aguardávamos o momento ideal, uma funcionária nos avisou para que aguardássemos um pouco, pois ela estava se arrumando.

A partir dessa informação, implicamos que, para nossa entrevistada, o momento seria de grande formalidade, seriedade e, portanto, de não espontaneidade. Embora tenha nos recebido de forma educada, pudemos notar que estava nervosa e muito ansiosa com a entrevista.

A importância de um olhar para todas as pistas contextuais se faz muito necessário para a compreensão das falas e até mesmo das atitudes tomadas pela entrevistada. Um momento que represente um desconforto ou algo forçado e excessivamente formal pode fazer com que o falante deixe até mesmo de fornecer informações importantes para o pesquisador.

Para essa entrevista estávamos somente nós duas (a entrevistadora e a entrevistada 2), o que tornou mais difícil ainda para a fluidez do discurso, pois causou à informante a sensação de um trabalho de muita seriedade de fala. Tal impressão nos foi comprovada por percebermos que a entrevistada 2 (RS) se limitava em responder as perguntas com, praticamente, "sim" ou "não" apenas.

Entrevistador: você fala espanhol?

Entrevistada 2: si

Entrevistador: fluente? É, éé

Entrevistada 2: si

Entrevistador: fala ... aqui você só conversa em espanhol?

\footnotetext{
${ }^{151}$ A informante tem 38 anos, nasceu na cidade de Elvas, Portugal, e vive em Olivença há 14 anos. É casada com um português e tem dois filhos que vivem com ela e falam a LH em casa. Trabalha como cozinheira em um restaurante de proprietários espanhóis. O restaurante serve tanto pratos portugueses, como o "bacalhau português", como pratos todos típicos da Espanha.
} 


\section{(...)}

Entrevistador: eles estudam aqui em escola pública?

Entrevistada 2: si

A informante, embora viva há 14 anos na cidade de Olivença, mantém suas características culturais preservadas e, em seu ambiente familiar, conserva também a LH:

Entrevistada 2: em casa só falamu؟ purtuguêf!!!

Entrevistador: só falam português?

Entrevistada 2: só em purtuguêf

\section{$(\ldots)$}

Entrevistada 2: coas amigaf, em casa só em purtuguêf, em casa não se fala a não ser purtuguêf! [a entrevistada se refere a filha que fala com as amigas em espanhol, mas em casa português]

A ênfase dada para a elocução "em casa só falamus purtuguêf!!!" deixa-nos a pista contextual de que falar português é muito importante para ela. Não podemos negar que o sentimento de pertença linguística entre os informantes até aqui descritos é algo intrínseco.

O fato de responder tão enfaticamente a uma simples pergunta leva-nos a postular um "provável interesse epistêmico do pesquisador" (Schwarz, 1999:96), pois a informante, por saber que somos brasileiros, falantes do mesmo idioma, faz questão de exaltar seu uso entre o ambiente familiar. Seus filhos são falantes bilíngues, falando a LH em casa e o espanhol na escola e entre os amigos.

A informante, também classificada por nós como integrante do estágio de self central (Damásio, 2011:225), articula mecanicamente português-espanhol (falante bilíngue) é capaz de utilizar ambas as línguas com pouca interferência de uma na outra.

A entrevistada veio com seu marido para Olivença somente a trabalho, deixando claro que sua ligação com sua família é frequente:

Entrevistador: ééé vocês, é seus filhos têm contato com os portugueses? 
Entrevistada 2: todu $u \int$ finf de semana vão

$$
\text { (...) }
$$

Entrevistador: aí veio pra cááá?

Entrevistada 2: pra trabalhar, arranjar um trabalhinho fiquei aquii, $i$ prontu, $i$ aqui levamos a nossa vida, muito mió do qui ali..em Purtugal taji muitaa

Durante toda a conversa, as repostas eram com poucas palavras, praticamente truncadas e não espontâneas. Na tentativa de que a informante nos fornecesse elocuções mais completas, muitas vezes repetíamos a pergunta, no entanto, a conversa não passava do acréscimo de algumas palavras, como podemos observar no trecho abaixo:

Entrevistador: u u seus filhos já... então, nasceram aqui?

Entrevistada 2: Já. Não querem ir a Purtugal

Entrevistador: não querem ir pra Portugal?

Entrevistada 2: vão trêf diaf, passar três diaf, já diz: ah mãe, vem me bufcar

Entrevistador: seus pais moram lá?

Entrevistada 2: mora

Entrevistador: sua família toda é de lá?

Entrevistada 2: toda, toda, toda

Reconhecemos que a entrevistada estava num estado de tensão e nervosismo por se tratar de uma entrevista "formal" e que em sua mente era algo muito sério, limitandose em nos responder apenas o necessário.

O não abandono da categoria da Quantidade, através das máximas "fazer contribuição informativa o suficiente para a compreensão" e "não fazer contribuição além do necessário", foi, neste caso, um recurso utilizado pela preocupação em expor uma elocução que não agrade a entrevistadora ou que ela considere "incorreta". Neste caso, também podemos falar em uma inferência do "provável interesse epistêmico do pesquisador" (Schwarz, 1999:96). 
A informante, embora não seja de uma geração de muita idade, pode ser base para ratificar uma de nossas hipóteses iniciais, de que entre os falantes mais velhos a língua portuguesa seria preservada, mesmo que esteja por muitos anos em contato com outra. Falantes de uma língua nativa ou LH, mesmo que não percebam, trazem consigo uma herança cultural que não se apaga com o tempo ou lugar.

Os filhos dessa geração já não sentem a LH como seus pais, não a usam como eles, porém, se sentem parte desse grupo de falantes, e por mais que estejam envolvidos com seu país de nascimento, acabam fazendo uso da língua de seus familiares. Isso se confirma com a fala em que assegura o sentimento pelas raízes e a necessidade do uso e preservação da LH:

Entrevistada 2: mó que passamos da porta pra dentro, acabou-se Ifpanha, só purtuguêf, purque si não perdemooss o toque..

Nossa entrevistada 2 nos informou que muitos espanhóis falam o português pelas ruas, assegurando o quanto sua LH tem se tornado importante em Olivença. Embora não tenhamos nos deparado com a situação proposta pela informante, percebemos já existir uma movimentação muito grande para o ensino de Língua Portuguesa. Tal fator se deve ao sentimento de LH entre os portugueses oliventinos.

Entrevistada 2: aqui é tudo, mesmo, mesmo na rua a i tudo há muitas pissoaf, passam pela ruaf e ouçam falare purtuguêf e não são purtuguesef... são daqui

$$
(\ldots)
$$

Entrevistada 2: mesmo não sendo purtuguêf. Só, a partir dus, trinta e cinco, trinta e seis anos pra cima, é que só falam todos só ifpanhol, mas todos, ou seja, pra baixo, a partir duu, dus trinta e cinco pra cima, quase todos, todos só só si falam purtuguêe, meu patrão fala purtuguêf..

A informante 2, tem a consciência de que o espanhol interferiu na sua língua nativa, deixando marcas e sotaques. Durante nossa entrevista, percebemos algumas palavras que são usadas, provavelmente num estágio de "protosself", saem naturalmente, sem que ela perceba:

Entrevistada 2: Mudou! Muda! Muda porque si tamus muito tempo é qui tu leva muito tempo, muito tempo, muito tempo só pra elef, eu 
agora vou dua horas à casa, quando voltar sempre sempre só falare, então vai vai tirando um poquito, poquito. Si!

$$
(\ldots)
$$

Entrevistada 2: já escapou muitas vezes, escapa são muitof anof. [a entrevista se refere à interferência do espanhol quando fala em português]

Nas poucas falas em que a informante abandona a categoria da Quantidade, nossa compreensão se torna prejudicada, sendo necessário o uso de implicaturas, e da compreensão de todo o contexto discursivo para que possamos adentrar no Princípio da Cooperação, tal como é proposto por Grice (1982). Vejamos um exemplo de tal abandono:

Entrevistador: tão próximo, (...) as cidades né? O idioma português está se perdendo tanto aqui em Olivença, né?

Entrevistada 2: sim ... aqui tá, tá purque muitas vezes, eu lembro-me quando vi pra qui trabalhar, teve uma sinhora, tava aqui jáá'..(...) Minha filha disse..."ai mãe, mas é que a senhora é igual como nóf... mãe é que ela tá (...) com a gente. (...) É que ela é igual (...) com minha filha, intendeu ela é igual a ti, chorar i tudo maif, maif é tudo igual a isso não tem diferença não ... hoji os miúdos hoje em dia são muito criticados por isso, há muitos que são (...) cá muitos

Implicatura: a informante diz que eles fazem parte do mesmo grupo (de portugueses) que a senhora que já vivia em Olivença. Propõe que todos os portugueses são e devem ser tratados iguais, mas hoje não são.

Como é possível depreender da elocução acima, o abandono das categorias da Quantidade, da Qualidade e do Modo provocou uma dificuldade de compreensão:

(i) abandono da categoria Quantidade: nos trouxe informações muito além das necessárias;

(ii) abandono da categoria Qualidade: nos trouxe uma informação que 'provavelmente' não acredita. Afirmamos isso por conhecer todo o contexto discursivo: a informante já nos confirmou anteriormente que o português está sendo falado até entre os espanhóis, o que leva tal afirmação a ser contraditória

(iii) abandono da categoria Modo: através do abandono das máximas "não produzir expressões obscuras", "não produzir elocuções ambíguas", 
“evitar expressões desnecessárias" e "ser ordenado", nossa elocução passa a não ser compreendida com clareza.

Diante do contexto de cooperação, é possível que tenham ocorrido dois fatores para tal elocução:

(i) a entrevistada não compreendeu a pergunta feita pelo pesquisador e, para não deixar de responder, produziu algo de forma espontânea, tal como Damásio (2008) apresenta: os seres humanos podem interagir e tomar atitudes sem que haja consciência.

(ii) a entrevistada por inferir que nós gostaríamos de valorizar o uso do PLH, fala sobre a importância da LH ser tratada com o mesmo valor inferência de um "provável interesse epistêmico do pesquisador", tal como propõe Schwarz (1999).

Nossa entrevista se encerra com um comentário de que alguns portugueses não ensinam a LH para seus filhos e a informante 2, mais uma vez, deixa claro o sentimento de pertença da LH e a necessidade de que seja preservada:

Entrevistada 2: ai isso não, isso é má notícia (...) acabo... são

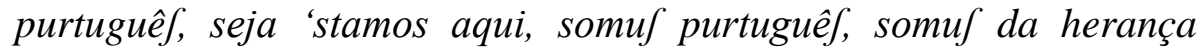
purtuguesa.

Entrevistada $3(\mathrm{JN})-58$ anos

Nossa entrevista com a informante $3(\mathrm{JN})^{152}$ ocorreu no restaurante onde ela trabalha, no seu horário de entrada, por não ter movimento nenhum. A gravação foi feita com a presença de mais dois acompanhantes brasileiros e um espanhol, o qual nos levou até lá e nos apresentou à entrevistada.

\footnotetext{
${ }^{152}$ A informante 3 tem 58 anos nascida em Jerumenha (Portugal) e hoje, vivendo em Olivença há três anos, trabalha como cozinheira em um restaurante da cidade, cujos proprietários são espanhóis. Casada com um angolano, tem filhos já casados que moram em Portugal.
} 
Pelo fato de estarmos em mais pessoas e de ter por perto um amigo espanhol, nossa entrevistada se apresentou de forma espontânea, falando-nos sobre sua vida e rotina de forma muito tranquila.

A informante 3, embora viva em Olivença há apenas três anos, convive diariamente com espanhóis. Veio para a cidade espanhola pelo mesmo motivo de todos os demais entrevistados, para trabalhar:

Entrevistada 3: Há trêf anuf, de de que comecei a trabalhar no Carlof em Olivença! De de que vim trabalhar para o Carluf do Olivenza, comecei aqui viver!

É falante dos dois idiomas de forma mecânica, num estágio de self central, tal como propõe Damásio (2011). No entanto, tem consciência de que ainda possui alguns problemas com o idioma local:

Entrevistador: Sempre na mesma localidade? e aqui você tá, você... você fala em espanhol?

Entrevistada 3: Não! Nãããooo! habitual não muito bem, af esforçar o ifpanhol, não consigo! entendo, à veze dou umaf palavraf, com um tanto ifpanhol maf, com maif com o meu purtuguêf.

Em um trecho adiante, com o abandono das categorias Qualidade e Modo, formula uma elocução que nos obriga a utilizar implicaturas conversacionais:

Entrevistador: Ah sim! e você tá ... se habituou com o idioma?

Entrevistada 3: Sim! Sim! É ... me habituei muito bem porque meu pai foi contrabandista toda a vida.

Implicatura: se acostumou com o espanhol porque seu pai, por viajar muito, tinha contato com o idioma e transmitia aos filhos.

Como podemos depreender, a entrevistada abandonou em sua elocução as categorias Modo e Qualidade, obrigando-nos a fazer usos das implicaturas conversacionais para podermos compreender o sentido da sua proposição, num processo de Princípio da Cooperação:

(i) abandono da categoria Qualidade, através da supermáxima: "trate de fazer uma contribuição que seja verdadeira". Como vemos, nossa informante já havia dito anteriormente que ainda não consegue utilizar o 
idioma local muito bem e, portanto, sua fala se torna não compreensível: o que ela considera "me habituei muito bem"? Fala bem o idioma ou apenas se acostumou a ouvir? Inferimos a segunda hipótese, pois caso seja a primeira, teremos uma falsa informação, por já ter nos dito antes o contrário.

(ii) abandono da categoria Modo, através da máxima: "não produzir elocução ambígua". Percebemos, neste caso, uma contradição entre as elocuções: "as esforçar o espanhol, não consigo!" e "Sim! Sim! É...me habituei muito bem" [referindo-se ao espanhol]. O sentido de se habituar seria o quê? Poderíamos ter as duas hipóteses já mencionadas em (i).

Na continuação da conversa, a entrevistada 3 nos informa que tem contato com os moradores de Olivença desde o tempo da Guerra de Espanha ${ }^{153}$, e fala sobre sua boa relação com os moradores da cidade:

Entrevistada : Eu dô muito bem com o pissoal oliventino.

Quanto ao contato com portugueses, diz que os encontra esporadicamente, por trabalhar muito e não ter tempo. Sendo assim, convive mais entre os espanhóis do que com seu grupo étnico, no entanto, garante que sua língua nativa e a LH falada com seus filhos será sempre preservada e deixa bem claro o seu sentimento de pertença as suas origens:

Entrevistada 3: (...) e dipoif, por a noite, àf veze $\int$ nos domingof aqui no baile,ou no sábado, que vejo alguém conhecido, comunico eu né, porque eu dif, conheço aqui muita gente.

Eu pra mim Purtugal é Purtugal, eu gofto quanto 'stou aqui, sempre me dei bem com gente de Olivença, maf o meu paíf é meu paíf.

\section{(...)}

A nossa origenf, à veze sempre daquele lucal, e nóf nunca digamuf perdere as nossaf origens.

Ao ser questionada sobre o tratamento dado aos portugueses, ou seja, se são tratados com diferença em Olivença, a informante diz não sentir diferença nenhuma, e tal afirmação é ratificada através do seu relacionamento com os espanhóis.

\footnotetext{
153 cf no capítulo sobre o locus da pesquisa.
} 
Entrevistada 3: eu sou, eu sinto tratada igual, além disso, já há muitof anof que mi dava com purtuguesif, eu também tinha u riftaurante, tinha e tenho riftaurante em jurumeia, que minha clientela oitenta por cento era oliventino, e de Badajoz, sempre tenho me dado muito bem.

A informante, também classificada por nós como integrante do estágio de self central (Damásio; 2011), por articular mecanicamente português-espanhol (embora apresente dificuldade no uso do espanhol), é capaz de fazer uso da língua da sociedade receptora sem perder ou deixar que essa interfira na sua língua nativa. No entanto, tal como os demais informantes, percebe que, muitas vezes, em momentos isolados, ou seja, provavelmente em estágio de protosself (Damásio, 2011), recebeu palavras de sua LH ou da língua da sociedade receptora, num cruzamento comunicativo típico de codeswitching. Tanto quanto os outros entrevistados, ela própria reconhece o fato:

Entrevistador: Você tem usado coisas es ... de espanhol? palavras (resposta simultânea ... sim) no seu dia a dia?

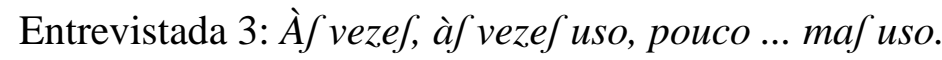

$$
\text { (...) }
$$

Entrevistada 3: Por vez sim! por vez estou, até digo sem as perceber tô a falar ifpanhol ... (risadas)

$$
\text { (...) }
$$

Entrevistada 3: O meu filho com o maif novo, se reminham...o meu filho, o meu filho mais novo, abla com o ifpanhol, fala igual como sendo um ifpanhol.

Em outro momento da entrevista, a informante concebe o fato de usar o espanhol num estágio de protosself (não consciente):

Entrevistador: Sim! entendi! No seu dia a dia, com seu marido cê usa espanhol?

Entrevistada 3: Não!

Entrevistador: Nem um pouco?

Entrevistada 3: Só às vezes distraída! 
Entrevistada 3: às vezes tô a dizer ifpanhol mas não tô a percebere que já 'stou a dizere em ifpanhol, à veze já tem dito em casa mesmo pra o meus filhuf, olha jas tá a falar ifpanhol

$\mathrm{Na}$ elocução seguinte, a informante ratifica nossa hipótese inicial, de que entre os falantes mais velhos a língua portuguesa seria preservada, estando mais incrustada, dificultando, inclusive, o uso da língua sociedade receptora.

Entrevistada 3: Eu é, sente maif dificuldade em aprender que o maif novo, prontu! que o maif novo, é sempre é assim, vinham pra aqui amigof pra difcotecaf, ah se juntavam naf feftaf, dos veranof, e essaf coisas assim, i olha, verano (...)

Em um momento da entrevista, perguntamos o que a informante pensava sobre morar na fronteira de seu país, se isso era um fator que contribuía para a preservação da cultura portuguesa entre eles. A resposta dada foi a seguinte:

Entrevistada 3: Sim, fronteira pa, a língua já está mui... (...) pra entender, nós aqui uf purtuguesif, frequenta muito comércio ifpanhol ... a maioria dos purtuguesif ganham, purtanto, purtuguesif que vivem aqui, Olivenza, Badajoz. Ah, gasta mais dinheiro em Ifpanha do que Purtugal, em vistuário, em calçado, em tudo.

Implicatura: A informante acredita que, por estar mais perto de seu país e os portugueses frequentarem muito o comércio da fronteira, fica mais fácil a preservação da LH, tal como temos proposto.

O conteúdo de sua fala vai de encontro à nossa hipótese, pois ratifica o fato de a língua portuguesa e o PLH estarem em uma cidade fronteiriça, torna seu uso muito mais forte e preservado entre seus falantes.

Na elocução acima, por ter abandonado as categorias da Quantidade, através da máxima "não fazer contribuição além do necessário" e do Modo, através dá máxima "não produzir expressões obscuras", mais uma vez, obrigou-nos a implicar o sentido de sua proposição.

O sentimento de pertença da língua nativa na informante 3 é intrínseco, pois na forma como expõe o amor e a necessidade de preservação é intenso, sendo observado no modo como fala: 
Entrevistada 3: Sim, penso que sim!Purque eu, eu se tivesse vi.. toda a minha vida aqui, tivesse aqui uf meuffilhof, eu ensinava eles dua línguas.

Entrevistador: $A h$ !

Entrevistada 3: Porque é muito melhor (...) exatamente (...)

Ao perguntarmos para a entrevistada 3 se ela acreditava que os portugueses sentiam que sua língua fosse inferior à língua espanhola, obtivemos uma resposta que abandona as categorias da Quantidade, através da máxima "não fazer contribuição além do necessário" e do Modo, através da máxima "não produzir expressões obscuras". Devido o abandono dessas máximas, mais uma vez, fomos obrigados a utilizar implicaturas conversacionais. Vejamos:

Entrevistador: (...) você sente que os portugueses têm a língua deles como inferior ao espanhol? Que moram aqui? Po.r..é...assim, eu conversei com um rapaz e ele só fala em espanhol com os filhos (...)

Entrevistada 3: Isso eu acho que é uma grande afneira, (...) tanto é que eu tenho em minha família, a um sobrinho que foi para a Romênia, nasceu na ifcolas da rainha, que minha sogra é das ifcolas da rainha, meu marido veio da Angola, meu marido é angolano.

I intão acontece, o miúdo, ééé é filho do pais separados, o miúdo foi trabalhar por, purtanto, o homem que atualmente, 'stava com a mãe, e hoje não sabe falar purtuguêf.

A mãe dipoif voltou a separar-se do companheiro, ele não quif a mãe ficou com ele, i ele não sabe falar purtuguêf, que uma afneira que minha cunhada viveu com ele tantos anos na Alemanha, tinha-lhe ensinado as dua línguaf.

E tem uma filha Almam, tanto desse senhor, que ela também não sabe purtuguêf. Quando chega aqui, a perto de nós, vem visitar em fériaf, a miúda tá sempre a olhare assim, nem ela entende o que nóf dizemu」 nem nós entendemu o que ela diz, por quê? cupa da mãe!

Implicatura: A informante acredita que os portugueses se sentem inferiores e por isso não ensinam a LH, atitude que é não aceita por ela.

A fim de confirmarmos o que havíamos implicado, fizemos uma nova pergunta, que ratificou nossa compreensão do momento:

Entrevistador: Não quis ensinar a língua? 
Entrevistado 3: Porque pensam que a gente que põe o meu Purtugal inferior a tudo, mas acho que não é.

Eu pra mim Purtugal é Purtugal, eu goftu quando 'stou aqui, sempre me dei bem com gente de Olivença, mafo meu paífé o meu paíf.

A compreensão comunicativa só ocorreu por observarmos todo o conteúdo contextual, no qual nos informa o 'não uso da LH' como algo que a entrevistada reprova enfaticamente. Para isso, tivemos que fazer uso de todo o background, tal como propõe Dascal (1982). O abandono das categorias ocorreu da seguinte forma:

(i) abandono da categoria Quantidade, através da máxima "não fazer contribuição além do necessário": a informante produziu uma elocução além do necessário. $\mathrm{O}$ excesso de informação exige maior atenção do interlocutor para que não ocorra prejuízo de sentido.

(ii) abandono da categoria Modo, através da máxima "não produzir expressões obscuras": a entrevistada não foi clara em sua resposta, o que nos obrigou a utilizar implicaturas conversacionais.

Acreditamos que, abandonar tais categorias foi uma atitude comunicativa de se abster em julgar os falantes de seu próprio grupo étnico. Embora, mediante a resposta dada, fica claro que ela perceba o sentimento de inferioridade linguística dos portugueses, preferindo não dizer isso diretamente, até mesmo para preservar sua face.

Finalizamos a entrevista com a informante 3 ratificando nossa hipótese inicial sobre a preservação da língua portuguesa nos falantes de mais idade:

Entrevistada 3: A nossaf origens, àf veze sempre daquele lucal, e nós nunca digamos perdere af nossaf origens, que é hoje o que se perde todas as tradiçõef, as pissoaf mudam de lucal, é, purtanto, eu sou alantejana, eu não comigo, isso não acontecia (...)

(...) Eu vá pra onde vai eu nunca 'squeço a minha terra.(...) 


\section{Entrevistado $4(\mathrm{CR})-41$ anos}

Coincidentemente, ao adentrarmos em uma lanchonete da cidade de Olivença, deparamo-nos com dois portugueses que moravam na região e foram prestativos em nos ajudar com a entrevista, que ocorreu de forma tranquila e espontânea.

A entrevista com os dois informantes ocorreu ao mesmo tempo, numa conversa a três: o entrevistado 4, entrevistado 5 e entrevistador. No entanto, durante alguns momentos da gravação, havia a interferência de algumas pessoas que estavam no local.

O entrevistado $4(\mathrm{CR})^{154}$, ao ser questionado sobre seus filhos, nos informa que nenhum deles utiliza a LH, tendo muita dificuldade para compreender seus avós paternos. Informa-nos que somente a filha tem interesse na LH e que um dia haverá de aprendê-la. Vejamos o trecho da conversa em que isso é demonstrado:

Entrevistador: E seus filhos não têm interesse em aprender o português?

Entrevistado 4: ah, minha filha sim, minha filha há de com o tempo dizer alguma coisa em purtuguêf, que ela maif ao menuf sabe, diz maf não é muito rápido, meu filho, o meu filho, meu filho, fala igual a saber purtuguêf ou não, eu é de, mas vamus lá, dus meus paif, vamuf ouvir uf meuf paif, meuf paif falam pra ele óh eu falo pra meu pai, mas não percebem, intão meu filho pregunta, pai que tá dizendo ao avô?

O entrevistado 4 sente-se culpado por não ter ensinado a LH aos filhos enquanto eram pequenos, percebendo agora o quanto ela os torna próximos de seu grupo étnico:

Entrevistado 4: e eu tenho que dizere, que tá a dizere ao pai a meu filho, e guftava que ele falasse (...) mas foi burrice minha não ter falado purtuguêf pra ele, quando era (...)

Por viver 23 anos na cidade, seu contato é muito maior com os espanhóis do que com os portugueses, o que o torna um falante num processo de self central (Damásio, 2011:225), por articular mecanicamente português-espanhol (falante bilíngue), sendo,

\footnotetext{
${ }^{154} \mathrm{O}$ entrevistado 4 trabalha em obras como pedreiro de construção civil na cidade de Olivença, é casado com uma espanhola e tem dois filhos que não falam o português. Mora na cidade há 23 anos e tem um baixo nível de instrução.
} 
como os entrevistados anteriores, capaz de fazer uso da língua da sociedade receptora sem perder ou deixar que essa interfira na sua língua nativa.

Entrevistado 4: conheço mai gente aqui que em Purtugal, purque levo maif metade da minha vida aqui que ali

Ao ser perguntado sobre a interferência de uma língua sobre a outra, responde mecanicamente que 'não', apresentando seu estágio de self central, tal como propõe Damásio (211):

Entrevistador: Quando você conversa, você considera que você mistura as duas línguas ou não?

Entrevistado 4: não! si eu, é agoraa, si eu falo purtuguêf pa você, eu falo purtuguêf, si tiver com ifpanhol, ifpanhol!

$$
\text { (...) }
$$

Entrevistador: português ((risos)) seu sotaque é português?quando você fala espanhol, você tem sotaque português?

Entrevistado 4: não! desde que falo ifpanhol, não, ninguém sabe que sou purtuguêf!

No entanto, logo em seguida, percebe que a LH não fica completamente fora do seu dia a dia, mas que acontece, provavelmente em estágio de protosself (Damásio, 2011:225), recebendo palavras de sua LH e vice-versa, num cruzamento comunicativo típico de code-switching:

Entrevistador: só espanhol?

Entrevistado 4: sim! mas alguma vez pur ixemplo, eu tô a falar com você memo em purtuguêf, e salta alguma palavra em ifpanhol

Entrevistador: e o mesmo acontece ao contrário?

Entrevistado 4: ao contrário também,

Entrevistador: Você está falando espanhol, e o seu siii

Entrevistado 4: sim sim, em vez enquando salta alguma coisa, salta oo, é custume já, é custume de, iftamos a falare, alguma palavra, na verdade não lembro de uma palavra em purtuguêf, então, salta o ifpanhol, ou (...) salta o purtuguêf 
Em outro momento de nossa entrevista, pudemos notar o abandono da categoria Relevância por parte do informante 4. Vejamos o trecho em que ocorre:

Entrevistador: Ninguém sabe que você é português?

Entrevistado 4: essi que tava aqui sim, purque esse fala muito mal ifpanhol [o entrevistado 4 se refere ao entrevistado 5, que necessitou sair por um momento]

Entrevistador: ele?

Entrevistado 4: esse não sabe falar ifpanhol, e leva vinte e quatro anos e não aprende, não vira pra vim cá falar ifpanhol (...)

Como pudemos notar, embora a pergunta fosse sobre sua fala, de forma espontânea, num processo quase que involuntário, abandona a categoria Relevância. O que era relevante para o pesquisador, torna-se "marginalmente relevante" para o entrevistado (Dascal, 1982:117). Naquele momento específico, a relevância estava em nos informar que seu amigo vive tanto tempo em Olivença e ainda não aprendeu o idioma. Somente depois de expor o que era mais relevante é que nos responde a pergunta, mas, logo em seguida, retornou ao que considerava relevante - a fala do amigo:

Entrevistado 4: e eu pra di, desdi bucaninho qui eu falooo ifpanhol pur tarmu aqui na fronteira é sempre maif (...) eu falo ifpanhol e ninguém sabe que sou purtuguêf, se eu puser a falar purtuguêf com um purtuguêf sim, mas si tivere ouvi ifpanhol (...)

Entrevistador: só fala espanhol e ninguém percebe que você é português?

Entrevistado 4: sim pruque, i a outro sim, outro sim, pur quanto não sabe falar ifpanhol, é outro mescla, mescla

Entrevistador: aquele seu amigo que estava aqui?

Entrevistado 4: sim! esse mescla tudo, esse não sabe nem purtuguêf, nem ifpanhol (...) às vezes não entendo nem eu

Outro encaminhamento de nossa pesquisa estava em saber qual era a relação do nosso entrevistado com sua língua nativa, e perguntamos se ele gostava mais do espanhol ou do português, e sua resposta nos obriga a implicar um sentido que não estava expresso nas palavras, mas nas entrelinhas: 
Entrevistador: você gosta mais de espanhol?

Entrevistado 4: eu goftar, gofto maif do purtuguêf,

Entrevistador: você gosta mais do português?

Entrevistado 4: é minha vida tá aqui, intão, tô contente de tá aqui a Ifpanha, dá mais possibilidades, qui Purtugal não tem...

Implicatura: $O$ entrevistado 4 gosta do português, porém o espanhol lhe é mais útil.

O entrevistado também nos informa sobre a relação fronteiriça, explicando que os professores que dão aula na cidade são portugueses, e os que dão aula de espanhol em Portugal são espanhóis. De início, fala que as fronteiras são abertas a ambos os países, no entanto, se contradiz com tal afirmação, como podemos ver abaixo:

Entrevistado 4: são contratados pra isso! Há prufessorif purtuguesif, logo como há ifpanhóif em Purtugal também, prufessorif ifpanhóif também,

Entrevistador: que dão aula lá?

Entrevistado 4: e médicu ifpanhóis também em Purtugal

Entrevistador: as fronteiras aqui estão abertas?

Entrevistado 4: tá, aqui af fronteiraf 'stão abertas,

$$
(\ldots)
$$

Entrevistador: então as fronteiras são abertas? quem quer trabalhar lá, quem quer trabalhar aqui...

Entrevistado 4: aber, aberta, aberta não, um purtuguêf quer vir aqui trabalhar, ou (...) trabalhar ali, tem que teri, premisso de residência, premisso de um contrato de trabalho, pa poder tatrabaio, tem que ter premisso de residência, pra tere, os seus descontos tudo para, a seguro da social e essas coisas toda.

No início da sua elocução, ocorre o abandono da categoria Qualidade, através da máxima "fornecer apenas evidência adequada". Ao afirmar "tá, aqui af fronteiraf ‘stão abertas”, faz o interlocutor ter uma compreensão duvidosa, sendo necessária a confirmação da pergunta. Num processo de Princípio da Cooperação (Grice, 1982:87), percebe a confusão causada pelo abandono de tal categoria e elabora uma auto-correção: “aber, aberta, aberta não”. 
Durante algum tempo de gravação, o assunto de relevância passou a ser sobre as festas que os adolescentes faziam nas ruas ou na praça em Olivença. No entanto, por uma pergunta feita pelo entrevistador, o tópico se modifica totalmente e a relevância naquele momento passa a ser a festa do touro que ocorre na cidade. Vejamos como ocorre o abandono da categoria da Relevância anterior:

((barulhos e mistura das falas))

Entrevistador: e março?

Entrevistado 4: ((risadas ao fundo)) a festa do touro

Entrevistador: aquela que eles judiam do touro?

Entrevistado 4: matam, toriro, toureiro, isso, é a festa do touro. O fim de semana efte, nã não cabes na rua, tudo cheio, tudo cheio assim, em março, isso is março.

Entrevistador: E os portugueses participam?

Entrevistado 4: Vêm toreiros portugueses muitas vezes, torureiros portugueses (...)

((mistura de fala dos dois entrevistados))

Entrevistado 4: venham mais a tourear, a toureare

Entrevistador: Vocês gostam desta festa do touro?

Entrevistado 4: Eu vou vere

\section{$(\ldots$.}

Entrevistado 4: $O$ gosto da festa é, o ambiente, o ambiente, nós $i$ a praça vê-lo.

Naturalmente, o discurso passa a ter relevância na festa dos touros que acontece todo ano na cidade de Olivença. Como já é sabido, a festa é cultural e todos os moradores se divertem muito com ela. No entanto, quando perguntamos ao entrevistado 4 se ele gostava da festa, a resposta é: "eu vou vere".

Nesse momento, podemos dizer que ocorre uma inferência sobre o entrevistador, o que chamamos de "provável interesse epistêmico do pesquisador" (Schwarz, 1999:96). O fato de não ter dito claramente que gostava da festa pode ter como 
motivação o contexto em que se encontrava: uma conversa com brasileiros que não gostam desse tipo de festa.

É claro que, pelo conhecimento cultural do país, da cidade e pelas pistas de contextualização deixadas pelo entrevistado, implicamos que, com certeza ele gosta da festa, caso contrário, teria dito: "não gosto".

O que ocorre nesse trecho do discurso é o abandono da categoria Modo, através da máxima "não produzir expressões obscuras". O abandono é consciente e tem como objetivo não fornecer a resposta clara para não causar uma má impressão no entrevistador. Tal implicatura se ratifica com a resposta seguinte: "gosto da festa é, o ambiente, o ambiente, nós i a praça vê-lo”.

Essa inferência que fizemos parece ficar mais clara com a continuação de sua fala:

\author{
Entrevistador: Dá muita dó \\ Entrevistado 5: quem gosta dos touro (....) \\ Entrevistador: Eu tenho dó dos touros! \\ Entrevistado 4: não, mas em Purtugal não matam os touros, \\ Entrevistado 5: Purtugal não os mata \\ Entrevistado 4: Purtugal não mata!
}

Com a fala do entrevistador "Eu tenho dó dos touros", a inferência do entrevistado 5 se confirmou e rapidamente ele tenta amenizar o nosso sentimento quanto ao gosto dos portugueses pela festa dizendo: "Purtugal não mata!”.

Esta análise apresenta todo o jogo que ocorre entre os participantes do discurso, os quais, dentro de um processo de inferências e implicaturas, montam suas falas de forma a tornar a interação de forma mais agradável.

Notemos que a entrevista com o informante 4 termina com as explicações sobre a festa do touro, mas sempre amenizando a participação de Portugal, que indica uma preservação na imagem de seu país, mais uma vez notamos o que já imaginávamos: sentimento de pertença da cultura de seu país. 


\section{Entrevistado 5 (JP) - 40 anos}

A entrevista com o informante $5(\mathrm{JP})^{155}$ ocorreu simultaneamente à do informante 4, em uma lanchonete da região de Olivença. No local, além dos dois portugueses havia alguns espanhóis que bebiam e conversavam por perto.

Durante a entrevista, o informante 5 se ausentou por alguns minutos, momento em que o entrevistado 4 nos contou que ele (entrevistado 5) vivia há muitos anos na Espanha e não aprendera o idioma, inclusive, não falando bem nem mesmo sua língua nativa. Fica-nos nítido o quanto é um fator percebido pelos seus companheiros de convívio. Vejamos um trecho da fala em que demonstra o inconformismo de seu parceiro (entrevistado 4):

Entrevistado 4: sim! esse mescla tudo, esse não sabe nem purtuguêf, nem ifpanhol (...) à veze $\int$ não entendo nem eu

Entrevistador: ele, será que é porque talvez não conversa com muitas pessoas?

Entrevistado 4: não, sim fala sim, conversa com muitos ifpanhóif, $e$ mefmo assim ... não é capaz, não é capaz, não queri, não sabe, não, não, não vai mai não, não tem mais capacidade

Após alguns minutos da gravação, o entrevistado 5 retorna. Nesse momento em que o assunto era sobre a grande quantidade de portugueses que visitam ou moram em Badajoz, uma cidade também fronteira com Portugal e vizinha de Olivença, pudemos ouvir o seguinte:

Entrevistador: por aqui? fui estive lá semana retrasada em Badajoz, muito bom, também tem bast, tem portugueses lá também?

Entrevistado 4: tem, tem muito, tem muitos portugueses também, tem,

Como forma de tomar o turno conversacional, lança no discurso a seguinte elocução:

\footnotetext{
155 O informante 5 (JP), tem 40 anos, vive em Olivença há 21 anos, trabalha no campo e tem baixo nível de instrução. Não fala o idioma local e já não articula mais com fluência sua LH. A fala do entrevistado é chamada pelos oliventinos de "chaporreu": um falar desprestigiado entre a comunidade local.
} 
Entrevistado 5: em Elvas tem muito ifpanhóis vivendo ai!

Entrevistador: em Elvas, também, espanhóis?

Entrevistado 5: sai mai a barata a vivenda mai barata, a vivenda a casa é mai barata ali em Purtugal comprando,

Entrevistador: em Elvas?

Entrevistado 5: em Elvaf! intão, metade do preço, aqui uma casa pode valer, vamo por de 24 mil euro, 30 mil euro, 25 mil euro, podi té valer $15,12,13,14$

Assim, o entrevistado 5 abandona a categoria da Relevância (o que era relevante no momento: portugueses em Badajoz), mudando o cenário discursivo para "espanhóis que vivem em Elvas", obrigando os demais participantes, no caso o entrevistador e o entrevistado 4, a mudar o tópico discursivo.

Tal atitude tem uma única estratégia: entrar no turno conversacional. Essa estratégia invasiva tem um custo: anão relevância além de uma certa desconexão tópica já em andamento. Analisamos essa atitude apoiando-nos em Damásio (1999) e Caldas (1999), os quais propõem a possibilidade de que o indivíduo tome atitudes fora do plano da consciência, "induzidas de uma forma não consciente” (Damásio, 1999:68).

É claro que a atitude teve seu objetivo planejado, que era de participar da conversa, mas a elocução, não foi pensada, simplesmente lançada espontaneamente, talvez induzida, minimamente, por algo do discurso anterior, o que provocou a mudança total do cenário discursivo. A partir dessa atitude, a conversa passa a ter outra relevância: a comparação do custo de vida na Espanha e em Portugal.

Embora não fale o idioma local, o efeito da língua espanhola é muito grande no entrevistado 5, utilizando em seu discurso os dois idiomas ao mesmo tempo, o que nós chamamos de portunhol, chamado por eles de chaporreu. Vejamos um trecho de sua fala:

Entrevistado 5: (...) aqui na Epanha, peri comprar, o gáf é mai barato, o gáf aqui é mai barato. E o gáf, a gasolina e o gasóleo. Uma garrafa de gáf, em Purtugal vale 25 eurof, e aqui vale 16

Entrevistador: Nossa! muito diferente! 
Entrevistado 5: Muita diferença

Entrevistador: Só que as vivendas lá são mais baratas?

Entrevistado 5: Afvivenda lá, é muito mai barata!

$$
(\ldots)
$$

Entrevistado 5: i o salário (...) o salário mínimo de Purtugal, são 400 euro, 500 euro, o aqui o mínimo, o mínimo são 600 euro. Tem una dif'rença de cento euro.

Entrevistador: Qualidade de vida em Portugal é melhor?

Entrevistado 5: Não, não, aqui..(...) sanidade, mio aqui, é, tem muito sanida, médico (...) bom aqui (...)

$$
(\ldots)
$$

(...) aqui tem supermercado, muito grande, qui na Epanha, e ele não fornece pra mercado grande, só supermercado bucanino.

$$
(\ldots)
$$

mai barato aqui! purque se o (...) é grande, supermercado mui grande, mui grande, $i$ intão você pode até (...) em Purtugal memo em Elva, (.....) chico, depois (...) não ha banana, (.....) se for marcado (...) claro, porque (...) um bucadino, entro em outro, aqui não, aqui se não (...) ou quanto mai competêntia tene, mai baixo o preço (...) mai competene, você pode competi em (...)

No discurso dos entrevistados 4 e 5, torna-se perceptível que vieram para a Espanha pelas melhores condições de trabalho e que, embora o entrevistado 5 não consiga mais falar a língua nativa com fluência, chegando a ser, até mesmo, incompreensível em alguns trechos, não deixa de usá-la, mesmo que de forma mesclada.

Durante algum tempo de gravação, nosso tópico de conversa, ou seja, a relevância conversacional, era sobre o custo de vida em ambos os países, no entanto, mais uma vez, o informante 5 mudou o cenário discursivo. Vejamos:

Entrevistado 4: sim, mas pratos num num quere, pur ixemplof, se viemuS pra cumere, viestif cumere aqui nu ristaurante, vá ali em Purtugal Europa, come quatro pissoaf, pagam memo que duaf aqui.

Entrevistador: Sim! Foi o que nós percebemos 
Entrevistado 5: Na Ispanha, Ispanha tem unia, Ispanha tem unia coisa muito rica com Brasil, não sabe? lo canaval e la festa

Entrevistador: é então, eu perguntei se aqui tinha carnaval

Entrevistado 4: agora cumeço, pra montar a cartunice

Entrevistador: começa agora?

Entrevistado 4: começa sexta-feira

A atitude do abandono da categoria Relevância, mais uma vez é tomada pelo entrevistado 5, que já não mais tem o assunto anterior como relevante, e muda o tópico discursivo 'custo de vida em ambos os países fronteiriços' para o 'carnaval que acontecerá em pouco tempo'. Naquele momento, atendendo ao Princípio de Cooperação, todos os participantes da interação discursiva abandonam a relevância anterior, adentrando no tópico proposto pelo entrevistado 5.

A característica de abandono da categoria da Relevância do entrevistado 5, geralmente, ocorre sem um motivo ou sem relação com as falas anteriores, como num processo de atitude linguística sem consciência, ou seja, num estágio de protosself (Damásio, 2011:225). Tal atitude linguística ocorre como se as ideias simplesmente viessem do nada em sua mente e, independentemente do que está em discussão, as expõe, mesmo que não tenham o menor sentido naquele contexto discursivo. Vejamos mais um trecho da gravação em que isso ocorre:

Entrevistado 5: nhié carnaval não é frio heim?? ((risadas))

((misturas das falas dos dois entrevistados))

Entrevistado 5: Não, tem, mai tem una diferença do epanhol (...) aqui, éé em Elva no, em Elva tem ajuntamento de carregar água, (...) água. Aqui em Epanha (....) ((risadas, barulhos)). Em Purtugal, ali, o meter, câmara, câmara municipal, o meter trabalhamos em lugare a partidaro (...) los comparsas, tem direito (...) aqui não, aqui é risco, só risco

((mistura de falas))

Entrevistado 4: o pissoal (...) sempre bêbado nestas esquinas

Entrevistador: sério?

Entrevistado 4: si, si, si, sim 
Entrevistador: em Purtugal eu não vi bêbado

Entrevistado 4: não, não, em Purtugal é qui tá proibido bebêr no bar. Aqui nós pudemof no sábado a noite, aqui (...) o pissoal no bare, (...) bebe, (...) garrafa natural né, e bebem memo.

\section{((mistura das falas $))$}

Entrevistado 5: A juventude agora, é dez euro, tem (...) ao bare bebere, nóf junto, dia quinze, entre todo, compro alguna coisa cocacola, compro alguna coisa uisque, compro o lugar, e se vê o pai, parou o carro, abree a mala do carro, e vamo ligar, ligare em tufono. (...) La fiesta no final de semana não pode valer 5 euro, pa cada uno! a cada uno, (...) um bom dineiro, (...) num bare, (...) tudo sábado, maifnum sinto que pareço bocalhô, já não lembro um bocalhô, e o caso, compro tudo laco, se junta tudo, bebem, fumam, num baile, já não é discoteca, aqui é a minha discoteca, e a discoteca tá no ar, $i$ tudo já, sai mui caro uma discoteca, trei euro, e com trei euro, trei pra ternoite e (...)

Como podemos notar, o entrevistado 5, de forma muito confusa, passa a falar sobre outro assunto totalmente diferente do anterior. Nesse momento, o assunto 'diferença no custo de vida entre Portugal e Espanha' passa a representar algo 'marginalmente relevante' para ele, optando pela mudança de tópico.

Ocorre, mais uma vez, que o assunto não tem sentido dentro do contexto anterior, parecendo-nos uma elocução sem consciência para o momento, mas que toma um sentido após a cooperação entre os demais participantes, que, por conhecerem o contexto de conversa com o entrevistado 5, se envolvem no novo contexto discursivo e lhe dão continuidade. Isso é o que podemos realmente chamar de um "Princípio da Cooperação" (Grice, 1982:86).

\section{Entrevistado 6 (ED) - 48 anos}

Nosso contato com o entrevistado 6 (ED) ${ }^{156}$ ocorreu na Universidade Popular de Olivença, local onde ele leciona a disciplina de Língua Portuguesa, não como parte do currículo, mas como um curso de idiomas.

\footnotetext{
156 O entrevistado 6 (ED) é professor da Universidade Popular de Olivença, dando cursos de Língua
} Portuguesa como disciplina opcional. Mora em Olivença há 32 anos, casado com uma espanhola e tem 
Em nosso primeiro encontro, ao informarmos que gostaríamos de gravar uma entrevista, solicitou que aguardássemos um contato posterior, pois marcaria um horário em que ele pudesse nos atender com calma, dizendo que sabia que seria uma conversa longa, ou seja, "provável interesse epistêmico do pesquisador" tal como propõe Schwarz (1999). Nossa entrevista ocorreu no dia seguinte, em uma sala vazia da Universidade.

No momento da gravação, estávamos em quatro pessoas: o entrevistado 6, a entrevistadora e dois acompanhantes, que ficaram sentados em cadeiras próximas. Logo que adentramos a sala, o entrevistado 6 nos perguntou sobre o interesse da gravação, porém sem que completássemos nossa informação, respondeu o que ele já havia inferido desde nosso primeiro contato: “História demográfica também?”. Vejamos o contexto completo:

Entrevistado 6: Qualé vossa ideia, ã ã, qualé sua ideia â, é de fazer um trabalho só de língua, ou fazer... (simultâneo)

Entrevistador: não, do ponto de vista cognitivo, é a questão de e é um

Entrevistado 6: História demográfica também?

Entrevistador: Vou ter que entrar pela questão de fronteira, porque eu poderia ...

Entrevistado 6: Pode vir pra qui, pode trazer a cadeira se quiser

Nesse momento do discurso, num processo de inferência do interesse do pesquisador, o que ocorre é que o entrevistado infere que o interesse da entrevistadora é saber sobre a cidade, sua geografia, os problemas de políticas linguísticas e históricos, pois já havia dado algumas entrevistas sobre isso.

Logo em seguida, após uma movimentação para a mudança de lugar da entrevistadora, o turno é retomado com um pouco do objetivo da entrevista e, logo em seguida, o entrevistado 6 inicia sua fala quase ininterruptamente:

filhos nascidos na cidade que são falantes bilíngues (português e espanhol). O informante é um dos representantes da Associação Além Guadiana, a qual trabalha em defesa da preservação da cultura portuguesa em Olivença. 
Entrevistador: porque eu poderia pegar qualquer país que tem imigrante, mas esse não é o meu foco, meu foco é imigrante de língua de fronteira, é a vivência na fronteira, a questão (ruído) histórica também por Olivenza ter pertencido a Portugal

Entrevistador: Sempre trabalhou aqui?

Entrevistado 6: Não, sempre não. Já eu dei aulas em muitas lucalidades aqui da da iftremadura. Em Purtugal temof a zona da iftremadura qui chama Lis... é, ã, zona de Lifboa ss em se Situbal, quifta a quarenta quilômetro a (...) iftremadura, mas essa iftremadura não tem nada ver com aquela, $i$ essa chama si iftremadura, essa zona qui, zona de Badajoz e Cásiris. i então eu (...) é sempre dei aula de unf cursof qui são de daqui na no purque em Ifpanha era um Guverno Rigional é $i$ então do guverno rigional da iftremadura sempre vous a um cabinete qui si chama Gabinete de Iniciativa daf Fronteriça, qui não iftá aberto só a isso iftá aberto ã, é não só a Purtugal se não outruf paísif, geralmente é Purtugal. I intão elef criaram uns cursof qui são chamadus cursof de, de língua e cultura purtuguesa que é pra levar a todas as lucalidades qui é também pra te uma proximação Purtugal pur quê! Purque fronteira purtuguesa e ifpanhola sempre, uf purtuguesifp'recem tiveram viradof di costaf.

Implicatura: deu aulas em várias localidades de Portugal e agora o governo está levando a Língua Portuguesa para a região fronteiriça para que Portugal não fique por baixo, pois antes estava "de costas para os outros".

O que percebemos em sua fala é que a dificuldade em compreender se dá pelo fato de ter abandonado a categoria da Quantidade, obrigando-nos a lançar mão das pistas contextuais para interpretarmos todo o enunciado ou pelo menos parte dele. A implicatura foi extraída por conhecermos parte do contexto de relações de discórdia entre Portugal e Espanha. Mais uma vez, sem adentrarmos no discurso como um 'enquadre/frame', tal como propõe Bateson (1998), nossa compreensão se tornaria prejudicada.

Nossa entrevista com o informante 6, por se tratar de um professor universitário, participante dos movimentos de valorização da cultura portuguesa em Olivença, ficou presa em informações históricas. Durante quase toda a gravação, somente o entrevistado falava, numa espécie de palestra: 
Entrevistado 6: Historicamente, a rilaçõe ẽ matrimoniaif atravé da dinastias ã monárquicas nunca deram resultado (barulho da porta) eram sempre prublema. Purtugal e me ... tinha era caftelo então a saída natural era ao mar. é, dipoif em 1492 criou-se Ifpanha. Purtugal também teve má rilações purque de 1580 a 1640 ã o mesmo rei que guvernava Ifpanha, guvernava Purtugal

(Entrevistador): $\operatorname{Sim}$

Entrevistado 6: Foram uf Filipes, intão o que que aconteceu? Sempre houve, sempre houve maif é, é, um é rilaçõe e há uma coisa curiosa, no século XX havia duaf ditaduraf, uma em Purtugal outra na Ifpanha (...) foram as últimas ditaduras da Europa Ocidental e ap'sar disso, de ter umas ditaduras da mefma cor também não havia boaf rilaçõefs. Quando é que há boa rilações entre Purtugal e Ifpanha? Desdã 1986 que é quando se entra na comunidade europeia. Então a rilação entre Purtugal e Ifpanha hoje são magníficas na qu'ftão social, econômica, política. Há boas rilações. O que é que se vê de putencial também é purque as fronteiras estão sempre em rivalidade

Entrevistador: Sim

Entrevistado 6: é o próprio cumércio, quando o cumércio tem êxito dum lado, do outro lado não tem, semp foi assim historicamente. Então alguma das coisas que fez foi putenciar a língua na ne em todas as lucalidades. $O$ caso dã Olivença é um caso dif'rente, eu aqui es... dou aula há quatro anuf.

Durante toda a fala do entrevistado 6, uma verdadeira aula sobre os aspectos históricos da cidade de Olivença, o trecho "O que é que se vê de putencial também é purque as fronteiras "stão sempre em rivalidade" foi o que mais nos chamou a atenção, pois ratifica, mais uma vez, a hipótese que lançamos sobre as fronteiras, que é a representação de uma batalha constante, que tem início desde o sentido mais primitivo da palavra ${ }^{157}$.

Durante a gravação, iniciamos um tópico novo, propondo o abandono da categoria Relevância. A relevância conversacional, até o momento, era sobre as relações entre Portugal e Espanha, mas nossa intenção era falar sobre a rotina do entrevistado e o uso da LH e, então, propusemos a mudança do cenário conversacional:

Entrevistador: E mora em Olivença?

\footnotetext{
${ }^{157}$ Cf na Introdução e no capítulo 1, seção 1.2. "A língua em regiões fronteiriças".
} 
Entrevistado 6: Eu moro em Olivença desdêêêêe, eu eu (...)videntemente Oli...em Olivença não, muito longe maf há 32 a...

Entrevistador: 32 anos morando aqui?

Entrevistado 6: Sim. Maif ou menof. Então, acontece uma coisa quã é, mas Olivença as aulas de purtuguêf tem outro sentido purque? Purque Olivença foi 500 anof purtuguesa

Entrevistador: Sim

Entrevistado 6: De 1297 até 1801 então é é as quiftões dã Olivença são dif'rentes a outraf quiftões agora. Se falarmuf de termof linguísticos e de termof é até pudíamos dizer etnográficof até hiftóricof. Há outras lucalidades de int'resses de iftudo ao longo da raia se e esse, purque Olivença é u é uma qu'ftão muito 'spcífica. Eu agora explico a qu'ftão dã Olivença, mas é hm a qu'Jtão dã da raia tem est... tem Barrancof, Barrancof é uma lucalidade que 'stá aqui a 80 ã oi... aproximadamente $80 \mathrm{~km}$ daqui e tem uma coisa curiosa, $\hat{e} \hat{e}$ isso tem um tem um purque ifplicando (barulho) vamuf lá vê se sai ou não sai maf é maif ou menu〕 assim (barulho de folhas de caderno) isso é um mapa purtuguêf desenhado assim, à pressa.

Como podemos notar no trecho acima da entrevista, nosso objetivo de mudança de tópico não teve êxito, pois o entrevistado 6 estava mergulhado na relevância por ele estipulada. Nosso assunto poderia ser relevante para nós, mas ocorre que, para o entrevistado, era apenas 'marginalmente relevante' (Dascal, 1982:115), o que o fez optar em continuar 'imerso' na enunciação anterior.

Além disso, se pensarmos em um "provável interesse epistêmico do pesquisador" tal como propõe Schwarz (1999), podemos afirmar que o fato de estar diante de alguém que o iria entrevistá-lo provocou-lhe a pressuposição de que necessitaria demonstrar conhecimento, principalmente por ser apresentado como professor universitário.

A atitude tomada pelo informante, talvez não seja algo consciente, mas esteja em um estágio de protosself, tal como propõe Damásio (2011). Quando falamos em atitude, não estamos nos referindo à fala do informante, pois esta tem coerência e é absolutamente consciente, chegando, inclusive a um grau de self autobiográfico, tal como propõe Damásio (2011). O estágio de self autobiográfico revela-se na apropriação de conteúdos alheios, que foram naturalmente incorporados ao seu discurso como se 
fossem seus. Enquanto fala, produz reflexões sobre as situações e coloca-se como um ser mais consciente dos acontecimentos por ele explanados.

Quando avaliamos a atitude, deparamo-nos com um falante que não permite outro tipo de assunto que não seja o que ele tem em mente. Para falarmos da atitude do informante 6 em não permirtir que adentremos o território de decisões discursivas, permanecendo praticamente quase toda a entrevista imerso no mesmo assunto, fazemos uso das teorias da mente tratadas no capítulo 1, as quais propõem que muitas atitudes são tomadas num plano fora da consciência, mas "induzidas de uma forma não consciente" (Damásio, 2008:68). Não podemos, adicionalmente, afirmar que não cooperou, pois sua forma de cooperação baseava-se num plano que não era compartilhado, mas que era totalmente plausíve.

No capítulo 1 também apresentamos os estudos de Jeannerod (2002), que tratou da interação dos indivíduos como "representação partilhada". Naquele momento, concordamos que que a maioria das representações da ação se constrói de maneira não consciente, até mesmo as próprias intenções. Na perspectiva de Damásio (2008), tivemos oportunidade de ratificar essa ideia, pois esse autor expõe exemplo de seres humanos interagindo e tomando atitudes sem implicar consciência.

Diante dos pressupostos teóricos elencados neste trabalho de pesquisa, podemos perceber que o falante não nos deixa adentrar ou modificar o cenário discursivo propositadamente, ou porque só ele quer falar, mas por uma atitude que está fora de um plano consciente de ação. Acreditamos que se perguntássemos a ele o porquê de não nos permitir a mudança de tópico, certamente diria que isso não ocorreu, ou nos pediria desculpas e diria que foi sem "intenção".

Aqui, fica claro o quanto os indivíduos tomam atitudes por 'impulsos', sem, muitas vezes, nem saber o porquê estão tomando. Até mesmo para tais atitudes 'inconscientes', durante o processo interativo, é necessário que haja uma cooperação para que não ocorra um conceito errôneo sobre o outro.

Se essas pistas contextuais e os elementos que envolvem a mente humana não pudessem participar da forma como as pessoas organizam seus discursos, então seríamos levados a concluir que o informante teve um péssimo comportamento por não 
nos permitir a fala durante a entrevista. Para finalizar, apresentamos mais um trecho da gravação com o informante 6 , que demonstra a necessidade de permanecer inalterado o tópico de relevância:

Entrevistado 6: Aqui o Guadiana faz isto, o Guadiana.

Entrevistador: Ah sim

Entrevistado 6: Então é 1297 houve um tratado que é o tratado de Alcanices qui incorpuraram a Purtugal todas as terras a Oriente do Guadiana, então 'stá Moura e outraf lucalidades $i$ aqui as do Rio Bacoa (Sem precisão) há aqui um rio afluente do Doro que é o rio Coa e também tem rio daf Terras (sem precisão) maf falando 'spcificamente de Barrancuf tem uma qu'ttão curiosa, Barrancuf 'stá isulado, purtanto quem... não há um sítio de passagem a Purtugal tem expressamente

Entrevistador: Ah sim

Entrevistado 6: A primeira lucalidade maif próxima de Barrancuf 'stá do lado Ifpanhol a $9 \mathrm{~km}$ é mais perto do que a que 'stá em Purtugal que 'stá aí uns 30

Entrevistador: Sim.

Entrevistado 6: Então historicamente Barrancus tem maif afinidade com Purtu... com a Ifpanha do que com Purtugal que está em

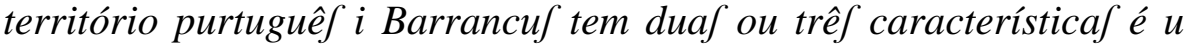
primeiro sítio em Purtugal onde é admitido uf touros de morte que em Purtugal 'stá proibido matar o touro mas em Barrancuf tem um 'statuto 'spcífico e historicamente faziam af as touradaf, matavam o touro e dipoif dê $\hat{e} \hat{e} e$ até introduziam o touro de uma forma clandestina na praça of tourerof entravam de uma forma a serem clandestina e em Barrancof há até um ditado um livro que é filologia Barranquenha é que purque eles têm uma miftura de purtuguêf e ifpanhol na fala

Entrevistador: Ah sim.

Entrevistado 6: E tem muitas qu's... coisas ifpanholas na própria atividade diária

Entrevistador: $\mathrm{Na}$ verdade eles criaram então uma língua própria deles.

Entrevistado 6: Tem, eles até tem uma filologia editada eles falam barranquenho

Entrevistador: Com variantes. 
Entrevistado 6: Não é purtuguêf nem Ifpanhol, é barranquenho, é uma miftura e quando, quando eles é hm é tem a festa deles principal qué 28 de agosto, nesta data é eles fazem a feira, a festa e tem coisas que em Purtugal não existe por exemplo: comer, na festa delef, a carne com tumate qui é uma coisa típica ifpanhola, danças Sevilhana que é um baile típico da Luiza, bebem o tinto com, tinto de verano que é vinho tinto cum casera que é uma gasosa que há aqui na IJpanha,

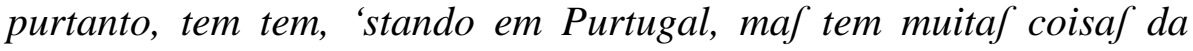
própria raia, purtanto, Barrancuf

Entrevistador: Espanhola

Entrevistado 6: Barrancus tem o seu próprio, tem o seu próprio dã dã qu'stões etnográfica linguísticas até própria a maneira de ser é dif'rente

Entrevistador: Você não sente isso aqui em Olivença?

Entrevistado 6: Ma ma Olivença é dif'rente, ma a agora vou expliar é que Barrancuf nunca foi ifpanhola, é e intão Barrancuf tem essa característica, dipoif tem aqui no norte, tem uma lucalidade que se chama Miranda do Douro. Em Purtugal, em Purtugal só há duaf língua oficiaif, é o purtuguêf e o mirandêf.

Entrevistador: Ah tá.

Entrevistado 6: Desde 1999 aprovado pela pelo hum Assembleia da República, no parlamento Purtuguêf, foi aprovado e reconhecido mirandêf, porque que o mirandêf, qué que qué que o mirandêf tem, não pudemos esquecer que, eh, essa zona daqui antigamente foi, demorou muito a ser repovoada, então teve muitas influências do lionês purque essa zona daqui da IJpanha era Lião, é Lião, era o Reino de Lião. Então tem muitas influênciaf do lionêf, intão o mirandêf tem influências o lionêf, é purtuguêf e do ifpanhol e elef editaram uma filologia, houve um prufessor que editou uma filologia eh, reconheceram o mirandêf no parlamento e hoje em dia é o único sítio em Purtugal que além de se ensinar purtuguêf, ensina-se outra língua dentru du território que é o mirandêf. $O$ mirandêf, a própria te, as terras de Miranda têm muito intr'esse em em têm muito intr'esse defde esse pontu di vifta pra 'studar eeeeh por isso também digo que é um sítio de intr'esse, purtanto, $i$ dipoif tem um, maif a cima, aqui mefmo do cantinho, há uma cidade chamada Bragança, a $20 \mathrm{~km}$ de Bragança está uma lucalidade que se chama Rio de Onor

Entrevistador: Isso tudo em Portugal?

Entrevistado 6: Tudo em Purtugal, tem Rio de Onor, sem " $h "$ ", do lado purtuguêf e Rio de Honor, do lado Ifpanhol, com "H", Honor é Honra em ifpanhol então foi uma lucalidade que durante muito tempo passou (não compreendido) para Purtugal, Purtugal para (não 
compreendido) até que um dia 'stamos sem nossas fronteiras e então foi dividido ao meio. Houve familiares a viver du lado ifpanhol e du lado purtuguêf, a senhora o mesmo qui vai aqui nessa rua e qui vai entrar num edifício é e dizer du lado está em Purtugal e du lado está Ifpanha, não há fronteiras, então a própria lucali, é toda uma lucalidade, mas uma área ifpanhol e outru lado é purtuguêf e tanto si fala ifpanhol comu si fala purtuguêf e até si falam u rionores qui é a língua du norte que tem essa miftura, purtanto, ao longo da fronteira sítiof (não compreendido) para studar como defde esse ponto de vista tem Olivença, tem Barrancof, tem eh u mirandêf du Mirandouro e o Rionores independentemente (não compreendido) o caso de Olivença e difr'ente, u Olivença é uma lucalidade que, dê 1297 até 1801 é purtuguesa, em 1801 entram as tropaf, por isso foi pelaf invasões francesas é o Napoleão pretendia era conquistar Purtugal i havia um indivíduo ifpanhol qui era diz supostamente qui é o amante da da da rainha ifpanhola que era Godoy é que foi o que eles pretendem (...)

\section{Entrevistado 7 (PD) - 39 anos}

O entrevistado $7(\mathrm{PD})^{158}$ concedeu a entrevista em seu local de trabalho, sendo bastante receptivo conosco, conversando de forma espontânea e desinibida. A entrevista ocorreu de forma tranquila, sendo interrompida em alguns instantes por algumas ligações telefônicas que o entrevistado necessitava atender.

Durante todo o tempo de gravação, não sentimos nenhum tipo de desconforto ou insegurança por parte do informante, que, embora estivesse em seu trabalho, nos deixou tranquilos quanto ao tempo de que necessitávamos.

Diferente dos demais entrevistados, o informante 7 chegou em Olivença ainda criança, com apenas 12 anos, o que poderíamos pressupor uma incorporação da cultura espanhola muito maior. A condição em que imigrou tem um diferencial, pois pelo fato de vir junto com seus pais, posteriormente conseguira se estabilizar no país, tornando-se um empresário.

\footnotetext{
${ }^{158} \mathrm{O}$ entrevistado 7 (PD) tem 39 anos, nasceu e viveu em Portalegre (Portugal) e mora em Olivença há 26 anos. É casado com espanhola e tem dois filhos que falam pouco o português. Trabalha e é proprietário de um centro automotivo no Polígono Industrial de Olivença.
} 
Completou o que os portugueses chamam de $\operatorname{ciclo}^{159}$ na cidade espanhola, tendo, portanto, contato com os espanhóis desde o período escolar. O informante não continuou seus estudos, no entanto, hoje é proprietário de uma mecânica.

Ao perguntarmos sobre uso da LH, informa-nos que a utiliza em casa, e que seus filhos estão aprendendo, especificando que ultimamente é "moda" falar português em Olivença:

Entrevistador: Qual a convivência da língua portuguesa aqui com vocês? Vocês falam em língua portuguesa em algum momento?

Entrevistado 7: Eu em casa sim...com filhof aprendere...mas agora ifta começar a...(...) a moda falare em purtuguêf...tá...é como...é moda, $i$ intão, (...) Fizeram uma entrevifta, (...)uma entrevifta de qui...é da algun que vinha aqui apanhar nacionalidade purtuguesa...i intão vi ao pirciber a forma que catuava...falava, digo...é moda. É adaptaram moda aqui, aprender purtuguêf...a moda ter nacionalidade purtuguesa, fala purtuguêf...(sons de telemóvel tocando)

Como podemos notar, o informante 7 percebe o quanto a LH está em um momento de grande valorização e não como uma língua inferior e de desprestígio, tal como era considerada antes. No entanto, para ele, acostumado com a conotação que recebe uma língua minoritária, pensa que se trata apenas de um momento, ou seja, uma "moda" entre os moradores locais. A impressão que temos é que ele não acredita que sua LH pode se tornar importante em Olivença, mas que é apenas uma fase de valorização passageira.

Sem nos dizer, percebemos o quanto o entrevistado 7 tem sua língua nativa em uma situação de inferioridade na sociedade espanhola. Por viver entre os espanhóis desde muito cedo, não percebe que seu grupo étnico tem se manifestado a favor de que a cultura portuguesa não desapareça de Olivença.

Como podemos ver no trecho abaixo, o entrevistado 7 não quer que a LH deixe de fazer parte de sua família. De acordo com ele, embora não falem o português, compreendem bem o idioma:

\footnotetext{
${ }^{159} \mathrm{O}$ ciclo em Portugal compreende o Ensino Básico, que é dividido em 3 ciclos: $1^{\circ}$ ciclo $\left(1^{\circ}\right.$ ao $4^{\circ}$ ano $)$, $2^{\circ}$ ciclo $\left(5^{\circ}\right.$ e $6^{\circ}$ ano $)$ e $3^{\circ}$ ciclo $\left(7^{\circ}\right.$ ao $9^{\circ}$ ano $)$.
} 
Entrevistador: E of seus filhoffalam purtuguêf?

Entrevistado 7: É...entende tudo ma não fala purtuguêf

Entrevistador: Não falam nada?

Entrevistado 7: Nada...si eu zobrigam a falá, falam...si eu digo não...(...) falam em purtuguêf, é maf...tem u acentu purtuguêf maf não há prublema.

Entrevistador: Eles têm o acento português?

Entrevistado 7: Si si o acento quandu fala, quandu fala purtuguêf, falam em purtuguêf purtuguêf...hummm...seja...tem u sutaque purtuguêe...

Entrevistador: Sim! Quando falam em português?

Entrevistado 7: Sim. Mas tem, mas temus obriga a fala purtuguêf, purque ali na migué é refponde ifpanhol a...é falare purtuguêf $i$ é refponder efpanhol a...ali na migué (...) aprender purtuguêf purque...é... a língua purtuguesa é uma língua que dá facilidade pa aprender e outruf idioma. I ao mefmo tempo perdi-si a vergonha di fala outra língua...(....) preder essa vergonha...perdi-si a vergonha falar qualquer língua...

A fala desse entrevistado nos revela que seus filhos, embora não falem a LH, já carregam uma herança cultural: o sotaque, demonstrando que, mesmo nascidos na cidade espanhola, sua pertença ao grupo étnico português existe.

No decorrer da gravação, o informante, ao abandonar a categoria da Quantidade, expõe uma elocução bastante confusa, mas que, por estarmos envolvidos no processo interativo, utilizamos as pistas deixadas e o conhecimento sobre o contexto pragmático para implicar que, de acordo com o informante, os espanhóis não se esforçam para falar outros idiomas. A causa para isso reside no sentimento de que sua língua é ‘superior’ e não precisam:

Entrevistado 7: Em Purtugal iftudei o françêf, até o doze anu iftudei u francêf em Purtugal...é quandu vi pa Ifpanha, não havia francêf...tinha que iftudar o inglêf ou si ó si (.....) Há dois anuf tô a iftudar alemão.

Entrevistador: Muito bem

Entrevistado 7: Goftei gofto de aprendê línguaf, não tenho i queri que eu ifteja.... 
Entrevistador: é, por que percebo que os portugueses são bilingues...sempre...com todos que eu converso falam espanhol, falam português, às vezes, até outras línguas. O espanhol não, né?

Entrevistado 7: Não, não, não! US ifpanhóis têm ideia que co entende elef todo o mundo, i quando sai fora daqui já ifta (...) eli vá za lá comere $i$ quando chegua aquelas a fronteira ali um reftaurante, já sabia, intende, si si ali sim, (....) tem qu'intendê váriuf (...) Já vai vere u que vai acontecê. Essi aqui já cousa até digo, aqui elif num fala purtuguêf, aqui elif num falam purtuguêf...elif falam alantijano...(risadas). Agora o real mefmo elif falam purtuguê nof

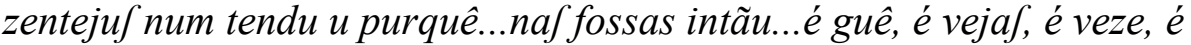
parece um pouco (...) às vezes um ifpanhol falar purtuguesi i falam um ifpanhol como si os purtugueses tivesse intendê sem iffurça nada...é muito (....)

Ao perguntarmos ao entrevistado se sua esposa falava a língua portuguesa, forneceu-nos uma resposta bastante interessante, que revelou o que ele próprio sente sobre seu português oliventino:

Entrevistador: e sua esposa, é espanhola?

Entrevistado 7: ifpanhola sim

Entrevistador: ah, já nascida aqui?

Entrevistado 7: si,si,si si

Entrevistador: fala português, ela?

Entrevistado 7: entende tudo purtuguêf, ma não fala purtuguêf

Entrevistador: como seus filhos?

Entrevistado 7: tem vergonha de falar purtuguêf

É possível depreender eu sua esposa tem "vergonha" de falar em português, algo que ela, provavelmente, não deve ter dito a ele, mas, por ele próprio sentir-se falante de uma língua considerada "inferior", infere que seus familiares sentem o mesmo.

Para ratificar a ideia de que os espanhóis não se esforçam para falar o português, lança o seguinte discurso:

Entrevistador: Tem vergonha de falar português? 
Entrevistado: Sim, é, é curioso porque, é, eu crie-me em Purtugal, é, é meu pai viram antif pa Ifpanha, meu pai viram quando eu tinha oito anu, meu pai (...) o meu irmão, o du meio, essi veiu co elif...i eu, eu fiquei lá, em casa de meu〕 avóf, (.....) muito difici, há muituf anuf, a (...) $i$ então digamuf (...) um pouco (.......) Ifpanha. Éééé $i$ então, eu crie co minha vó, (...) eu te, eu tenho uma relação muito íntima com minha vó... iiii a minha muié, quando vai a Purtugal, em casa de minha vó, é u meu vô e minha vó, comu são jovenf ainda, setenta e tal (...) i i a minha vó fala em purtuguêf, i a minh a minha muié fala ifpanhol, as duas entende prefeitamente u que diz uma da outra, (risadas), mas nenhuma fala o idioma da outra...(...) prefeitamente a minha vó entende prefeitamente o ifpanhol, a minha muié entende prefeitamente o purtuguêf ma ...

Entrevistador: ai quando sua vó pergunta em português a sua esposa responde espanhol?

Entrevistado 7: responde ifpanhol

\section{(risadas)}

Entrevistado 7: é curioso (...) (risadas...)

Entrevistador: uma pergunta em português, resposta em espanhol, é interessante

Entrevistado 7: é curioso sim, maf...digamos que, minha vó já pa idade que tem de idade não qué aprender ifpanhol (...) daf vezee sai dali...agora u...é curioso, é curioso.

$\mathrm{Na}$ interação discursiva acima, podemos perceber que ocorre o abandono de algumas categorias tais como:

(i) a categoria da Quantidade, através da máxima: "fazer contribuição informativa o suficiente para a compreensão". Para falar sobre o sentimento de vergonha que acredita ter sua esposa, expõe uma elocução extensa demais.

(ii) a categoria do Modo, através da máxima: "não produzir expressões obscuras”. Para dizer que sua esposa não gosta de falar português, usa a informação de que durante a conversa com sua vó, somente responde em espanhol. 
O abandono das máximas nos obriga a lançar mão do nosso conhecimento contextual para que possamos implicar o sentido. Durante toda sua extensa fala, o entrevistado lança a seguinte pista contextual:

"é curioso sim, maj...digamos que, minha vó já pa idade que tem de idade não qué aprender ifpanhol”.

Como podemos notar, o argumento lançado nos leva à seguinte implicatura: sua esposa não fala português porque não quer, pois, por ser nova ainda, poderia muito bem aprender o idioma, ao contrário da vó (portuguesa), que não aprende por já estar com a idade avançada.

O contato do informante 7 é diversificado, pois mantém relações tanto com espanhóis quanto com portugueses devido ao seu empreendimento. Assim, como falante bilíngue, num estágio de self central, tal como proposto por Damásio (2011), afirma não ter interferência do espanhol em sua língua:

Entrevistador: Isso o que eu ia te perguntar...e quando você fala português, você se surpreende falando espanhol?

Entrevistado 7: não, não , não, não, sei, sei mudar bem u.

Entrevistador: você consegue separar bem o português?

Entrevistado 7: é (....) O difcu, a parte até, mudu u difcu i já via até que, mudo até...é...

Entrevistador: o som?

Entrevistado 7: u som...mudo u som, mai mudo u som ai, em francêf, efpanhola, é 'lemão i u purtuguêf. Mudu som...totalmente, é que, acoftumei ma isso, ou seja, as línguas paraaa, ou falas comu eles ou intão...

Logo em seguida, com a sequência de seu discurso, percebemos que ocorre o abandono das categorias Qualidade e Modo, dando a sua fala um sentido contraditório. Vejamos:

Entrevistador: E o seu sotaque? O seu acento?

Entrevistado 7: Se eu chego, si eu chego lá, a primeira hora, dizem que vem de fora, quandu passa uma hora já não... 
Entrevistador: Ah sim, então quando você conversa...

Entrevistado 7: Converso no primeiro momento...

Entrevistador: Sabe que é português???? Aí depois não???

Entrevistado 7: Não! Ou seja, a pissoaf dizem (...) "tem um acento assim...um poucu...dif'rente" maf, mas já quando passa um pouco já não...

Percebe-se que a intenção do entrevistado é assegurar que muda de uma língua para outra com facilidade e sem interferências. Ocorre que, em sua fala, contradiz-se com sua intenção, não permitindo que tenhamos essa certeza. Sendo assim, verificamos que ocorre o abandono das categorias da seguinte forma:

(i) abandono da categoria Qualidade, através da supermáxima: "trate de fazer uma contribuição que seja verdadeira". Embora o entrevistado afirme mudar de uma língua para outra sem interferência, sua fala se contradiz: "Se eu chego, si eu chego lá, a primeira hora, dizem que vem de fora".

(ii) abandono da categoria Modo, através da máxima: "não produzir elocuções ambíguas". O fato de ser contraditório deixa-nos inseguros quanto ao que realmente ocorre: “não, não, não, não, sei, sei mudar bem u.." (não tem interferência linguística) X "e eu chego, si eu chego lá, a primeira hora, dizem que vem de fora" (possui interferência linguística).

Diferentemente dos demais entrevistados, o informante 7 possui uma influência muito grande do país de contato, explicada pelo fato de ter chegado no país muito criança. Assim, pelo seu sotaque, afirma que as pessoas o reconhecem como espanhol, da cidade de Sevilha, e não como português:

Entrevistado 7: nãa, nãa, não, ou seja, eu, a mim, a mim aqui em Ifpanha, dizem que sou de Sevilha

Entrevistador: Ah, dizem que você é de Sevilha!!!

Entrevistado 7: Como cóquerum (qualquer um) a ma'ria, a ma'ria (a maioria) du purtuguêse a que tu falare co elif, automaticamente vamu dizê efti efti é purtuguêf, consegue um trabalhinhu automaticamente, mas a mim a pissoas difvia... 


\section{(...)}

eu vô qualqué parte IJpanha...i dizi...sivilhianu

A entrevista nos revela que o fato de conviver desde sua tenra idade entre os espanhóis, sente que suas características são espanholas, no entanto, a cultura de seu país não é perdida, estando incrustada entre os pertencentes de seu grupo étnico.

Como vemos, durante o processo de interação discursiva, ou seja, num processo de interação face a face, tal como propõe Goffman (1998), ocorre a necessidade de um olhar para o discurso como um 'enquadre/frame' (Bateson, 1998:57), um olhar para as "pistas de contextualização" (Gumperz, 1998:100), perceber que "atos linguísticos", ocorrem de "momento a momento", num contexto de "mundos possíveis", tal como propõem Erickson e Shultz (1998:144) e perceber que todo discurso nada mais é do que a resposta ao "Princípio de Cooperação" (Grice, 1982:86).

\subsubsection{O sentimento de pertença dos descendentes de imigrantes portugueses - Os falantes de LH}

Sentindo a necessidade de saber como era a relação da LH entre a geração mais jovem, dirigimo-nos ao Instituto de Ensino Puente Ajuda ${ }^{160}$ a fim de realizar uma entrevista com filhos ou netos de portugueses que vivem em Olivença.

No local, verificamos que os alunos possuem na matriz curricular do Instituto de Ensino aula de Língua Portuguesa como disciplina opcional, e que, naquele momento, havia um grupo de mais ou menos vinte alunos.

Solicitamos à direção da escola autorização para conversar com os alunos da escola que fossem descendentes de portugueses e nosso pedido foi prontamente atendido. Assim, a entrevista foi realizada com cinco meninas, as únicas descendentes de portugueses, em uma sala de aula que estava disponível. Embora todas estivessem na mesma sala e acompanhavam a fala das outras, cada uma falava em um momento diferente.

${ }^{160}$ Cf no capítulo sobre a Metodologia de pesquisa, seção sobre a característica da amostra - os descendentes de $2^{\mathrm{a}}$ e $3^{\mathrm{a}}$ geração de portugueses. 
As entrevistas não puderam passar de 7 minutos cada uma, pois sabíamos que todas elas estavam em horário de aula, o que nos obrigou a realizar um contato com poucas perguntas, mas que foram o suficiente para termos a noção da relação: LH e geração mais jovem.

\section{Entrevistada1 (AN) ${ }^{161}-17$ anos}

A entrevistada 1 é neta de portugueses, sendo, portanto, pertencente à $3^{\text {a }}$ geração de imigrantes portugueses que vivem em Olivença. Fala o espanhol, porém, atualmente, está frequentando aulas de Língua Portuguesa na IES Puente Ajuda.

Assim que todas as entrevistadas adentraram a sala para conversarmos, percebemos que estavam muito encabuladas e, portanto, respondiam exatamente o necessário, não havendo em nenhum momento o abandono da categoria da Quantidade (Grice, 1982:87). Como já explanamos anteriormente, tal atitude foi tomada pela insegurança em falar num momento de gravação.

Iniciamos nossa conversa com a entrevistada 1 perguntando o nome, idade e escolaridade e, logo em seguida, perguntamos que idioma ela falava, no entanto, ela opta por responder o idioma que utiliza com seus avós. Vejamos a resposta:

\section{Entrevistadora: Que língua você fala AN?}

Entrevistada 1: Eu falo purtuguês, mas às vezes falo com uи о теи avô purtuguês, eu saio falo espanhol, mas as vezes falo com o meu avô e a minha vó em purtuguês

Entrevistadora: Português? Em casa você conversa em que língua?

Entrevistada 1: É...com a minha família falo espanhol, mas com o meu avô, falo portuguê!

\footnotetext{
${ }^{161}$ Optamos por tratar as informantes por siglas. A informante tem 17 anos, nascida em Olivença é filha de espanhóis e neta de portugueses. No período da gravação estava cursando o $1^{\circ}$ ano de bacharelado, que na Espanha é um preparatório para a Universidade. Nossa gravação durou apenas 6 minutos, pois não poderíamos ocupar muito tempo com as alunas, pois estavam em horário de aula. Além disso, não se tratava de uma gravação para análise linguística, pois sabíamos que eram espanholas e, portanto, falam o idioma local, provavelmente utilizando a LH não com fluência.
} 
Entrevistadora: Ah sim, com ele você conversa português?

Entrevistada 1: Sim!

Como vemos, o que ocorre na fala da informante 1 é um "provável interesse epistêmico do pesquisador" (Schwarz, 1999:96), pois, já sabendo que éramos brasileiros, infere que nós gostaríamos de ouvir que usa a LH com seus familiares.

A entrevistada não simplesmente fala de seu uso, como a coloca na posição de relevância em seu discurso, abandonando a categoria da Relevância (Grice, 1982:87) proposta pela entrevistadora. Como vemos na fala, a entrevistadora pergunta a língua usada em casa, mas ela opta por responder a língua que usa com seus avós.

A entrevistada 1 responde novamente a pergunta inicial após a entrevistadora tornar a perguntar, no entanto, fala de forma bem rápida, "espanhol”, trazendo logo em seguida para o tópico o que ela considera relevante informar: " mas com o meu avô, falo portuguê!"’. A entrevista nos revelou a importância da LH para a informante 1, que faz questão de deixar em evidência o seu uso com seus avós, os únicos falantes.

Em sequência à nossa entrevista, perguntamos a língua usada por ela no seu dia a dia, ou seja, na escola, com os amigos e, mais uma vez, trouxe para o contexto de relevância a LH. Vejamos como faz isso:

Entrevistadora: É...na escola você só fala em espanhol, ou não?

Entrevistada 1: Sim, mas às vezes, em brincade, brincadeira falo em purtuguês.

Para nos fornecer a importância do português, afirma que algumas palavras já estão sendo utilizadas entre eles como se fossem próprios da comunidade local, e fornece como exemplo a palavra "gafanhoto", que, em espanhol, significa "saltamontes". Vejamos a informação:

Entrevistadora: ... Quando você fala, conversa em espanhol no seu dia a dia, alguma palavra...você sente que alguma coisa tem de português ou não?

Entrevistada 1: É...há algumas palavras que usa-se em espanhol mas também são purtuguesa, mas aqui em Olivença, muitas que mudaram pra me re... A ver, me refiro que algumas palavras do purtuguês passaram a ser espanhola aqui em Olivença solo... 
Entrevistadora: Você, você pode me dar um exemplo?

Entrevistada 1: Claro, hay, puede ser do (não compreendido)?

Entrevistadora: Qual? Por exemplo? Você lembra alguma?

Entrevistada 1: Ahora mesmo não pero como nós oliventinos temos e...temos sido portugueses há algumas palavras que herdaram... gafanhoto

Entrevistadora: Gafanhoto?

Entrevistada 1: Pur exemplo.

Entrevistadora: Gafanhoto é do português?

Entrevistada 1: Sim

Entrevistadora: E espanhol?

Entrevistada 1: Não, é português, mas em Olivença continua sendo...

Entrevistadora: Continua sendo gafanhoto?

Entrevistada 1: Sim

Entrevistadora: E vocês falam gafanhoto?

Entrevistada 1: Sim

Entrevistadora: Espanhol como é gafanhoto?

Entrevistada 1: Saltamontes

A entrevistada percebe que o português deixou tantas marcas em Olivença, que seus usos estavam entre a comunidade local como se fossem parte do idioma espanhol.

Já, a informante 1, ao ser questionada se possuía algum tipo de sotaque português, demonstrou indecisão ao responder, mas as amigas ratificaram que sim, e ela acabou confirmando:

Entrevistador: Bom, você, vocês, você tem algum sotaque português? Sotaque que digo acento

Entrevistada 1: Acento? (não compreendido) 
Entrevistador: Tem? Ela tem acento português? [a entrevistadora se dirige às outras entrevistadas que estavam na sala]

Outras entrevistadas: Sim, muito

Entrevistador: Muito? Você tem um pouquinho?

Entrevistada 1: Um pouquinho sim

A fala demonstra que o sotaque da LH está presente na fala da entrevistada 1, sendo, inclusive, confirmada pelas amigas, no entanto, sabemos que isso ocorre não de uma forma consciente e planejada, mas por estar na mente da informante como fato indissociável. Mesmo sendo espanhola, acabou expondo no seu falar um estágio de protosself, tal como propôs Damásio (2011).

A entrevistada 1, diante da pergunta sobre uma possível superioridade do idioma espanhol, argumenta que realmente existe essa diferença e explica que o fato ocorre pelo contexto histórico já explanado anteriormente ${ }^{162}$. Vejamos a fala:

Entrevistadora: Você acha que o espanhol considera a língua deles superior ao português?

Entrevistada 1: É...algumas pessoas que como não estavam de acordo ao passo de Olivença há ser espanhola, consideram o purtuguês inferior, mas as pessoas que estão de acordo com que o purtuguês, se iria sendo o purtuguês de Purtugal seguem pensando como uma língua como la demais.

A entrevista se encerra com a conclusão de que a entrevistada tem muito orgulho de estar estudando a língua de seus avós, pois sabe que ela faz parte de seu grupo e é um vínculo com seus ancestrais.

Além disso, pudemos perceber que a LH em Olivença está longe de ser apagada entre os portugueses e nem mesmo entre seus descendentes, pois resiste viva, com marcas bem presentes que ecoam de geração em geração, numa espécie de "efeito catraca", tal como propõe Tomasello (1999).

\footnotetext{
${ }^{162} \mathrm{Cf}$ no capítulo sobre o locus da pesquisa.
} 


\section{Entrevistada $2(E S)^{163}-17$ anos}

A entrevistada 2 é filha de pai português, sendo, portanto, pertencente à $2^{\mathrm{a}}$ geração de imigrante português que vive em Olivença. Fala espanhol, porém, frequenta, atualmente, aula de português na IES Puente Ajuda.

A entrevista se inicia com a pergunta sobre a língua falada em casa e, tanto quanto a primeira entrevistada, nos responde com a língua utilizada com os avós paternos. Vejamos o trecho da fala:

\section{Entrevistadora: Ah sim! que língua você fala em casa?}

Entrevistada 2: Espanhol, mas quando vô à caça da minha vó, falo purtuguês.

Entrevistador: você fala português quando vai à casa da sua vó! sua vó mora próximo?

\section{Entrevistada 2: sim!}

A elocução da entrevistada 2 abandona a relevância proposta pela entrevistadora, e coloca a LH como tópico discursivo, também num "provável interesse epistêmico do pesquisador" (Schwarz, 1999:96). É provável que a relevância possa ter sido considerada aquela ditada pelos seus pares, ou seja, como já houve uma resposta anterior formulada nessas bases e esta fora aceita como pertinente, repeti-la pareceria o caminho mais seguro também para sua resposta.

A entrevistada 2 , tanto quanto a entrevistada 1 , coloca a LH na posição de relevância em seu discurso, abandonando a categoria da Relevância (Grice, 1982:87) proposta pela entrevistadora. Como vemos na fala, a entrevistadora pergunta a língua usada em casa, mas ela opta por responder a língua que usa com seus avós.

A entrevistada informa que no seu dia a dia fala somente o espanhol, mas usa o português de forma mecânica num estágio self central, tal como propõe Damásio (2011). Além disso, tem consciência de que as marcas de LH no seu dia a dia aparecem,

\footnotetext{
${ }^{163} \mathrm{~A}$ informante tem 16 anos, nascida em Olivença é filha de mãe oliventina e pai português. No período da gravação estava cursando o $1^{\circ}$ ano de bacharelado, que na Espanha é um preparatório para a Universidade. Nossa gravação durou apenas 5 minutos e 48 segundos.
} 
mas de forma involuntária, num estágio de protosself (sem consciência). Vejamos que apresenta tal fato de forma indecisa:

Entrevistadora: Você tem acento português?

Entrevistada 2: Não.

Entrevistadora: Nenhum? *perguntando para a colega* ela tem?

Outras entrevistadas que estavam na sala: sim, sim, sim, tem

Entrevistadora: *risadas* Bom, é...quando você está se comunicando em espanhol, pela influência do seu pai você acha que ce a...usa palavras do português?

Entrevistada 2: algumas coisa si...digo em purtuguêf

Entrevistadora: você sabe... ce lembra alguma ou não?

Entrevistada 2: Quando alguma coisa ah...faço bem digo: agora si, antes não.

A entrevistada 2, ao abandonar a categoria da Qualidade, através da máxima “não dizer o que pensa ser falso", tal como propõe Grice (1982), fornece, de início, a informação de que não tem influência da LH, porém, logo em seguida, corrige sua fala, apresentando o contrário. Podemos atribuir o abandonado de tal máxima, pautados nas teorias de Damásio (1999) e Caldas (1999), os quais propõem a possibilidade de que o indivíduo tome atitudes fora do plano da consciência, "induzidas de uma forma não consciente" (Damásio, 1999:68).

Percebemos um plano inconsciente na resposta inicial, de que não fala nada em português, pois, ao ser refutada pelas amigas, toma consciência de sua ação de rompimento com a máxima da qualidade sobre o assunto. A consciência disso a faz corrigir sua resposta: "algumas coisa si...digo em purtuguêf”.

Além disso, demonstra ter consciência também de que a LH, mesmo não sendo falada por ninguém em sua casa, apresenta marcas evidentes. Vejamos o que fala:

Entrevistado 2: O meu pai fala efpanhol, mas quando hum por alguma ra razão, chateia-se, fala o purtuguêf 
Ao ser questionada sobre a diferença entre o português e o espanhol, a entrevistada 2 apresenta o sentimento de superioridade que alguns espanhóis têm:

Entrevistadora: Você acha que os espanhóis fazem diferença do... acham que a língua deles é superior ao português?

Entrevistada 2: Algumas pessoas si

Nossa entrevista com a informante 2 revelou, mais uma vez, que a LH está presente entre os portugueses oliventinos e que, por mais distante que seja, suas marcas não são completamente apagadas. No máximo, modificações e adaptações dessa língua ao novo contexto.

\section{Entrevistada 3 (IS) ${ }^{164}-16$ anos}

A entrevistada 3 é filha de pai português e mãe espanhola. Nasceu em Campo Maior, cidade de Portugal, mas desde sempre viveu em Olivença. De acordo com a entrevistada, foi registrada em Portugal apenas para ter o nome de seu avô :

Entrevistada 3: Hã...eu nasci ali (...) registrada ali, mas sempre vivi em Olivença.

\section{(...)}

Entrevistada 3: Pru que é minha família era de Olivença, mas é eu tinha que ter o apelido de o meu avô, então tinha que ser registrar em Portugal para pude ter o apelido.

Fala em casa e entre os amigos somente o espanhol, porém frequenta, atualmente, aula de português na IES Puente Ajuda, o que indica o interesse em não perder sua LH. Durante a entrevista, ao ser questionada sobre o uso da LH, nos responde diretamente que "não", nem mesmo em casa. Vejamos o trecho da gravação:

${ }^{164}$ A informante tem 16 anos, nascida em Campo Maior, Portugal, viveu desde sempre em Olivença. É filha de mãe oliventina e pai português. No período da gravação estava cursando o $1^{\circ}$ ano de bacharelado, que na Espanha é um preparatório para a Universidade. Nossa gravação durou apenas 5 minutos e 04 segundos. 
Entrevistador: Em casa você conversa em português?

Entrevistada 3: Não. Meu pai fala português, eu falo em espanhol

Entrevistador: Seu pai fala português... e seu pai... e... seu pai fala português e você fala espanhol?

Entrevistada 3: si

Entrevistador: Você consegue entender bem o português?

Entrevistada 3: *não compreendido*

Entrevistador: consegue falar bem o português?

Entrevistada 3: sim, mas é costume

A entrevistada informa que sabe falar o português, porém não utiliza, mesmo tendo o estímulo do pai. Além disso, por abandonar a categoria do Modo, através da máxima "não produzir expressões obscuras", prejudica o sentido da informação que fala português por "costume".

Diante do abandono de tal máxima, ficamos sem saber o que seria "falar por costume". Seria falar de forma involuntária, em um estágio de protosself, no qual fala sem ter consciência de seu uso, como muitos dizem "sem querer"? Ou seria em estágio de self central, no qual ela utiliza de forma mecânica, apenas replicando o uso?

Durante a conversa com a informante 3 , notamos a insistência em nos afirmar que não usa a LH em casa e, muito menos, no seu dia a dia. Para que não tenhamos dúvidas, nos responde respeitando a máxima da Quantidade:

Entrevistador: Ah sim. É... Que língua você conversa com os seus amigos na escola?

Entrevistada 3: Espanhol

Entrevistador: Só? Solo?

Entrevistada 3: Si

Entrevistador: Não fala nada em português?

Entrevistada 3: Não 
Ao ser questionada sobre a possibilidade de usar a $\mathrm{LH}$ de uma forma involuntária, mais uma vez, a resposta é fornecida de forma enfática:

Entrevistador: É...quando você conversa em espanhol, você acha que algumas palavras você usa em português? Sem querer? Chega usar palavras sem querer em português?

Entrevistado 3: Ah não

Entrevistador: Nunca? Nem um tipo de palavra?

Entrevistado 3: Não.

Em outro momento da entrevista, entramos na questão sobre o sentimento de inferioridade da LH entre os espanhóis e vejamos a resposta obtida:

Entrevistador: É... Você acha que a língua portuguesa é uma língua inferior ao espanhol?

Entrevistado 3: Não

Entrevistador: Não? Eles acham isso? Os espanhóis fazem diferença do português?

Entrevistado 3: Hummm eu acho que não

Implicatura: Há a possibilidade de que a entrevistada acredite que os espanhóis se considerem superiores.

Como é possível notar, a informante, de início, responde de forma certa que ela não sente que sua LH é inferior ao espanhol, porém já não acredita que esse sentimento seja recíproco por parte da comunidade espanhola ao dizer: "Hummm eu acho que não". $\mathrm{Na}$ verdade, vemos uma indecisão em sua resposta, o que não ocorreria se ela sentisse que não há, categoricamente, essa diferença entre portugueses e espanhóis.

Na elocução anterior ocorre o abandono da categoria Modo, através da máxima "não produzir expressões obscuras", obrigando-nos a implicar o sentido. O abandono de tal categoria pode ocorrer por dois motivos: (i) a entrevistada sente a diferença entre as duas comunidades, mas não tem certeza; ou (ii) a informante não quer expor de forma 
direta a informação de que há o sentimento de superioridade espanhola, então para se abster da resposta, produz uma elocução no plano dubitativo: "acho que não".

Na sequência da entrevista, mais uma vez, a entrevistada 3 nos obriga a implicar o sentido, pois abandona a categoria Modo, através da máxima "não produzir expressões obscuras". Vejamos como ocorre:

Entrevistador: Acha que não? Ah, não há superioridade de línguas em Olivença?

Entrevistado 3: As pessoas mais velhas falam português.

Implicatura: A entrevistada percebe que os mais velhos se recusam em falar espanhol, o que pode representar uma diferença entre os grupos.

O fato de produzir uma expressão obscura obriga-nos, mais uma vez, a implicar o sentido, porém o sentido implicado, pode não ser o que realmente a entrevistada quis nos informar. O abandono da categoria Modo, tal como propõe Grice (1982), causa esse tipo de problema no processo de interação discursiva.

A entrevista revelou-nos que, embora a LH não seja praticamente utilizada, a informante 3 recebe a influência de sua família para que seu uso permaneça entre seus membros. Além disso, fica claro que participar das aulas de português na escola, sendo uma disciplina opcional, é um grande indício do sentimento de pertença da LH.

\section{Entrevistada $4(\mathrm{DN})^{165}-16$ anos}

A entrevistada 4 é filha de pai português e mãe espanhola. Nasceu em Lisboa, cidade de Portugal, mas chegou em Olivença com 2 anos de idade. Fala em casa e entre os amigos somente o espanhol, porém frequenta atualmente aula de português na IES Puente Ajuda, o que indica o interesse em não perder sua LH. Vejamos o trecho da entrevista:

\footnotetext{
${ }^{165}$ A informante tem 16 anos, nascida em Lisboa, Portugal e veio para Olivença com dois anos de idade. É filha de mãe oliventina e pai português. No período da gravação estava cursando o $1^{\circ}$ ano de bacharelado, que na Espanha é um preparatório para a Universidade. Nossa gravação durou apenas 4 minutos e 32 segundos.
} 
Entrevistadora: Ah sim, tudo bem. Que língua você fala em casa "Isabela"? Desculpa é Daniela, né?

Entrevistada 4: Español

Entrevistadora: Em casa espanhol?

Entrevistada 4: Sim

Entrevistadora: Só espanhol?

Entrevistada 4: Sim

Entrevistadora: Compreende bem o português?

Entrevistada 4: Sim, sim

Entrevistadora: Que língua você fala na escola?

Entrevistada 4: Em espanhol

Entrevistadora: Só espanhol?

Entrevistada 4: Mas na sala se hace portuguê, pois... português

Entrevistadora: Nas aulas de português, todas vocês fazem aula de português?

Entrevistada 4: $\mathrm{Si}$, si

No seu dia a dia e em casa, a entrevistada somente se comunica através do idioma local, mesmo tendo o estímulo do pai, que é português, utilizando a LH somente entre os familiares que não sabem falar o espanhol, no caso os primos e avós paternos:

Entrevistadora: (...) seu pai fala que língua em casa?

Entrevistada 4: Português

Entrevistadora: Quando seu pai fala em português você responde em português?

Entrevistada 4: Não, en español

Entrevistadora: Seu pai te pergunta em português e você responde em espanhol?

Entrevistada 4: Sim, sim, sim 
Entrevistada 4: Com a família eu falo português, mas com meus primos, avós, isso.

Ao ser questionada sobre a possibilidade de ter algum sotaque português, responde que não possui nenhuma marca da $\mathrm{LH}$ :

Entrevistadora: Nada. Bom...quando você está conversando no seu dia a dia com os seus pais, com a sua família você usa algum acento português?

Entrevistada 4: Eu não tenho já acento português

Entrevistadora: Nenhum?

Entrevistada 4: Não

A entrevistada 4, embora diga no início da gravação que não usa a LH nem mesmo com o pai português, passa a nos dizer que seu uso entre seus familiares existe, o que nos leva, mais uma vez, a postular a preservação da LH entre a camada mais jovem de falantes em Olivença:

Entrevistadora: É... e com seus, né... bom... se não tem com a família, você acredita não ter com os amigos também né? [aqui a entrevistadora se refere ao sotaque português]

Entrevistada 4: Com a família eu falo português, mas com meus primos, avós, isso.

Entrevistadora: Só espanhol? É isso?

Entrevistada 4: Espanhol e português

O sentimento de inferioridade linguística também é percebido pela entrevistada 4 que, embora diga que não considerar o português uma língua inferior, acredita que algumas pessoas a consideram. Vejamos o trecho da fala que apresenta essa avaliação:

Entrevistador: Aah tá. É...Você considera que o português é uma lingua inferior?

Entrevistada 4: Não

Entrevistador: Não? Você acha que os espanhóis consideram? 
Entrevistada 4: Algumas pessoas consideram que é inferior, mas outras eu acho que não

Entrevistador: Não? Eles acham que a língua deles é mais importante? É mais forte no mundo?

Entrevistada 4: Não, isso não

Entrevistador: Não? Você acha que eles acham que o português é igual ao espanhol?

Entrevistada 4: Sim, algumas pessoas sim, mas outras não.

Embora a entrevistada sinta que exista um sentimento de inferioridade da língua portuguesa, tem a convicção de que não é por parte de todos, pois sabe que, como ela e suas amigas que estão estudando o idioma, ainda muitos falantes da LH fazem questão de que ela esteja bem presente entre a comunidade oliventina.

Fica claro que nenhuma das entrevistadas nega ou não aceita o uso da LH; ao contrário, estão estudando para que ela se mantenha viva, pois sabem que fazem parte de um grupo étnico forte e capaz de lutar para que suas marcas permaneçam presentes por todas as gerações de falantes. 


\section{CONCLUSÃO}

Nenhum indivíduo nasce com sua identidade pronta. Nenhum indivíduo permanece sua vida ilusoriamente completo e imutável. Todas as pessoas, em alguma fase de sua vida, passarão por revoluções (físicas, biológicas, psíquicas ou atitudinais) que lhe alterarão o estado de ser. Algumas pessoas (se não todas), em algum inescapável momento, sofrerão turbulências psicológicas que as conduzirão a assumir uma posição ética, ideológica ou psicológica diferente da que vinha 'coerentemente' (ou inocentemente) desempenhando em sua trajetória de ser. O resultado é que, em cada uma dessas revoluções ou turbulências, cada uma dessas pessoas inevitavelmente passará a se perceber melhor, a se enxergar melhor e, desse processo, não é possível sair ileso. Constroem-se identidades, constroem-se autobiografias, revelam-se heranças.

Essas revoluções e turbulências não são apenas internas. Elas manifestam-se em espaços físicos, por onde os corpos deslizam, atuam, interagem. Falar de espaço é falar de gente em movimento. Quando esse espaço é fronteirizado politicamente em decorrência de ações e de atitudes humanas impostas, é irreversível que surjam identidades fronteiriças e que estas se mantenham respirando insuspeitamente. Foi exatamente o que presenciamos no espaço intermédio entre Olivença e Elvas.

Ter reconhecido um espaço em que identidades são fluidas a depender do contexto foi a motivação para a realização desta pesquisa. Passamos a reconhecer o sentimento de pertença da língua de herança $(\mathrm{LH})$ entre falantes da língua portuguesa. $\mathrm{O}$ interessante é que a oficialidade da língua espanhola, que transpira maior prestígio, é guiada por um grande caráter impositivo. De outro lado, a língua portuguesa, sem demandas, emana em situações diversas uma identidade lusitana ora saudosa, ora presente e viva.

Olivença é, assim, uma cidade que, embora pertença politicamente à Espanha, tem um passado português. Tendo sido parte integrativa do território português ${ }^{166}$, uma certa "rivalidade" linguística vez por outra é presentificada entre os habitantes de forma

${ }^{166}$ Cf no capítulo 2 "O locus da pesquisa”. 
quase velada. E foi nesse contexto histórico de uma situação de 'dominação' espanhola, que a língua portuguesa na cidade foi sendo enclausurada nos lares, as heranças culturais foram sendo preservadas entre os membros do grupo minoritário e insuspeitamente em vários lugares públicos. Explicamos: por se tratar de região fronteiriça com Portugal, Olivença tornou-se um ambiente propício para que situações de bilinguismo envolvendo a LH tivessem espaços específicos para se revelarem e a descoberta dessas situações foi outro aspecto de inspiração para a realização desta pesquisa.

Vários autores, já apresentados na introdução desta tese, afirmavam que quanto maior a proximidade geográfica, mais intensa seria a presença de costumes e hábitos culturais. Assim, pudemos evidenciar que o fator "fronteira" foi altamente importante para que os imigrantes pudessem manter sua língua nativa e sua LH, mesmo que inconscientemente. Essa forma de conviver também nunca foi muito percebida pelos demais membros da comunidade, o que causou uma vala de comunicação entre bilíngues simultâneos, os camaleões. Essa invisibilidade (camuflada) foi o mistério que nos moveu durante os últimos anos de estudo e pesquisa. Sobre esse tema, elaboramos esta tese, que organizamos em capítulos de apresentação, fundamentação teórica, revisão do tema e análise propriamente dita.

Logo na introdução (de forma superficial) e mais profundamente no capítulo 1, apresentamos autores que discutiram o sentido do termo fronteira desde o século XV, período em que começou a ser utilizado na Europa. De acordo com os autores, a palavra estabelecia relação com "defesa", "competitividade" e até mesmo "luta" pelo seu espaço, o que nos favoreceu associar com o contexto de língua e LH dos portugueses oliventinos, vez por outra em verdadeira batalha com espanhóis.

Esses oliventinos camaleões reverberam a língua como um dos componentes mais importantes de sua identidade. Esta, por sua vez, pôde ser melhor compreendida pela descrição orientada por um feixe de abordagens: a variacionista (Labov, 1976), que permitiu recortar a comunidade pelas diferenças e chegar ao que unificava segumentos sociais. Completaram essa abordagem os estudos de empréstimos, de interferências mútuas e de assimilações. Diante dos resultados observados, perguntamo-nos: quais seriam as variáveis linguísticas que mais sofreram alterações na língua dos portugueses que vivem em Olivença? Quais seriam as estruturas desses elementos linguísticos? E, 
ainda, qual seria a distribuição estratificada, tendo em vista que Olivença possui pouquíssimos portugueses, cujos descendentes pertencem a uma geração de filhos e netos de portugueses?

Para obter as respectivas respostas, sabíamos que a correlação seria necessária, pois uma das hipóteses plausíveis sustentava-se no fato de que uma língua em contato com uma língua majoritária poderia inibir o uso entre os indivíduos mais jovens e refrear - mas não impedir - o uso entre os mais idosos. Contrariamente aos resultados de estudos variacionistas, verificamos que a atividade profissional está mais relacionada com os usos incorporados. No caso da língua portuguesa falada em Olivença, poderíamos pensar em uma grande influência da língua espanhola pelo fato de que muitos dos informantes trabalham em restaurantes ou em outras ocupações frequentadas pela comunidade majoritária, estando, portanto, mais suscetíveis aos diversos contatos. No entanto, de acordo com os resultados aferidos, embora o contato com os espanhóis fosse intenso, as variações apresentadas pouco se relacionaram com a língua majoritária. Essa foi a razão por que recorremos a Gumperz e Wilson (1971). Esses autores propõem que as mudanças podem ocorrer sob duas formas: por convergência, em que ocorrem perdas devido ao contato com outras línguas ou à interferência, que é a introdução de formas novas, devido ao contato. Ocorre que - e isso pudemos atestar claramente - o português em Olivença, por estar em uma comunidade de língua espanhola, recebeu, sim, influência do espanhol; contudo, surpreendentemente, a influência foi muito menor do que imaginávamos.

Quanto às variações estilísticas, estas tendem a ser idênticas às variações sociais, pois os falantes, à medida que interagem com outros de diferentes níveis ou com diferentes etnias, procuram se aproximar o máximo possível do padrão interacional. Sendo assim, para além dos bilíngues simultâneos (que nascem falando duas línguas - a de casa e a majoritária), creditamos o processo de bilinguismo em Olivença ao fato de que, por seus falantes considerarem o espanhol uma língua superior e de maior importância, procuram usá-la da melhor forma, tentando, o máximo possível, não permitir interferências de uma língua na outra. Sendo assim, as marcas linguísticas que mais nitidamente evidenciam a etnia são evitadas.

As contribuições que proporcionamos com esta tese, somadas aos resultados de pesquisas resenhadas e citadas nos capítulos precedentes (Matias, 1984; 2001; 
Fernández, 2004) ratificam que, atualmente, embora com um número muito pequeno de falantes, o português tem se revelado forte e presente em variados contextos de uso. Várias foram as características típicas do português oliventino, dentre as quais as variações fonéticas, lexicais e sintáticas, que independiam do nível de instrução ou nível sócioeconômico.

As variações fônicas, identificadas durante esta pesquisa permitiram afirmar que o português falado em Olivença apresenta pouquíssima influência do espanhol, com exceção da fala de um informante (entrevistado 5 - JP, vide capítulo IV), que foi descartado da análise global por ser um caso estigmatizado pelos próprios oliventinos como "chaporreu”, que é uma mescla do português com o espanhol. A substituição vocálica de /i/ > [e]: [piquena] e $/ \boldsymbol{o} />[\boldsymbol{u}]:$ [vamu lá] é comum entre os portugueses oliventinos e compatível com alguns usos da língua portuguesa no território português. Os casos fonéticos de síncope, tal como [memo (mesmo)] e aférese, com em [tando (estando], não puderam igualmente ser relacionados com as variáveis sociais. De outra perspectiva, são assemelhadas ao que ocorre do outro lado da fronteira, ou seja, no lado português. As apócopes, como em [si (sim)], apresentaram-se correlacionadas a mais baixo nível de instrução (informantes 1,2 e 4), em especial na supressão do $m$ da palavra sim, constituindo-se este um indício de interferência do espanhol no nível pragmático. Muitas foram as ocorrências de paragóge, tal como o acréscimo de elemento vocálico e no final das palavras terminadas em $r$ : [tare]; [melhore], usos correntes entre os portugueses alentejanos, independentemente da variável social. Os casos de inversões de consoantes, tais como [preguntar], foram associados a um nível de instrução mais baixo, mas não corrente entre todos os informantes.

No campo do léxico, algumas peculiaridades podem ser apresentadas. Os oliventinos empregam a palavra miúdo para se referirem a menino, um uso já não tão frequente entre portugueses, daí postularmos que, em Olivença, a língua nativa mantémse entre os portugueses oliventinos, o que nos fez ratificar as considerações de Matias (1984, 2001) e de Fernández (2004). A única palavra identificada com uma influência do país hospedeiro é bucanhino ou pocaninho. Esses usos concorrem o tempo todo com a palavra pequeno, termo que designa "criança" ou "pequeno".

Quanto aos aspectos morfológicos, as influências espanholas rarearam-se sobremaneira. Os pronomes de primeira pessoa do plural variaram entre os usos [a 
gente] [nós], ratificando o que descreveu Vilela (1999), para quem o pronome a gente é generalizado em Portugal na modalidade falada, independentemente da variável social. O pronome de tratamento Você concorreu com $t u$, mas essa variação só pôde ser associada a raros usos na fala de indivíduos com baixo nível de instrução. As formas de tratamento preferidas pelo informante 5, que possui o maior nível de instrução, foram $o$ senhor e a senhora.

Entre as classes mais gramaticais, trataremos das conjunções e das preposições. $\mathrm{Na}$ conexão das orações, as conjunções selecionadas coincidiram com as empregadas pelos portugueses em Portugal. Nesse sentido, falantes bilíngues simultâneos empregam elementos mais gramaticais em consonância com a língua em uso no momento da fala, sem os confundir. Notamos que a conjunção 'porque' é mais frequente entre os falantes de português, independentemente da variável social. Apenas um deles empregou a conjunção 'pois', que foi imediatamente substituída pela de uso comum (porque), numa espécie de autocorreção: "e tenho minha casa à venda... pois proque aquilo meus filhos não quere" (Entrevistada $3 \mathrm{JN}$ ). Somente um uso conjuncional chamou a atenção pela diferença. Trata-se de condo, em lugar de quando, claramente uma alteração fônica que se associa à baixa escolaridade. Além desse, a excepcionalidade revelou-se com o emprego da locução conjuncional por quando. No que se refere às preposições, verificamos que a preposição pra é muito frequente em todas as variáveis sociais, substituindo quase que totalmente sua forma correspondente para.

A preposição em sendo usada no lugar de na revela uma variação bastante interessante, principalmente pelo fato de que, embora tenha aparecido em poucos dados, ocorre independentemente das variáveis sociais selecionadas nesta pesquisa, o que indica um uso comum e desvinculado de classe social. As preposições pelo e por são incomuns, embora tenhamos verificado que por a noite foi preferido em lugar de pela noite (1 ocorrência apenas). A expressão prepositiva cas no lugar de com as é um fenômeno típico do português falado e também do português oliventino.

Sobre os verbos selecionados pelos sujeitos entrevistados, pouca diferença estes revelam, aproximando dos usos do português de Portugal:

1. 'achar' e 'pensar' no portguês oliventino têm aparecido com o sentido de 'acreditar' ou 'concordar': [por que acho que devia] (eu acredito/concordo que devia) Entrevistado 1 (FR) 
2. 'dever' como primeiro verbo de uma locução verbal foi encontrado com o sentido de 'necessitar' ou 'precisar': [deve deve sempre deve ensinar a língua a língua que tem] (precisa/necessita sempre ensinar a língua que tem) - Entrevistado 1 (FR)

3. 'esperar' aparece no português oliventino sob a forma 'peraí', funcionando como um verbo de função conversacional: [então peraí que eu digo espanhol] (aguardar um tempo para que diga espanhol) - Entrevistado 1 (FR)

4. 'estar' aparece com muita frequência na fala de todos os falantes na realização 'tá', 'tive', 'tô', 'tamus', etc., num processo de aférese: [mesmo tando, mesmo tando aqui a dez minutos] - Entrevistado 1 (FR)

5. 'ter' e 'haver' existenciais ocorre praticamente na mesma frequência entre os falantes do português em Olivença, fato típico somente do português e não do espanhol, em cujos usos somente o verbo 'haver' se emprega no sentido de existir. Sendo assim, verificamos que, mais uma vez, a influência da língua da sociedade receptora não se apresentou no português oliventino. Este não abandonou o uso do verbo ter existencial; ao contrário, utiliza-o com muita frequência como ocorre tanto no português de Portugal quanto no do Brasil.

6. 'perceber' também apresentou uma alteração com o verbo 'saber' ou 'conhecer', tal como ocorre em Portugal, afastando-nos qualquer ligação com influência espanhola: [não pircebem nada de ifpanhol] [não sabem/conhecem nada de ifpanhol] Entrevistado 1 (FR)

7. 'levar' no sentido de 'ter' ou 'estar'. Esses dados apareceram somente na fala de um de nossos entrevistados, o qual pertence a um nível mediano de escolaridade. No entanto, não parece ser esse caso suficiente para atrelar tal uso a qualquer variável social. [há! pedreiro, de construção civil (...) já leva aqui vinte eee três anos] [há! pedreiro, de construção civil (...) já tem/estou aqui vinte eee três anos] - Entrevistado 4 $(\mathrm{CR})$

Sobre advérbios e locuções adverbiais, é possível notar uma reverberação dos usos alentejanos. Os únicos que mostraram uma influência do espanhol foram os advérbios de intensidade 'pouco' e 'sim', os quais mostraram usos como 'poco' (tal como no espanhol, mas poderia, sem sombra de dúvidas, ser uma alteração fônica 
comum em Portugal) e ' $f i$ ' ou 'si' (no espanhol sí). Neste último caso, o de afirmação, observamos essa influência mais acentuada na entrevistada 2, a qual tem baixo nível de instrução. Para negar, os entrevistados fizeram uso do advérbio 'não' com a alteração bem peculiar da língua portuguesa: 'nem': [nem nada fazem]. O advérbio de tempo 'depois' aparece também nas realizações variáveis 'dipois' e 'dipoif', igualmente característica da fala dos portugueses alentejanos.

Outras palavras, que flutuam entre categorias, revelaram-se usos interessantes:

- melhor - miore: influência do português alentejano

- tal = pouco (indefinido, aproximativo): [cheguei aqui às duas e tal da manhã] [cheguei às duas e pouco da manhã] - Entrevistada 3 (JN)

Entre as análises dos advérbios, o que mais nos chamou a atenção foi o advérbio de lugar 'aqui', o qual está sendo muito usado entre os falantes do português em Olivença. Sua variante concorrente cá, que era muito utilizada em Portugal parece que está cedendo lugar ao uso do 'aqui': [vem aqui a viver pra IJpanha] [vem cá a viver pra Ifpanha] - Entrevistado 1 (FR). Neste caso, mesmo o uso de 'cá' podendo ser usado com muita clareza, o informante optou pelo uso de 'aqui'. Já, com os advérbios de frequência, as variações que encontramos entre os falantes do português oliventino estão associadas a uma influência típica do próprio português de Portugal: 'muitas vezes' com ‘sempre', 'de vez em quando' com ‘em vez em quando', ‘às vezes’ e 'por vezes'.

$\mathrm{Na}$ expressão 'vida satura' para representar 'uma vida muito difícil' ou 'encostinho' para se referir ao 'lar' foram usos que não se explicam pelo espanhol, o que nos faz imaginar que seja uso típico do português alentejano. Além disso, as variações para os graus comparativos entre os falantes de português têm se mostrado bastante diversificadas, surgindo usos com as construções: [tão...como] [tanto...como] $\sim$ [como...como] $\sim$ [nem...nem] [tanto...quanto]. Nesse sentido, é possível notar que os portugueses oliventinos, embora de forma variadas, mantêm as características típicas da língua portuguesa: [ele tan fala ifpanhol como purtuguêf com eles] - Entrevistado 1 (FR). É possível notar, também, que, ao avaliar os adjetivos na forma comparativa de superioridade e no grau superlativo, 'muito' e 'mais' são os usos mais frequentes, o que nos garante uma característica típica do português: [muito mió do qui ali] - Entrevistada 2 (RS).

Evidenciamos que é muito comum entre os falantes do português oliventino construções sintáticas em que a estrutura não obedece a ordem prototípica ou canônica 
da língua portuguesa, qual seja SVO. Os casos em que se revelam são comuns no português alentejano e contemplam o princípio da iconicidade. Por exemplo, na fala do entrevistado 1 (FR): [tudo, tudo perdi-si muito mais qui é um é uma coisa tem a fronteira pur ixemplo... Elvas e Olivença] - ênfase na informação deslocada, para indicar a importância da perda relatada.

Quanto às colocações pronominais usuais entre os falantes do português oliventino revelam que o espanhol não interferiu nos usos, ao contrário, se revestem de todo o recurso que o português pode apresentar, tais como as próclises motivadas [e lhe já aprendermos], as ênclises esperadas [casei-me com uma purtuguesa] e usos tipicamente oliventinos: [me tem o inglês e me tem o purtuguêf]. A feição sentencial também se preservou como no português de Portugal, não deixando que o espanhol causasse interferência, como, por exemplo, o uso do verbo 'haver' muito mais do que o verbo 'ter', inclusive, não fazendo mais uso deste último em seu sentido existencial, tal como ocorre no espanhol. Como temos visto, o verbo 'haver' existencial é muito frequente entre os falantes do português oliventino, sendo uma variável do verbo 'ter' existencial, ocorrendo quase que com a mesma frequência de uso. Além disso, o verbo ter evidenciou rica variação na sua feição sentencial do português em Olivença: ter com o sentido de dever ou precisar: [ah tinha, tinha que apreender as duas com certeza...risada...], ter com o sentido de possuir: [sim tem três filhos], ter com um sentido ambíguo ou como auxiliar: [sempre tenho me dado muito bem].

Nesta análise também nos preocupamos em apresentar o aspecto durativo verbal por meio do infinitivo, que nos mostraram também ricas variações: 'estar a + infinitivo', 'continuar a + infinitivo', 'verbo + a + infinitivo', ' $Q$ verbo a + infinitivo' como também utilizavam o gerúndio com a terminação em 'ndo'. Separamos as construções encontradas em gerúndio da seguinte forma: gerúndio em [verbo + material interveniente $+\mathrm{a}+$ infinitivo]: [Eu tenho, tenho lá, agora tenho lá um primo meu, também da Universidade a fazer um trabalho lá!] (Entrevistado 1 FR) e gerúndio em [® verbo a + infinitivo]: [todo dia, todo dia, a falar com eles, i a falar com eles] (Entrevistada $2 \mathrm{RS}$ ). Quanto ao aspecto durativo verbal por meio do gerúndio, no português oliventino existem duas formas que os falantes utilizam: oração reduzida de gerúndio = oração subordinada adverbial temporal: [com esta vida não se pode, vida da restauração é uma vida que nós temo sendo preso, nós não podemos ter um dia de natal 
como tem outra pissoa qualquer com a família, não se tem um dia] (Entrevistada 3 JN) e em construção durativa na configuração: estar + gerúndio [então meu filho pregunta, pai que tá dizendo ao avô?] (Entrevistado $4 \mathrm{CR}$ ).

O sistema de concordância no português oliventino apresenta [não concordância] apenas entre os entrevistados menos escolarizados, já que estão fora dos limites da oficialidade dessa língua: [uma vez qui falamos inglês eles já aceita nós e a gente consegui falar com eles] - (Entrevistado 1 FR). Não encontramos ocorrências com ausência de concordância do entrevistado que é professor universitário, o que nos leva a postular as variações desse tipo mais relacionadas ao nível de instrução.

Entre os falantes de português em Olivença encontramos algumas expressões que nos chamaram a atenção, as quais revelam uma característica bastante peculiar desse grupo étnico. Assim, como pudemos depreender das ocorrências copiadas a seguir, uma das expressões - "prontu" foi encontrada em mais de um entrevistado, o que nos indica ser um uso próprio dos portugueses: [saíram, saíram saíram a minha mãe, a minha mãe não, a minha mãe prontu não tá] - (Entrevistado $1 \mathrm{FR}$ ) e "lá ta": [falam, principalmente, pelo outro visão lá tá uma vez mais os canais de desenhos animados e dessas coisas] - (Entrevistado 1 FR).

As entrevistas que fizemos em Olivença nos permitiram observar o quanto o português em Olivença possui uma riqueza de usos e variações que preservam os traços linguísticos típicos do português de Portugal, sem quase nenhuma influência do espanhol, nem mesmo nas expressões próprias da fala. Além de uma análise pautada por postulados teóricos da sociolinguística, recorremos a elementos sociointeracionais que enfatizam o papel da face e da situação (principalmente, Goffman, 1998; Bateson, 1998; e Grice, 1982). Diante do pensamento negativo de alguns pesquisadores sobre o trabalho qualitativo, apresentamos uma descrição das falas dos entrevistados a qual pudesse trazer à tona diversos elementos de circunstâncias importantes para a pesquisa, seguindo o que Duarte (2008) e Alves e Silva (1992) propõem que é uma pesquisa sistemática e que preservasse uma descrição holística, ou seja, envolvendo o contexto sociointerativo. Essa seria uma estratégia eficiente para garantir a qualidade da pesquisa científica. 
Adotamos, complementarmente, uma metodologia de análise qualitativa para que pudéssemos recolher informações que, a despeito de pouco frequentes, pudessem contribuir para a compreensão das atitudes dos usuários da LH e do português oliventino. Essa foi a razão para decidirmo-nos pela forma semiestruturada de entrevista, pois, sem a preocupação com a proliferação de dados, nos deteríamos nos elementos contextuais peculiares que envolvem todo o processo comunicativo de cada entrevista. Essa decisão foi proveitosa e favoreceu que atentássemos para os níveis de consciência dos entrevistados, inspirados no modelo em gradação, tal como postula Damásio (2008; 2011).

Essas estratégias favoreceram que reconhecêssemos a independência do impacto da variável social ou do contexto em que as falas ocorrem quando o objeto a ser avaliado é o sentimento de pertença da LH e da língua nativa. Este se revelou intrínseco e claramente colocado por alguns informantes, que reconhecem suas marcas como manifestação de uma herança cultural. Contraditoriamente, na fala de todos os entrevistados, concorria um sentimento de inferioridade linguística, este graus distintos de consciência. Muitos disseram que a língua portuguesa é importante, embora os espanhóis não a considerem.

Através da fala de sujeitos imigrantes, pudemos confirmar uma das hipóteses aventadas inicialmente, qual seja, a relação proporcional inversa entre a preservação da LH e a residência em região fronteiriça. Muitos, inclusive, sentem que as relações fronteiriças não são tão amistosas como esperavam que fossem, ratificando nossas intuições iniciais sobre a preservação da LH como marca de rivalidade herdada na disputa entre Portugal e Espanha.

É proveitoso, neste momento, esclarecer que todos os imigrantes entrevistados para esta pesquisa foram classificados como integrantes do estágio de self central (Damásio, 2011:225), por articularem mecanicamente o português-espanhol (falantes bilíngues simultâneos) sendo capazes de fazer uso da língua da sociedade receptora sem perder ou deixar que esta interfira na sua LH. Percebem que, muitas vezes, em momentos isolados, ou seja, provavelmente em estágio de protosself (Damásio, 2011:225), algumas palavras do espanhol acabam ecoando. 
Os entrevistados da faixa etária de 46 a 55, tal como havíamos hipotetizado, deixaram evidente que, entre os falantes mais velhos, o português seria preservado, mesmo que estivesse por muitos anos em contato com outra língua majoritária. A explicação é óbvia: falantes da língua portuguesa, mesmo que não percebam, trazem consigo uma herança cultural que não se apaga com o tempo ou lugar, mas que talha a identidade individual em resposta a instabilidades vivenciadas/sentidas. $\mathrm{O}$ entrevistado 5 (JP), por não ter se adaptado ao idioma da comunidade local, criou sua própria língua por adaptação, numa mescla entre o português e o espanhol, chamado entre os oliventinos como "chaporreu", uma língua estigmatizada por as ambas as comunidades. É uma resposta identitária também, ainda que desagregada dos grupos mais representativos.

Para responder a última questão pendente, que dizia respeito à longevidade da LH, precisaríamos analisar o que diziam as gerações mais jovens de oliventinos de herança portuguesa. Estes seriam a grande esperança de manutenção do português numa região de língua majoritária e oficial espanhola, justamente porque são eles os que conduziriam a LH aos cadinhos de convivência compatriótica no cotidiano. Para dar conta dessa questão, reunimo-nos com alguns jovens descendentes de portugueses e mantivemos uma conversa informal sobre sua herança cultural. O resultado foi que todas as entrevistadas (todas eram meninas) diziam sentir a necessidade de manter viva a língua familiar. Justificaram com o quanto essa língua é responsável pelo vínculo com a comunidade minoritária da qual elas também fazem parte.

O que notamos é que a $\mathrm{LH}$ circula entre os falantes mais novos de forma despercebida por muitos oliventinos, sendo utilizada como se fosse parte do idioma local. Essa constatação é baseada no depoimento dessas garotas que dizem empregar algumas palavras cotidianamente, como é o caso da palavra "gafanhoto", que, em espanhol, corresponde a "saltamontes". Suas falas exaltam a LH, mas, contraditoriamente, revelam um sentimento de inferioridade linguística, que se justifica, segundo elas, no fato de que o português não é considerado como uma língua importante por algumas pessoas. Essa é a razão por que, no seu dia a dia, falam somente o espanhol, embora para dizer isso continuem a usar o português de forma mecânica num estágio self central, tal como propõe Damásio (2011). Além disso, elas têm consciência de que as marcas de LH no seu dia a dia aparecem, mas de forma 
involuntária, num estágio de protosself (sem consciência), num processo de code switching (marca de bilinguismo simultâneo) em LHs.

Supomos que o português como LH em Olivença está longe de ser apagado entre os descendentes de portugueses, pois resiste viva, com marcas bem presentes que ecoam de geração a geração, numa espécie de "efeito catraca” (Tomasello, 1999). Além dessas, as marcas identificadas na fala da comunidade minoritária de Olivença só fortalecem essa constatação. Como se não bastassem, ainda há muito de herança, presentificando o sentimento de pertença, em pistas encontradas pelas ruas da cidade. Tais pistas nos provam que a língua, num processo evolutivo, se modifica no tempo histórico, porém, mantém marcas que não se apagam por completo.

As diversas turbulências, pressões e estigmas por que passa a LH portuguesa em Olivença têm fortalecido a união em torno do sentimento de pertença comum entre os portugueses e seus descendentes. O que há para além da fronteira é uma linha em movimento da qual pouco se sabe em termos de identidade linguística. Talvez Elvas surpreenda com um povo português que se sinta espanhol, talvez. O que sabemos com o final desta tese é que, em Olivença, há camadas populacionais que se entrecruzam, interagem. São pessoas de etnia diversa (alguns portugueses e alguns espanhóis), alguns dos quais camaleões (bilíngues simultâneos) e outros com identidade por lapidar. Ainda assim, é preciso saber que não há movimento sem espaço, não há espaço sem fronteiras, não há fronteiras sem lutas e batalhas. 


\section{REFERÊNCIAS BIBLIOGRÁFICAS}

ABRANTES, Ventura, Ledesma. Anais da Velha Vila Portuguesa de Olivença. Lisboa: Da Sociedade Geografia - Secção de História - Sub-secção de Estudos Oliventinos, Círculo de Estudos Históricos de Olivença e da Associação dos Arqueólogos Portugueses, 1951, p. 49-80.

ALMEIDA, Fortunato de. História de Portugal. Lisboa: Promoclube, Lda, v. 4, 1495.

ALVES, Zélia Maria Mendes Biasoli e SILVA, Maria Helena G.F. Dias da. Análise Qualitativa de dados de entrevista: uma proposta. Ribeirão Preto: Paideia, FFCLRP USP, 1992, v. 2.

BARRIOS, Graciela. Etnicidad y lenguaje: la aculturación sociolinguística de los inmigrantes italianos en Montevideo. Montevideo: Coleccion Carlos Vaz Ferreira, 2008.

BARRIOS, Graciela. Discursos hegemónicos y representaciones linguísticas sobre lenguas em contacto y de contacto: Español, Portugués y Portuñol fronterizos. In: HORA, Demerval da e LUCENA, Rubens Marques de (Orgs.). Política Linguística na América Latina. João Pessoa: Ideia/Editora Universitária. 2008.

BARTH, Fredrik. Ethnic Groups and bondaries.Long Grove/Illinois: Waveland Press, INC. 1998.

BASTOS, J. T. da Silva. Diccionário etymlógico, prosódico e orthográphico da Língua Portuguesa. $1^{\text {a }}$ ed. Lisboa: Livraria Editora, 1928.

BATESON, Gregory. Uma teoria sobre brincadeira e fantasia. In: RIBEIRO, Branca Telles e GARCEZ, Pedro M. (orgs). Sociolinguística Interacional: Antropologia, Linguística e Sociologia em Análise do Discurso. Porto Alegre: AGE, 1998.

BECERRA, Joaquín Fuentes. Ruas de Olivença voltam a ter nomes portugueses. Jornal Diário de Notícias, 11 de junho de 2010.

BITTENS, Cássia e JENNINGS-WINTERLE, Felicia. O começo do começo: A promoção do vínculo afetivo e o desenvolvimento emocional e cognitivo pela língua de herança. In: JENNINGS-WINTERLE Felicia e LIMA-HERNANDES, Maria Célia (orgs). Português como Língua de Herança: A filosofia do começo, meio e fim. New York: Brasil em mente. 2015. 
BOIX, E. Triar no és trair. Identitat y llengua em els joves de Barcelona. Barcelona: Barcelona Edicions. 1993.

BORUCHOWSKI, Ivian Destro. Diretrizes e princípios norteadores para um currículo de língua de herança. In: JENNINGS-WINTERLE Felicia e LIMA-HERNANDES (orgs). Português como Língua de Herança: A filosofia do começo, meio e fim. New York: Brasil em mente. 2015.

CABRAL, F. Caldeira. Alentejo: geografia humana e econômica:agricultura e criação de gado. In. Verbo: Enciclopédia Luso-brasileira de cultura I. Lisboa, 1963, p. 11081110 .

CALDAS, Alexandre Castro. A herança de Franz Joseph Gall:O cérebro ao serviço do comportamento humano. Lisboa: McGraw-Hill. 1999.

CALDAS, Júlio. Olivença - A cidade Portuguêsa que a Espanha administra. Edição de O mundo Português. Lisboa: Jornal para o Diário de Portugal, 1975.

CAMPESINO, Fernández, A. e FERRERA, Martinez, M. Olivença y la articulación de su espacio comarcal fronterizo.Olivenza: Revista Hispano-Portuguesa de Investigadores em Ciencias Humanas y Sociales - Encuentros, I., 1989, p. 53.

CASTILHO, Ataliba Teixeira de. O PHPB/SP - O Português Popular de SP. In: HORA, Demerval e LUCENA, Rubens Marques de. Política Linguística na América Latina. João Pessoa: Ideia/Editora Universitária, 2008.

CHORÃO, Maria José Mexia Bigotte; MACEDO, Maria Luísa; SILVA, José Antônio. Sociedade Científica da Universidade Católica Portuguesa. Exposição Documental sobre Santa Maria de Aguiar e Riba-Côa - Comemorações do $7^{\circ}$ Centenário do Tratado de Alcanices. Casa da Cultura Figueira de Castelo Rodrigo: Antunes \& Amílcar, Lda 1997.

COLL, Magdalena. El habla de los esclavos africanos y sus descendientes en Montevideo en los siglos XVIII y XIX: representación y realidade. Academia Nacional de Letras do Uruguai. 2010.

CONSIGLIERI, Carlos e Brito, Antônio. A actualidade da "questão de Olivença". Edição do autor, 2012.

CORREIA, Antônio Mendes, et al. Grande Enciclopédia Portuguesa e Brasileira. Lisboa: Editorial Enciclopédia, Limitada, 1940, v. 9.

DALGALARRONDO, Paulo. Evolução do Cérebro - Sistema nervoso, psicologia e psicopatologia sob a perspectiva evolucionista. Porto Alegre: Artmed. 2011. 
DAMÁSIO, A. R. E o cérebro criou o homem. Trad. Laura Teixeira Motta. São Paulo: Companhia das Letras. 2011.

O sentimento de si: corpo, emoção e consciência. Lisboa: Temas e Debates - Círculo de Leitores. 1999.

DASCAL, Marcelo. Relevância Coversacional. In: DASCAL, Marcelo (org). Fundamentos Metodológios da Linguística. Campinas: Financiada pelo próprio organizador com a colaboração de professores e alunos do departamento de linguística, Instituto de Estudos a Linguagem, UNICAMP, 1982.

DEFENDI, Cristina Lopomo. "Portanto, conclui-se que": processos de conclusão em textos argumentativos. 2013. Tese (Doutorado em Filologia e Língua Portuguesa) Faculdade de Filosofia, Letras e Ciências Humanas, Universidade de São Paulo, São Paulo, 2013. Disponível em: <http://www.teses.usp.br/teses/disponiveis/8/8142/tde06052013-104720/>. Acesso em: 2013-11-03.

DEFENDI, Cristina Lopomo. A reduplicação no português culto falado em São Paulo: possível gramaticalização? Dissertação de Mestrado, São Paulo: USP, 2008.

DELL-HYMES. The ethnography of speaking. In: GLADWIN, $\mathrm{T}$. and STURTEVANT, W. (eds). Antropology and human behavior. Washington: Antropological Society of Washington, 1962.

DUARTE, José B. Estudos de caso em educação. Investigação em profundidade com recursos reduzidos e outro modo de generalização. Revista Lusófona de Educação, 2008, v. 11, pp. 113-132.

ELIZAINCÍN, Adolfo. Gramática em contato e em conflito: Português e Espanhol em América. In: HORA, Demerval e LUCENA, Rubens Marques de. Política Linguística na América Latina. João Pessoa: Ideia/Editora Universitária, 2008.

. Estado actual de los estudios sobre el fronterizo uruguayo-brasileño.

Cuadernos del Sur (Bahía Blanca ), 12, pp. 119-140. 1979.

. The emergence of bilingual dialects on the Brazilian Uruguayan border. International Journal of the Sociology of Language, v. 9, pp. 120134. 1976.

Algunas aspectos de la sociolingüística del dialecto fronterizo. Temas de de Lingüística (Montevideo), 3 (completo). Montevideo, Universidad de la República. 1973.

ENCREVÉ, Piérre. Les sens commun - Willian Labov - sociolingistique. Paris: Les Editions de Minuit. 1976.

ERICKSON, Frederick e SHULTZ, Jeffrey. "O quando" de um contexto: Questões e métodos na análise da competência social. In: RIBEIRO, Branca Telles e GARCEZ, 
Pedro M. (orgs). Sociolinguística Interacional: Antropologia, Linguística e Sociologia em Análise do Discurso. Porto Alegre: AGE, 1998.

ERVIN, M. Susan. Language Acquisition and Communicative Choice. California: Stanford University Press. 1973.

FASOLD, Ralph. The Sociolinguistics of Language. Oxford: Blackwell Publishers, 1997.

FENTON, Esteve. Etnicidade; tradução Joana Chaves. Lisboa: Colecção Epistemologia e Sociedade, Instituto Piaget, 2009.

FERNÁNDEZ. Manuel Jesus Sánchez. Português de Espanha - Exemplo: o de Olivença. Revista Barbera Del Vallès, 2004.

FISHMAN, Joshua A. Sociolinguistique. Bruxelas: Labor. 1971.

FLORES, Cristina e MELO-PFEIFER, Silva. O conceito "Língua de Herança" na perspectiva da Linguística e da Didática de Línguas. Considerações pluridisciplinares em torno do perfil linguístico das crianças lusodescendentes na Alemanha. Revista Domínios de Linguagem. São Paulo, v.8, n.3, p.16-45, 2014.

FRITZEN, Maristela Pereira. Linguas em contato/conflito: em foco uma escola rural em zona de imigração alemã no sul do Brasil. Anais do CELSUL, 2008.

GARCIA, Érica. Frequencia (relativa) de uso como sintoma de estrategias etnopragmáticas. In: Klaus Zimmermann (ed). Lenguas em contacto em Hispanoamerica. Frankfurt/Madrid: Vervuert/Iberoamericana, p.51-72, 1995.

GALlEGO, Gregório Torres. Historia de Olivenza. Edição do autor. Terceira edición ampliada, (data conferir com Luna)

GIRÃO, A. de Amorim. Geografia de Portugal. $2^{\text {a }}$ ed. Porto: Editora Portucalense, S. A. L., 1949, Esboço de uma carta regional de Portugal. Coimbra, 1933, p. 118-119.

GOFFMAN, Erving. A situação negligenciada. In: RIBEIRO, Branca Telles e GARCEZ, Pedro M. (org). Sociolinguística Interacional: Antropologia, Linguística e Sociologia em Análise do Discurso. Porto Alegre: AGE, 1998.

GOMES, Juliana Azevedo. A criatividade como meio para as aulas de PLH: o trabalho com brasileirinhos na região da Catalunha (Espanha). In: JENNINGSWINTERLE Felicia e LIMA-HERNANDES, Maria Célia (orgs). Português como Língua de Herança: A filosofia do começo, meio e fim. New York: Brasil em mente. 2015. 
GRICE, Herbert Paul. Lógica e Conversação. In: DASCAL, Marcelo (org). Fundamentos Metodológios da Linguística. Campinas: Financiada pelo próprio organizador com a colaboração de professores e alunos do departamento de linguística, Instituto de Estudos a Linguagem, UNICAMP, 1982.

GUMPERZ, Jonh. J. Convenções de contextualização. In: RIBEIRO, Branca Telles e GARCEZ, Pedro M. (org). Sociolinguística Interacional: Antropologia, Linguística e Sociologia em Análise do Discurso. Porto Alegre: AGE, 1998.

HANDLER, R. Is "Identity” a Useful Cross-Cultural Concept? In: GILLIS, J. R. (Ed.). Commemorations. The politics of National identity. New Jersey: Princeton, 1994.

JEANNEROD, Marc. A natureza da mente. Lisboa: Instituto Piaget. 2002.

JENNINGS-WINTERLE, Felicia e FINCATTI, Patricia. Aprender a ouvir dentro da palavra: o meio pelo qual brasileirinhos lerão o mundo. In: JENNINGS-WINTERLE Felicia e LIMA-HERNANDES, Maria Célia (orgs). Português como Língua de Herança: A filosofia do começo, meio e fim. New York: Brasil em mente. 2015.

KLUSÁKOVÁ, Lud'a and ELLIS, Steven G. Frontiers anf identities. Exploring the Research Area. Edizione Plus Pisa University Press, 2006.

KNAPP, Mark L. Comunicação não-verbal na interação humana. Tradução Mary Amazonas Leite de Barros. São Paulo: JSN, Editora. 1999.

LABOV. Willian. Sociolinquistic patterns. Filadélfia: University of Pennsylvania Press. 1972.

LABOV, William. Modelos sociolingüísticos. Madrid: Ediciones Cátedra, S.A. Tradução de José Miguel Marinas Herreras, 1983 [1972].

LICO, Ana Lucia Cury. Família, escola e comunidade no processo de ensinoaprendizagem de PLH: do começo ao fim. In: JENNINGS-WINTERLE Felicia e LIMA-HERNANDES, Maria Célia (orgs). Português como Língua de Herança: A filosofia do começo, meio e fim. New York: Brasil em mente. 2015.

LIMA-HERNADES, Maria Célia e CIOCCHI SASSI. Língua de Herança como integradora de identidades. In: JENNINGS-WINTERLE Felicia e LIMAHERNANDES, Maria Célia (orgs). Português como Língua de Herança: A filosofia do começo, meio e fim. New York: Brasil em mente. 2015.

LIMA-HERNANDES, Maria Célia (orgs). Português como Língua de Herança: A filosofia do começo, meio e fim. New York: Brasil em mente. 2015. 
Evolução linguística e gramaticalização. Material do minicurso apresentado de 17 a 19 de junho de 2013.

.O princípio da iconicidade e sua atuação no português do Brasil. Revista Universidade de São Paulo - Filologia e Língua Portuguesa. São Paulo, v. 8, n.8, p. 83-96. 2006.

A interface sociolinguística/gramaticalização: estratificação de usos de tipo, feito, igual e como. Tese de doutorado. Campinas: ÚNICAMP.

LOPES, Ana Maria Macário, eti ali. As construções com portanto no PE e no PB.BH: Scripta, v. 5, n.9, 2001.

LUNA, Carlos Eduardo da Cruz. Uma jornada do Português de Olivença - um estrondoso êxito. Jornal Alto Alentejo, 11 de março de 2009.

Apelo a espanhóis e portugueses para salvação de uma língua - A situação da Língua Portuguesa em Olivença.Bragança: Atas finais do Colóquio da Lusofonia, 2005.

Heróis de Évora. Jornal Diário do Sul, 2006.

Nos caminhos de Olivença. Estremoz: Gráfica

Calipolense, Ltda., Vila Viçosa. $3^{\mathrm{a}}$ ed. 2000.

MACKEY, William Francis. Bilinguisme et contact des langues. Paris: Editions Klincksieck,1976.

MANETA, Luís. Ruas de Olivença voltam a ter nomes portugueses. Jornal Diário de Notícias, 11 de junho de 2010.

MARTÍN, José-Luis; SHAW, Carlos Martínez e TUSELL, Javier (org). História de España.Tauros Pensamento, 1998.

MARTÍNEZ, Angelita e SPERANZA, Adriana. ?Cómo analizar los fenómenos de contacto linguístico? Uma propuesta para ver El árbol sin perder de vista El bosque.In: Linguística ALFAL. v.21, pp.87-107, 2009.

MARTÍNEZ Angelita. Lenguas en contacto: gramaticalización y frecuencia de uso. Conferencia plenária. Actas Del Encuentro de Lenguas Indígenas Americanas, Santa Rosa, La Pampa, Universidad Nacional de La Pampa y Subsecretaria de Cultura Del Gobierno de la Provincia de La Pampa - 1-24, 2006. 
MATIAS, Maria de Fátima Rezende. A agonida do português em Olivença. Revista de Filologia Românica, 2001, v. 18, p. 159-170.

. Bilinguismo e níveis sociolinguísticos numa região

luso-espanhola (concelhos de Alandroal, Campo Maior, Elvas e Olivença). Coimbra: Separata da Revista Portuguesa de Filologia, 1984,v. XVIII e XIX.

MATURANA, Humberto R. Biology of language: The Espistemology of Reality. New York: Academic Press, p. 27-63, 1978.

MICHAELIS, Dicionário escolar Espanhol. São Paulo: Editora Melhoramentos, 2009.

MIRA MATEUS, Maria Helena e NASCIMENTO, Fernanda Bacelar do (orgs). A língua portuguesa em mudança. Lisboa: Caminho, 2005 p.81-94.

MITHEN, Steven. A pré-história da mente: uma busca das origens da arte, da religião e da ciência. Tradução de Laura Cardellini Barbosa de Oliveira. São Paulo: Editora da Unesp, 1998[1996].

MORONI, Andreia. O português como língua de herança: o começo de um movimento. In: JENNINGS-WINTERLE Felicia e LIMA-HERNANDES, Maria Célia (orgs). Português como Língua de Herança: A filosofia do começo, meio e fim. New York: Brasil em mente. 2015.

MORONI, Andreia e GOMES, Juliana Azevedo. O Português como Língua de Herança hoje e o trabalho da Associação de pais de Brasileirinhos na Catalunha. Revista de Estudios Brasileños. Catalunha, v.2, n.2, p.21-35, 2015.

OLIVEIRA, José Fernando Reis. A Ponte Velha da Ajuda: uma ruína romântica, entre Elvas e Olivença. Vigaprintes, Lda, 2012.

PARREIRA, Alcides. Olivença o tabu ibérico. Revista Pormenores. Julho/Agosto de 2010.

PEREIRA, António Manuel. A Terra Portuguesa de OLIVENÇA - Como a obtivemos e a perdemos. Edição do Autor. Tip. e Enc. Domingos de Oliveira, Sucrs, L. da Porto.1968.

PEZATTI, Erotilde Goreti. Portanto: conjunção conclusiva ou advérbio? BH: Scripta, v.4, n. 7, 2000.

PICÃO, José da Silva. Através dos campos. Usos e costumes agrícolo-alentejanos (concelho de Elvas). 2a ed.Lisboa: Neogravura, Ltda, 1947, p. 335-343. 
PRAÇA, Afonso. Um momento de ternura e nada mais. Lisboa: Editorial Notícias. 1995.

QUIRANT, Marcelino Cardalliaguet. História de extremadura. Biblioteca Popular de Extremadura: Universitas Editorial, 1993.

RIBEIRO, Orlando. Geografia e civilização: Temas portugueses. Lisboa: ChorographiaColecção de Estudos de Geografia Humana e Regional - Instituto de Alta Cultura - Centro de Estudos Geográficos da Universidade de Lisboa, 191.

ROCHA, Carine de Oliveira. O papel dos pais na transmissão de LH: planejamento e prática. In: JENNINGS-WINTERLE Felicia e LIMA-HERNANDES, Maria Célia (orgs). Português como Língua de Herança: A filosofia do começo, meio e fim. New York: Brasil em mente. 2015.

RODRÍGUEZ, Amaya, Esteban. Don Juan Alfonso de Albuquerque, canciller de D. Pedro El Cruel. In. Revista de EstudiosExtremeños, Badajóz, 1949, v. 5, p. 180-192 e 241-245.

ROMAINE, Suzanne. Bilingualism. Oxford: Blackwell Publishers Ltd. $2^{a}$ edição, 1995.

SAFFRAN, Eleanor M. Evidence from language breakdown: implications for the neural and functional organization of language. In: BANICH, Marie T. and MACK, Molly. Mind, brain and language. New Jersey: Lawrence Erlbaum Associates, Inc, Publishers. 2003.

SÁNCHEZ FERNÁNDEZ, Manuel Jesus. Português de Espanha. Exemplo: o de Olivença. Revista Portal Galego da Língua, 2008.

SARTIN, Elisangela Baptista de Godoy. A língua de herança na fronteira Portugal $x$ Espanha. In: CHULATA, Kátia de Abreu (org.). Português como Língua de Herança: Discursos e percursos. Lecce: Pensa Multi Media. 2015.

SARTIN, Elisângela Baptista de Godoy, Gramaticalização orações para mais infinitivo no Português do Brasil. Dissertação de Mestrado. SP. 2008.

SAUSSURE, Ferdinand de. Curso de linguística geral. Organização de Charles Bally e Albert Sechehaye com a colaboração de Albert Riedlinger. Tradução de Antônio CHELINI, José Paulo Paes e Izidoro Blikstein. SP: Pensamento - Cultrix. 24 edição, 2002.

SCHWARZ, Norbert. Self-Reports:How the questions shape the answers. American Psychologisty Association. 1999, vol. 54, n. 2, pp. 93-105. 
SEQUEIRA, Gustavo de Mattos e Júnior, Rocha. Olivença, Lisboa. 1924, p. 104105.(citado na página 24 - verificar).

SEWERIN, Olga and SMAGACZ, Marta. Frontiers and identities: Approaches and inspirations in sociology. In: KLUSÁKOVÁ, Lud'a and ELLIS, G. Steven (orgs). Frontiers anf identities. Exploring the Research Area. Edizione Plus Pisa University Press, 2006.

SILVA, Alfonso Franco. La Villa de Olivenza (1229-1801). Salamanca: Gráficas Oteca. $21^{a}$ edição, 1984.

SILVA, V. Gláucia. O fim é apenas o começo: o ensino de português língua de herança para adolescentes e adultos. In: JENNINGS-WINTERLE Felicia e LIMAHERNANDES, Maria Célia (orgs). Português como Língua de Herança: A filosofia do começo, meio e fim. New York: Brasil em mente. 2015.

SOUTO, José Correia do. Dicinário de História de Portugal. Biblioteca Nacional de Lisboa. [s.l.: s. n.], 1965.

SPAZIANI, Lídia. A gramaticalização do item fora no Português do Brasil: a unidirecionalidade do processo. Dissertação de Mestrado. SP. 2008.

STALNAKER, Robert C. Pragmática. In: DASCAL, Marcelo (org). Fundamentos Metodológios da Linguística. Campinas: Financiada pelo próprio organizador com a colaboração de professores e alunos do departamento de linguística, Instituto de Estudos a Linguagem, UNICAMP, 1982.

TOMASELLO, Michael. 1999. The Cultural Origins of Human Cognition. Cambridge: Harvard University Press.

TRUDGILL, Peter. Sociolinguistics. An introduction. Great Britain: Penguin Books Ltd, 1974.

VÂNIA, Maria e CALDAS, Alexandre Castro. 20 Neurociências e Cognição. Lisboa: Universidade Católica Editora, Unipessoal, Europress, Lda. 2012.

VASCONCELOS, J. Leite. O português de Olivença. In.Porto: Revista Lusitana, II, 1980, p. 347-349.

VEIGA, S. P. M. Estácio da.Gibraltar e Olivença: Apontamentos para a história da usurpação destas duas praças. Typographia da Nação. Rua da Encarnação. Lisboa. 1863.

VELOSO, J. M. de Queirós. Como perdemos Olivença. Lisboa: Academia das Ciências de Lisboa - Biblioteca de Altos Estudos, 2a ed. 1939. 
VICENTE, Renata Barbosa. Mudança Gramatical da Palavra AFINAL e sua gramaticalização num contraste entre variedades lingüisticas: Português do Brasil e de Portugal. Dissertação de Mestrado. 2009

VICENTE, Renta Barbosa. Inicar é abstrato?É o lugar? É o tempo?É o espaço do caos cognitivo. Dissertação de Mestrado. 2014

VILELA, Mário. Gramática da Língua Portuguesa. Coimbra: Livraria Almedina, 1999.

VITÓRIO, Elyne Giselle de Santana Lima Aguiar. Aquisição e variação dos verbos ter e haver existenciais no PB. Veredas on line, v.1, pp. 53. 2010.

WALL, Frans B. M. de and FERRARI, Pier Francesco. Towards a bottom-up perspective on animal and human cognition. Trends in Cognitive Sciences, v.14, n. 5, pp. 201-207, 2010.

WILSON, M. Thomas and DONNAN, Hastings. Border identities. Nation and state at inernational frontiers. Cambridge: Cambridge University Press, 2000.

\section{Referências da internet}

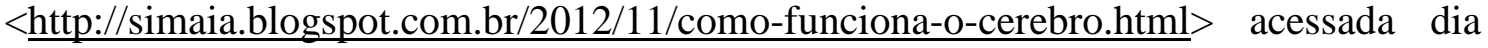
$11 / 10 / 2015$

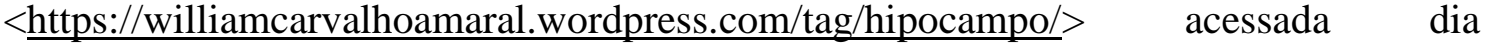
$11 / 10 / 2015$.

$<$ http://www.medicinageriatrica.com.br/2012/07/10/sudorese-hiperhidrosehipotalamica/> acessada dia 11/10/2015.

<<https://www.google.com.br/?gws_rd=ssl\#q=mapa+de+oliven\%C3\%A7a+portugal >> acessado dia 04/05/2015.

<<https://www.google.com.br/?gws_rd=ssl\#q=mapa+de+oliven\%C3\%A7a+portugal >> acessado dia 04/05/2015.

Imagem retirada do blog HTTP://depoisfalamos.blogspot.pot/

http://trajesdeportugal.blogspot.pt/2007/02/pelico-e-safes.html.

<www.infoescola.com> acessada dia 18/05/2015

<www.alemguadiana.com $>$

<HTTP://algalgz.org/blogues/index.php/bolindri/2005/10/07/o_portugues_oliventino_ja nao_existe_par> 
http://olivencaportuguesa.forumeiros.com/t4-olivenca-ou-olivenza

Blog http://depoisfalamos.blogspot.pt/ - Publicado em 19 de janeiro de 2015.

$<\mathrm{http}: / /$ www.alemguadiana.com/portugues/quienes\%20somos\%20somos\%20por/espan hol.html>

http://observador.pt/2014/12/26/oitenta-habitantes-deolivenca-pedem-para-serportugueses/

<http://port.pravda.ru/news/sociedade/05-07-2010/30048-olivenca-0/> 
ANEXO I - Placas das ruas de Olivença (Parte I)
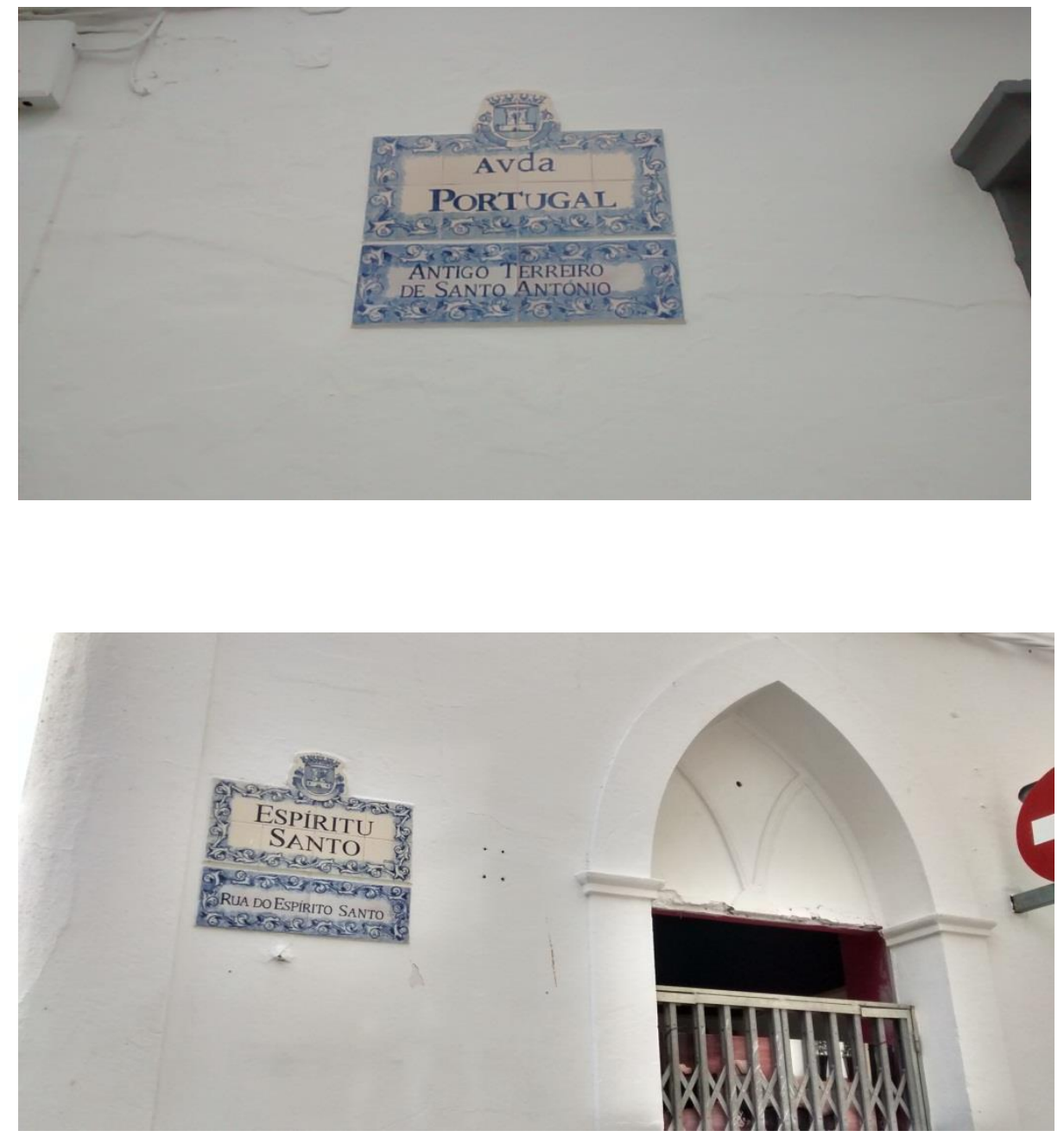
ANEXO I - Placas das ruas de Olivença (Parte II)
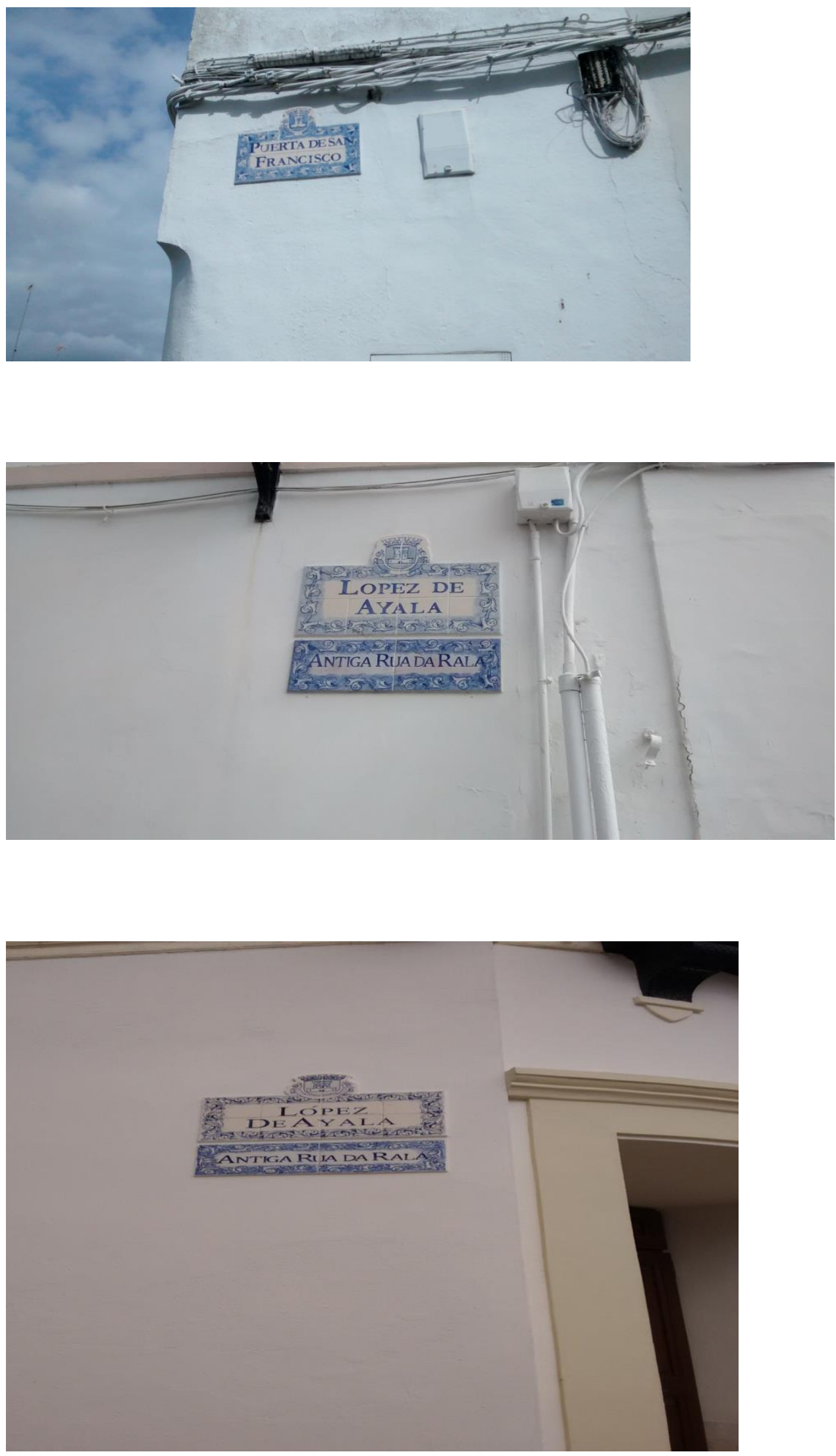
ANEXO II - Tratado de Alcanices (Biblioteca Nacional de Lisboa) - Parte I

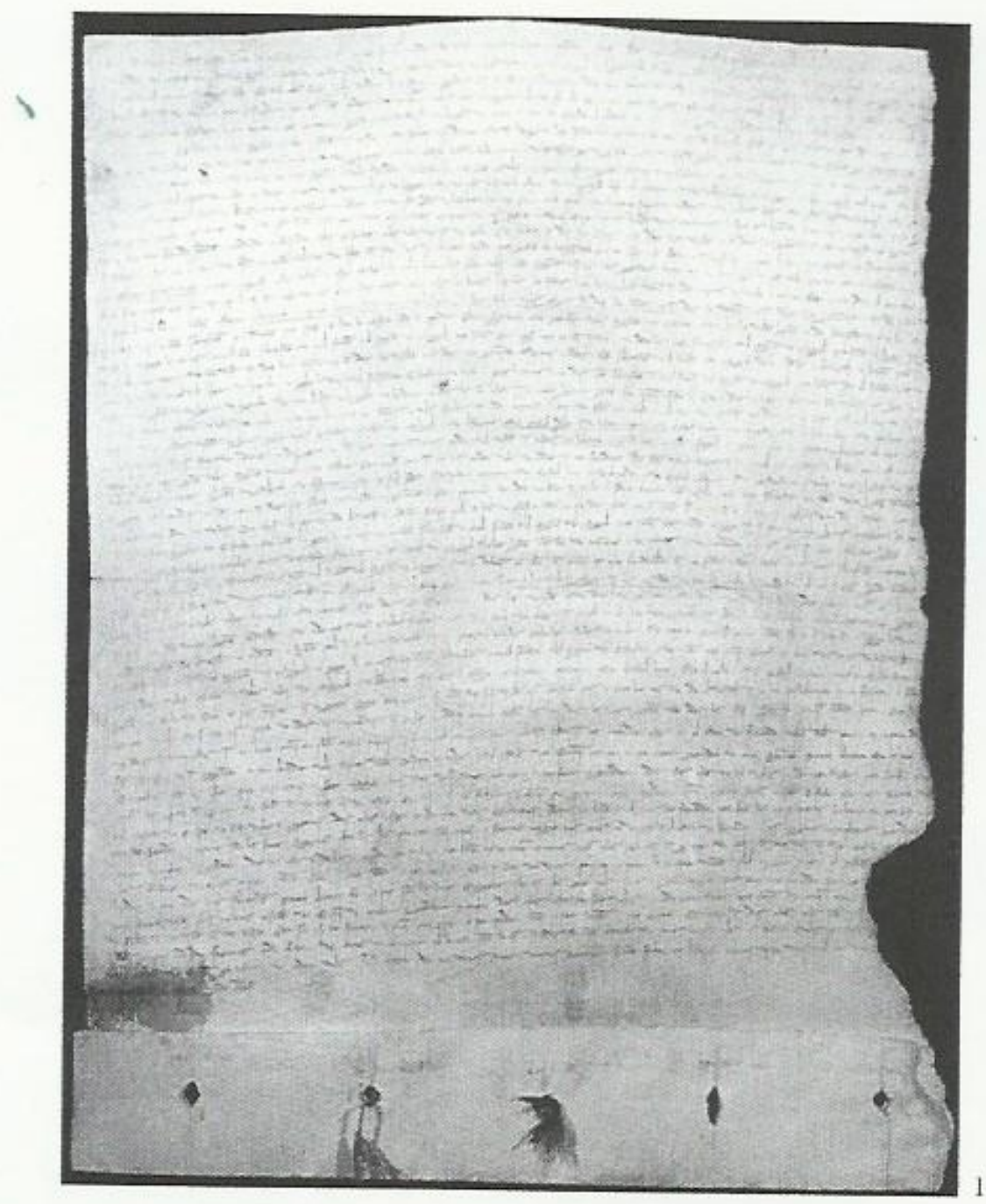

Tratado de Alcanices.

TT: Gaveta 18, Maço 9, n. 3 
ANEXO II - Tratado de Alcanices - Parte II

\section{OS DOCUMENTOS HISTÓRICOS}

Não há melhor coisa a fazer do que começar pelo tratado de Alcañices (1297), mediante o qual, definitivamente, Olivença passou para o Reino de Portugal, pondo-se fim a 69 anos de dúvidas.

\section{Documento 1}

\section{TRATADO DE ALCAÑICES (1297)}

«En o Nome de Deos Amen.

Sabham quanto esta Carta virem, e leer ouvirem, que como fosse contenda sobre Vilhas, Castelos, e Termos e partimentos, e posturas, e preitos antre nós Dom Fernando pela graça de Deos Rey de Castella, de Leon, de Toledo, de Galiza, de Sevilha, de Cordova, de Murça, de Jaen, do Algarve, e Senhor de Molina de hua parte, e Don Diniz pela graça de Deos Rey de Portugal, do Algarve da outra, e por razon destas contendas de suso ditas nacessem antre nós muitas guerras, e omizios e eixessos en tal maneira, que nas terras dambos foron, muitas roubadas, e quiemadas, e astragadas, en que se fez hi muito pezar a deos por morte de muitos homeez; veendo, e guardando, que se adiante fossem estas guerras, e estas discordias, que estava a nossa terra dambos en ponto de se perder pelos nossos pecados, e de vir a mãos dos enimigos da nossa Fé. A acyma por partir tão grão deservisso de Deos, e da Santa Heygreja de Roma nossa Madre, e tão grandes danos, e perdas nossas, e da Christandade por ajuntar paz, e amor, e grão serviço de Deos, e da Heygreja de Roma, eu Rey Dom Fernando sobredito con consolo, e com outurgamento, e per outuridade da Rainha Dona Maria Minha Madre e do Infante Don Anrique meu Tio, e meu Tutor, e Guarda de meus Reinos, e dos Infantes Dom Pedro, e Dom Filipe meus irmãos, e de Dom Diego de Haro Senhor de Biscaia, e de Dom Sancho filho do Infante Dom Pedro, e de Dom Joham o bispo de Tui, e de Dom Joham Fernandes Adeantado aior de Galiza, e Dom Fernão Fernandez de Limha, e de Dom Pedro Ponço, e de Dom Garcia 
Fernandes de Villa Mayor, e de Dom Affonso Pires de Gosmão, e de Dom Fernão Pires Maestro de Alcantara, e de Dom Stevão Pires, e de Dom Telo Justiça Mayor de minha Caza, e de outros Ricos Homees, e Homees boos de meus Reinos, e da germaydade de Castella, e de Leon, e dos concelhos desses Reinos, e de minha Corte e eu Rey Dom Diniz de susso dito com conselho, e com outorgamente da Rainha Dona Izabel minha Molher, e do Infante Dom Affonso mei Irmão e de Dõ Martinho Arcebispo de Bragaa, e de Dom Joham o bispo de Lisboa, e de Dom Sancho o Bispo do Porto, e de Dom Vaasco o bispo de Lamego, e dos Mestres do Templi, e de Aviz, e de Dom Johão Affonso, meu Moordomo Mayor Senhor de Alboquerque, de Dõ Martim Gil meu Alferez, e de Dom Joham Rodrigues de Briteiros, e de Dom Pedro Eanes Portel, e de Lourenço Soares de Valladares, e de Martim Affonso, e de João Fernandes de Lima, e de Johane Meendes, e de Fernão Pires de Barboza meus Ricos Homees, e de Johão Simhom Meirinho Mayor de minha aza, e dos Concelhos de meus Reinos, e de minha Corte, ouvemos acordo de nos aviarmos, e fazemos aveença antre nós e esta maneira que se segue, convém a saber; que eu Rey Dom Fernando sobredito entendendo, e conocendo, que os Castellos, e as Villas de Terra de Arouche, e de Arecena, com todos seus Termos, e com todos seus direitos com todas sas pertenças, que erão de direito do Reino de Portugal, e seu Senhorio, e que os ouve El Rey Dom Affonso meu Avoo de El Rey Dom Affonso nosso Padre contra sá voontade, seendo estes Lugares de direito de El Rey Dom Affonso nosso Padre; e que outro si estivera El Rey Dom Sancho meu Padre, e eu, e por esso pusi com vosco em Cidade, que vos desse, e vos entregasse essas Villas, e esses Castellos, ou cambho por elles a par dos nossos Reinos, de que vós vos pagassedes des dia de Sam Miguel, que passou da Era de Mil, e trezentos, e trinta, e quatro annos atáa sex mezes; e por que volo assi nom compri, dou vos por essas Villas, e por esses Castellos, e polos seus Termos, e polos fruitos, delles, que onde ouvemos meu Avoo El Rey Dom Affonso, e meu Padre El Rey Dom Sancho, e eu outro si atáa o dia de oje, convem a saber, Olivença, e Campo Mayor, que som apar 


\section{ANEXO III - Documento sobre a Guerra da Sucessão da Espanha (Parte I)}

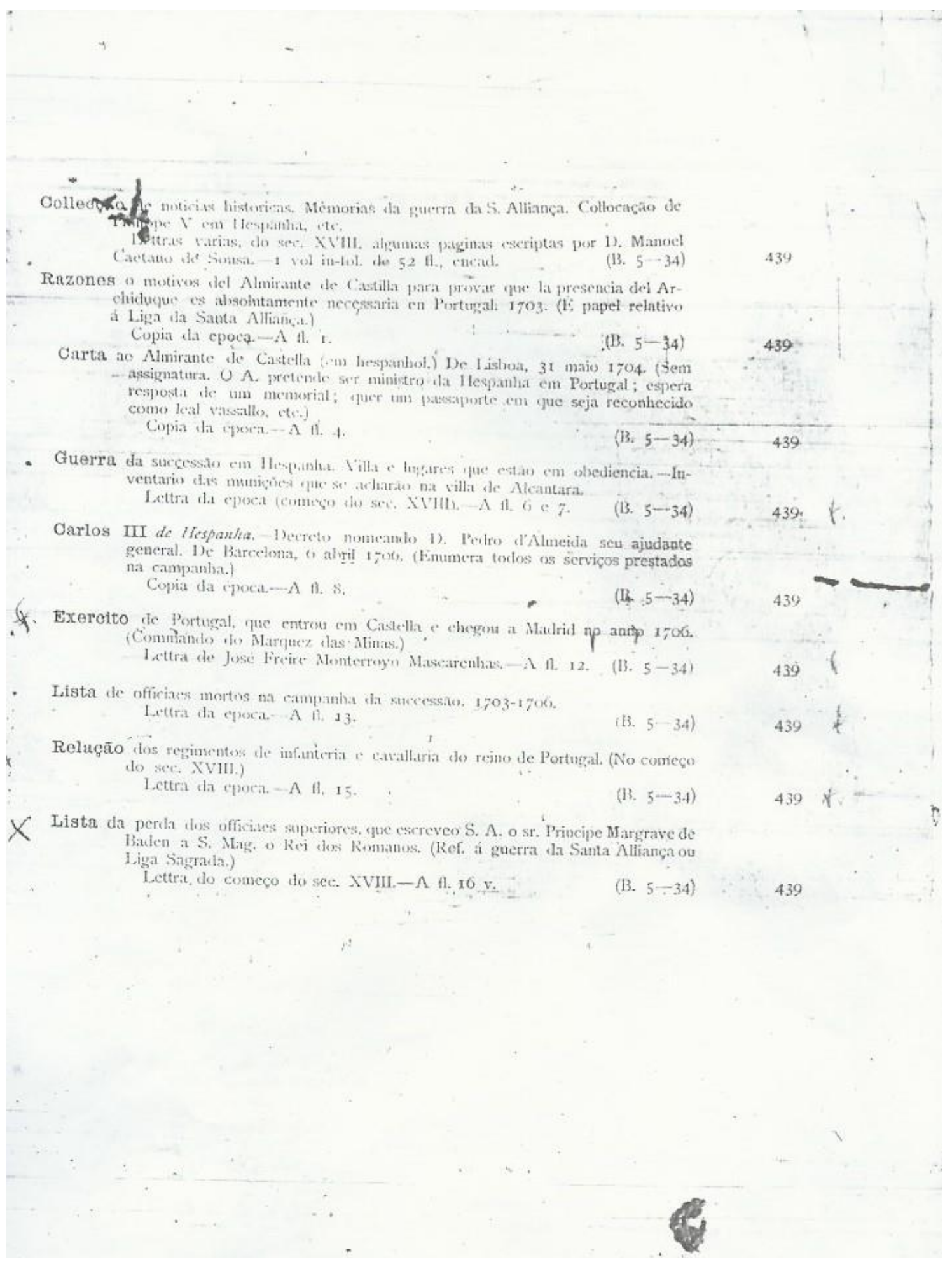


ANEXO III - Documento sobre a Guerra da Sucessão da Espanha (Parte II)

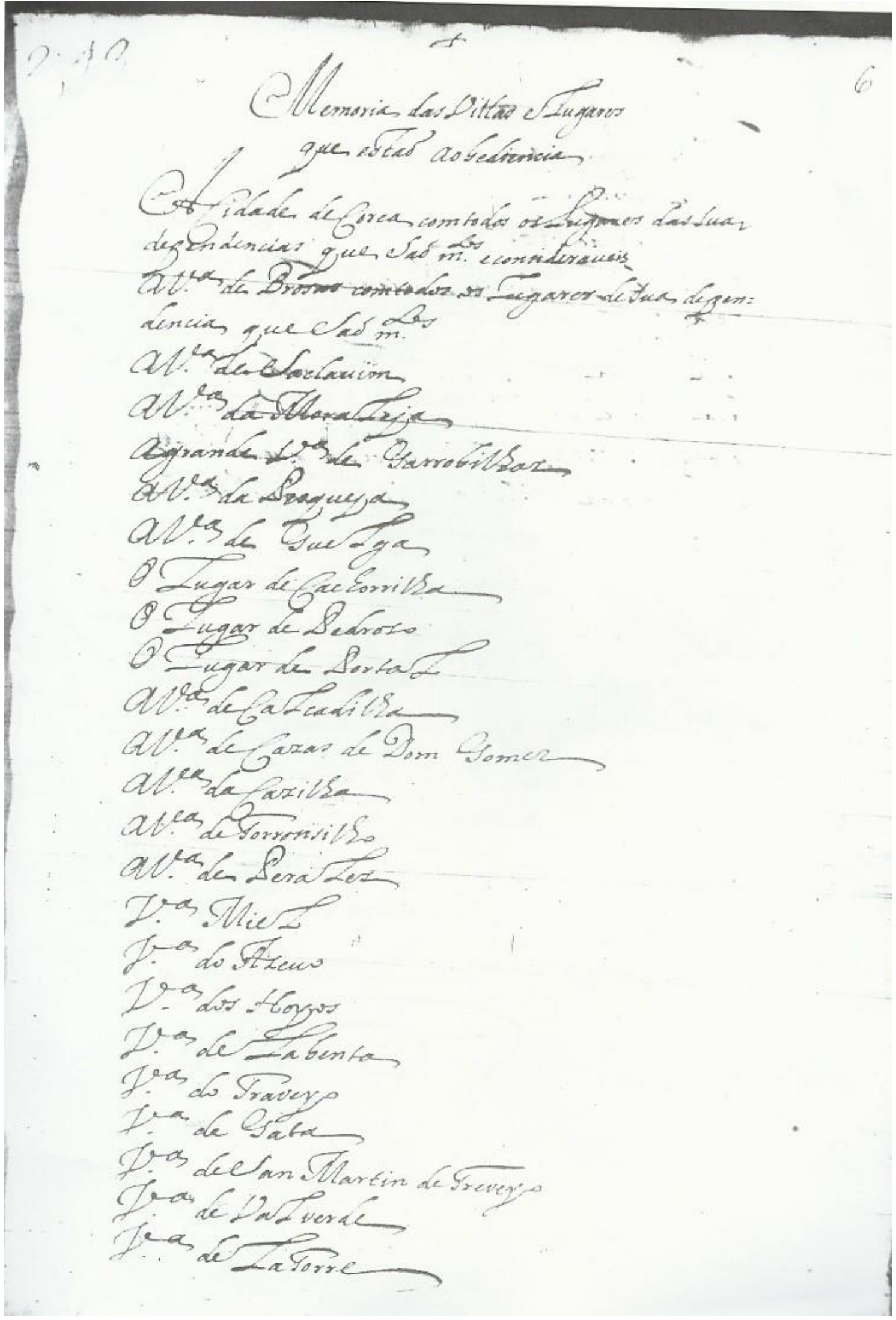


ANEXO III - Documento sobre a Guerra da Sucessão da Espanha (Parte III)

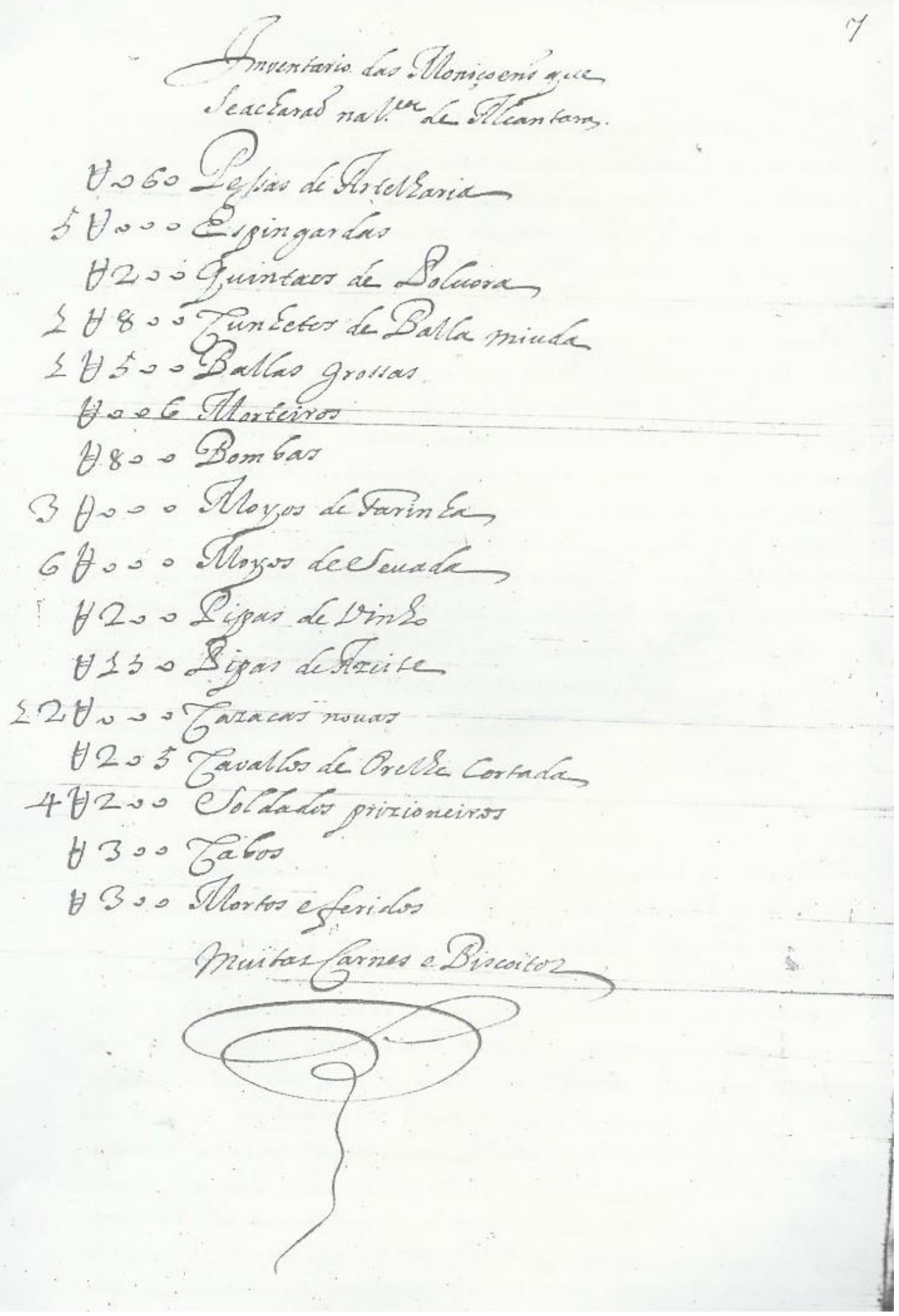


ANEXO III - Documento sobre a Guerra da Sucessão da Espanha (Parte IV)

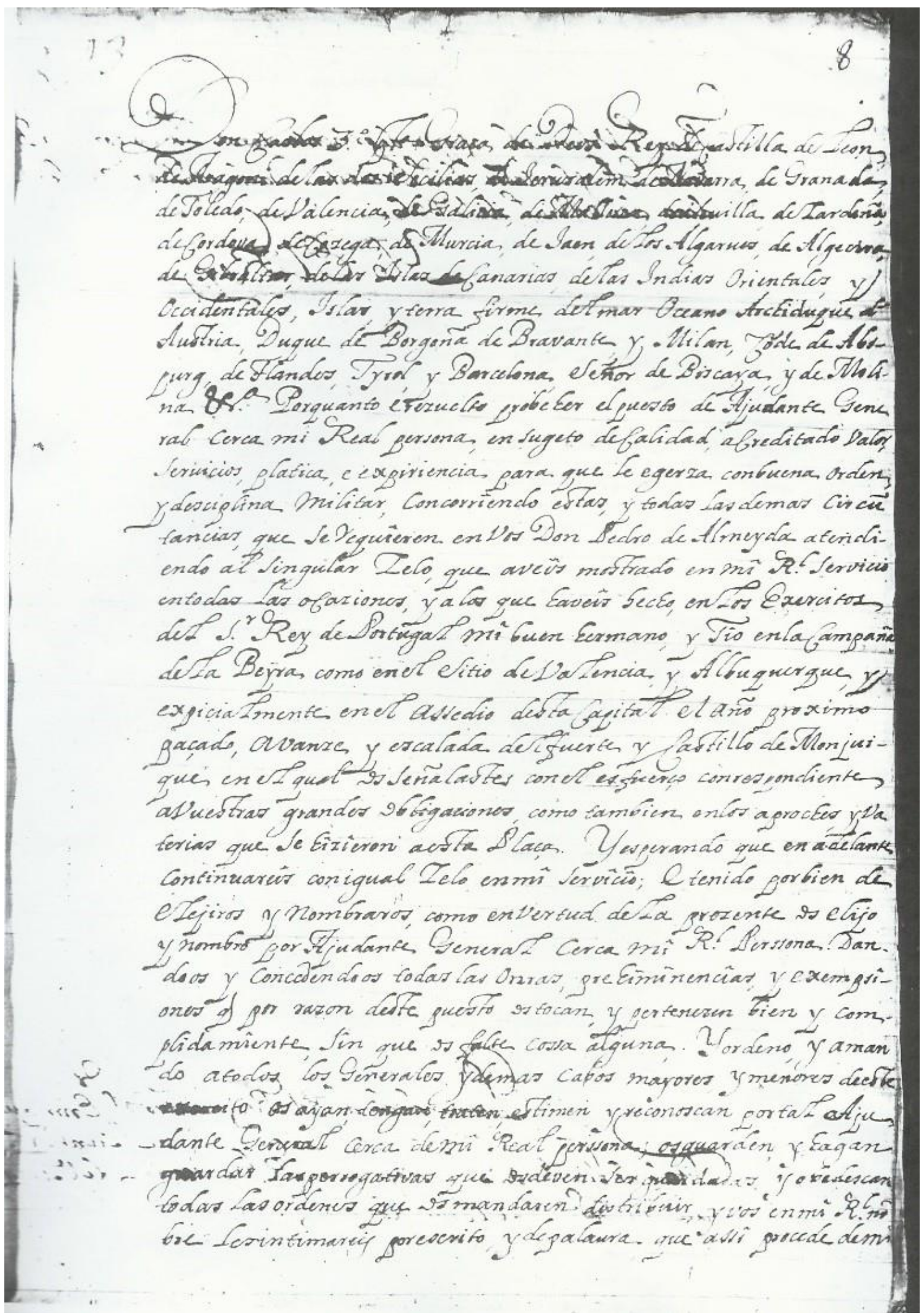


ANEXO III - Documento sobre a Guerra da Sucessão da Espanha (Parte V)

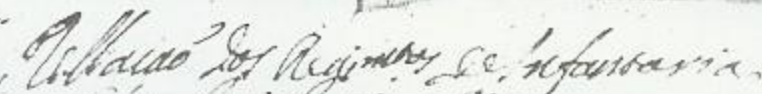

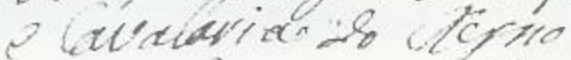

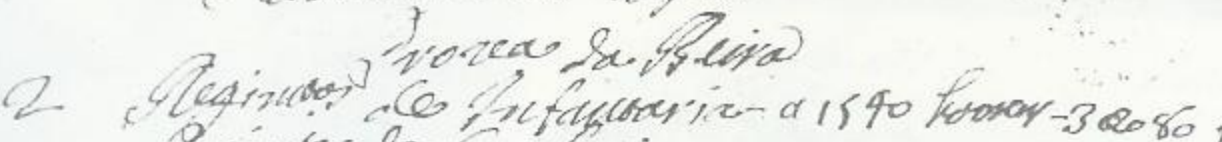

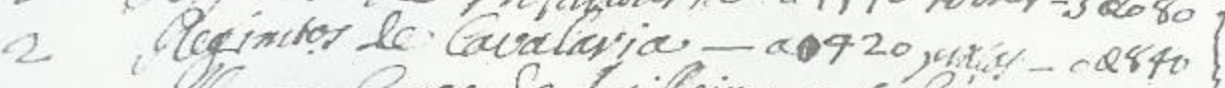

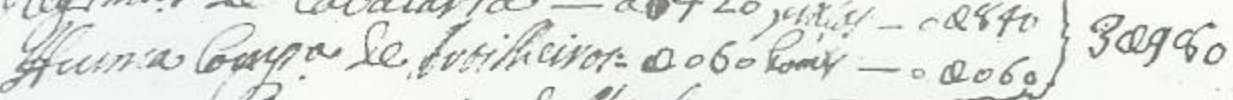

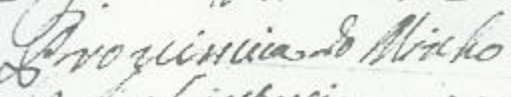

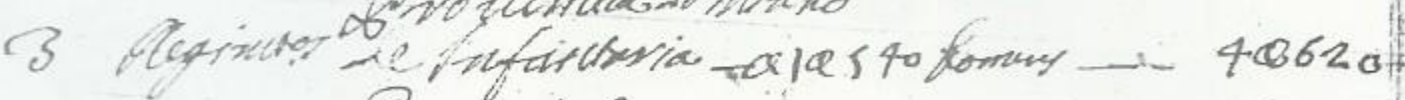

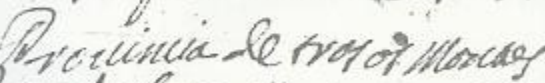

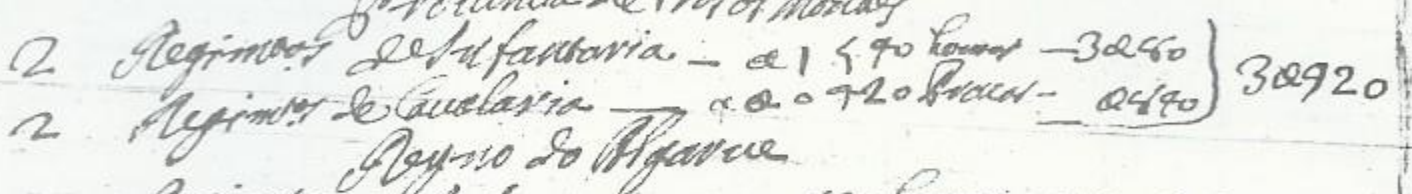

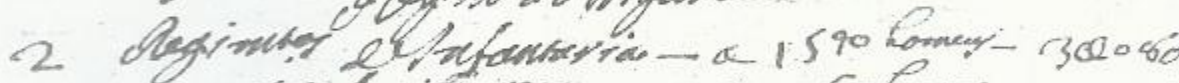

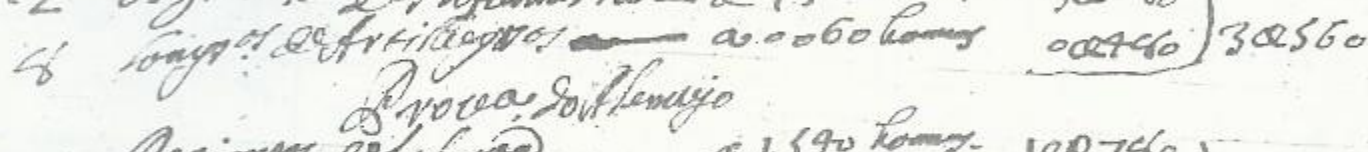

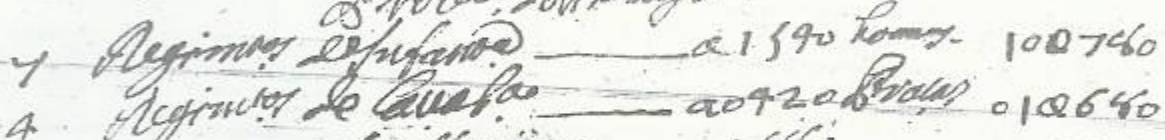

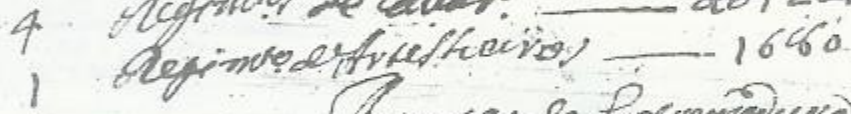

- foreca la fromerneuve

5 Seqinution lentanteria

a) 590 tang -70700

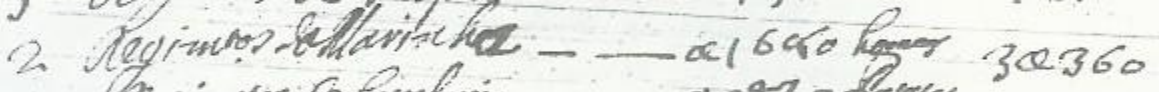

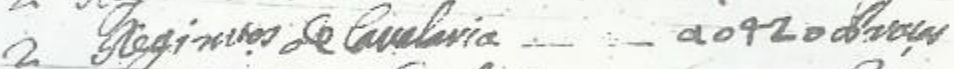

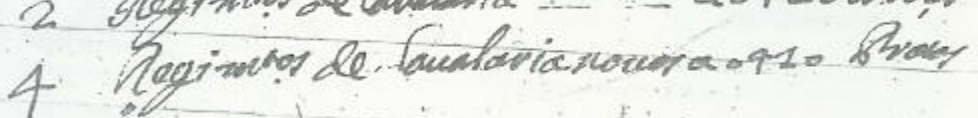
ocesto

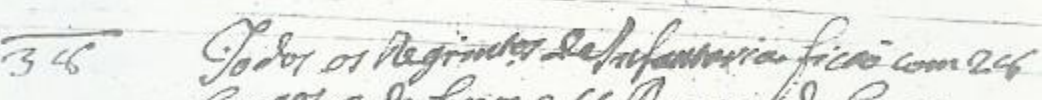

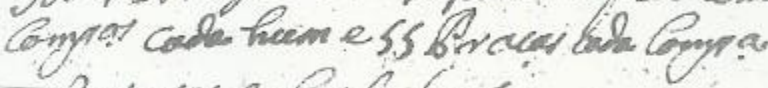

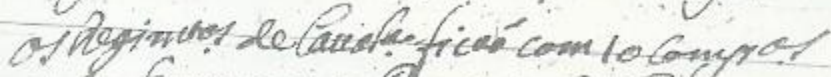

caba fum e 412 dorrios cah Empra

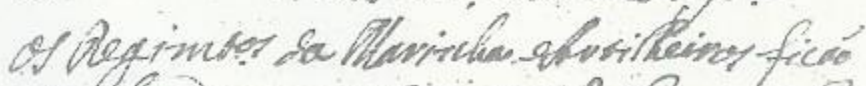

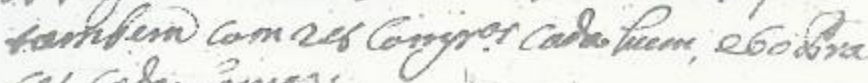

cor cosos amy?

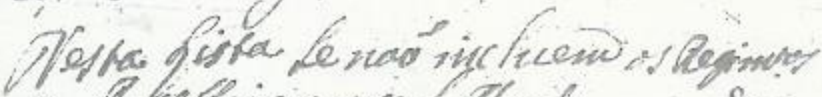

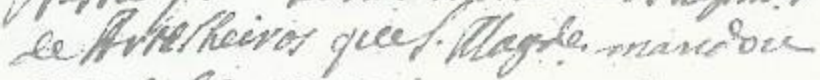

arear acentro 
ANEXO III - Documento sobre a Guerra da Sucessão da Espanha (Parte VI)

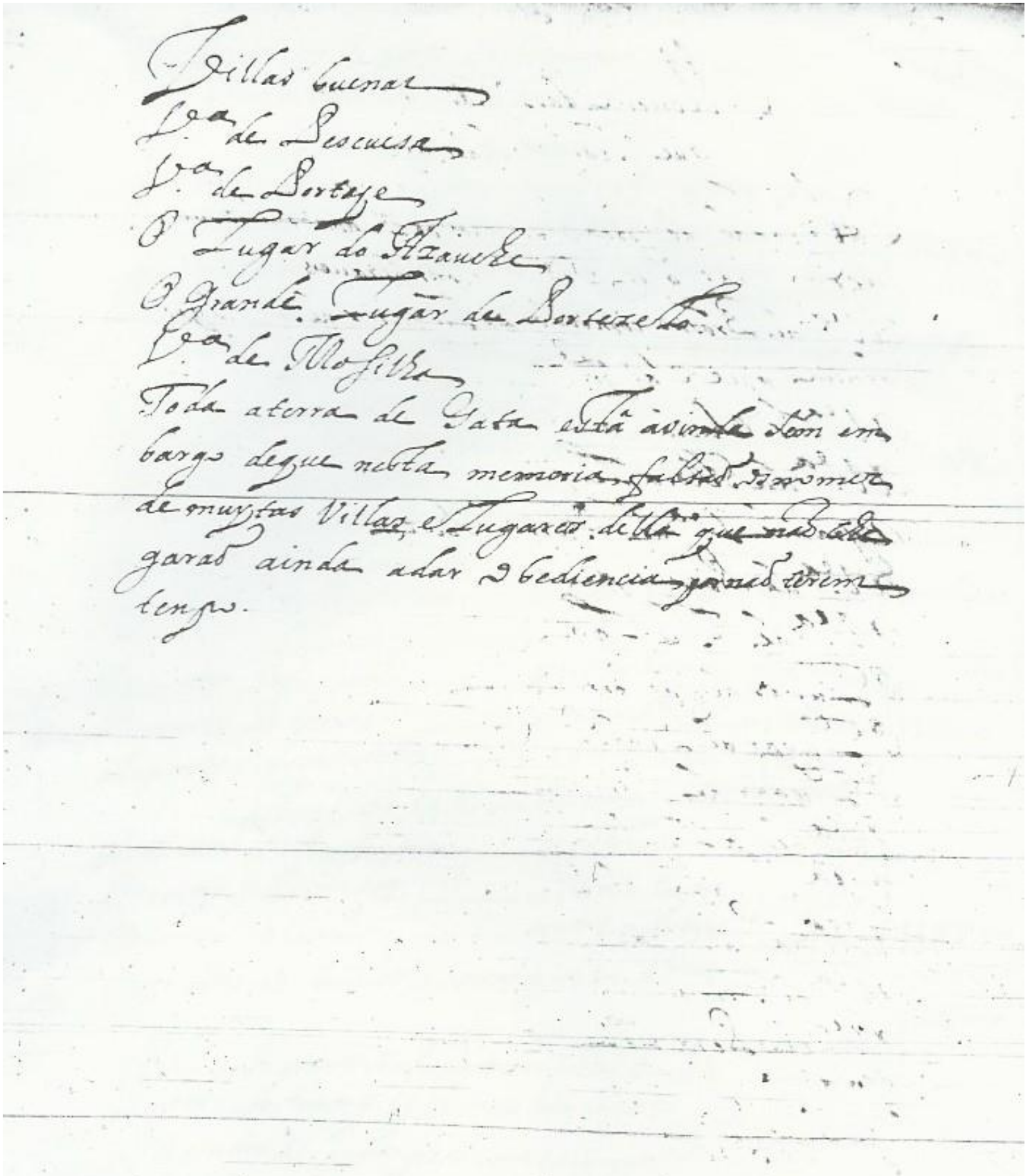


ANEXO III - Documento sobre a Guerra da Sucessão da Espanha (Parte VII)

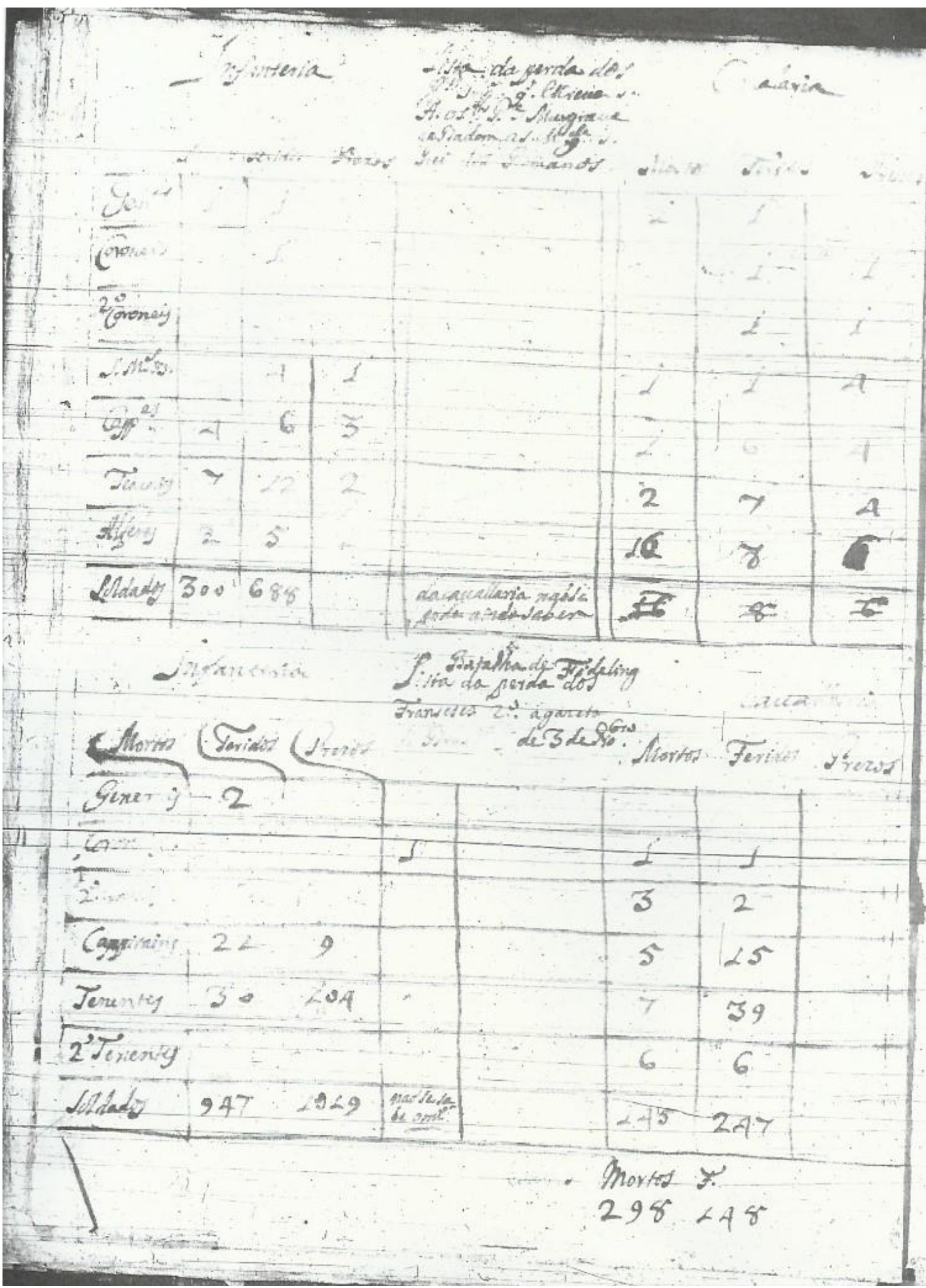


ANEXO IV - RELATÓRIO DA C.I.A.

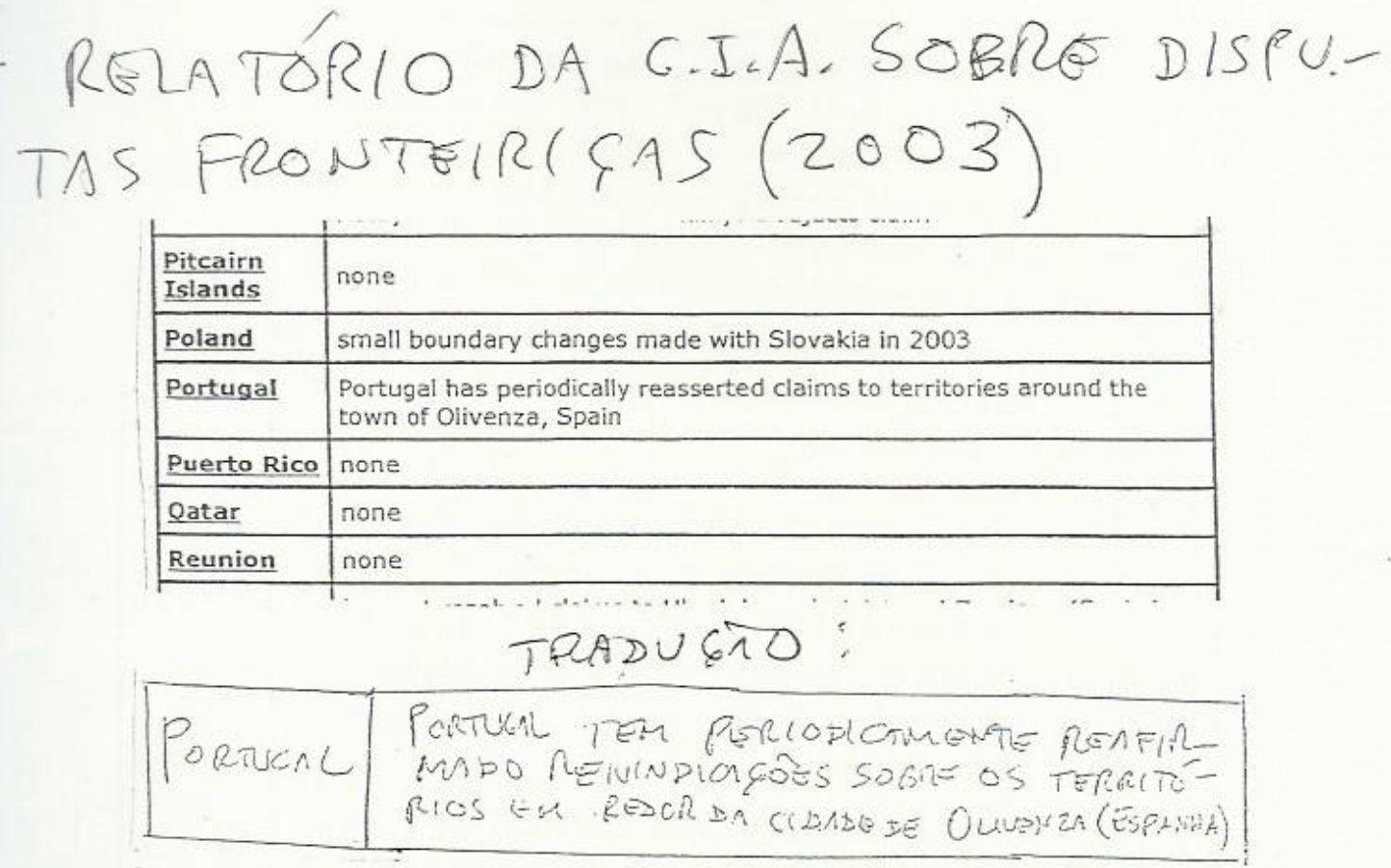

\begin{tabular}{|c|c|}
\hline $\begin{array}{l}\text { thern } \\
\text { Ocean }\end{array}$ & $\begin{array}{l}\text { Antarctic Treaty defers claims (see Antarctica entry), but Argentina, } \\
\text { Australia, Chile, France, NZ, Norway, and UK assert claims (some } \\
\text { overlapping), including the continental shelf in the Southern Ocean; several } \\
\text { states have expressed an interest in extending those continental shelf } \\
\text { claims under the United Nations Convention on the Law of the Sea (LOS) to } \\
\text { include undersea ridges; the US and most other states do not recognize the } \\
\text { land or maritime claims of other states and have made no claims } \\
\text { themselves (the US and Russia have:reserved the right to do so); no } \\
\text { formal claims have been made in the sector between } 90 \text { degrees west and } \\
150 \text { degrees west }\end{array}$ \\
\hline Spain & $\begin{array}{l}\text { Gibraltar residents vote overwhelmingly in referendum against "total } \\
\text { shared sovereignty" arrangement worked out between Spain and UK to } \\
\text { change } 300 \text {-year rule over colony; Morocco protests Spain's control over } \\
\text { the coastal enclaves of Ceuta, Melilla, and Penon de Velez de la Gomera, } \\
\text { the islands of Penon de Alhucemas and Islas Chafarinas, and surrounding } \\
\text { waters; Morocco also rejected Spain's unilateral designation of a median } \\
\text { line from the Canary Islands in } 2002 \text { to set limits to undersea resource } \\
\text { exploration and refugee interdiction; Morocco allowed Spanish fishermen to } \\
\text { fish temporarily off the coast of Western Sahara after an oil spill soiled } \\
\text { Spanish fishing grounds; Portugal has periodically reasserted claims to } \\
\text { territories around the town of Olivenza, Spain }\end{array}$ \\
\hline $\begin{array}{l}\text { Spratly } \\
\text { Islands }\end{array}$ & $\begin{array}{l}\text { all of the Spratly Islands are claimed by China, Taiwan, and Vietnam; parts } \\
\text { of them are claimed by Malaysia and the Philippines; in 1984, Brunei } \\
\text { established }\end{array}$ \\
\hline
\end{tabular}


ANEXO V - Colaboradores e informantes
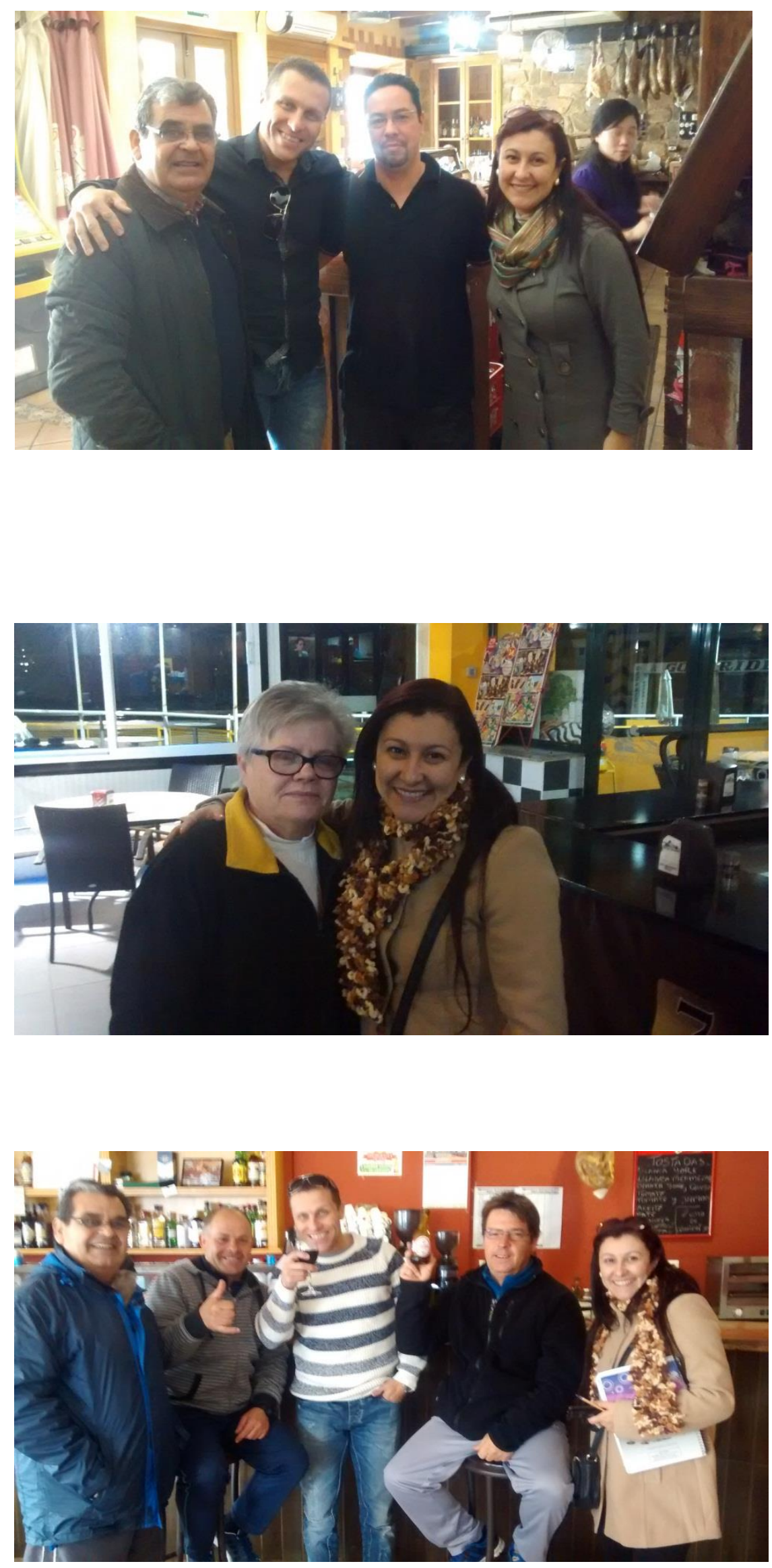